\title{
Program Modalidades Flexibles: Integrated Curriculum Guide-Segundo semestre
}

Population Council

Follow this and additional works at: https://knowledgecommons.popcouncil.org/departments_sbsr-pgy

Part of the Civic and Community Engagement Commons, Family, Life Course, and Society Commons, and the Gender Equity in Education Commons How does access to this work benefit you? Let us know!

\section{Recommended Citation}

"Program Modalidades Flexibles: Integrated Curriculum Guide-Segundo semestre." Guatemala City: Population Council, 2018. 

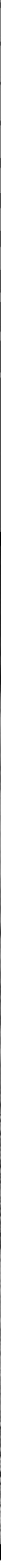

Programa Modalidades Flexibles Nivel de Educación Media, Ciclo de Educación Básica Segunda etapa, segundo semestre

\footnotetext{
POPULATION
COUNCIL 


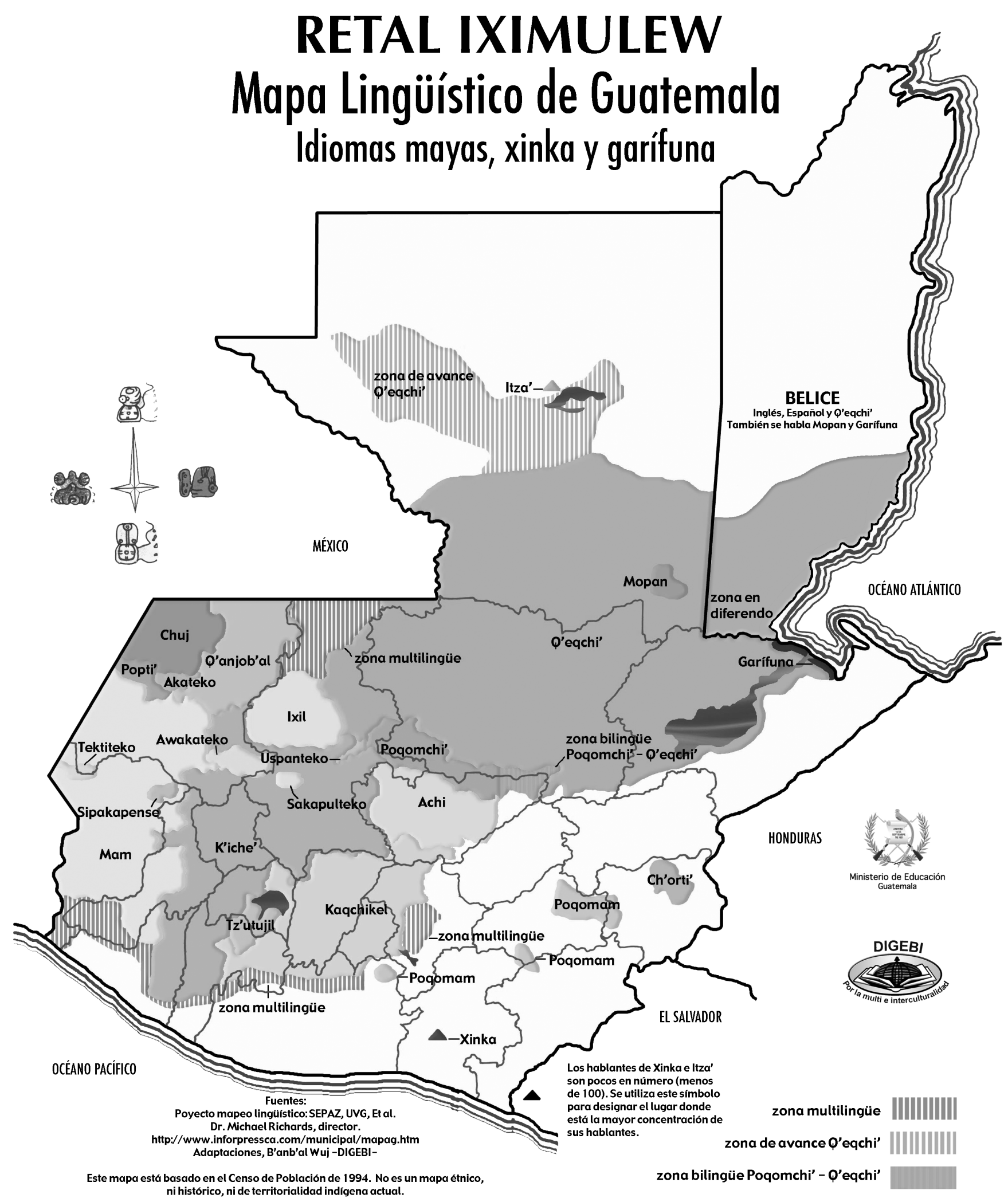

Fuente: http://www.mineduc.gob.gt/digebi/documents/mapaLinguistico.pdf 


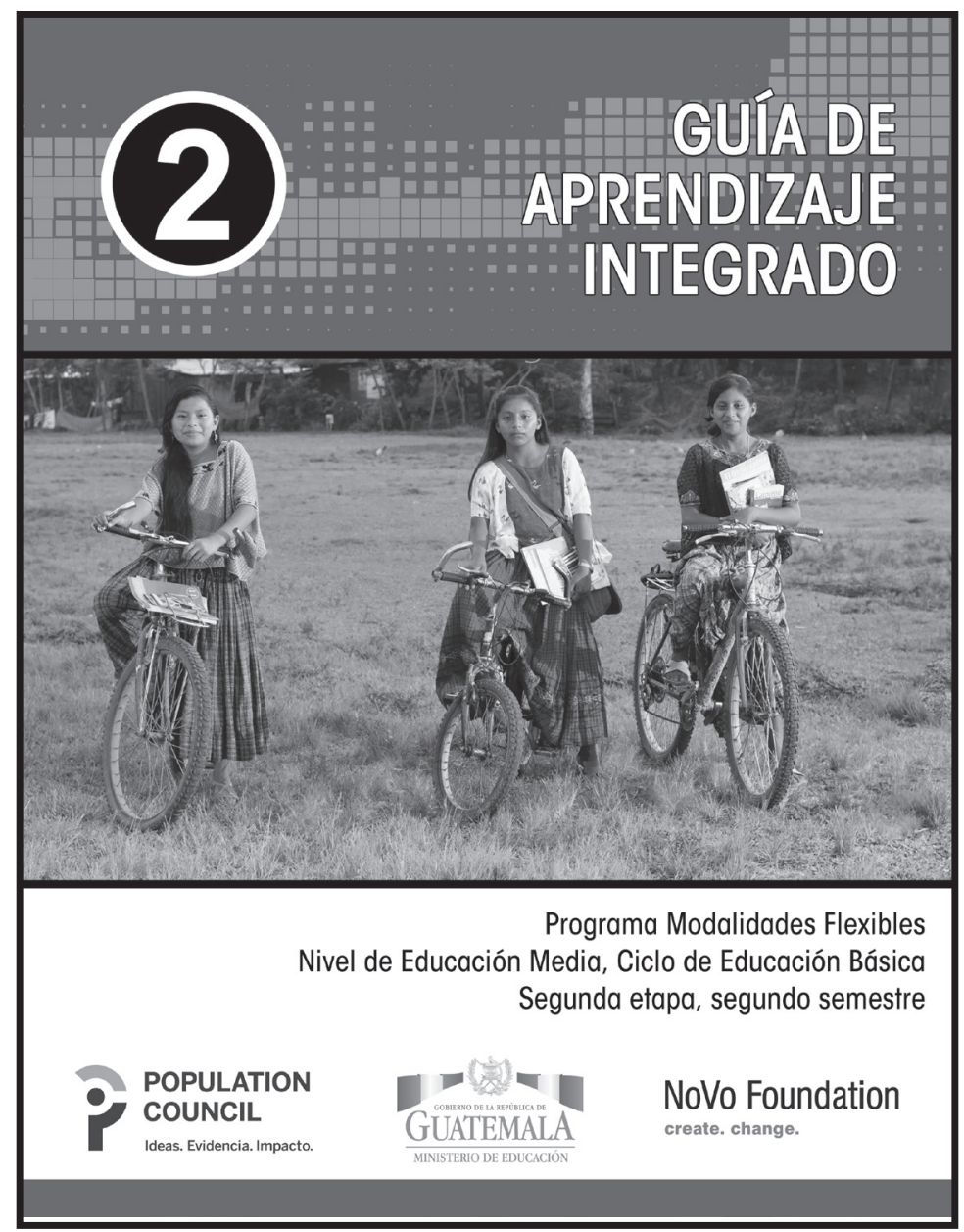

Programa Modalidades Flexibles

Nivel de Educación Media, Ciclo de Educación Básica

Segunda etapa, tercer grado

La Guía de aprendizaje integrado 2 para la segunda etapa del Programa de Modalidades Flexibles es una obra colectiva, creada, diseñada, realizada y supervisada por el siguiente equipo:

María Cecilia Garcés Iduvina Hernández Batres
Coordinación general y supervisión Coordinación Editorial y adecuación al enfoque de derechos humanos y perspectiva de género.

\section{Autoría:}

Gloria Hernández

Maria Isabel Escobedo

Gladis Fidelina Barrientos González Héctor Fernando Reyes Gramajo Margarita Ramírez Vargas Julio Floresache Claudia Roche

\section{Comunicación y Lenguaje}

Matemáticas

Ciencias Naturales

Ciencias Sociales y Formación Ciudadana

Productividad y Desarrollo

Expresión Artística

Diseño de cubierta y realización gráfica

\section{POPULATION} COUNCIL

Ideas. Evidencia. Impacto.

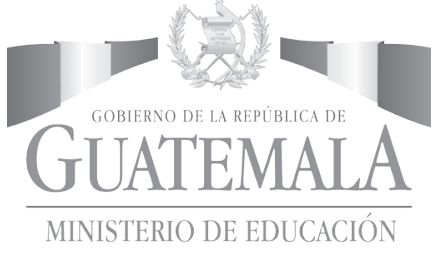

NoVo Foundation

create. change. 


\title{
Autoridades del Ministerio de Educación
}

\author{
Oscar Hugo López Rivas \\ Ministro de Educación \\ Héctor Alejandro Canto Mejía \\ Viceministro Técnico de Educación \\ María Eugenia Barrios Robles de Mejía \\ Viceministra Administrativa de Educación \\ Daniel Domingo López \\ Viceministro de Educación Bilingüe e Intercultural \\ José Inocente Moreno Cámbara \\ Viceministro de Diseño y Verificación de la Calidad Educativa \\ Juan de Dios Simón Sotz \\ Director General de Educación Extraescolar, DIGEEX.
}

D.R. (C) 2017

Population Council/Ministerio de Educación de Guatemala

19 Avenida 0-35 zona 15 Vista Hermosa II

Ciudad de Guatemala 01015

Guatemala

Producto centroamericano, hecho en Guatemala

ISBN: 978-9929-734-01-2

Impreso en

\section{NOTA:}

Esta publicación se realiza con el apoyo técnico de Population Council en el marco de apoyo al Ministerio de Educación de Guatemala; y en particular al fortalecimiento de programas con modalidades flexibles de la Dirección General de Educación Extraescolar, DIGEEX.

Los derechos patrimoniales de autor de este material son del Ministerio de Educación de Guatemala y Population Council.

Se permite la reproducción parcial o total de la obra y por cualquier medio; siempre y cuando se cite la fuente, se reconozcan los créditos institucionales y morales del equipo de creación, edición y realización y no se alteren los contenidos; únicamente con finalidades educativas. Queda prohibido todo uso de estos materiales, de sus reproducciones o de sus traducciones con fines comerciales.

La creación y publicación de esta obra fue posible gracias al financiamiento de: NoVo Foundation. 


\section{Presentación}

Guatemala ha enfrentado grandes desafíos para garantizar a sus habitantes el acceso a la educación. La universalización del Nivel de Educación Primaria a nivel nacional trae, a la vez, la necesidad de ofrecer una respuesta al deseo de la población joven por continuar sus estudios en Ciclo Básico. La inexistencia de Institutos en las comunidades más alejadas representa, particularmente para las mujeres jóvenes, mayores retos para continuar su vida escolar. Estos retos son tanto económicos como sociales.

Ante esta realidad el Population Council, en el marco del Programa Abriendo Oportunidades ${ }^{\circledR}$, se suma a los esfuerzos de la Dirección General de Educación Extraescolar -DIGEEX- del Ministerio de Educación para acercar el Nivel de Educación Media a las comunidades. Esto se está logrando al incorporar el Programa Modalidades Flexibles para Ciclo Básico como componente clave en la atención a la población joven y más excluida del sistema escolar.

Esta estrategia ofrece una alternativa flexible de estudio a jóvenes y personas adultas que han completado el Nivel de Educación Primaria y por diversas razones no han podido continuar sus estudios en el Ciclo Básico. La iniciativa por completar los recursos educativos necesarios para este ciclo del Programa Modalidades Flexibles es motivada por la evidencia recabada por el Population Council y otras organizaciones socias de la DIGEEX.

Mediante el diseño y elaboración de esta guía de aprendizaje se ofrece un recurso para estudiantes y docentes, que están participando en el segundo semestre II de la etapa II del Ciclo Básico del programa Modalidades Flexibles. Su diseño responde específicamente a la modalidad semipresencial y de integración curricular por proyectos. El abordaje de Modalidades Flexibles en este semestre, desarrolla competencias de todas las áreas curriculares enfocándose en la identificación del fenómeno de las adicciones como un problema de salud social y su impacto, la necesidad de promover un cuerpo individual y comunitario sano, así como un esfuerzo por el aprovechamiento de los recursos para la producción de energía sana, en favor del desarrollo.

Este material se ha realizado como complemento del programa Abriendo Oportunidades ${ }^{\circledR}$ de Population Council en estrecha relación y colaboración con la Dirección General de Educación Extraescolar y la Dirección General de Currículo del Ministerio de Educación. Esta primera edición constituye el material para pilotaje que luego será sometido a un proceso de validación. Este estará a cargo de tutoras y estudiantes del componente Abriendo Oportunidades a la educación secundaria por medio de Modalidades Flexibles, liderado por Population Council, actualmente implementado en los municipios de San Luis, Dolores y Poptún, en el departamento de Petén. 


\section{Mi Guía de aprendizaje por dentro}

Este libro es la Guía de aprendizaje 2 para la etapa II. La misma me va a servir en mi proceso de formación como estudiante del Programa de Modalidades Flexibles, del Nivel de Educación Media, en el Ciclo de Educación Básica, en la Segunda etapa, durante el segundo semestre. Se integra con tres proyectos, tres evaluaciones y 20 semanas de trabajo integrado.

Conforme se realice cada uno de los proyectos educativos podré desarrollar o consolidar diversas competencias, nece-

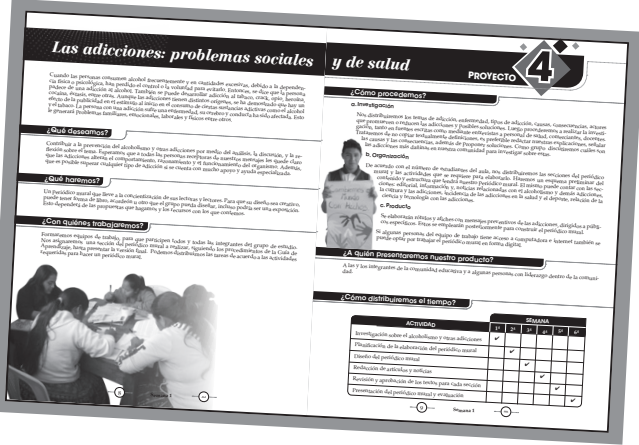
sarias para mi formación. Esto lo lograré mediante la realización de actividades de investigación-acción, autoformación, así como trabajo colaborativo, reflexión y autoevaluación.

Encontraré en las páginas de esta Guía de Aprendizaje, varias imágenes o iconos representan las fases del proceso de aprendizaje significativo.

\begin{tabular}{|c|c|c|}
\hline Icono & Etapa & Propósito \\
\hline & Desafío & $\begin{array}{l}\text { Planteamiento de uno o varios problemas o dificultades cuya } \\
\text { solución permitirá nuevos aprendizajes. }\end{array}$ \\
\hline & $\begin{array}{l}\text { Exploración de } \\
\text { conocimientos } \\
\text { previos }\end{array}$ & $\begin{array}{l}\text { Son ideas o conocimientos cuya base está en aprendizajes } \\
\text { anteriores. Trae a la conciencia presente la información y } \\
\text { experiencias previas. }\end{array}$ \\
\hline & $\begin{array}{l}\text { Puentes } \\
\text { cognitivos }\end{array}$ & $\begin{array}{l}\text { Como su nombre lo indica, son un vínculo que permite enlazar } \\
\text { los conocimientos previos con los nuevos. }\end{array}$ \\
\hline & $\begin{array}{l}\text { Nuevos } \\
\text { aprendizajes }\end{array}$ & $\begin{array}{l}\text { Son los contenidos en todas las actividades en las distintas } \\
\text { áreas que nutrirán de información que permitirá resolver las } \\
\text { situaciones de aprendizaje. }\end{array}$ \\
\hline & $\begin{array}{l}\text { Integración } \\
\text { de los } \\
\text { aprendizajes }\end{array}$ & $\begin{array}{l}\text { En estos ejercicios se aplican los conocimientos para resolver } \\
\text { situaciones que integran los contenidos de lasa otras áreas. } \\
\text { Sirven para desarrollar las competencias. }\end{array}$ \\
\hline & Evaluación & $\begin{array}{l}\text { Son situaciones que se plantean al final de la unidad, proyecto o } \\
\text { bloques de aprendizaje, que plantean el reto de mostrar el nivel } \\
\text { de logro de las competencias. }\end{array}$ \\
\hline
\end{tabular}

Con el trabajo de cada semana podré mostrar lo que he logrado por medio de la integración de áreas y sub áreas del Currículo Nacional Base (CNB).

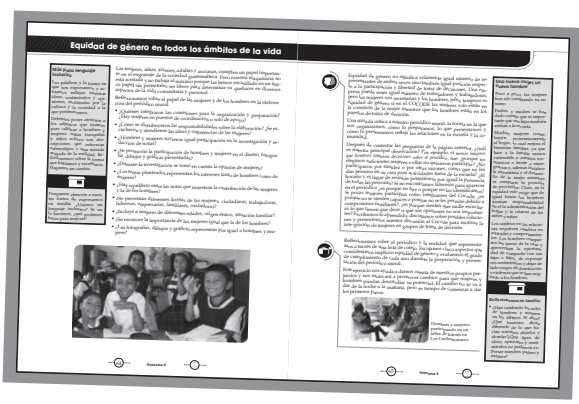


Una parte fundamental de la integración también es conocer y practicar el significado de la equidad de género, el respeto a las demás personas, así como a ejercer, proteger y defender los derechos humanos.

A través del proyecto 4 conoceré sobre cómo las adicciones pueden afectar la vida personal, familiar y comunitaria. Podré participar en la discusión y análisis para proponer soluciones a esta problemática.
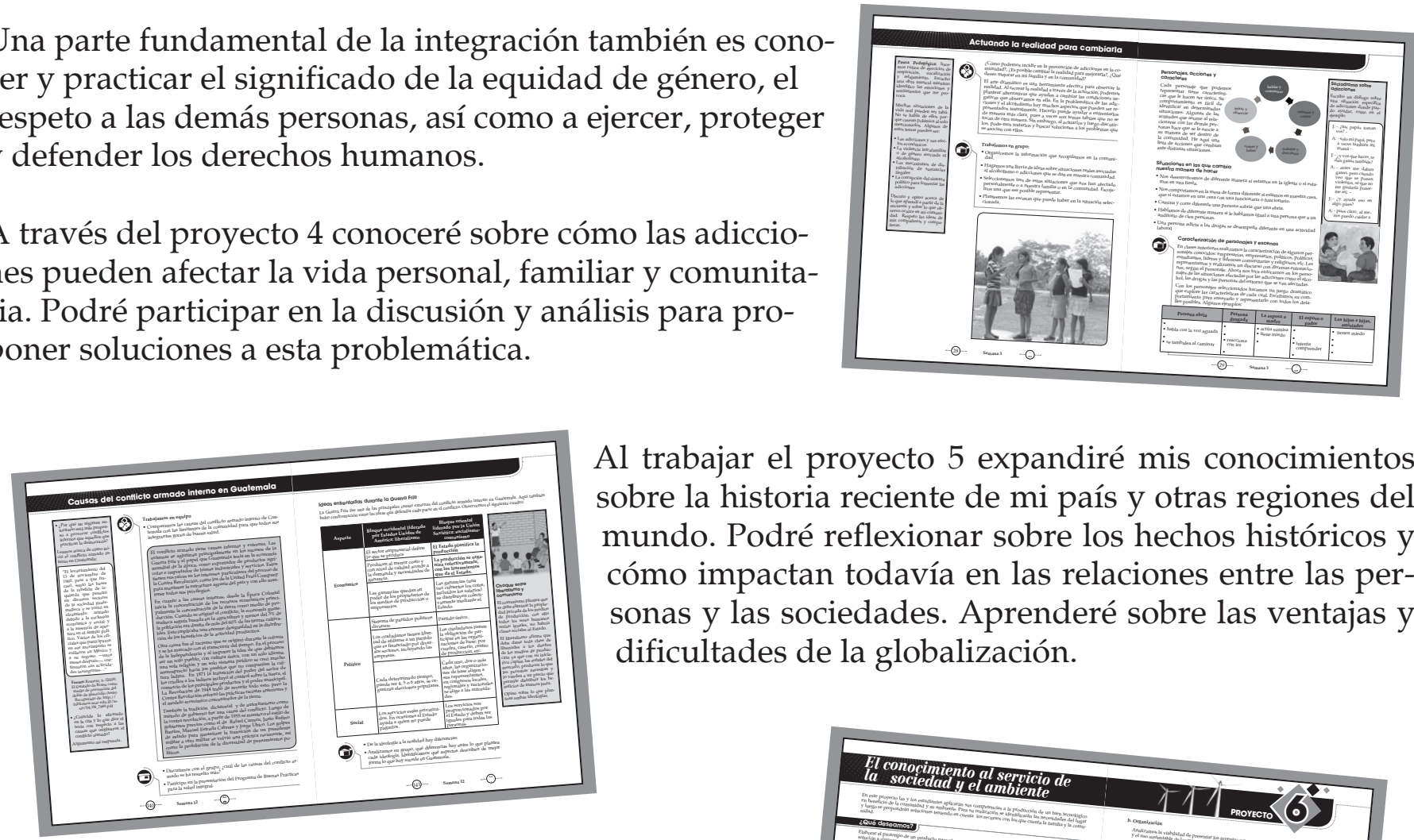

Al trabajar el proyecto 5 expandiré mis conocimientos sobre la historia reciente de mi país y otras regiones del mundo. Podré reflexionar sobre los hechos históricos y cómo impactan todavía en las relaciones entre las personas y las sociedades. Aprenderé sobre las ventajas y dificultades de la globalización.

En el proyecto 6 podré identificar necesidades de uso de energía en mi comunidad y proponer una alternativa de solución a por lo menos una de ellas.

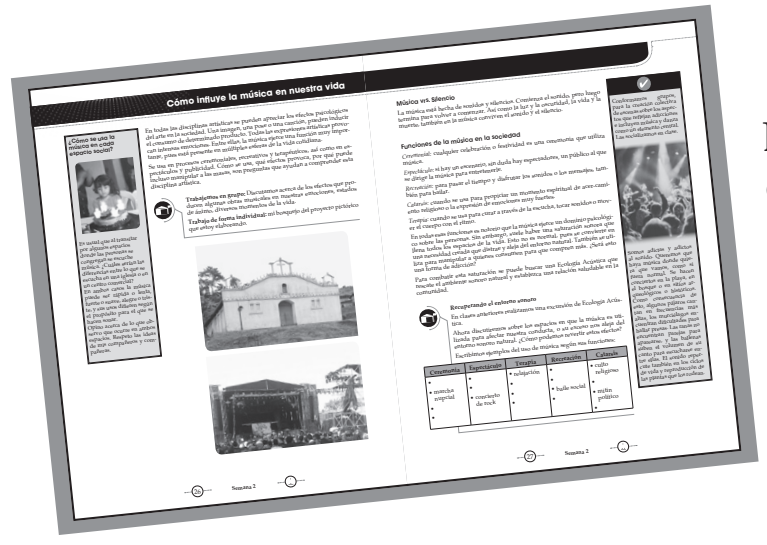

Durante el desarrollo de los contenidos, podré completar diversas actividades relacionadas con mi realidad y los temas que se abordan. Según se indica en cada una de las áreas y a lo largo de cada semana, estas actividades las realizaré tanto en el Espacio de Convergencia Andragógica (ECA) como en casa.

Al final de cada uno de los tres proyectos autoevaluaré cuánto he logrado en el desarrollo de las competencias y reflexionaré sobre el entorno en el que lo he realizado.

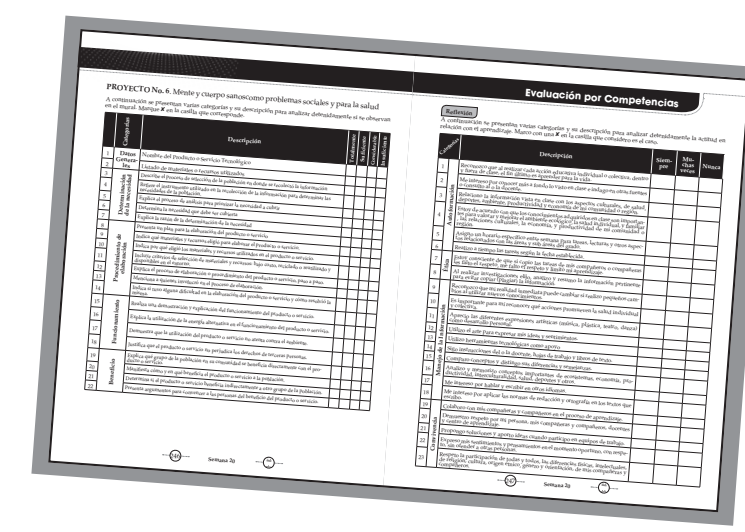


Proyecto 4

Las adicciones: problemas sociales y para la salud

8

Semana 1

10

Semana 2

16

Semana 3

28

Semana 4

40

Semana 5

52

Semana 6

64

Evaluación Proyecto 4

76

Reflexión

Proyecto 5

Mente y cuerpo sanos

78

Semana 7

80

Semana 8

92

Semana 9

104

Semana 10

116

Semana 11

128

Semana 12

140

Evaluación Proyecto 5

152

Reflexión 


\section{Proyecto 6}

El conocimiento al servicio de la sociedad y el ambiente

Semana 13

Semana 14 168

Semana 15 180

Semana 16 192

Semana 17 204

Semana 18 216

Semana 19 228

Semana 20 240

Evaluación Proyecto 3

Reflexión

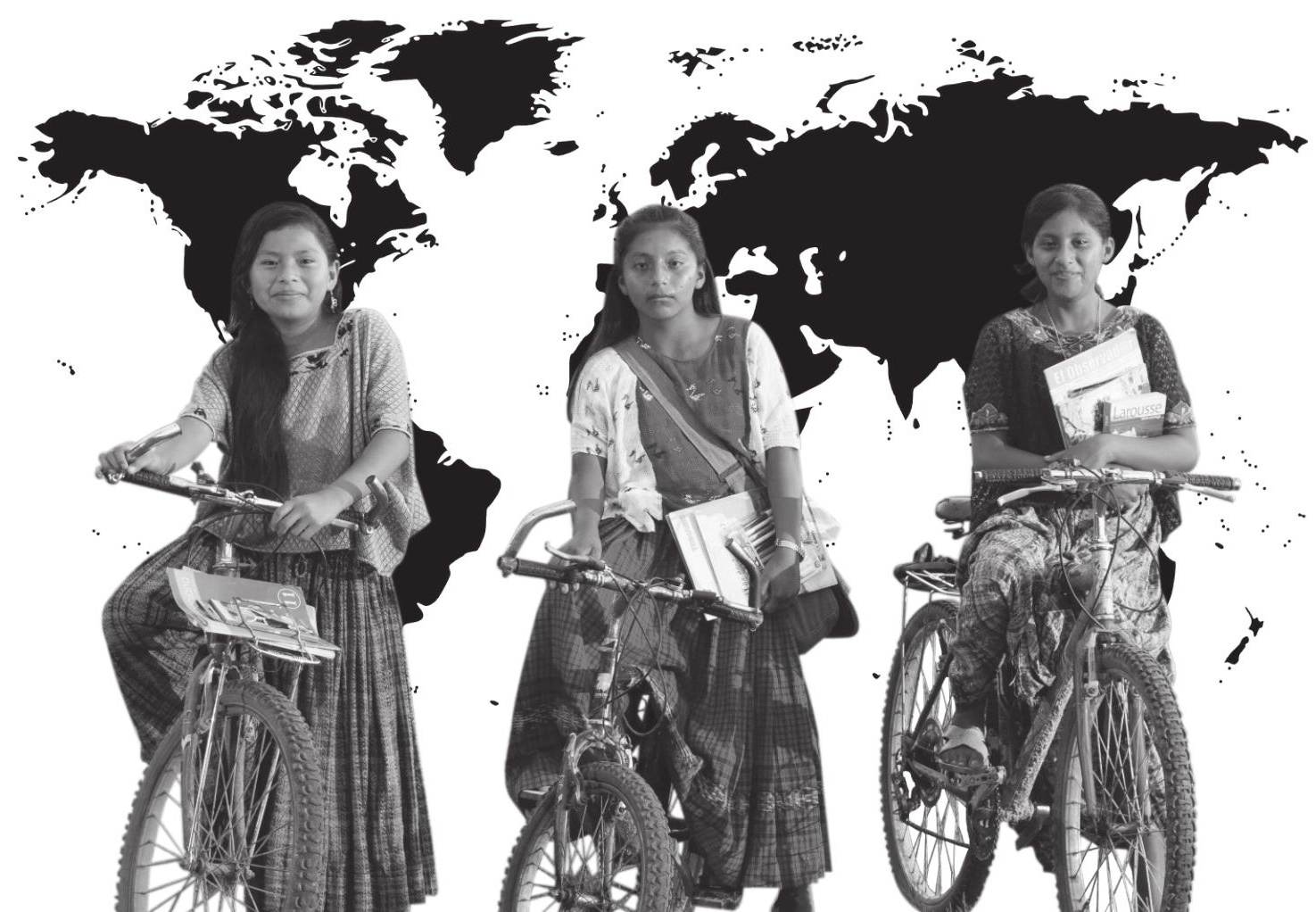




\section{Las adicciones: problemas sociales}

Cuando las personas consumen alcohol frecuentemente y en cantidades excesivas, debido a la dependencia física o psicológica, han perdido el control o la voluntad para evitarlo. Entonces, se dice que la persona padece de una adicción al alcohol. También se puede desarrollar adicción al tabaco, crack, opio, heroína, cocaína, éxtasis, entre otras. Aunque las adicciones tienen distintos orígenes, se ha demostrado que hay un efecto de la publicidad en el estímulo al inicio en el consumo de ciertas sustancias adictivas como el alcohol y el tabaco. La persona con una adicción sufre una enfermedad, su cerebro y conducta ha sido afectada. Esto le generará problemas familiares, emocionales, laborales y físicos entre otros.

\section{¿Qué deseamos?}

Contribuir a la prevención del alcoholismo y otras adicciones por medio del análisis, la discusión, y la reflexión sobre el tema. Esperamos que a todas las personas receptoras de nuestros mensajes les quede claro que las adicciones alteran el comportamiento, razonamiento y el funcionamiento del organismo. Además, que es posible superar cualquier tipo de adicción si se cuenta con mucho apoyo y ayuda especializada.

\section{¿Qué haremos?}

Un periódico mural que lleve a la concientización de sus lectoras y lectores. Para que su diseño sea creativo, puede tener forma de libro, acordeón u otro que el grupo pueda diseñar, incluso podría ser una exposición. Esto dependerá de las propuestas que hagamos y los recursos con los que contemos.

\section{¿Con quiénes trabajaremos?}

Formaremos equipos de trabajo, para que participen todos y todas las integrantes del grupo de estudio. Nos asignaremos una sección del periódico mural a realizar, siguiendo los procedimientos de la Guía de Aprendizaje, hasta presentar la versión final. Podemos distribuirnos las tareas de acuerdo a las actividades requeridas para hacer un periódico mural.

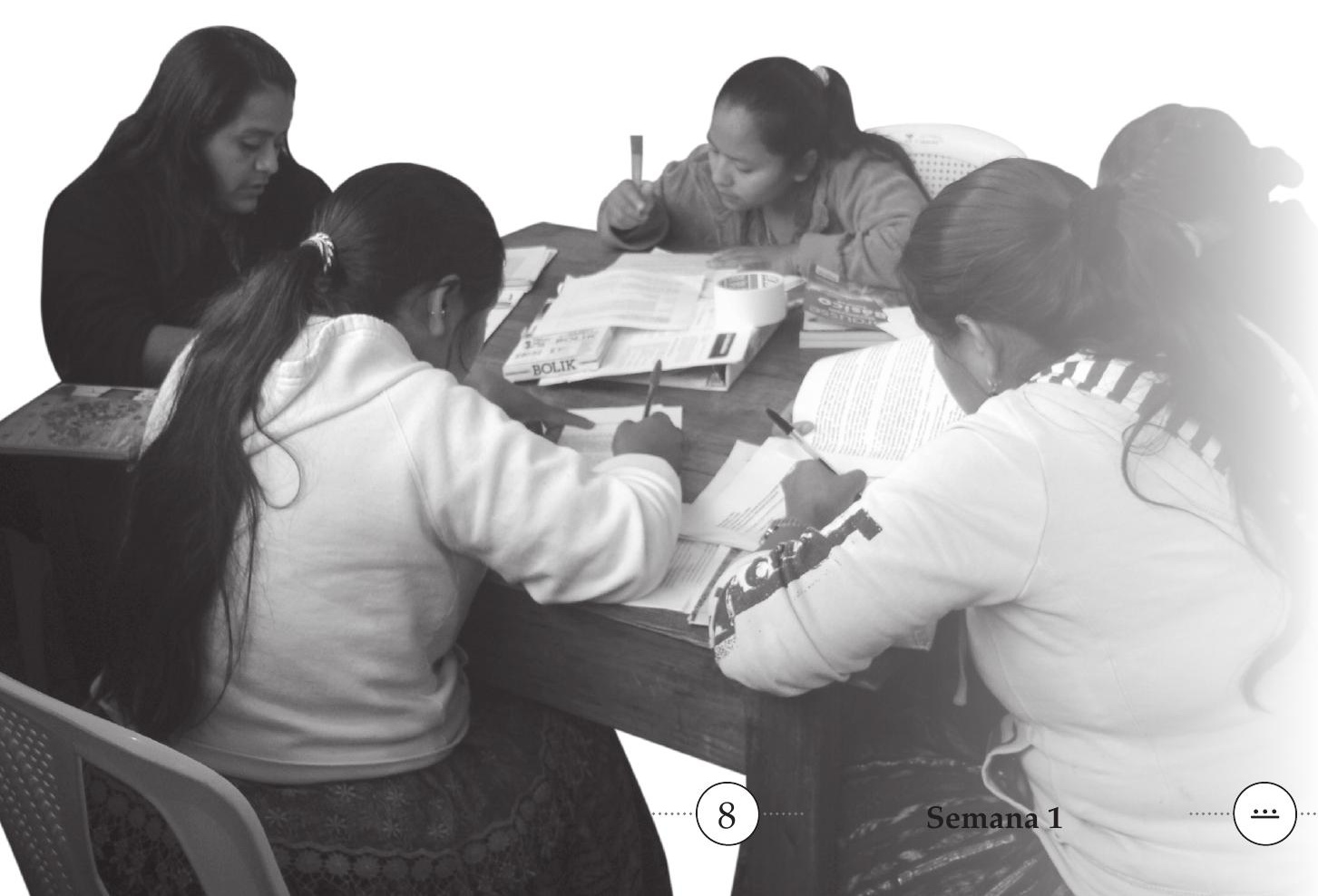




\section{y de salud}

PROYECTO

\section{¿Cómo procedemos?}

\section{a. Investigación}

Nos distribuiremos los temas de adicción, enfermedad, tipos de adicción, causas, consecuencias, actores que promueven o reducen las adicciones y posibles soluciones. Luego procederemos a realizar la investigación, tanto en fuentes escritas como mediante entrevistas a personal de salud, comerciantes, docentes.

Trataremos de no copiar textualmente definiciones, es preferible redactar nuestras explicaciones, señalar las causas y las consecuencias, además de proponer soluciones. Como grupo discutiremos cuáles son las adicciones más dañinas en nuestra comunidad para investigar sobre estas.

\section{b. Organización}

De acuerdo con el número de estudiantes del aula, nos distribuiremos las secciones del periódico mural y las actividades que se requiere para elaborarlo. Haremos un esquema preliminar del contenido y estructura que tendrá nuestro periódico mural. El mismo puede contar con las secciones: editorial, información y, noticias relacionadas con el alcoholismo y demás adicciones, la cultura y las adicciones, incidencia de las adicciones en la salud y el deporte, relación de la ciencia y tecnología con las adicciones.

\section{c. Producto}

Se elaborarán rótulos y afiches con mensajes preventivos de las adicciones, dirigidos a públicos específicos. Estos se emplearán posteriormente para construir el periódico mural.

Si algunas personas del equipo de trabajo tiene acceso a computadora e internet también se puede optar por trabajar el periódico mural en forma digital.

\section{¿A quién presentaremos nuestro producło?}

A las y los integrantes de la comunidad educativa y a algunas personas con liderazgo dentro de la comunidad.

\section{¿Cómo distribuiremos el tiempo?}

\begin{tabular}{|c|c|c|c|c|c|c|}
\hline \multirow[b]{2}{*}{ ACTIVIDAD } & \multicolumn{6}{|c|}{ SEMANA } \\
\hline & $1^{\mathrm{a}}$ & $2^{\mathrm{a}}$ & $3^{\mathrm{a}}$ & $4^{\underline{a}}$ & $5^{\mathrm{a}}$ & $6^{\mathrm{a}}$ \\
\hline Investigación sobre el alcoholismo y otras adicciones & $\checkmark$ & & & & & \\
\hline Planificación de la elaboración del periódico mural & & $\checkmark$ & & & & \\
\hline Diseño del periódico mural & & & $\checkmark$ & & & \\
\hline Redacción de artículos y noticias & & & & $\checkmark$ & & \\
\hline Revisión y aprobación de los textos para cada sección & & & & & $\checkmark$ & \\
\hline Presentación del periódico mural y evaluación & & & & & & $\checkmark$ \\
\hline
\end{tabular}




\section{Arte para vivir mejor}

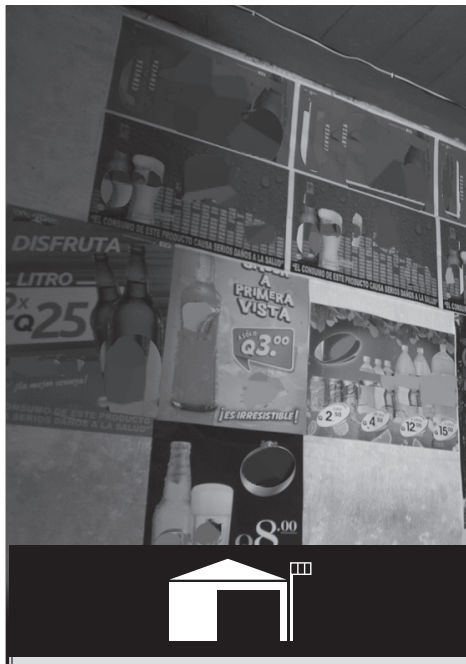

Influencias negativas que usan arte

Observemos la publicidad de licores y tabaco. También podemos ver los videos de canciones y películas que presentan el comer cio de productos que generan adicción. Ahí hay uso de música en las canciones y efectos sonoros, y de teatro en la actuación. También podemos observar danza en los bailes y arte plástico en los escenarios. Las historias que se cuentan son de opulencia y derroche, poco mencionan los efectos sociales que generan esos productos.

“En un mensaje publicitario puede aparecer información de dos tipos: una informativa y otra persuasiva. Ésta última, se dirige a nuestros sentimientos y es más peligrosa porque nos convence más fácilmente $\mathrm{y}$ muchas veces, sin darnos cuenta".

Tomado de: http://pedagogiaticucm.blogspot. com/2012/01/como-influyela-publicidad-en-la.html

- ¿Qué opino sobre la influencia del arte publicitario en la vida de mi comunidad?
Realizamos una rutina breve de respiraciones para la relajación y seguidamente escuchamos una obra musical y observamos obras de arte. Luego reflexionamos sobre las siguientes preguntas:

- ¿Hacer arte ayuda a mejorar la vida? ¿Existe relación entre el arte y la salud? ¿Cómo usamos el arte para tener una vida sana?

Apreciamos las obras de arte porque nos provocan y generan reacciones. Cada disciplina artística nos implica realizar numerosas acciones. Es notable que las cuatro disciplinas que estudiamos ejercen sobre nosotros la motivación a realizar acciones concretas.
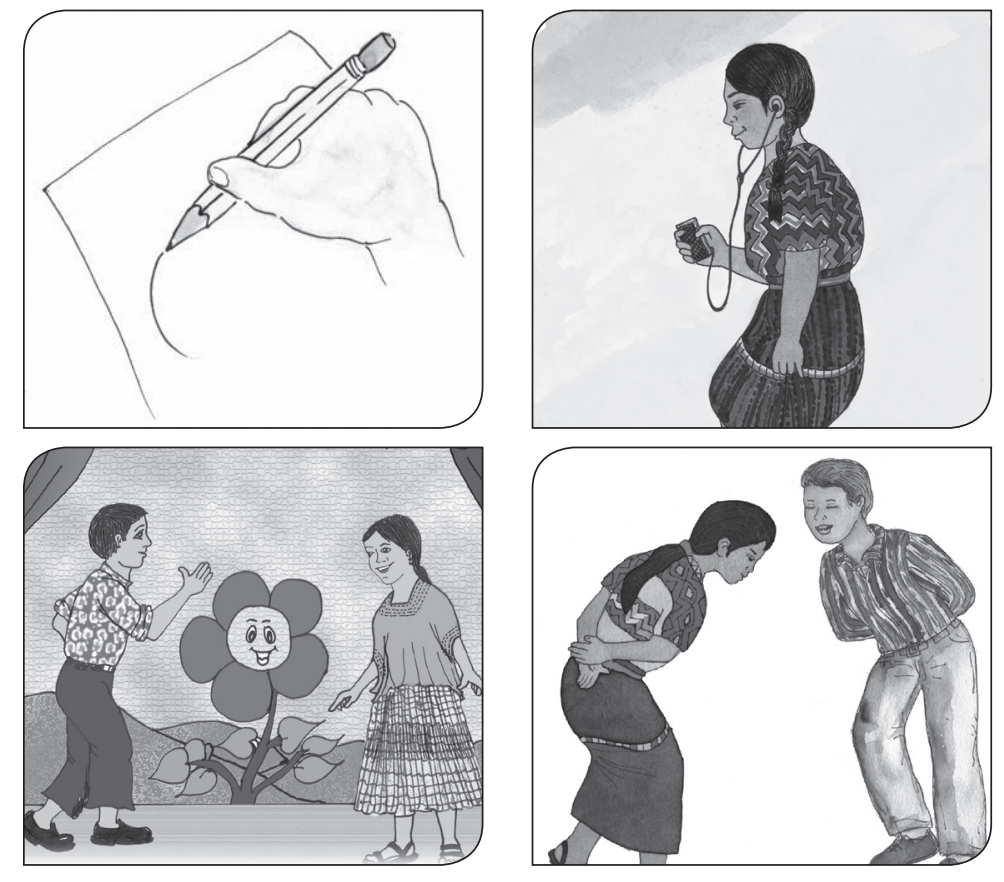

Estas acciones pueden ser de movimiento, trazo, audición, entonación, desplazamiento y actuación. Pero hay una acción abstracta: imaginar. La imaginación la podemos usar para nuestro bien y el de la comunidad, haciendo arte saludable para todos y todas.

\section{Trabajemos en grupo}

Por medio de obras de dibujo narraremos historias que cuentan la vida de personas y cómo ha influido la publicidad para consumir productos que generan adicciones. También podemos considerar cómo se da la violencia y cómo afecta a las mujeres. Escribo en mi idioma materno la historia que quiero narrar en mi obra pictórica.

Investigo en libros, periódicos, revistas o internet:

- ¿Cómo influye la música y las imágenes de la publicidad en las y los consumidores? 


\section{Hacia un liderazgo inclusivo y diverso}

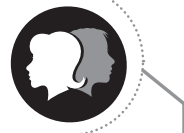

Tipos de liderazgo: el participativo toma en cuenta la opinión de las y los demás antes de tomar una decisión; el autocrático impone su decisión; el burocrático sigue un plan sin hacer modificación alguna; el carismático transmite energía, inspiración y motivación, mientras que el transformacional busca cumplir los objetivos anteponiendo el bien común.

Tradicionalmente han sido hombres mayores los líderes comunitarios. Pero el liderazgo de personas de diferente sexo, edad, ocupación y posición socioeconómica será más inclusivo.

La diversidad de pensamiento y actitudes ayudará a comprender mejor la realidad de la comunidad y a solucionar sus problemas desde distintas perspectivas. Garantizar el derecho a la participación de todas y todos asegura también más representatividad en los órganos de gobierno.

\section{Reflexionemos:}

- ¿Cómo reconocemos públicamente la labor de la comadrona?

- ¿Se toma en cuenta la opinión de la juventud en las discusiones y decisiones del Cocode? ¿Por qué es importante incorporar a jóvenes en las discusiones sobre prevención de adicciones?

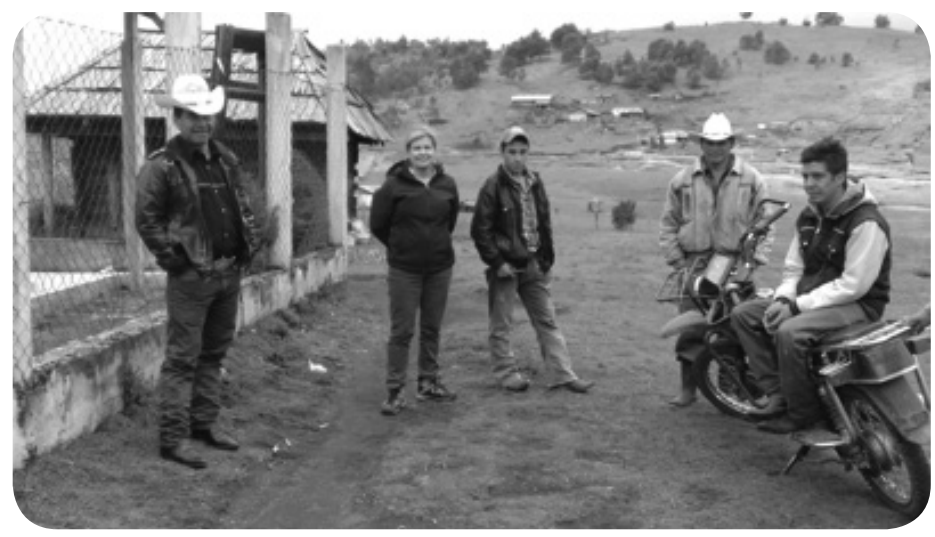

Integrantes de diversas edades del Cocode de una comunidad de Los Cuchumatanes.

Nos organizamos en tres grupos para investigar y discutir sobre los tipos de liderazgo y su influencia sobre otras personas.

Elaboro fichas sobre cada uno de los tipos de liderazgo.

\section{Jóvenes y consumo} de alcohol

El consumo de alcohol está aumentando entre hombres y mujeres a edad muy temprana, debido a factores como baja autoestima, dificultad para solucionar problemas, presión de grupo, influencia de la publicidad y otros. La adicción al alcohol produce enfermedades, accidentes, pérdida de empleo, desintegración familiar y problemas económicos. Por eso es importante que las personas jóvenes tengamos espacios para desarrollar nuestras habilidades sociales, empresariales, deportivas, artísticas; para soñar y alcanzar metas. Las organizaciones y el liderazgo juvenil positivo ayudan a reforzar la autoestima, la reflexión, el respeto y la tolerancia para el crecimiento personal y el desarrollo de la comunidad.

Resultados de encuesta entre escolares de 13 a 15 años

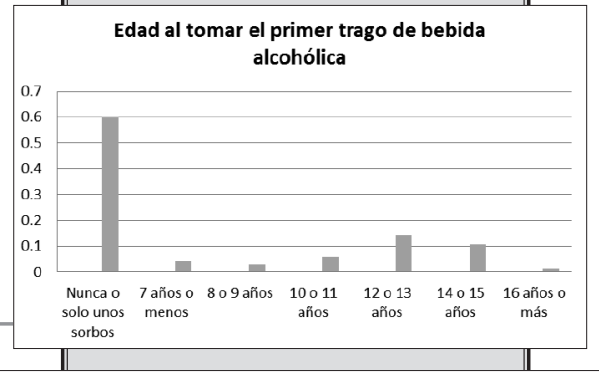

Si alguno de tus mejores amigos 0 amigas te ofreciera una bebida alcohólica, ¿te la tomarías?

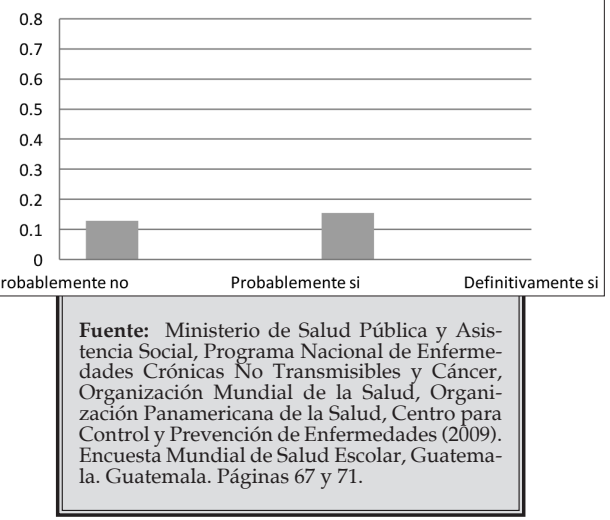




\section{Rélciciones y operaciones entre conjuntos}

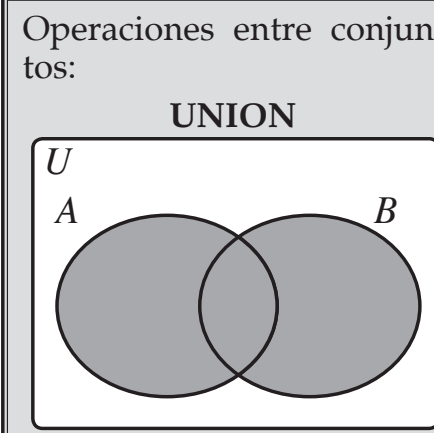

$A \cup B$

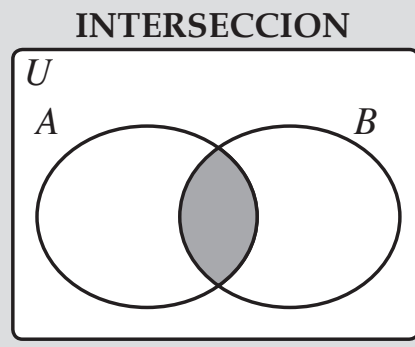

$A \cap B$

DIFERENCIA

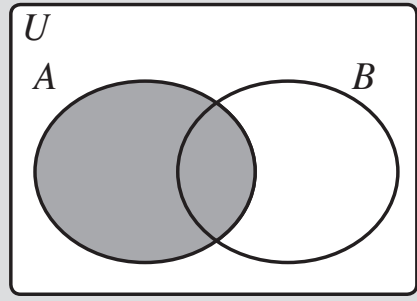

$A \cap B$

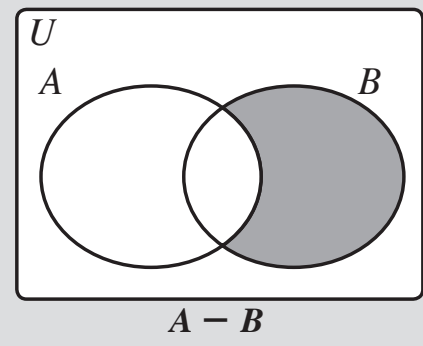

\section{COMPLEMENTOS}

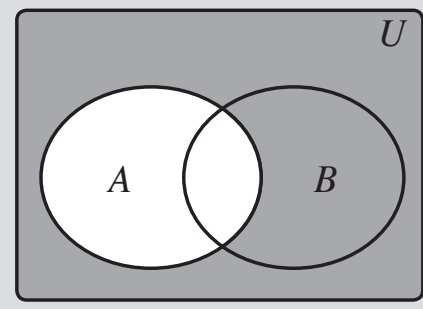

$\bar{A}$

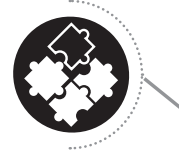

Nos organizamos en equipos y realizamos la siguiente actividad:

Llenamos la siguiente tabla, preguntando a personas adultas que estén a nuestro alcance, si beben alcohol, fuman cigarrillos o ambos. Debemos incluir personas de ambos sexos y de varias edades. Colocamos la información en una tabla como esta:

\begin{tabular}{|l|c|c|c|c|}
\hline Persona & Bebe alcohol & $\begin{array}{c}\text { Fuma } \\
\text { cigarrillos }\end{array}$ & Bebe y fuma & $\begin{array}{c}\text { Ninguno de } \\
\text { los dos }\end{array}$ \\
\hline Ejemplo 1 & $\mathrm{X}$ & & & \\
\hline Ejemplo 2 & & & $X$ & \\
\hline Ejemplo 3 & & & & $X$ \\
\hline
\end{tabular}

Después de haber organizado la información colocamos los datos recolectados en un diagrama de Venn como este:

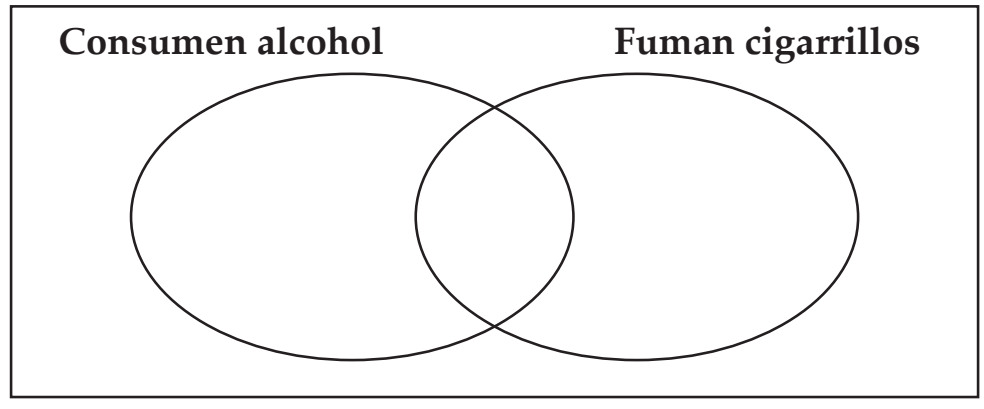

Utilizamos el diagrama anterior para contestar las siguientes preguntas:

- ¿Cuántas personas fuman cigarrillos?

- ¿Cuántas personas beben alcohol?

- ¿Cuántas personas fuman cigarrillos y beben alcohol?

- ¿Cuántas personas beben alcohol, pero no fuman cigarillos?

- ¿Cuántas personas no beben alcohol?

Resolvemos la siguiente situación utilizando un diagrama de Venn:

En una comunidad se entrevistó a 58 personas acerca de sus hábitos alimenticios. De ellas, 28 dijeron que tomaban diariamente bebidas gaseosas; 27 afirmaron comer frituras a diario y 39 aseguraron que todos los días comían dulces. Otras 12 personas diariamente comen frituras y toman gaseosas, 16 ingieren frituras y dulces y 17 comen todos los días dulces y beben gaseosas. Dos personas consumen las tres cosas a diario.

- ¿Cuántas personas consumen solamente frituras?

- ¿Cuántas personas no consumen ninguno de los tres productos?

- ¿Cuántas personas no consumen gaseosas ni frituras todos los días? 


\section{Indicadores de salud en Guatemala}

Los indicadores son unidades de medida que describen la condición y las características de un objeto, una población, un hecho. $\mathrm{Al}$ reunir varios indicadores se obtiene índices, como el Índice de Desarrollo Humano que "mide el progreso conseguido por un país en tres dimensiones básicas del desarrollo humano: disfrutar de una vida larga y saludable, acceso a educación y nivel de vida digno." (PNUD, 2016).

Entre los indicadores de salud están:

1. Mortalidad: cantidad de personas que fallece en un lugar, tiempo y por una causa determinada.

2. Natalidad: cantidad de personas que nace en un lugar y un periodo de tiempo determinado.

3. Desnutrición crónica: cantidad de menores de cinco años con un peso y tamaño menor al que se espera.

4. Esperanza de vida al nacer: cantidad de años que se espera alcance a vivir una persona.

La desnutrición crónica y otras enfermedades están asociadas a la pobreza, la falta de educación y la dificultad de acceder a los alimentos. La condición social de una comunidad se refleja en términos de salud de sus habitantes: el estado nutricional, la esperanza de vida de los diversos grupos, las experiencias de atención de mujeres en el embarazo y el parto entre otras.

Investiga la situación de tu municipio en los siguientes indicadores: desarrollo humano, esperanza de vida, mortalidad en adultos y adultas, mortalidad materna, mortalidad adolescente, desnutrición infantil.

\section{Discutimos y respondemos lo siguiente:}

1. ¿Qué información, acerca de las adicciones en esta comunidad, nos interesaría conocer?

2. Propón cómo mediríamos el acceso que tienen los y las jóvenes a productos que generan adicciones en esta comunidad.

Investigo en documentos electrónicos, centro de salud, y consultando a personas expertas acerca de:

- Productos adictivos que se consumen más frecuentemente en nuestra comunidad.

- Enfermedades y otras consecuencias que produce la adicción por su consumo en nuestra comunidad.

- Causas que provocan el inicio del consumo de estos productos en nuestra comunidad.

- Grupos más afectados por la adicción de estos productos en nuestra comunidad.

Elaboro un organizador gráfico, digital si es posible, que diagrama Causa -Efecto sobre las adicciones.
Adicción: es la búsqueda enfermiza de la recompensa $\mathrm{y} / \mathrm{o}$ alivio a través del uso de una sustancia $u$ otras conductas.

El consumo de drogas es dañino para todos los sistemas del cuerpo y puede generar adicciones. Cuando se vuelve una adicción impacta en la vida de las personas, causa alteraciones psicológicas y sociales.

Probar alcohol, tabaco y drogas a una edad temprana (12-13 años) aumenta el riesgo de consumo en la vida adulta. Por factores biológicos, sociales y psicológicos, la población adolescente es vulnerable a desarrollar adicciones.

Las drogas pueden clasificarse en dos grandes grupos:

a. legales (tabaco, alcohol, cafeína y medicamentos),

b. ilegales (marihuana, cocaína, anfetaminas, heroína y otras).

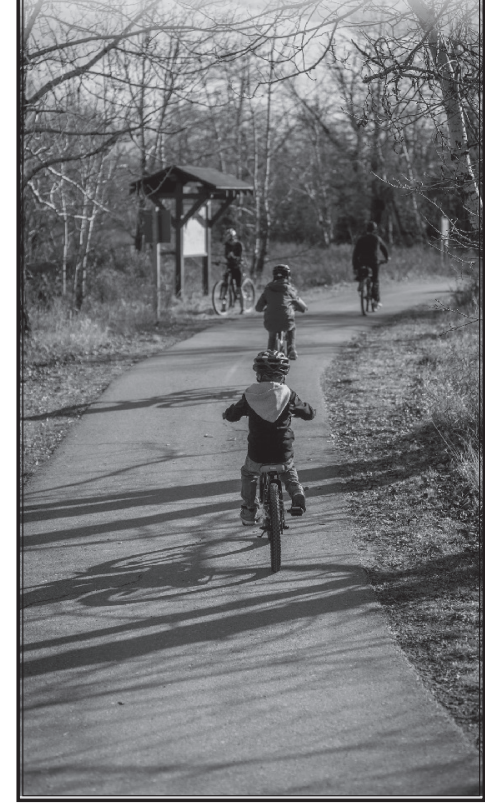




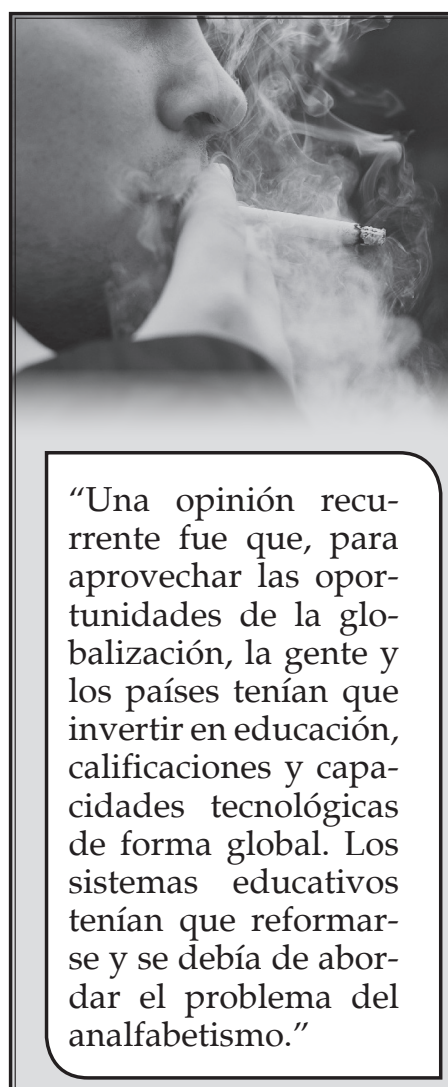

Fuente: Organización Internacional del Trabajo (s.f.) La Globalización y sus efectos. Recuperado de: http:/ / www.ilo.org/public/spanish/wcsdg/docs/rep2.pdf

- ¿Qué opino sobre esta exigencia de la globalización?

- ¿Qué tipo de educación nos propone la globalización?

- ¿Qué tipo de educación queremos nosotros?

- ¿Qué esfuerzo(s) ha hecho la escuela, el instituto en mi comunidad por prevenir las adicciones entre las y los jóvenes? ¿Qué resultados ha tenido el esfuerzo (s)?
La globalización es proceso que tiende a unir a los países en enormes economías mundiales, en las que se venden productos y servicios con origen nacional muy diverso. Entre países aumenta la inversión extranjera y los bancos y financieras transnacionales dominan los mercados nacionales. La globalización ha avanzado rápidamente gracias al enorme avance en las tecnologías de la información y comunicación, y a la eliminación de algunos obstáculos al comercio y la inversión entre países.

La globalización agudiza algunos situaciones y genera otras
nuevas. Por ejemplo: pone en competencia a pequeños negocios
nacionales con grandes empresas internacionales, las exigencias
laborales sobrepasan los niveles educativos y de capacitación de
muchas personas y los recursos naturales se encuentran amena-
zados por usarse, sin medida, en la producción de bienes y ser-
vicios. A través del aumento de la publicidad pero también del
incremento de la pobreza, se han generado efectos sobre la salud
y la convivencia comunitaria.

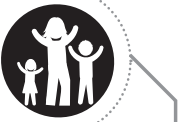

En complemento a la investigación que estamos realizando, vamos a analizar algunos problemas sociales contemporáneos, como el incremento de adicciones y otras enfermedades. Luego de la investigación y el análisis vamos a poder explicar:

- por qué las adicciones son enfermedades

- la relación entre adicciones y los efectos de la globalización

- qué problemas de salud pueden causar, algunos efectos de la globalización como las presiones laborales, los bajos ingresos económicos, el deseo de consumir más bienes y de mayor precio.

Con la información que encuentre en mi investigación empiezo a escribir un artículo sobre:

- ¿Qué es una adicción, sus tipos, sus causas y consecuencias?

- ¿Cuál es la situación de las adicciones en mi comunidad?

- ¿Cómo se relaciona la globalización con los problemas que generan las adicciones en mi comunidad?

Las condiciones de trabajo, de relacionamiento y de gobierno que se han instalado con la globalización pueden generar muchos problemas emocionales en las personas y, a la vez amplía la publicidad y la oferta de sustancias que les permiten sentirse mejor y olvidarse de los problemas por unas horas. 


\section{La palabra: una herramienta indispensable para conocer, entender y decidir mejor}

\section{Periódico mural}

Es un medio de comunicación que se elabora en un establecimiento. Resulta muy útil para promover conocimientos, tradiciones, costumbres, el arte y la cultura de la comunidad. Se elabora en las etapas siguientes:

\section{Decidir el tema,}

2. Definir las secciones,

3. Investigar y

4. buscar los materiales

5. Elaborar los artículos y la estructura del periódico mural con una buena combinación entre imágenes y lenguaje escrito.

6. Presentación pública del periódico mural.

Su elaboración permite fomentar el diálogo y la creatividad de las personas, promover la colaboración en la comunidad educativa, desarrollar la capacidad crítica y analítica ante las noticias, sucesos y publicidad, facilitar la expresión de opiniones y comentarios sobre un tema e integrar a las personas en grupos de trabajo.

Las secciones de un periódico mural son: título (atractivo, con colores y letra llamativa), editorial (una reflexión que revela una opinión sólida sobre el tema del periódico), noticias, cultura, deportes, sociales, arte y literatura. Todas las secciones deben tener como tema central el que se haya consensuado.

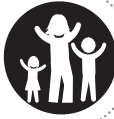

Sigamos los lineamientos para construir nuestro periódico mural con el tema de las adicciones, su relación con nuestra comunidad y posibles soluciones. Vamos a incluir nuestros artículos, obras de arte, ensayos y otros que presenten nuestros puntos de vista sobre el tema. Nos organizamos en equipos para elaborar las secciones del periódico mural.

Recordemos que al ser una herramienta de comunicación nos permite ejercer nuestro derecho a la libre expresión, esto implica que somos responsables de lo que publicaremos. Llenemos en conjunto la siguiente tabla, identificando nuestros derechos y responsabilidades al publicar información, opinión y conclusiones en un medio de información público.

\begin{tabular}{|l|l|}
\hline Derechos & Responsabilidades \\
\hline & \\
\hline & \\
\hline & \\
\hline
\end{tabular}

Registro en fichas de investigación la información que he recopilado a través de mi ejercicio de investigación. Recuerdo incluir los datos de la fuente, así como establecer si son fichas de resumen, paráfrasis o de cita textual.
Los signos de puntuación nos ayudan a redactar con claridad nuestro texto.

Dos puntos: sirven para anunciar una enumeración y escribir los elementos en la misma línea o en líneas diferentes. Ejemplos:

Para hacer un artículo se necesita: investigar y analizar el tema.

Algunas sustancias adictivas son:

- Bebidas alcohólicas

- Cigarros de tabaco

También se usan dos puntos, para expresar una relación de causa y efecto. Ejemplo: "Ella anunció que se recuperaría: dio la vuelta y se fortaleció."

Los puntos suspensivos: Indican la omisión de palabras que señala una pausa larga dentro del texto. Siempre se escriben tres. Ejemplo:

Las adicciones son enfermedades... afectan a la persona... pueden superarse.

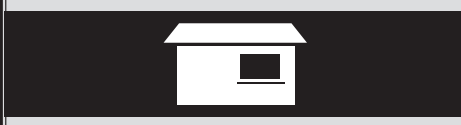

Elaboro tres oraciones en idioma extranjero, usando signos suspensivos, en las que doy a conocer información importante sobre las adicciones. Estas las podré incorporar posteriormente en afiches a incluir en el periódico mural. 


\section{La publicidad y nuestra alimentación}

\section{Azúcar: la nueva adicción}

Consumir pan dulce y bebidas gaseosas nos produce placer, porque el azúcar entra rápidamente al cuerpo y nos pone alertas. Así comienza la adicción.

El exceso de azúcar, disminuye las defensas de nuestro organismo, produce caries dental, obesidad, y alienta la reproducción de células cancerígenas y la diabetes.

Las bebidas energéticas contienen hasta el triple del consumo recomendado de azúcar al día y debido a su alto contenido de cafeína elevan la presión arterial.

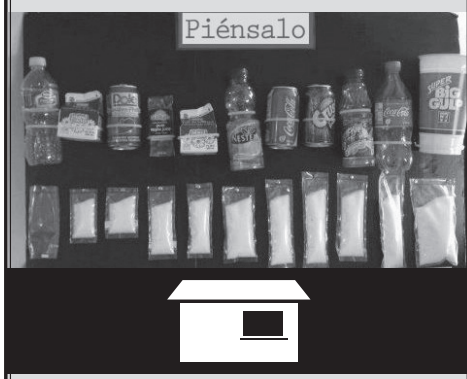

Una cucharada colmada de azúcar tiene aproximadamente 30 gramos. El consumo sugerido de azúcar son 50 gramos diarios.

Revisemos nuestro consumo diario de azúcar anotando en un día la cantidad de azúcar que consumimos en los alimentos preparados en casa y los que compramos.

\section{Publicidad y mala alimentación}

Visitamos una tienda y observamos los afiches publicitarios.

- ¿Cuántos promueven el consumo de alimentos sanos?

- ¿Cuántos promueven hábitos saludables?

- ¿Cuántos promueven el consumo de sustancias adictivas?

- Comparemos el precio de una bolsa de golosinas con el precio de un huevo. También comparemos el precio de un doble litro de bebida gaseosa con el precio de una mano de limones.

En las tiendas, periódicos, radio y televisión abundan los anuncios de cigarros, bebidas alcohólicas, bebidas azucaradas y energizantes, sopas instantáneas y golosinas. Algunos son alimentos baratos, pero con poco aporte nutricional porque contienen grandes cantidades de azúcar o sustitutos, grasa, sodio, preservantes y colorantes, todos dañinos para la salud.

El objetivo de la publicidad es aumentar el número de ventas. Por eso presenta la idea que al consumir esos productos se tendrán experiencias como la: felicidad, modernidad, libertad, estatus e incluso, pertenencia a un grupo. Identificamos las marcas por sus logotipos, sus colores y sus canciones. La niñez y la juventud son las poblaciones más bombardeadas por la publicidad.

Estos productos son fabricados por grandes empresas transnacionales que tienen la capacidad de llevar lo que venden hasta los rincones más lejanos de un país, a veces más que los medicamentos y los libros que sí mejorarían nuestra vida. El consumo de esos productos también afecta el bolsillo.

- ¿Qué acciones pueden tomar lideresas y líderes para mejorar la nutrición y la salud integral de la niñez y adolescencia?

- ¿Qué medidas podemos tomar para evitar adicciones?

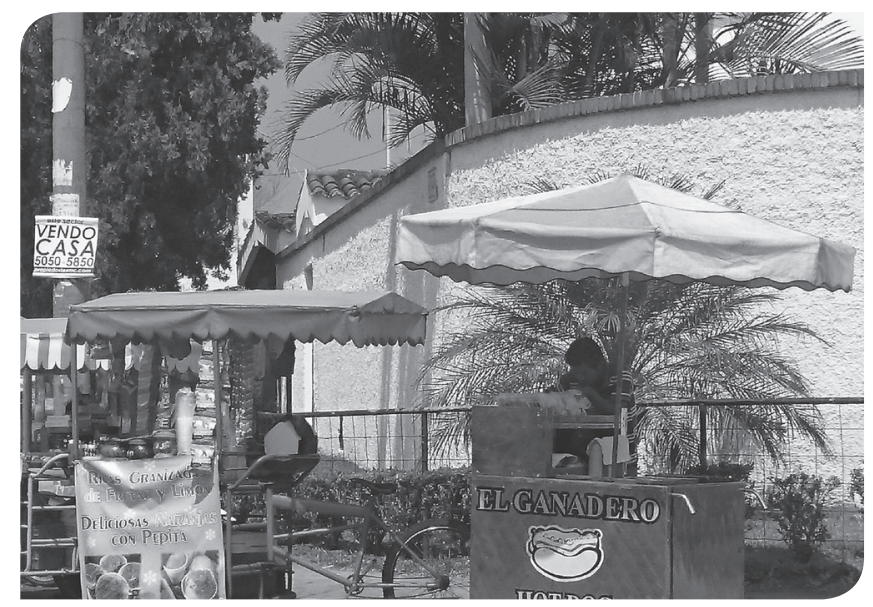

El aceite recalentado tiene un olor desagradable, produce humo, tiene residuos carbonizados y es de color oscuro. Evitémoslo para cuidar nuestra salud. 


\section{Líderes y lideresas que promueven la salud comunitaria}

En la cultura maya, al igual que en otras culturas antiguas como la china y la hindú, la salud la integra mente, cuerpo, espíritu y comunidad. La búsqueda de salud es también la búsqueda de equilibrio y armonía con nosotras y nosotros mismos y entre nosotras y nosotros, la naturaleza y la comunidad. El bienestar se relaciona con el equilibrio del cuerpo físico, el espíritu, las emociones, los sentimientos, los pensamientos y la creatividad.

El equilibrio se alcanza por medio de la gratitud, el respeto y la convivencia con todo lo que existe a nuestro alrededor. En la cultura garífuna escuchar y reverenciar a las y los ancestros es vital para la sanación.

La cultura occidental en cambio, separa los males del cuerpo de los del espíritu y son atendidos por diferentes profesiones. Sin embargo, en años recientes, la ciencia médica ha constatado que una actitud proactiva, de esperanza y de fortaleza ante las dificultades facilita procesos de recuperación de la salud y, en algunos casos, la erradicación de enfermedades.

Ésta se centra únicamente en el o la paciente mientras que en la cultura maya se comprende que las adicciones tienen efectos sobre las personas individuales, sus familias y la comunidad.

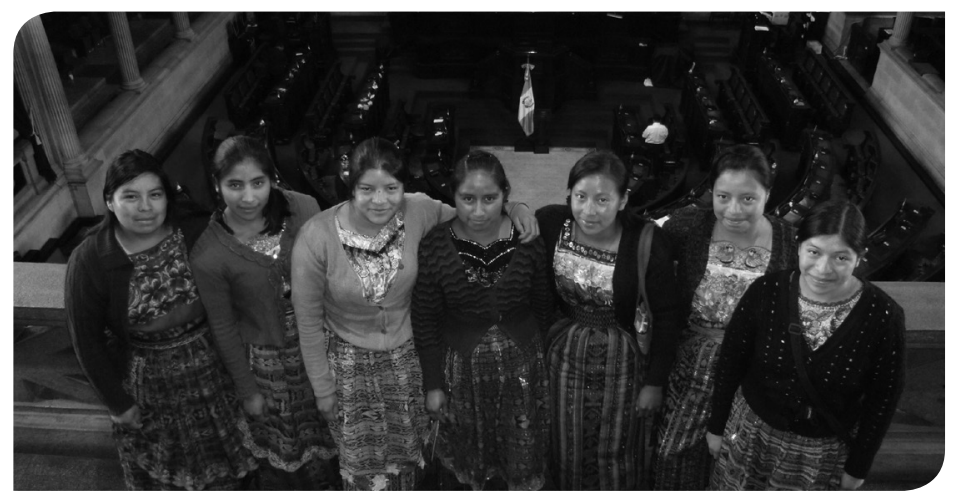

En equipo compartimos nuestras fichas de información sobre lo que investigamos sobre los tipos de liderazgo y sobre las y los líderes de la comunidad. Elaboramos un organizador gráfico para conocer a nuestros líderes, lideresas y sus campos de acción.

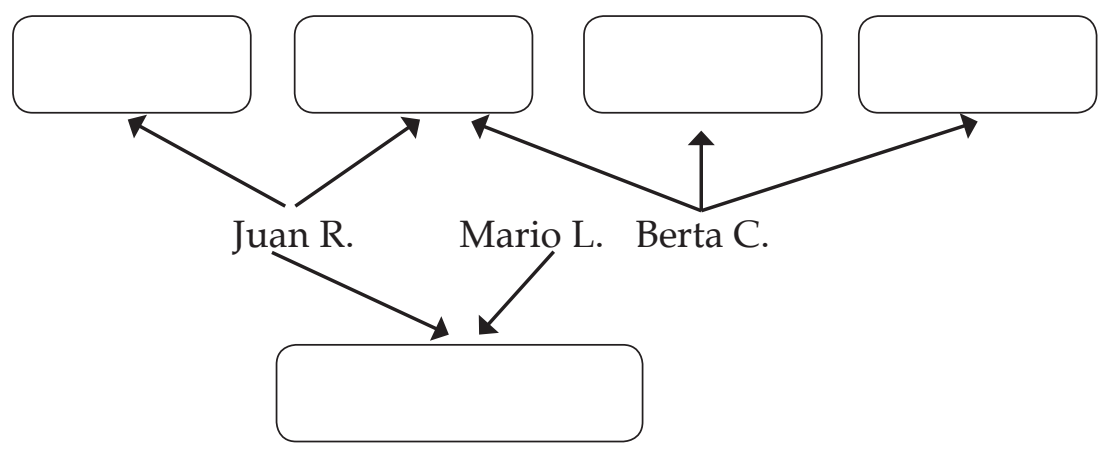

Esforcémonos por ser creativos y darle una forma fácil de leer. Esta gráfica nos ayudará a entender mejor la organización comunitaria.

\section{Educación integral en} sexualidad -EIS-

Las personas jóvenes tienen el derecho de acceder a la información necesaria sobre su cuerpo, sus emociones y las relaciones con otras personas, que les permitan desarrollar hábitos saludables. Existe demanda de conocimientos en salud sexual y salud reproductiva, temas que pocos padres y madres se animan a conversar con sus hijas e hijos, aunque reconocen su importancia. La educación integral en sexualidad (EIS) propone una preparación adecuada para el desarrollo integral a lo largo de la vida, favorece la salud y el bienestar de las y los jóvenes, al evitar la discriminación, la violencia física, sexual y emocional, la explotación sexual, y embarazos no planificados. 


\section{La argumentación para prevenir las adicciones y promover la salud}

\section{Adverbios de lugar \\ Hay dos tipos: \\ Adverbios demostrativos (aquí, ahí, allí, acá y allá) y los adverbios de relación de lugar. \\ Los de lugar, se distribuyen en parejas de antónimos, y se clasifican en dos grupos. \\ Adverbios de ubicación \\ (indican un lugar específico) \\ Delante - detrás \\ Encima - debajo \\ Dentro - fuera

\begin{tabular}{|c|}
\hline $\begin{array}{c}\text { Adverbios de } \\
\text { orientación }\end{array}$ \\
(indican una dirección) \\
\hline Adelante - atrás \\
Arriba - abajo \\
Adentro - afuera \\
\hline
\end{tabular}

Estas reglas son de consideración generalizada y que su uso, varía de acuerdo con el lugar de origen.

«La distinción entre afuera y fuera es normal en España, pero en Hispanoamérica tiende a neutralizarse en favor de un uso generalizado de afuera:

Sentí la desgracia como si la llevara adentro.

Ahora la veo afuera. Vagando por afuera de la vida.»

[RAE: Diccionario panhispánico de dudas. Madrid: Santillana, 2005]
Argumentar consiste en defender con razones una opinión con el fin de que la otra persona haga suya la idea que se le está presentando. Su eficacia dependerá de la consistencia, veracidad y la fuerza de los argumentos.

Consta de tres elementos: el emisor o emisora es quien realiza la argumentación, el destinatario o destinataria es a quien va dirigida y el modo de comunicación que va a determinar su eficacia.

La opinión o idea que se respalda recibe el nombre de tesis y las razones que se alegan en su defensa son los argumentos.

Para que la argumentación logre convencer, quien la emite debe tener presente las características y creencias de las personas a las que se dirige; solo así podrá conocer a qué argumentos son más sensibles.

El emisor que presenta las argumentaciones, puede manifestarse en primera persona y hablarle directamente al destinatario o destinataria con el fin de implicarle en el discurso. Cuando se prefiere dar a la argumentación una apariencia de objetividad, el texto se construye en tercera persona.

Los argumentos se apoyan en valores, creencias o premisas que se suponen caceptados por la mayor parte de la comunidad. Entre los tipos de argumentos frecuentes están:

- El argumento de la mayoría: Lo mayor o más numeroso es preferible a lo menor o menos numeroso.

Ejemplo: "El aceite Dorado es el que más se vende, así que debe ser muy bueno."

- El argumento de utilidad: Lo útil es preferi-

ble a lo que no lo es.

Ejemplo: "Respetar la integridad de las niñas y jóvenes de la comunidad nos beneficiará a todos."

- El argumento ético: Lo moral es preferible a lo inmoral.

Ejemplo: "Señores diputados y diputadas, es a su solidaridad que apelamos por la ayuda a nuestro municipio."

- El argumento hedonista: «Lo placentero es preferible a lo desagradable».

Ejemplo: "Consuma un pastel de crema: el paraíso en su paladar."

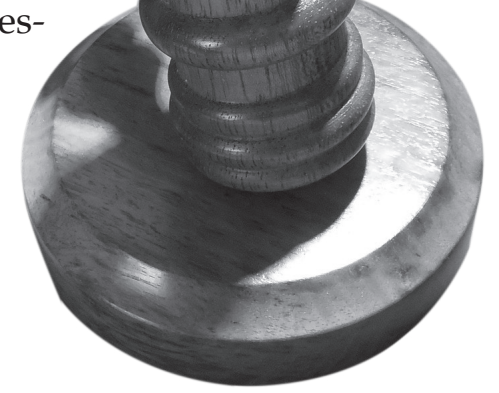

Escribe oraciones empleando el uso correcto de palabras confusas: adentro-dentro; afuera-fuera; arriba-encima; abajodebajo; adelante-delante. 


\section{Los silogismos y las falacias, dos maneras de argumentar}

Los silogismos son razonamientos por medio de los cuales, a partir de dos juicios, se concluye un tercero. Es un razonamiento deductivo pues se parte de información ya conocida para llegar a una conclusión no conocida, pero presupuesta. Usamos silogismos para demostrar una teoría o defender nuestro punto de vista. Por ejemplo, cuando una abogada, pide que a su defendido se le trate como a un ciudadano inocente, apela a la aplicación de una ley:

"Si todo acusado o acusada debe ser considerada inocente en tanto se no se demuestre su culpabilidad y no se ha demostrado la culpabilidad de mi defendido, entonces, este debe ser considerado inocente."

Este silogismo presenta tres partes: 1 . Premisa o razonamiento 1, 2. Premisa o razonamiento 2 y 3 . conclusión. Los términos en la conclusión deben provenir de cada una de las premisas o razonamientos previos.

Cuando los intereses que se argumentan van en contra de las demás personas, se suelen usar silogismos falsos llamados falacias. Son argumentos que no tienen validez ya que las razones dadas para soportarlo no están relacionadas con el tema, aunque parecen estarlo. Veamos un ejemplo:

"Si algunos políticos son corruptos y Álvaro Vásquez es político; entonces, Álvaro Vásquez es corrupto."

Evidentemente, aquí algo anda mal...

Nos interesa ver algunas de las falacias porque es posible que nos afecten en nuestra vida cotidiana y es importante que sepamos identificarlas:

- Argumento contra la persona: "Señora Directora, no debe creer la versión de Mariana porque ella es niña y una niña no puede decir la verdad."

- Apelación a la fuerza: "Guatemala debe apoyar la propuesta de los Estados Unidos; de lo contrario, se le retirará la ayuda en los temas de salud y seguridad."

- Apelación a la ignorancia: "La Tierra es cuadrada puesto que nadie ha demostrado que sea redonda."

- Apelación a la misericordia: "Maestro, póngame una buena nota en el curso porque, de lo contrario, puede que pierda el año y me retire de los estudios."

- Apelación al pueblo: "Las gaseosas son buenas, porque más del $80 \%$ de la población disfruta de tomarlas."

- Apelación a causa falsa: "Fumaré desde hoy porque quienes fuman son ganadores."
La publicidad se vale de estas falacias a menudo para ganar compradores de los productos que anuncian.

Escribe algunos silogismos falsos que se dicen en la comunidad. Para cada uno escribe un argumento que persuada a la veracidad.

Realiza el ejercicio usando tu idioma materno.

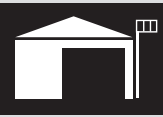

En nuestro equipo de trabajo analicemos los argumentos que presentan los anuncios publicitarios para persuadirnos al consumo de sustancias adictivas.

Dialoguemos:

- ¿Con qué argumentos tratan de convencernos que incorporemos las sustancias nocivas como el tabaco y el alcohol a nuestro cuerpo?

Escribamos sus argumentos falsos en fichas.

Pausa pedagógica: se forma en dos hileras, una frente a la otra a una distancia de cin-co metros.

Quien facilita sonará el silbato, una vez para que caminen hacia el frente y dos para que ca-minen hacia atrás. Luego sonará el silbado de forma cada vez más frecuente, a manera de que el grupo tendrá que movilizarse más rápidamente. 


\section{Consecuencias de una adicción}

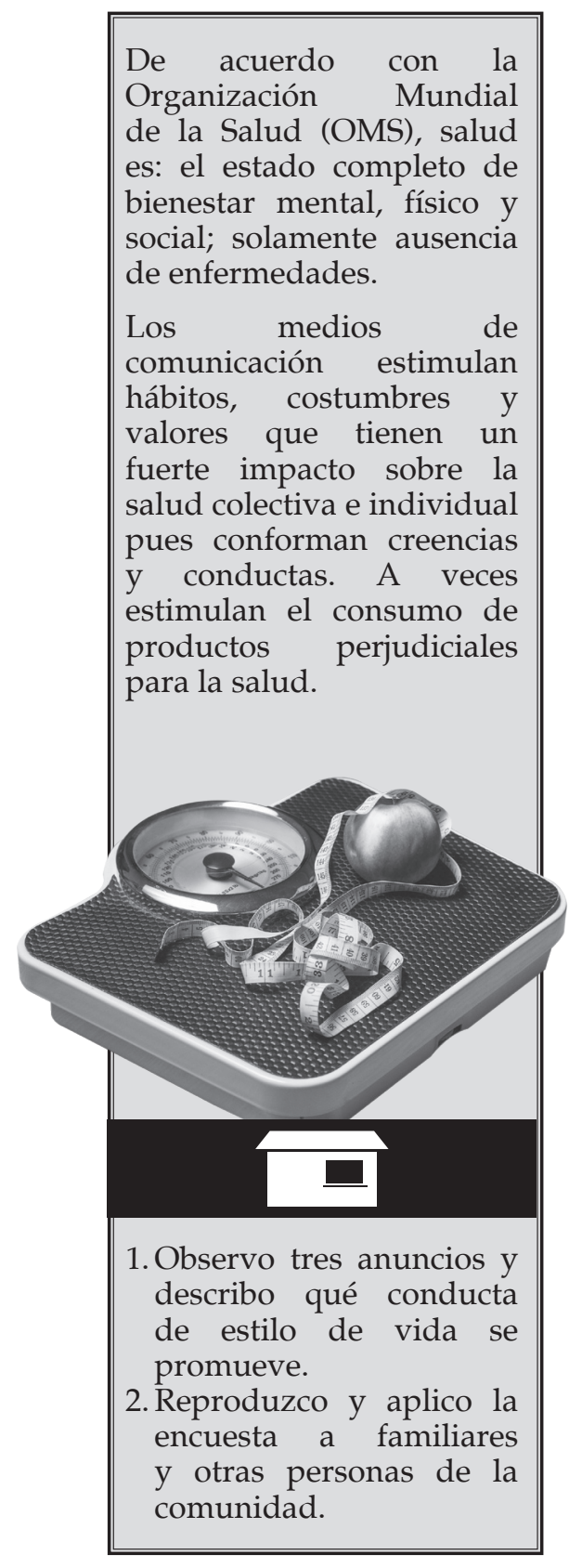

Una de las adicciones más comunes es el consumo de tabaco, el cual es de venta libre para adultas y adultos. Las consecuencias de fumar cigarrillos se extienden incluso a personas no fumadoras que están en contacto con otras que sí lo son. Se les conoce como fumadores de segunda mano.

Observamos y comparamos las siguientes imágenes de los pulmones de una persona que fuma y los de una persona que no fuma. Describimos las similitudes y las diferencias (tamaño, color, proporción de los órganos).

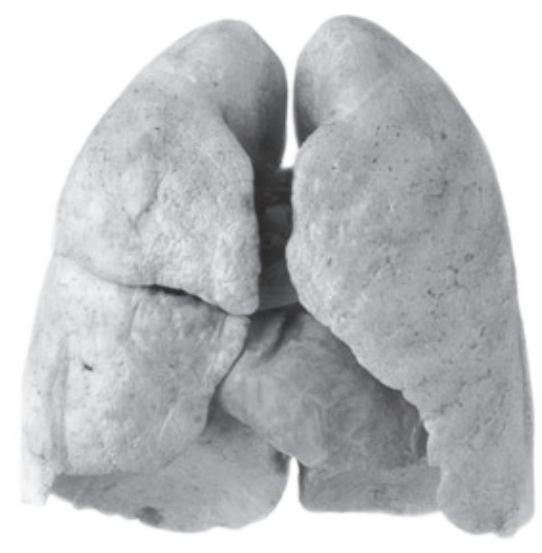

Pulmones sanos

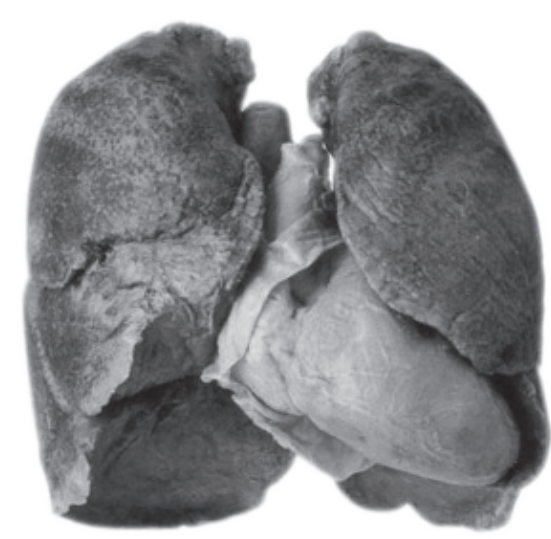

Pulmones de fumador
En una población algunas personas que sufren de adicciones inician con una serie de síntomas que son indicativos de una enfermedad. Los efectos pueden observarse en cambios en el aspecto físico, trastornos de apetito, úlceras, insomnio, fatiga, hepatitis, cirro-sis, trastornos cardiovasculares entre otros.

Es importante darle atención inmediata a una adicción; y para ello existen tres pasos: la aceptación, la convicción y la ayuda. La prevención y curación de estas enfermedades exigen un cambio en el estilo de vida.

\section{En grupos:}

- Dialogamos sobre el uso y abuso de drogas en la comunidad; principales grupos sociales afectados, causas y consecuencias, grupos responsables de la promoción del consumo de drogas y productos que generan adicciones.

- Definimos aspectos a incluir en la encuesta, relacionados con las adicciones y el consumo de sustancias nocivas a la salud.

- Elaboramos las preguntas de nuestra encuesta y la población a la que se la pasaremos. 


\section{Conductas saludables}

El estilo de vida, o sea los hábitos y las costumbres que tiene una persona, puede beneficiar o dañar su salud. Por ejemplo, una persona con adecuados hábitos de higiene, buena alimentación y actividad física podrá gozar de buena salud. Por lo contrario, una persona que come y bebe en exceso, no descansa lo suficiente y fuma, está en riesgo de sufrir enfermedades que pueden causarle incapacidad y hasta la muerte. Un estilo de vida saludables incluye:

- Hábitos de higiene: son prácticas que mantienen la limpieza y evitan que microorganismos traspasen nuestras barreras protectoras (piel y mucosa).

- Consumir una dieta saludable: rica en frutas y verduras que proporcionan vitaminas y minerales, que incluya también lácteos, carnes y azúcares en menor cantidad.

- Realizar ejercicio: estimula al sistema inmunológico ayudando a prevenir enfermedades y mejorar las funciones cerebrales. También evita el estrés.

- Dormir y descansar lo suficiente: se estima que ocho horas al día son necesarias para la reparación del organismo; ayuda a la memoria.

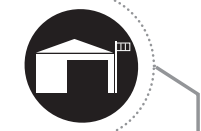

Escribimos un listado de prácticas y condiciones que dificultan una vida saludable en esta comunidad, luego proponemos cómo se pueden superar esas limitantes para mejorar los hábitos de higiene.

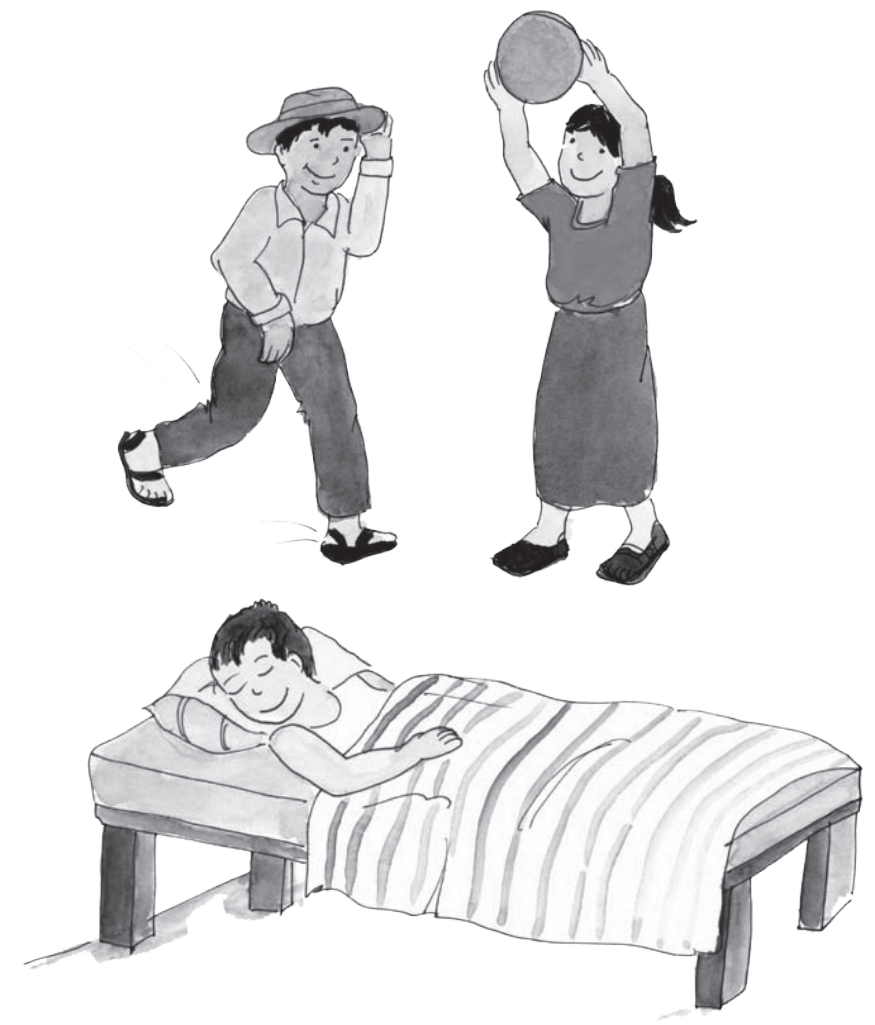

Elaboro un organizador gráfico para exponer conjuntos de acciones que permiten mantener la salud.
Parte de la vida saludable es evitar las adicciones y el consumo de drogas.

Entre las adicciones más comunes se encuentra a la comida chatarra y golosinas, al azúcar, al teléfono celular, a la televisión, al internet, a la pornografía, a los videojuegos, a los juegos de azar, a las redes sociales. Algunas de estas adicciones son muy peligrosas; fundamentalmente porque las personas no consideran que sean perjudiciales a la salud. Por ejemplo, el consumo habitual de laxantes y antiácidos. También las aguas gaseosas y bebidas estimulantes y los alimentos procesados industrialmente a los cuales se le adicionan sustancias que las hacen adictivas. 


\section{Bloques económicos}

Un grupo de países, con mucha frecuencia pertenecientes a la misma región geográfica, que se organizan para obtener beneficios económicos, principalmente de carácter comercial, forman un bloque económico. Dichos bloques han surgido, cambian y se diversifican debido a la globalización.

De acuerdo con esta definición, la esencia de los bloques económicos son las relaciones comerciales. Esto es lo que sirve para clasificar a los tipos de bloques. El nivel más sencillo es el bloque formado por un área con preferencia comercial; en éste los países, acuerdan libre comercio para determinados productos, por ejemplo: alimentos. También se puede crear una zona de libre comercio en donde los países intercambian toda clase de mercancías. Otro bloque es el de unión aduanera, en donde se acuerda un arancel (cobro que se le hace a las importaciones) para los países miembros del bloque y otro para los no miembros. El mercado común no establece ningún tipo de tarifa para los países del bloque, solo para el resto. El nivel más alto entre los bloques económicos está constituido por la unión económica que incluye una zona de libre comercio, unión aduanera y moneda común, un ejemplo es la Unión Europea.

\begin{abstract}
- ¿En esta institución se respeta el derecho de las personas adictas a recibir atención de acuerdo con las características de su enfermedad? ¿Tiene un protocolo diferenciado para atender mujeres?

Para "... el tratamiento, rehabilitación $\mathrm{y}$ reinserción social de la población drogodependiente, SECCATID crea el Centro de Tratamiento Ambulatorio (CTA)" De forma gratuita el CTA atiende a la población "... mediante la modalidad ambulatoria con metodologías que permitan modificar la conducta de cada una de las personas que lo solicitan, a las cuales se atiende con el apoyo del equipo multidisciplinario..." Abarca lo psicológica, medico, social y espiritual.
\end{abstract}

Fuente: Secretaría Ejecutiva de la Comisión Contra las Adicciones y el Tráfico Ilícito de Drogas (s.f.) Centro de Tratamiento Ambulatorio. Recuperado de: http:// www.seccatid.gob.gt/index. php?option=com_content\&vie $\mathrm{w}=$ article\&id $=126 \&$ Itemid $=1194$

Opino con respecto al Centro de Tratamiento Ambulatorio de SECCATID.

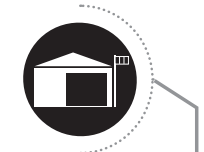

\section{Trabajemos en grupo.}

- Hagamos una presentación de lo investigado sobre las adicciones, sus causas y consecuencias. Reflexionemos y expliquemos, ¿cómo afectan las adicciones a las mujeres?

- Elaboremos un organizador gráfico para registrar la información sobre las adicciones.

- Discutamos acerca de los efectos que tienen las adicciones en la salud de las personas y la mejor atención que pueden darles las instituciones estatales correspondientes.

- Si un grupo de países acuerda impedir el tránsito de drogas, ¿formarían un bloque económico? Argumenten su respuesta.

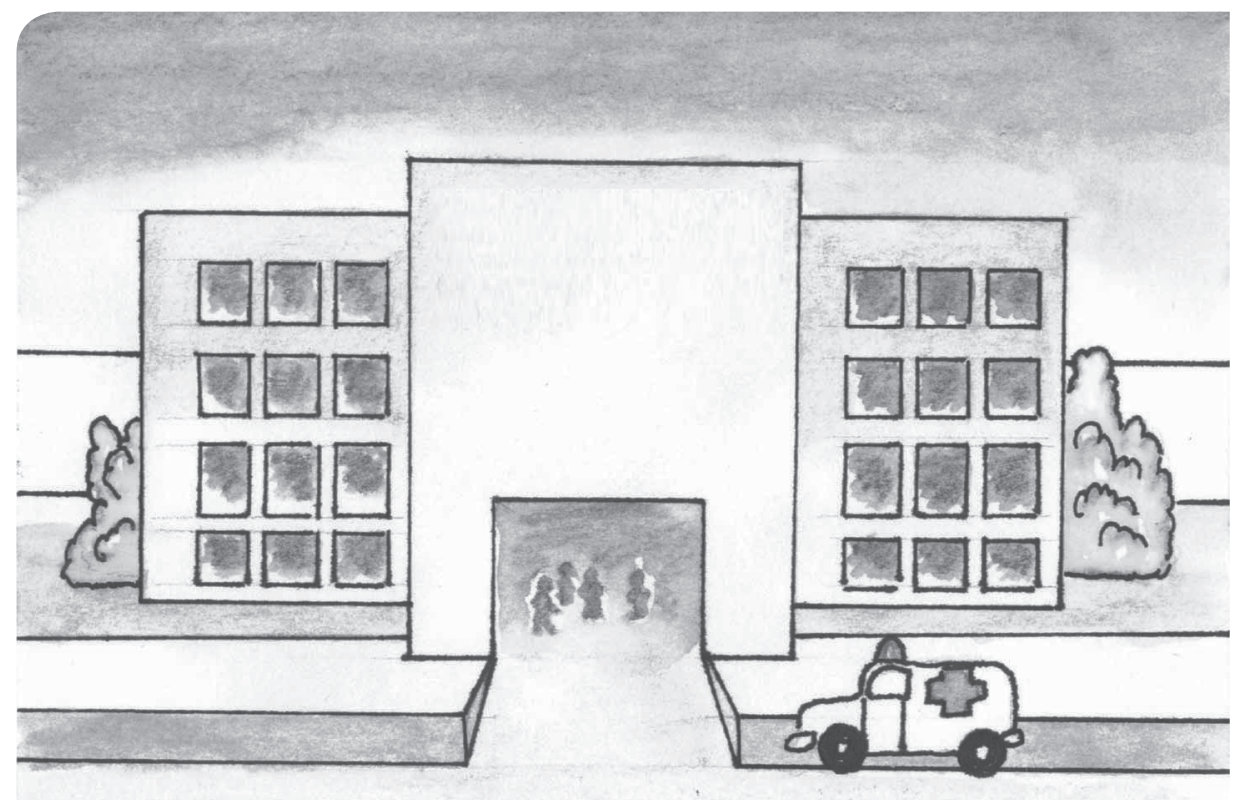




\section{Tratados de integración}

La base política y legal para concretar un bloque económico lo constituye un tratado, sea este de naturaleza comercial, libre comercio, unión aduanera, mercado común o unión económica.

Guatemala suscribió un tratado de libre comercio en 2003 con Estados Unidos de Norte América, El Salvador, Honduras, Nicaragua, Costa Rica y República Dominicana. Además ha suscrito acuerdos de libre comercio, como parte de Centroamérica, con México, Colombia, Chile, la Unión Europea y Taiwán.

Nuestro país también firmó el Protocolo (reforma de un acuerdo o tratado internacional) a la Carta de la Organización de Estados Centroamericanos (ODECA). Por medio de dicho protocolo se creó el Sistema de Integración Centroamericano (SICA), vigente desde 2003, que además de proponerse formar una unión económica, promueve el fortalecimiento de la democracia y el respeto de los derechos humanos, la seguridad de la región, un sistema regional de justicia, la convergencia de las políticas sociales y preservación del medio ambiente. Forman parte del SICA: Guatemala, Belice, Honduras, El Salvador, Nicaragua, Costa Rica, Panamá y República Dominicana.

\section{Trabajemos en grupo.}

- Redactamos los lineamientos para aplicar una encuesta sobre las adicciones que se observan en la comunidad.

- Planificamos la realización de un debate sobre las alternativas para tratar el alcoholismo. Este debate lo realizaremos la próxima semana.

- Analizamos la conveniencia de establecer políticas de salud y atención de las adicciones a nivel local, nacional y centroamericano; particularmente cuando tienen perspectiva de género.

Aplico la encuesta, en el sector asignado, para obtener información sobre las adicciones observadas en la comunidad.

- Analizamos la información obtenida en la investigación documental para obtener criterios relacionados con las adicciones en la comunidad.

- Discutimos el papel de los medios de comunicación en las sociedades globalizadas y su influencia en la adquisición de adicciones.

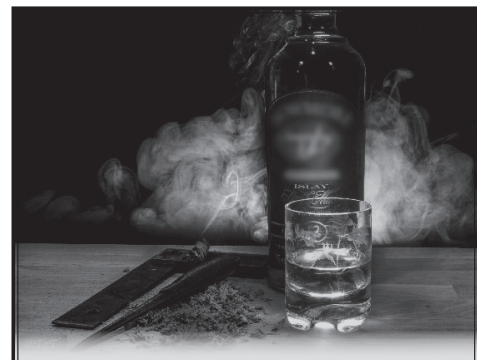

Retos para el sector salud de Centroamérica y República Dominicana:

- Mantener el abordaje integral de los problemas por consumo de substancias adictivas en el más alto nivel de prioridad dentro de los ministerios de salud.

- Facilitar el acceso a financiamiento que permita contar con recursos humanos calificados adecuados y servicios de promoción, prevención, tratamiento y rehabilitación, basados en los sistemas de salud pública nacionales con énfasis en la atención primaria, que satisfagan las necesidades de la población en general y de los grupos vulnerables.

- Desarrollar un marco jurídico para controlar la comercialización, publicidad y el patrocinio del alcohol.

Fuente: Sector de Salud de Centroamérica y Panamá (2014). Acuerdo de la XXX Reunión.

Recuperado de: http:/ /www. paho.org/resscad/images/ stories/2014_XXX_RESSCAD/ informe_presentaciones $/ 21$ Acuerdos_XXX_RESSCAD-ELS. pdf?ua $=1$

- ¿Cómo se relacionan la inversión de los países en los servicios de salud y las adicciones en estos retos? 


\section{El plano cartesiano}

El son guatemalteco es una forma musical única en el mundo. Su origen es anterior a la llegada de los europeos. Puede ser cantado $\mathrm{y}$ tocado con instrumentos.

Se puede medir en tiempos de tres o de seis, lo que lo convierte en compás ternario.

Durante la colonia solo era propio de los pueblos indígenas, pero los criollos y mestizos lo llegaron a utilizar en el siglo XIX. Así surge una clasificación del son: tradicional, chapín, zapateado, barreño, de pascua.

\section{El Plano Cartesiano}

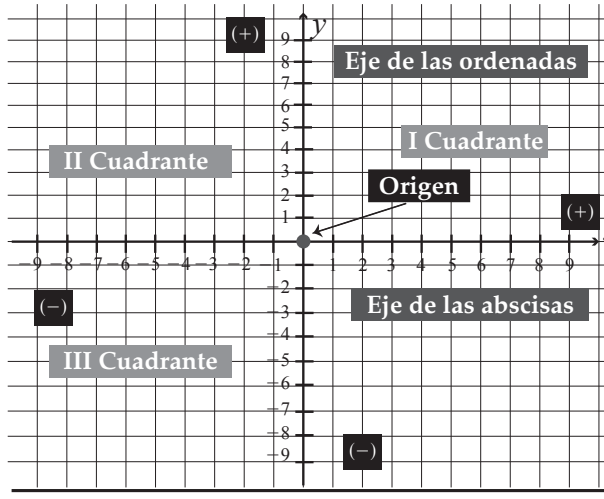

En equipos observamos la siguiente figura y hallamos las coordenadas de los puntos: $A, B, C, D, E$ y $F$. Los anotamos en nuestro cuaderno y comparamos respuestas.

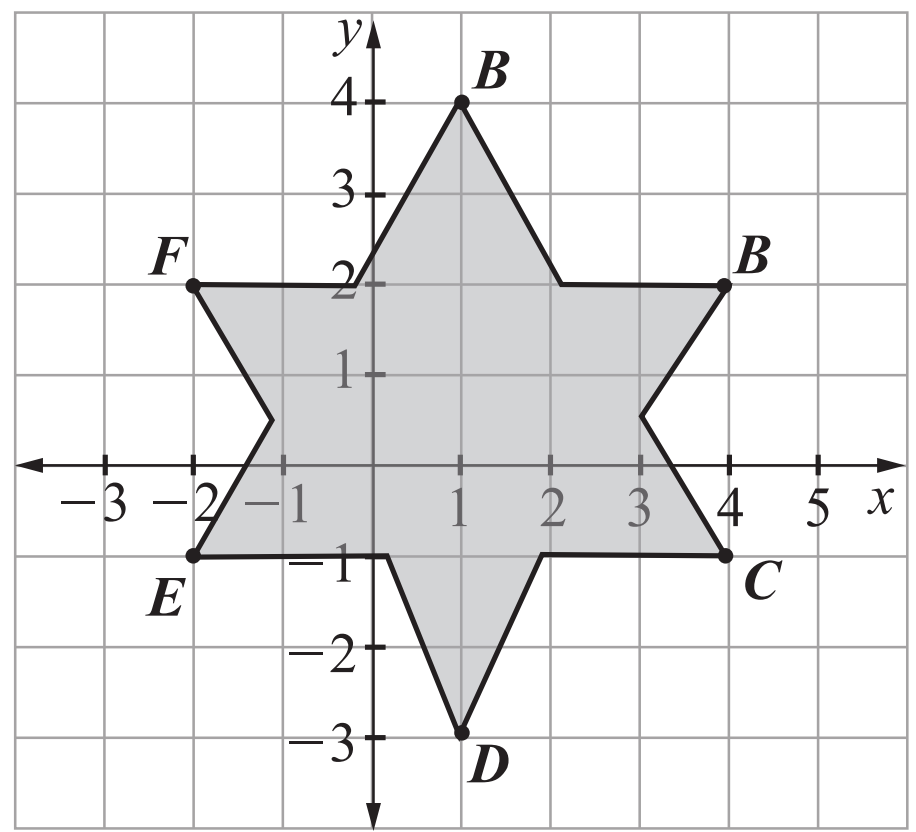

- ¿Qué estrategia utilizamos para ubicar las coordenadas de los puntos anteriores?

- ¿Qué relación observamos entre el punto $A$ y $D$ ? ¿Y entre el punto $B$ y $F$ ?

- ¿Qué situaciones cotidianas pueden ser representadas en un plano cartesiano?

Compartimos nuestras respuestas y discutimos.

- ¿Qué estrategia utilizamos para ubicar las coordenadas de los puntos anteriores?

En media cartulina, y utilizando el primer cuadrante de un plano cartesiano, ubicamos la siguiente información relacionada con la altura de una planta de maíz luego de varios días de observación.

\begin{tabular}{|c|c|c|c|c|c|c|c|c|c|c|c|}
\hline Días & 1 & 2 & 3 & 4 & 5 & 6 & 7 & 8 & 9 & 10 & 11 \\
\hline $\begin{array}{c}\text { Altura } \\
(\mathrm{cm})\end{array}$ & 13 & 13 & 14 & 14.5 & 15 & 15.6 & 17 & 17.5 & 18 & 19 & 20 \\
\hline
\end{tabular}

En este cuadrante del plano cartesiano, ¿qué tipo de gráfica podemos construir a partir de la información anterior? ¿Utilizamos la misma escala en el eje $X$ y en el eje $Y$ ?

- ¿La altura de la planta depende de cuántos días han transcurrido o los días que pasan dependen de la altura de la planta?

- ¿Qué sucedió con la altura de la planta al pasar los días? ¿Qué tipo de relación observamos entre las variables días y altura de la planta?

Compartimos y discutimos nuestras respuestas. 
Observamos las siguientes gráficas sobre la cantidad de adolescentes en Guatemala en el año 2015 e interpretamos la información de cada una de ellas.

Cantidad de niños adolescentes comprendidos entre 10 y 19 años por edades simples. En total, este grupo poblacional conforman el $24.1 \%$ del total de hombres y $11.8 \%$ del total de la población.

Cantidad de niñas adolescentes comprendidas entre 10 y 19 años por edades simples. En total, este grupo poblacional equivale al $22.5 \%$ del total de mujeres y al $11.5 \%$ del total de la población.
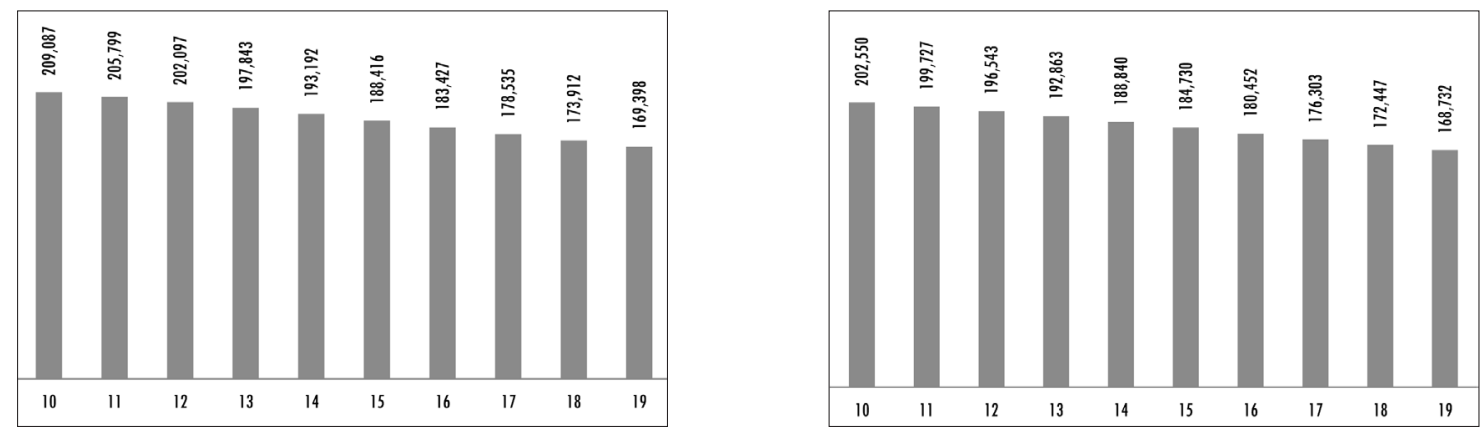

Fuente: INE, Proyecciones de población 2000-2020 con base al censo 2002.

\section{Contestamos lo siguiente:}

- ¿Qué tipo de gráfica son las anteriores?

- ¿En el año 2015 hubo más niños o niñas?

- ¿Qué coordenadas, en X y Y, corresponden al punto máximo de la cantidad de niños de 14 años?

- ¿Qué coordenadas, en X y Y, corresponden al punto máximo de la cantidad de niñas de 14 años?

Buscamos alguna noticia en un periódico que incluya un gráfico y que muestre algún tipo de información que relacione dos variables numéricas. Interpretamos su información y localizamos los puntos importantes en dicho gráfico. Anotamos los puntos en nuestro cuaderno.

Compartimos con el resto de compañeras y compañeros la información que se presentó en la gráfica.

Observamos la siguiente gráfica y discutimos con nuestro grupo la información que presenta.

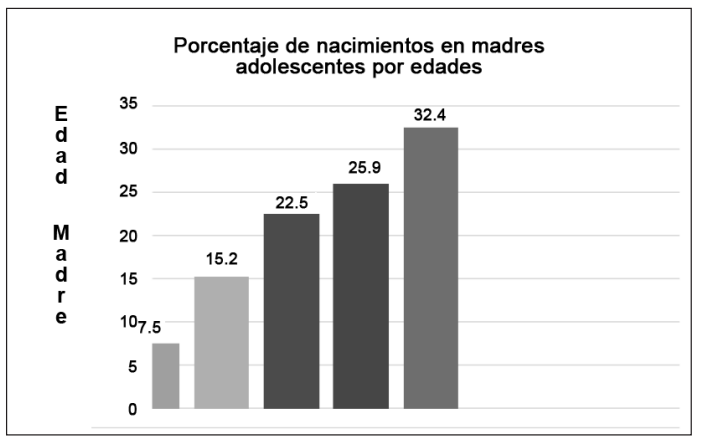

Si se desea trasladar a una tabla la información que la gráfica presenta, ¿qué datos corresponden a cada punto máximo de cada barra? Completamos la tabla con la esa información.

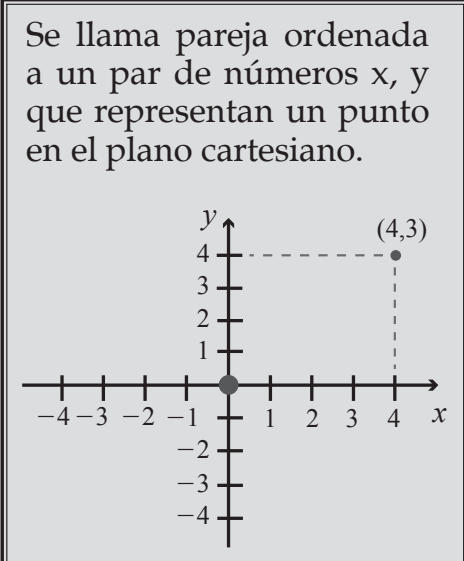




\section{Cömo influye la música en nuestra vida}

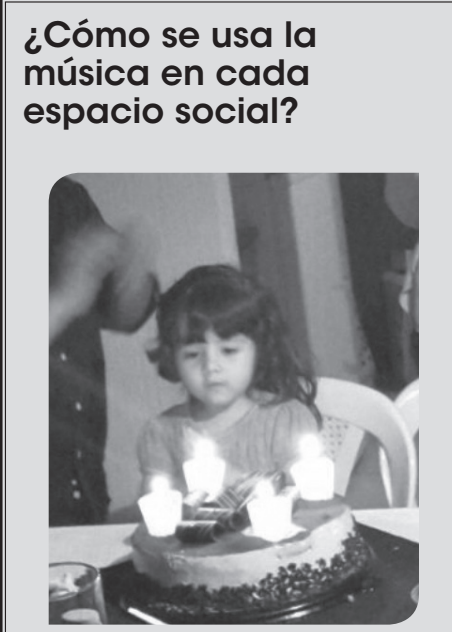

Es usual que al transitar por algunos espacios donde las personas se congregan se escuche música. ¿Cuáles serían las diferencias entre lo que se escucha en una iglesia o en un centro comercial?

En ambos casos la música puede ser rápida o lenta, fuerte o suave, alegre o triste, y sus usos difieren según el propósito para el que se hacen sonar.

Opino acerca de lo que observo que ocurre en ambos espacios. Respeto las ideas de mis compañeros y compañeras.
En todas las disciplinas artísticas se pueden apreciar los efectos psicológicos del arte en la sociedad. Una imagen, una pose o una canción, pueden inducir el consumo de determinado producto. Todas las expresiones artísticas provocan intensas emociones. Entre ellas, la música ejerce una función muy importante, pues está presente en múltiples esferas de la vida cotidiana.

Se usa en procesos ceremoniales, recreativos y terapéuticos, así como en espectáculos y publicidad. Cómo se usa, qué efectos provoca, por qué puede incluso manipular a las masas, son preguntas que ayudan a comprender esta disciplina artística.

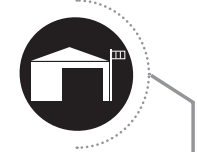

Trabajemos en grupo: Discutamos acerca de los efectos que producen algunas obras musicales en nuestras emociones, estados de ánimo, diversos momentos de la vida.

Trabajo de forma individual: mi bosquejo del proyecto pictórico que estoy elaborando.
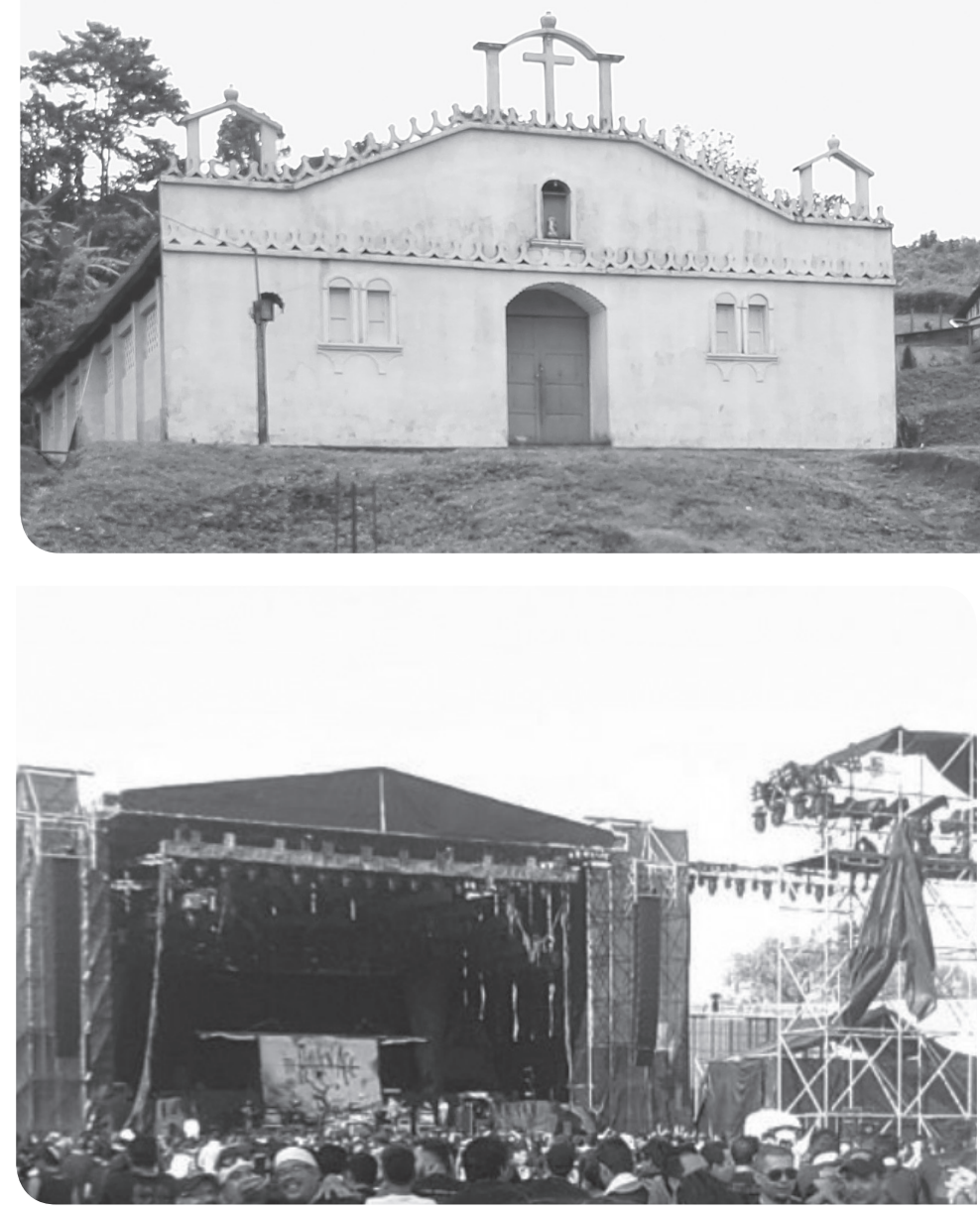


\section{Música vrs. Silencio}

La música está hecha de sonidos y silencios. Comienza el sonido, pero luego termina para volver a comenzar. Así como la luz y la oscuridad, la vida y la muerte, también en la música conviven el sonido y el silencio.

\section{Funciones de la música en la sociedad}

Ceremonial: cualquier celebración o festividad es una ceremonia que utiliza música.

Espectáculo: si hay un escenario, sin duda hay espectadores, un público al que se dirige la música para entretenerle.

Recreación: para pasar el tiempo y disfrutar los sonidos o los mensajes, también para bailar.

Catarsis: cuando se usa para propiciar un momento espiritual de acer-camiento religioso o la expresión de emociones muy fuertes.

Terapia: cuando se usa para curar a través de la escucha, tocar sonidos o mover el cuerpo con el ritmo.

En todas esas funciones es notorio que la música ejerce un dominio psicológico sobre las personas. Sin embargo, suele haber una saturación sonora que llena todos los espacios de la vida. Esto no es normal, pues se convierte en una necesidad creada que distrae y aleja del entorno natural. También se utiliza para manipular a quienes consumen para que compren más. ¿Será esto una forma de adicción?

Para combatir esta saturación se puede buscar una Ecología Acústica que rescate el ambiente sonoro natural y establezca una relación saludable en la comunidad.

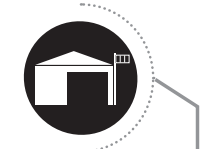

\section{Recuperando el entorno sonoro}

En clases anteriores realizamos una excursión de Ecología Acústica.

Ahora discutiremos sobre los espacios en que la música es utilizada para afectar nuestra conducta, o su exceso nos aleja del entorno sonoro natural. ¿Cómo podemos revertir estos efectos?

Escribimos ejemplos del uso de música según sus funciones:

\begin{tabular}{|c|c|c|c|c|}
\hline Ceremonia & Espectáculo & Terapia & Recreación & Catarsis \\
\hline $\begin{array}{l}\text { - } \\
\text { nupcha } \\
\text { nupcial } \\
\text { - }\end{array}$ & $\begin{array}{l}- \\
\text { - concierto } \\
\text { de rock }\end{array}$ & $\begin{array}{l}\text { - relajación } \\
\text { - } \\
\text { - }\end{array}$ & $\begin{array}{l}\bullet \\
\bullet \\
\text { - baile social } \\
\text { - }\end{array}$ & $\begin{array}{l}\text { - culto } \\
\text { religioso } \\
\text { - } \\
\text { - mitin } \\
\text { político } \\
\text { - }\end{array}$ \\
\hline
\end{tabular}

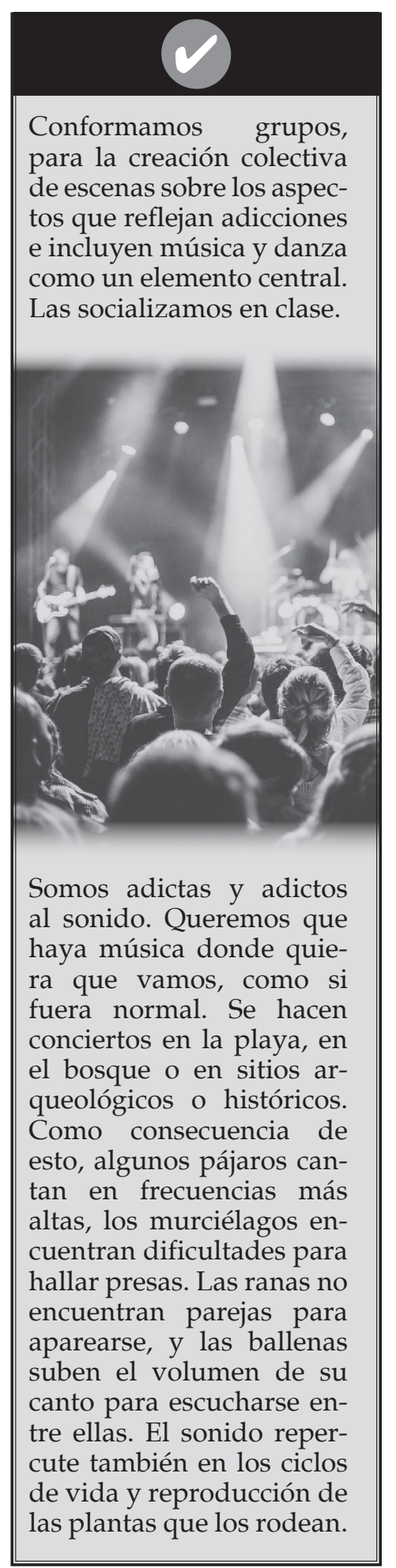




\section{Actuạndo la realidad para cambiarla}

Pausa Pedagógica: hacemos rutina de ejercicios de respiración, vocalización y relajamiento. Escucho una obra musical mientras identifico las emociones y sentimientos que me provoca.

Muchas situaciones de la vida real pueden ser tabú. No se habla de ellos porque causan polémica al solo mencionarlos. Algunos de estos temas pueden ser:

- Las adicciones y sus efectos económicos

- La violencia intrafamiliar o de género asociada al alcoholismo

- Los mecanismos de distribución de sustancias ilegales

- La corrupción del sistema político para fomentar las adicciones

Discuto y opino acerca de lo que aprendí a partir de la encuesta y sobre lo que observo ocurre en mi comunidad. Respeto las ideas de mis compañeros y compañeras.

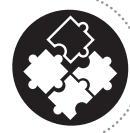

¿Cómo podemos incidir en la prevención de adicciones en la comunidad?, ¿Es posible cambiar la realidad para mejorarla?, ¿Qué deseo mejorar en mi familia y en la comunidad?

El arte dramático es una herramienta efectiva para observar la realidad. Al recrear la realidad a través de la actuación, podemos plantear alternativas que ayuden a cambiar las condiciones negativas que observamos en ella. En la problemática de las adicciones y el alcoholismo hay muchos aspectos que pueden ser representados teatralmente. Hacerlo puede ayudar a enfrentarlos de manera más clara, pues a veces son temas tabúes que no se tocan de otra manera. Sin embargo, al actuarlos y luego discutirlos, pode-mos tratarlos y buscar soluciones a los problemas que se asocian con ellos.

\section{Trabajemos en grupo:}

- Organicemos la información que recopilamos en la comunidad.

- Hagamos una lluvia de ideas sobre situaciones reales asociadas al alcoholismo o adicciones que se dan en nuestra comunidad.

- Seleccionemos tres de estas situaciones que nos han afectado personalmente o a nuestra familia o en la comunidad. Escojamos una que sea posible representar.

- Planteemos las escenas que puede haber en la situación seleccionada.

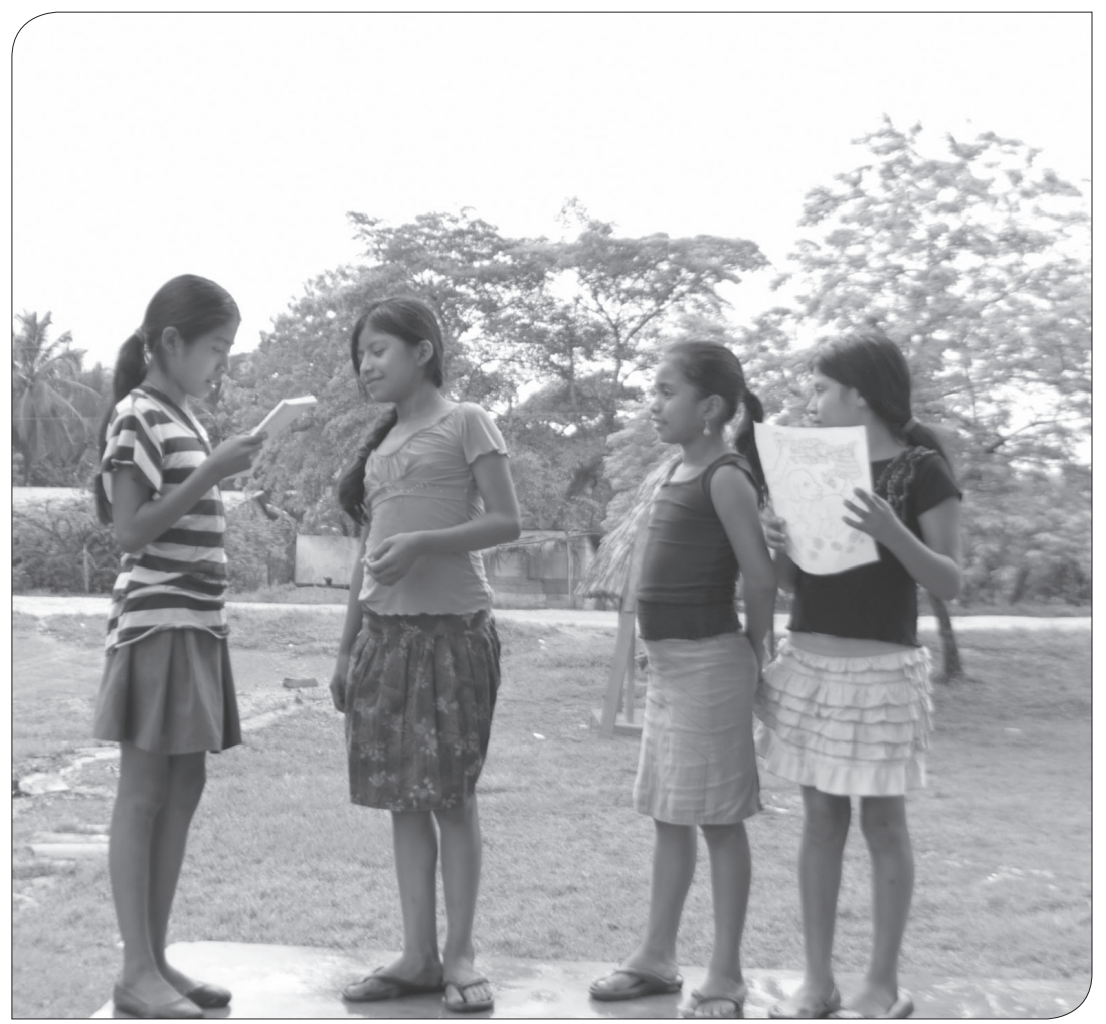




\section{Personajes, acciones y caracteres}

Cada personaje que podemos representar tiene características que le hacen ser único. Su comportamiento es fácil de identificar en determinadas situaciones. Algunas de las actitudes que asume al relacionarse con las demás personas hace que se le asocie a su manera de ser dentro de la comunidad. He aquí una lista de acciones que cambian ante distintas situaciones.

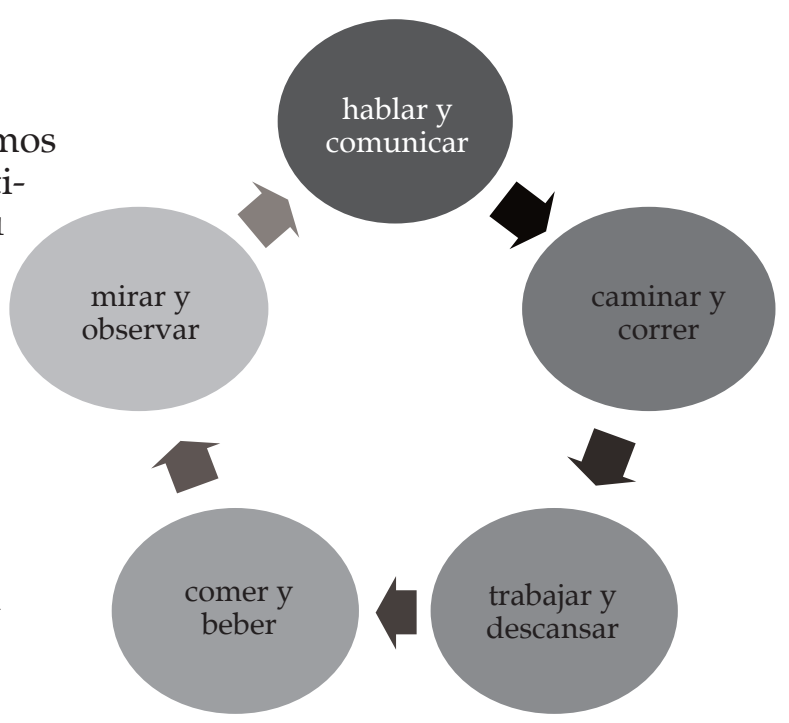

\section{Situaciones en las que cambia nuestra manera de hacer}

- Nos desenvolvemos de diferente manera si estamos en la iglesia o si estamos en una fiesta.

- Nos comportamos en la mesa de forma diferente si estamos en nuestra casa, que si estamos en una cena con una funcionaria o funcionario.

- Camina y corre diferente una persona sobria que una ebria.

- Hablamos de diferente manera si le hablamos igual a una persona que a un auditorio de cien personas.

- Una persona adicta a las drogas se desempeña diferente en una actividad laboral

\section{Caracterización de personajes y escenas}

En clases anteriores realizamos la caracterización de algunos personajes conocidos: empresarias, empresarios, políticos, políticas, estudiantes, líderes y lideresas comunitarias y religiosos, etc. Les representamos y realizamos un discurso con diversas entonaciones, según el personaje. Ahora nos toca enfocarnos en los personajes de las situaciones afectadas por las adicciones como el alcohol, las drogas y las personas del entorno que se ven afectadas.

Con los personajes seleccionados hacemos un juego dramático que explore las características de cada cual. Escribimos su comportamiento para ensayarlo y representarlo con todos los detalles posibles. Algunos ejemplos:

\section{Sociodrama sobre adicciones}

Escribo un diálogo sobre una situación específica de adicciones donde puedo ayudar, como en el ejemplo:

J: - ¿tus papás toman vos? -

A: - solo mi papá, pero a veces también mi mamá -

J: - ¿y vos que haces, te dan ganas también?

A: - antes me daban ganas, pero cuando veo que se ponen violentos, sé que no me gustaría ponerme así. -

J: - ¿y ayuda eso en algo, pues?

A: - pues claro, al menos puedo cuidar a

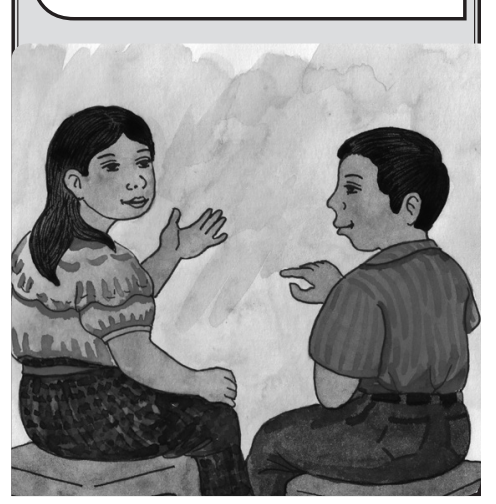

\begin{tabular}{|c|c|c|c|c|}
\hline Persona ebria & $\begin{array}{l}\text { Persona } \\
\text { drogada }\end{array}$ & $\begin{array}{c}\text { La esposa o } \\
\text { madre }\end{array}$ & $\begin{array}{c}\text { El esposo o } \\
\text { padre }\end{array}$ & $\begin{array}{c}\text { Los hijos e hijas, } \\
\text { amistades }\end{array}$ \\
\hline $\begin{array}{l}\text { - } \\
\text { - } \text { habla con la voz aguada } \\
\text { - se tambalea al caminar }\end{array}$ & $\begin{array}{l}- \\
- \\
\text { - reacciona } \\
\text { con ira }\end{array}$ & $\begin{array}{l}\text { - actúa sumisa } \\
\text { - tiene miedo } \\
\text { - }\end{array}$ & $\begin{array}{l}- \\
\text { - intenta } \\
\text { comprender }\end{array}$ & $\begin{array}{l}\text { - } \text { tienen miedo } \\
\text { - } \\
\text { - } \\
\text { - }\end{array}$ \\
\hline
\end{tabular}


Los gráficos de barras son también conocidos como gráficos de columnas. Muestran la información con barras separadas proporcionales a las medidas que representan. Pueden tener una orientación vertical u horizontal.

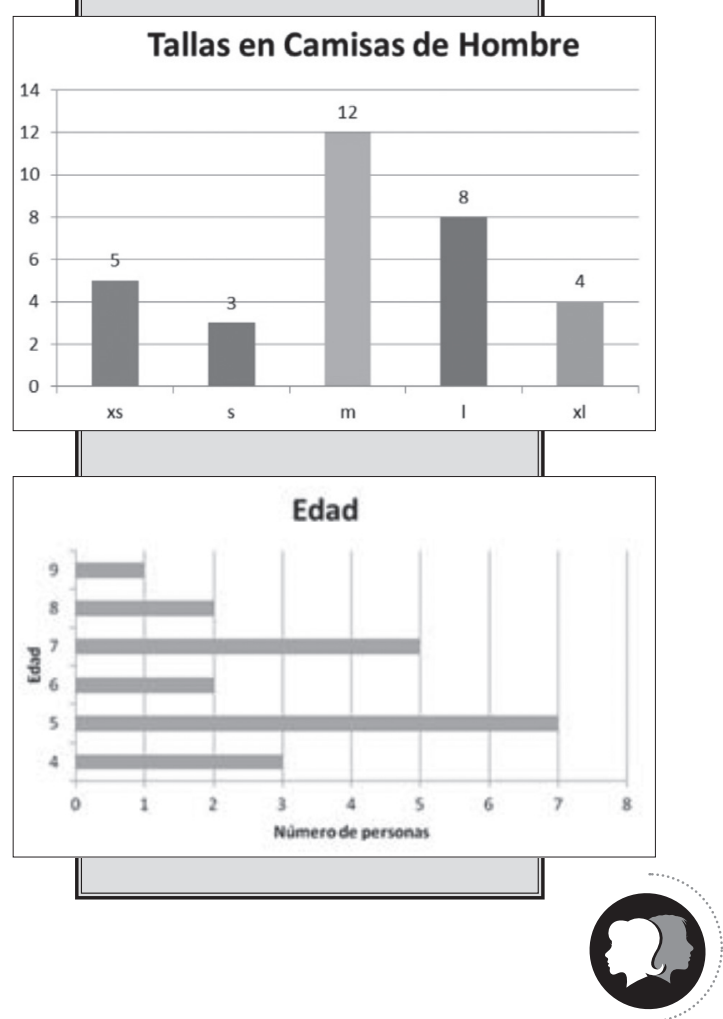

La siguiente gráfica muestra información de la edad a la que un grupo de jóvenes, hombres y mujeres guatemaltecas, probaron su primer cigarrillo. Comentamos la información con el resto de compañeras y compañeros, podemos comparar los datos entre las edades y qué prevalece en nuestra comunidad.

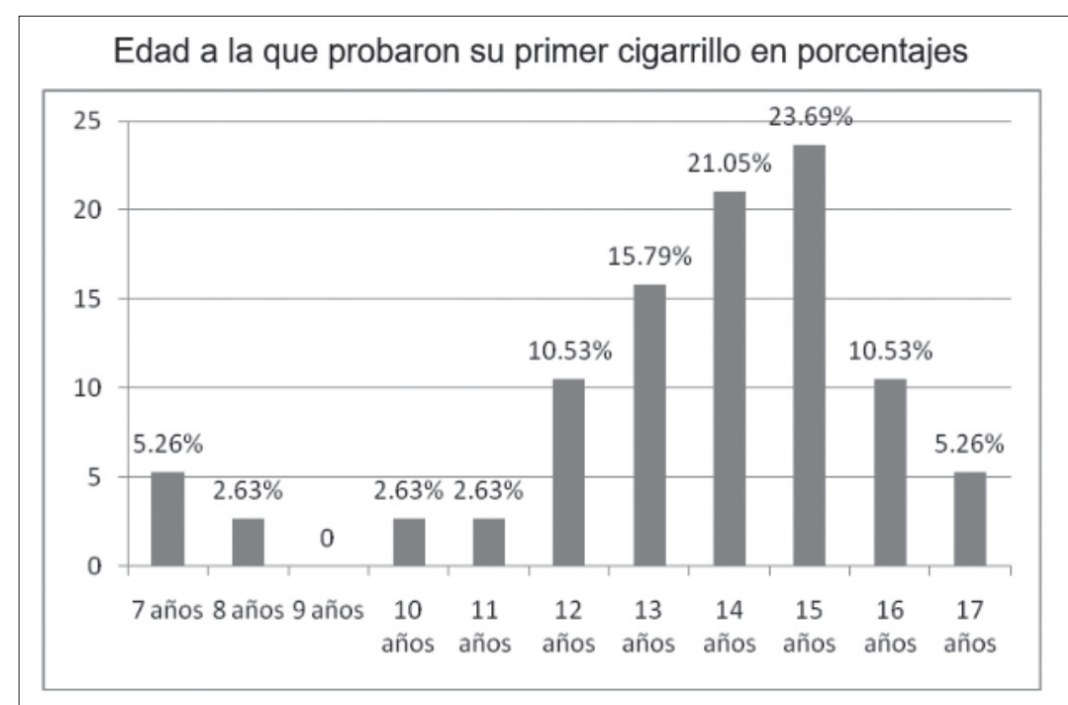

Fuente: Imaginario social de los jóvenes acerca del fumador: Inicio del consumo de cigarrillos en adolescentes. Tesis. Alma Gatica. USAC 2012.

En equipos resolvemos las siguientes situaciones:

- ¿Cuál es la pareja ordenada que corresponde al punto más alto de la gráfica?

- ¿Cuál es la pareja ordenada que corresponde al punto más bajo de la gráfica?

- ¿Cuál es el porcentaje de diferencia entre las y los jóvenes que probaron su primer cigarrillo a los 15 años y quienes lo hicieron a los 13 años?

- Si la muestra que se utilizó fue de 200 personas ¿Cuántas personas probaron el cigarrillo a los 16 años? 
El siguiente gráfico de líneas muestra una estimación de la cantidad de muertes a causa del tabaco en Guatemala, según diferentes escenarios futuros.

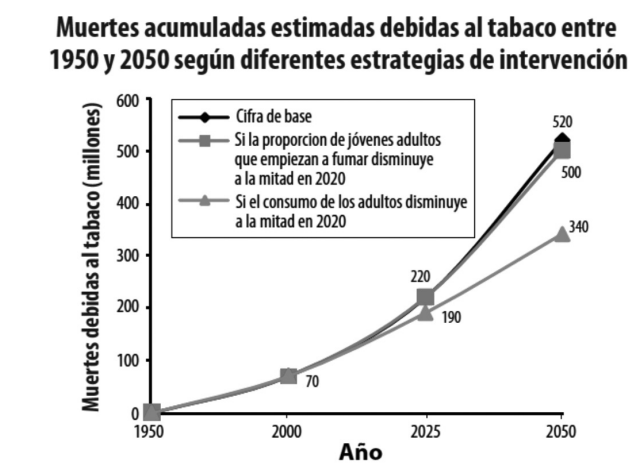

Fuente: La epidemia de tabaquismo: Los

\section{Contestamos y comentamos.}

- ¿Por qué se presentan tres distintas líneas en la misma gráfica?

- ¿Qué coordenadas se encuentran marcadas en cada línea?

- ¿Cuántoas millones de muertes se esperarían en el año 2050 si no se disminuye el consumo del tabaco?

- ¿Por qué son útiles las gráficas que comparan varios escenarios?

Ingresamos en una tabla la información recopilada por medio de la encuesta hecha. Nos organizamos en equipos para analizar los resultados elaborando gráficas con todos los datos.

Las dibujamos la gráfica en un pliego de papel o de cartulina.

\section{Comentamos:}

- ¿Qué aprendemos de la situación de adicción en nuestra comunidad?

- ¿Qué tipo de apoyo necesitamos?

- ¿Cómo prevenir las adicciones?
Los histogramas también representan la información utilizando barras proporcionales a las medidas realizadas. Se utilizan para datos que han sido agrupados en intervalos y por ello las barras se colocan una junto a la otra.

El histograma a continuación muestra la puntuación, sobre 50 puntos, que un grupo de estudiantes obtuvo en una prueba de razonamiento matemático.

Puntajes Obtenidos

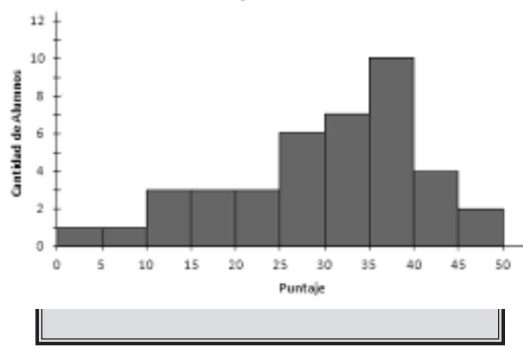

Evaluaremos el desempeño del resto del grupo utilizando la siguiente escala de rango, una para cada compañera o compañero.

\begin{tabular}{|c|l|c|c|c|}
\hline No. & \multicolumn{1}{|c|}{ Aspecto } & $\begin{array}{c}\text { Siempre } \\
(\mathbf{1 0} \text { puntos })\end{array}$ & $\begin{array}{c}\text { Algunas veces } \\
\text { (5 puntos) }\end{array}$ & $\begin{array}{c}\text { Nunca } \\
\text { (1 punto) }\end{array}$ \\
\hline 1 & Pasó la encuesta a quienes le correspondía. & & & \\
\hline 2 & Colaboró con la tabulación de los datos obtenidos. & & & \\
\hline 3 & Participó activamente en la creación de la gráfica. & & & \\
\hline 4 & Hizo aportes valiosos para analizar la gráfica. & & & \\
\hline 5 & Respetó la opinión de sus compañeros y compañeras. & & & \\
\hline 6 & Participó con interés y entusiasmo. & & & \\
\hline
\end{tabular}




\section{Un ensayo para promover nuestra salud}

\section{El mapa conceptual}

Ilustra gráficamente las ideas relacionadas con un concepto específico. Se llama "mapa" porque nos permite ver de manera clara e inmediata la relación que se establece entre sus elementos. Para que sea claro, es necesario que a partir del concepto central, se desprendan las ideas relacionadas, en orden de importancia. La relación entre ellas se ilustra por medio de flechas, dibujos o palabras de enlace: las principales, de primero; y luego, las secundarias. Veamos un mapa conceptual que presenta las las partes de un ensayo:

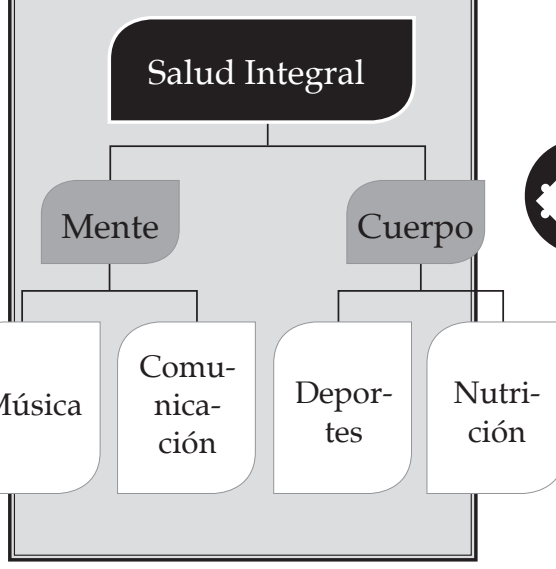

Al escribir un ensayo transmitimos nuestro punto de vista acerca de algún asunto con efectividad. El ensayo debe tratar el tema con argumentos de actualidad, tomar en cuenta el público a quien va dirigido, dialogar con la persona que lo lee, enfocarse solo en una parte del tema pues no es posible abarcar todos sus aspectos, invitar a la reflexión, causar interés sobre el tema $\mathrm{y}$, por supuesto, contener la opinión de quien lo escribe.

1. Investigar sobre el tema elegido: información en general, otros trabajos que se hayan hecho sobre el tema (otros ensayos, libros, artículos de revista y/o Internet).

2. Realizar una lluvia de ideas para escoger las ideas centrales que vamos a desarrollar en nuestro ensayo.

3. De la lluvia de ideas, elegir la idea principal y tres o cuatro ideas secundarias o de apoyo para conformar el argumento del ensayo.

4. Con esta selección, conformar un esquema tópico con las ideas que vamos a desarrollar y especialmente el orden, teniendo en cuenta las partes del ensayo.

5. Escribir el ensayo y ponerle un título atractivo.

6. Leer el ensayo, revisando redacción, ortografía, orden de ideas y claridad el mensaje.
Con este conocimiento, ahora desarrollemos las primeras dos fases de la producción de un ensayo: la investigación del material y su organización inicial en una lluvia de ideas: reflexionemos sobre el tema de nuestro proyecto y su incidencia en nuestra comunidad, realicemos la lectura análisis de noticias, editoriales, artículos y reportajes de periódicos que tengan que ver con el alcoholismo y las adicciones.

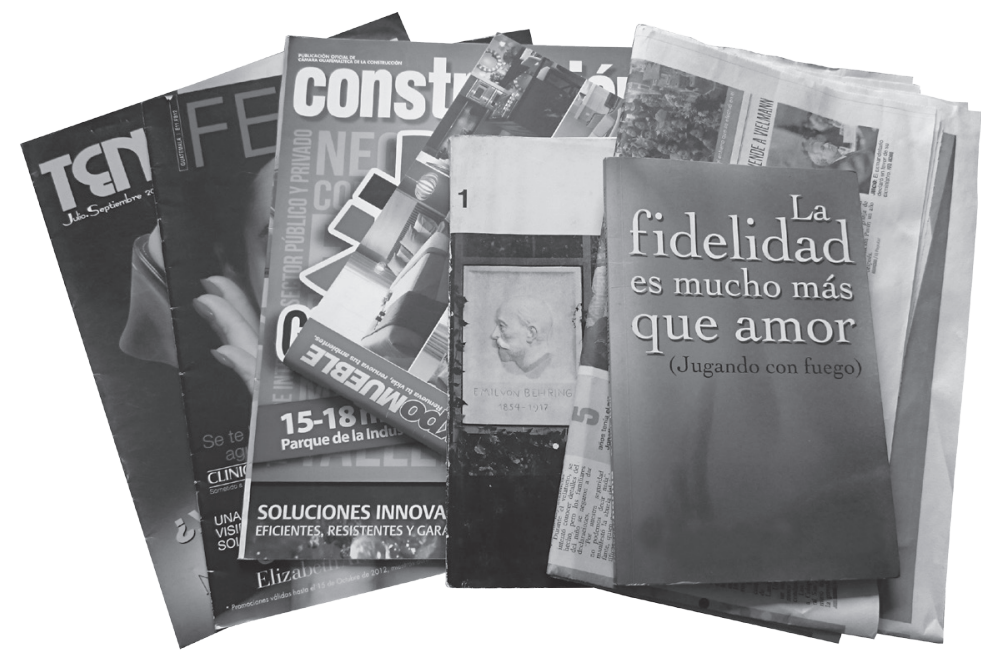




\section{Sustentación de un argumento}

Para que sea efectivo, un ensayo o un discurso debe estar redactado correctamente. De esa manera, su contenido y su forma se apoyarán para transmitir el mensaje deseado. Veamos algunas normas de redacción para apoyar nuestra escritura:

\section{¿Cuándo usamos la, lo o le?}

El uso de la, las, lo, los, le y les está muy bien especificado en gramática. Para comprender la diferencia es necesario analizar cómo funciona el objeto directo y el objeto indirecto en la oración.

El objeto directo es aquello sobre lo que recae directamente la acción del verbo. Para identificarlo se pregunta ¿qué?:

- Mi prima compró medicinas.

- Mi prima las compró.

- Escribí un ensayo.

- Lo escribí.

En la oración, la persona, animal u objeto que obtiene algún beneficio de la acción del verbo, indicado por las preposiciones "a" o "para", se llama objeto indirecto y puede ser reemplazado por los pronombres le o les.

- Traje helado para mis hijos.

- Les traje helado.

- Daniela explicó su proyecto a Juan.

- Daniela le explicó su proyecto.

El empleo incorrecto de estos pronombres se llama laísmo, loísmo o leísmo. Algunos ejemplos más:

- La di un libro de prevención de adicciones. (forma correcta: Le di un libro de prevención de adicciones.)

- Los mandé una encuesta para contestar. (forma correcta: Les mandé una encuesta para contestar.)

- Vi a mis amigos y amigas en el campo jugando.

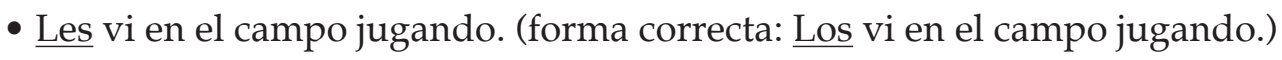

\section{¿Cómo le damos validez a nuestro ensayo o discurso?}

Un ensayo o discurso bien sustentado generalmente es producto de una investigación combinada con la reflexión de parte de quien la escribe. Así, podemos realizar varias acciones para respaldarlo:

1. Buscar datos concretos, en una investigación bibliográfica, en: libros, artículos de periódicos y revistas, informes en papel y en la Internet.

2. Después de revisar los materiales anteriores, reunir más información directamente de la realidad por medio de la experimentación, la observación, el trabajo de campo, las encuestas y las entrevistas, entre otros.

3. Procesar los datos y ordenar la información: tomar notas, hacer fichas bibliográficas, de cita textual, de resumen y de comentario.

4. Analizar los datos respondiendo a preguntas planteadas.

5. Obtener un punto de vista externo. 


\section{Sistemas del euerpo humano en saludable equilibrio}

El sistema nervioso periférico regula, integra $y$ coordina nuestros órganos internos, por medio de los axones; está formado por 12 pares de nervios craneales y 31 pares de nervios espinales.

Algunas enfermedades, trastornos y afecciones del sistema nervioso son:

Accidente cerebrovascular (Derrame cerebral): afección cerebral con lesión.

Esclerosis múltiple: pérdida de mielina del sistema nervioso central.

Esclerosis lateral amiotrófica: Afección de las neuronas que controlan la vía motora.

Neuralgia del trigémino: dolor de la cara por acción del nervio trigémino.

Parkinson: destrucción de células situadas en la sustancia gris, en la región del mesencéfalo o cerebro medio.

Vértigo: sensación de giro o rotación del cuerpo (ilusión de movimiento).

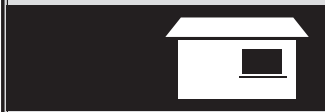

Averiguo si en mi familia, hay alguien que padezca alguna afección del sistema nervioso.

Identifico qué remedios o tratamientos se usan en la comunidad para aliviar los síntomas del insomnio, ansiedad, depresión, estrés, migraña y epilepsia.

\section{Sistema Nervioso}

A partir de nuestros saberes previos, completamos la información del mapa conceptual.

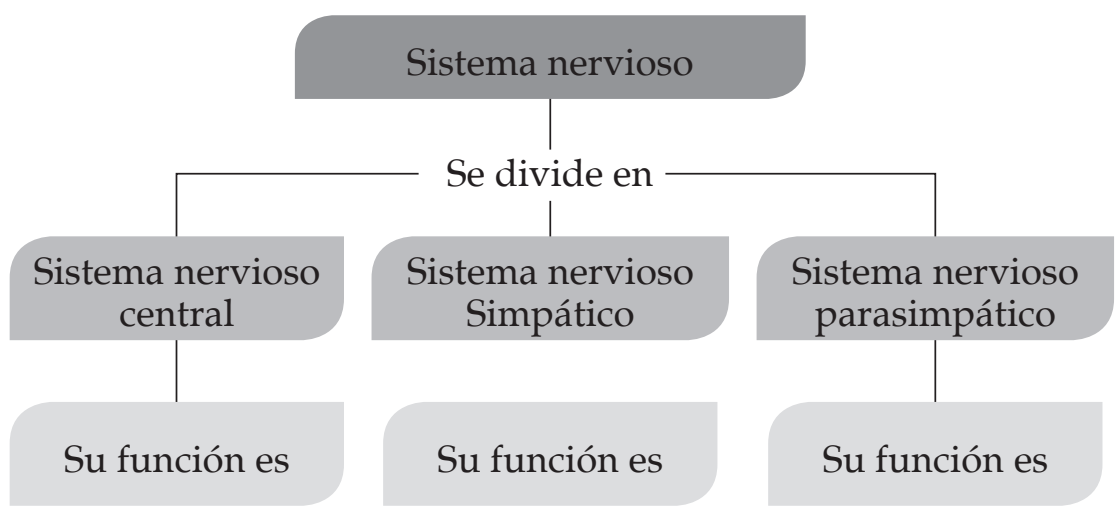

Los seres vivos estamos formados de numerosas células. En los seres pluricelulares, existen células especializadas que forman tejidos. Los tejidos a su vez, forman órganos. Los órganos combinan sus funciones lo que da como resultado una variedad de sistemas. La cooperación entre los sistemas produce el buen funcionamiento del cuerpo humano. Es una perfecta coordinación entre los sistemas que conforman el organismo: óseo, muscular, digestivo, circulatorio, nervioso, endocrino, respiratorio, excretor, reproductor y linfático.

Los sistemas nervioso y endocrino son llamados sistemas de relación porque ejercen control sobre los demás sistemas del organismo humano. El sistema nervioso contribuye a mantenernos en contacto con el mundo exterior y con algunos de los procesos del interior del organismo. Controla los otros sistemas, por ejemplo: regula los latidos del corazón, vigila el nivel de oxígeno y bióxido de carbono en la sangre, activa los músculos que permiten la respiración y contribuye a controlar la manera en que nos movemos.

Identificamos los órganos que forman el sistema nervioso.

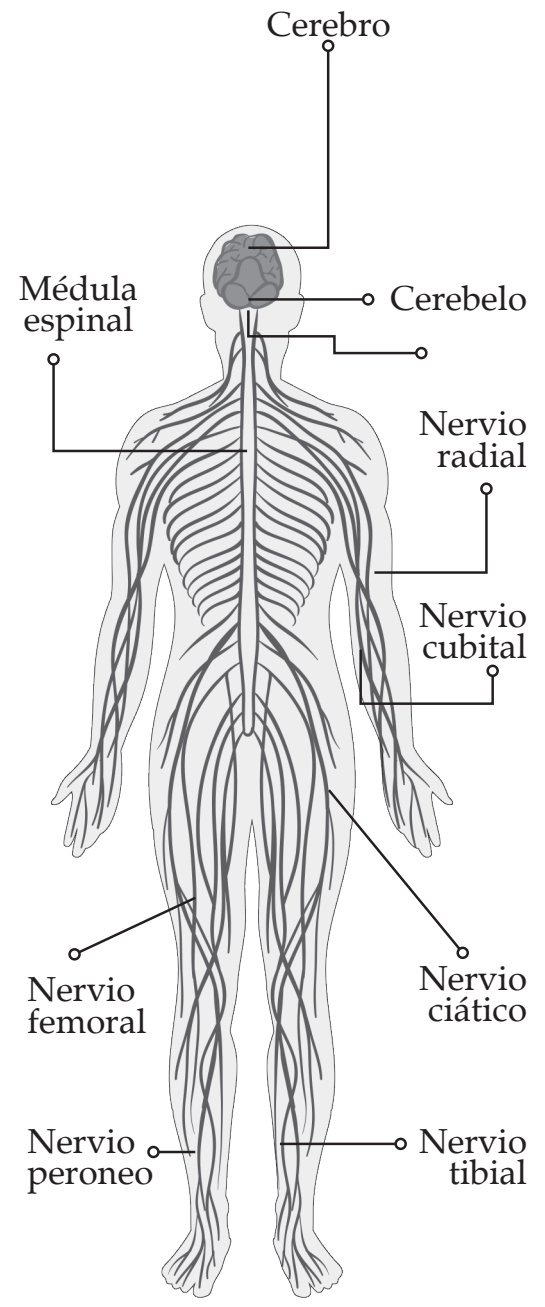

tibial 


\section{Sistema endocrino}

El sistema nervioso influye también en las acciones de la glándula pituitaria que al mismo tiempo gobierna las actividades de las otras glándulas endocrinas. El sistema endocrino segrega hormonas que regulan funciones importantes en el cuerpo como el crecimiento, la reproducción y el nivel de diferentes sustancias en la sangre, como la glucosa.

\section{Efectos de las drogas y adicciones en la salud}

Las adicciones provocar trastornos en la salud de las personas, aún en casos que no son del todo perceptibles. Por ejemplo, el uso excesivo de aparatos digitales como teléfonos inteligentes y televisión, genera exposición a ondas electromagnéticas. Aunque estas no son visibles para la mayoría de personas, cada vez se conoce más sus efectos dañinos en el sistema nervioso.

Consumo excesivo de aguas gaseosas y refrescos envasados, produce daños al colon, hígado y huesos, puede provocar desnutrición. Es causante de diabetes, enfermedades renales e hipertensión; entre otros males. Los alimentos con preservantes (productos para conservalos envasados), y los cereales industrializados actuales provocan toxemia (presencia de sustancias tóxicas en la sangre), que luego produce trastornos en el metabolismo.

Algunos efectos de las drogas en el sistema nervioso son: alteración de las conexiones entre las neuronas, lo que produce que no llegue la información al cerebro; surgen cambios neuroquímicos y funcionales en el cerebro, disminuyen los niveles de dopamina, que eleva el umbral del placer. También hay pérdida de control de esfínteres. Muchos medicamentos de la industria farmacéutica, ocasionan efectos secundarios. Ciertas drogas, como las estatinas recomendadas a mujeres en etapa posterior a la menopausia para disminuir el colesterol, son causantes de diabetes. Estudios recientes indican que la diabetes duplica el riesgo de padecer alzheimer.

Elaboramos un organizador gráfico a partir de la información recopilada en la encuesta.

Participamos en el debate y aportamos información para determinar como el alcoholismo afecta diferentes órganos, especialmente del sistema nervioso.

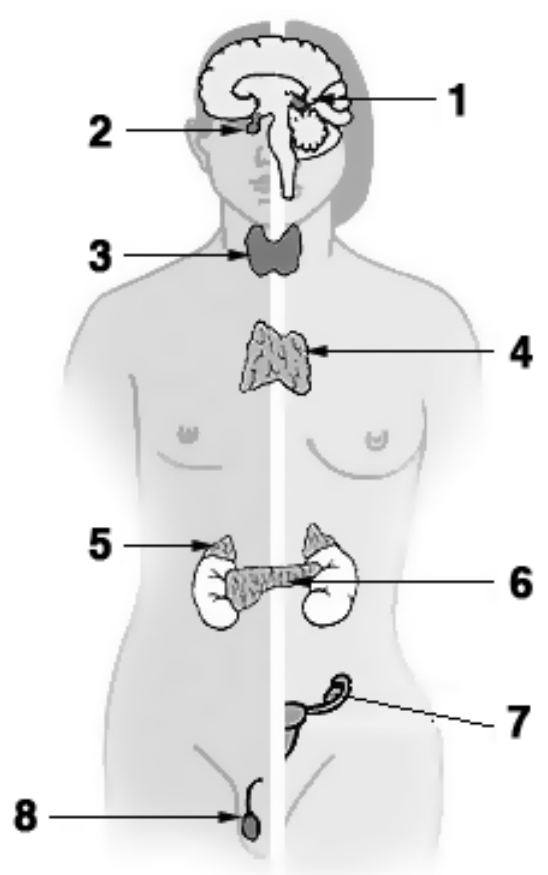

Sistema endocrino: 1. Glándula pineal, 2. Hipófisis, 3. Glándula tiroides, 4. Timo,5. Glándula Testículo
Algunas enfermedades del sistema endocrino:

Diabetes: falta de regulación del azúcar en la sangre, causada por poca producción de insulina en el páncreas o resistencia a ella.

Obesidad: acumulación excesiva de grasa en el cuerpo.

Hipotiroidismo: déficit de las hormonas tiroideas; produce cansancio, sensibilidad al frío, y alteraciones menstruales.

Hipertiroidismo: excesiva secreción de hormonas tiroideas; provoca bocio, hiperactividad, aceleración de los latidos del corazón y ojos saltones, entre otros síntomas.

Insulinoma: tipo poco común de tumor pancreático pequeño, muy pocas veces canceroso. Produce un exceso de la hormona insulina.

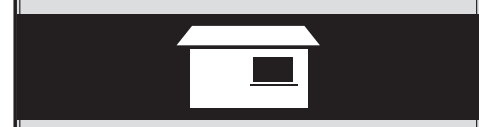

Elaboro un artículo para el periódico mural, relacionado con las adicciones y sus consecuencias. Elijo uno de los temas sugeridos:

- Efecto de la adicción a las aguas gaseosas sobre el páncreas.

- Consecuencias comunitarias a corto, mediano y largo plazo por la promocióm de comidas no saludables que generan adicción.

- Probabilidades que personas de la comunidad, que consumen cotidianamente golosinas y exceso de carbohidratos desarrollen enfermedades como diabetes y obesidad. 


\section{Podemos solli de la culfura de violencia en Guatemala}

"Algunos idiomas (los que tienen base latina, como el italiano, el español, el francés -y el inglés moderno-, pero no los de base germánica, como el alemán y el noruego) hacen invisible a la mujer al utilizar la misma palabra para el género masculino que para el conjunto de la especie humana. El importante movimiento pro escritura no sexista es un buen ejemplo de una transformación cultural intencionada para romper con la violencia cultural."

Fuente: Galtung, J. (2003). Violencia Cultural. Recuperado de: http:/ / www. gernikagogoratuz.org/web/ uploads/documentos/20289 2edd66aafe5c03dacf1298fd7f 8938fae76.pdf

- Escribo al menos tres ejemplos de discriminación contra las mujeres que se dan en mi familia, escuela y comunidad.

- Nombro formas en que los hombres también sufren violencia cultural y discriminación por la forma en que se les exige ser.

- Explico como la promoción del consumo de las sustancias adictivas que dañan la salud son formas de violencia.

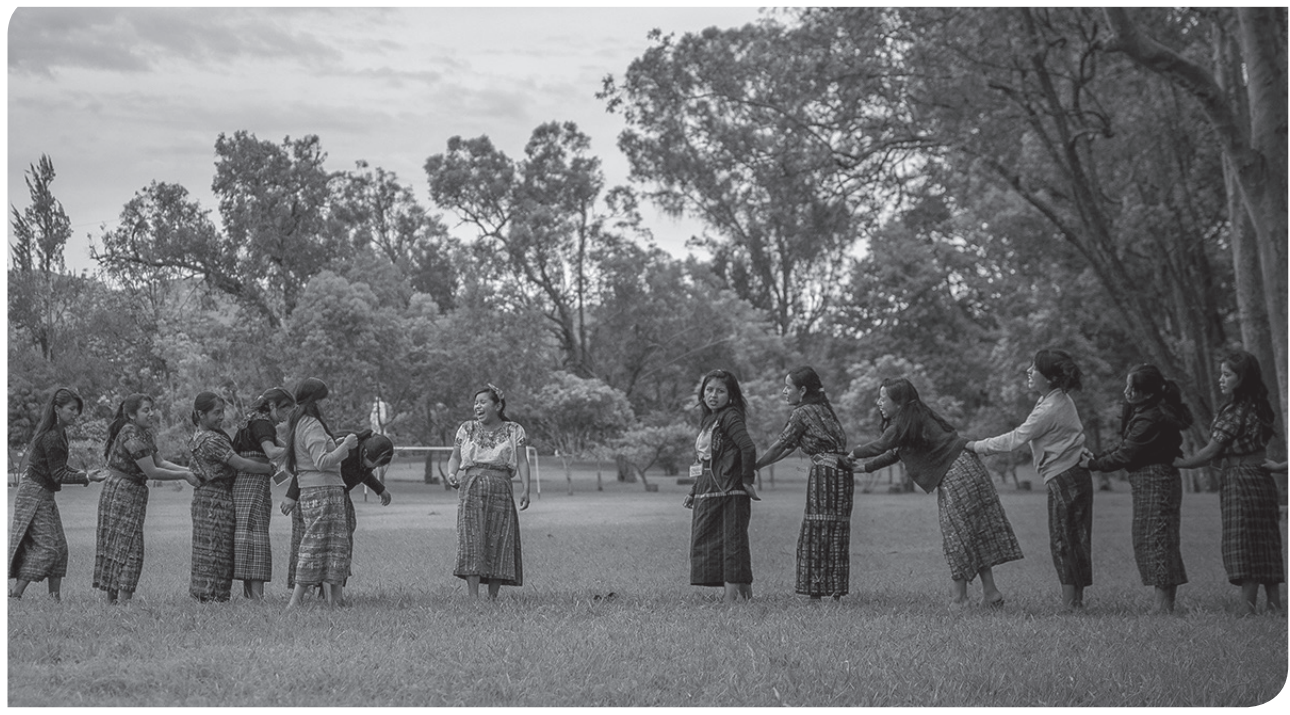

Cuando las personas piensan que la mejor forma de resolver los conflictos es por medio de la imposición, el irrespeto y la fuerza; si un grupo de personas justifica la destrucción de un bosque y no le importan los daños que causa a la comunidad; si las personas piensan que la solución para resolver el problema de la delincuencia es matando a quien robe, secuestre, extorsione o trafique drogas, en todos estos casos prevalece una cultura de violencia. La cultura de violencia se ha practicado desde hace muchos siglos en Guatemala.

Durante la conquista y la colonia se quemaron aldeas, torturaron personas, violaron a mujeres, agredieron a quienes se oponían a la conquista. En la historia reciente el Estado impuso su orden mediante el asesinato y desapareción de opositores políticos y la masacre de pueblos.

Por el contrario, cuando se reconoce que toda persona y ser vivo tiene dignidad y por ello se piensa que la mejor forma de resolver los conflictos es por medio del diálogo y la negociación, que debe prevalecer el bienestar de la comunidad por encima del interés de una persona y que la mejor forma de combatir la delincuencia es por medio de la ley y la justicia social, entonces prevalece la cultura de paz.

Hay que conocer y reconocer también, que es muy positivo que en estos mismos siglos han habido también muchas manifestaciones de la cultura de paz que expresan el amor a otras personas: solidaridad con las víctimas, respeto a diferentes culturas, diálogo y encuentro entre quienes piensan diferente, conservación del medio ambiente, la defensa de los derechos de las mujeres y las niñas, entre otras.

\section{Con nuestro equipo de trabajo:}

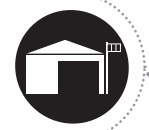

- Elaboremos un cuadro con soluciones al problema del alcoholismo que compare propuestas desde la perspectiva de la cultura de paz, con propuestas desde la perspectiva de la cultura de violencia.

- Organicemos y sistematicemos la información recopilada en la encuesta acerca de las adicciones en nuestra comunidad. 


\section{Conflicto armado y cultura de violencia}

Aún antes de que se desarrollara el conflicto armado interno en Guatemala en 1960, en muchos aspectos de la vida cotidiana la cultura de violencia ya estaba presente. Se pensaba que golpear a un hijo o hija era la mejor manera de educarle, ahorcar o fusilar a un criminal era considerado un acto justo y decir que la "la letra con sangre entra".

Luego del triunfo de la contrarrevolución, en 1954, el gobierno prohibió todo partido político que se opusiera a los lineamientos del gobierno militar dictatorial y su alianza con algunas empresas extranjeras. A quienes habían apoyado a los gobiernos de la Revolución de 1944 y defendían sus logros, se les persiguió, encarceló o mató. Ante el cierre de toda oportunidad de resolver los problemas de manera pacífica y por la vía democrática, escaló la cultura de la violencia como mecanismo para hacer valer las posiciones de cada parte. Todo esto hizo que se reforzara la cultura de la violencia como una forma de vida cotidiana y legítima tanto desde el actuar del estado como en la vida privada de las familias guatemaltecas.

Durante más de 30 años de conflicto armado la cultura de la violencia se fortaleció. Esto porque, además de la violencia política, en algunos sectores de la sociedad comenzaron a desarrollarse organizaciones delincuenciales que extorsionaban, secuestraban, traficaban y robaban. Sus actos violentos eran opacados por la violencia política, pero después de la firma de los Acuerdos de paz en 1996, se comenzaron a notar y sus organizaciones se fortalecieron.

Leemos las noticias de los diarios, las que escuchamos por radio y televisión identificamos señales de cultura de violencia.

(iii)

televisión identificamos señales de cultura de violencia.

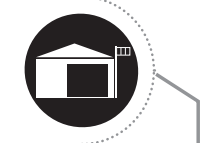

Discutimos acerca del significado del foro y elaboramos lineamientos para participar en dicha actividad.

- Selecciono una película, artículo, historia y la propongo para realizar el foro.

- Redacto algunas preguntas generadoras para la discusión del foro.

- Recopilo información para elaborar artículo de noticias de los periódicos.

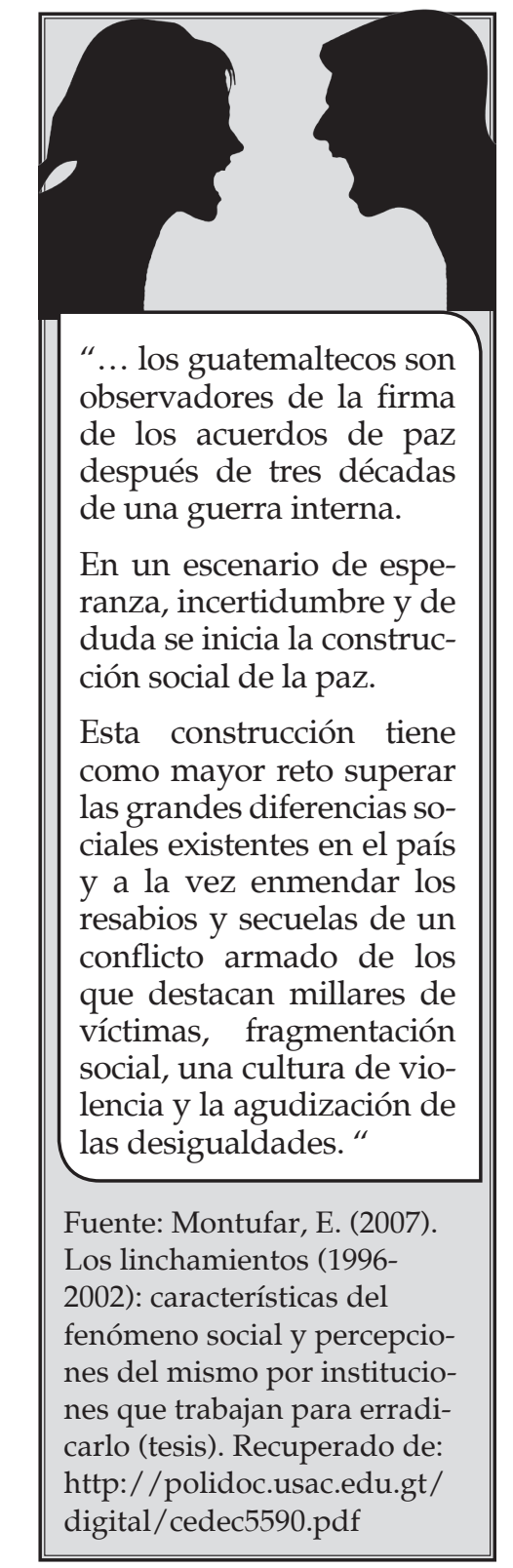

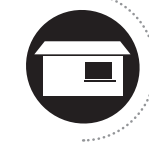




\section{Oiưdodạnía y medios de comunicación}

Radios comunitarias, la voz del pueblo

Las radios comunitarias son radios locales que difunden noticias y avisos de interés para la comunidad; también promueven la educación y cultura local en el idioma de la región.

Trabajan en favor de las comunidades. Las radios comunitarias apoyan la democratización de los medios de comunicación al hacerlos accesibles al pueblo para la promoción de sus intereses y satisfacción de sus necesidades.

\section{AQuí se resplia la diferencia}

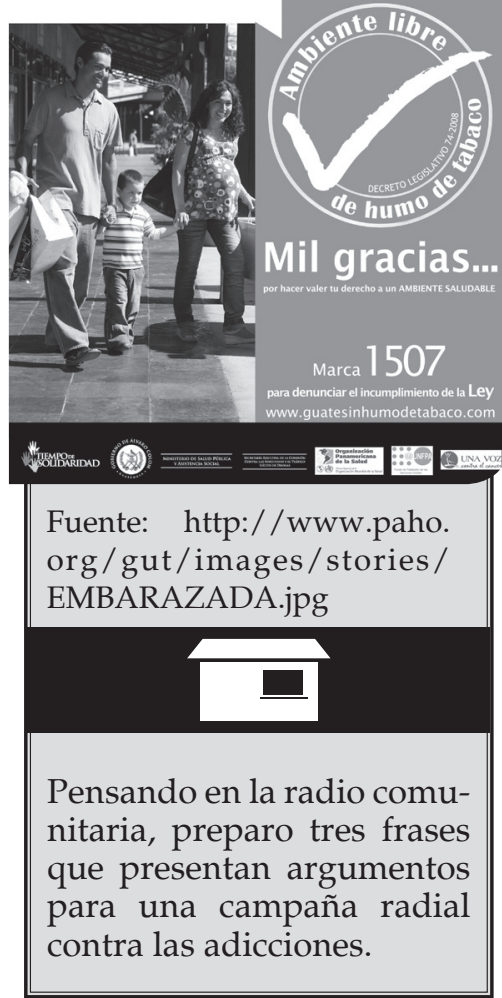

\section{Preparación para el debate}

Evaluemos si estamos preparadas y preparados para el debate que realizaremos la próxima semana. ¿Ya realizamos las siguientes acciones?:

- Escoger el tema para el debate.

- Seleccionar a las y los participantes de cada grupo de debate y a la persona moderadora.

- Cada grupo escoge la postura que defenderá y estudia los argumentos a favor y los posibles contraargumentos.

- Buscar un lugar para realizar el debate y conseguir, si es posible, equipo de sonido con micrófono.

- Obtener suficientes sillas para las y los participantes, así como el público.

- Enviar invitaciones a líderes y lideresas de la comunidad y representantes de instituciones y público en general.

- Seleccionar personas para el jurado y obtener su aprobación.

La próxima semana, el debate se realizará de la siguiente manera:

- Preparamos el lugar del debate con un lugar para la persona moderadora y un espacio para cada grupo participante.

- La persona que modera presentará el tema sobre el que se va debatir explicando su importancia y luego presentará a quienes participan.

- Cada grupo presenta en un tiempo limitado los argumentos que defienden su postura, y el otro grupo rebate y presenta sus argumentos.

- Antes de terminar la actividad, el público, dirigido por la persona moderadora, puede hacer preguntas.

- El jurado califica la actuación de cada grupo y selecciona al equipo ganador.

Nos organizamos en grupos para realizar las distintas actividades del debate y seleccionamos a:

- las y los integrantes de los equipos del debate,

- la persona moderadora,

- quiénes integran el jurado, y

- grupos que estarán a cargo de la organización del lugar.

Prepara y practica en casa tu participación en el debate. 


\section{Ciudadanía y medios de comunicación}

Los medios de comunicación, como la radio, los periódicos, la televisión y las redes sociales, posibilitan expresar y difundir nuestras investigaciones, ideas y opiniones a un número mayor de personas, incluso a personas desconocidas.

También nos permiten enterarnos de una diversidad de opiniones e ideas que podemos analizar.

Todas las personas, sin importar la edad, sexo, residencia, orientación sexual, religión o afiliación política, tenemos derecho a expresar nuestras ideas y opiniones sin temor a que nos moleste alguna autoridad civil, militar o religiosa.

También tenemos derecho a escuchar las ideas que expresan las demás personas.

Pero, de igual forma tenemos la responsabilidad de transmitir información veraz, que no incite a la cultura de la violencia. Estar pendientes de la radio comunitaria y otros medios de comunicación independientes es una manera de hacernos conscientes de nuestras obligaciones y defender nuestros derechos para fortalecer una ciudadanía participativa.

El debate y el periódico mural que estamos preparando son ejercicios de ciudadanía activa. Para evaluar el trabajo de esta semana marcamos con una $\mathrm{X}$ la casilla correspondiente.

\begin{tabular}{|l|c|c|}
\hline \multicolumn{1}{|c|}{ Actividades } & Si & No \\
\hline Comprendemos los efectos de las adicciones en el cuerpo humano & & \\
\hline Organizamos la información sobre adicciones & & \\
\hline $\begin{array}{l}\text { Clasificamos los datos sobre adicciones que usaremos en el debate y en } \\
\text { el periódico mural }\end{array}$ & & \\
\hline Analizamos el impacto de las adicciones en la comunidad & & \\
\hline
\end{tabular}

Guatemala tiene valiosas deportistas, que, con trabajo, esfuerzo y mucho entrenamiento han logrado romper estereotipos sobre actividades "apropiadas" para mujeres practicando deportes que requieren fuerza y resistencia.

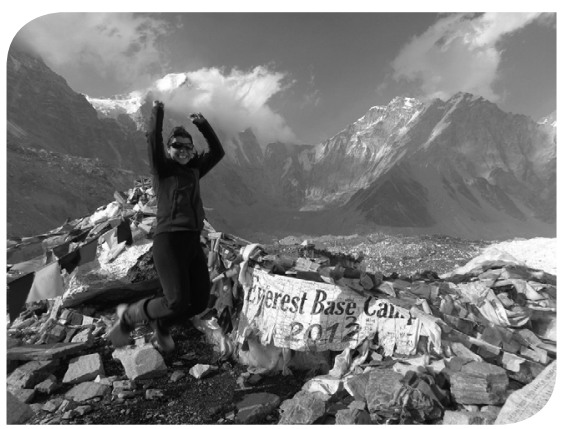

Foto: Bárbara Padilla, andinista

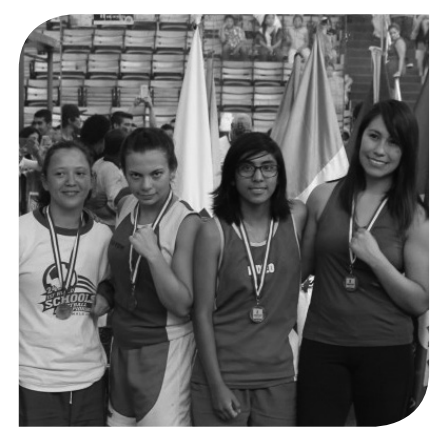

Foto: Ganadoras del Campeonato Nacional de Boxeo Femenino, Juvenil y Élite, 2016.

\section{Ciudadanía activa y} redes sociales

La ciudadanía reconoce a todas las personas derechos y obligaciones desde que nacimos y sin importar el lugar en el que habitamos. $\mathrm{Al}$ involucrarnos en las actividades y asuntos de nuestra comunidad y país nos convertimos en ciudadanos y ciudadanas activas.

En años recientes las redes sociales han facilitado, por ejemplo, la denuncia de actos de corrupción y también la convocatoria de la ciudadanía a participar en movimientos de protesta. El 16 de mayo 2015, una manifestación pacífica reunió a más de 60,000 personas en las plazas de la Ciudad de Guatemala y de otras ciudades del país. Personas de distintas edades, condiciones laborales, sociales y económicas protestaron a una misma voz contra la corrupción.

Organizo una discusión
en la familia o con amigas
y amigos sobre la forma
en que el consumo de al-
cohol afecta la salud y las
relaciones entre personas.
Tomo nota de algunas
ideas para incluir en el pe-
riódico propuestas de pre-
vención y combate a las
adicciones. Estas las escri-
bo en idioma extranjero.




\section{Conjuntos y pláno cortesiano para difundir información}

La diferencia simétrica entre dos conjuntos se representa como $A \Delta B$ y corresponde a $(A-B) \cup(B-A)$ ó $(A \cup B)-(A \Delta B)$

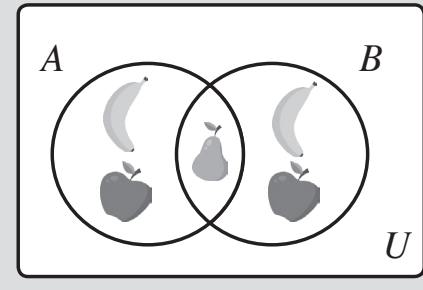

Observamos los siguientes diagramas de Venn de dos conjuntos que se intersectan. Comentamos con nuestros compañeros y compañeras de equipo antes de contestar.

a)

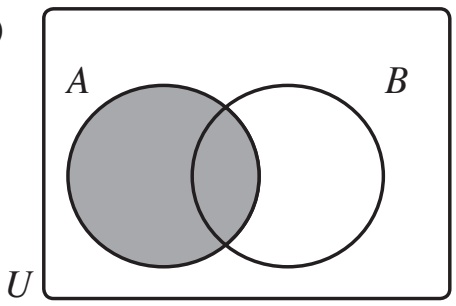

c)

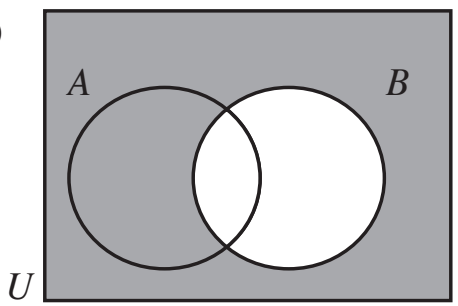

b)

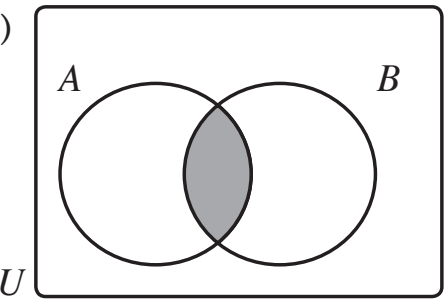

d)

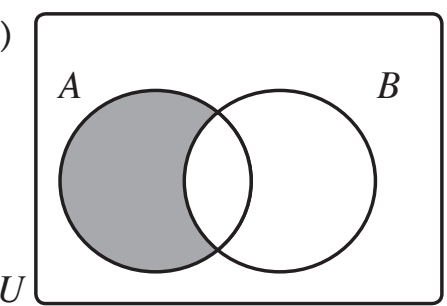

- ¿Qué representa el área sombreada en cada uno de los diagramas?

Anotamos las respuestas en nuestro cuaderno y las comparamos con los otros grupos.

Copiamos los siguientes diagramas y sombreamos los conjuntos o las operaciones indicadas.

a) $A-B$

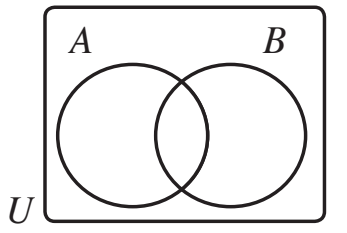

b) $A \cup B^{\prime}$

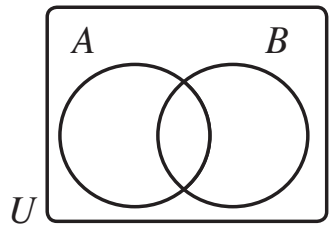

c) $B^{\prime}$

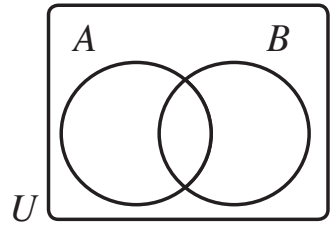

Intentémoslo ahora con tres conjuntos. Sombreamos las regiones indicadas.

a) $B \cap C$


Los diagramas de Venn también son utilizados para representar características comunes y no comunes de dos o más objetos o situaciones.

Observamos el ejemplo:

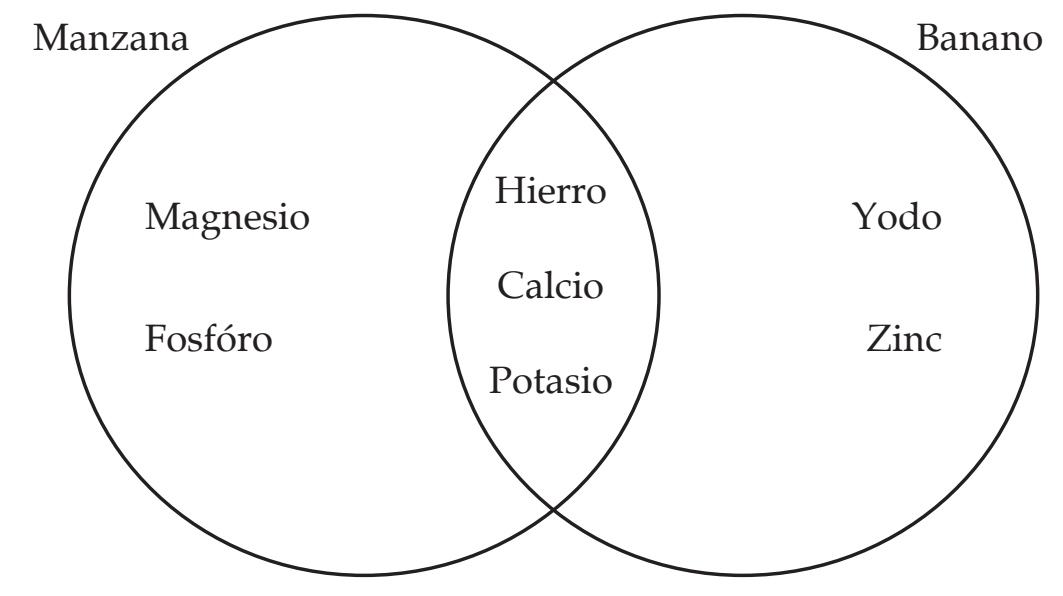

\section{Respondemos en nuestro cuaderno:}

- ¿Qué minerales podemos encontrar tanto en la manzana como en el banano?

- ¿Qué minerales encontramos en el banano?

- ¿Qué minerales encontramos en la manzana, pero no en el banano?

En un pliego de papel o en una cartulina realizamos un diagrama de Venn que represente la información obtenida sobre los efectos negativos de las adicciones. Colocamos en los espacios correspondientes aquellas consecuencias que sean comunes en dos o tres adicciones. Preparamos el diagrama para incluir en el periódico mural.

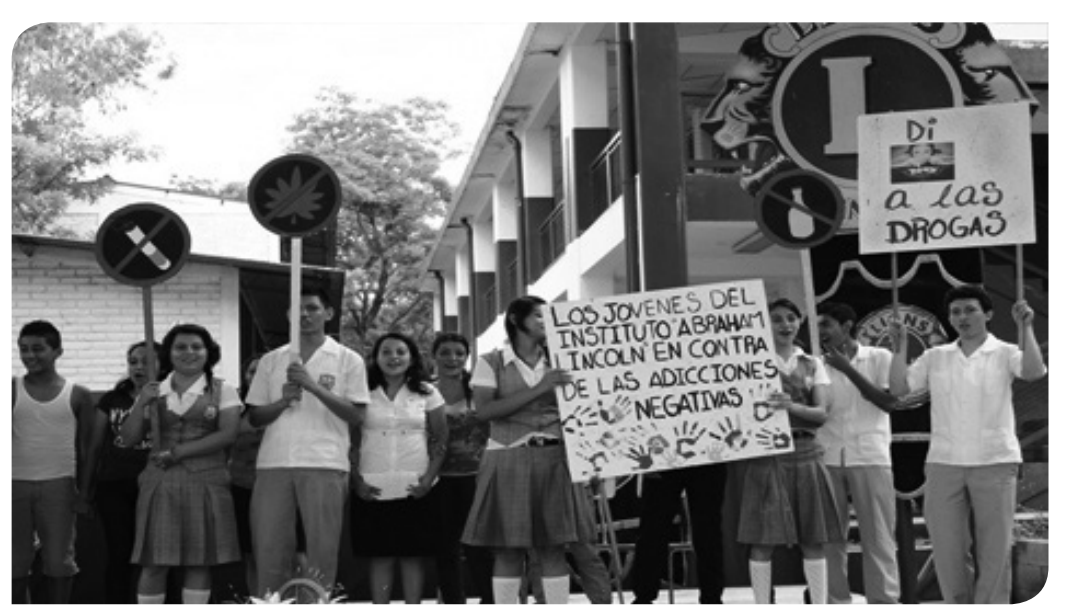

Dos o más conjuntos son disjuntos si no tienen ningún elemento en común. Al representarlos gráficamente se colocan separados, sin intersección.

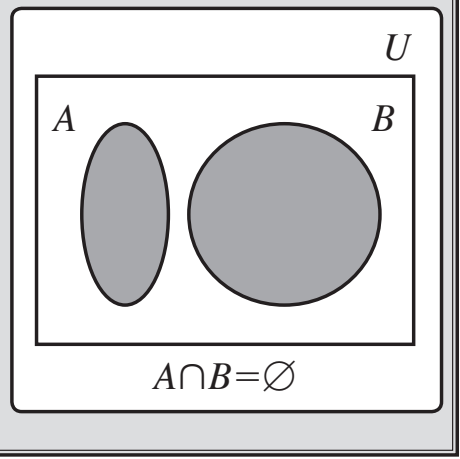




\section{Riesgos de las adicciones y el consumo de drogas para la salud}

El alcohol etílico es un compuesto orgánico, ingrediente básico de las bebidas alcohólicas.

Causa el síndrome de dependencia conocido como alcoholismo, un trastorno mental y del comportamiento.

Entre personas de 20 a 39 años de edad, es causante del $25 \%$ de muertes. Su uso nocivo causa más de 200 enfermedades. Trastornos del sistema nervioso, traumatismos, intoxicación alcohólica, cirrosis hepática, algunos tipos de cáncer, enfermedades cardíacas, tuberculosis y VIH/sida, se asocian a su consumo nocivo.

OMS/Alcoholismo:

http://www.who.int/mediacentre/ factsheets/fs349/es/

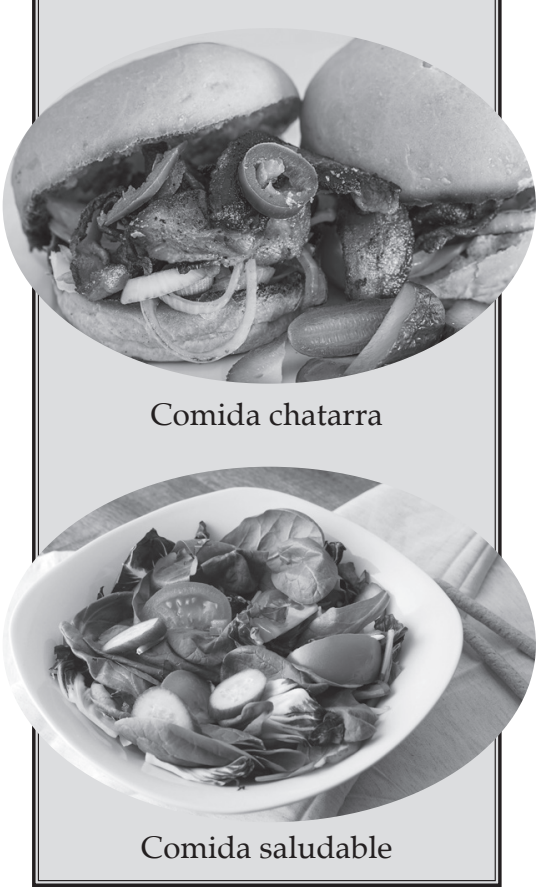

\section{Trabajamos en grupos:}

Leemos los artículos e insumos que ya elaboramos para el periódico mural y respondemos con base en la información:

- ¿Cuál de las adicciones se presenta con mayor frecuencia en la comunidad?

- ¿Qué condiciones facilitan el desarrollo de esa adicción?

- ¿Existe en las personas de la comunidad el riesgo de padecer alguna enfermedad causadas por una adicción?

- ¿Qué podría modificarse para prevenir que se genere la adicción?

1. Analizamos la información de la siguiente tabla.

\begin{tabular}{|l|l|}
\hline Enfermedad & \multicolumn{1}{|c|}{ Causa } \\
\hline Obesidad & $\begin{array}{l}\text { Comer en exceso comida chatarra, azúcar } \\
\text { y cereales industrializados; junto con mante- } \\
\text { ner una vida sedentaria. Un hombre es obe- } \\
\text { so cuando su perímetro abdominal es igual o } \\
\text { mayor a } 102 \mathrm{~cm} \text {; en la mujer si es igual o ma- } \\
\text { yor a } 88 \mathrm{~cm} .\end{array}$ \\
\hline Diabetes & $\begin{array}{l}\text { Exceso en el consumo de azúcar, harina de tri- } \\
\text { go y carbohidratos en general. Estar en con- } \\
\text { dición de obesidad. Problema de funciona- } \\
\text { miento del páncreas. Dificultades de asimilar } \\
\text { o producir insulina. }\end{array}$ \\
\hline Toxemia & $\begin{array}{l}\text { Absorción de toxinas o deficiente eliminación } \\
\text { de las toxinas en el cuerpo, causada por el } \\
\text { consumo de bacterias y sustancias químicas } \\
\text { venenosas presentes en alimentos industriali- } \\
\text { zados; por el consumo de drogas y alcohol, así } \\
\text { como por el consumo de alimentos con gluten } \\
\text { e hiperactividad hormonal. }\end{array}$ \\
\hline Alcoholismo & $\begin{array}{l}\text { Consumo frecuente de bebidas alcohólicas } \\
\text { derivado de dependencia biológica y psicoló- } \\
\text { gica. }\end{array}$ \\
\hline
\end{tabular}

2. Leo la siguiente información que nos comparte la Organización de Naciones Unidas y la Organización Mundial de la Salud acerca de la nutrición y la comparo con la realidad de la comunidad:

- A nivel mundial, 2000 millones de personas sufren sobrepeso u obesidad.

- La nutrición deficiente provoca casi la mitad (45\%) de las muertes de niñas y niños menores de 5 años: 3.1 millones de niños y niñas al año.

- En 2016, se reportaron 422 millones de personas en el mundo afectadas por diabetes. El 80\% de casos se reportó en países con ingresos económicos bajos y medios. 
Las drogas, el alcohol y ciertos alimentos procesados; en especial el azúcar y productos derivados del trigo alteran el funcionamiento normal de las neuronas. Drogas como la marihuana y la heroína, engañan a los receptores en las neuronas y provocan la transmisión de mensajes confundidos. Sustancias como las anfetaminas y la cocaína provocan exceso de actividad de las neuronas que afecta o colapsa su comunicación natural.

El estímulo en exceso producido por las drogas, provoca euforia y sensación de placer; genera un sistema interno de recompensa en el cerebro, que resulta en mayor deseo de consumo de las mismas. De esta manera el cerebro envía señales positivas para repetir la experiencia con estos elementos. A largo plazo se pierde la capacidad de experimentar placer y la persona adicta, puede sentirse aplacada, sin vida y deprimida. Ya no disfruta de lo que antes le resultaba placentero.

\begin{tabular}{|l|l|}
\hline \multicolumn{1}{|c|}{$\begin{array}{l}\text { Relacionamos los indicadores de salud con las adicciones, escri- } \\
\text { biendo como éstas provocan mortalidad y desnutrición. }\end{array}$} \\
\begin{tabular}{|l|l|}
\hline Indicador \\
Mortalidad \\
general
\end{tabular} & \multicolumn{1}{|c|}{ Relación con adicciones } \\
\hline $\begin{array}{l}\text { Mortalidad } \\
\text { infantil }\end{array}$ & \\
\hline $\begin{array}{l}\text { Desnutrición } \\
\text { crónica }\end{array}$ & \\
\hline $\begin{array}{l}\text { Desnutrición } \\
\text { aguda }\end{array}$ & \\
\hline
\end{tabular}
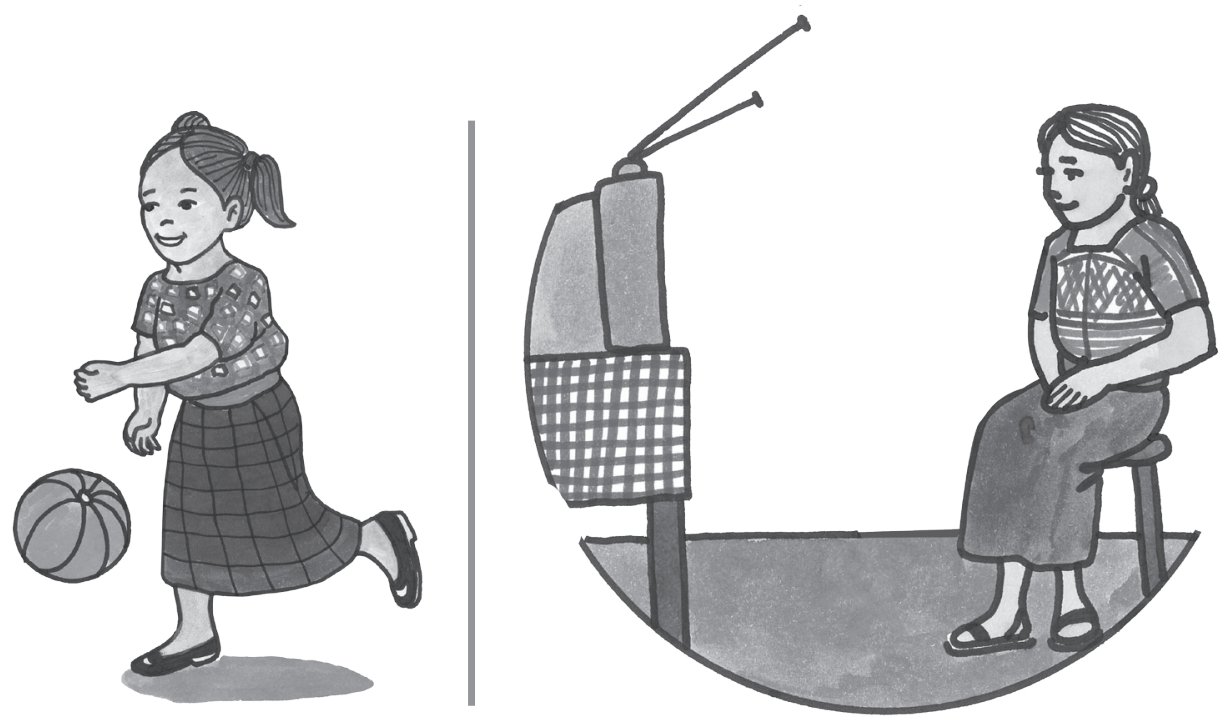

El consumo prolongado de las sustancias adictivas puede provocar daños neurológicos, afectar la memoria, inhibir la conciencia, provocar deseos incontrolables por volver a consumir el componente al que la persona es adicta. Se pierde el autocontrol y la capacidad de tomar decisiones acertadas.

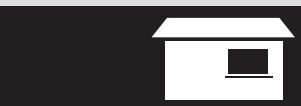

1. Observo si en la comunidad existen algunos de los siguientes factores de riesgo:

- Falta de supervisión en las actividades de las niñas, niños y jóvenes.

- Uso generalizado de cigarrillos y bebidas alcohólicas.

- Fácil acceso a drogas para niños, niñas y jóvenes.

- Fácil acceso a la comida chatarra, en las escuelas y la comunidad en general.

- Influencia de la publicidad que promueve el consumo de alcohol, cigarrillos y comida chatarra.

2. Discuto con mi familia: una acción que puede realizarse en la casa y en la comunidad para proteger a las niñas, niños y jóvenes del consumo y la adicción a drogas.

3. Observo las imágenes. Cuál de las actividades es un factor de protección para mi salud. 


\section{Globalización e independencia económica}

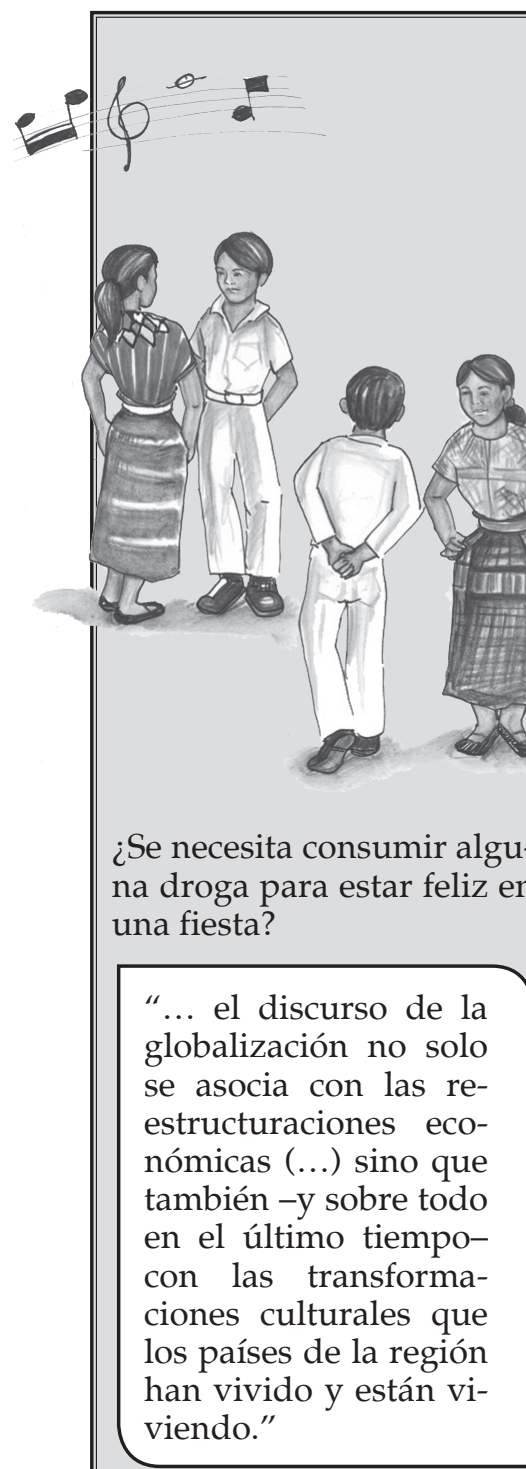

Fuente: Roviara, C. (2003). Dependencia y globalización. Nueva perspectiva para una vieja temática. Recuperado de: http://www.facso.uchile.cl/ publicaciones / sociologia / articulos/17/1703-RoviraKaltwasser.pdf

Describo algunos cambios en la cultura de mi comunidad y explico qué relación tienen con la globalización.

\section{Globalización e independencia económica}

Una de las características de la globalización económica es que la venta de mercancías entre los países del mundo se libera, esto significa que se dejan de cobrar impuestos a los productos extranjeros por ingresar a un país, así mismo se dejan de cobrar impuestos a los productores de mercancías nacionales por llevar sus productos a los mercados extranjeros, también se limitan los obstáculos a las inversiones financieras, como los bancos y las aseguradoras. Mientras que el intercambio de productos se facilita para aumentar las ganancias, las condiciones de trabajo se ven afectadas: se evitan los pactos colectivos, se limitan los salarios mínimos para que no sean altos y en casos se reducen las prestaciones laborales. Estas políticas permiten que aumenten las ganancias de las empresas extranjeras y nacionales.

La independencia económica de un país se expresa en su capacidad para orientar una parte importante de la producción hacia el desarrollo sostenible y humano. Es decir, que se cuida el ambiente natural y se procura el bienestar de la población. Esto es posible cuando se fortalece a las empresas del país que producen para los consumidores nacionales, se pagan salarios adecuados y se aprovechan responsablemente los recursos naturales.

Entonces, la globalización y la independencia económica, en países como el nuestro, resultan contradictorias. Al darle toda clase de libertades al ingreso y venta de los productos extranjeros, se afecta a los productores nacionales. La facilidad que se ofrece a las empresas extranjeras para que inviertan en nuestro país posibilita que vengan y tomen los recursos naturales. La flexibilización de las condiciones de trabajo en el mercado laboral, limita que el bienestar de la mayoría de personas se logre.

\section{Discutamos en grupo}

En foros internacionales, el ex presidente Otto Pérez (2012-2015) hizo suyo un planteamiento: legalizar el comercio de las drogas como una forma distinta de abordar esta problemática.

- ¿Cómo afectaría esta propuesta el consumo de drogas a nivel internacional? Argumentamos nuestras respuestas.

- Empleamos las opiniones surgidas del análisis grupal para participar en el Foro. 


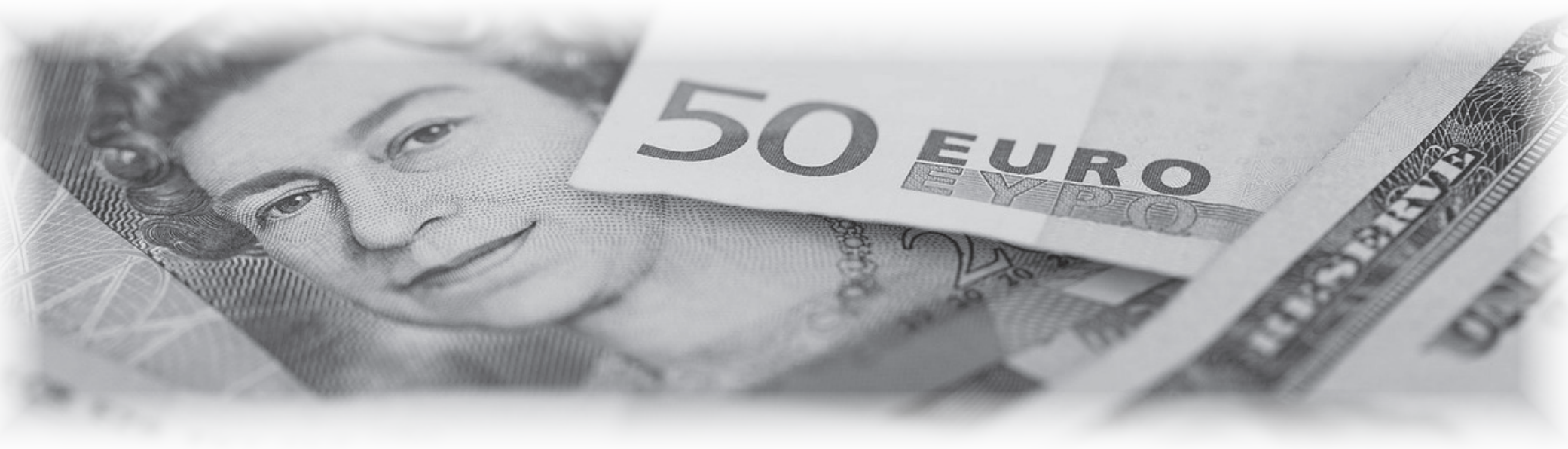

El papel de algunas organizaciones internacionales en la globalización

- Organización Mundial del Comercio, OMC. Regula el comercio entre los países, establece reglas para que los intercambios de mercancías sean abiertos y estables. Entre sus principales normas están regular las medidas sanitarias que se deben cumplir para importar o exportar productos, los trámites de importación, el comercio de servicios, la propiedad intelectual y la eliminación de la competencia desleal en los mercados internacionales por medio de precios subsidiados, aspectos ecológicos, condiciones sociales, entre otros.

- Fondo Monetario Internacional, FMI. Pretende estabilizar el sistema monetario internacional. Para ello establece la forma en que se puede pagar o cobrar una transacción internacional, es decir qué monedas y otras formas de intercambiar productos se pueden utilizar. También acuerda el tipo de cambio de las monedas, es decir la equivalencia del valor entre dos monedas, por ejemplo: un dólar equivale a siete quetzales con cincuenta centavos.

- El Banco Mundial, BM. Su función es otorgar préstamos y dar asistencia técnica a los estados, instituciones gubernamentales y empresas privadas que tengan el aval del gobierno para que se fomente el desarrollo económico y social. Los préstamos que da son pagaderos a largo plazo y los intereses que cobra son relativamente más bajos que los cobrados por los grandes bancos privados que operan a nivel internacional.

Estas tres organizaciones, a lo largo de su historia, han favorecido a los países de origen de las grandes empresas transnacionales.

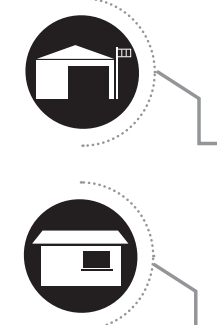

Presentamos, en clase, los artículos que seleccionamos en los diarios para elaborar nuestro periódico mural.

Elaboramos la propuesta para las secciones del periódico mural, que incluirá temas como: estrés, enfermedades psicosomáticas, tipos de adicciones, causas y consecuencias.

"La causa de la actual crisis financiera ha sido la falta de reglamentación del sistema financiero de los Estados Unidos, cuyas autoridades no han querido, o no han logrado, acotar la creatividad de los participantes en los mercados de instrumentos crediticios dentro de un marco cautelar eficaz."

Fuente: Lamy, P. (2008). La OMC es una póliza de seguro global para la economía mundial. Recuperado de: https:/ /www. wto.org/spanish/news_s/ sppl_s/sppl102_s.htm

La cita es parte de la respuesta que dio el Director General de la Organización Mundial del Comercio cuando se les dijo que esta institución, así como el Fondo Monetario Internacional y el Banco Mundial, no ayudaban a evitar la crisis económica. Hasta la actualidad, la crisis ha afectado a casi todas las economías del mundo. ¿Cuál es tu opinión al respecto? Argumenta tu respuesta. 


\section{Un discurso que convence}

\section{Uso de la tilde} diacrítica

Se llama tilde diacrítica a la que da un valor diferente a dos palabras que se escriben igual y les cambia la categoría gramatical. Es conveniente recordar que las palabras monosílabas no se tildan, con excepción de estas. Veamos ejemplos:

\begin{tabular}{|l|l|}
\hline \multicolumn{1}{|c|}{ Sin tilde } & \multicolumn{1}{c|}{$\begin{array}{c}\text { Con tilde } \\
\text { diacrítica }\end{array}$} \\
\hline $\begin{array}{l}\text { Artículos de } \\
\text { periódico. }\end{array}$ & Dé el ejemplo. \\
\hline El mercado. & Él llegó. \\
\hline Mi libro. & $\begin{array}{l}\text { Se dirigió a } \\
\text { mí. }\end{array}$ \\
\hline $\begin{array}{l}\text { Argumentó la } \\
\text { respuesta. }\end{array}$ & $\begin{array}{l}\text { Sé una joven } \\
\text { feliz. }\end{array}$ \\
\hline $\begin{array}{l}\text { Tu mirada es } \\
\text { alegre. }\end{array}$ & $\begin{array}{l}\text { Tú lo } \\
\text { convenciste. }\end{array}$ \\
\hline
\end{tabular}

\begin{tabular}{|c|c|}
\hline \multicolumn{2}{|c|}{$\begin{array}{l}\text { Uso de la diéresis } \\
\text { Se llama diéresis al signo } \\
\text { formado por dos puntos } \\
\text { que se ponen sobre la le- } \\
\text { tra "u" en la sílaba güe y } \\
\text { güi, para indicar que esta } \\
\text { debe pronunciarse. Veamos } \\
\text { ejemplos: }\end{array}$} \\
\hline Sin diéresis & Con diéresis \\
\hline Águila & Pingüino \\
\hline Guitarra & Cigüeña \\
\hline Guisado & Ungüento \\
\hline \multicolumn{2}{|c|}{$\begin{array}{l}\text { Acento en los adverbios } \\
\text { terminados en mente } \\
\text { Los adverbios terminados } \\
\text { en "mente" deben conservar } \\
\text { la tilde que llevaban cuando } \\
\text { eran adjetivos. Ejemplos: }\end{array}$} \\
\hline Adjetivos & $\begin{array}{l}\text { Adverbios } \\
\text { terminados en } \\
\text { "mente" }\end{array}$ \\
\hline Ágil & Ágilmente \\
\hline Común & comúnmente \\
\hline Rápida & Rápidamente \\
\hline
\end{tabular}

El debate y el foro son reuniones que se organizan para conversar sobre un tema particular. En ellos participan varias personas de diversa formación, reunidas por un interés común. Tradicionalmente se llevan a cabo en espacios físicos, pero con el avance de la tecnología pueden realizarse virtualmente, por medio de la red. La diferencia entre el debate y el foro radica en que en el primero participan dos personas que poseen visiones contrarias sobre un tema y propuestas alternativas a una situación determinada. En cambio, en el foro, la discusión está abierta al público. Sus normas son:

En el debate: quien modera abre el encuentro con una introducción. Luego, cada participante debe exponer con claridad y razones válidas su posición y su propuesta. Al final, debe lograrse un consenso o un acuerdo que será aprobado por la mayoría de asistentes.

En el foro: el o la moderadora abre la sesión y anuncia el problema a resolver. Luego, presenta a quienes expondrán y anuncia que, al final, el auditorio podrá participar. Al terminar las exposiciones, los asistentes pueden participar.

La escritura de un ensayo o artículo de opinión Después de la investigación bibliográfica y de campo y la organización de la información reunida en un esquema de las ideas centrales y las secundarias, se procede a la escritura del ensayo. Recordemos su estructura: presentación, desarrollo y conclusión. En la presentación debe incluirse por lo menos dos párrafos, uno de introducción, donde se va a describir y a justificar la elección del tema y el segundo de presentación más formal del mismo. El desarrollo debe contener tantos párrafos como aspectos diferentes tenga el tema central del ensayo: entorno, ideas, argumentos, ventajas y desventajas, ejemplos. La conclusión debe aportar inferencias, resumen de las ideas presentadas y una visión personal sobre el asunto tratado.

Organicemos nuestras ideas para la elaboración del artículo o ensayo, mediante un organizador gráfico en el que establezcamos ideas centrales y secundarias a abordar.

Con la información obtenida en las investigaciones que realizamos y a partir del organizador gráfico hecho en clase, redactemos el borrador de nuestro ensayo o artículo de opinión. Redactemos párrafos adecuados a los temas y subtemas contemplados en el esquema de ideas y relacionemos uno con otro de manera lógica. Recordemos que estos textos serán utilizados en nuestro proyecto de periódico mural.

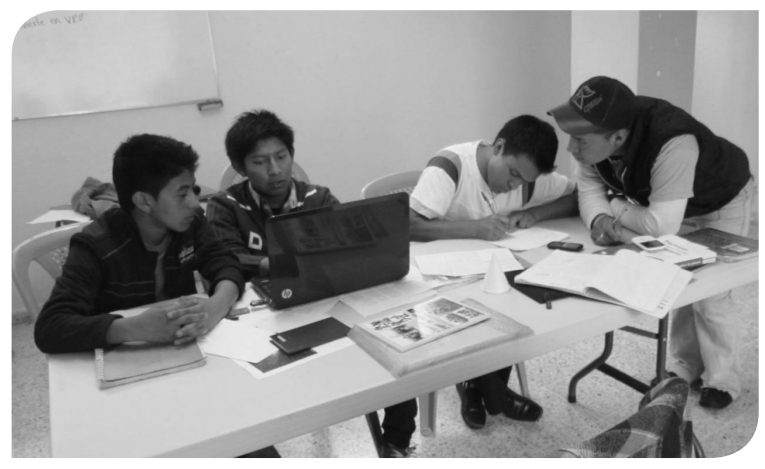




\section{La lógica interna de un texto escrito: coherencia y cohesión}

Un texto tiene coherencia cuando sus ideas están relacionadas entre sí de manera que tengan sentido y que presenten una estructura lógica. Esto se logra por medio del uso de temas y subtemas; de ideas principales e ideas secundarias en un párrafo. Así, para el lector del texto será más fácil captar el sentido global de lo que ha leído, si fue un texto.

La cohesión se logra por medio de recursos formales y de expresión que le darán al texto una forma atractiva y fácil de leer o de escuchar. Dentro de estos recursos podemos citar los lingüísticos o gramaticales, es decir, a la manera de utilizar las palabras, las oraciones, la puntuación y los párrafos.

Lo anterior, entonces, nos dice que el contenido de un ensayo lo va a regular la coherencia en tanto que, a la forma, la va a normar la cohesión. A partir de ahora podemos referirnos a coherencia y cohesión y sabremos que estamos refiriéndonos a la lógica y la armonía internas en un texto. Para lograrlos podemos valernos de herramientas de redacción como los conectores (palabras o frases que permiten enlazar una oración o un párrafo con otro); la sustitución (el uso de palabras sinónimas de las que se repiten en el texto); y la correferencia (la alusión a una idea ya contenida en el texto) para ampliar un subtema o enlazarlo con otro.

\section{Los códigos en la publicidad}

La publicidad genera hábitos culturales, sociales, familiares y de consumo. Nos empuja a aceptar códigos que, a su vez, nos van a condicionar para el intercambio comercial de bienes y servicios. Algunos de estos códigos son las imágenes de éxito, los modelos de triunfo, los paradigmas de felicidad, etc. Debemos prestar atención a los mensajes y al lenguaje persuasivo de los signos en publicidad para identificar en qué es lo que nos tratan de influir.

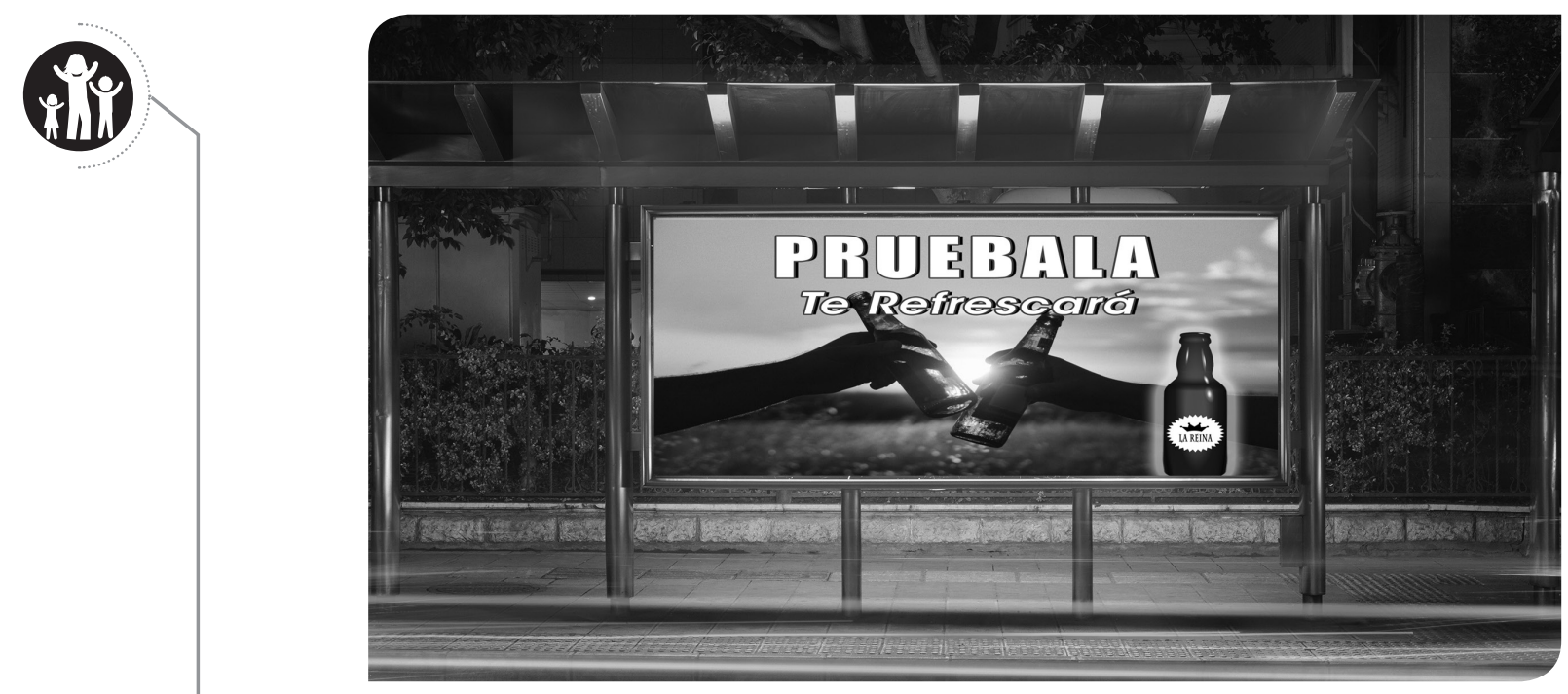

Analicemos la publicidad que invita al consumo de bebidas alcohólicas y de cigarrillos.

- ¿Qué códigos utiliza?

- ¿Su significado es directo o tiene un mensaje oculto?

- ¿En qué nos basamos para decirlo?

- ¿Qué significado adquiere al relacionarlo con los otros elementos y códigos?

Presentemos los resultados en forma escrita. Luego elaboremos anuncios que cuestionen los anuncios analizados. 


\section{Habilidades motoras y movimientos reflejos en el arte}

Desde que nacemos aprendemos a desplazarnos porque desarrollamos la habilidad motora que nos permite conocer el medio donde nos movemos. La habilidad de caminar implica un desarrollo amplio de los sentidos con respecto al espacio y el tiempo de desplazamiento. Al movernos también se desarrollan los movimientos reflejos ante lo que sucede en el entorno. Un ejemplo de habilidad motora y movimiento reflejo es el acto de agarrar una pelota. La primera vez el estímulo visual provoca que se evite el encuentro con la pelota, pero el aprendizaje por movimiento reflejo nos provoca atraparla en el aire.

Al bailar, al pintar, al tocar instrumentos, y al actuar, múltiples destrezas motoras han permitido que desarrollemos igual número de movimientos reflejos. Sin embargo, estas destrezas y reflejos se ven afectados cuando se desarrollan adicciones, ante lo cual, es posible que el arte ayude a su recuperación.

\section{Trabajemos en grupo}

- Hagamos una lluvia de ideas sobre los movimientos que realizamos con cada expresión artística.

- Ahora, la lluvia de ideas será sobre los movimientos que hacemos con otras actividades físicas.

- Planteemos posibles atrofias o fallas que se manifiesten en estas actividades al hacerlas bajo efectos de sustancias adictivas.

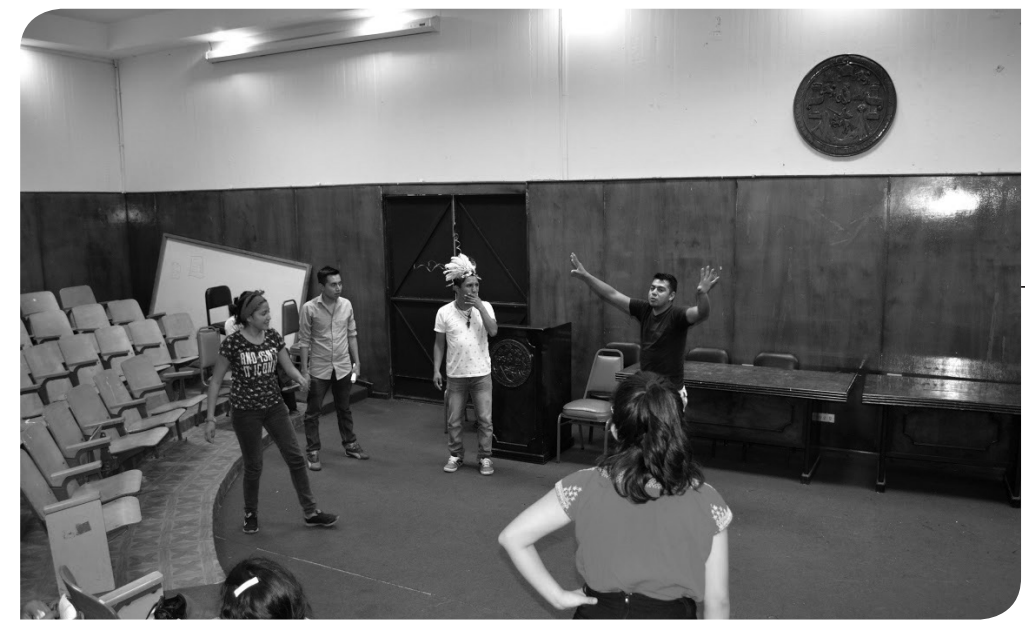

\section{Psicomotricidad fina y reflejos muy precisos}

\begin{tabular}{|c|c|c|c|}
\hline Danza & Teatro & Música & Artes Plásticas \\
\hline $\begin{array}{l}\text { El desplazamiento de la } \\
\text { danza requiere del ma- } \\
\text { nejo de un espacio que se } \\
\text { aprende inmediatamente } \\
\text { al bailar. En una fiesta } \\
\text { todas y todos bailan se- } \\
\text { parados entre sí, aunque } \\
\text { posiblemente en parejas, } \\
\text { pero no están chocándose } \\
\text { constantemente, pues la } \\
\text { habilidad motora les per- } \\
\text { mite guardar la distancia. }\end{array}$ & $\begin{array}{l}\text { El uso de la voz y de los } \\
\text { movimientos corporales } \\
\text { interactúa como una des- } \\
\text { treza motora que contro- } \\
\text { la el espacio donde se de- } \\
\text { sarrolla la actuación. Las } \\
\text { y los actores se desplazan } \\
\text { en espacios reducidos, } \\
\text { pero pueden dar la idea } \\
\text { de moverse en espacios } \\
\text { muy grandes. }\end{array}$ & $\begin{array}{l}\text { Al mover los dedos o las } \\
\text { manos, una destreza mo- } \\
\text { tora de calibre muy fino, } \\
\text { produce el aprendizaje } \\
\text { del desplazamiento a lo } \\
\text { largo y ancho de los ins- } \\
\text { trumentos. Los instru- } \\
\text { mentos llegan a ser una } \\
\text { extensión del cuerpo de } \\
\text { los ejecutantes. }\end{array}$ & $\begin{array}{l}\text { El manejo del pincel y } \\
\text { el lápiz requiere de psi- } \\
\text { comotricidad fina para } \\
\text { desarrollar trazos suma- } \\
\text { mente precisos. Quien } \\
\text { esculpe aplica peso al } \\
\text { martillo para romper la } \\
\text { piedra y esculpir las cejas } \\
\text { de un rostro. Los movi- } \\
\text { mientos reflejos son muy } \\
\text { importantes para realizar } \\
\text { este arte tan complejo. }\end{array}$ \\
\hline
\end{tabular}




\section{Circunstancias que afectan la habilidad motora y movimientos reflejos}

La dopamina es un neurotransmisor natural que todas las personas producimos. Su función está relacionada con las sensaciones de placer en sus diferentes manifestaciones. Las drogas alteran el efecto de la dopamina, pues aumentan o limitan las sensaciones que el cerebro percibe. Esto provoca que la habilidad motora se vea comprometida de tal manera que los movimientos llegan a ser más lentos, o bien más animados. Si esto fuera normal, todo estaría bien, pero al ser una condición provocada por sustancias adictivas, sus efectos trascienden a la persona y alcanzan a su entorno.

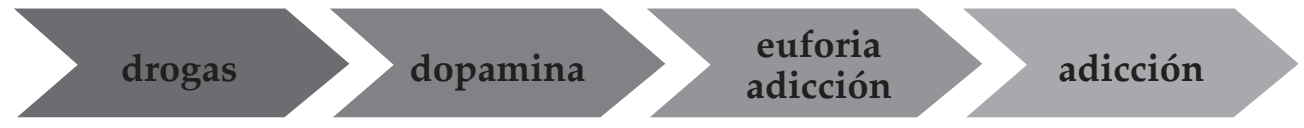

Una persona adicta a las drogas necesita dosis cada vez más frecuentes o mayores de ellas para sentir el placer y la euforia que provocan. Sin embargo, al diluirse las sustancias en el organismo, hay una sensación de resaca que provoca una gran necesidad de repetir las dosis. Por eso es que muchas personas se vuelven alcohólicas o drogodependientes.

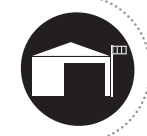

\section{Juego escénico: La Dopamina se altera y causa estragos}

- En grupos, organizaremos un juego escénico para mostrar la forma en que afectan las adicciones, las destrezas motoras y reflejos.

- Cada grupo contará la historia, usando los personajes y el argumento que se sugiere.

Personajes: persona adicta 1 (A1), persona adicta 2 (A2), Guarito, Coquis, Dopamina, víctimas

\section{Argumento y Relato para actuar:}

Acto 1: A1 y A2 van al parque de paseo, planean ir en sus bicicletas a un lugar de recreo. A1 es una persona adicta al alcohol, A2 a la cocaína. En el parque anda Guarito y Coquis ofreciendo sus productos. A1 y A2 compran sus bolsitas y las consumen en el parque.

Acto 2: Mientras A1 y A2 consumen en esa esquina, en el centro del escenario. Aparece Dopamina, dormitando en una silla. Se despierta. Gesticula mucha felicidad en el rostro. Va creciendo su felicidad. En la medida que en la esquina A1 y A2 consumen, Dopamina comienza a desesperarse, actúa cada vez más rápido, comienza a correr de un lado a otro en la sala, se tira al piso, da vueltas, se levanta rápidamente, sigue corriendo, se detiene de pronto y comienza a hacer sonidos escandalosos, se cae, se levanta, sigue corriendo hasta que cae de nuevo, rendida y cansada en la silla.

Acto 3: Tanto a A1 como A2 les ha afectado mucho lo que consumieron. Deciden ir al parque de recreo. Se ponen de acuerdo y se dirigen a sus bicicletas, las montan y se van. A1 y A2 sienten euforia y necesitan otra dosis. Paran en una calle y se aplican otro trago y otra inhalación. Siguen manejando cada vez más rápido. Llegan rapidísimo a un espacio lleno de gente, un mercado o una calle muy transitada. Les está costando controlar sus movimientos. Los dejan ir y atropellan a varias víctimas que están caminando o paseando en ese espacio.
Discusión grupal sobre los efectos

En grupos, realizamos una mesa redonda o un foro para opinar sobre las formas en que el consumo de sustancias adictivas afecta nuestro rendimiento en actividades físicas.

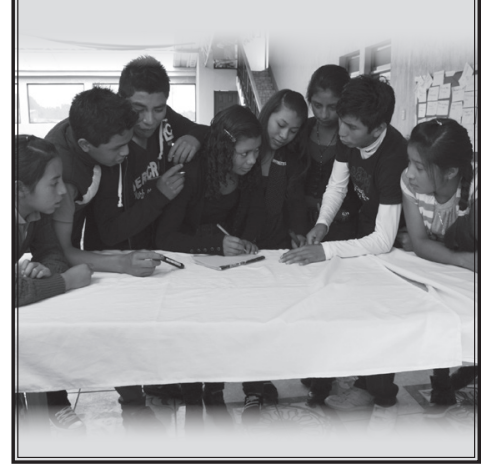




\section{Liderazgo y desarrollo humano}

\section{Huertos escolares y familiares}

Gran parte de la niñez guatemalteca sufre desnutrición crónica debido a la falta de consumo de una dieta suficiente sana y variada.

Estos niños y niñas se reconocen por ser de baja estatura para su edad. Además del peligro de muerte, corren el riesgo de que su cerebro, músculos y otros órganos no se desarrollen adecuadamente.

Debido a la lejanía, la falta de transporte y la pobreza, muchas familias ofrecen a sus hijos e hijas comidas elaboradas a base de maíz como principal alimento.

Los huertos familiares y escolares son una opción para obtener variedad de frutas y verduras que proporcionen una dieta balanceada. Un huerto bien trabajado y cuidado puede proporcionar alimentos para la familia e incluso para vender.

El cuidado de un huerto también puede ser una actividad educativa y terapéutica, que ayude a usar el tiempo libre y brindar paz, enseñar paciencia, disciplina y perseverancia a personas que están tratando de abandonar alguna adicción.

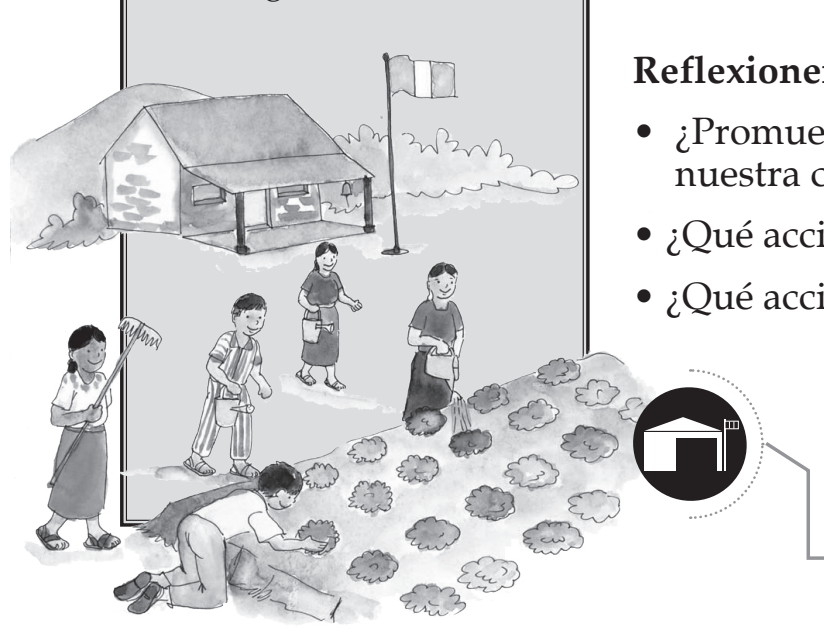

Revisemos nuestra propuesta de periódico mural y reflexionemos ¿estamos creando conciencia sobre el impacto de las adicciones en él ? 
En la actualidad más jóvenes, mujeres y hombres, tienen acceso a la educación; por lo tanto, tienen mejores herramientas para exigir a las autoridades municipales y organizaciones gubernamentales el cumplimiento a sus derechos.

La población joven representa el presente de la comunidad, el vínculo entre generaciones, pueden dar continuidad a los conocimientos ancestrales en nuevas circunstancias. La juventud enfrenta nuevos desafíos: desempleo, narcotráfico, trata de personas, migración y otros. Necesitamos una visión fresca y dinámica para encontrar soluciones creativas que permitan el desarrollo de cada persona.

\section{Reflexionemos:}

- Identifiquemos a líderes y lideresas de nuestra comunidad: incluyamos hombres y mujeres ¿hay jóvenes de ambos sexos?

- ¿En qué ámbitos aportan: social, económico, político, salud u otro?

- ¿Qué tipo de proyectos han promovido?

- ¿Qué tipo de reconocimiento reciben: familiar, comunitario, municipal?

- ¿Qué segmentos de la población se benefician con los proyectos que han promovido?

Podemos llenar un cuadro similar que nos ayudará a conocer y discutir el impacto de los líderes y lideresas en el desarrollo de nuestra comunidad:

\begin{tabular}{|l|l|l|l|l|l|l|}
\hline Nombre & Sexo & Edad & Ámbito & Beneficio & Proyectos & Reconocimiento \\
\hline & & & & & & \\
\hline & & & & & & \\
\hline
\end{tabular}

Estamos organizando y preparando material para la elaboración de nuestro periódico mural. Revisemos:

- ¿Hemos investigado el tema de las adicciones desde distintas perspectivas?

- ¿Hemos relacionado la información investigada con la realidad de nuestra comunidad?

- ¿Conocemos las iniciativas de distintas organizaciones locales para prevenir o disminuir las acciones en nuestra comunidad?

- ¿Conocemos las opiniones y el sentir de personas adictas y sus familias?

- ¿Estamos listos y listas para analizar el impacto de las adicciones en nuestra comunidad?
Derechos de la mujer y empoderamiento femenino

Las mujeres que conocen sus derechos comienzan a ejercerlos y a crear cambios sociales para lograr una sociedad más equitativa.

Crean un ambiente más favorable en su hogar al priorizar el diálogo como herramienta de comunicación con su pareja en una búsqueda por un "andar juntos", en el que él también cuida el hogar y los niños mientras la mujer se capacita y también participa en proyectos que apoyan económicamente al hogar y al bienestar comunitario.

Lideresas están al frente de asociaciones femeninas que generan ingresos económicos.
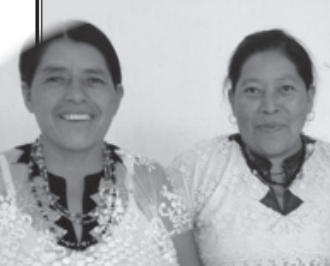

Lideresas, Comité de Mujeres Trabajadoras Las Orquídeas, Cunén, Quiché. 


\section{H oapltalismo ollobal y la expansión del consumo}

En nuestro país hay movimientos que defienden los recursos naturales. ¿Cuáles has escuchado que son las preocupaciones que tienen las y los defensores de los recursos naturales? ¿cuál es la responsabilidad del Gobierno frente a los derechos de la población?

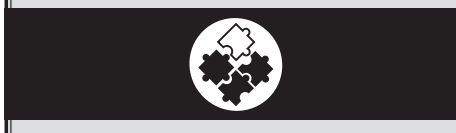

“... el crecimiento mundial durante el segundo semestre de 2015, de $2.8 \%$, fue más débil de lo previsto anteriormente y registró una desaceleración importante durante el último trimestre del año. Esta inesperada debilidad de finales de 2015 fue consecuencia, en gran medida, de una moderación de la actividad en las economías avanzadas, en especial en Estados Unidos, pero también en Japón y otras economías avanzadas de Asia."

Fuente: Fondo Monetario Internacional (2016). Perspectivas de la economía mundial. Crecimiento demasiado lento por demasiado tiempo. Recuperado de: https: / / www. imf.org/external/spanish/ pubs/ft/weo/2016/01/ sspdf/texts.pdf

Cuando disminuyen los ingresos de la mayoría de la población, también disminuye el consumo. ¿Cuál es la relación con el limitado crecimiento de las economías avanzadas?

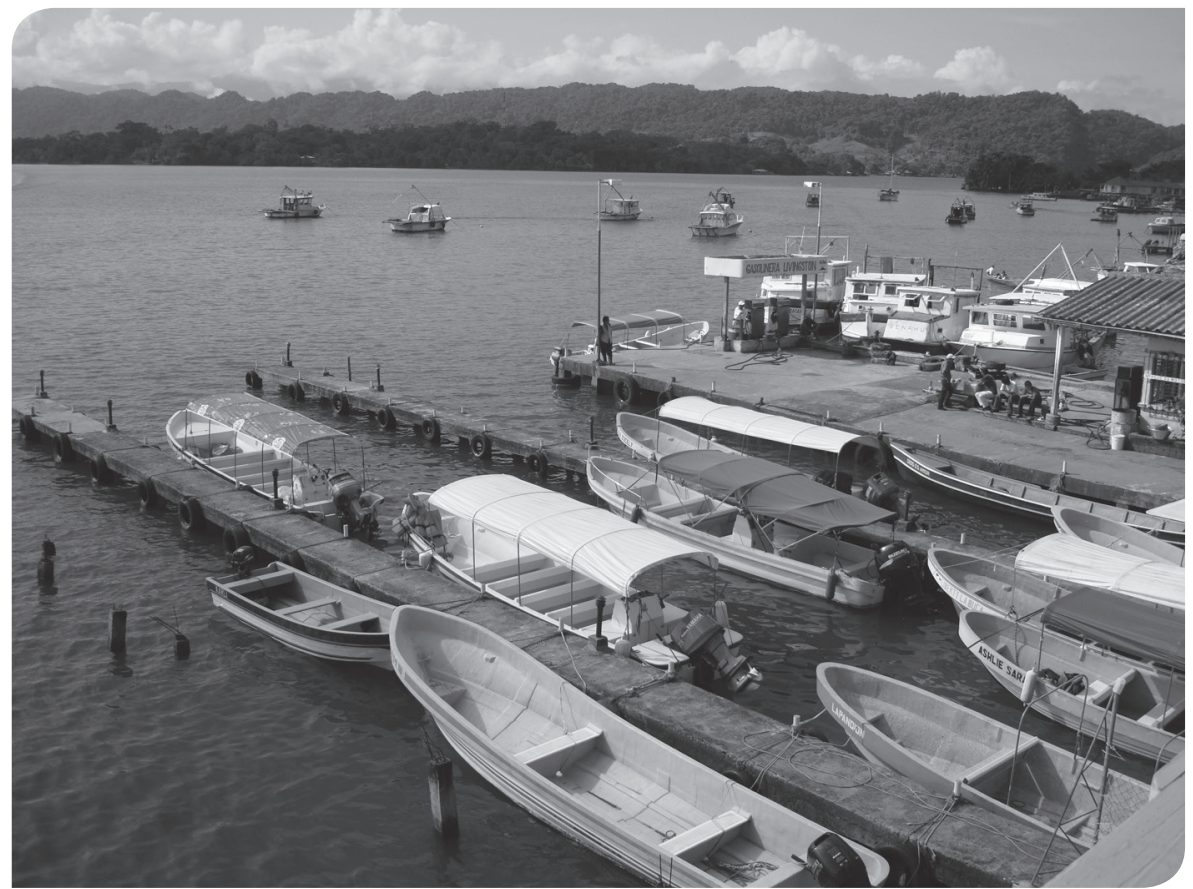

El sistema de libre empresa que se desarrolla en un mundo globalizado se llama capitalismo global. Una de sus características principales es que los mercados financieros, donde se hacen préstamos y se aseguran negocios y personas, son los que alcanzan más ganancias y acumulan mucho poder. Los mercados financieros tienden a obtener ganancias por el conocimiento que tienen del cambio de precio de las monedas, por ejemplo: conceden préstamos que a corto plazo subirán de interés.

El capitalismo global apoya medidas para que el Estado tenga menos ingresos y reduzca su tamaño. Con la reducción del Estado, dejan de ofrecerse servicios públicos a la ciudadanía como educación, salud y transporte y esto permite nuevos negocios para las empresas privadas. El Estado se limita en su capacidad de proteger el ambiente natural. Con el debilitamiento de los estados, las grandes empresas transnacionales ofrecen y cobran por más servicios. Llegan a tener más poder que muchos gobiernos.

A partir de 2007, el capitalismo global es inestable. En el mundo se están produciendo más bienes y servicios de los que la población puede y necesita comprar. El desarrollo de la tecnología e innovaciones productivas aumenta pero, generalmente limitadas al grupo de personas que tiene más recursos para producir y adquirirlas. Esto genera más riqueza para un grupo limitado de personas; y las sociedades se hacen más desiguales. La pobreza se incrementa pues los salarios reales valen menos y el desempleo aumenta. Se han presentado grandes movimientos sociales en su contra, cuestionando a muchos gobiernos que promueven el sistema.

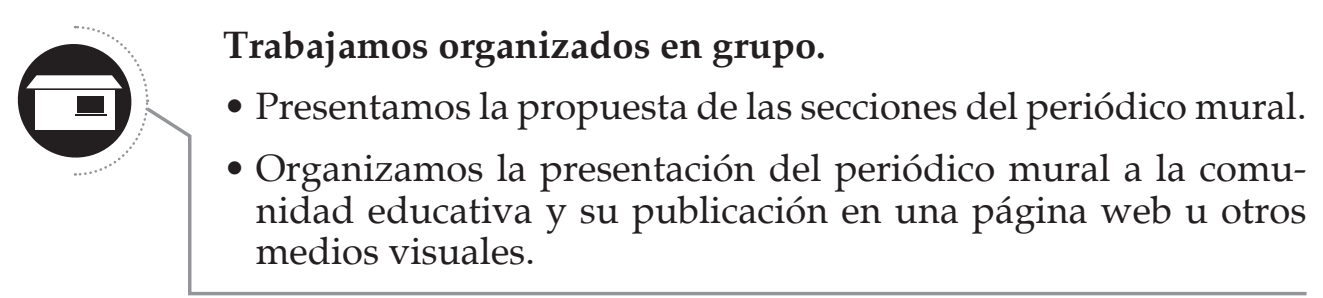




\section{Nuevos bloques económicos}

Cuando la crisis del capitalismo global comenzó a expandirse, en 1998, varios países tomaron medidas para evitar que sus economías sufrieran las consecuencias o que los efectos fueran menores.

Países como Noruega, Suecia e Islandia han enfrentado la crisis con medidas nacionales:

- hacer más eficiente al Estado,

- regularizar el valor de sus monedas,

- proteger el bienestar de la población a través de inversión social y *mejorar su comercio interno y externo.

Otros países optaron por crear nuevos bloques económicos para enfrentar la crisis. El proyecto que más ha avanzado es el impulsado por cuatro países emergentes: Brasil, Rusia, India y China. Se les llama emergentes porque su crecimiento ha sido relativamente alto y se ha mantenido por varios años. Por ello se piensa que a largo plazo se equipararán con los países de mayor desarrollo económico. A este bloque se le llamó BRIC, palabra formada con la letra inicial de cada nombre de los cuatro países; luego con la incorporación de Sudáfrica se llamó: BRICS. La importancia de este bloque radica principalmente en su recurso humano. Estos países cuentan en conjunto con más del $44 \%$ de total de la población mundial, la enorme riqueza de sus recursos naturales y el desarrollo de sus fuerzas productivas.

El bloque BRIC comenzó proponiendo que los organismos multinacionales, como el FMI, BM y OMC, hagan más públicas sus decisiones y acciones, además de democratizar su funcionamiento. En los últimos años ha tomado medidas unificadas: emplear las monedas de sus respectivos países para el intercambio comercial, realizar reuniones cumbre cada año, concentrar recursos económicos para apoyarse en situaciones de emergencia y la creación de un Banco de Desarrollo.

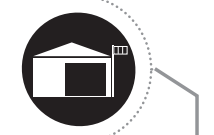

Con nuestro grupo, comentamos las diferentes estrategias en las acciones que los países han tomado para evitar que la crisis mundial afecte drásticamente sus economías. ¿Qué inversión sería una prioridad para prevenir la expansión de las adicciones, en caso de que hubiera una crisis en nuestra comunidad?

- Realizamos la preparación final de materiales para la presentación del periódico mural a la comunidad.

- Adecuamos los materiales para subirlos a la página web o presentarlos en otro formato visual.

En 2016, el senado de Brasil destituyó a la presidenta Dilma Rousseff y el nuevo gobierno realizó cambios en las medidas económicas del país. ¿Cómo afectan acontecimientos como este, al BRICS?

Muchos críticos opinan que los países que integran el BRICS tienen diferencias económicas, políticas y culturales que les impedirá mantenerse como bloque. Emito mi opinión con respecto al criterio que propone que la diversidad es un impedimento para coordinarse y fortalecerse en conjunto? 


\section{Conjuntos y plano cartesiano}

En los diagramas de Venn los espacios que se comparten entre dos o más conjuntos representan los elementos que esos conjuntos tienen en común. El diagrama siguiente muestra, en cada región, la cantidad de personas que tienen preferencia por cierta fruta: fresa, durazno y chico.

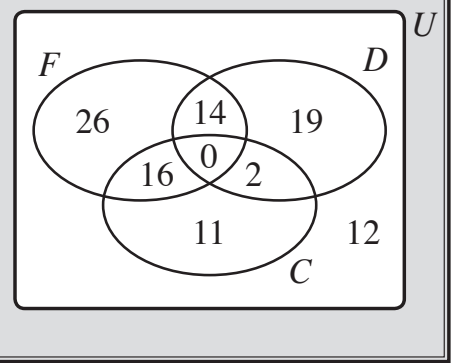

En equipos nos reunimos para intentar resolver el siguiente problema:

En una comunidad se reciben tres distintos periódicos impresos: $A, B$ y $C$. En el último mes el $20 \%$ de la población recibió el periódico $A, 24 \%$ recibió el $B$ y el $28 \%$ recibió el $C$. Se sabe también que el $4 \%$ de la población recibió los periódicos $A$ y $B$, el $5 \%$ recibió el $A$ y $C$ y el $6 \%$ recibió el $B$ y el $C$. El $1 \%$ de los habitantes recibió los 3 periódicos.

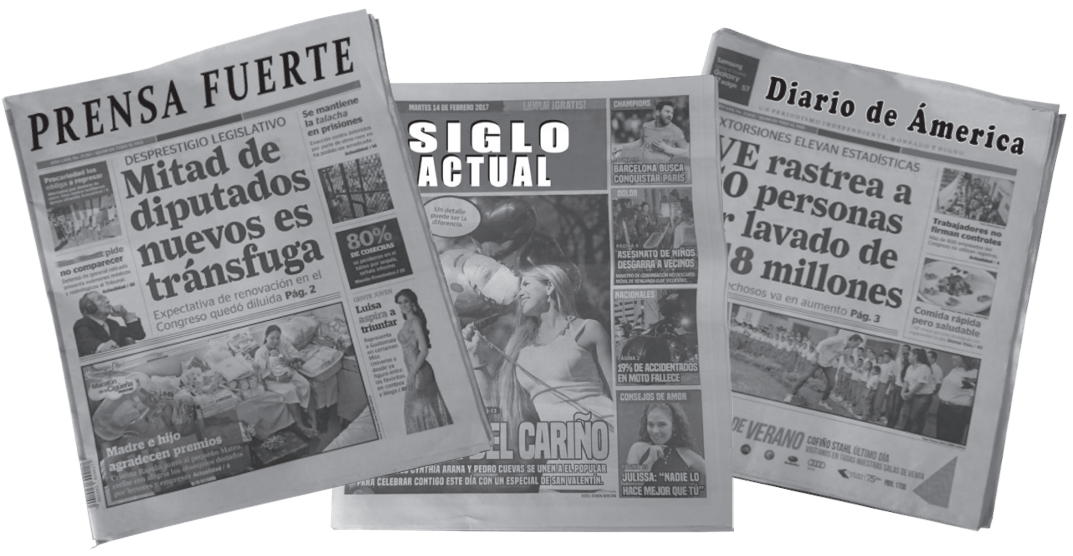

Copiamos en nuestro cuaderno un diagrama como este. Colocamos los porcentajes que corresponden en cada región según los datos de cuántas personas reciben cada periódico. Comparamos nuestras respuestas con las de los demás equipos.

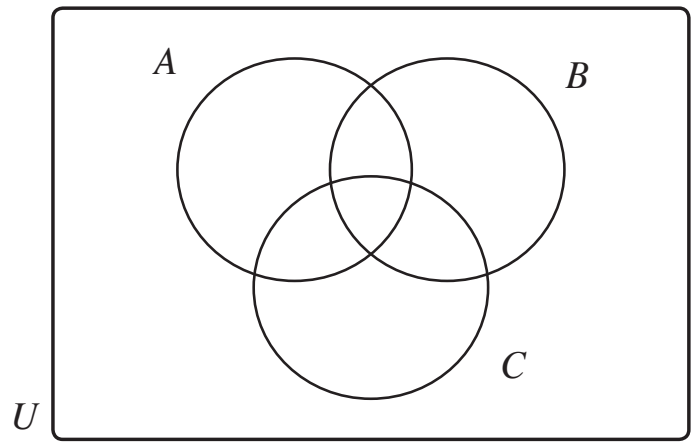

En los mismos grupos nos reunimos para contestar:

- ¿En qué lugares de nuestra comunidad se venden cigarrillos y bebidas alcohólicas? ¿Podemos representar esa información con un diagrama de Venn?

- ¿Qué otras situaciones de la vida real se pueden representar con diagramas de Venn?

Mencionamos al menos dos ejemplos y los compartimos con el resto de compañeras y compañeros. 
El diagrama a continuación muestra la cantidad de personas de una comunidad que se dedican al cultivo de tomate $(T)$, banano $(B)$ y sandía $(S)$. Analizamos su información y luego contestamos.

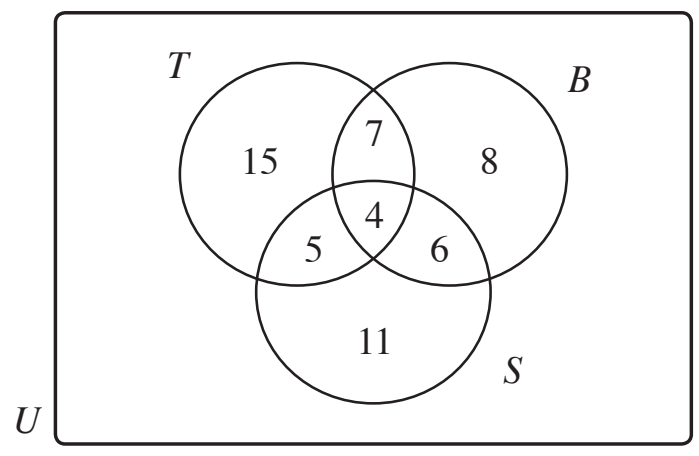

- ¿Cuántas personas cultivan cada tipo de fruta?

- ¿Cuántas personas solo cultivan banano?

- ¿Cuántas personas cultivan tomate, pero no banano?

- ¿Cuántas personas cultivan banano y sandía, pero no tomate?

Revisamos la información que tenemos para colocar en el periódico mural y analizamos si alguna puede ser representada por medio de un diagrama de Venn. Dibujamos nuestras propuestas y las compartimos con el resto de compañeras y compañeros. Discutimos para determinar cuál propuesta es la más adecuada.

Utilizamos un diagrama de Venn para representar la siguiente situación en nuestro cuaderno. Dejamos constancia de los cálculos realizados.

En una escuela a 38 estudiantes se les pasó una encuesta acerca de sus habilidades manuales. En sus respuestas, 15 dijeron que podían dibujar, 12 que podían tejer y 23 dijeron que podían modelar barro. También 9 afirmaron que podían modelar barro y dibujar, 5 podían dibujar y tejer y 6 dijeron que eran capaces de tejer y modelar con barro.

- ¿Qué cantidad de estudiantes pueden únicamente modelar barro?

- ¿Qué cantidad de estudiantes no tienen ninguna de las tres habilidades?

- ¿Qué cantidad de estudiantes tienen exactamente dos de las tres habilidades mencionadas?
Un conjunto $A$ es subconjunto de otro conjunto $B$ si todos los elementos de $A$ están contenidos en el conjunto $B$. Gráficamente se representa así:

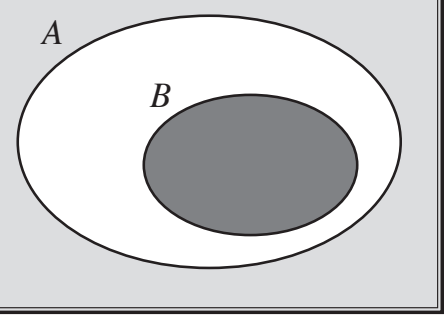




\section{La revisión del texto en la culminación del ensayo}

Uso de preposiciones

Una preposición es la palabra que enlaza dos elementos en una oración. Da información como punto de partida, dirección, posición, lugar, motivo, origen, etc., $y$ puede ser: a, ante, bajo, con, contra, de, desde, en, entre, hacia, hasta, para, por, sin, sobre, según y tras.

Ejemplos:

- Mi padre llegó a casa.

- Ana viene de la escuela.

- El periódico está bajo el libro.

- No la veo desde ese día.

- Me gusta las tortillas con queso.

- Escribiré mi ensayo sobre el tabaquismo.

- Luchemos juntos contra las adicciones.

- Caminemos hacia el parque para ejercitarnos.

- Raquel argumentó su punto ante la injusticia.

- Los hijos remodelaron la casa tras su partida.

- Estudiaré hasta graduarme.

- A Carmen le gusta la casa en el lago.

- Pela las verduras para cocinarlas.

- Mariela llegó a la universidad por sus esfuerzos.
Al terminar de escribir el borrador o la primera versión de un ensayo o un artículo de opinión, el siguiente paso es evaluarlo con base en los objetivos y metas que nos propusimos en un principio. Conforme vamos leyendo el trabajo, seguramente descubriremos errores de redacción e ideas que necesitan reforzarse. Se pueden escribir anotaciones al margen o en un cuaderno aparte, de todos los cambios que deben hacerse al texto. Al concluir la revisión del borrador inicial, deben hacerse los ajustes necesarios y corregirse en función de su forma final.

Las personas expertas también recomiendan:

- dejar un tiempo de reposo suficiente al texto para que, cuando volvamos a leerlo, resalten los errores y los aciertos y los podamos corregir con mayor objetividad;

- dejar la revisión del desarrollo antes de la introducción y las conclusiones, así, cuando leamos estas otras partes, veremos si están enlazadas apropiadamente;

- leer el trabajo en voz alta y dárselo a leer a una persona con más experiencia que nosotros para que nos haga sus sugerencias para mejorarlo.

- Revisemos nuestros textos en todos los aspectos previos. Intercambiemos los trabajos.

- Elaboremos una lista de cotejo para hacer esta evaluación. Sometamos nuestro trabajo a la lectura de una persona calificada para que nos haga sugerencias para mejorarlo.

- Luego, redactemos la versión final del trabajo.

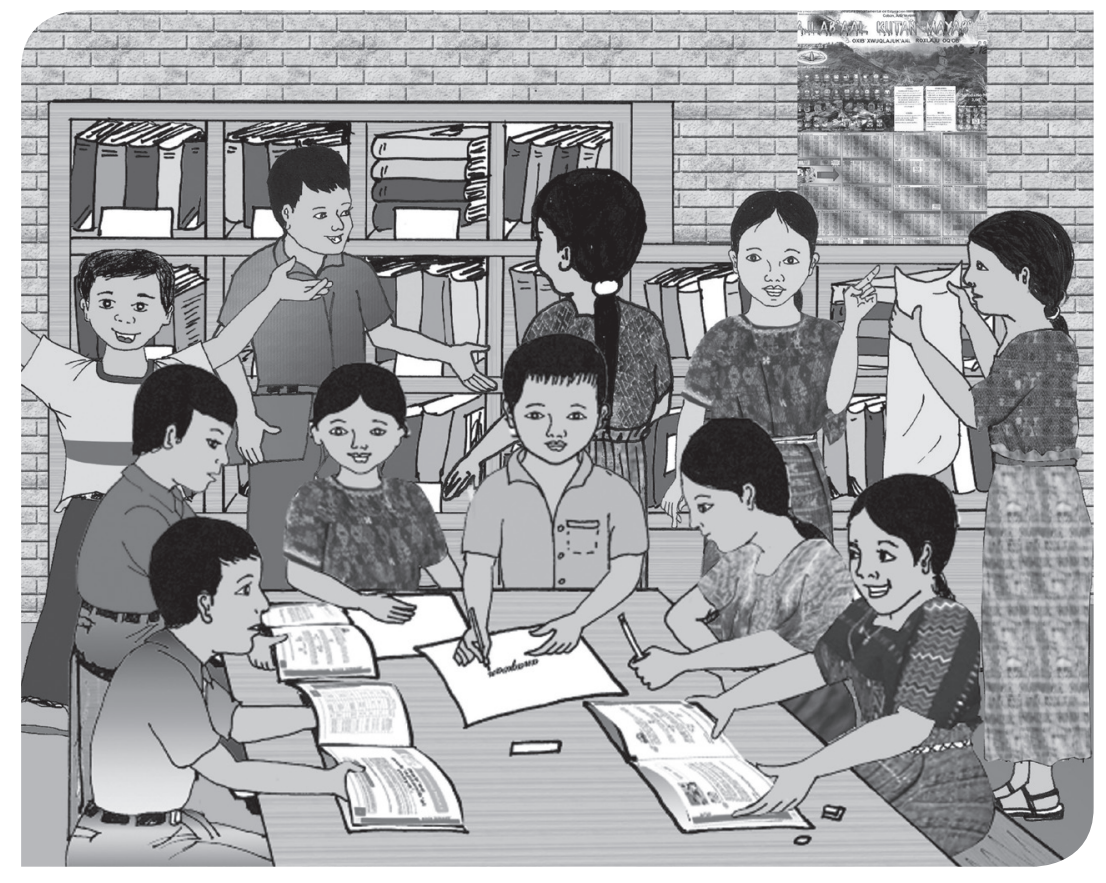




\section{Problemas que dificultan la comunicación oral o escrita}

El proceso de la comunicación resulta muy natural entre los seres humanos. Sin embargo, más a menudo de lo que pensamos, se entorpece debido a razones de diversa índole que, en Lingüística, se llaman ruido. A la vez, hay componentes que favorecen el proceso comunicativo. Veamos algunos factores que inciden en la efectividad de la comunicación:

\begin{tabular}{|l|l|}
\multicolumn{1}{|c|}{ Factores que facilitan } & \multicolumn{1}{c|}{ Factores que dificultan } \\
\hline $\begin{array}{l}\text { Comprender y manejar los códigos } \\
\text { de la comunicación en la cultura } \\
\text { donde se está. }\end{array}$ & $\begin{array}{l}\text { Hacer afirmaciones sin fundamento, } \\
\text { radicales o dogmáticas. }\end{array}$ \\
\hline $\begin{array}{l}\text { Escuchar atentamente a quien nos } \\
\text { habla. }\end{array}$ & Redundar \\
\hline Hablar con libertad y naturalidad. & $\begin{array}{l}\text { Usar el lenguaje con dificultad } \\
\text { inadecuadas o de doble sentido, tono } \\
\text { inapropiado de voz, letra ilegible. }\end{array}$ \\
\hline $\begin{array}{l}\text { Hablar con claridad, autenticidad } \\
\text { y respeto. }\end{array}$ & Hablar con rodeos. \\
\hline $\begin{array}{l}\text { No sentirse juzgado o juzgada ni } \\
\text { estar a la defensiva. }\end{array}$ & No respetar a las demás personas. \\
\hline $\begin{array}{l}\text { Hablar más acerca de lo que une, } \\
\text { que de lo que separa. }\end{array}$ & $\begin{array}{l}\text { No admitir el debate y las ideas } \\
\text { diferentes. }\end{array}$ \\
\hline
\end{tabular}

\section{La lista de cotejo}

En nuestra educación se es necesario evaluar nuestros avances para alcanzar la eficiencia. Para ayudarnos en esta tarea usamos una lista de cotejo. Esta es un listado de aspectos que han de valorarse en diferentes grados. Puede incluir aspectos como habilidades, conductas, conocimientos, etc. Algunas listas de cotejo incluyen un puntaje, una nota o una valoración en palabras (bueno, malo, regular, excelente). En educación resulta una herramienta muy útil para calificar los logros o los desaciertos de indicadores. Por ejemplo:

\begin{tabular}{|l|l|l|l|}
\hline \multicolumn{2}{|c|}{ Lista de Cotejo para la evaluación del proceso de organizar un foro } \\
\hline $\begin{array}{l}\text { Se escogió el tema y se establecieron sus } \\
\text { alcances }\end{array}$ & Hecho & No hecho & Pendiente \\
\hline $\begin{array}{l}\text { Se anunció la actividad en la } \\
\text { comunidad }\end{array}$ & & & \\
\hline Se invitó a las y los participantes & & & \\
\hline $\begin{array}{l}\text { Se preparó el lugar donde se llevará a } \\
\text { cabo el foro }\end{array}$ & & & \\
\hline
\end{tabular}

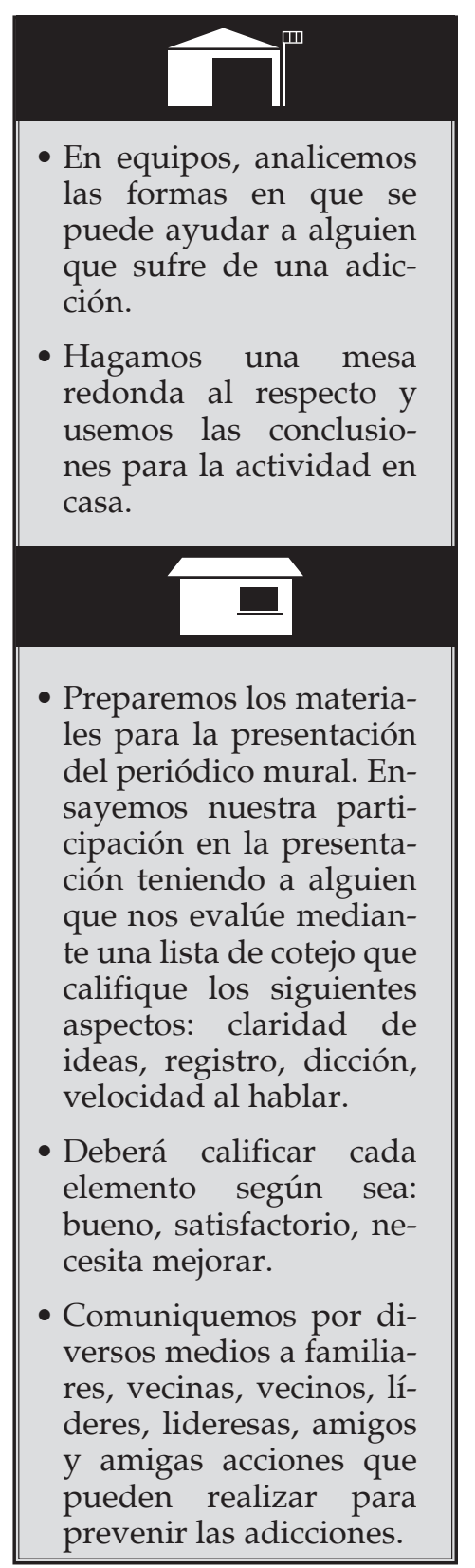




\section{Equifọa de género para una sociedad más justa}

\section{Bienestar y desarrollo para todos y todas}

La sociedad es como el engranaje de un reloj de agujas. Todas las personas somos importantes y cumplimos un papel especial en el engranaje de la sociedad guatemalteca. Muchas veces sentimos que este engranaje se ha trabado, porque no hemos reconocido la importancia del más grande hasta el más pequeño de las piezas de esta maquinaria. Para que esta maquinaria trabaje bien, debemos engrasarla con justicia social, limpiarla de la desigualdad y hacerla brillar con oportunidades de bienestar para todos y todas.

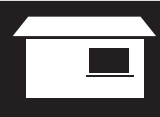

Elabora un horario y anota las actividades que todas las personas que integran tu familia realizan en un día cualquiera. Tienes un ejemplo:

\begin{tabular}{||c|c|c|}
\hline Hora & Mamá & Pap \\
\hline 4:00 am & & \\
\hline $5: 00$ am & & \\
\hline $\begin{array}{l}\text { Discute con tu familia los } \\
\text { resultados. ¿Hay alguien } \\
\text { con más carga de trabajo? } \\
\text { ¿Cómo podemos colaborar } \\
\text { para disminuir esa carga? } \\
\text { ¿Qué otros cambios pode- } \\
\text { mos hacer? }\end{array}$ \\
\hline
\end{tabular}

El Articulo 1 de la Declaración Universal de Derechos Humanos, establece que todos los seres humanos nacemos libres e iguales en dignidad y derechos. Hombres y mujeres tenemos derecho al mismo trato y oportunidades porque tenemos las mismas capacidades a pesar de las diferencias físicas.

Las diferencias biológicas entre hombre y mujer no determinan las capacidades de cada sexo. Sin embargo, la sociedad y la cultura influyen en la forma de ser, actuar y pensar de hombres y mujeres, designándoles roles de género. Los hombres gozan de más privilegios que las mujeres por el rol que la sociedad les ha asignado como protector y proveedor de la familia en detrimento de la manifestación de sus sentimientos. A la mujer se le ha designado como protectora y cuidadora de su familia lo que limita sus posibilidades de realización en otras áreas, como la económica o la política, por ejemplo. Estos patrones de pensamiento y comportamiento hacen que las mujeres sean más vulnerables ante situaciones de abuso y violencia, incluida la explotación sexual.

El respeto a los derechos humanos es indispensable para lograr el desarrollo humano. Para conseguirlo comencemos por sentir empatía: ponernos en los zapatos de la otra persona nos permite reconocer su dignidad. El segundo paso es identificar las situaciones y acciones que invisibilizan, desvalorizan y limitan el acceso a las oportunidades para uno mismo y los demás. Un tercer paso, es actuar para cambiar. Buscar la equidad permitirá, tanto a mujeres como hombres, liberarse de las ideas que les limitan y sobreponerse a conductas dañinas que se fundamentan en la dominación y discriminación.

- ¿Qué aprendizajes se inculcan a los hombres y las mujeres sobre su relación con productos que generan adicciones como el alcohol?

- ¿Qué problema genera, para las mujeres y para los hombres, cuando hay adicciones en la familia?

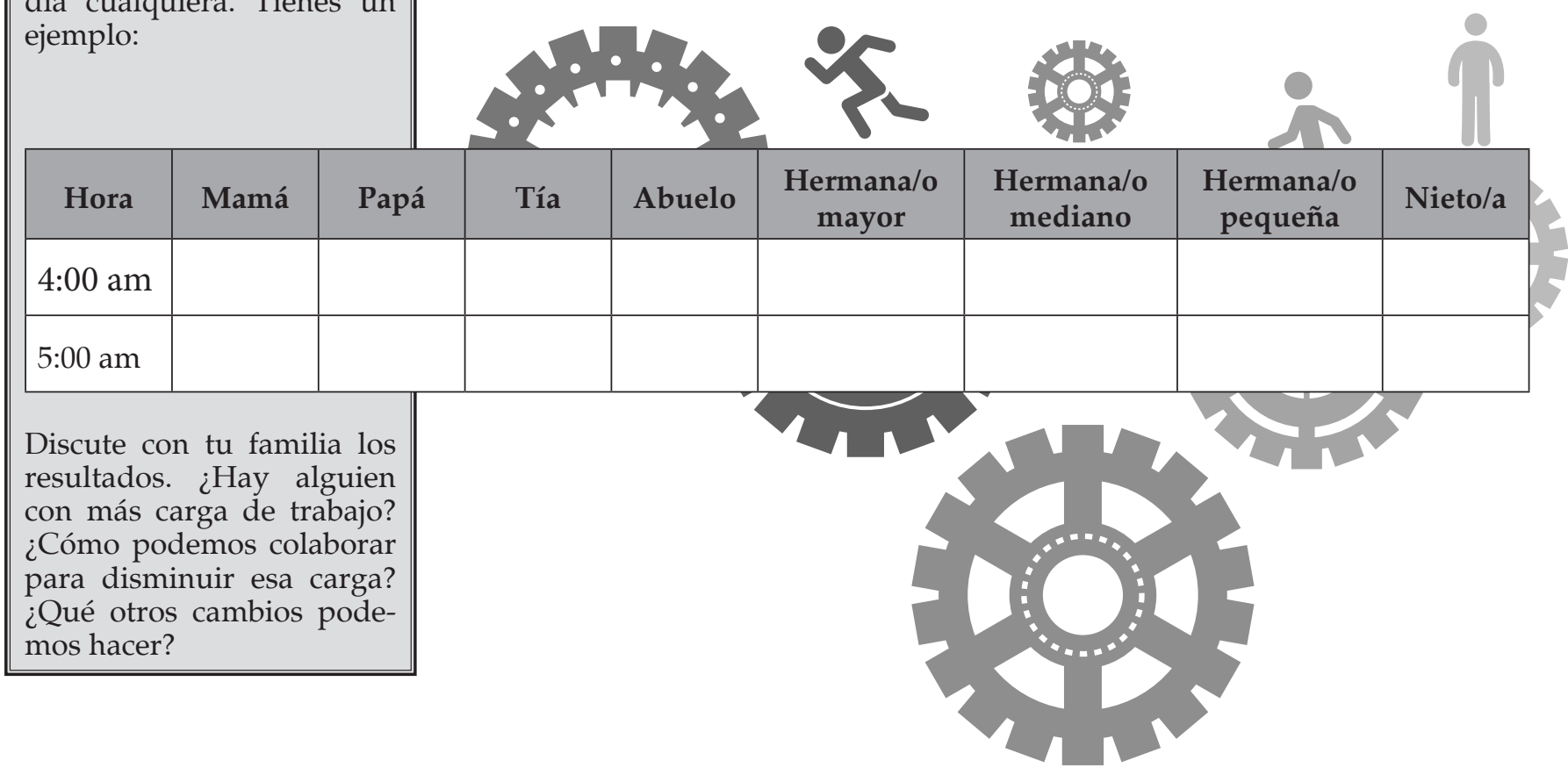




\section{Análisis de género aplicado a un periódico}

Como parte de la preparación del periódico mural analizaremos el contenido de un periódico. Nos organizamos en grupos de tres personas. Cada grupo tomará una hoja de un periódico y observará lo siguiente:

- ¿Qué tipo de sección incluye la página (editorial, reportaje, columnas de opinión, anuncios, otros)?

- ¿Cómo están presentadas las diferentes noticias u otra información en la página? ¿Hay alguna información que destaca más que otra?

- ¿Qué muestran las fotografías que acompañan al texto?

- ¿Cuál tipo de información resalta más por el tamaño del texto?

- ¿Las noticias presentan hechos con evidencia o incluyen opiniones?

Compartimos con las compañeras y compañeros lo que encontramos al analizar nuestra página. Entre todas y todos tratamos de responder lo siguiente:

- ¿Las noticias u otras informaciones representan de igual manera a hombres y mujeres? ¿a personas indígenas y no indígenas?

- Respecto a quienes escriben, ¿hay igual número de hombres y mujeres? ¿indígenas y no indígenas? ¿de diferentes posiciones políticas o religiosas?

- ¿Cómo describen a hombres y mujeres? ¿Utilizan lenguaje escrito o visual con equidad de género?

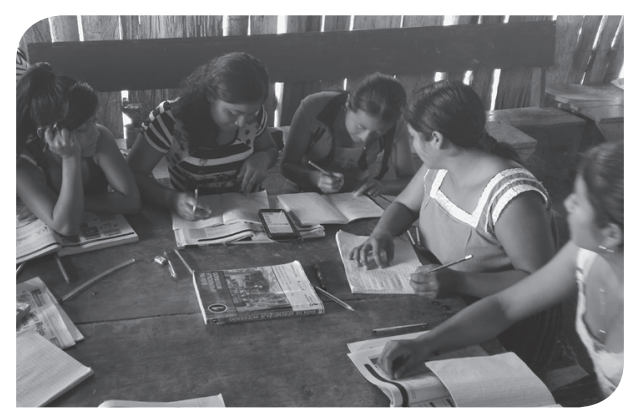

Jóvenes de Sehamay, San Luis Petén

Apliquemos la lista de cotejo para verificar que el periódico mural tenga un trato equitativo hacia las mujeres.

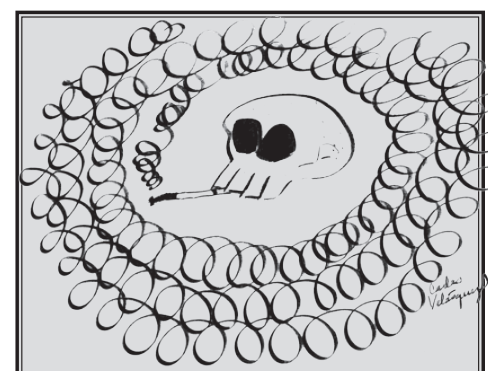

La caricatura, otro medio de expresión

En un periódico, la caricatura es una columna de opinión gráfica que expresa por medio de un dibujo la opinión de quien la hizo respecto a la situación.

Utiliza metáforas visuales para transmitir con humor el análisis de algún asunto.

Quien hace caricatura, al igual que quien escribe opinión, lee y analiza los acontecimientos para presentar sus argumentos por medio del dibujo.

- Si hay alguna persona en la escuela o la comunidad a quien le gusta dibujar, propóngale que participe en el periódico mural. Desarrollamos caricaturas que promocionan la prevención de las adicciones y las colocamos en afiches en los lugares públicos de nuestra comunidad y en el periódico mural.

\begin{tabular}{|c|c|c|}
\hline & $\mathrm{Si}$ & No \\
\hline ¿Participan como autores hombres y mujeres por igual? & & \\
\hline $\begin{array}{l}\text { ¿Participan alumnas en la investigación y redacción de noticias con contenido políti- } \\
\text { co? }\end{array}$ & & \\
\hline ¿Expresan las alumnas su opinión sobre aspectos comunitarios? & & \\
\hline ¿Las noticias se refieren a acciones positivas de hombres y mujeres? & & \\
\hline ¿Se presentan las opiniones de mujeres sobre aspectos de la comunidad? & & \\
\hline
\end{tabular}




\section{Creatividad, equilibrio y ritmo}

\section{Planificando el} proyecto

Para llevar a cabo un proyecto como el periódico mural, es necesario plantear un plan que permita proyectar los procesos que le darán forma. Desde el plano artístico, la obra ha de ser planificada de acuerdo a las necesidades que el tema requiere, cuidando el equilibrio y el ritmo de la obra. Esto implica el uso de numerosas técnicas del diseño de las artes visuales, tales como trazos, formas, luz y color.
Al realizar cualquier obra nueva donde se implica el arte, siempre estamos usando la creatividad. Aunque usemos los esquemas realizados con anterioridad, al pensar en el tema nuevo que abordamos, estamos usando nuestra creatividad. Pero la creatividad no surge solo así. Es necesario pensar e imaginar cómo nos gustaría que quedara nuestro producto artístico y cómo queremos que quienes lo observen también lo aprecien. En el caso del periódico mural que estamos realizando, es necesario que tenga varias características asociadas a las artes visuales:

- debe ser agradable a la vista,

- los mensajes deben ser claros,

- debe obedecer a un orden temático, y

- debe atraer la atención de las y los lectores.

Para ello, no basta con tener creatividad, hay que buscar el equilibrio interno y externo de la obra. Además, los contenidos noticiosos, documentales y visuales deben manifestar un ritmo que permita su comprensión.

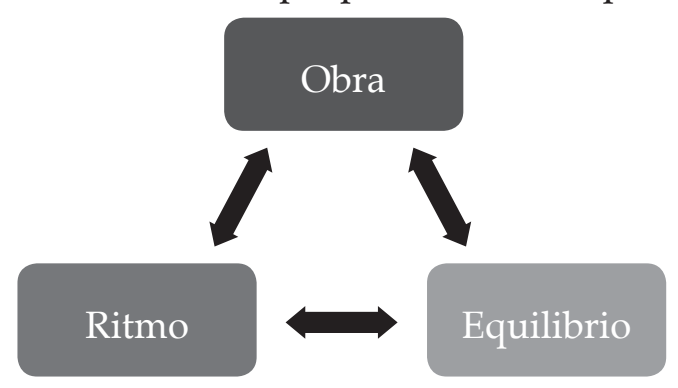

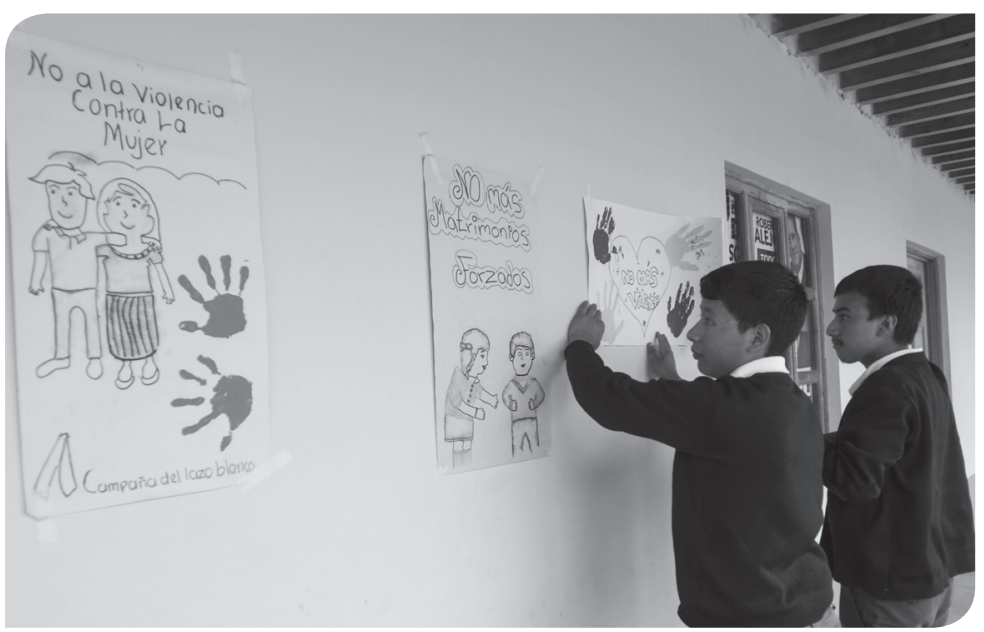

El equilibrio se refiere tanto al contenido (interno) como a la forma (externa). Un periódico mural contiene textos, gráficos e imágenes. Lo que se proyecta visualmente a quien observa debe mantener ese equilibrio entre los tres tipos de contenido. Intercalar imágenes es una estrategia eficaz para darle ritmo visual a los mensajes.

También el orden de los textos según los temas abordados puede guardar un ritmo adecuado, por ejemplo: intercalar textos noticiosos entre otros más complejos como editoriales o artículos de opinión.

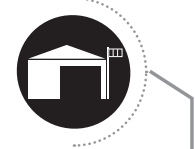

\section{Armando del proyecto}

Escribimos un proyecto breve sobre el periódico mural que contenga las secciones que hemos decidido como clase y los integramos en un diseño que tenga equilibrio y ritmo. Hacemos un bosquejo de cómo proponemos que sea la distribución de los elementos a incluir, los colores a usar, las imágenes que acompañarán los textos etc. Enumeramos los recursos que se necesitarán para elaborar el periódico mural y nos organizamos para conseguirlos. 


\section{Organizando las partes de nuestro periódico mural}

Estamos creando un periódico mural para fomentar la comunicación y el intercambio de opiniones sobre las adicciones.

Estableceremos un diálogo con quienes lo leen, a quienes mostramos los hallazgos de la investigación y las conclusiones del grupo.

- ¿Qué secciones integraremos en nuestro periódico mural?

- ¿Están listas todas para ser integradas?

\section{Formas, Trazos y Claroscuro}

El claroscuro es la técnica que se usa para pintar los tonos de la luz que se proyectan sobre un objeto. La luz ilumina el objeto, pero no en todo el objeto la luz se ve con la misma intensidad. Para reflejarlo, se realizan trazos más concentrados o más difusos a partir de los contornos de la imagen. Se necesitan por lo menos dos tipos de lápiz, uno suave $(\mathrm{H})$ y uno fuerte (B). Si esto no es posible, hay que ubicar el lápiz más oscuro que se pueda encontrar.

Observa el siguiente trabajo de claroscuro hecho por una estudiante de tercero básico:

\section{Pasos para el claroscuro:}

1. Trazar la forma que se quiere realizar. Círculos, triángulos, cuadrados, rombos y trapezoides sirven como líneas guía para los primeros trazos.

2. Unir las figuras geométricas para lograr la forma completa del dibujo a realizar. Borrar las líneas guía.

3. Colocar los detalles del dibujo, para este caballo, los ojos, las orejas, la nariz, el cabello, usando líneas mixtas.

4. Comenzar a trazar el claroscuro concentrando primero las líneas más suaves donde hay tonos más claros. Realizar los trazos fuertes donde hay tonos más oscuros.

5. Cuidar que los tonos oscuros definan las formas de los contornos más finos, como los músculos o los espacios donde la luz no se refleja con mucha intensidad. 


\section{Adicoiones y enfermedades asociadas}

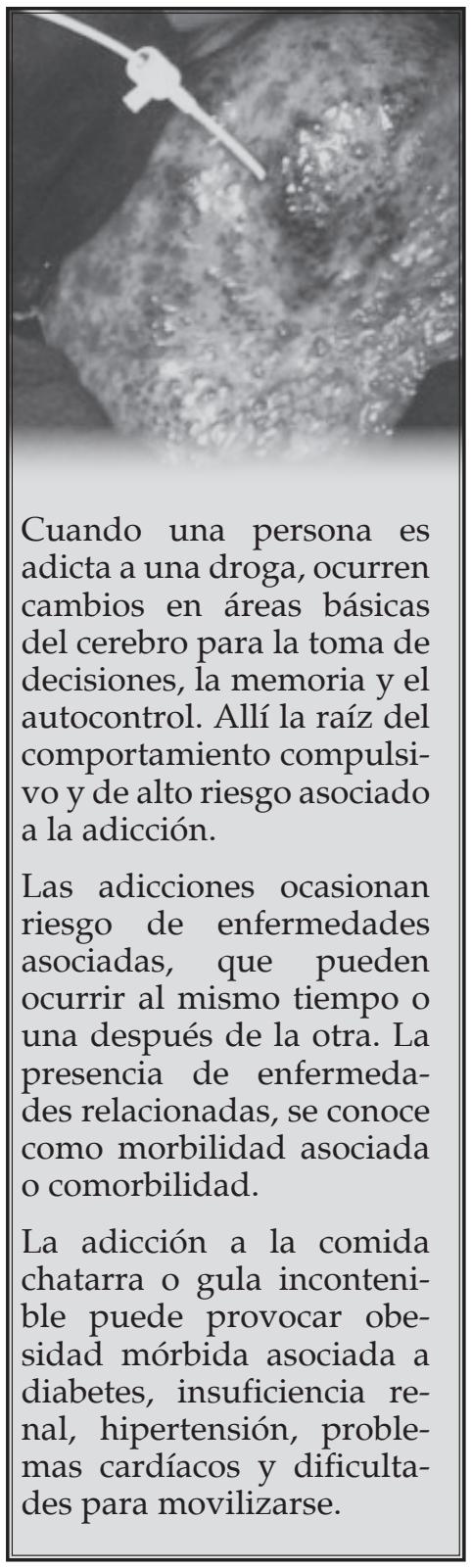

La drogadicción resulta de la intoxicación ocasional o prolongada sobre el cuerpo de una persona que consume drogas. Se identifican tres niveles de consumo: esporádico, cuando transcurre bastante tiempo entre un consumo y otro; consumo de abuso, cuando es parte de su rutina, pero puede vivir sin la droga; y adicción, cuando una persona necesita la droga para vivir. El consumos de drogas cambia el funcionamiento del cerebro, altera la conducta de las personas y puede modificar sus prioridades. La adicción o la condición de drogadicción tiende a duplicar las posibilidades de que una persona sufra trastornos en el estado de ánimo, psicosis, ansiedad o depresión.

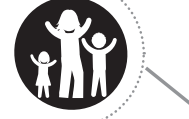

Analizamos la información del esquema y comentamos si en nuestras investigaciones encontramos más información sobre estos padecimientos y la drogadicción.

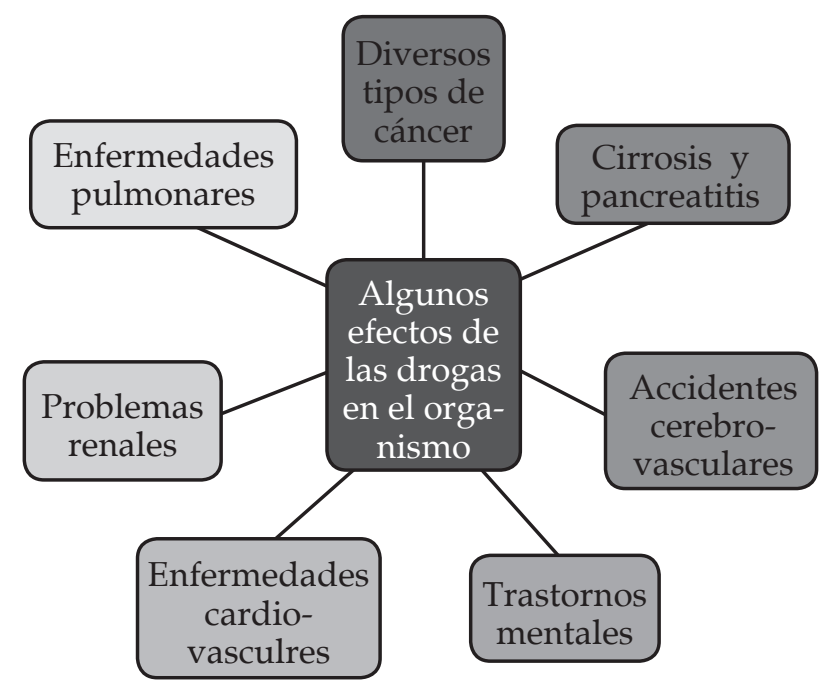

\section{Revisamos las secciones del periódico mural:}

- Integramos los artículos elaborados por cada integrante del grupo, según los diferentes temas.

- Evaluamos la información del periódico mural según la siguiente escala de rango.

\begin{tabular}{|l|l|l|l|}
\hline & A. Logrado & $\begin{array}{c}\text { B. Parcialmente } \\
\text { logrado }\end{array}$ & C. No logrado \\
\hline $\begin{array}{l}\text { Incluye promoción } \\
\text { de vida saludable }\end{array}$ & & & \\
\hline $\begin{array}{l}\text { Incluye aspectos de } \\
\text { prevención }\end{array}$ & & & \\
\hline $\begin{array}{l}\text { Los conceptos } \\
\text { son expuestos con } \\
\text { claridad }\end{array}$ & & & \\
\hline $\begin{array}{l}\text { Incluye todos los } \\
\text { temas abordados } \\
\text { cada semana }\end{array}$ & & & \\
\hline
\end{tabular}




\section{Prevención ante el consumo de drogas}

La prevención es la preparación anticipada para evitar riesgos. Para evitar el consumo de drogas jóvenes, madres y padres de familia, líderes y lideresas comunitarias y los organismos del Estado, pueden realizar acciones que eviten el consumo en alguna persona. La prevención primaria busca reducir o eliminar los factores que pueden provocar el consumo de tabaco, alcohol o drogas ilegales. La vulnerabilidad a la adicción está influenciada por varios factores, como los genes, el grupo étnico, el sexo, el entorno social y familiar, el afecto, la presión social, y la influencia de amistades; entre otros.

La drogadicción se puede evitar, al identificar los factores de riesgo. La prevención debe orientarse a que la población participe activamente. La familia, docentes, tutores y autoridades de los centros educativos pueden convertirlo en un centro promotor de salud. Para ello, será necesaria la participación activa de la comunidad, organizaciones de la sociedad civil, medios de comunicación y organismos y entidades del Estado, en especial del sector salud; con una perspectiva intersectorial y coordinada. Debe trabajarse a la vez en la prevención, como en la promoción de la salud, así como en los factores positivos que pueden disminuir el riesgo de que una persona consuma tabaco, alcohol u otra droga y que contribuyen a condiciones de vida digna.

Leemos y en plenaria exponemos nuestra opinión: ¿Cómo los objetivos de desarrollo sostenible fortalecen la prevención de las adicciones?

- El objetivo 3 de desarrollo sostenible busca que cada país llegue a "Garantizar una vida sana y promover el bienestar para todas las personas sin importar su edad".

- El objetivo 11 pretende "Lograr que las ciudades y los asentamientos humanos sean inclusivos, seguros, resilientes y sostenibles".
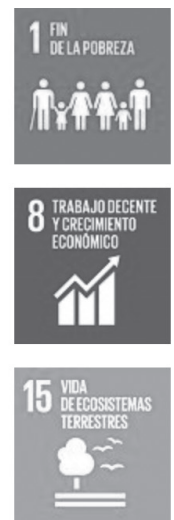
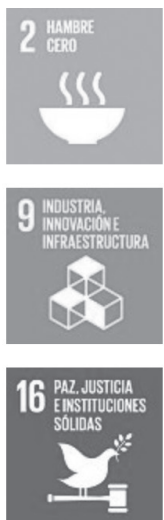
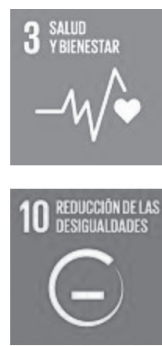

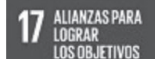
8
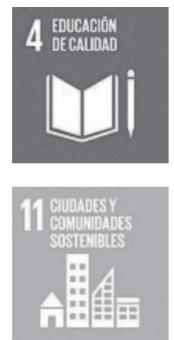

(2)

OBJETIVOS

DEDESARROLLO

SOSTENIBLE
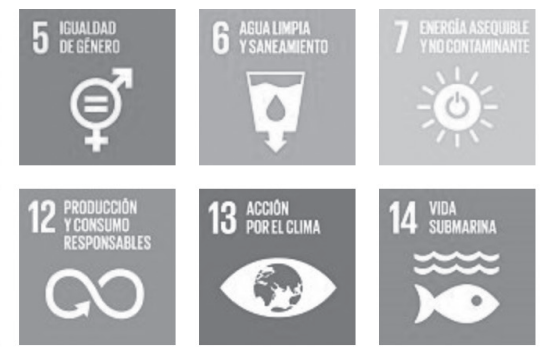

El conocimiento de que consumir drogas es perjudicial, contribuye a que adolescentes y jóvenes reduzcan la intención o tendencia al consumo. La drogadicción se puede evitar si la persona nunca consume drogas.

Al mismo tiempo, es conveniente evitar estereotipos como criminalizar a la persona adicta, generalizar las adicciones, sin establecer diferencias entre una y otra, así como descalificar a la persona adicta, como dedicada a la vagancia o la delincuencia.

La recreación en familia ayuda a la prevención.

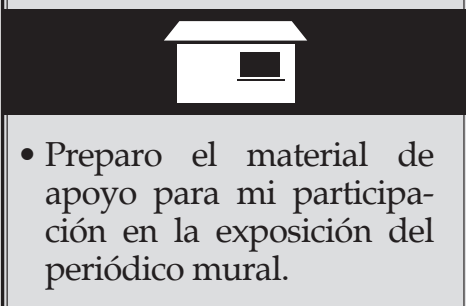




\section{Fquídad de oénerio en todos los ámbitos de la vida}

\section{Más para lenguaje} inclusivo

Las palabras y la forma en que nos expresamos y actuamos reflejan nuestras ideas, sentimientos y opiniones, moldeadas por la cultura y la sociedad a la que pertenecemos.

Debemos poner atención a los adjetivos que usamos para calificar a hombres y mujeres: niñas tranquilas y niños activos son descripciones que refuerzan estereotipos y una mirada sesgada de la realidad. Reflexionemos sobre la forma que hablamos y escribimos. Hagamos un cambio.

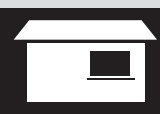

Pongamos atención a nuestra forma de expresarnos en familia. ¿Usamos un lenguaje inclusivo? Si no lo hacemos, ¿qué podemos hacer para mejorar?
Las mujeres, niñas, jóvenes, adultas y ancianas, cumplen un papel importante en el engranaje de la sociedad guatemalteca. Pero nuestra maquinaria no está aceitada y no trabaja al máximo porque las hemos encasillado en un único papel sin permitirles ser libres para determinar su quehacer en diversos aspectos de la vida comunitaria y personal.

Reflexionamos sobre el papel de las mujeres y de los hombres en la elaboración del periódico mural.

- ¿Quiénes integraron las comisiones para la organización y preparación? ¿Hay mujeres en puestos de coordinación o solo de apoyo?

- ¿Cómo se distribuyeron las responsabilidades sobre la elaboración? ¿Se escucharon y atendieron las ideas y sugerencias de las mujeres?

- ¿Hombres y mujeres tuvieron igual participación en la investigación y redacción de notas?

- ¿Se promovió la participación de hombres y mujeres en el diseño, fotografía, dibujos y gráficas presentadas?

- ¿Durante la investigación se tomó en cuenta la opinión de mujeres?

- ¿Los temas planteados representan los intereses tanto de hombres como de mujeres?

- ¿Hay equilibrio entre las notas que muestran la contribución de las mujeres y la de los hombres?

- ¿Se presentan diferentes facetas de las mujeres: ciudadanas, trabajadoras, lideresas, empresarias, familiares, cuidadoras?

- ¿Incluye a mujeres de diferentes edades, origen étnico, situación familiar?

- ¿Se reconoce la importancia de las mujeres igual que la de los hombres?

- ¿Las fotografías, dibujos y gráficas representan por igual a hombres y mujeres?

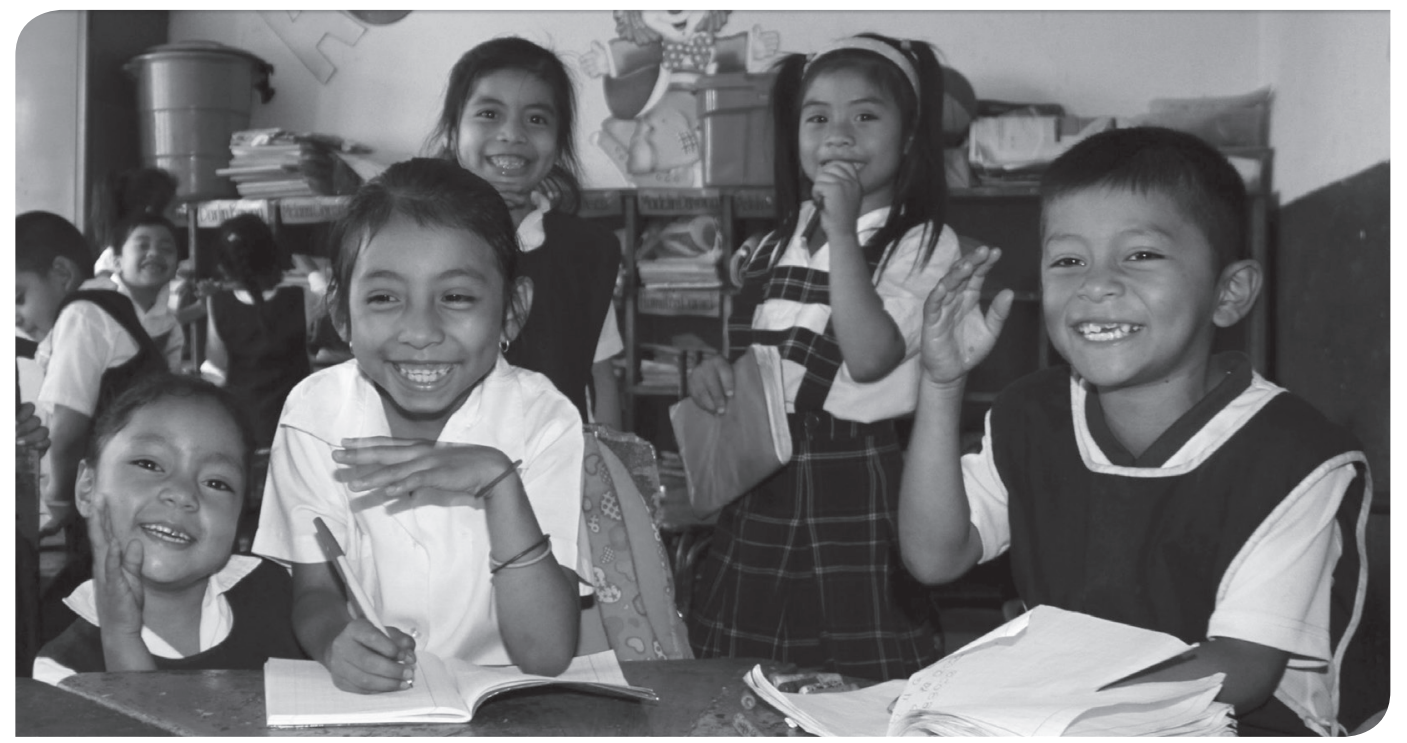




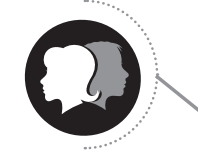

Equidad de género no significa solamente igual número de representantes de ambos sexos sino también igual posición respecto a la participación y libertad de toma de decisiones. Una empresa puede tener igual número de trabajadores y trabajadoras, pero las mujeres son secretarias y los hombres, jefes; tampoco es equidad de género si en el COCODE las mujeres solo están en la comisión de la mujer mientras que los hombres están en los puestos de toma de decisión.

Una mirada crítica a nuestro periódico mural, la forma en la que nos organizamos, cómo lo preparamos, lo que presentamos y cómo lo presentamos refleja las relaciones en la escuela y la comunidad.

Después de contestar las preguntas de la página anterior, ¿cuál es nuestra principal observación? Por ejemplo, si menos mujeres que hombres tomaron decisiones sobre el periódico, fue: ¿porque no elegimos suficientes mujeres o ellas no quisieron participar? ¿No participaron por timidez o por otras razones, como que no les dan permiso en su casa para actividades fuera de la escuela? ¿El horario y el lugar de reunión permitieron por igual la presencia de todas las personas? Si no encontramos lideresas para aparecer en el periódico ¿es porque no hay o porque no las identificamos? $\mathrm{Si}$ pocas mujeres participan como integrantes del Cocode, ies porque no se sienten capaces o porque no se les permite debido a compromisos familiares?, ¿es porque sienten que nadie escuchará lo que tienen que decir o que sus opiniones no son importantes? Escribamos lo aprendido, discutamos sobre posibles soluciones y presentemos nuestra discusión al Cocode para motivar la inte-gración de mujeres en grupos de toma de decisión.

Reflexionemos sobre el periódico y la realidad que representamos a través de una lista de cotejo. Escojamos cinco aspectos que consideramos implican equidad de género y evaluemos el grado de cumplimiento de cada uno durante la preparación y presentación del periódico mural.

Este ejercicio nos ayuda a darnos cuenta de nuestros propios prejuicios y nos motivará a promover cambios para que mujeres y hombres puedan desarrollar su potencial. El cambio no se va a dar de la noche a la mañana, pero es tiempo de comenzar a dar los primeros pasos.

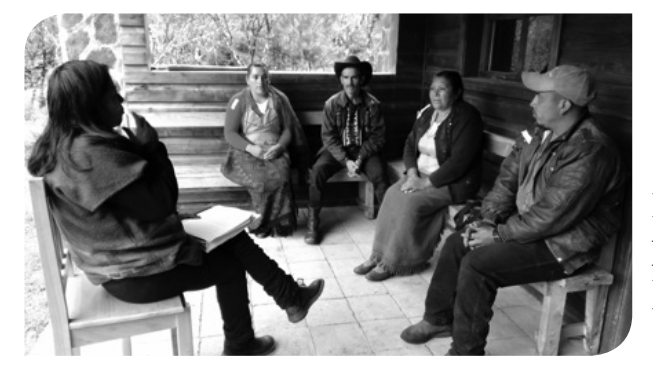

Hombres y mujeres participando en un taller de líderes en Los Cuchumatanes.

\section{Una nueva mujer, un} nuevo hombre

Poco a poco, las mujeres han ido cambiando su entorno.

Padres y madres se han dado cuenta que es importante que sus hijas también asistan a la escuela.

Muchas mujeres contribuyen económicamente al hogar, lo cual mejora el bienestar familiar, ya que hace a la familia menos vulnerable a cambios económicos o frente a emergencias y, además fortalece la autoestima y el desarrollo de la mujer mientras se comparte la posición de proveedor. Claro, en la equidad esto exige que de igual forma los hombres asuman responsabilidad en el la administración del hogar y la crianza de los niños y niñas.

Los cambios en las relaciones requieren cambios en actitudes y comportamientos. Los hombres comparten las tareas de la casa y aprovechan la oportunidad de compartir con sus hijas e hijos, de expresar sus sentimientos y dejar de lado rasgos de dominación y violencia que se han asignado a los hombres.

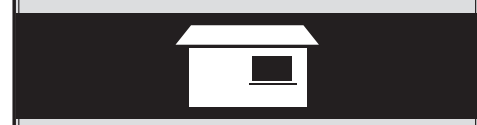

Reflexionemos en familia:

- ¿Han cambiado los roles de hombres y mujeres en los últimos 50 años? ¿Qué hacemos ahora diferente de lo que hacían nuestros abuelos y abuelas?¿Qué tipos de ideas, opiniones y sentimientos no pudieron expresar nuestros padres y madres? 


\section{Adicciones y VIH/sida}

Según ONUSIDA, en 2015 unas 36 millones de personas en el mundo vivían con sida. Sin embargo, con los nuevos medicamentos que no curan la enfermedad, pero disminuyen o evitan la reproducción del virus, las muertes asociadas al SIDA han ido disminuyendo.

Así la persona infectada puede llevar una vida más saludable y a la vez tener mayor esperanza de vida, a condición de no interrumpir el tratamiento.

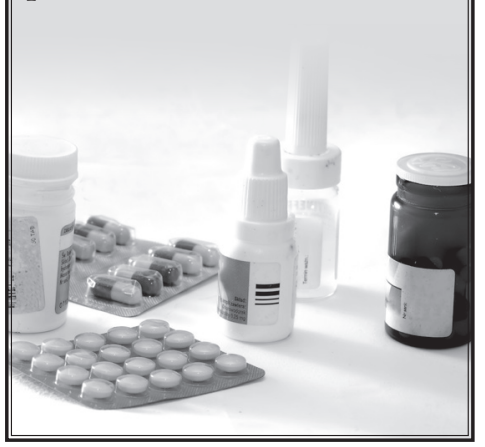

El término "VIH" significa virus de la inmunodeficiencia humana, es un virus que daña gravemente el sistema inmunitario y causa el síndrome de inmunodeficiencia adquirida o SIDA. Como consecuencia deja al cuerpo incapaz de protegerse de las enfermedades. El proceso desde el contagio del virus hasta el desarrollo del SIDA:

El VIH infecta células del sistema inmunitario: T CD4 positivas (CD4+), que son esenciales para combatir las infecciones.

El VIH convierte a las células T CD4+ en productoras de más virus del VIH que infecta a otras células sanas y con el tiempo destruye las células $\mathrm{T}$ CD4+.
Así, se debilita el sistema inmunológico y la persona infectada se vuelve más propensa a las enfermedades e infecciones comunes.
Virus y bacterias aprovechan la falta de defensas del organismo contagiado con VIH; provocan infecciones oportunistas como: herpes, pneumonia, salmonella, tuberculosis y otras.

Las transmisión del VIH, se da mediante contacto entre algunas secreciones de una persona portadora del virus con las vías circulatorias de otra. El contagio del VIH ocurre a consecuencia del ingreso del virus al torrente sanguíneo de la persona en riesgo. Puede suceder mediante transfusiones de sangre que llevan el virus o mediante la práctica de relaciones sexogenitales sin protección adecuada.

Desde el descubrimiento del VIH/sida, se ha identificado la enorme relación que tiene con el abuso y la adicción a las drogas, en especial, el uso de drogas intravenosas al compartir las agujas entre las personas adictas, donde una de ellas es portadora de VIH.

La asociación entre drogas y VIH, se incrementa cuando el efecto de las drogas ha disminuido la capacidad de la persona de implementar las medidas de prevención necesarias. El abuso de drogas y la adicción también pueden empeorar los síntomas del SIDA, por ejemplo, causando mayor daño al sistema nervioso y deterioro cognitivo; así como los daños en otros órganos y sistemas del organismo pueden comprometer aún más al sistema inmunológico de las personas adictas.

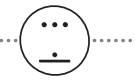




\section{Tratamiento de las adicciones}

Las adicciones son enfermedades crónicas, en las que las personas adictas, no pueden dejar de consumir la sustancia adictiva fácilmente. El tratamiento no es sencillo, pero es posible. En la mayoría de casos, los pacientes deben estar bajo cuidado durante mucho tiempo de manera que no consuman la droga durante el tratamiento, a la vez que se reincorpora a la vida productiva. Esto incluirá que se logre un estilo de vida libre de drogas, sana recreación, actividades que requieran ciertas responsabilidades, el apoyo de la familia y la comunidad. No siempre se pueden curar las adicciones, pero los pacientes pueden aprender a vivir libres de su consumo y recuperar el control de sus vidas.

El tratamiento de pacientes con adicción debe ser integral. Las personas afectadas deben cambiar comportamientos, estar preparados para retomar, mejorar o cambiar el tratamiento en caso haya recaídas. Deberá aceptar y tener el apoyo de personas expertas para seguir el tratamiento. Se deben cuidar todos los aspectos que influyen en la adicción y atender todas las necesidades.

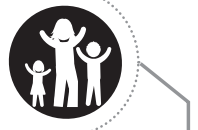

Interpretamos la información de la tabla para identificar qué drogas son más propensas a facilitar el contagio del VIH por su forma de administración.

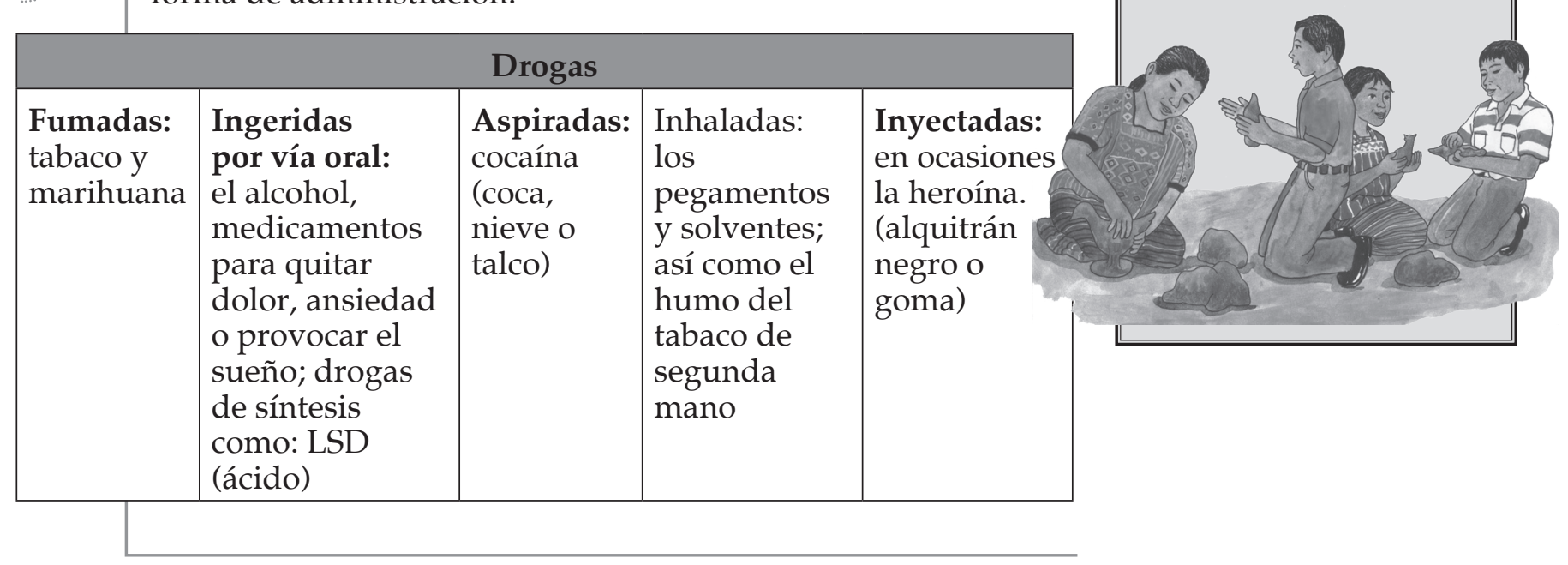

La prevención de las adicciones en adolescentes y jóvenes resulta eficaz a medida que forma parte de un programa integral que tome en cuenta los factores de riesgo y las posibilidades de protección.

Mediante el estudio adecuado de las causas que motivan a las personas a consumir tabaco, alcohol y drogas ilegales, la realización de acciones que eviten que adolescentes y jóvenes se inicien en su consumo. En estos programas se debe determinar si hay personas con mayor riesgo de consumir drogas de modo que se atiendan las causas del riesgo.

\section{Participo en la presentación del periódico mural.}

Elaboro PNI con relación a los temas abordados en este proyecto. 


\section{Harte en una sociedad más justa y feliz}

\section{Danza Moderna, un proceso liberador}

La danza moderna se basa en la libertad expresiva y espontánea de quien la realiza. Su principal característica es la espontaneidad con que se puede ejercitar a nivel individual o colectivo. Al no estar fijada por movimientos estructurados, lo que se busca es que la persona se deje llevar por el sentido musical y genere frases de movimiento.

Frases de movimiento: la secuencia de dos o más movimientos forma una frase: dar dos pasos, girar 180 grados, regresar dos pasos, ya es una frase.

Para experimentar con ella:

- Hacemos un ejercicio de relajación y estiramiento.

- Con una música de ritmo medianamente suave, nos desplazamos libremente por el salón, caminando a voluntad.

- Mientras caminamos, subimos y bajamos los brazos al ritmo que cada quien lo desee.

- Cambiamos música, ahora con un ritmo ligeramente enérgico, los movimientos de acuerdo al ritmo.

- Caminando más rápido y expresando con los brazos hacia delante y hacia atrás, con libertad de desplazamiento.
Hemos trabajado el proyecto enfocado en la revisión de las adicciones y sus efectos en la sociedad. Es notable que la principal adicción, en muchas sociedades, es la del alcohol por la facilidad con que se promueve su consumo.

Hay toda una industria publicitaria que está continuamente reforzando la cultura alcohólica de su audiencia. Aprendimos cómo toda esa publicidad se vale de productos artísticos para la promoción de bebidas alcohólicas.

Aprendimos cómo las adicciones transforman a las personas en dependientes de los narcóticos y estupefacientes. También observamos cómo algunas prácticas que parecen inocentes generan adicción y alteran las relaciones sociales: alimentos poco sanos, uso excesivo de internet, redes sociales y videojuegos, el consumo de música comercial, entre otros.

$\mathrm{Al}$ observar esos productos que generan adicción, es fácil descubrir que detrás de su consumo hay todo un sistema que se beneficia de ese fenómeno.

Por eso, la presentación del periódico mural debe ser una oportunidad de reconocer el problema y proponer soluciones a corto y mediano plazo. Buscar que la vida transcurra libre de drogas y en equilibrio, donde se disfrute de las cosas buenas que podemos hacer los hombres y mujeres.

\section{Cuánto aporta el arte a la construcción del periódico mural}

Recordando las actividades que se han realizado podemos resaltar los siguientes:

\begin{tabular}{|c|c|c|c|}
\hline Música & Teatro & Danza & Artes Plásticas \\
\hline $\begin{array}{l}\text { - La observa- } \\
\text { ción crítica del } \\
\text { consumo de la } \\
\text { música. } \\
\text { - La propuesta } \\
\text { de ejercicios } \\
\text { de relajación y } \\
\text { respiración }\end{array}$ & $\begin{array}{l}\text { - Creación y } \\
\text { montaje de } \\
\text { escenas sobre } \\
\text { el problema de } \\
\text { las adicciones } \\
\text { - Fortaleci- } \\
\text { miento de las } \\
\text { habilidades } \\
\text { *histriónicas } \\
\text { para hablar en } \\
\text { público }\end{array}$ & $\begin{array}{l}\text { Ejercicios de } \\
\text { relajación y } \\
\text { desplazamien- } \\
\text { to corporal }\end{array}$ & $\begin{array}{l}\text { - Diseño del pe- } \\
\text { riódico mural } \\
\text { - Elementos de } \\
\text { artes visuales } \\
\text { para ilustrar } \\
\text { - Productos } \\
\text { de expresión } \\
\text { artística para } \\
\text { potenciar los } \\
\text { mensajes ex- } \\
\text { puestos. }\end{array}$ \\
\hline
\end{tabular}

* histriónico: gesticulación y actuación teatral, a veces un poco exagerada.

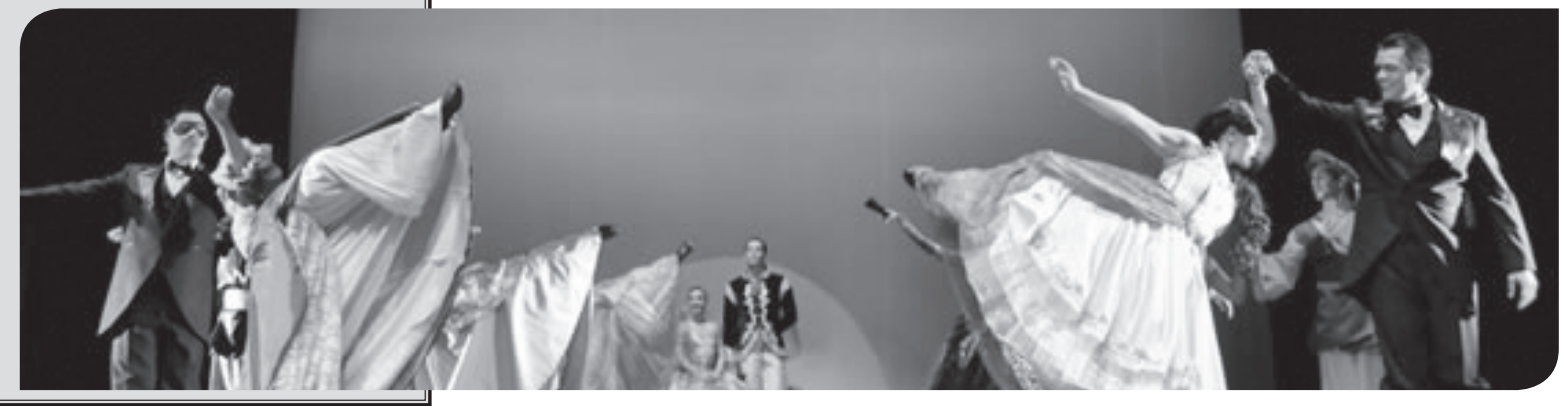




\section{Ensayando la obra de teatro}

En clases anteriores abordamos el tema desde la escenificación de situaciones asociadas a las adicciones. Seleccionamos algunas de las escenas que fueron más efectivas en transmitir el mensaje. Una lista de aspectos que se podían tratar en las escenas incluye:

- Las adicciones y sus efectos económicos

- La violencia intrafamiliar o de género asociada al alcoholismo

- Los mecanismos de distribución de sustancias ilegales

- La corrupción del sistema político para fomentar las adicciones

Las historias se pueden dramatizar de manera independiente enfocando cada uno de esos aspectos, o bien se pueden plantear desde una visión de conjunto. Es decir, una obra que refleje todos esos problemas juntos en varias escenas intercaladas.

\begin{tabular}{|l|l|l|l|l|l|}
\hline \multicolumn{1}{|c|}{ Actividad } & $\mathbf{1}^{\underline{\mathbf{a}}}$ & $\mathbf{2}^{\underline{\mathrm{a}}}$ & $\mathbf{3}^{\underline{\mathrm{a}}}$ & $\mathbf{4}^{\underline{\mathbf{a}}}$ & $\mathbf{5}^{\underline{\mathrm{a}}}$ \\
\hline Colaboré con el diseño del periódico mural & & & & & \\
\hline Realicé y participé en las actividades de música & & & & & \\
\hline Realicé y participé en las actividades de danza & & & & & \\
\hline Realicé y participé en las actividades de teatro & & & & & \\
\hline Participé en la construcción del periódico mural & & & & & \\
\hline $\begin{array}{l}\text { Participé en la presentación artística final del } \\
\text { proyecto }\end{array}$ & & & & & \\
\hline
\end{tabular}

\section{Preparemos y presentemos la obra y las escenas}

Al tener claro si queremos hacer una historia por cada aspecto o una sola con todos los aspectos incluidos, preparémosla para presentarla al público:

- Organicemos las escenas

-Asignemos los personajes principales y secundarios, así como a quienes los interpretarán,

- Escribamos un guión que sirva de guía

- Ensayemos toda la obra

- Definamos los aspectos logísticos, vestuario, escenografía,

- Ensayemos hasta que la sepamos de memoria

- Presentémosla a la comunidad.

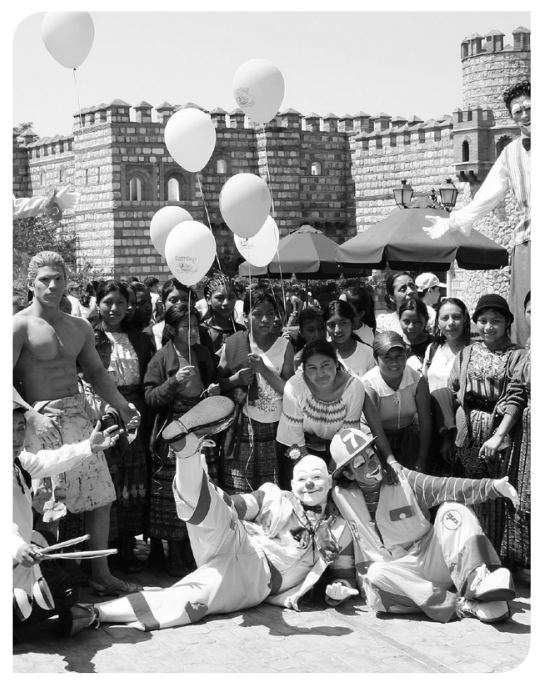




\section{Cloballización y red de comunicaciones}

\section{¿Qué usos prefiero darle} a internet?

“La «escuela virtual» es aquella escuela que no imparte docencia dentro de un único espacio físico (escuela) ni dentro de unos horarios fijos (horario escolar) y en ella cualquier alumno o profesor puede conectarse e interactuar sin restricciones especiales ni temporales. Estas escuelas virtuales proporcionan grandes oportunidades a los estudiantes que no pueden asistir al curso regular por diferentes motivos y en algunos casos la tecnología puede ser un modelo con mayor éxito que la educación convencional."

Fuente: Tesouro M. y Puiggalí, J. (2006). La escuela virtual: la tecnología al servicio de la educación. Recuperado de: https: / / dialnet.unirioja.es / descarga/articulo/2089306. pdf

- Escribo los aspectos positivos y las limitaciones que tienen estas escuelas virtuales.

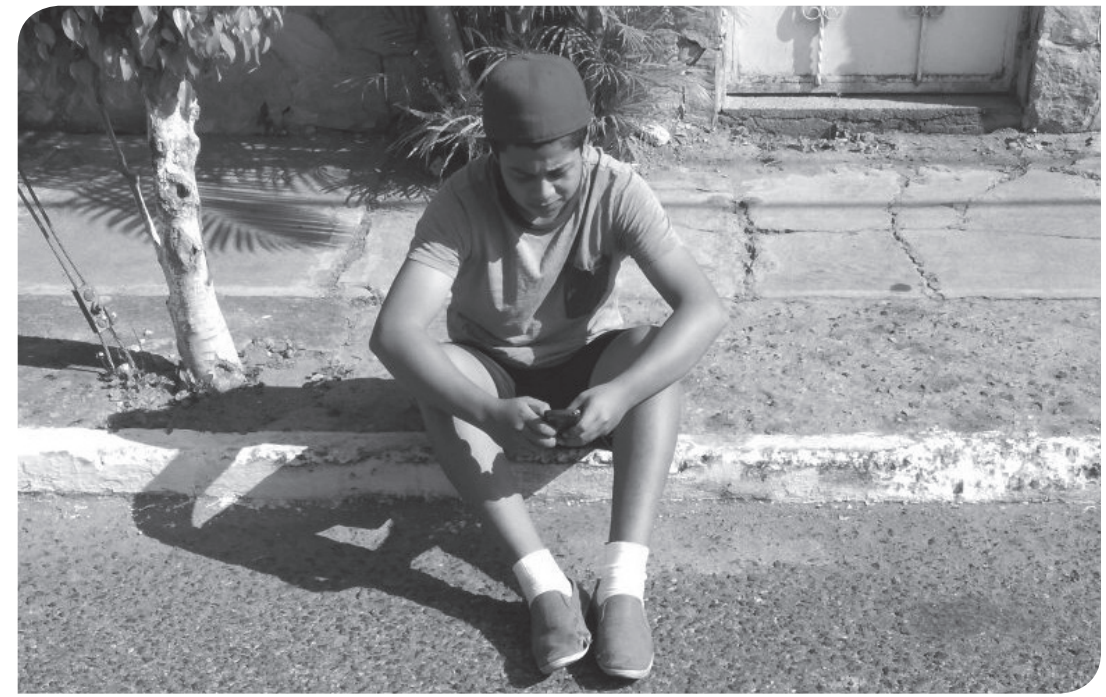

La globalidad ha adquirido dos sentidos: interconexión de las economías e intercomunicación de las personas. En páginas anteriores, hemos hablado de la interconexión entre las economías. Pero también han habido cambios en los medios que se emplean para interconectar las economías y para que las personas se comuniquen.

Para lograr interrelación entre mercados y personas se necesitó de tres innovaciones: los satélites de comunicación que se encuentran, en un espacio muy cercano a la Tierra, captando y transmitiendo señales; la fibra óptica, que permitió transmitir enormes cantidades de información y la integración de los sistemas de comunicación con las computadoras y los teléfonos móviles. Entonces, los recursos que hacen posible la globalización son la computarización, la miniaturización, la digitalización, las comunicaciones vía satélite, la fibra óptica y el Internet.

Internet es un grupo de redes de comunicación digital que está descentralizado, pero que se encuentra interconectado y tiene alcance mundial. En cada red que la forma no hay un centro, hay muchos centros que pueden funcionar de manera autónoma o bien subordinada unos con respecto de otros.

Si comparamos el mundo global con una persona, internet sería su sistema neuronal.

En la actualidad, la información se ha convertido en una mercancía. Se vende toda clase de información: base de datos, conocimiento científico, procesos tecnológicos, etc. Los procesos de comunicación virtual que se desarrollan en internet también se han convertido en el medio que se emplea para intercambiar las mercancías. Por medio electrónico se acuerdan precios, volúmenes de intercambio, lugares de entrega y también se efectúan los pagos acordados.

- Comentemos, con nuestro equipo, las mejores experiencias que han tenido al emplear internet.

- Presentamos el periódico mural a la comunidad educativa con los temas acordados. 


\section{La cultura de masas}

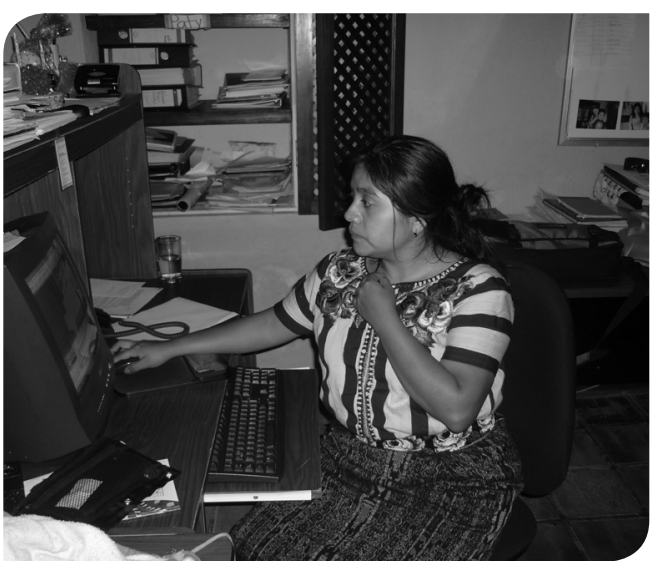

La cultura de masas busca desarrollar una manera uniforme, similar y hasta única, de pensar en la sociedad y entre sociedades. Una de sus características es plantear que el presente es lo único importante, se deja de buscar las causas de los problemas y de proyectar soluciones a futuro. Por esta razón se piensa que esta cultura hace que las personas tengan una forma de pensar muy simple, con poco razonamiento.

Otra característica de la cultura de masas es que exagera el individualismo. Todos sus mensajes transmiten la idea de que cada persona debe preocuparse solo de sí misma y resolver sus problemas de manera individual y que no debe esperar ayuda de las y los demás ni proporcionar apoyo a nadie. A esto contribuye el hecho de que las personas cada vez se relacionan más por medios electrónicos y menos en forma presencial. Es una de las contradicciones de la sociedad, las personas se encuentran más interconectadas virtualmente, pero más aisladas unas de otras.

Un componente fundamental de la cultura de masas es que orienta a las personas a consumir muchos productos que en realidad no necesitan, les hace pensar que entre más compren más felices serán. Esta cultura también fomenta la idea de que descansar el mayor tiempo posible, permanecer sin realizar actividades productivas, es algo que toda persona debe buscar porque es la mejor vida que se puede tener. Con ello, la cultura de masas mitiga la responsabilidad social, la conciencia de participación ciudadana y el sentido de pertenencia a una colectividad.

La función de los medios de comunicación es doble: producen y difunden la cultura de masas. De hecho, la función empresarial, el uso de tecnología y la forma en que están organizados responden a una cultura de masas. Esto también se hace evidente en su diseño y características estéticas, cada vez dominan más los aspectos visuales y características uniformes en todos los medios.

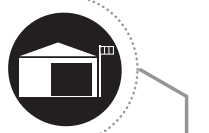

Analizamos la lista de cotejo para guiar la coevaluación del proceso de elaboración y presentación del periódico mural.

Redactamos un plan de mejoramiento para la elaboración futura de un periódico mural.

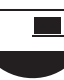

¿Nos vuelve más individualistas la tecnología actual? ¿Por qué?

Ante la cultura de masas prevalecen dos puntos de vista: la apocalíptica, que la considera una amenaza para las culturas originarias, y la integracionista, que sostiene una visión positiva ya que considera que las culturas se pueden enriquecer mutuamente.

“... dos fuerzas esenciales que apuntan en sentido contrario a la estandarización que pudiera presuponerse acompaña al fenómeno de la globalización y es que, debido a la presencia de las nuevas tecnologías, por primera vez en la historia de la humanidad, los sujetos estamos en posibilidad de expresar condiciones de diferenciadoras de nuestra identidad que permiten la generación de nuevos espacios de interacción."

Fuente: Casas, M. (2005). Globalización y tecnologías de la comunicación. Razón y Palabra 48. Recuperado de: http:/ / www.razonypalabra. org. $\mathrm{mx} /$ anteriores/n48/bienal/mesa12.pdf

- ¿Qué condiciones diferenciadoras de nuestra identidad queremos difundir masivamente en las redes sociales?

$$
\text { de un periódico mural. }
$$




\section{Herramientas para representar la}

realidad concreta

El conjunto de los números reales puede ser representado con un diagrama de Venn. En él se observa la relación de pertenencia entre sus subconjuntos.

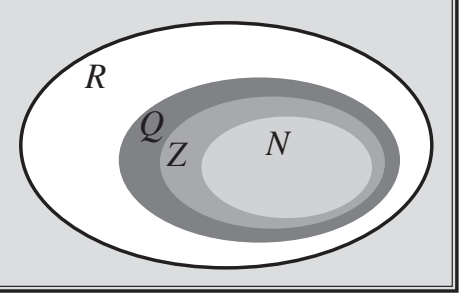

Copiamos en nuestro cuaderno el siguiente esquema para completarlo con la información que haga falta. Recurrimos a la información que hemos aprendido para completar cada región con al menos un elemento.

\begin{tabular}{|l|l|}
\hline \multicolumn{1}{|c|}{ Enfermedades causadas } & \multicolumn{1}{c|}{ Enfermedades causadas } \\
\hline por el consumo de alcohol & por el consumo de tabaco \\
\hline
\end{tabular}

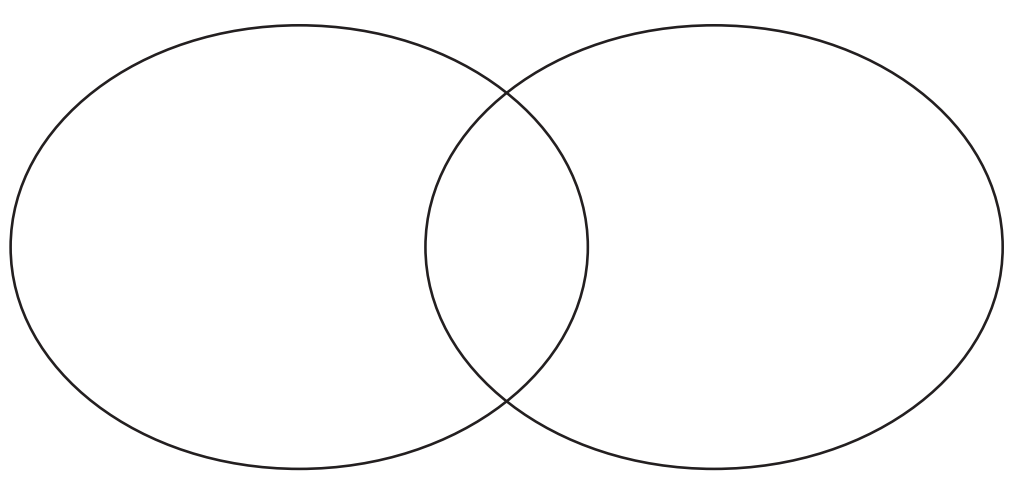

Si el conjunto de las enfermedades causadas por el consumo de alcohol se representa con la letra $A$ y el conjunto de las enfermedades causadas por el tabaquismo se representa con la letra $B$, explicamos con palabras los resultados de las siguientes operaciones:

$$
\begin{aligned}
& B-A \\
& A \cap B \\
& B \Delta A
\end{aligned}
$$

En un estudio realizado recientemente con 55 jóvenes de una pequeña comunidad se obtuvieron los siguientes resultados.

- 10 jóvenes no consumen alcohol ni cigarrillos.

- 22 jóvenes consumen solo tabaco.

- 23 jóvenes consumen solo alcohol.

Realizamos un diagrama de Venn para representar la información y colocamos la cardinalidad correspondiente a cada región.

Discutimos: ¿Qué conclusiones podemos obtener del diagrama que acabamos de dibujar? 
En equipos nos reunimos para comentar:

- ¿Qué información, referente a las adicciones, consideramos importante transmitir a nuestra comunidad?

- ¿Cuál es la forma más apropiada para que la información llegue a más personas?

- ¿Los diagramas de Venn son una herramienta útil para transmitir dicha información?

Anotamos los aportes de cada grupo y, en conjunto, decidimos qué información; sobre las adicciones, vamos a representar en el periódico mural a través de un diagrama de Venn. Definimos de qué forma explicaremos esta información a la comunidad.

Utilizamos un diagrama como este para representar la información que escogimos. Tomamos en cuenta las opiniones de todos los compañeros y compañeras.

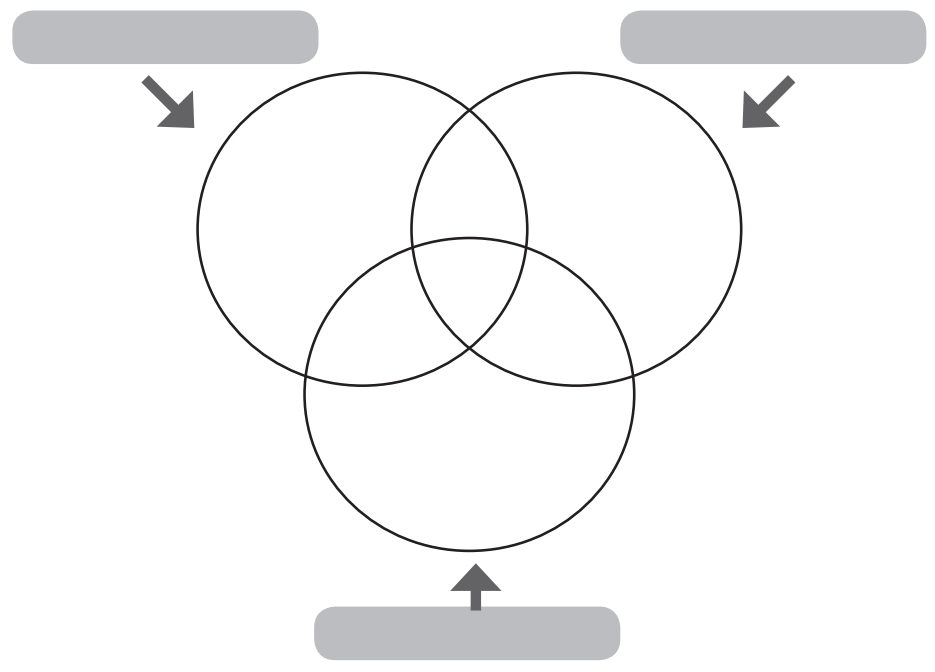

- Después de haber realizado un borrador, copiamos el esquema en un pliego de papel o cartulina.

- Definimos de qué forma se dará a conocer a la comunidad.
Los diagramas de Venn también son útiles para representar relaciones entre conjuntos. El producto cartesiano, representado en el diagrama, resulta de todos los pares ordenados que se pueden obtener de los elementos de dos conjuntos.

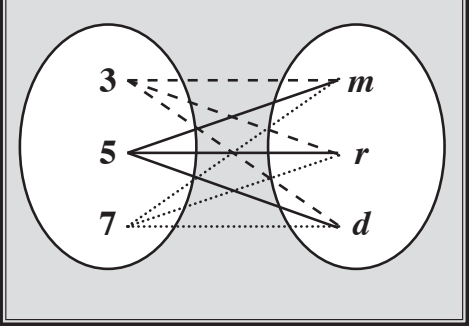

Utilizamos la siguiente lista de cotejo para evaluar nuestro diagrama de Venn.

\begin{tabular}{|c|l|c|c|c|}
\hline No. & \multicolumn{1}{|c|}{ Aspecto } & Sí & No & Observaciones \\
\hline 1 & La información contenida en el diagrama es clara y precisa. & & & \\
\hline 2 & Cada conjunto representa un aspecto delimitado. & & & \\
\hline 3 & $\begin{array}{l}\text { Los elementos en común entre varios conjuntos están bien } \\
\text { ubicados. }\end{array}$ & & & \\
\hline 4 & La información representada es completa. & & & \\
\hline
\end{tabular}




\section{Presentacióôn del ensayo y periódico mural}

\section{Gestos y lenguaje corporal}

Constituye un lenguaje por medio del cual nos expresamos de manera física.

Este lenguaje delata nuestros sentimientos. A veces, resulta más importante que lo que se dice porque con el cuerpo damos validez a nuestro discurso oral. Conocer el significado social de algunas posturas nos ayuda a mejorar nuestra comunicación con las personas.

\section{Cabeza}

- inclinada ligeramente hacia arriba: evaluación; *inclinada hacia un lado: interés;

- inclinada hacia abajo: desaprobación o negación.

\section{Brazos}

- cruce tradicional: postura defensiva o inseguridad;

- cruce con los puños cerrados: hostilidad;

- cruce tomándose los brazos con las manos: restricción.

\section{Piernas}

- cruce tradicional: actitud defensiva;

- posición de loto: competencia, discusión.

- Inclinarse demasiado hacia la otra persona: agresividad.

- Mantener los brazos cruzados por mucho tiempo durante una charla: poco interés.

- Postura encogida o agachada: aburrimiento.

- Postura relajada con brazos y piernas ligeramente abiertas: confianza y seguridad.

- Postura erguida: seguridad, valor e interés en lo que se hace.

\section{El discurso y sus fases}

Retórica o el arte del buen hablar y cuyos nombres aún permanecen en latín, la lengua madre del español:

\begin{tabular}{|c|c|c|c|c|c|}
\hline \multicolumn{6}{|c|}{ Proceso de producción de un discurso y sus fases } \\
\hline Intellectio & Inventio & Dispositio & Elocutio & Memoria & Pronuntia- \\
\hline $\begin{array}{l}\text { Elección } \\
\text { del tema y } \\
\text { el género } \\
\text { del discur- } \\
\text { so. }\end{array}$ & $\begin{array}{l}\text { Investi- } \\
\text { gación } \\
\text { de ideas, } \\
\text { datos y ar- } \\
\text { gumentos } \\
\text { del discur- } \\
\text { so. }\end{array}$ & $\begin{array}{l}\text { Organiza- } \\
\text { ción de los } \\
\text { materiales } \\
\text { encontra- } \\
\text { dos de ma- } \\
\text { nera cohe- } \\
\text { rente. }\end{array}$ & $\begin{array}{l}\text { Redacción } \\
\text { del discur- } \\
\text { so. }\end{array}$ & $\begin{array}{l}\text { Evocación } \\
\text { de la repre- } \\
\text { sentación } \\
\text { mental del } \\
\text { discurso. }\end{array}$ & $\begin{array}{l}\text { t10 } \\
\text { Pron u n- } \\
\text { ciación del } \\
\text { discurso. }\end{array}$ \\
\hline
\end{tabular}

Generalmente, usamos la prosa para elaborar nuestros discursos. En la fase de Intellectio, después de elegir el tema de nuestro texto, escogemos el género a emplear: la narración, la descripción, el informe y la argumentación, entre otros. No olvidemos que, en todos los casos, nuestro objetivo al elaborar nuestro discurso es persuadir.

La narración hace una relación correlativa de hechos o acciones acerca de un suceso en particular. La descripción enumera los detalles, los rasgos o características de un elemento o de una situación dada. El informe es muy parecido a la narración, pero se diferencia de esta en que es mucho más objetivo y puntual en señalar los hechos de una situación. Por último, la argumentación expone una realidad y llega a conclusiones por medio de un razonamiento.

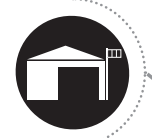

\section{Realiza tu presentación y escucha la de los demás grupos.}

- Reflexionemos sobre el tema de las adicciones. ¿Cómo podemos incidir en un cambio en nuestro entorno? ¿Cómo afectan las adicciones los indicadores de salud entre nuestra comunidad? ¿Cómo y por qué afecta a las mujeres?

- Elaboremos un decálogo personal para la prevención de las adicciones en la comunidad. Luego de elaborarlo presentémoslo a la comunidad, familia, vecinos y amigas.

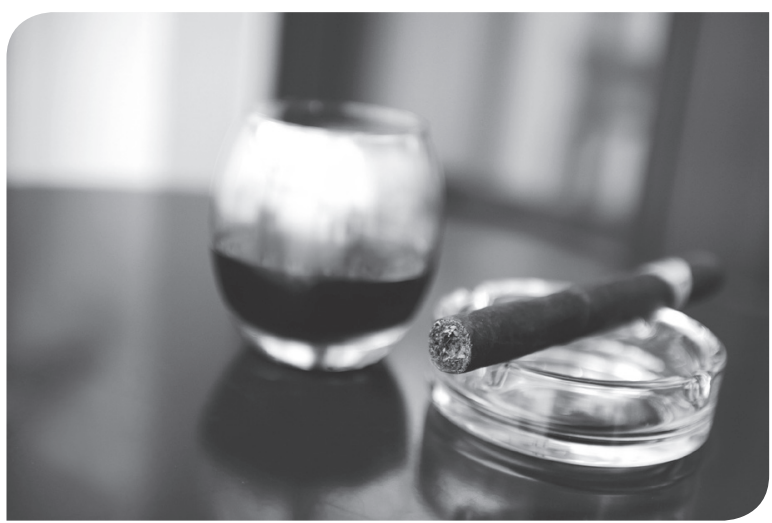




\section{Realicemos una ponencia con ayuda de recursos audiovisuales}

Cuando exponemos un tema ante un público resulta más novedoso y atractivo apoyarnos con algunos recursos que realcen su importancia y faciliten su comprensión. Estos recursos van desde carteles, hasta películas; son muy versátiles y posibilitan toda clase de combinaciones.

Es imprescindible que adaptemos el material a exponer a las necesidades específicas de nuestro público y al espacio físico en donde se realizará la ponencia para que este cumpla su función a cabalidad. Esta función es la de ayudar a comprender el tema que se va a tratar y a recordarlo con mayor facilidad porque se está apelando tanto al sonido como a la imagen. A la vez, mostrar un ejemplo en vez de describirlo produce un impacto más certero en la conciencia del público interlocutor. Los principales tipos de apoyo audiovisual son: las maquetas, los objetos, material pictórico (organigramas, diagramas, mapas, caricaturas, fotos y pinturas), presentaciones de videos, audios, películas y proyección de diapositivas por medio de la computadora y un retroproyector.

Otros apoyos de este tipo son la televisión; la teleconferencia, que permite el intercambio directo de ideas, información entre varias personas que están en diferentes lugares, a través de un sistema de telecomunicaciones; videoconferencia, un servicio que permite la comunicación en tiempo real, persona a persona o grupo a grupo, con la diferencia de que, además de la voz, se transmite imágenes fijas de fotografías, datos y textos e imágenes en movimiento de personas individuales o de grupos; cedés, equipos de sonido y micrófonos para la amplificación de la voz.

\section{- Investiguemos sobre la Kinésica y el lenguaje gestual y corporal.}

- Realicemos una demostración de ejercicios que mejoran la rapidez de movimientos reflejos, invitando al público a participar.

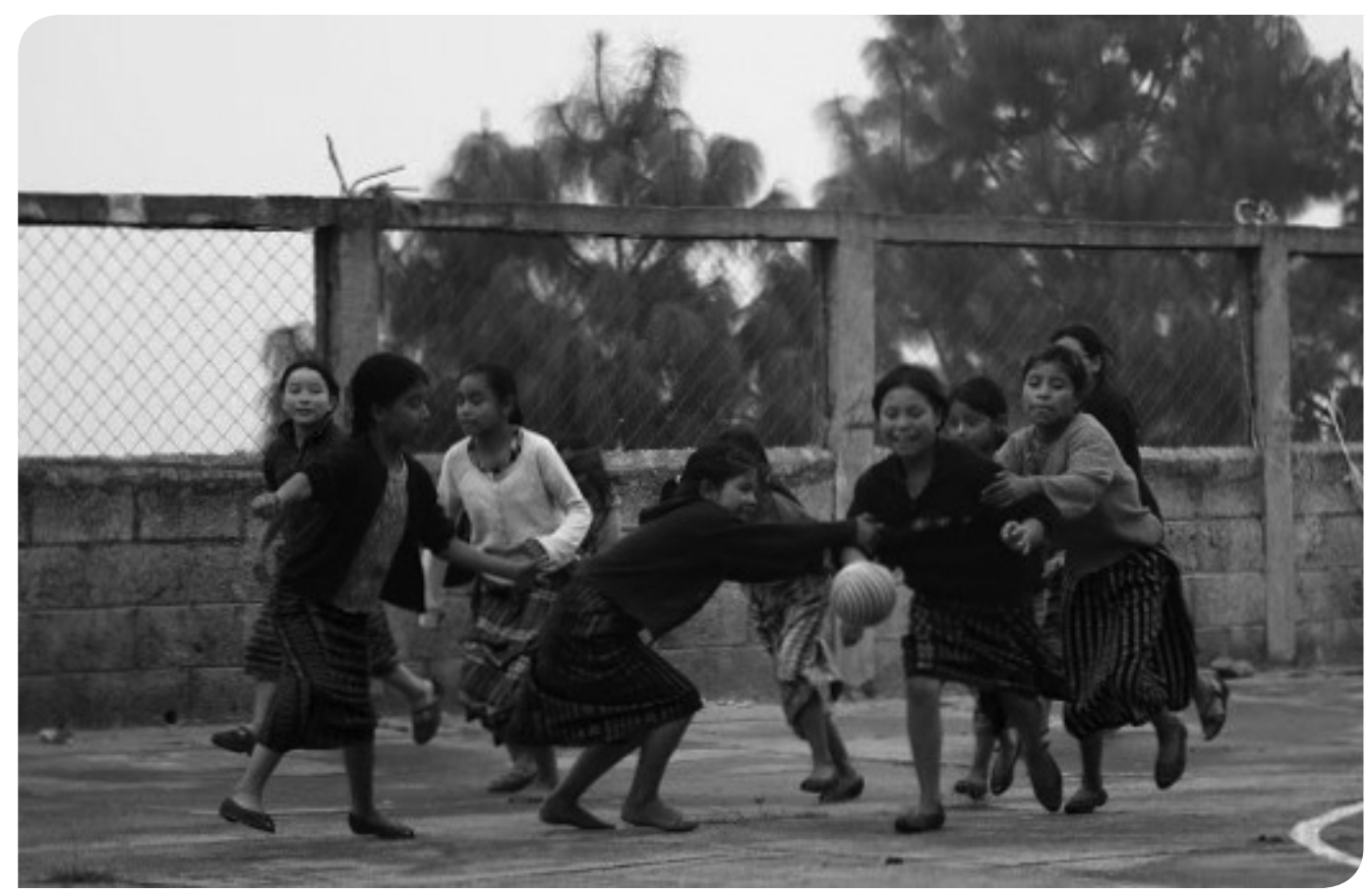




\section{PROYECTO No. 4. El alcoholismo y otras adicciones como problemas sociales y para la salud}

A continuación se presentan varias categorías y su descripción para analizar detenidamente si se observan en el mural. Marque $\boldsymbol{X}$ en la casilla que corresponde.

\begin{tabular}{|c|c|c|c|c|}
\hline & Categorías & Descripción & Sí & No \\
\hline 1 & \multirow{3}{*}{$\begin{array}{l}\text { Generales } \\
\text { Datos }\end{array}$} & Identificación del tema en el título del mural & & \\
\hline 2 & & Identificación del centro de aprendizaje & & \\
\hline 3 & & Nombre de las y los integrantes & & \\
\hline 4 & \multirow{3}{*}{ Organización } & El título del mural está en un lugar estratégico para atraer a las y los lectores & & \\
\hline 5 & & Organiza las secciones del mural con la intención de atraer a las y los lectores & & \\
\hline 6 & & $\begin{array}{l}\text { Sección editorial (información general que el equipo de trabajo incluye con relación al } \\
\text { desempeño individual de quienes integran el grupo) }\end{array}$ & & \\
\hline 7 & \multirow{14}{*}{$\begin{array}{l}\text { Desarrollo } \\
\text { del tema }\end{array}$} & Fundamenta el tema con información científica y social. Incluye fuentes. & & \\
\hline 8 & & Describe algunas causas que provocan el problema del alcoholismo y las adicciones & & \\
\hline 9 & & Incluye datos estadísticos que respalden sus argumentos. & & \\
\hline 10 & & $\begin{array}{l}\text { Incluye información de la situación real de alcoholismo y adicciones de la comunidad, } \\
\text { las localidades cercanas y/o la región. }\end{array}$ & & \\
\hline 11 & & $\begin{array}{l}\text { Motiva a pensar acerca de las consecuencias de las adicciones con testimonios o ejem- } \\
\text { plos reales de la comunidad o región. }\end{array}$ & & \\
\hline 12 & & $\begin{array}{l}\text { Propone soluciones prácticas individuales y colectivas que pueden ser utilizadas en la } \\
\text { comunidad cercana para prevenir las adicciones. }\end{array}$ & & \\
\hline 13 & & $\begin{array}{l}\text { Motiva a las y los lectores a tomar buenas decisiones en sus hábitos diarios de salud } \\
\text { individual y colectiva para prevenir las adicciones. }\end{array}$ & & \\
\hline 14 & & Incluye información deportiva para promover vida saludable y prevenir las adicciones. & & \\
\hline 15 & & $\begin{array}{l}\text { Motiva el ejercicio físico en las y los lectores como estilo de vida saludable para preve- } \\
\text { nir las adicciones. }\end{array}$ & & \\
\hline 16 & & $\begin{array}{l}\text { Utilizan medios alternativos artísticos para prevenir las adicciones y promover vida } \\
\text { saludable en su comunidad. }\end{array}$ & & \\
\hline 17 & & $\begin{array}{l}\text { Incluye experiencias del equipo de trabajo (anécdotas, aprendizajes, fotografías, entre } \\
\text { otros). }\end{array}$ & & \\
\hline 18 & & Utiliza la síntesis para escribir la información del tema. & & \\
\hline 19 & & Aplica las reglas gramaticales al exponer la información y argumentación del tema. & & \\
\hline 20 & & Aplica reglas ortográficas en la información expuesta. & & \\
\hline 21 & \multirow{4}{*}{ Diseño } & El tamaño del mural es adecuado para la información y el espacio del local. & & \\
\hline 22 & & Utiliza los colores apropiados para provocar el interés por la lectura del tema. & & \\
\hline 23 & & $\begin{array}{l}\text { Utiliza recursos gráficos como: fotografías, estadísticas, dibujos, pinturas; que resalten } \\
\text { la importancia del cambio de estilo de vida para prevenir adicciones. }\end{array}$ & & \\
\hline 24 & & $\begin{array}{l}\text { Diferencia el tamaño de letra del título, subtítulos y párrafos, para atraer a las y los } \\
\text { lectores. }\end{array}$ & & \\
\hline
\end{tabular}




\section{Evaluación por Competencias}

\section{Reflexión}

A continuación se presentan varias categorías y su descripción para analizar detenidamente la actitud en relación con el aprendizaje. Marco con una $\boldsymbol{X}$ en la casilla que considero es el caso.

\begin{tabular}{|c|c|c|c|c|c|}
\hline \multicolumn{2}{|c|}{$c^{0^{2 b^{2}}}$} & Descripción & $\begin{array}{l}\text { Siem- } \\
\text { pre }\end{array}$ & $\begin{array}{l}\text { Mur- } \\
\text { chas } \\
\text { veces }\end{array}$ & Nunca \\
\hline 1 & \multirow{6}{*}{ 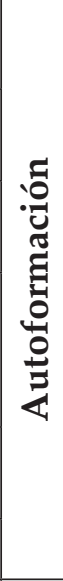 } & $\begin{array}{l}\text { Reconozco que al realizar cada acción educativa individual o colectiva, dentro } \\
\text { y fuera de clase, el fin último es aprender para la vida. }\end{array}$ & & & \\
\hline 2 & & $\begin{array}{l}\text { Me intereso por conocer más a fondo lo visto en clase e indago en otras fuentes } \\
\text { o consulto al o la docente. }\end{array}$ & & & \\
\hline 3 & & $\begin{array}{l}\text { Relaciono la información vista en clase con los aspectos culturales, de salud, } \\
\text { deportes, ambiente, productividad y economía de mi comunidad o región. }\end{array}$ & & & \\
\hline 4 & & $\begin{array}{l}\text { Estoy de acuerdo con que los conocimientos adquiridos en clase son importan- } \\
\text { tes para valorar y mejorar el ambiente ecológico, la salud individual, y familiar } \\
\text {, las relaciones culturales, la economía, y productividad de mi comunidad o } \\
\text { región. }\end{array}$ & & & \\
\hline 5 & & $\begin{array}{l}\text { Asigno un horario específico entre semana para tareas, lecturas y otros aspec- } \\
\text { tos relacionados con las áreas y sub áreas del grado. }\end{array}$ & & & \\
\hline 6 & & Realizo a tiempo las tareas según la fecha establecida. & & & \\
\hline 7 & \multirow{2}{*}{ 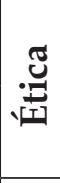 } & $\begin{array}{l}\text { Estoy consciente de que si copio las tareas de mis compañeros o compañeras } \\
\text { les falto el respeto, me falto el respeto y limito mi aprendizaje. }\end{array}$ & & & \\
\hline 8 & & $\begin{array}{l}\text { Al realizar investigaciones elijo, analizo y resumo la información pertinente } \\
\text { para evitar copiar (plagiar) la información. }\end{array}$ & & & \\
\hline 9 & \multirow{10}{*}{ 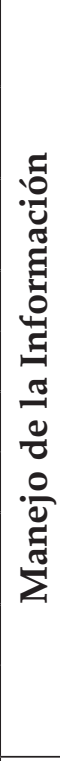 } & $\begin{array}{l}\text { Reconozco que mi realidad inmediata puede cambiar si realizo pequeños cam- } \\
\text { bios al utilizar nuevos conocimientos. }\end{array}$ & & & \\
\hline 10 & & $\begin{array}{l}\text { Es importante para mí reconocer qué acciones promueven la salud individual } \\
\text { y colectiva. }\end{array}$ & & & \\
\hline 11 & & $\begin{array}{l}\text { Aprecio las diferentes expresiones artísticas (música, plástica, teatro, danza) } \\
\text { como desarrollo personal. }\end{array}$ & & & \\
\hline 12 & & Utilizo el arte para expresar mis ideas y sentimientos. & & & \\
\hline 13 & & Utilizo herramientas tecnológicas como apoyo & & & \\
\hline 14 & & Sigo instrucciones del o la docente, hojas de trabajo y libros de texto. & & & \\
\hline 15 & & Comparo conceptos y distingo sus diferencias y semejanzas. & & & \\
\hline 16 & & $\begin{array}{l}\text { Analizo y memorizo conceptos importantes de ecosistemas, economía, pro- } \\
\text { ductividad, interculturalidad, salud, deportes y otros. }\end{array}$ & & & \\
\hline 17 & & Me intereso por hablar y escribir en otros idiomas. & & & \\
\hline 18 & & $\begin{array}{l}\text { Me intereso por aplicar las normas de redacción y ortografía en los textos que } \\
\text { escribo. }\end{array}$ & & & \\
\hline 19 & \multirow{5}{*}{ 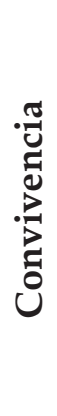 } & Colaboro con mis compañeras y compañeros en el proceso de aprendizaje. & & & \\
\hline 20 & & $\begin{array}{l}\text { Demuestro respeto por mi persona, mis compañeras y compañeros, docentes } \\
\text { y centro de aprendizaje. }\end{array}$ & & & \\
\hline 21 & & Propongo soluciones y aporto ideas cuando participo en equipos de trabajo. & & & \\
\hline 22 & & $\begin{array}{l}\text { Expreso mis sentimientos y pensamientos en el momento oportuno, con respe- } \\
\text { to, sin ofender a otras personas. }\end{array}$ & & & \\
\hline 23 & & $\begin{array}{l}\text { Respeto la participación de todas y todos, las diferencias físicas, intelectuales, } \\
\text { de religión, cultura, origen étnico, género y orientación, de mis compañeras y } \\
\text { companeros. }\end{array}$ & & & \\
\hline
\end{tabular}




\section{Mente y cuerpo sanos}

Todas las personas tenemos derecho a disfrutar de un estado de bienestar que se expresa en el equilibrio de la condición física, emocional y espiritual. Es lo que la organización Mundial de la Salud (OMS) define como la salud integral. Por lo tanto, todas y todos necesitamos oportunidades para desarrollar nuestra capacidades intelectuales, físicas y espirituales. La salud y el bienestar están íntimamente relacionadas con la forma en que asumimos la vida. Una persona sana disfruta la vida realizando actividades diversas: pensar, reflexionar, imaginar, soñar, proyectar, crear, deporte, expresión corporal, ejercicios de resistencia entre otros. El cultivo de las artes es también una forma de alcanzar la salud integral, pues involucra tanto al cuerpo como a la mente y a las emociones, por ejemplo, cuando se interpreta una pieza musical, se realiza una coreografía, se ejecuta una obra de teatro o se crea una obra plástica.

\section{¿Qué deseamos?}

Contribuir a la realización de prácticas de actividad que desarrollen la dimensión física, mental y emocional para aportar a la salud integral de la comunidad. Generar conocimiento, análisis, discusión, reflexión y conciencia sobre los aspectos que influyen de manera positiva en la salud de la mente, del cuerpo y de las emociones. Esperamos fomentar prácticas sanas a la vida cotidiana de la comunidad para favorecer el desarrollo de la salud integral.

\section{¿Qué haremos?}

Un programa de buenas prácticas para el mantenimiento de la salud integral. Diseñaremos y difundiremos un programa que describe acciones que son beneficiosas para el desarrollo de la persona y la comunidad. Las prácticas se presentarán en un orden lógico, apropiadas al contexto de la comunidad y usando lenguaje que sea comprendido por todas y todos. Estaremos abordando buenas prácticas para:

- la prevención y curación de enfermedades comunes;

- mediante el deporte, cuidando la inclusión de hombres, mujeres, todas las edades y personas con discapacidades;

- el fomento de hábitos alimenticios saludables; y

- el abordaje y solución pacífica de problemas sociales.

\section{¿Con quiénes trabajaremos?}

Formaremos equipos para que participen todos y todas las integrantes del grupo en la elaboración de las secciones del programa. Cada grupo aportará a las diversas dimensiones de la salud integral.

\section{¿Cómo procedemos?}

\section{a. Investigación}

Distribuiremos los temas sobre salud corporal, emocional y mental. Recabaremos información en torno a las actividades de la comunidad que favorecen la salud mental, física y emocional. Indagaremos sobre las prácticas que ejercen efectos negativos en el bienestar y deben ser eliminadas. Investigaremos por medio de entrevistas, encuestas, observaciones y revisión documental. Haremos síntesis de la información obtenida y redactaremos cuáles son las prácticas favorables para la salud integral.
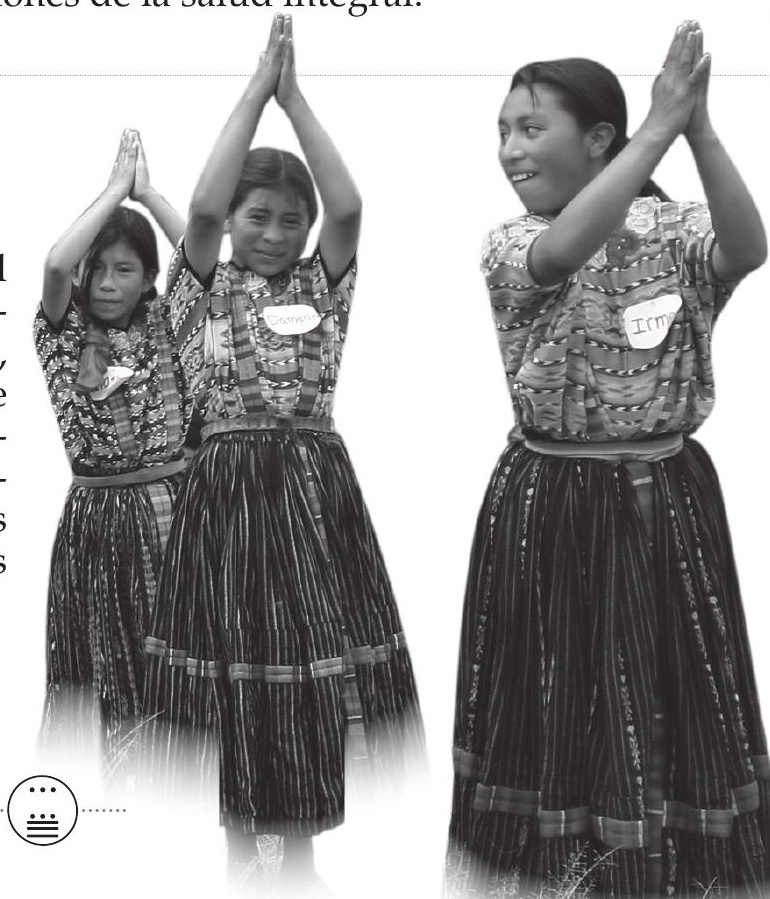


\section{b. Organización}

Definiremos las secciones a incluir en nuestro programa, atendiendo todas las dimensiones de la salud integral. En grupos de trabajo elaboraremos las secciones del programa general de buenas prácticas para la salud integral.

\section{c. Producto}

El programa de buenas prácticas servirá para toda la comunidad. Contendrá información definiciones sobre el derecho a la salud integral, salud mental y corporal sus dimensiones, y buenas prácticas recomendadas , así como las prácticas que cultivan una mente y cuerpo sanos. El programa incluirá dos pequeños relatos sobre prácticas relacionadas con la salud integral, como entre ellas, el ejercicio físico, el consumo adecuado de alimentos, la apreciación y creación artística, lectura de ficción, reflexión y crítica filosófica o científica, el juego colectivo como recreación, expresión de emociones. Contendrá las siguientes secciones: Glosario, Relatos de prácticas que inciden en la salud integral, Decálogo de buenas prácticas, Alerta de conductas de riesgo.

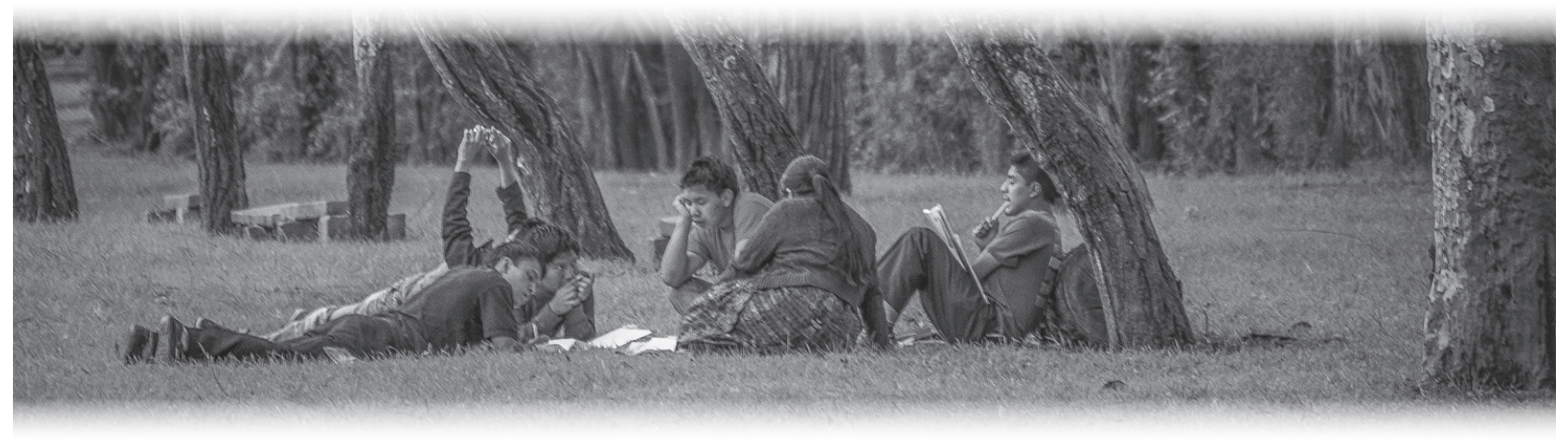

\section{¿A quién presentaremos nuestro producto?}

A toda la comunidad educativa y a las y los promotores de salud de la comunidad en general. El programa se presentará en forma de exposición teatral y un trifoliar con texto e ilustraciones de recortes, fotografías o imágenes. Se buscará la reproducción y difusión del trifoliar.

\section{¿Cómo distribuiremos el tiempo?}

\begin{tabular}{|l|c|c|c|c|c|c|}
\hline \multicolumn{2}{c|}{ ACTIVIDAD } & \multicolumn{5}{c|}{ SEMANA } \\
\hline Planificación de la elaboración del programa de salud integral & $\boldsymbol{V}$ & & & & & \\
\hline Investigación sobre buenas prácticas de salud integral & & $\boldsymbol{1}$ & & & & \\
\hline Diseño del programa, secciones & & & $\boldsymbol{V}$ & & & \\
\hline Redacción de los textos de las secciones del programa & & & & $\checkmark$ & & \\
\hline Ensayo de exposición y elaboración de trifoliar & & & & & $\checkmark$ & \\
\hline Presentación de teatro y trifoliar, evaluación & & & & & & $\checkmark$ \\
\hline
\end{tabular}

(79) Semana $7 \quad \ldots$




\section{Investigamos sobre salud integral}

Signo lingüístico es la combinación de un concepto asociado a una imagen que puede ser percibida por uno o más sentidos humanos. La palabra es el signo lingüístico más importante del idioma escrito. Está compuesto por tres elementos:

- Significante es la cadena de sonidos que emitimos al hablar o los signos que usamos al escribir.

- Significado es el sonido que usamos para interpretar y dar forma al signo lingüístico. El dibujo mental que tenemos de él.

- Referente es el objeto real al que se refiere el signo.

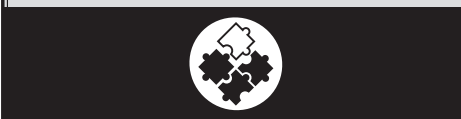

Elabora un mapa conceptual del signo lingüístico que explique la relación entre el significante, el significado y el referente. Utiliza como ejemplo la palabra salud.

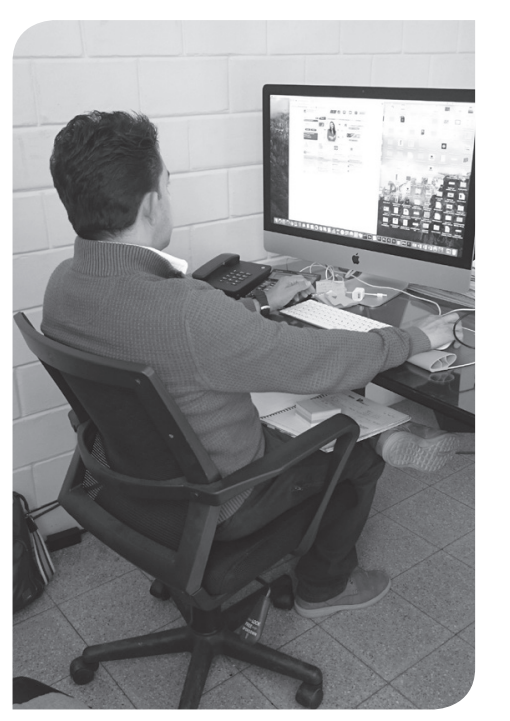

\section{Recabar información: entrevistas y revisión de documentos}

Es una conversación sobre un tema determinado, entre una o más personas. Usualmente, quien entrevista hace preguntas previamente estructuradas a otra persona, para conocer su punto de vista u opinión.

\section{Fichas}

Se usan para anotar los datos obtenidos de la investigación bibiliográfica: conceptos, resúmenes e ideas relacionadas. Pueden ser tarjetas de cartulina rectangulares que se clasifican y almacenan en un fichero o archivo. Cuando se tiene el recurso de la computadora, la información se guarda en bases de datos y otros soportes electrónicos.

Existen diferentes tipos de fichas:

\section{Bibliográficas:}

Contienen los datos de los libros usados para la investigación. Se registra el nombre del autor o autora, el título del libro, ciudad o país de la publicación, la editorial, el número de edición y el año de publicación. Luego de estos datos se escribe la información relevante, las ideas centrales o los datos que se han encontrado y que serán útiles para la investigación que se está realizando.

\section{Hemerográficas:}

Registran información obtenida de un periódico o revista. Contienen los datos de la fuente: el título del periódico o revista, los años que lleva circulando, el número de la publicación, la ciudad y país donde se imprimió y la fecha.

\section{Textuales:}

Son útiles para registrar textos que son tan valiosos que se quieren incluir idénticos en la investigación. Estos deben identificarse con comillas y citando al/la autora. En la ficha se anota el texto copiado entre comillas. También contienen los datos bibliográficos del libro del cual provienen y el número de página de la cual se obtuvo la cita textual.

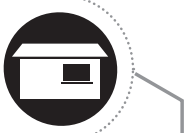

En grupos de dos o tres personas investigaremos sobre prácticas cotidianas de la alimentación, la actividad física, las relaciones etc. en nuestra comunidad a través de entrevistas a personas de la comunidad.

\section{Organizándonos en equipos:}

Investigaremos en referencias bibliográficas o si tenemos acceso a computadora con conexión a internet, sobre uno de los siguientes temas:

- Lactancia materna y su relación con el desarrollo físico e inmunológico.

- Enfermedades causadas por alimentación inadecuada.

- Trastornos psicosomáticos, síntomas y medidas de prevención.

- Infecciones de transmisión sexual, causas y consecuencias.

Registramos información que encontramos, en fichas. 


\section{La habilidad de expresarse}

Después de la expresión corporal, la expresión oral es el modo de comunicación más antiguo que se conoce entre los seres humanos. El idioma es un sistema de signos verbales que varía entre una cultura y otra. A partir de la oralidad se desarrolló la escritura: los símbolos gráficos que contribuyeron a la difusión del lenguaje. Escuchar hablar a otra persona hace que el contacto con ella sea más cercano, más íntimo e intenso. La manera de expresarse verbalmente dice mucho de la personalidad de cada persona. A través de la expresión oral se expresan ideas, sentimientos, se dan órdenes, se mantienen discusiones y diálogos. Además, ayuda a conservar y cultivar la cultura de un grupo determinado.

Los aspectos que más debemos cuidar cuando nos comunicamos son la voz, el volumen, la fluidez, el ritmo, la claridad, la coherencia, la emotividad y la dicción, pues a través de ellos enviamos mensajes a quienes nos escuchan:

Voz: sentimientos y actitudes.

Volumen: intensidad o apatía

Fluidez: dominio del tema y de las palabras

Ritmo: armonía

Claridad: precisión

Coherencia: expresión lógica

Emotividad: emoción que despierta el tema en el comunicador

Dicción: buen dominio del idioma, del significado de las palabras y su pronunciación.

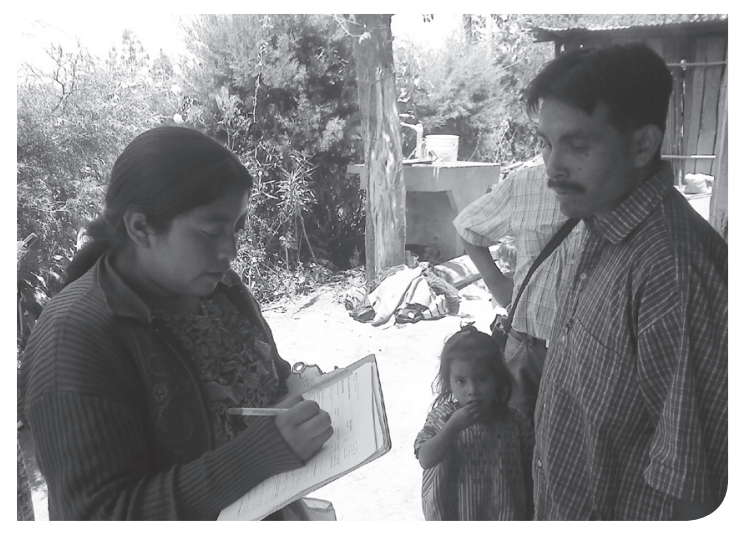

Aprendamos de nuestra facilitador o facilitadora qué es un programa de buenas prácticas. Pongamos atención a los temas que abordaremos, la forma de presentación a la comunidad, sección de propuesta de acciones saludables.

En este programa de buenas practicas abordaremos los siguientes temas:

1. Enfermedades comunes

2. Prácticas deportivas de la comunidad

3. Hábitos alimenticios

4. Problemas sociales y su efecto en la comunidad.

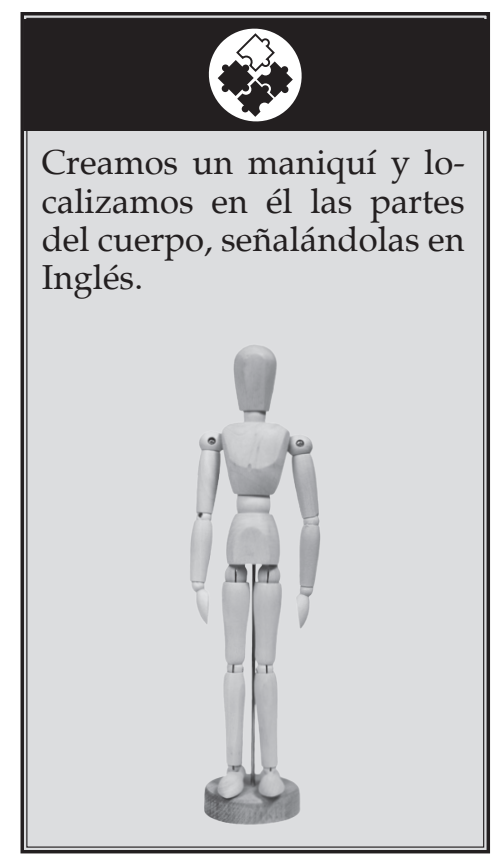

Creamos un maniquí y localizamos en él las partes del cuerpo, señalándolas en Inglés. 


\section{Soilud para la vida: lactancia materna}

\section{Glosario:}

Alimento: sustancia sólida o líquida que se consume con fines nutricionales.

Dieta: regulación de la cantidad de nutrientes que ingiere una persona.

Enfermedad: alteraciones del funcionamiento normal del organismo.

Enfermedades infecciosas: aquellas causadas por microorganismos patógenos.

Inmunidad: resistencia natural o adquirida que poseen los organismos frente a una enfermedad o un ataque a un agente infeccioso.

Metabolismo: reacciones químicas y biológicas que se producen en las células que realizan las funciones para la vida.

Nutrientes: sustancias contenidas en algunos alimentos, que son esenciales para las funciones del organismo.

Patógeno: microorganismo que ocasiona enfermedad.

Para más información puedes consultar la fuente: http:// www.who.int/topics/infectious_diseases/es/

En pequeños grupos, observemos la tabla y dialoguemos: ¿qué sugiere la tabla sobre la relación entre la lactancia materna y la desnutrición crónica en niños y niñas menores de 5 años?

Indicadores Básicos de salud

\begin{tabular}{|l|c|c|}
\hline & $\begin{array}{l}\text { Año } \\
\mathbf{2 0 1 2}\end{array}$ & Año 2015 \\
\hline $\begin{array}{l}\text { Lactancia materna exclusiva menor de } \\
\text { 5 meses }\end{array}$ & 49.2 & 53.2 \\
\hline $\begin{array}{l}\text { Desnutrición crónica en niños y niñas } \\
\text { menores de 5 años }\end{array}$ & 49.3 & 37.6 \\
\hline
\end{tabular}

Fuente: datos de UNICEF, ENSMI 2015 y OMS

- ¿Es común la lactancia materna en nuestra comunidad?

- ¿Cuál es el tiempo promedio de lactancia en la comunidad?

- ¿Qué dificultades hay para practicar la lactancia materna? ¿Por qué es importante?

La alimentación sana y los cuidados prenatales de la madre son básicos para la salud de ella y su bebé, fortalecen su inmunidad. Una mala nutrición, hábitos y actitudes inadecuadas pueden reducir la inmunidad y aumentar la posibilidad de contraer enfermedades que alteren su desarrollo.

La lactancia es el periodo en el que los mamíferos se alimentan únicamente de leche. Cuando el proceso de alimentación es con el pecho de manera natural se denomina lactancia materna. En seres humanos, es la única fuente de alimentación recomendable durante los primeros seis meses de vida. Durante ese tiempo no se recomienda ningún otro alimento, ni siquiera agua, agua con miel, atoles u otros, salvo indicaciones médicas especiales.

\section{(1)}
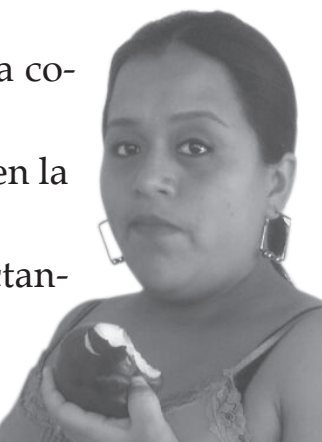

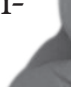

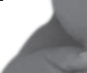


La lactancia, principal fuente de alimentación en los dos primeros años de vida de los seres humanos, favorece el desarrollo sensorial y cognitivo y disminuye la mortalidad infantil. Las niñas y niños amamantados con leche materna reciben los nutrientes y energía necesaria para su desarrollo; obtienen defensas contra infecciones y tendrán menos probabilidades de padecer alergias, y enfermedades digestivas, entre otras.

El calostro, es un líquido amarillento y más denso que la leche materna. Es el alimento natural que la madre proporciona a su bebé al nacer y durante los primeros días de vida. El calostro y la leche materna, son determinantes en el desarrollo del sistema inmunológico. Es la primera inmunización de las y los recién nacidos. La lactosa desarrolla la flora intestinal y la leche materna en general, ayuda a la maduración del intestino para la adecuada digestión. A partir de los seis meses y con la asesoría médica, la leche materna se combinará gradualmente con otros alimentos hasta que se sustituya totalmente.
La lactancia materna contribuye al crecimiento de la o el infante y a su desarrollo ya que fortalece la prevención de enfermedades. Cuando una bebé o un bebé no disfrutan de la lactancia materna pueden ser más vulnerables al riesgo de enfermedades infecciosas gastrointestinales y respiratorias, otitis e infecciones urinarias.
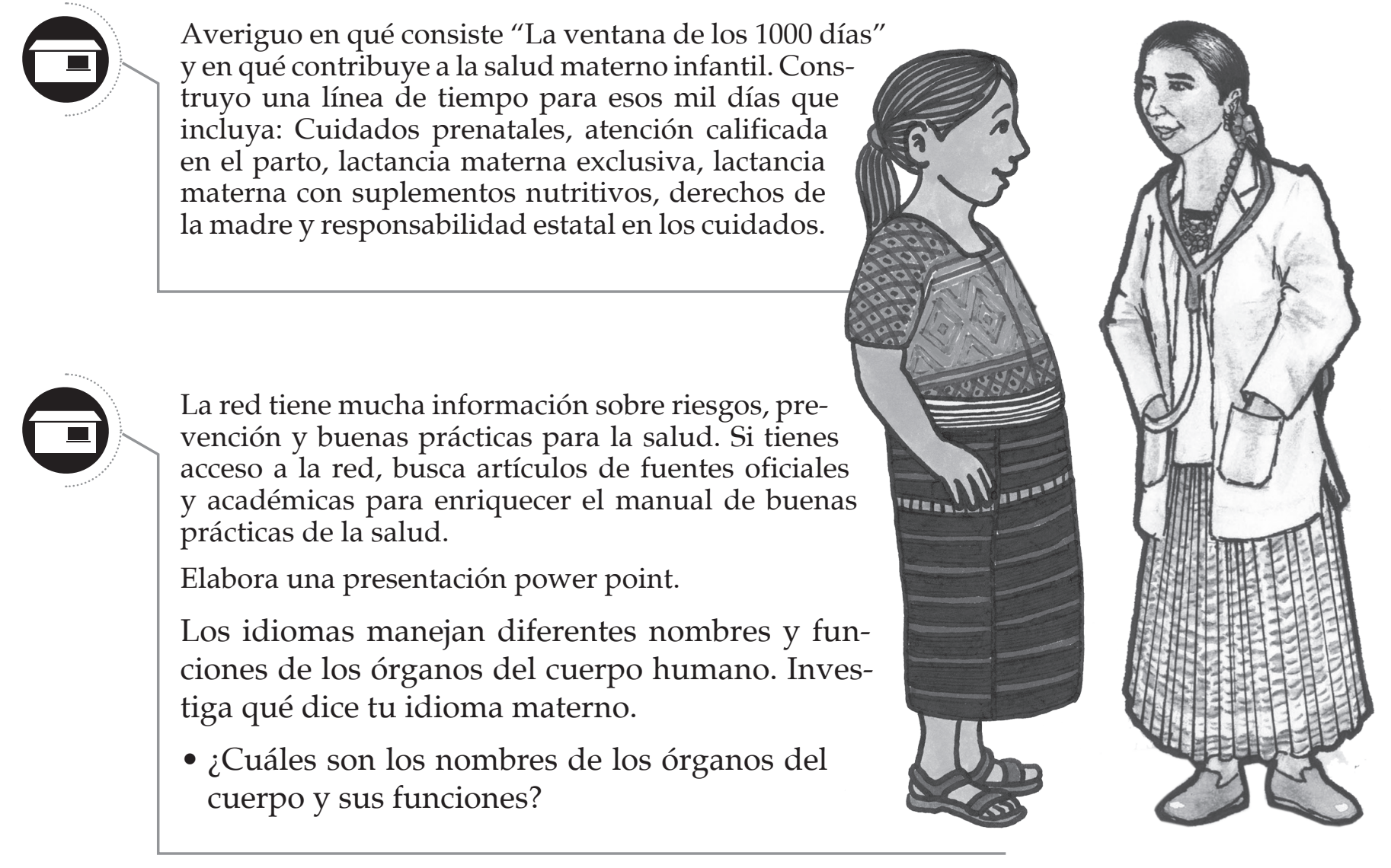


\section{Un Estado comprometido con el bienestar integral}

- ¿Qué responsabilidades sociales el Estado con los derechos laborales de las ciudadanas y ciudadanos?

\section{El Salario}

Cada año, la Comisión Nacional del Salario recomienda al Presidente los salarios mínimos. Desde hace varios años el salario mínimo es menor al costo de la Canasta Básica Alimentaria -CBA- (delo que gasta una familia para tener una dieta saludable) y al costo de (precio de la canasta básica alimentaria)brisus la Canasta Básica Vital -CBV(incluye el consumo de otros bienes básicos como ropa, vivienda, servicios básicosmedicamentos, educación etcétera) (precio de la canasta básica vital). Los precios de la CBA y CBV se actualizan mensualmente, los podemos consultar en: https://www.ine.gob.gt/ index.php/estadisticas-continuas/indice-de-precio-al-consumidos

- ¿Protege el Estado a la población aprobando un salario que es menor al costo de la canasta básica vital?

- ¿El salario que reciben las mujeres es igual al de los hombres?

- ¿Cómo incide el ingreso de una familia sobre las oportunidades que tiene para su desarrollo integral?

Argumento mis respuestas.

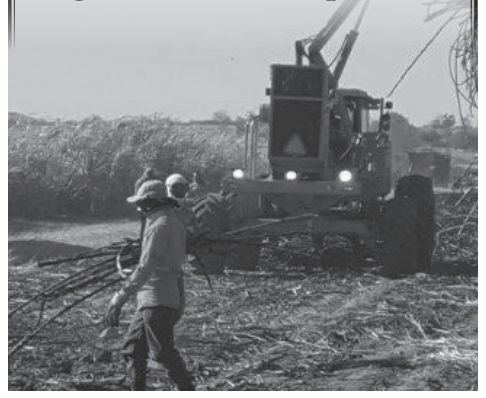

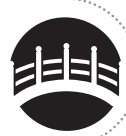

La Constitución Política de la República de Guatemala establece como finalidad del Estado el bien común de la población, para lo cual le asigna la responsabilidad de proteger a la persona y a la familia, garantizar a todas las personas la vida, libertad, justicia, seguridad, paz y su desarrollo integral. Para ello, el Organismo Legislativo, aprueba leyes específicas; y el Organismo Ejecutivo se ha organizado en una estructura que le permita cumplir sus responsabilidades. Por ejemplo, para garantizar el desarrollo integral de las personas se aprueban la Ley de Educación Nacional y el Reglamento Orgánico del Ministerio de Educación, entre otras. En este caso, se crea la Estructura del Ministerio de Educación, con los órganos de dirección central, las direcciones departamentales, supervisiones, hasta llegar a los centros educativos.

El cumplimiento de las leyes no siempre se alcanza. El Estado tiene una gran deuda con su población en materia de educación, salud, libertad, justicia, seguridad, bien común y desarrollo integral. Dicho incumplimiento se refleja en los indicadores de desarrollo humano que ya hemos estudiado.

Todas las personas debemos colaborar para resolver esta problemática. Las autoridades han de cumplir con sus responsabilidades, administrar con honradez y eficiencia los recursos. Todas las personas adultas deben tributar, en una proporción de acuerdo a sus ingresos de forma que quienes tienen menos ingresos puedan acceder a más oportunidades para mejorar su desarrollo integral y colaborar plenamente también. Los ciudadanos y ciudadanas podemos y debemos participar, apoyar proyectos de desarrollo, supervisar el gasto público, exigir a las autoridades y personas en el Estado la rendición de cuentas, aprovechar y cuidar los bienes estatales y comunitarios.

Elaboramos el instrumento de entrevista para integrantes de la comunidad y verificamos que contiene todos los aspectos que nos permiten obtener la información de temas como:

- Enfermedades comunes (niños, jóvenes, adultos)

- Prácticas deportivas de la comunidad

- Hábitos alimenticios

- Problemas sociales y el efecto que causan en la comunidad (Instituciones de la comunidad que colaboran con la temática abordada)

Nos aseguramos de incluir alguna pregunta sobre la forma en que la municipalidad, los ministerios, el COCODE colabora con el cumplimiento de servicios. 


\section{Deberes y derechos cívicos y políticos}

El Título II, Capítulo III de la Constitución Política de la República establece cuáles son los deberes y derechos cívicos y políticos de sus ciudadanas y ciudadanos. El Artículo 135, aclara que hay otros derechos y deberes cívicos y políticos contemplados en otros capítulos de la Constitución, así como en otras leyes de la República.

Los deberes y derechos cívicos que se mencionan en dicho capítulo son:

- Servir y defender a la Patria

- Cumplir, y velar porque se cumpla, la Constitución de la República

- Trabajar por el desarrollo cívico, cultural, moral, económico y social de los guatemaltecos y las guatemaltecas

- Contribuir a los gastos públicos

- Obedecer las leyes

- Guardar el debido respeto a las autoridades

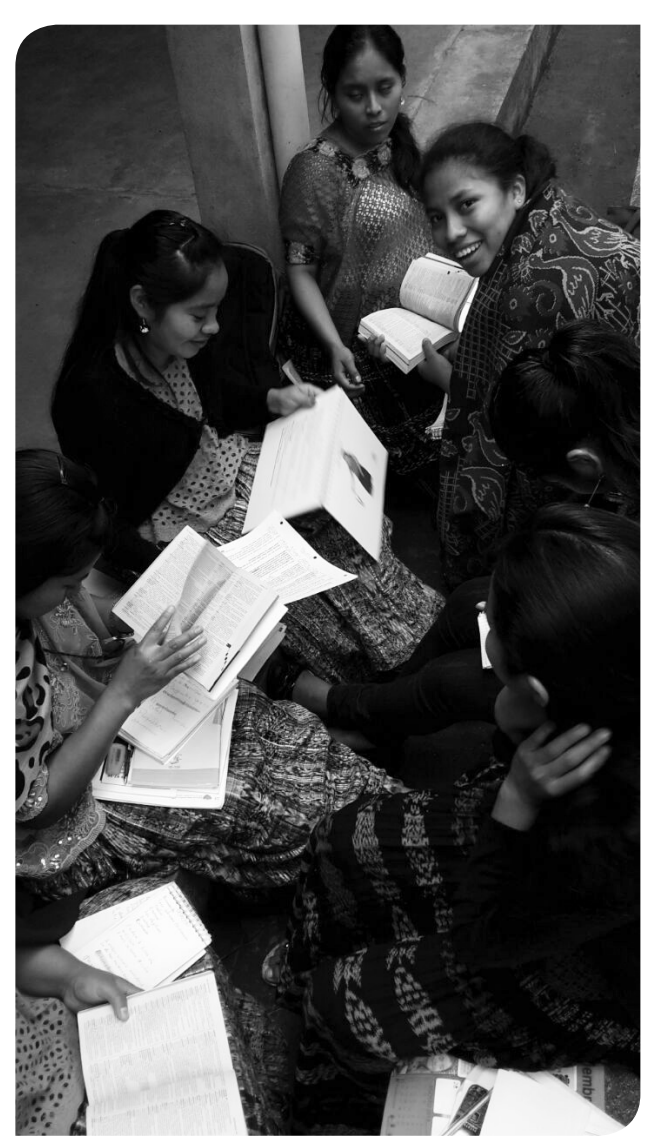

- Prestar servicio militar o social

Los deberes y derechos políticos son:

- Inscribirse en el Registro de Ciudadanos

- Elegir y ser electo (a)

- Velar por la libertad y efectividad del voto y la pureza de las elecciones

- Optar a cargos públicos

- Participar en actividades políticas

- Defender el principio de alternabilidad y no reelección del Presidente de la República

La Constitución también establece el derecho de petición en materia política. Esto significa que la población tiene el derecho de solicitar algo a las autoridades correspondientes que tenga relación con el proceso de elecciones de cargos públicos, actividades políticas de la ciudadanía o las acciones políticas de las autoridades.

Con nuestro equipo de trabajo, elegimos dos deberes y derechos cívicos y pensamos cómo su cumplimiento favorece el acceso a oportunidades de desarrollo salud integral.

\section{可}

- ¿Cuántas mujeres han sido presidentas de la república?

- ¿Cuántas mujeres de tu departamento son diputadas?

- ¿Cuántas alcaldesas ha habido en tu municipio?

- ¿Cuántas mujeres han sido presidentes o vicepresidentes del Comité Comunitario de Desarrollo?

- ¿Qué se puede hacer para que haya proporcionalidad entre los sectores de la población y sus representantes?

\section{Ley de servicio cívico}

En esta ley hay dos modalidades: el servicio militar y el servicio social. En 2011 comenzaron a ejecutar los primeros proyectos tanto de servicio militar como de servicio social. Los proyectos sociales cubren áreas como educación, salud, medio ambiente, juventud, investigación social, apoyo a personas de la tercera edad, entre otros. Mientras las áreas del servicio cívico militar fueron la prevención e investigación de desastres.

Legalmente, el servicio cívico es obligatorio. Cuando a una persona se le convoca a prestar el servicio cívico, puede manifestar si desea hacer servicio social o militar y nadie puede obligarle a realiza uno en particular.

Cuando cumpla 18 años, ¿en qué proyecto me gustaría participar? ¿Por qué? 


\section{Hementos cue hifiyen en nuestra condición de salud: varicibles dependientes y variables independientes}

Pensemos en las variables dependientes de nuestra salud integral:

Escribe en la línea una práctica que es dañina para la salud de tu corazón.

\section{Cuando \\ yo: $\quad$ hago \\ daño a la salud de mi \\ corazón.}

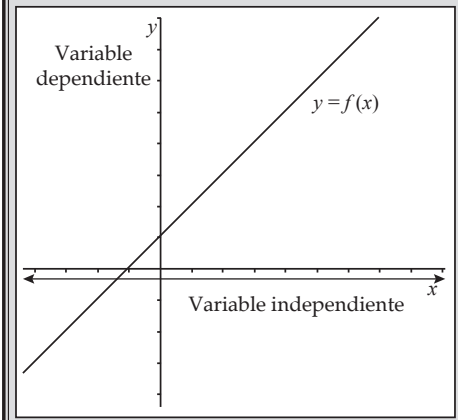

Respondemos: ¿Cuál es la variable independiente $y$ cuál es la dependiente? Explicamos.

Copiamos y completamos: "La

depende de

Escribimos una expresión algebraica que relacione ambas variables.
Según la Cámara de Industria de Guatemala existe una marcada diferencia salarial de acuerdo al nivel educativo de la persona. La gráfica a continuación muestra la variación de los salarios según el grado de escolaridad que se alcanza.

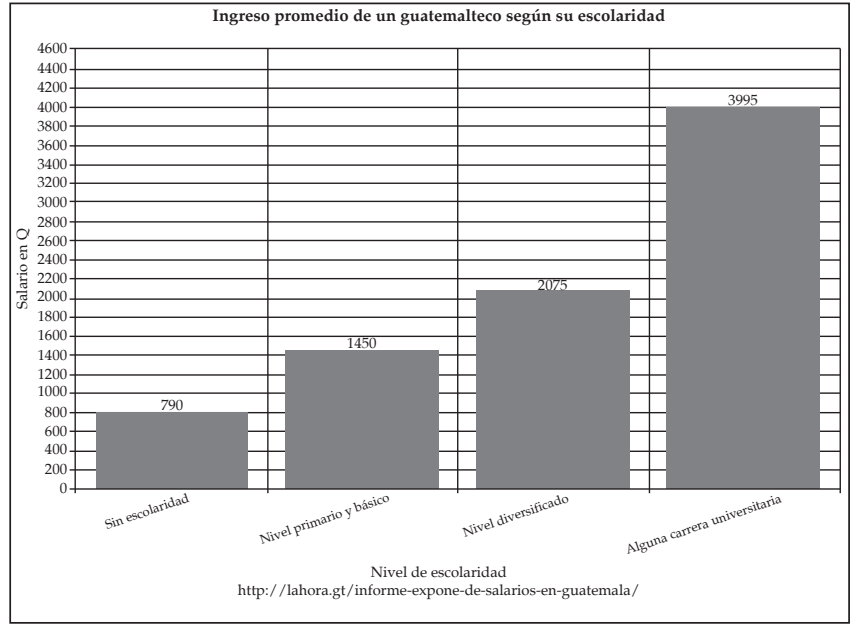

Luego de observar y analizar la gráfica comentamos:

- ¿Qué información se muestra en el eje $X$ ?

- ¿Qué información se muestra en el eje $Y$ ?

- ¿Qué sucede con el salario promedio de una persona en Guatemala conforme tiene mayor nivel de escolaridad?

- ¿Qué conclusión podemos obtener de la gráfica?

En los estudios científicos con frecuencia se intenta establecer la relación de causa y efecto entre dos fenómenos. En palabras matemáticas se busca identificar qué condición depende de otra: se les clasifica como variable dependiente y variable independiente. Una variable es un fenómeno observable o medible, que puede expresarse con una letra en una ecuación. La variable dependiente es el fenómeno que estamos observando que cambia como resultado de otro fenómeno. La variable dependiente es el hecho que influye y es capaz de modificar la variable independiente. En el ejemplo anterior, el salario se modifica en la medida en que aumenta el nivel educativo de la población. El salario depende del nivel educativo.

- ¿Cuál es la variable dependiente?

- ¿Cuál es la variable independiente?

Al representar dos variables en el plano cartesiano la variable independiente siempre se ubica en el eje $X$ y la variable dependiente en el eje $Y$.

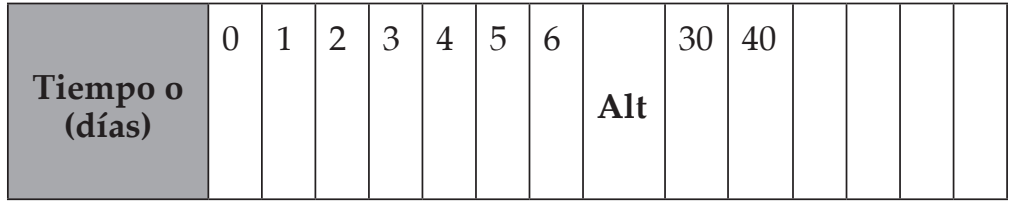

Comprobemos si se da así en la gráfica de los salarios y el nivel educativo. 
Conforme una de las variables aumenta o disminuye, la otra lo hace también. En una relación de proporcionalidad inversa mientras una variable aumenta la otra disminuye. Al representarla gráficamente se obtiene una línea curva llamada hipérbola.

En la gráfica que sigue se muestra la relación entre la velocidad de un vehículo y el tiempo que le toma recorrer cierta distancia.

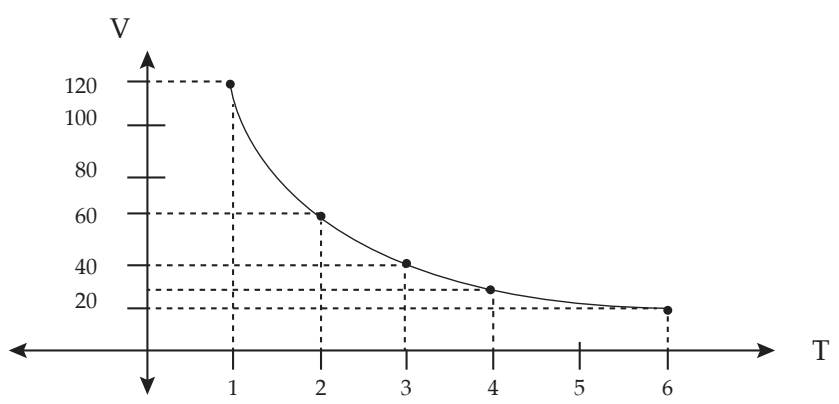

Una función es una relación en dónde una variable depende de una segunda variable. La regla para distinguir una función es que a cada elemento del conjunto $X$ (variable independiente) únicamente le corresponde un elemento del conjunto $Y$ (variable dependiente).

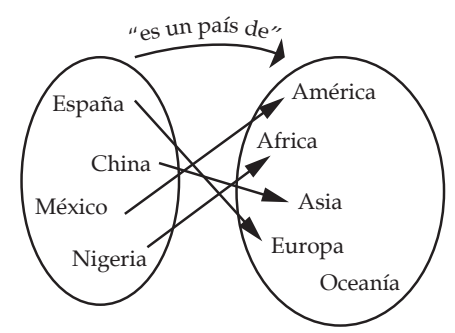

A cada elemento del conjunto "países" únicamente le corresponde un elemento del conjunto "continentes".

A partir de la información que está en el ladillo contestamos:

- ¿Qué tipo de funciones son las siguientes? Explicamos.
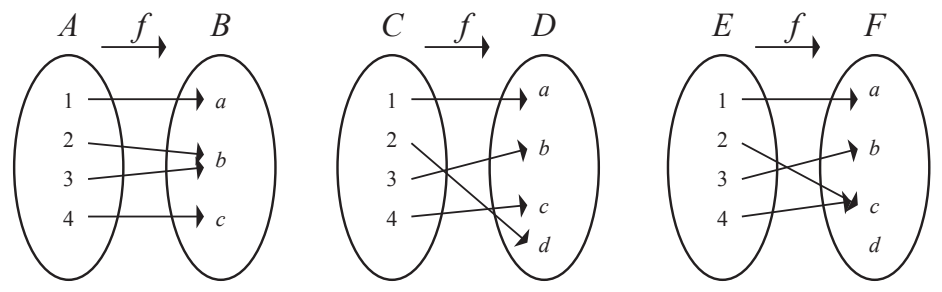

\section{Función Inyectiva}

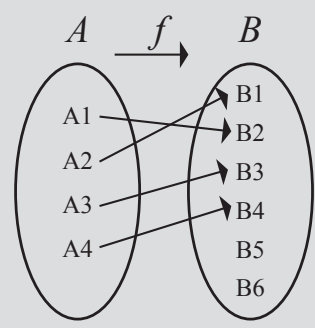

En todos los pares ordenados $(x, y)$ las y no se repiten.

\section{Función Sobreyectiva}

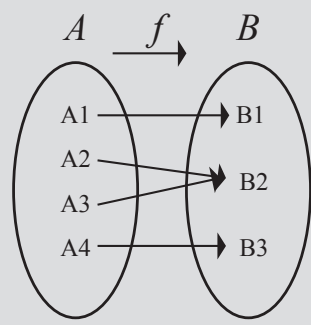

Todo elemento de y tiene, al menos, un elemento de $x$ que le corresponde.

\section{Función Biyectiva}

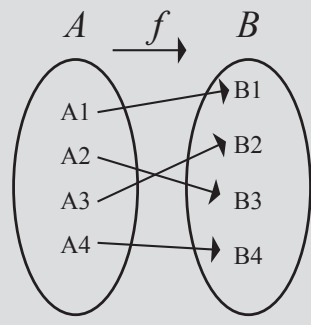

Si al mismo tiempo es inyectiva y sobreyectiva.

\section{Función Inversa}

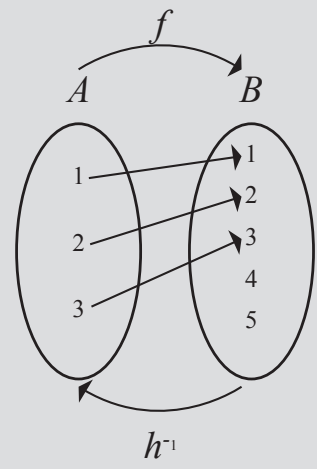

Una función es inversa de la otra si cumple con $f(a)=$ $b$ entonces $f^{-1}(a)=b$ 


\section{Arte y juego para la salud}

\section{Tangram, arte para recrear}

El tangram es un juego atribuido a la cultura china, sirve para formar cientos de figuras con solo siete piezas que resultan al dividir un cuadrado.

A. Pegamos 1 hoja de papel sobre un cartón de cualquier caja de tamaño mediano.

B. Trazamos un cuadrado y lo dividimos en las 7 partes según la imagen.

C. Pintamos de colores diferentes cada parte. Recortamos.

D. Armamos las figuras que se sugieren. Buscamos nuevas figuras para realizar.
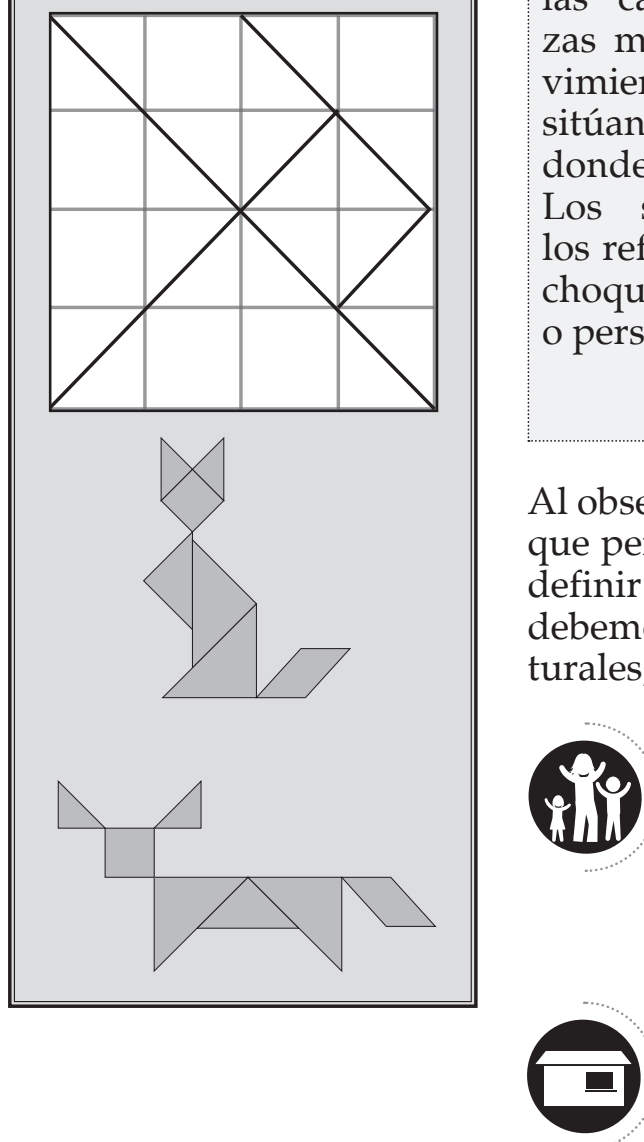

Al observar esto, notamos la importancia de mantener cuerpo y mente sanos que permitan realizar los procesos de la vida. Esto implica que es necesario definir prácticas adecuadas y razonables de actividad física. Al igual que debemos establecer equilibrio en el consumo de productos materiales y culturales, como el entretenimiento, las costumbres y los objetos de uso diario.

Al caminar y correr por Al trabajar en la parce- Los juegos colectivos las calles, las destre- la, nuestro cuerpo reali- requieren de un gran zas motoras y los mo- za múltiples movimien- esfuerzo de movimienvimientos reflejos nos tos, ya sean grandes o to y precisión. Algunos sitúan con el espacio mínimos. Pensamos juegos necesitan mucha donde nos movemos. con precisión para que concentración mental y Los sentidos activan el trabajo sea efectivo. creatividad.

los reflejos para que no Personas que trabajan choquemos con objetos en oficinas o en induso personas. trias, también se mueven pensando en hacer bien su trabajo.

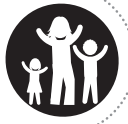

\section{Trabajemos en grupo}

Hagamos una lluvia de ideas de expresiones artísticas de nuestra comunidad que fomentan una vida sana, como juegos tradicionales, ritmos, melodías, celebraciones, rituales.

Busquemos al menos 1 persona que esté realizando alguna de las actividades enumeradas en la lluvia de ideas. Elaboremos una ficha de observación sobre la actividad anotando: qué esfuerzos físicos, mentales y emocionales requiere y cómo beneficia la salud integral. 
Todas las sociedades necesitan el trabajo para subsistir. Pero se da el caso de que muchas personas trabajan mucho y se distraen poco. Como todo en la vida, la salud se verá afectada según el equilibrio que se alcance en las actividades que realizamos. Cuando se pierde el equilibrio y se excede en el tiempo de beneficia se ven programas que estimulan la violencia pueden surgir efectos nocivos para la visión, la concentración y el estado de ánimo. Hacer actividades de tipo espiritual, cuando se realizan en plena libertad, genera y estrecha lazos de socialización. El pleno respeto a otras creencias es de vital importancia.

\section{Juegos y juguetes de la comunidad}

Todas las personas disfrutamos el juego por naturaleza. Los deportes son, antes que ejercicios físicos, juego para alegrar la vida. Por eso no vale la pena enojarnos cuando perdemos un partido de futbol o pierde nuestro equipo favorito. Y si ganamos, pues celebrémoslo jugando. Escribamos los juegos que hacemos en la comunidad, pueden ser físicos, de lenguaje, juegos de manos o con objetos. Cualquier actividad que nos hace jugar y pasarla bien sin hacerle daño a nadie.

\begin{tabular}{|c|c|c|c|c|}
\hline $\begin{array}{c}\text { Juegos } \\
\text { físicos }\end{array}$ & $\begin{array}{c}\text { Juegos del } \\
\text { lenguaje }\end{array}$ & $\begin{array}{c}\text { Juegos de } \\
\text { manos }\end{array}$ & $\begin{array}{c}\text { Juegos } \\
\text { con } \\
\text { objetos }\end{array}$ & $\begin{array}{c}\text { Otros que se } \\
\text { juegan en la } \\
\text { comunidad }\end{array}$ \\
\hline & & & & \\
\hline
\end{tabular}

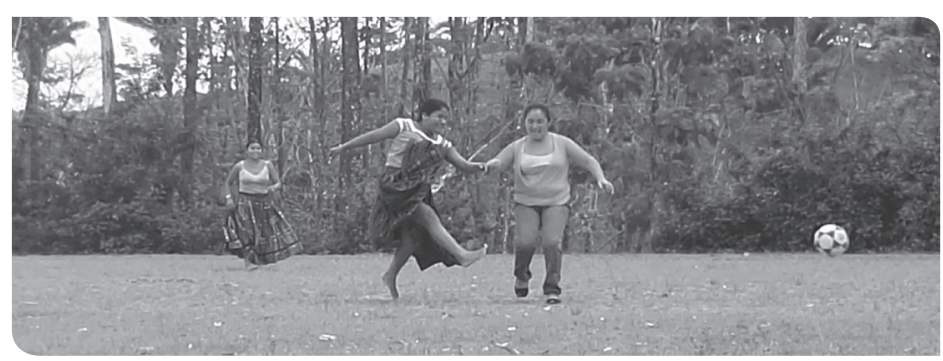

Preparémonos para realizar uno de los juegos que más nos gustan, realizando ejercicios de respiración, vocalización y relajamiento. Después de jugar, también podemos realizar estos ejercicios para continuar con las actividades de la sesión.

\section{Investigo sobre los juegos de mi comunidad}

- Consulto con mi familia, con vecinos y vecinas, sobre los juegos y juguetes que se han usado en la comunidad.

- Registro los hallazgos en una ficha. Realizo el juego con mi clase la próxima semana.

- Construyo el juguete y enseño el juego en la clase.

\section{Palíndromas y trabalenguas}

El palíndroma es un juego de palabras que se leen igual hacia adelante que hacia atrás.

Lee este palíndroma: "A mí, me mima,", en ambas direcciones.

Con ese palíndroma, intenta decir rápido el siguiente trabalenguas:

"A mí, me mima, A mí, me mima, A mí, me mima, A mí, me mima"

Ahora, disfruta este otro palíndroma y luego arma un trabalenguas con sus palabras:

“Échele leche, Échele leche, Échele leche"

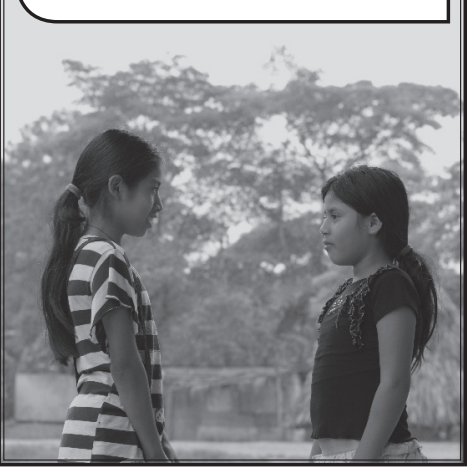




\section{Q alidod y salud en el proceso productivo}

\section{Empresas rurales}

La agricultura comercial provee ingresos a personas del área rural, muchas veces por medio de personas intermediarias, llamadas coyotes. Estas personas llegan a la puerta de la casa de quien produce y ofrecen pago inmediato a cambio de los artículos, pero a precios más bajos que el mercado. Luego estas personas venden el producto a un precio mayor en otro mercado. Para evitar los intermediarios $y$ obtener mejores precios de venta se necesita contactar directamente con empresas compradoras.

Un cliente empresarial, por ejemplo: una empresa agroexportadora, un supermercado o una cadena de restaurantes, requiere el cumplimiento de normas de calidad y un volumen alto de cosecha o mercadería. Productores o productoras de una o varias comunidades se asocian para trabajar en conjunto e invertir recursos, tiempo y esfuerzo en implementar cambios en la forma de producción, recolección y embalaje de los artículos.
El proceso productivo es el conjunto de actividades que se realizan utilizando tecnología para transformar los insumos en un producto. Por ejemplo, en un proceso productivo agrícola, los insumos son la tierra y las semillas, las cuales al utilizarlas aplicando tecnología, ya sea el chuzo, el arado o maquinaria, se transforman en productos vegetales.

Las etapas del proceso productivo agrícola son:

- Pre-labranza y labranza

- Siembra

- Cultivo: Cuidado de la siembra que incluye la fertilización, poda, riego, limpia y fumigación.

- Cosecha

- Postcosecha: Preparación del producto para su posterior uso, incluye la limpieza del producto, preservación, conservación, empaque y embalaje.

- Comercialización

La higiene es esencial en todas las actividades del proceso productivo de un alimento. Algunas medidas importantes son: utilizar agua limpia, impedir que los productos toquen el suelo, usar cajas limpias para recogerlo, tenerlo en un lugar fresco y que las personas que manipulan el producto tengan el pelo sujeto y las uñas cortas y limpias. En el caso de productos manufacturados, por ejemplo, jaleas o miel, los frascos deben estar limpios y esterilizados para evitar cualquier contaminación.

\section{Empaque}

Un buen empaque es importante porque ayuda a proteger y conservar el producto. En el caso de alimentos esto es imprescindible para evitar cualquier tipo de contaminación del producto o daño a la salud de quien lo consume. El empaque también tiene fines comerciales porque identifica al producto. Un buen empaque también permite el traslado del producto a puntos lejanos de venta.

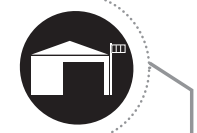

Visitemos a un vecino o vecina que forman parte de un proceso productivo artesanal, pecuario o agrícola que se practica en tu comunidad. Con su ayuda escribamos la lista de todas las actividades que realiza. Apuntemos cuáles son las normas de calidad que sigue y cómo empaca el producto.
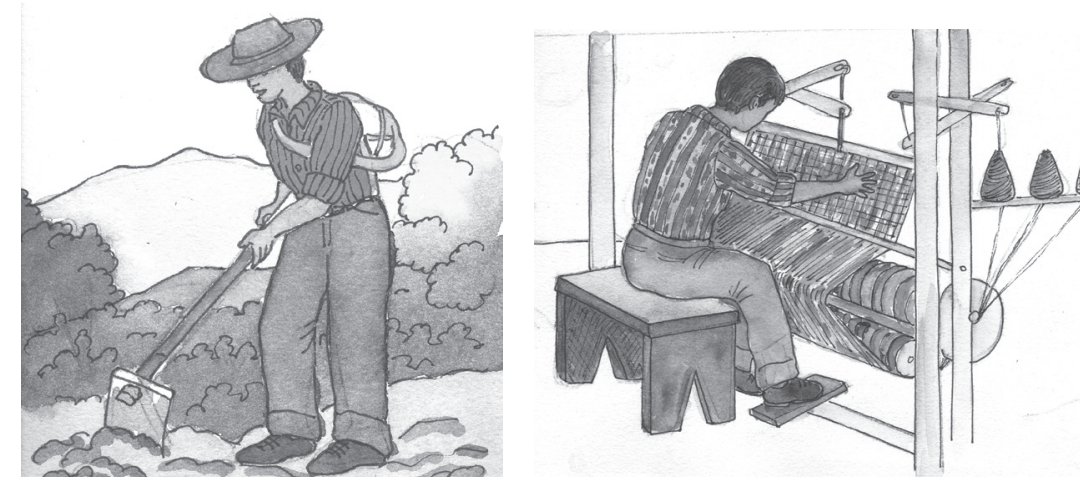


\section{Normas de calidad}

Se refieren al conjunto de requisitos que las empresas deben cumplir en el proceso productivo, el producto y el servicio, esto último en cuestión del costo, la comercialización y la satisfacción del cliente.

La calidad de un producto alimenticio se mide por la aplicación de medidas higiénicas y sanitarias: cómo se percibe el producto (sabor, olor, textura), sus componentes nutricionales y la relación cantidad-precio.

La higiene es el factor más importante en la calidad de un producto alimenticio. Esto incluye la limpieza del producto, del lugar y del personal. La rapidez con que se maneja el producto y la temperatura determinan su frescura, así como su sabor, olor y color.

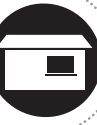

Elabora un mapa conceptual con los conceptos: proceso productivo, empaque y normas de calidad. Para facilitar la tarea, se puede ejemplificar con un producto.

Esta semana iniciamos la preparación de nuestro proyecto sobre prácticas de salud integral; corresponde, evaluar los avances al respecto.

\begin{tabular}{|l|l|l|}
\hline \multicolumn{1}{|c|}{ ASPECTOS A EVALUAR } & Sí & No \\
\hline $\begin{array}{l}\text { Elegimos uno o varios temas para trabajar nuestro } \\
\text { proyecto }\end{array}$ & & \\
\hline Iniciamos la búsqueda de información sobre el tema & & \\
\hline Organizamos equipos para investigar los temas & & \\
\hline Diseñamos el instrumento de entrevista & & \\
\hline $\begin{array}{l}\text { Incluimos variables dependientes e independientes en } \\
\text { nuestra investigación }\end{array}$ & & \\
\hline Relacionamos la expresión artística con la salud integral & & \\
\hline $\begin{array}{l}\text { Comprendemos la importancia de las normas de calidad } \\
\text { en los procesos productivos para la conservación de la } \\
\text { salud }\end{array}$ & & \\
\hline
\end{tabular}

Visita el mercado. Pon atención en la forma de utilizar los materiales de empaque para mantener la calidad del empaque. Haz una lista de empaques naturales que se usan en los puestos de venta.

\section{Empaques ecológicos}

En el 2016, San Pedro La Laguna, Sololá se convirtió en el primer pueblo de Guatemala en prohibir el uso de bolsas plásticas. Esta medida ha impulsado el uso de empaques ecológicos, tal y como se hacía hace varias décadas: hojas de plátano, tuza y papel, por ejemplo. Estos empaques son biodegradables, por lo tanto, no dañan el ambiente $\mathrm{y}$, además, conservan más frescos los alimentos.

El empaque es la forma más fácil de identificar un producto o una marca. Por eso, las empresas tienen cuidado en el diseño del mismo. Desde hace varios años, mujeres artesanas Jocotán, Chiquimula que cintas de petate ca reconocida de ron guatemalteco.

Visita el mercado. Pon
atención en la forma de
utilizar los materiales de
empaque para mantener
la calidad del empaque.
Haz una lista de empa-
ques naturales que se usan
en los puestos de venta.




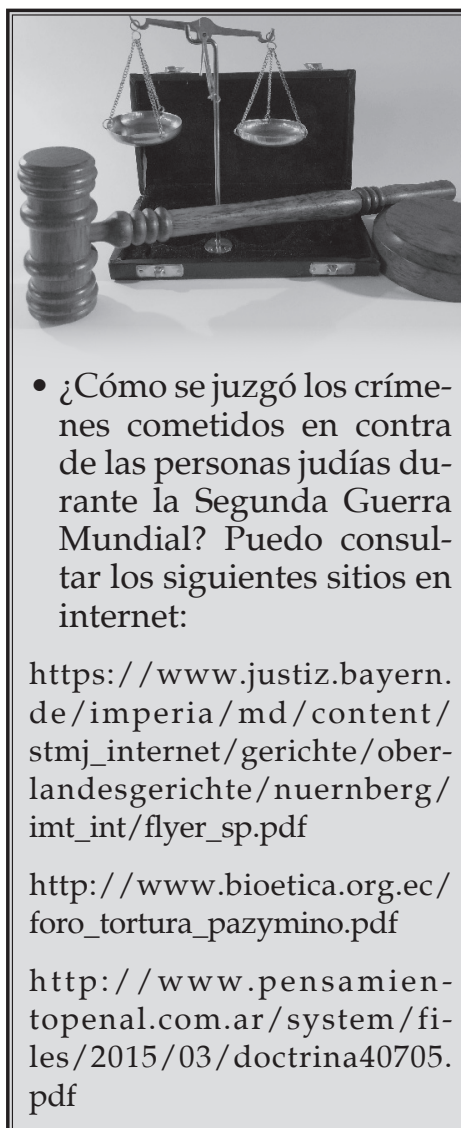

\section{El genocidio}

Se comete genocidio cuando un Estado promueve o realiza acciones para destruir, parcial o totalmente, a un grupo que se identifica como tal por razones étnicas, raciales, religiosas $\mathrm{o}$ culturales. Dentro de las acciones que se realizan están: exterminar a sus miembros, atentados graves contra la integridad de los y las integrantes del grupo, someter al grupo a condiciones de existencia que pueden destruir su existencia parcial o totalmente, impedir el nacimiento de más integrantes del grupo y trasladar niños y niñas pertenecientes a un grupo para que viva dentro de otro grupo.

De acuerdo con esta definición : ¿Qué acciones de genocidio hubo en Guatemala durante el conflicto armado interno?
Cuando hay un conflicto en la comunidad: ¿Como se afecta la vida cotidiana? ¿Qué cambios se dan en nuestra salud mental? ¿Qué derechos se dificultan cumplir?

De 1914 a 1919 sucedió la Primera Guerra Mundial en la que participaron 32 países. La causa fundamental fue dominar más territorios para hacer crecer las economías de los países que eran potencias en el momento. Causó más de 12 millones de muertes y la destrucción de recursos materiales. Después de esa guerra, los países del mundo enfrentaron una grave crisis económica que puso en peligro la salud y el bienestar de las poblaciones afectadas. Veinte años después inició la Segunda Guerra Mundial. En este período de 20 años y durante la Segunda Guerra Mundial ocurrieron hechos que aún horrorizan a la humanidad.

- Genocidio y holocausto del pueblo judío. En 1933 Adolfo Hitler se volvió canciller en Alemania. Su ideología nazi afirma que la raza aria es superior y que la comunidad judía era responsable de la crisis económica. Se emitieron leyes que les prohibieron laborar en el estado, les cerraron sus negocios y las sinagogas (sus iglesias), negaron su ingreso a los teatros, cines y lugares recreativos. Enviaron a campos de concentración a más de 30 mil personas judías. Más de la mitad de la población judía huyó de Alemania, Austria y Hungría. Durante la Segunda Guerra Mundial, se fusilaron a miles de judíos, se les obligó a trabajos forzosos y a vivir en reservaciones -ghettos. En 1942 decidieron exterminar a todas las personas judías y comenzaron a enviarles a los centros de matanza. Se estima que murieron más de 15 millones de personas provenientes de campos de concentración y reservaciones, de origen judío, polaco, ruso y también personas estigmatizadas como comunistas, gitanos y homosexuales. Esta barbarie se detuvo hasta que el grupo de países denominado Aliados derrotó al ejército nazi, en 1945.

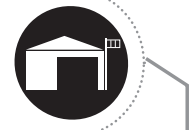

Durante la Segunda Guerra Mundial hubo grandes descubrimientos e inventos en el campo de la tecnología, como la bomba atómica, el radar y el helicóptero; pero todos destinados para la guerra. Casi nada se invirtió en mejorar las condiciones de vida de la población que se encontraba sobreviviendo una crisis económica severa.

- ¿En vez de liderar y financiar una guerra, cuáles hubieran sido buenas prácticas que promovieran para cuidar de la salud de la población?

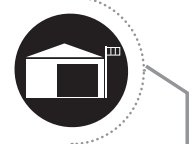

Discutamos sobre el mapa conceptual que elaboraremos. Incluirá: problemática, causas, consecuencias, acciones de prevención y de buenas prácticas. 
- Guerra civil española. 1936-1939. Su causa fue el conflicto entre los republicanos progresistas que gobernaban y los conservadores nacionalistas en la oposición. A los republicanos les ayudó la Unión Soviética, Francia y México con materiales para la guerra y llegaron brigadas de solidaridad de 30 países. A los nacionalistas los ayudaron Alemania, Italia, Portugal, Irlanda, Estados Unidos y Gran Bretaña. Como resultado de esta guerra, miles de familias tuvieron que marchar al exilio y perdieron sus posesiones, más de 250 mil personas fueron a prisión y hubo medio millón de muertos. Se destruyeron puentes, carreteras, fábricas, e infraestructura productiva; hubo pérdida de oro, plata y moneda extranjera. Se violaron los derechos fundamentales de las personas, la libertad política y la democracia. En el plano internacional, España vivió aislada durante 20 años.

- Bombardeo de Guernica. En abril de 1936, durante más de tres horas fue bombardeada la ciudad de Guernica, situada en el centro cultural del País Vasco, España. Casi toda la ciudad fue destruida y alrededor de 1,500 personas murieron. Dicho bombardeo lo llevó a cabo Alemania e Italia en apoyo a los nacionalistas durante la Guerra Civil. Los historiadores interpretan que Hitler quería probar la capacidad de destrucción que tenía su aviación de guerra.

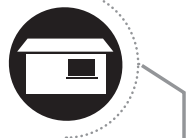

Escribimos una cosa en la que podría invertir la municipalidad para fomentar las buenas prácticas de salud integral en la comunidad.

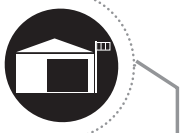

Quienes tuvieron acceso a la red y pudieron investigar en fuentes oficiales y académicas realizarán su presentación para enriquecer el manual de buenas prácticas.

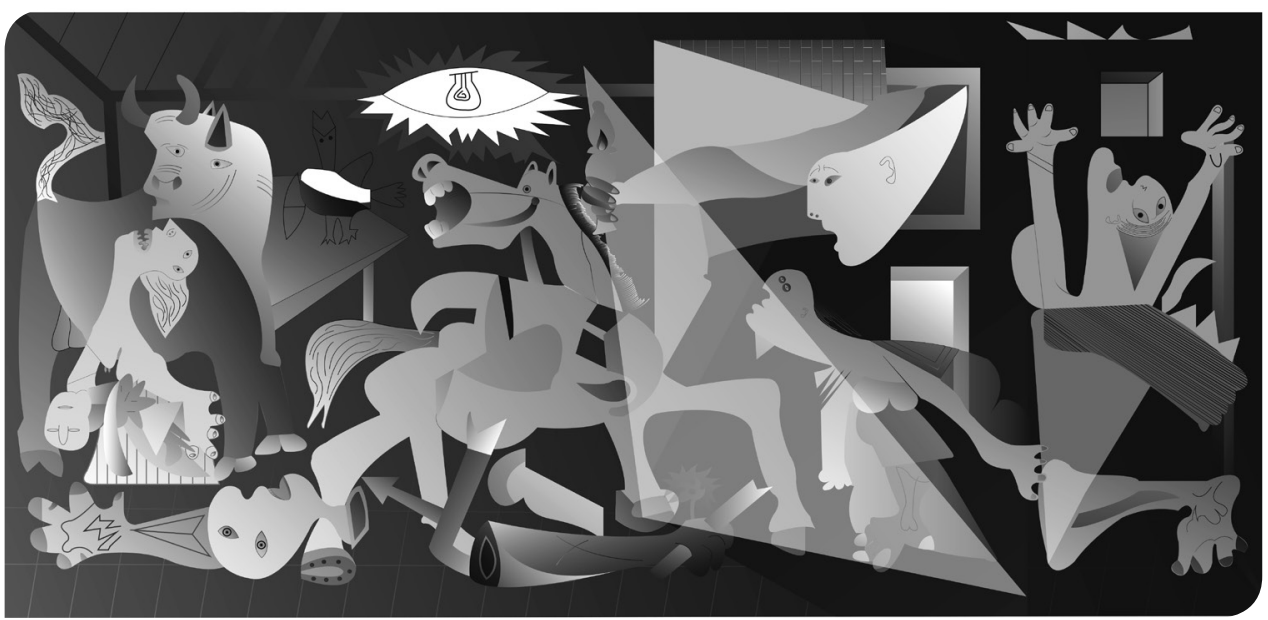

Pablo Picasso
- ¿Aún se sigue bombardeando ciudades y mueren civiles inocentes? ¿Por qué?

En las cunetas, en los bosques, junto a las tapias de los cementerios. En agujeros, enterrados como se da sepultura a los animales, hay todavía más de 100.000 civiles republicanos desaparecidos tras ser asesinados en la Guerra Civil y el franquismo. Cuando se acaban de cumplir 75 años del final de la contienda..."

Larrañeta, A. y Luna, V. (2014). 75 años después de la Guerra Civil, aún quedan más de cien mil desaparecidos por desenterrar. 20 minutos. Recuperado de: http:/ / www.20minutos. es/noticia/2102764/0/desaparecidos/guerra-civil/ exhumaciones $/$ \#xtor $=\mathrm{AD}$ $15 \& x t s=467263$

Comentamos casos que hemos escuchado de exhumaciones forenses en nuestro departamento que han dado con el paradero de las víctimas del conflicto armado interno. 


\section{Herramientais para nuestra mejor expresión}

\begin{tabular}{|c|c|}
\hline \multicolumn{2}{|c|}{$\begin{array}{l}\text { Los signos } \\
\text { de interro- } \\
\text { gación se } \\
\text { utili z a n } \\
\text { cuando se pre- } \\
\text { gunta algo. Quien lee mo- } \\
\text { difica en su mente el tono } \\
\text { de voz de la narración que } \\
\text { se vuelve inquisitiva. }\end{array}$} \\
\hline \multicolumn{2}{|c|}{$\begin{array}{l}\text { Los signos de ex- } \\
\text { clamación (llama- } \\
\text { dos también de } \\
\text { admiración) des- } \\
\text { tacan una emo- } \\
\text { ción. Indican un aumento } \\
\text { en el volumen de la voz, } \\
\text { expresan sorpresa, miedo, } \\
\text { alegría, enojo o pena. }\end{array}$} \\
\hline \multicolumn{2}{|c|}{$\begin{array}{l}\text { En español los signos de } \\
\text { interrogación ( } \text { ?) y de ex- } \\
\text { clamación (j!) son dobles, } \\
\text { es decir, abren y cierran } \\
\text { una oración. Nunca se } \\
\text { pone punto detrás de los } \\
\text { signos de interrogación / } \\
\text { exclamación. }\end{array}$} \\
\hline \multicolumn{2}{|c|}{ Veamos unos ejemplos: } \\
\hline & \\
\hline $\begin{array}{l}\text { María, ¿sa- } \\
\text { bes a qué } \\
\text { hora sale el } \\
\text { bus? }\end{array}$ & $\begin{array}{l}\text { María, } \\
\text { ¡apúrate } \\
\text { que nos va } \\
\text { a dejar el } \\
\text { bus! }\end{array}$ \\
\hline $\begin{array}{l}\text { ¿Me pue- } \\
\text { des dar } \\
\text { un poco } \\
\text { de agua, } \\
\text { Pedro? }\end{array}$ & $\begin{array}{l}\text { Tengo sed, } \\
\text { ¡Tráeme } \\
\text { agua, por } \\
\text { favor! }\end{array}$ \\
\hline
\end{tabular}

\section{Los sintagmas}

Todas las oraciones están formadas por dos grupos o unidades lingüísticas llamadas sintagmas. Podemos resumir que todas las palabras combinadas entre sí forman sintagmas y los sintagmas combinados entre sí forman oraciones, por lo que la fórmula para construir una oración es sintagma nominal + sintagma verbal.

\section{Sintagma nominal (SN):}

Esta unidad lingüística actúa como sujeto y tiene como núcleo un nombre o un sustantivo. El sujeto es la parte de la oración que define a la persona, animal o cosa de la que se habla: hombre, mujer, casa, mesa.

\section{Sintagma verbal (SV):}

El sintagma verbal es el predicado de la oración y su núcleo es un verbo. El predicado es lo que se dice acerca del sujeto (qué es lo que está haciendo el sujeto).

Ejemplos:

La médica visita a los enfermos una vez a la semana.

Sintagma nominal: La médica

Sintagma verbal: visita a los enfermos una vez a la semana

Núcleo del SN: médica

Núcleo del SV: visita

\section{Las jóvenes cuidamos nuestra salud y bienestar}

Sintagma nominal: Las jóvenes

Sintagma verbal: cuidamos nuestra salud y bienestar

Núcleo del SN: jóvenes

Núcel sel SV: cuidamos

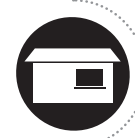

De los textos resultados de las entrevistas realizadas, escogeremos cinco ideas que aportan buenas prácticas alimenticias y las convertimos en oraciones con sintagma nominal y verbal para aportar al programa de buenas prácticas. Cuidamos el uso de los signos de puntuación.

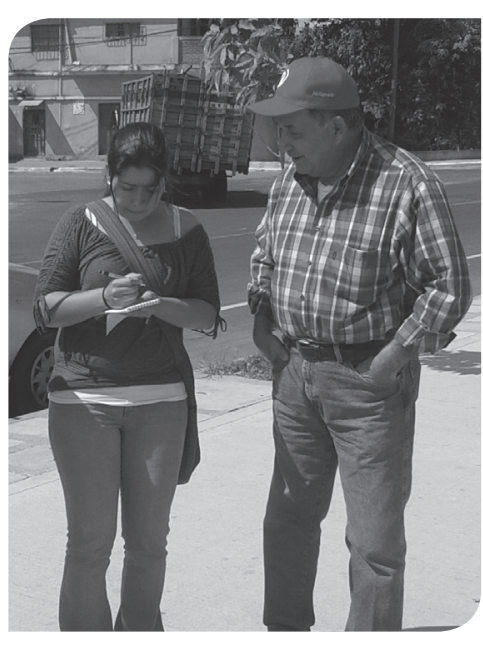




\section{Organizadores gráficos}

Los organizadores gráficos son la representación visual de los conceptos relevantes de un contenido. Hay muchas clases de organizadores gráficos, pero los más usados son:

\section{Mapa conceptual:}

Es una red de conceptos. Va de lo general a lo particular y se lee de arriba hacia abajo. Los nodos representan los conceptos y los enlaces la representación entre ellos.

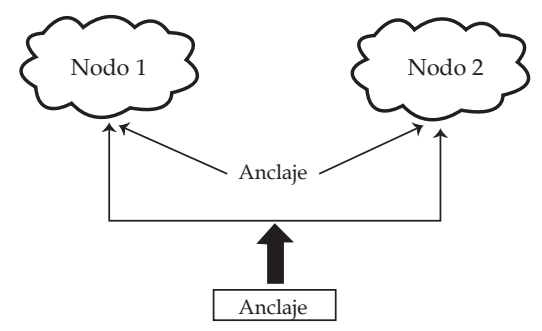

\section{Línea de tiempo:}

Ordena una secuencia cronológica de los eventos ocurridos para visualizar con claridad la relación temporal entre ellos. Las líneas de tiempo son muy útiles para comprender situaciones históricas o evolutivas y la duración de cada una de sus etapas.

\section{Organigrama:}

Representa la estructura jerárquica de una entidad y la relación entre los diferentes puestos y funciones que desempeña cada departamento o persona dentro de la misma.

\section{El peine:}

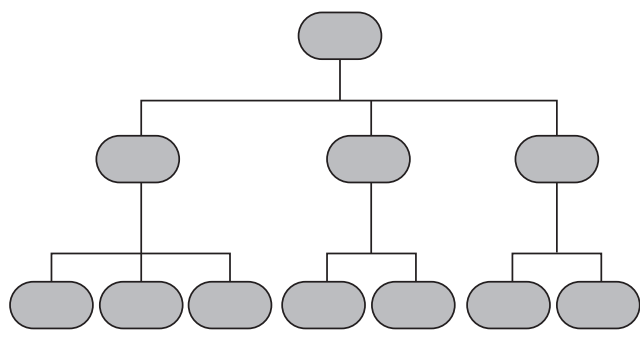

Se le llama así porque tiene la forma de un peine. En el mango se anota el tema central (Género narrativo) y en cada diente una variante (novela, fábula, cuento, leyenda, mito, etc.).

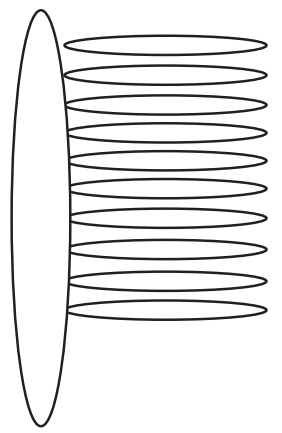

Cuando se van a realizar discusiones en una asamblea es importante establecer, previamente las normas parlamentarias que aseguren la participación de todas las personas integrantes del grupo y la deliberación amplia sobre el tema en discusión. Entre las normas más conocidas están:

1. Se delibera sobre un tema de forma exhaustiva, antes de entrar en el siguiente tema.

2. Todas y todos tienen derecho a participar, escuchar y ser escuchados.

3. Se establece y respeta un tiempo límite para cada intervención.

4. Se sigue la voluntad de la mayoría, se respeta la posición de la minoría.

- ¿Qué otras normas proponemos seguir para las exposiciones a realizar?

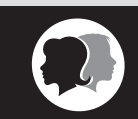

Elaboraremos un organizador gráfico para presentar la información que recopilamos en nuestra investigación.

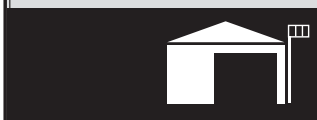

Escuchemos al primer grupo presentar su investigación sobre los hábitos alimenticios. Apoyamos su crecimiento evaluando su expresión oral. 


\section{se pue den graficar las buenas prácticas}

\section{Una función lineal es la que, al representarse gráficamente, es una línea recta.}

\section{Función creciente}

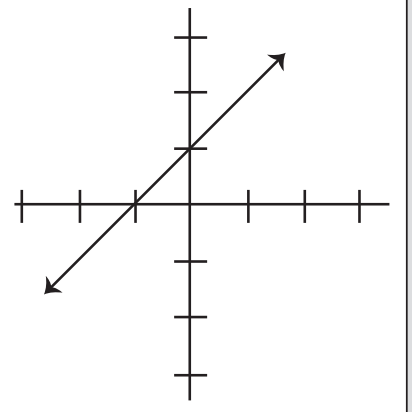

Función creciente

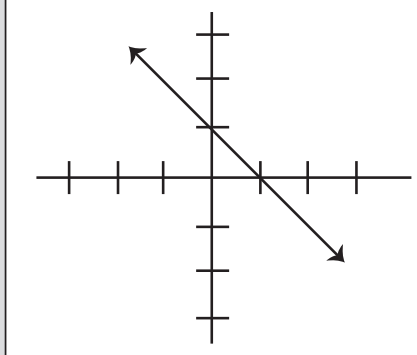

Función creciente

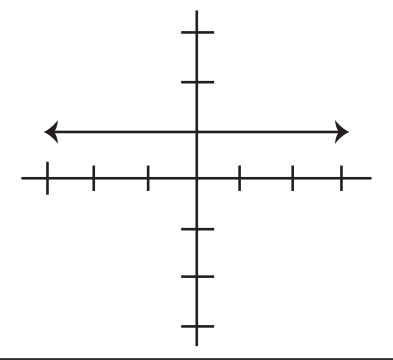

Una joven ciclista que va al instituto recorre una distancia (d) en un tiempo determinado $(\mathrm{t})$.

Relación entre tiempo y distancia que recorre la joven. 1 segundo recorre 6 metros 2 segundos recorre 12 metros 3 segundos recorre 18 metros 4 segundos recorre 24 metros 0 segundos recorre 0 metros

El área (a) de una siembra de lechuga orgánica, varía según la medida de su lado (l).

Relación entre la longitud del lado y área de la siembra de lechuga.

- $1 \mathrm{~cm}$ de longitud de lado equivale a $1 \mathrm{~cm}^{2}$ de área de siembra

- $2 \mathrm{~cm}$ de longitud de lado equivale a $4 \mathrm{~cm}^{2}$ de área de siembra

- $3 \mathrm{~cm}$ de longitud de lado equivale a $9 \mathrm{~cm}^{2}$ de área de siembra

- $4 \mathrm{~cm}$ de longitud de lado equivale a $16 \mathrm{~cm}^{2}$ de área de siembra

- $5 \mathrm{~cm}$ de longitud de lado equivale a $25 \mathrm{~cm}^{2}$ de área de siembra

Escogemos alguna de las dos situaciones de arriba y la graficamos en este plano

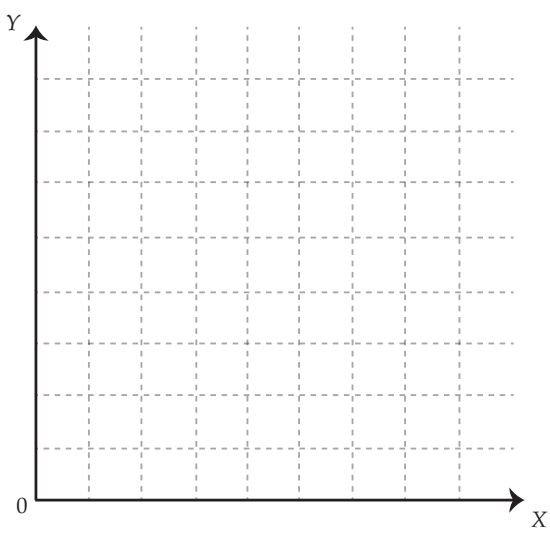

\section{Contestamos:}

- ¿Cuál es la variable independiente y la variable dependiente en ambas funciones? Explicamos.

- ¿Qué forma tiene la gráfica? ¿A qué se debe esa forma?

Discutimos y comparamos nuestras respuestas.

Elaboramos una gráfica para representar la siguiente situación. Luego contestamos las preguntas.

El número de calorías que se queman en una hora de correr dependen de la velocidad con que se práctica este deporte. Una persona que corre a $2 \mathrm{~km} / \mathrm{h}$ quema 210 calorías y si se corre a $6 \mathrm{~km} / \mathrm{h}$ se quemarán 370 calorías.

- ¿Qué tipo de función representa mejor la situación; una lineal o una cuadrática?

- ¿Qué expresión matemática representa la relación de la cantidad de calorías (c) con la velocidad con que se corre (v)? ¿Cómo hallamos esto? 
En una tienda de la comunidad se venden galletas nutritivas elaboradas por personas de la región. Se ha determinado que la ganancia diaria de la venta de los paquetes de la misma está dada por:

$$
\text { Ganancia }=-x 2+20 x \text {, en Quetzales }
$$

Donde $x$ es la cantidad de paquetes que se han vendido ese día y $y$ es....

Observamos la gráfica y contestamos:

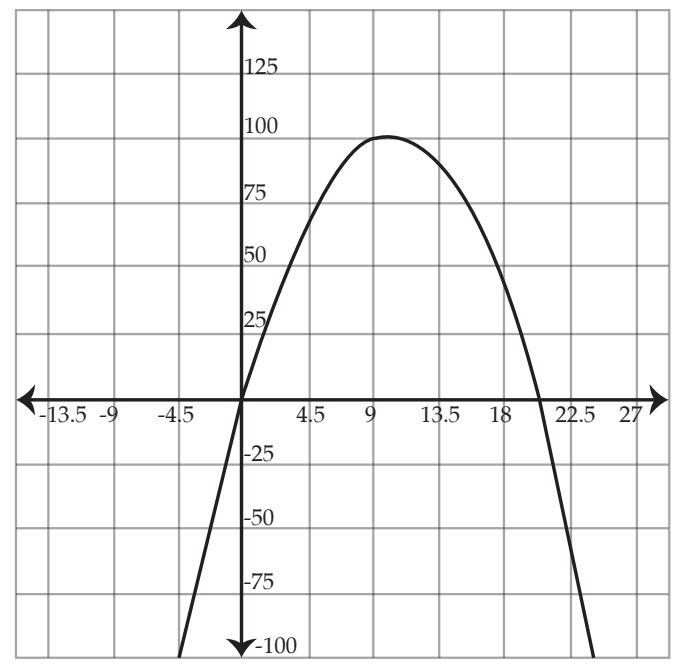

- ¿Qué tipo de función es la función de ganancias?

- ¿Cuál es la variable independiente y dependiente de la función?

- Aproximadamente, ¿cuál es el punto más alto de la gráfica?

- ¿Qué representa el punto más alto de la gráfica? Explicamos.

- ¿Cuál sería la ganancia si se venden 6 paquetes de galletas?

- ¿Qué ocurre con las ganancias después de llegar al punto máximo? Discutimos y explicamos.

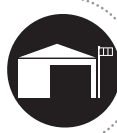

En equipos analizamos la información que hemos recolectado. Elaboramos tablas para ejemplificar la relación, ya sea lineal o cuadrática, entre las variables que estudiamos.

Determinamos, si es que existe relación, cuál es la variable independiente y la dependiente.

Representamos las relaciones en gráficos utilizando cartulinas y las presentamos a los demás compañeros y compañeras.

Elegimos un ejemplo de función lineal o de función cuadrática para representarlo en una cartulina y exponerlo al resto del grupo en la próxima clase.

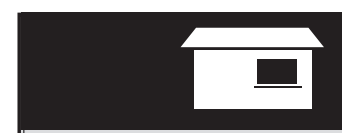

La gráfica de una función cuadrática es siempre una parábola.

Algunos tipos de función cuadrática:
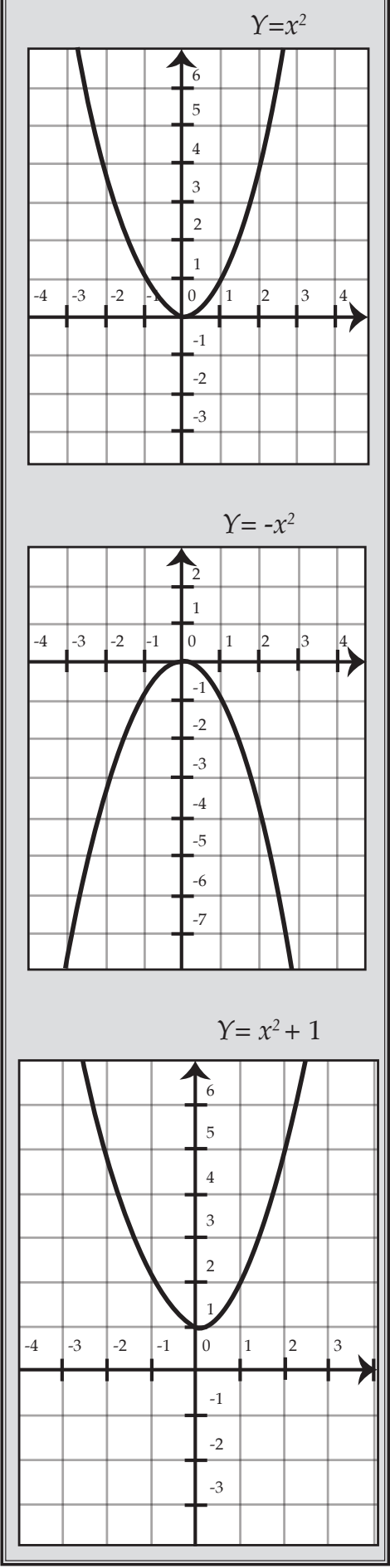


\section{Oonsumo responsable es bienestar integral}

\section{Desechos biológicos}

Los seres vivos producimos desechos biológicos, como las heces y las hojas podridas. Esto se convierten en dañinos por ejemplo, caen en exceso directamente en cuerpos de agua. Estos desechos producen bacterias que dejan al agua sin oxígeno lo que provoca la muerte de peces y plantas. Un mayor peligro ocurre cuando estas aguas se filtran a campos agrícolas o son utilizadas para regar cultivos porque contaminan los alimentos que luego consumimos.

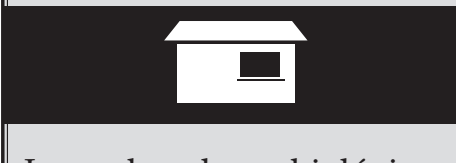

Los desechos biológicos también son aprovechables: una forma es el abono orgánico. Averiguo con mi familia o comunidad sobre el procedimiento para elaborar abono orgánico utilizando gallinaza o heces de marrano.

Los animales domésticos deben estar en un lugar especial separado de los ambientes familiares, de esa forma evitamos desechos en las áreas de habitación y prevenimos enfermedades.
El consumo responsable nos invita a reflexionar sobre el impacto de lo que consumimos en nuestra salud y el ambiente. Los herbicidas no distinguen entre las hierbas dañinas y las que son nutritivas o tienen propiedades medicinales. Por eso, los herbicidas químicos están provocando que variedades de plantas comestibles y medicinales estén desapareciendo en forma silvestre. A tal grado que ahora, plantas como el bledo, solo existen si se siembran. De esta manera estamos perdiendo alimentos y medicinas que la naturaleza nos ofrece.

La publicidad y la industria nos impulsan a comprar y gastar continuamente. Cada producto que consumimos trae un envase que suele ser desechable. El plástico, las bolsas metalizadas de las golosinas, y el duroport están inundando nuestras calles, barrancos y ríos. Este tipo de basura no puede ser degradado por ningún organismo vivo. Cuando estos materiales quedan en la calle o barrancos no se deshacen y cuando llueve, el agua los arrastra por barrancos hacia ríos y lagos y contaminan las fuentes de agua. Es así como nuestro consumo está degradando nuestras fuentes de alimento, de agua, nuestra salud y la del resto de seres vivos.

\section{Principio de las 4 Rs.}

Actualmente es inevitable utilizar objetos no biodegradables, pero podemos:

Reducir su uso: usar menos

Reutilizar:usar varias veces un mismo producto.

Reciclar: transformar un producto para darle un nuevo uso.

Recuperar materias primas: recolectar vidrio, plástico o aluminio, para volver a utilizarlos.

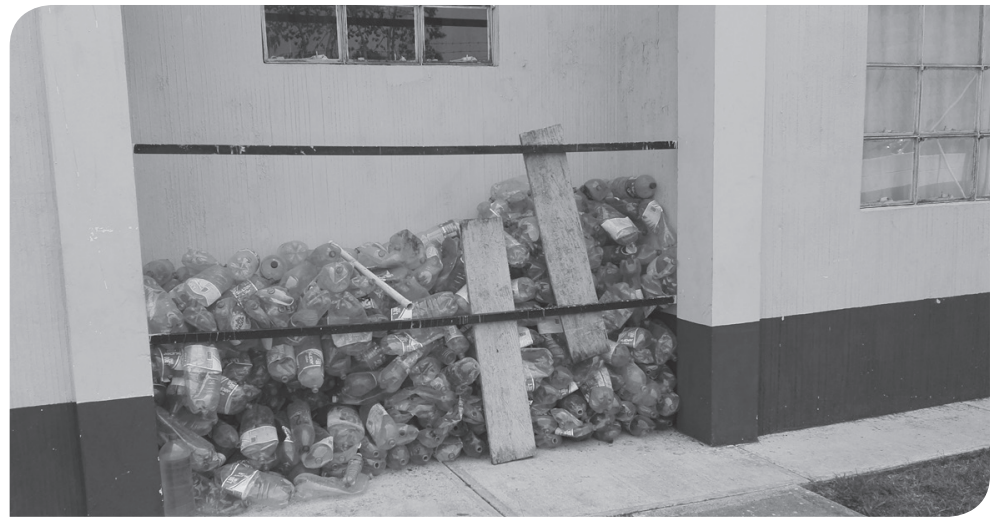

¿Qué acciones de consumo alimenticio responsable podemos llevar a cabo para el mantenimiento de la salud integral?

Los redactamos para incluir en nuestro programa. 


\section{Producción responsable}

Quien consume de forma responsable exige productos que se elaboren utilizando los recursos de manera eficiente, sin producir daños ambientales ni representar peligro para la salud de los seres vivos. Son las y los consumidores quienes a través de su preferencia de compra presionan a la industria para adoptar procesos productivos responsables y sostenibles.

Este cambio busca que la industria priorice el respeto y cuidado de los recursos naturales y los ecosistemas más que las ganancias económicas. Para ello hace falta reconocer el valor económico de los recursos ambientales, los cuales hasta ahora los tenemos por dados.

- ¿Has oído que las personas mayores dicen que antes las cosas duraban más? ¡Pues están en lo cierto! Estamos en la era de lo desechable, jusar y tirar! Esta actitud es impulsada por la industria para tener un ciclo sin fin de producción y ganancia, pero a costa de la salud del planeta, el cual estamos inundando de basura. La producción responsable toma en cuenta todo el ciclo de vida de los objetos que produce, lo cual incluye planificar su disposición al terminar su uso.

El objetivo de la producción responsable es evitar la situación actual: manchas o islas de basura plástica flotando en el mar; animales marinos lastimados por cuerdas y envases plásticos; la quema a cielo abierto de residuos electrónicos (partes de televisores, computadoras, celulares, etc.). En Guatemala, la falta de tratamiento de desechos sólidos y desechos industriales está contaminando ríos y lagos.

Elaboramos un cuadro sinóptico con información sobre el proceso productivo, el empaque de alimentos y las normas de calidad, tomando en cuenta el consumo y producción responsable.

Reflexiona, ¿cuánto cuesta una tabla de madera de caoba? Ahora, reflexiona, el monto asignado debe tomar en cuenta no solo el valor de esta madera, considerada preciosa, sino además el tiempo que el árbol ha necesitado para crecer y el servicio que nos presta como productor de oxígeno, hábitat de especies de animales, elemento importante en la producción de agua, regulador de vientos, reductor de erosión del suelo, sombra y otros. Qué valor le darías ahora?

\section{Tratamiento de} desechos sólidos en la comunidad

Pocas ciudades, pueblos y caseríos en Guatemala tienen un manejo adecuado de los desechos sólidos o basura. La descomposición de desechos orgánicos, como sobras de comida, produce malos olores y atrae a animales como ratas y zopilotes que portan enfermedades. La basura no tratada termina en ríos contaminando el agua. Pero la basura también puede traer beneficios. Lo primero es recuperar objetos reciclables, como papel, latas de aluminio, objetos plásticos y de metal. Los desechos orgánicos tratados adecuadamente se pueden transformar en abono orgánico.

En San Pedro La Laguna, un grupo de productores de café recolecta la basura del pueblo y utiliza los desechos orgánicos para elaborar lombricompost, un abono que utiliza lombrices Coqueta Roja.

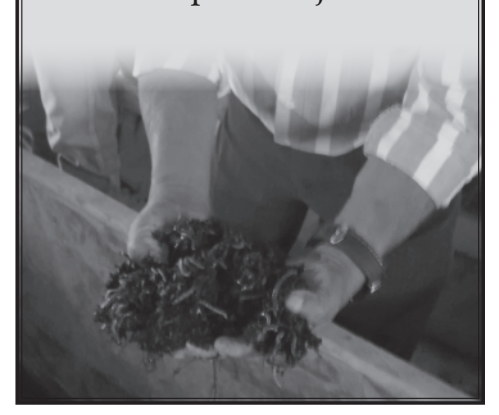




\section{Danzar, una actividad muy sana}

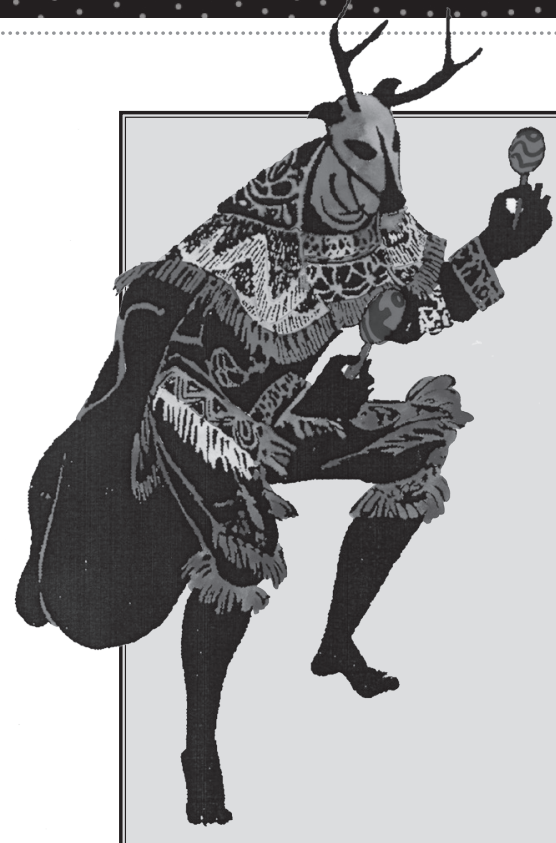

Pasos simples para cualquier baile de disfraces

Formando filas, individualmente, hacer la siguiente rutina de movimiento:

Pie izquierdo (Pi), Pie derecho (Pd)

1. Marcando el paso en cuentas de 2: 1-2, 1-2, 1-2, 1-Pi, 2-Pd

2. Pi marca el paso 1 en el mismo lugar, $\mathrm{Pd}$, adelanta en paso 2, retrocede en paso 2. El pie izquierdo se mantiene en el mismo lugar, solo el derecho avanza y retrocede.

3. Avanzan en el sentido de cada paso, 1-2, 1-2, 1-2,

\section{En parejas}

Frente a frente, se toman de la mano. Uno de los dos integrantes guía a la pareja. Se desplazan realizando el mismo paso, se desplazan por el espacio haciendo la misma rutina, 1-2, 1-2, 1-2, Cambian de paso cuando hacen series de 8 veces. Pueden hacer movimientos como vueltas en el mismo lugar, levantar los brazos de la pareja y pasar debajo, entre otros.
Guatemala posee una larga tradición de danzas que son parte de los grupos que convivimos en el país. Las danzas pueden catalogarse como buenas prácticas para la salud integral. También son parte de nuestro derecho a la recreación y a la identidad cultural.

Aprendimos sobre los tipos de danza que existen, tradicionales, populares y comerciales. Las danzas tradicionales son las que se usan dentro de una celebración de la comunidad y tienen un nexo de tipo religioso. Se hacen para determinadas fechas como ferias, convites y fiestas patronales o cantonales. Se pueden mencionar: baile de toritos, baile de moros y cristianos, el Paabank, el Urram, baile de los fieros, baile de mamarrachos.

\section{Bailes con disfraces:}

\begin{tabular}{|c|c|c|}
\hline $\begin{array}{c}\underline{\text { Baile de Mamarrachos }} \\
\text { Se celebra en San Ray- } \\
\text { mundo, Sacatepéquez a } \\
\text { finales de enero. } \\
\text { El sentido del baile es la } \\
\text { fiesta, con movimientos } \\
\text { que parecen ridículos o } \\
\text { fuera de lugar, por eso } \\
\text { usan los disfraces. } \\
\text { Caminan por las calles } \\
\text { haciendo formaciones } \\
\text { o coreografías simples } \\
\text { para hacer reír al pú- } \\
\text { blico. }\end{array}$ & $\begin{array}{c}\text { Baile de los Fieros } \\
\text { Se celebra en Villa } \\
\text { Nueva, Guatemala, a } \\
\text { principios de noviem- } \\
\text { bre. } \\
\text { Cada quien busca un } \\
\text { personaje de moda y se } \\
\text { disfraza para represen- } \\
\text { tarlo. } \\
\text { Caminan por las calles } \\
\text { del pueblo haciendo } \\
\text { formaciones y pro- } \\
\text { vocando la risa del } \\
\text { público. }\end{array}$ & $\begin{array}{c}\text { Los disfraces de ambos } \\
\text { bailes pueden fabri- } \\
\text { carse con materiales } \\
\text { simples: } \\
\text { Se usan sobre la ropa y } \\
\text { no requieren de acce- } \\
\text { sorios. } \\
\text { Las máscaras también } \\
\text { se pueden fabricar. } \\
\text { Puede hacerse con } \\
\text { cualquier ritmo que } \\
\text { sea pegajoso, aunque } \\
\text { el ritmo preferido es la } \\
\text { cumbia. } \\
\text { Las coreografías son } \\
\text { simples formaciones } \\
\text { de líneas, parejas y } \\
\text { grupos que bailan to- } \\
\text { mados de la mano. }\end{array}$ \\
\hline
\end{tabular}

\section{Trabajemos en grupo}

- Hagamos una lista de personajes que nos gustaría representar bailando en un convite.

- Deben ser personajes que motiven y estimulen las buenas prácticas de salud integral.

- Diseñemos un disfraz simple, que sea fácil de realizar con material de reciclaje.

- Diseñemos tres o cuatro pasos en solitario o en pareja para bailar.

- Practiquemos el baile con un corrido o una cumbia, o cualquier ritmo que cuadre con la cuenta de 2 . 


\section{Movimiento y alimento saludable}

Al bailar ocurren muchos procesos en el cuerpo. La liberación de endorfinas es uno de ellos, y al hacerlo, se produce una sensación de felicidad. Hay otros factores que ayudan a liberarla y esa sensación de bienestar es la clave para detectar que una actividad la está liberando en el cuerpo.

La alimentación es un proceso que también provoca placer, pero no todo lo que provoca placer es adecuado para la salud. En todo caso es preferible encontrar un equilibrio entre una adecuada alimentación, con productos orgánicos y un ejercicio físico. La actividad de la página 100 seguramente ayudará a liberar endorfinas y provocará placer al realizarla.

\section{Peligro para la salud}

- Hacemos una lluvia de ideas sobre las consecuencias de la alimentación dañina y la falta de ejercicio físico.

- Participamos en un conversatorio sobre el tema

- Redactamos conclusiones sobre la situación alimentaria en la comunidad y sus consecuencias. Estas formarán parte del Programa por lo que alguien debe tomar nota.

\section{Bailes con cuenta de 3}

El son guatemalteco se baila en cuentas de 3 .

Para hacerlo se cuenta: 1-2-3, 1-2-3, 1-2-3, 1-2-3

Pon a sonar cualquier son de Guatemala e intenta bailarlo asi:

Pi-Pd-Pi, marcando 1-2-3, luego Pd-Pi-Pd, cada pie de puntillas, como saltitos cortos, sin parar entre cada 1-2-3-1-2-3-1-2-3

Otros bailes en el mundo se cuentan en 3: el vals y el minué.

3 2

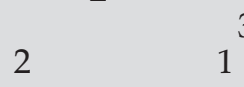

Sigue el esquema según los números:

Pi-Pd-Pi; Pd-Pi-Pd $1-2-3 \quad 1-2-3$

\section{Elaboro nuevas rutinas de movimiento}

Busco información sobre las rutinas de movimiento en otros bailes. Con mi grupo de trabajo selecciono música y materiales para la creación de una representación danzara en la que se incluya una rutina de ejercicios. 


\section{Importanoia y benéficios de la lactancia materna}

\begin{tabular}{|l||} 
Elaboro un cuadro compa- \\
rativo sobre el estado de \\
salud de una niña o niño a \\
quien se amamantó con le- \\
che materna hasta la edad \\
de seis meses y alguien que \\
no lo fue. \\
Enlisto buenas prácticas \\
vinculadas con la lactancia \\
materna.
\end{tabular}

La leche de la madre protege al bebé de enfermedades infecciosas y crónicas por medio del fortalecimiento del sistema inmune. Les protege de enfermedades frecuentes en la infancia: diarrea, neumonía y otras, evitando así la desnutrición infantil. Que una madre no pueda dar de mamar a menores de un año en condiciones de pobreza y pobreza extrema, agrava los indicadores de desnutrición, morbilidad y mortalidad infantil.

La lactancia materna también es importante para la madre, ya que, reduce el riesgo de cáncer de ovario y de mama, disminuye el riesgo de depresión y anemia post parto, contribuye a reducir hemorragias uterinas, a bajar de peso y previene riesgo de osteoporosis. Además, crea un vínculo afectivo entre madre y bebé.

La madre que da de mamar, necesita tener controles médicos, alimentarse y nutrirse. Debe ser apoyada por su familia y la sociedad porque su trabajo en esos días es muy importante. Tiene derecho a dar de mamar a su bebé en espacios públicos y si trabaja en relación de dependencia tiene derecho a disponer de tiempo para dar de mamar a su bebé y brindarle los cuidados necesarios.

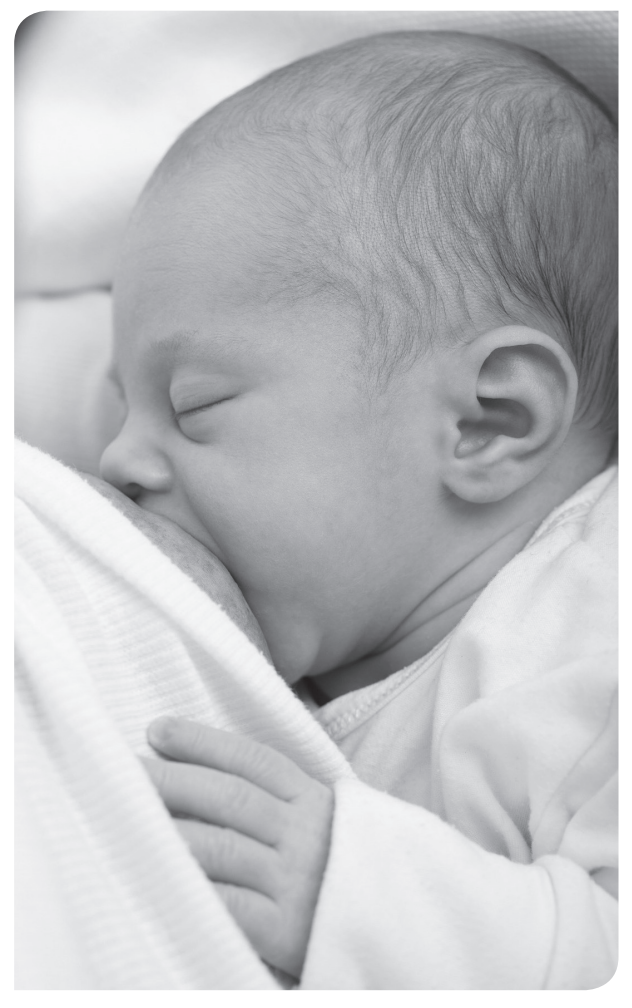

La madre tiene derecho de amamantar a su bebé a libre demanda, en espacios públicos y a ser respetada por toda la población. En algunos restaurantes se apoya la iniciativa: "Si necesita amamantar a su bebé, pase sin pedir permiso" y abren sus puertas a mamás que amamantan a sus bebés.

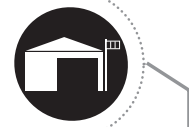

Analizamos el siguiente problema y la solución que recomienda la Organización Mundial de la Salud.

\section{Problema:}

La malnutrición es responsable de la muerte de aproximadamente 1 de cada 3 menores de 5 años, dado que no los niños y las niñas malnutridas no logran adquirir un desarrollo del sistema inmune para defender al cuerpo de algunas enfermedades.

\section{Recomendación:}

Iniciar la lactancia materna en la primera hora de vida, y mantenerla como única forma de alimentación durante los seis meses siguientes. Continuar con la lactancia complementada adecuadamente con otros alimentos.

Comentamos si en nuestra comunidad se practica la recomendación brindada por la OMS y qué factores dificultan o favorecen poner en práctica la misma.
} 


\section{Efecto inmunológico de la lactancia materna}

El sistema inmunológico es la defensa natural del cuerpo contra las infecciones. Combate, destruye o disminuye la proliferación de microorganismos infecciosos antes de que provoquen una enfermedad. Está compuesto por órganos primarios (médula ósea y timo) y órganos secundarios (ganglios linfáticos y el bazo). El sistema inmune también fabrica anticuerpos que son proteínas que detectan sustancias dañinas, llamadas antígenas. Los antígenos incluyen microorganismos, como bacterias, hongos, parásitos, virus o sustancias químicas.

Los órganos primarios proporcionan un ambiente ideal para las células del sistema linfático o linfocitos, que ayudan a combatir los microorganismos dañinos del cuerpo. Cuando una madre amamanta a su bebé, proporciona anticuerpos específicos para protección. A largo plazo, el sistema inmunológico maduro reconoce y ataca antígenos perjudiciales, a la vez que diferencia los que no son dañinos.

La capacidad de diferenciar los antígenos perjudiciales de los no dañinos, evitará reacciones alérgicas inflamatorias y el aparecimiento de enfermedades autoinmunes. También a largo plazo, la persona amamantada con leche materna tendrá mayor facilidad para el adecuado desarrollo físico y mental, debido a que recibió los nutrientes adecuados en la primera etapa de vida y tendrá menor riesgo de contraer enfermedades como diabetes y leucemia.

- Exponemos en clase sobre los temas investigados en la semana anterior según calendarización.

- Elaboramos en grupo un mapa de conceptos con el tema: Efecto inmunológico de la lactancia materna.

- Exponemos los trifoliares en el aula y cada grupo evalúa el trabajo del resto. Utiliza la siguiente lista de cotejo:

\begin{tabular}{|l|c|c|}
\hline \multicolumn{1}{|c|}{ CRITERIO } & Sí & No \\
\hline Incluye la función del sistema inmunológico & & \\
\hline Aparecen los nombres de los órganos que lo forman & & \\
\hline Definen las ventajas de brindar lactancia & & \\
\hline
\end{tabular}

Redactamos consejos para ingerir los alimentos presentados en la pirámida alimenticia, en Inglés.

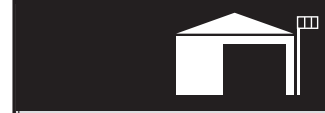

La lactancia materna, al menos durante los primeros seis meses de vida, evita o retarda la aparición del asma, la rinitis alérgica, la dermatitis atópica y la alergia alimentaria. Porque, la leche materna es responsable de la maduración de la barrera constituida por la mucosa intestinal para fortalecer al sistema inmunitario.

Para el desarrollo sensorial, cognitivo, físico e inmunitario del o la recién nacida es importante su alimentación. La lactancia materna se inicia con el calostro que es la primera secreción de la mama. Beneficios:

- El calostro es rico en nutrientes y anticuerpos

- El calostro contiene una sustancia (inmunoglobulina A) que forma una capa protectora sobre las membranas mucosas en intestinos, nariz y garganta 
Hacemos una lluvia de ideas de acciones realizadas por la municipalidad que fortalece prácticas de vida saludable.

La Secretaría de Planificación y Programación de la Presidencia, SEGEPLAN, ha realizado evaluaciones de los gobiernos municipales. Otorgó reconocimiento a las cinco alcaldías mejor evaluadas y publicado la lista de todas las municipalidades. Para llegar a estos resultados se evaluaron varios aspectos, entre los que destacan: garantizar y promover la participación ciudadana, gestionar adecuadamente los recursos financieros, transparentar la administración y gestión de la municipalidad y, realizar una adecuada planificación.

Esta evaluación fue realizada en 2013 y los resultados fueron publicados en 2015. Podemos consultar cómo salió evaluada nuestra municipalidad en: http:// www.segeplan.gob.gt/downloads/2015/RGM2013.pdf

Los criterios de evaluación empleados por SEGEPLAN pueden tomarse para que la comunidad hagamos auditoría social.

\section{Respondo:}

- ¿Las cinco municipalidades mejor evaluadas tienen mucha legitimidad?

- ¿Las municipalidades peor evaluadas se han deslegitimado?

Argumento mi respuesta.

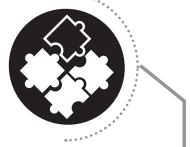

Vemos la presentación de la investigación del segundo equipo de trabajo. Luego con nuestro equipo de trabajo escribimos acciones en materia de salud pública que ganarían legitimidad al actual gobierno y acciones que le hacen perder legitimidad.

\section{Legitimidad}

Cuando las personas consideran que la estructura del Estado del que forman parte es la adecuada para cumplir con sus funciones, cuando consideran correctos los procedimientos que siguen los organismos del gobierno y cuando están de acuerdo con las decisiones que toma el gobierno porque son buenas para la población, entonces se dice que el Estado o Gobierno tienen legitimidad o apoyo social. Esto es importante para que la sociedad colabore y contribuya con los planes de trabajo establecidos por el gobierno. La pérdida de legitimidad ocurre cuando las personas dejan de creer en el Estado o gobierno, generalmente porque identifican que van en contra del bienestar de la población y se sienten amenazadas por el mismo.

Un ejemplo de pérdida de legitidad sucedió con el Estado colonial de Guatemala, cuando en el territorio de América, se tenían que seguir las órdenes de los monarcas en España. El estado colonial perdió legitimidad con cada movimiento independentista. También sucedió con el gobierno de Jorge Ubico, el cual por su carácter autoritario comenzó a perder legitimidad en 1938. Muchos sectores del pueblo se organizaron parar lograr en 1944 derrocarlo y realizar una revolución, de la cual surgió un sistema más democrático de gobierno.

Los señalamientos de corrupción hechos al gobierno del General Otto Pérez Molina, hicieron que perdiera legitimidad. Esta situación lo obligó a renunciar a él, a la vicepresidenta y a casi todos sus ministros.

Para que un gobierno o un Estado sea legítimo ha de contar con el respaldo de los sectores, instituciones y organizaciones de la sociedad civil que se encuentran activos. Son las personas y sus estructuras organizativas que opinan, apoyan, critican, se oponen y proponen las que le sostienen la legitimidad o plantean la ilegitimidad a un gobierno o Estado y cuando logran el apoyo popular se afianzará o vendrán los cambios.

\section{Con nuestro equipo de trabajo:}

Socializamos el mapa conceptual elaborado en casa.

- Elaboramos un mapa conceptual que integre los aportes del equipo y lo presentamos a la clase. 


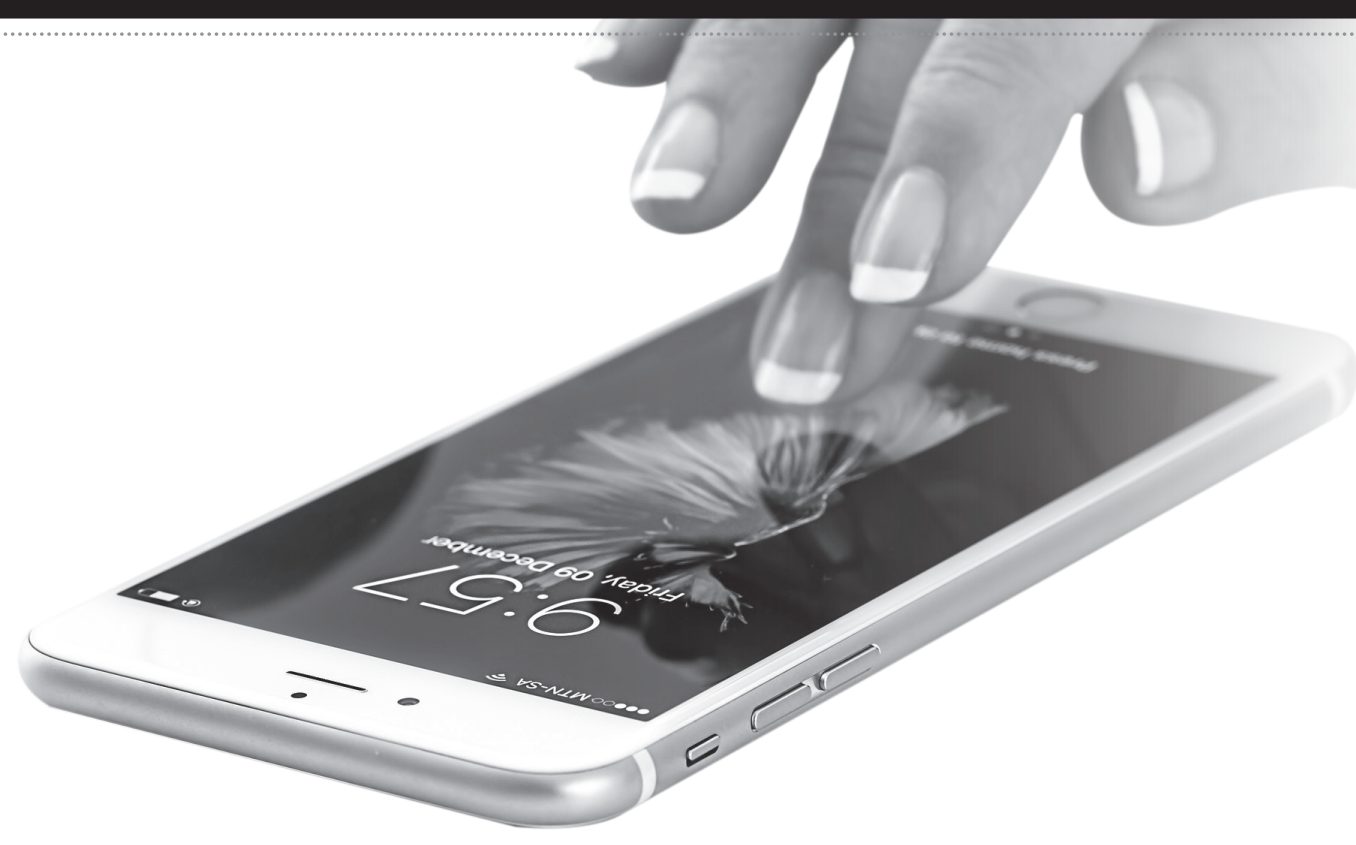

Opino con respecto a la influencia que tienen las redes sociales en la opinión de los y las integrantes de mi comunidad.

“Findasense señaló que este jueves, tras conocerse la dimisión de Otto Pérez Molina a la Presidencia, la etiqueta \#OPMrenunció alcanzó más de 50.000 publicaciones en Twitter" en pocas horas".

“Además, el 27 de agosto, una jornada de paro nacional en

La principal vía por la que las personas se enteran de las decisiones y acciones de un gobierno son los medios de comunicación. Por ello el manejo de la información resulta muy importante para la legitimidad de un gobierno. Mediante lo que los medios eligen para informar y lo que desechan comienzan a influir en la opinión pública. Si, por ejemplo, tienden a informar o a dedicarle más tiempo a las decisiones adecuadas y acciones positivas mejorarán la legitimidad; por el contrario, se genera ilegitimidad si dedican más espacio a criticar las decisiones o a señalar lo negativo de las acciones. Desde luego que esto tiene el límite de lo real. No se puede enfatizar en las decisiones acertadas o acciones positivas si no las hay o son muy pocas; tampoco se puede criticar lo negativo si esto no existe o es muy escaso.

El papel de los medios de comunicación ha variado en todo el mundo. En nuestro país, el impacto de algunos medios de comunicación como la radio y los periódicos ha disminuido y ha aumentado el papel de la televisión y las redes sociales. Pese que algunos telenoticieros han reducido su papel de influir en la opinión de las personas, siguen siendo importantes. En la crisis vivida por el gobierno de Guatemala en 2015, varios medios trataron de impedirla o de frenarla; pero los hechos generaron tanta deslegitimación que les fue imposible.

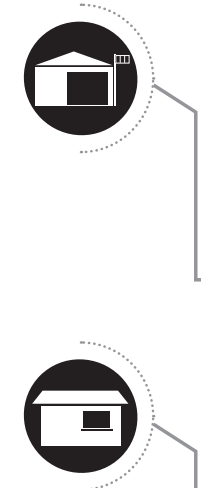

\section{Con nuestro equipo de trabajo:}

- Redactamos una lista de buenas prácticas alimenticias.

- Opinamos acerca de lo que informan los medios con respecto a las decisiones o acciones gubernamentales con respecto a las prácticas alimenticias.

Elaboración de la propuesta de buenas prácticas con relación al tema de enfermedades comunes que aportará al Programa de Buenas Prácticas. Guatemala para exigir la renuncia de Pérez Molina, quien está acusado por delitos vinculados con una red de defraudación que operaba en las aduanas, fue el día con más conversaciones en redes sociales en lo que va de 2015: casi 98.000."

EFE (2015). Redes sociales, claves en movimiento ciudadano que derrocó a Presidente de Guatemala. El Espectador. Recuperado de: http://www.elespectador. com/noticias/elmundo/ redes-sociales-claves-movimiento-ciudadano-derrocopres-articulo-584036

- ¿Estoy de acuerdo con lo que dice esta cita? ¿Por qué? 


\section{Estimamos la relación entre nuestras prácticas y nuestra condición de salud}

La variable de "entrada" en una función siempre es la variable independiente y la variable de "salida" es la dependiente.

\section{$\underset{\text { independiente }}{\stackrel{\text { variable }}{\longrightarrow}}$}

función
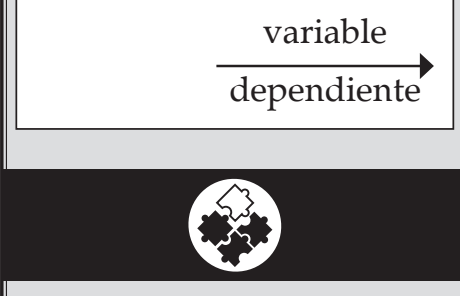

La olla alimenticia nos orienta sobre qué alimentos debemos ingerir. Intentemos crear una pirámide con los alimentos de nuestra comunidad en idio-ma extranjero.
Supongamos que al inicio del siglo $X X$ el guatemalteco y la guatemalteca promedio ingería aproximadamente 300 libras de pan y cereales al año. Luego, en los años cincuenta consumía menos de la mitad de esta cifra; sin embargo, está cantidad de nuevo va en aumento. La función:

$$
f(x)=0.059 x^{2}-7.423 x+362
$$

representa la relación entre el consumo $(y)$, en libras, de estos alimentos y los años a partir de $1900(x)$.

Completamos la siguiente tabla para determinar la cantidad de pan y cereales que consume una persona guatemalteca según el año. Así:

$$
f(15)=0.059(15)^{2}-7.423(15)+362
$$

\begin{tabular}{|c|c|c|c|c|c|c|c|c|}
\hline $\begin{array}{c}\text { Años } \\
\text { transcurridos } \\
\text { desde 1900 }\end{array}$ & $\begin{array}{c}15 \\
\text { Año: } \\
1915\end{array}$ & $\begin{array}{c}\text { Año: } \\
1935\end{array}$ & $\begin{array}{c}\text { Año: } \\
1960\end{array}$ & $\begin{array}{c}\text { Año: } \\
1985\end{array}$ & $\begin{array}{c}\text { Año: } \\
2000\end{array}$ & $\begin{array}{c}110 \\
\text { Año: }\end{array}$ & $\begin{array}{c}115 \\
\text { Año: }\end{array}$ & $\begin{array}{c}125 \\
\text { Año: } \\
2025\end{array}$ \\
\hline $\begin{array}{l}\text { Cantidad } \\
\text { de pan y } \\
\text { cereales } \\
\begin{array}{l}\text { consumidos } \\
\text { anualmente } \\
\text { (lb) }\end{array}\end{array}$ & & & & & & & & \\
\hline
\end{tabular}

Con la información anterior y, mediante el uso de un plano cartesiano con una escala apropiada, representamos gráficamente la función. A partir de la gráfica contestamos:

- ¿En qué año, aproximadamente, las y los guatemaltecos volvieron a consumir la misma cantidad de pan y granos que se consumían en 1900? Comparamos y discutimos nuestras respuestas.

- ¿Cuántas libras de pan y granos se espera que se consuman en el año 2025?

Mencionamos dos años en los que el consumo anual de pan y granos fueron los mismos.

- ¿En qué año, aproximadamente, el consumo de pan y cereales fue el más bajo de la historia?

\section{En equipos discutimos y contestamos:}

- ¿Aparte de la tabla y de la gráfica, de qué otra manera podemos encontrar la cantidad de libras de pan y de cereales que consume una o un guatemalteco en un año?

Utilizamos la función para hallar la cantidad de pan y cereales que se espera que consuma una persona guatemalteca en el año actual. 


\begin{tabular}{|c|c|}
\hline r factorización & Solución utilizando la fórmula \\
\hline $\begin{array}{l}\text { Para encontrar las soluciones de una } \\
\text { ecuación cuadrática cuando es posi- } \\
\text { ble factorizar seguimos los siguien- } \\
\text { tes pasos: } \\
1^{\circ} \text { Reordenar la ecuación para igua- } \\
\text { lar a } 0 \text {. } \\
2^{\circ} \text { Factorizar totalmente el lado de la } \\
\text { ecuación. } \\
3^{\text {o }} \text { Utilizar la ley del factor nulo para } \\
\text { cada factor. } \\
4^{\circ} \text { Resolver las ecuaciones lineales } \\
\text { resultantes. } \\
\text { Ejemplos: } \\
\qquad x^{2}=4 x \\
x^{2}-4 x=0 \\
x(x-4)=0 \\
x=0 \\
x-0 y 4 \\
6 x^{2}=11 x+10 \\
6 x^{2}-11 x-10=0 \\
(2 x-5)(3 x+2)=0 \\
x=5 / 2 \\
x-5 / 2 y-2 / 3\end{array}$ & 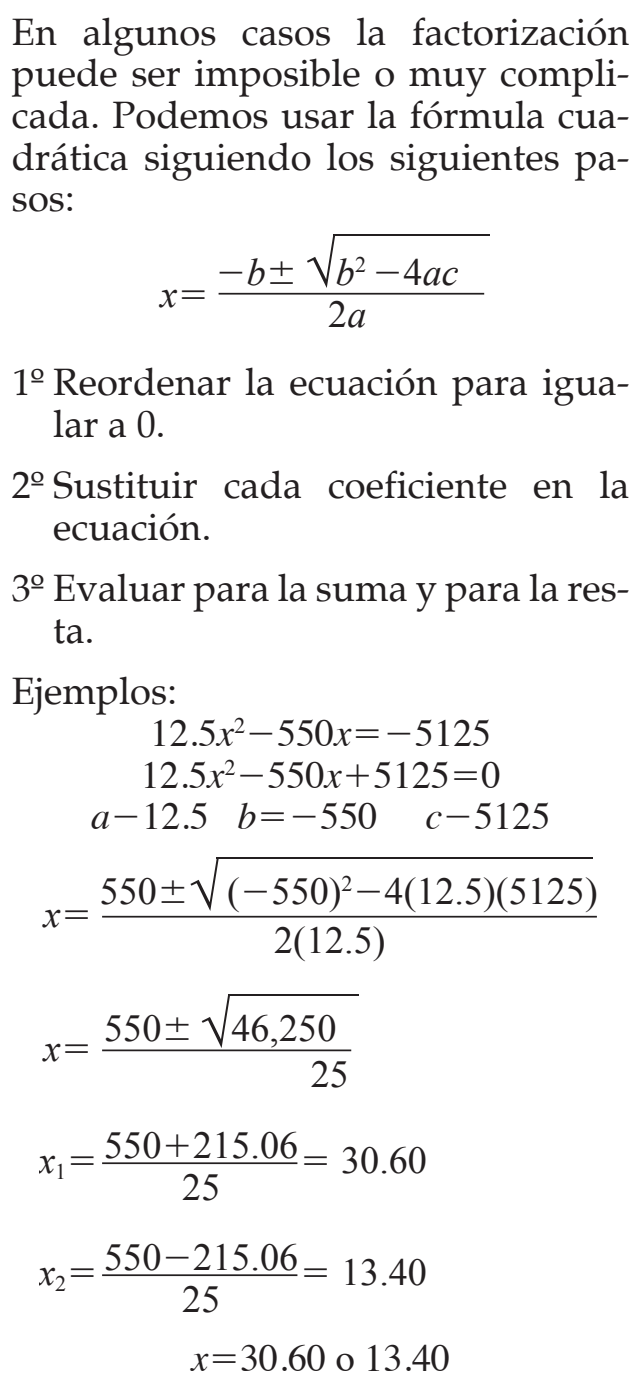 \\
\hline
\end{tabular}

Escogemos uno de los dos métodos estudiados para resolver ecuaciones cuadráticas y resolvemos tres ejemplos para compartir al resto de compañeras y compañeros.

Investigamos sobre cómo se representan en el plano cartesiano las inecuaciones o desigualdades lineales y cuadráticas. Anotamos la información más importante en nuestro cuaderno.

\section{Contestamos:}

- ¿Existe alguna relación matemática entre los hábitos alimenticios y las enfermedades comunes en los niños y las niñas? ¿De qué tipo, lineal o cuadrática? Explicamos.

- ¿Cuál es la variable dependiente en la relación anterior?

Escribimos una conclusión acerca de la relación entre hábitos alimenticios y enfermedades comunes en los niños y las niñas.

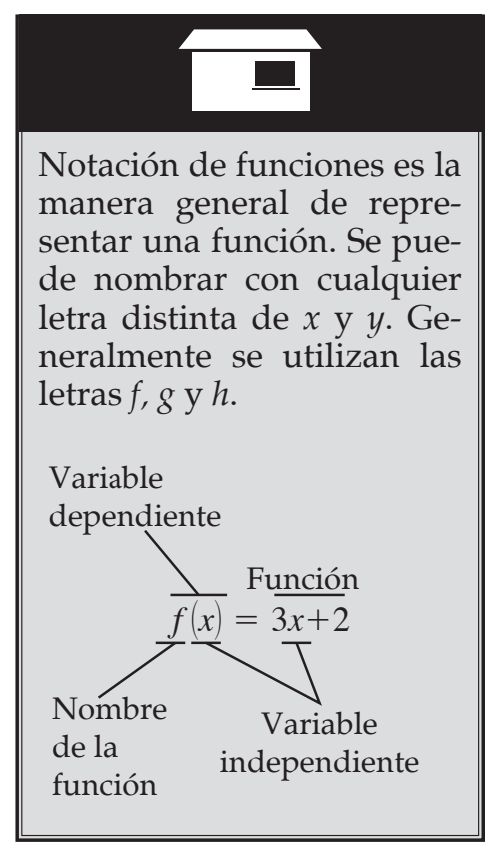

Notación de funciones es la manera general de representar una función. Se puede nombrar con cualquier etra distinta de $x$ y $y$. Generalmente se utilizan las letras $f, g$ y $h$.

Variable dependiente 


\section{Una allmentạetôn adecuada garantiza nuestra salud}

Las grasas también se presentan de diversas formas y en diversos alimentos. Es importante conocerlas para consumirlas de forma balanceada.

Grasas saturadas: se encuentra en queso, leche entera, helado, crema y carnes grasosas; algunos aceites vegetales, como el de palma; comida chatarra, papas fritas, pastelería y panadería industrial.

Grasas insaturadas: presentes en aguacate y aceites vegetales como el de oliva; frutos secos como las nueces, habas, maní y pistachos. Ciertos pescados como el salmón y el atún.

Grasas trans: surgen al transformar aceite líquido en grasa sólida a la que se añaden hidrógenos: margarinas, pastelería industrial, galletas, papas fritas y otras chucherías.

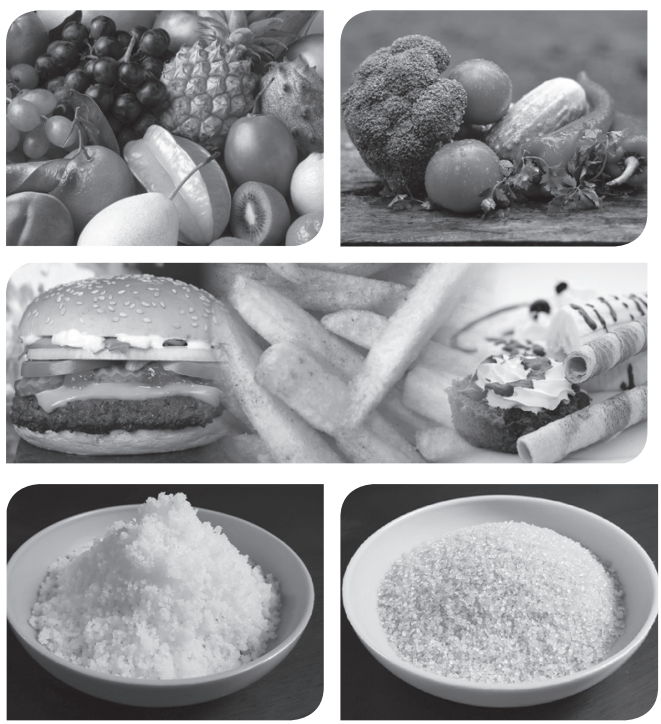

Para lograr una alimentación saludable se debe promover la práctica de una dieta variada, equilibrada y sana.

En grupo analizamos los siguientes consejos para tener una alimentación adecuada.

Escribimos un listado de las verduras, frutas y hortalizas que se pueden obtener en la comunidad y que al consumirles mejoramos nuestra nutrición.

\section{Frutas, verduras y hortalizas}

Con el fin de mejorar el consumo de frutas y verduras se puede:

- Incluir verduras en todas las comidas.

- Comer frutas frescas y verduras crudas como refacción.

- Comer verduras y frutas frescas de temporada y preferentemente de traspatio.

- Comer una selección variada de frutas y verduras.

\section{La sal y el sodio}

Reducir el consumo de sal del modo siguiente:

- No añadiendo sal, salsa de soya o salsa de pescado al preparar los alimentos.

- No poniendo sal en la mesa.

- Reduciendo el consumo de productos salados procesados.

- Eligiendo productos con menos contenido en sodio.

\section{Azúcar}

La ingesta de azúcar puede reducirse del modo siguiente:

- Limitando el consumo de alimentos y bebidas con alto contenido de azúcar (por ejemplo, bebidas azucaradas, aguas gaseosas y golosinas).

- Comiendo frutas y verduras crudas en lugar de productos industriales azucarados.

\section{Grasas}

La ingesta de grasas puede reducirse del modo siguiente:

- Modificando la forma de cocinar: separando parte grasa de la carne; utilizando aceites vegetales (de origen no animal); cociendo los alimentos o cocinándolos al vapor o al horno, en lugar de freírlos.

- Evitar el consumo de alimentos precesados elaborados con grasa de tipo trans, como snack salados, pizza,, y donas.

- Reduciendo el consumo de alimentos con un contenido alto en grasas saturadas (por ejemplo, queso, helados).

Agrego buenas prácticas a la lista en elaboración a partir de los nuevos conocimientos.

Elaboro y autoevalúo mi mapa conceptual considerando:

- que contiene la idea central, secundarias y complementarias.

- presenta la información en forma comprensible.

- evidencia coherencia y secuencia entre las ideas.

- presenta información completa. 


\section{La alimentación inadecuada nos hace vulnerables a enfermedades}

La alimentación inadecuada afecta la salud. Una dieta con elevadas cantidades de grasas saturadas puede provocar obesidad, hipertensión, alto colesterol y problemas cardiovasculares. El consumo desmedido de sodio, provoca la retención de líquidos, hipertensión arterial y daños renales. Por ello, la naturaleza nos ofrece el potasio; este puede disminuir los efectos negativos del consumo elevado de sodio y se encuentra en frutas y verduras.

El limitado consumo de frutas, verduras y hortalizas provocará problemas digestivos: estreñimiento, acidez, indigestión, colon irritable.

Él azúcar industrializada (blanca y muy fina) aumenta el riesgo de caries dental. Alimentos y bebidas con un alto contenido en azúcar contribuyen a la obesidad, acidez, cambian el metabolismo del cuerpo y generan diabetes y cáncer.

Los carbohidratos refinados, dañan los intestinos y evitan la absorción de nutrientes. Provocan desnutrición, diabetes y toxemia.

Analizamos las consecuencias del sobrepeso y la obesidad:

\begin{tabular}{|c|c|c|c|c|c|}
\hline $\begin{array}{c}\text { Gran } \\
\text { acumu- } \\
\text { lación de } \\
\text { grasa que } \\
\text { favorece el } \\
\text { desarrollo } \\
\text { de enfer- } \\
\text { medades }\end{array}$ & $\begin{array}{c}\text { Disminu- } \\
\text { actividad } \\
\text { física. }\end{array}$ & $\begin{array}{c}\text { Enfer- } \\
\text { medades } \\
\text { cardiovas- } \\
\text { culares y } \\
\text { derrames } \\
\text { cerebrales. }\end{array}$ & $\begin{array}{c}\text { Riesgo de } \\
\text { desarrollar } \\
\text { diabetes }\end{array}$ & $\begin{array}{c}\text { Riesgos } \\
\text { de tras- } \\
\text { tornos del } \\
\text { aparato } \\
\text { locomotor, } \\
\text { en especial } \\
\text { la osteoar- } \\
\text { tritis }\end{array}$ & $\begin{array}{c}\text { Riesgo de } \\
\text { algunos } \\
\text { cánceres }\end{array}$ \\
\hline
\end{tabular}

La comida industrializada se asocia con las grasas trans, azúcar, sales y compuestos tóxicos, que se utilizan como medio para su preservación. Los embutidos y otras comidas se consumen después de mucho tiempo de haber sido fabricadas, sus nutrientes han disminuido significativamente o tienen algún nivel de descomposición.

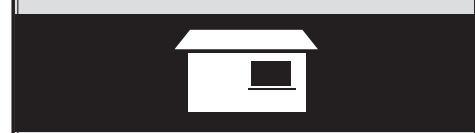

Investigo en internet, libros, personas en mi comunidad y el centro de salud sobre la importancia de la vacunación en niños y adultos, así como las consecuencias de no realizar la vacunación en el momento preciso.

Elaboramos propuestas de menús saludables, utilizando los productos naturales que se cosechan y consumen en la comunidad. Estos menús los incorporaremos al programa de buenas prácticas.
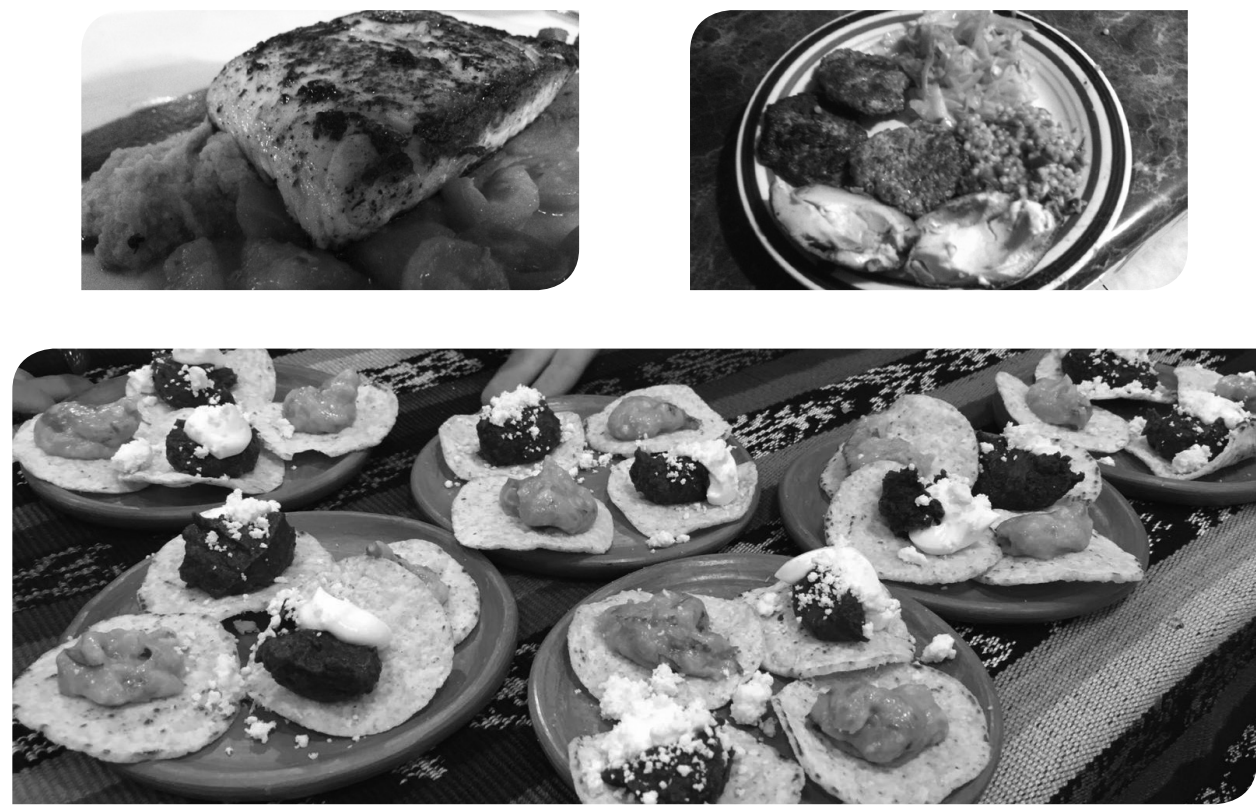


\section{Evifar confusiones con comunicación sana}

\section{La coherencia y la} cohesión textual

Como hemos visto con anterioridad, la coherencia y la cohesión textual convierten en texto a un conjunto de enunciados. Para que sea coherente, los enunciados deben referirse a un tema común y, para resultar congruentes, dichos enunciados deben estar relacionados correctamente entre sí. Los principales recursos para dar cohesión a un texto son:

La repetición: Utilizar la misma palabra o expresión en distintos puntos del texto.

La asociación: Las palabras utilizadas en el texto mantienen un vínculo que las complementa.

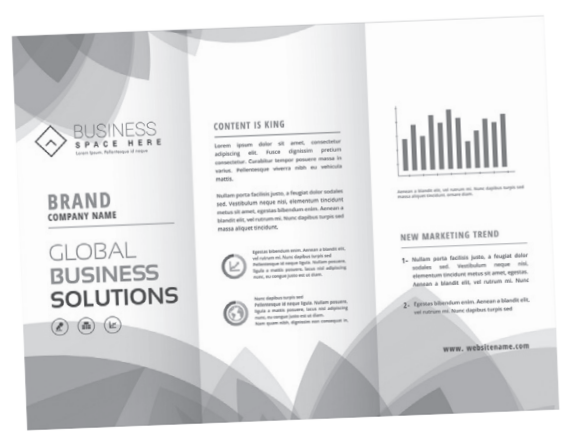

\section{Los signos de puntuación}

\section{Las comillas:}

Son un signo ortográfico doble. Al igual que otros signos dobles como el paréntesis, las comillas se usan para aislar o marcar un discurso secundario que se intercala dentro del principal. Ejemplo: Helen Keller dijo: "Mantén tu rostro hacia la luz del Sol y no verás la sombra".

\section{Los paréntesis:}

$\mathrm{Al}$ igual que las comillas, son un signo ortográfico doble [( )]. Se usan para insertar en un texto un comentario o aclaración. Aunque su uso es parecido al de las rayas o las comas, el paréntesis aísla más el texto en el que se inserta.

\section{Ejemplo:}

Augusto Monterroso (Honduras, 1921) es considerado un maestro de la mini-ficción.

El Ministerio de Educación (MINEDUC) es la institución responsable de la educación en Guatemala.

\section{La Negrita o negrilla:}

Se usa para trazo más grueso y se usa para destacar alguna palabra o palabras determinadas

\section{Ejemplo:}

La profesora de gimnasia habló sobre la necesidad de beber mucha agua para evitar deshidratarnos.

\section{La cursiva:}

O itálica, es la letra inclinada hacia la derecha y se usa para los títulos de libros, títulos de películas y apodos.

\section{Ejemplo:}

Sara sonríe de último, de Víctor Muñoz

Ixcanul, de Jairo Orellana

Vino el Colocho

Elaboraremos un trifoliar para informar sobra una de las enfermedades comunes presentadas en clase y cómo prevenirla. 


\section{La poesía}

Es uno de los géneros literarios más antiguos. Es considerada como la expresión de la belleza a través de la palabra escrita. Los poemas se escriben en verso y plasman los sentimientos, emociones y visión que tiene del mundo el autor o autora.

Las partes de las que se compone un poema y que forman su métrica son:

Verso: Cada una de las líneas que forman el poema.

Estrofa: Cada una de las partes en las que se divide un poema.

Rima: Es la repetición de los sonidos a partir de la última sílaba acentuada y, por ello, dan musicalidad al poema. La rima puede ser consonante (cuando se repiten todas las vocales y consonantes a partir de la última sílaba acentuada) o asonante (ocurre cuando solo riman las vocales de la última palabra de cada verso).

\section{Poema con rima consonante:}

Yo soy un hombre sincero, de donde crece le palma;

yo antes de morirme quiero, echar mis versos del alma.

Extracto de "Versos Sencillos" de José Martí

\section{Poema con rima asonante:}

Madre, acaricie a sus niños. Padre, abrácelos firmemente.

Permita que ellos sepan que los aman

por la mañana, al mediodía, y por la noche.

Ponga sus brazos alrededor de ellos

sosténgalos cerca suyo, sienta el latir de sus corazones, la vida nueva que Usted hizo. Ruede por el suelo con ellos, bromee, ría y juegue, escuche lo que tienen que decirle,

ellos tienen mucho para contarle.

Extracto del poema "Abrace a sus niños" Anónimo

Nos reuniremos en parejas e inventaremos dos poemas de tres estrofas con cuatro versos cada una. Uno con rima consonante y uno con rima asonante, el poema expresará los beneficios de la vida sana. Lo pueden hacer en español o en otro idioma que conozcan. 


\section{Danza, música y salud integral}

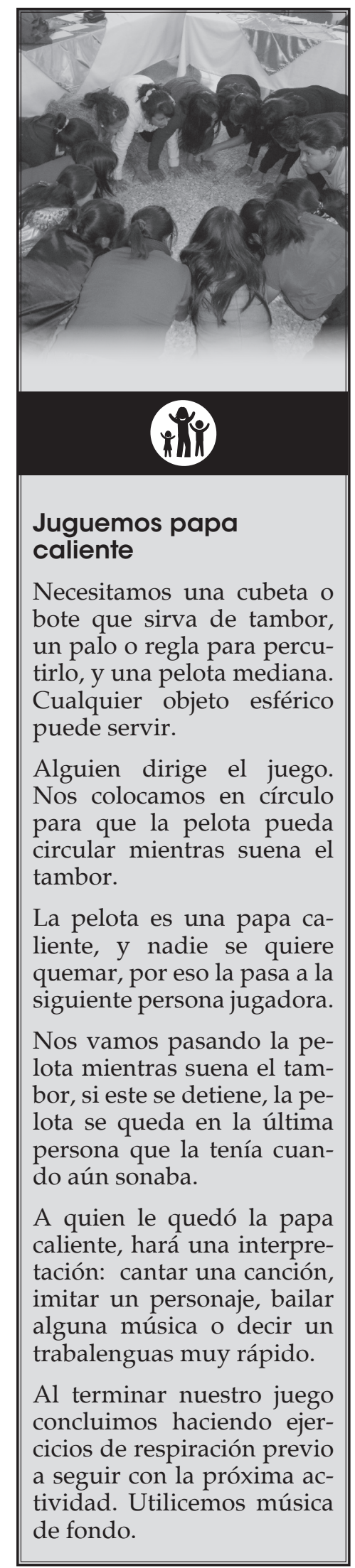

Hay musicalidad en la forma como hablamos. Por ejemplos pronunciamos de diferente forma una pregunta que una afirmación. No hablamos todo en un mismo tono, sino que a cada palabra le damos una entonación en la sílaba más fuerte. Las sílabas fuertes de todas las palabras suenan con un tono más alto que el resto de sílabas.

Las canciones son una combinación entre música y literatura. La música natural de las palabras permite la creación de canciones. Los juegos musicales ayudan a la creación.

\section{Más trabalenguas:}

Compadre no compro coco, no compro coco compadre

Porque como poco coco como, poco coco compro

Pasaba la pasa pasando Pasabién, bien pasaba pasando la pasa

Parra tenía una perra y Guerra tenía una parra.

Y la perra de Parra se subió a la parra de Guerra.

Guerra pegó con la porra a la perra de Parra.

Le dijo Parra: ¿por qué le pegaste con la porra a la perra?

Respondió Guerra: Si la perra de Parra no hubiera subido a la parra de Guerra

No habría salido Guerra, ni le pegaría con la porra a la perra.

\section{Trabajemos en grupo}

Digamos los trabalenguas en tres velocidades: lento, moderado y rápido. Luego cada quien escoge el que más le gusta y lo dice solo lo más rápido posible.

Entre todos y todas le ponemos música, los sonidos que queramos, y armamos una canción con el trabalenguas. Lo mostramos al resto de la clase.

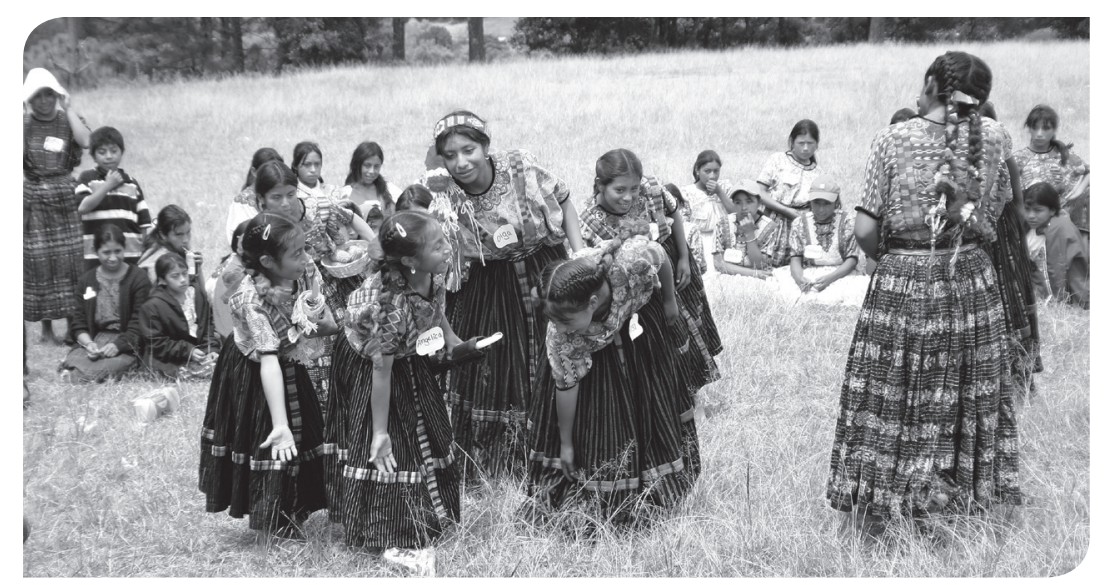




\section{Las coreografías en movimiento}

Veremos cómo organizar una coreografía. Para comenzar, escogemos la música pues, el ritmo que tenga influye en el tipo de movimientos y formaciones que queremos lograr. Luego medimos las frases de la música para contar los movimientos. Esto es fácil si es una canción con letra, y si no, tienen espacios donde van notas rápidas y notas lentas o largas. Casi siempre las piezas tienen series de 4, 8, 12 o 16 tiempos, hay que distinguirlos y anotar la cantidad para crear nuestra coreografía.

Tomemos como ejemplo El Ferrocarril de los Altos, del compositor quezalteco Domingo Betancourt. Si contamos cada pulso fuerte notaremos que son tiempos de 4 . Entonces la pieza forma frases de 4 hasta llegar a 16. Se pueden hacer formaciones en 16 tiempos antes de la repetición de la música o el cambio de frase.

Para crear una coreografía debo:

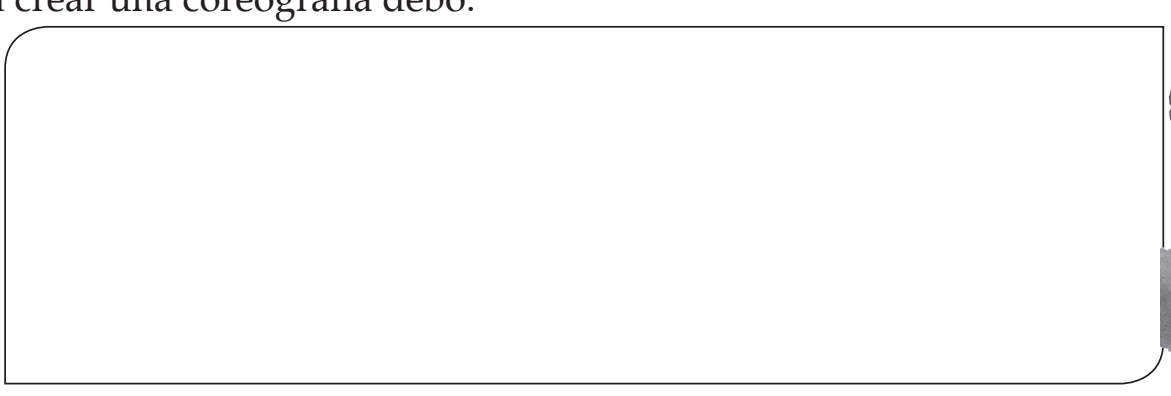

\section{Cualquier ritmo es adecuado para bailar}

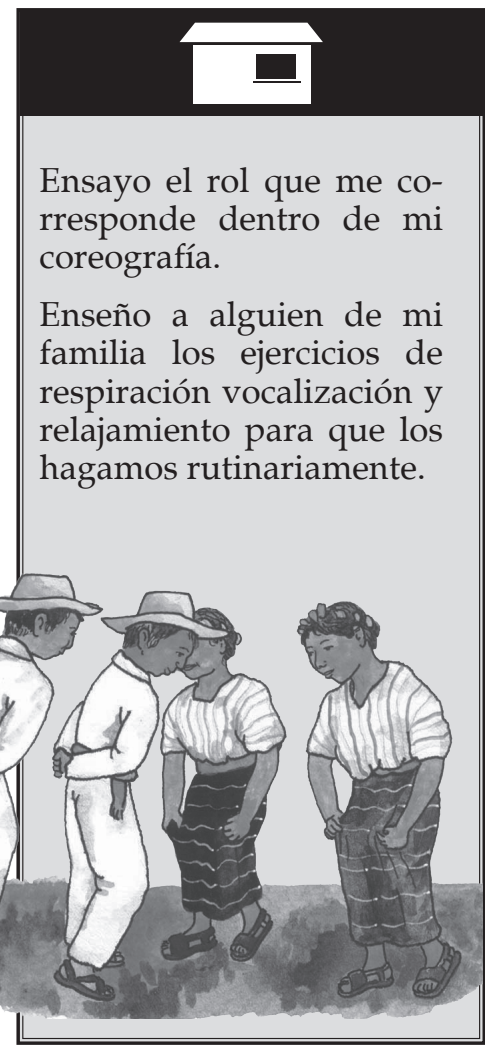

No hay ritmo que sea malo para bailar. Lo negativo puede estar en el texto si es una canción violenta, sexista o racista.

Todos los ritmos pueden servir para nuestra coreografía. Lo importante es el movimiento coordinado del cuerpo en las series de desplazamiento. Filas que se desplazan en líneas rectas, en círculos, hacia adelante y atrás, elevan y bajan brazos, forman parejas y se separan, se encuentran en un punto y se vuelven a separar.

Puedo encontrar sugerencias de formaciones, pasos, ritmos y coreografías en videos, buscando videos en internet.

\section{Creando nuestra coreografía}

Usando las herramientas que se mencionaron, seleccionamos una pieza musical. Contamos las frases posibles y escogemos los tipos de formaciones que queremos hacer. Tomamos nota de los tiempos de cada frase, diseñamos todos los desplazamientos y ensayamos para memorizar. El siguiente es un ejemplo, pero tenemos libertad de crear nuestros movimientos:

\begin{tabular}{|c|c|c|c|c|}
\hline Serie 1 & Serie 2 & Serie 3 & Serie 4 & Serie 5 \\
\hline $\begin{array}{l}\text { - } 2 \text { o } 4 \text { filas de va- } \\
\text { rios integrantes } \\
\text { caminan } 8 \text { pasos } \\
\text { hacia adelante } \\
\text { hasta el cambio } \\
\text { de la música } \\
\text { - }\end{array}$ & $\begin{array}{l}\text { - cada fila re- } \\
\text { trocede en } 8 \\
\text { tiempos con } \\
\text { la música } \\
\text { - }\end{array}$ & $\begin{array}{l}\text { - forman pare- } \\
\text { jas y bailando } \\
\text { marcan el } \\
\text { paso sobre el } \\
\text { mismo lugar } \\
\text { en } 8 \text { tiempos } \\
\text { - }\end{array}$ & $\begin{array}{l}\text { - intercambian } \\
\text { parejas en el } \\
\text { transcurso de } \\
16 \text { tiempos } \\
\text { - } \\
\text { - } \\
\text { - }\end{array}$ & $\begin{array}{l}\text { - vuelven a la } \\
\text { formación original } \\
\text { para saludar } \\
\text { al final de los } \\
\text { últimos } 8 \text { tiempos } \\
\text { - } \\
\text { - } \\
\text { - }\end{array}$ \\
\hline
\end{tabular}

Una coreografía también comunica mensajes, al crearla, debe proponerse un mensaje claro. 


\section{El Mejoramiento Continuo}

\section{Plan de emergencia} familiar

Es importante que la familia planee qué hacer en caso de emergencia por un accidente, enfermedad, un embarazo o parto de alto riesgo. También pueden darse emergencias por cambios en las condiciones climáticas o desastres. Se sugiere desde ya:

- Tener a mano contacto de personas a cargo de la salud, recetas de personas enfermas.

- Pensar en una ruta de evacuación y compartirla.

- Acordar un punto de reunión familiar.

- Mejorar el plan periódicamente.

- Tener lista una mochila de emergencia.

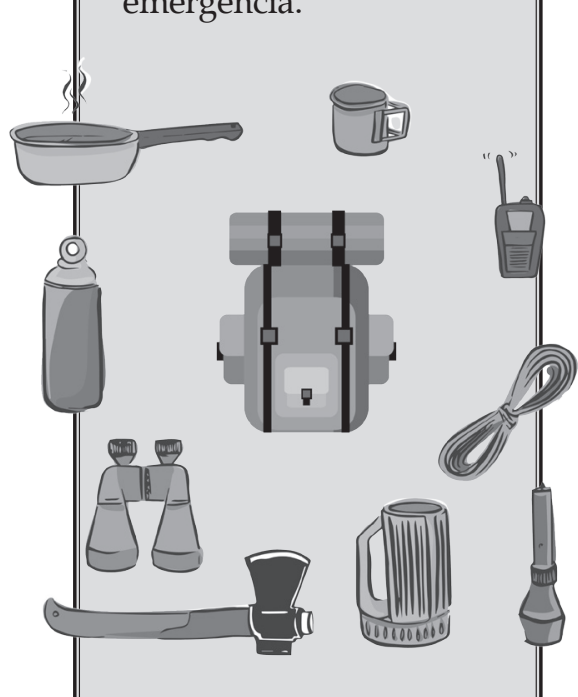

Es importante tener una mochila de emergencia lista siempre.
El mejoramiento continuo es una herramienta que utilizada periódicamente nos ayuda a alcanzar la calidad total. Nos permite observar dificultades y debilidades a superar $\mathrm{u}$ oportunidades que aprovechar. Se necesita la participación de todas las personas involucradas, una actitud crítica así como una mente amplia y creativa. Aunque el proceso se realiza internamente se toma en cuenta a proveedores, acreedores, clientes, familias, autoridades y sobre todo, al personal.

Solo así se logrará hacer cambios más eficientes y efectivos, pero solo si los hacemos en el momento justo. Este momento puede ser al finalizar una cosecha, después de despachar la orden de un producto o después de un problema o pérdida como también después de haber hecho una buena venta. La clave está en hacer consciente el proceso de búsqueda de mejora. Una herramienta fácil de utilizar es el FODA así encontraremos:

Fortalezas: Lo que nos hace fuertes y nos distingue de otras comunidades $u$ organizaciones.

Oportunidades: Situaciones favorables que podemos aprovechar para mejorar.

Debilidades: Lo que nos pone en desventaja frente a otros y que podemos mejorar.

Amenazas: Situaciones eternas desfavorables a las que debemos poner atención para disminuir su efecto.

\begin{tabular}{|l|l|l|l|l|}
\hline & $\begin{array}{c}\text { Ambiente } \\
\text { interno }\end{array}$ & $\begin{array}{c}\text { Ambiente } \\
\text { externo }\end{array}$ & $\begin{array}{c}\text { Ambiente } \\
\text { interno }\end{array}$ & $\begin{array}{c}\text { Ambiente } \\
\text { externo }\end{array}$ \\
\hline Fortalezas & $\begin{array}{c}\text { Oportunida- } \\
\text { des }\end{array}$ & Debilidades & Amenazas \\
\hline Proceso & & & & \\
\hline Producto & & & & \\
\hline Servicio & & & & \\
\hline
\end{tabular}

El FODA permite reflexionar sobre una situación en un momento preciso. Es el momento de buscar y encontrar soluciones a las dificultades, elaborar un plan de acción y ponerlo a trabajar. El plan debe incluir acciones a corto, mediano y largo plazo, así como responsables. También debe establecerse un medio de seguimiento y control para establecer que se estén alcanzando las metas trazadas.

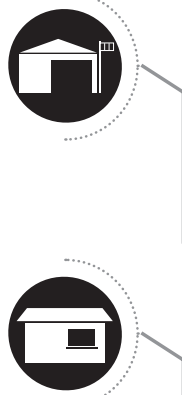

Seleccionamos un proceso productivo que se realice en la comunidad e invitamos a las personas responsables del mismo. Realizamos el FODA utilizando el formato anterior. Luego planteamos acciones para el mejoramiento continuo y la persona responsable de cada acción y cómo se medirán los avances.

Reflexionemos en familia sobre el impacto que la aplicación de normas de calidad a la producción de alimentos tiene en la salud y la prevención de enfermedades. 
Personas que integran empresas urbanas y también las personas que integran empresas rurales se encuentran en procesos de mejoramiento continuo para competir exitosamente. Ya conocemos las medidas higiénicas que estas empresas incorporan al proceso productivo de alimentos. El mejoramiento continuo también aplica para la producción pues con el apoyo de ingenieros agrónomos utilizan nuevas formas de seleccionar semilla, aplican distancia apropiada entre plantas, cantidades adecuadas de fertilizantes y plaguicidas, formas de recolectar la cosecha y de almacenar.

Las y los productores dicen que, si bien, aplicar estas medidas ha significado mayor inversión en dinero y en tiempo, el rendimiento de las cosechas ha aumentado, la calidad de los productos ha mejorado. El proceso de mejoramiento continuo reduce el riesgo de rechazo de la empresa compradora por no cumplir las normas de calidad esperadas y garantiza mayores ganancias y la probabilidad de aumento de ventas.

Nos organizamos en tres grupos. Cada grupo presenta una exposición sobre uno de estos temas: proceso productivo, empaque de alimentos y normas de calidad.

Esta semana trabajamos en el programa de salud integral que forma parte del Proyecto 5. Evaluemos los que hemos aprendido y cuánto hemos avanzado en las actividades del proyecto.

\begin{tabular}{|l|l|l|}
\hline \multicolumn{1}{|c|}{ ASPECTOS A EVALUAR } & Sí & No \\
\hline Redactamos una lista de buenas prácticas alimenticias. & & \\
\hline Escribimos un poema sobre las buenas prácticas. & & \\
\hline $\begin{array}{l}\text { Conocimos los elementos que deben ir en la mochila de } \\
\text { emergencia. }\end{array}$ & & \\
\hline $\begin{array}{l}\text { Realizamos una lista de buenas prácticas de hábitos } \\
\text { saludables y prevención de enfermedades comunes. }\end{array}$ & & \\
\hline Elaboramos propuestas de menús saludables. & & \\
\hline $\begin{array}{l}\text { Creamos colectivamente una coreografía y seleccionamos } \\
\text { la música que acompaña. }\end{array}$ & & \\
\hline
\end{tabular}

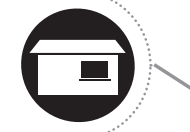

Ha llegado el momento de consultar y dialogar con nuestra familia acerca de las prácticas que incluíremos en el manual de buenas prácticas.

- ¿Les parecen viables y válidas?

- ¿Sugieren otras nuevas?

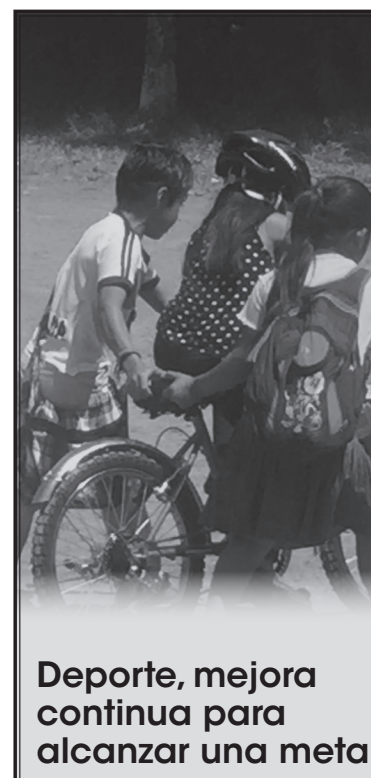

La actividad física es importante para la salud. Muchas veces creemos que, con caminar al trabajo o tareas en el trabajo o la casa, cuentan como actividad física. Sin embargo, no es así. Para que una actividad física realmente ayude a mantener y mejorar la salud debe dedicársele un tiempo exclusivo; se recomienda al menos 30 minutos diariosde actividad continua, ya sea caminando, corriendo, andando en bicicleta, bailando o haciendo deporte.

Los y las deportistas tienen un plan de entrenamiento. Persigue que las personas que lo practican poco a poco consigan la fuerza, la resistencia y las destrezas para competir y alcanzar sus metas. Practicar un deporte requiere disciplina, compromiso y responsabilidad, así como respeto y solidaridad hacia otras personas competidoras. 


\section{Solución grófica de inecuaciones ineales y cuadraticas}

Símbolos utilizados en desigualdades:

$<$

- Es menos que

- Es menor que

$>$

- Es mayor que

- Es más que

- Excede

$$
\leq
$$

- Es menor o igual que

- No es más que

- Es a lo sumo

- Como mínimo

$\geq$

- Es al menos

- Es mayor o igual que

- No es menos que

- ¿Puedes formar enunciados que mencionen variablas dependentientes e independientes que describan los problemas de salud de la comunidad?
Formando grupos intenten representar cada una de las siguientes situaciones usando expresiones matemáticas. Compartamos nuestras propuestas.

1) Juana debe tener al menos 2) Más del $52 \%$ de la población 18 años para votar. guatemalteca vive en pobreza extrema.

3) Lo recomendable es que menos del $35 \%$ de las calorías que se ingieren diariamente correspondan a grasas.

4) En un tramo de carretera cercano a una comunidad la velocidad de los automóviles debe ser menor a los 50 $\mathrm{km} / \mathrm{h}$

Copiamos la recta numérica en nuestro cuaderno y la utilizamos para representar las siguientes situaciones que representan desigualdades.

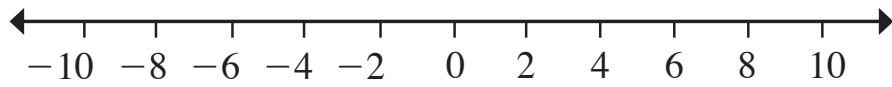

1) $x$ es mayor que 3

2) $x$ es menor o igual que 0

3) $x$ es mayor o igual que 10

4) $x$ es menor que 5

Indicamos si cada desigualdad es verdadera o falsa.

1) Un grupo de 12 estudiantes más otro grupo de alumnos $\mathrm{y}$ alumnas es menor que 20. El grupo que se añadió es de 9 personas.

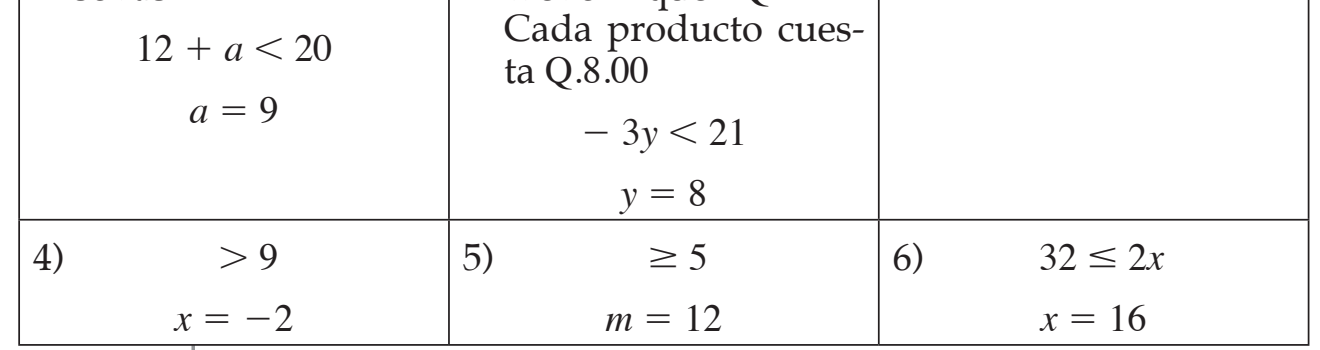

2) Flor ha ido a la tienda y se ha llevado tres productos con el mismo costo. Los pagará hasta mañana, pero su deuda es menor que Q.21.00 Cada producto cues3) $15-b>6$ $b=8$ 
Al graficar las desigualdades en una recta numérica o en un plano cartesiano es imposible mostrar todos los valores que las hacen verdaderas, es por ello que las respuestas se representan con intervalos.

\section{Desigualdades lineales}

Las desigualdades o inecuaciones lineales, al igual que las ecuaciones $\mathrm{y}$ funciones lineales, son de grado 1. Para resolver desigualdades lineales debemos tomar en cuenta las siguientes propiedades:

Propiedad aditiva: al sumar o restar un mismo número en ambos lados de la desigualdad el sentido permanece igual.

$x+6>7$

$x>7-6$

$x>1$

Solución como intervalo: $(-\propto, 1)$

Solución gráfica:

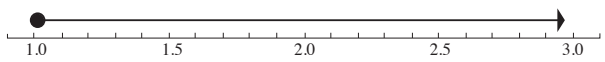

Propiedad multiplicativa: al multiplicar o dividir por un mismo número positivo ambos lados de la desigualdad el sentido se conserva. No ocurre lo mismo con números negativos.

- $4 x-2 \leq 8$

- $4 x \leq 8+2$

- $4 x \leq 10$

$x \geq-10 / 4=-5 / 2$

Solución como intervalo: $[-5 / 2, \propto)$

Solución gráfica:

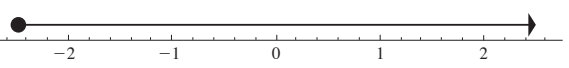

\section{Desigualdades cuadráticas}

Las desigualdades o inecuaciones cuadráticas, al igual que las ecuaciones y funciones cuadráticas, son de grado 2.

Para resolver desigualdades cuadráticas seguimos los mismos pasos que para resolver ecuaciones cuadráticas; ya sea factorizando o con la fórmula cuadrática. Debemos también tomar en cuenta las propiedades de las desigualdades lineales.

Las soluciones o raíces de la desigualdad serán los puntos críticos, los localizamos en la recta numérica. Ahora tenemos tres partes en la recta numérica, seleccionamos valores de prueba para cada sección y evaluamos en la desigualdad.

$\mathrm{Al}$ evaluar obtendremos valores positivos o negativos y de acuerdo a la expresión que tengamos decidiremos qué región es solución o no.

$x 2-2 x-35 \geq 0$

$(x+5)(x-7) \geq 0$

Puntos críticos: 7 y -5

Evaluamos un punto de cada región y si el resultado es mayor o igual a cero es parte de la solución.

Solución como intervalo:

$(-\propto,-5]$ o $[7, \propto)$

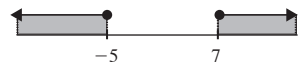

La solución gráfica está indicada con el color celeste.
Representación gráfica de las desigualdades.

\begin{tabular}{|c|c|}
\hline In & $\begin{array}{l}\text { ervalo abierto } \\
\text { ervalo cerrado }\end{array}$ \\
\hline $\begin{array}{l}x>a \\
(a, \propto)\end{array}$ & $\begin{array}{l}\longrightarrow \\
\underset{a}{\longrightarrow}+\propto \\
\text { El conjunto so- } \\
\text { lución es ma- } \\
\text { yor, pero no } \\
\text { igual, que } a .\end{array}$ \\
\hline $\begin{array}{l}x \geq a \\
{[a, \propto]}\end{array}$ & $\begin{array}{l}\underset{a}{\longrightarrow}+\propto \\
\text { El conjunto so- } \\
\text { lución es ma- } \\
\text { yor o igual que } \\
a .\end{array}$ \\
\hline $\begin{array}{l}x<a \\
(-\propto, a)\end{array}$ & $\begin{array}{l}\longleftarrow \\
-\propto \\
\text { El conjunto so- } \\
\text { lución es me- } \\
\text { nos, pero no } \\
\text { igual, que } a \text {. }\end{array}$ \\
\hline $\begin{array}{l}x \leq a \\
{[-\propto, a]}\end{array}$ & $\begin{array}{l} \\
-\propto \\
\text { El conjunto so- } \\
\text { lución es me- } \\
\text { nor o igual que } \\
a .\end{array}$ \\
\hline
\end{tabular}

Resolvemos en nuestro cuaderno las siguientes desigualdades. Escribimos las respuestas en forma de intervalo y las graficamos en la recta numérica.
a) $x^{2}-2 x-35<0$
b) $x^{2}-2 x^{2}-x-6 \geq 0$
c) $-3 x^{2}+x+2>0$
d) $-2 x^{2}+3 x+2 \leq 0$
e) $x^{2}-4 x \leq 0$
f) $18 x-2 x^{2}>0$ 


\section{Los benéficios de expresarnos correctamente}

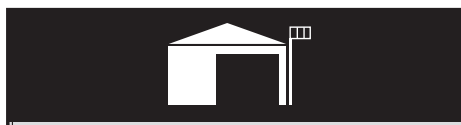

Escuchemos atentamente la presentación del tercer grupo para conocer más sobre la relación entre mente y cuerpo sano. Identifiquemos si su presentación incluye alguno de los siguientes vicios de dicción.

\section{Vicios de dicción}

Uso incorrecto de las palabras y de las oraciones mal construidas, que pueden causar confusión.

Los más usuales son:

Vulgarismo o barbarismo: cambiar ciertas letras de una palabra: «diabetis» en lugar de diabetes, «sia» en vez de silla, «vinistes» en lugar de viniste etc.

Extranjerismo: usar palabras en otro idioma, aunque exista su equivalente en español: «Voy a ir de shopping» por «Voy a ir de compras.

Arcaísmo: uso de palabras antiguas que han caído en desuso: "yantar" por comer y "agora" por ahora.

Redundancias: se dice lo mismo con diferentes palabras: «par de dos».

Muletillas: se repite una expresión al final o al principio de una oración «Fuimos al parque ¿sabes? y no encontramos a María ¿sabes?»

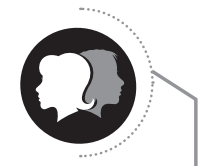

\section{Género y sexo gramatical}

El género masculino se asocia casi siempre con las personas o animales del sexo masculino. Se presenta en las palabras terminadas en -o y en -e.

El género femenino se asocia a las personas o animales del sexo femenino. Se presenta en las palabras terminadas en -a.

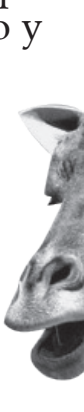

Hay algunas palabras como "pez" o "cebra" que se usan para representar a ambos sexos. No se dice "peza" ni tampoco "cebro".

Hay nombres o sustantivos que son comunes a ambos géneros. Se dice un policía y también se puede decir una policía.

En los sustantivos el género gramatical puede ser... gramatical puede ser morfológico o léxico. Los morfológicos son los que cambian una $-O \mathrm{O}$ bien una - e por una - a: médico, médica; presidente, presidenta; los que agregan una $-a$ a la raíz: pelón, pelona; y los que modifican ligeramente la terminación de la palabra: rey, reina; tigre, tigresa. Los léxicos son los que cambian una palabra por otra para diferenciar al masculino del femenino de una misma especie: caballo, yegua; hombre, mujer; toro, vaca.

En los objetos inanimados, existen los llamados ambiguos. Estos son a los que puede anteponerse un artículo masculino o uno femenino, siendo ambos correctos: el mar, la mar; el azúcar y la azúcar.

En equipos, discutiremos acerca de la diferencia entre sexo y género y los efectos de la discriminación o desventaja social de la mujer en la salud. Generemos por lo menos dos conclusiones sobre esta situación para exponer y dialogar como clase. 


\section{Figuras literarias}

Son recursos del lenguaje que enriquecen, mejoran la expresión y dan mayor expresividad a los sentimientos y emociones. Es la utilización de las palabras de una forma no convencional, que la aleja de su uso habitual, por lo que terminan transformando en artístico el lenguaje común y corriente. Reciben también el nombre de recursos literarios, recursos retóricos, etc.

\section{Las figuras literarias más utilizadas son:}

El símil o comparación: Sirve para establecer una relación entre un elemento real y uno imaginario unidos por un nexo comparativo («como», "cual», «igual que». Ejemplo: Corrió tan rápido como un rayo. Tenía los ojos negros bellos como la noche.

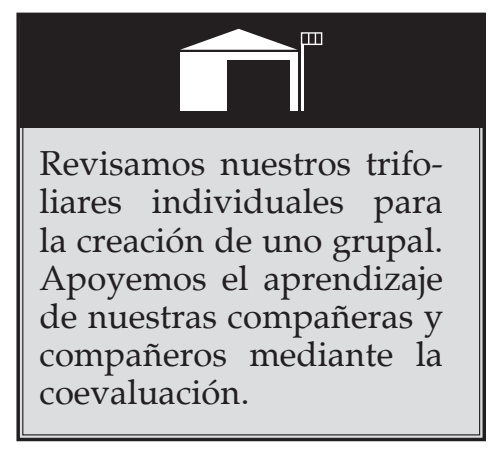

La metáfora: Es siempre una imagen. No compara un elemento real con uno imaginario, sino que consiste en ver de otra forma la realidad. Ejemplo: Al dejarme me partió el corazón en mil pedazos.

Sinécdoque: Utiliza una parte de algo para referirse a un todo. Ejemplo: Llegó a protegerla toda la policía de municipio.

Eufemismo: Se llaman así a las palabras que, de forma menos ofensiva, sustituyen a una de mal gusto $u$ ofensiva. Ejemplo: «Pasado de tragos = borracho».

Ironía: La ironía es una burla disimulada. Es dar a entender algo contrario a lo que se dice, a través del lenguaje corporal o de la entonación que se dé a la voz. Ejemplo: «Hoy es un día perfecto para pasear en el campo» (cuando está lloviendo).

Onomatopeya: Es la palabra que imita el sonido de algo natural. Ejemplo: «Clap, clap» (para indicar aplausos); «Toc, toc» (tocar la puerta); «Tic, tac» (las manecillas del reloj).

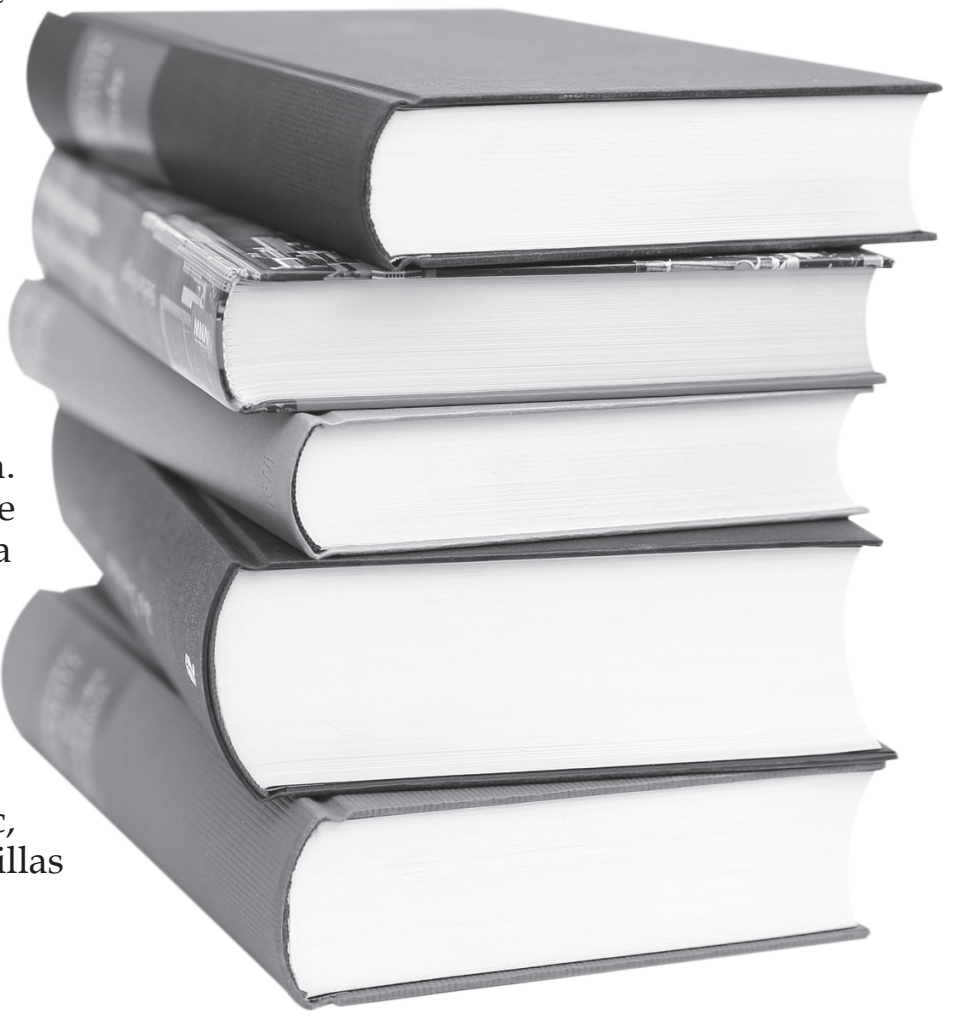

En Internet o en la escuela buscamos obras poéticas de mujeres como Gabriela Mistral, Alfonsina Storni, Delmira Agustini, Maya Cu, María García Granados, Alaíde Foppa e identificamos las figuras literarias. En nuestro cuaderno escribamos tres ejemplos de cada una de estas figuras literarias y autoevaluamos nuestro trabajo antes de entregarlo en la sesión de tutoría. 


\section{Las enfermedades no transmisibles}

Nutrición: ingesta de alimentos según las necesidades del organismo. Lo contrario es Malnutrición.

Desnutrición: dieta deficiente en uno o varios nutrientes esenciales o mala asimilación de los mismos. Hay tres tipos:

Aguda: deficiencia de peso para la altura (P/A). Delgadez extrema, por pérdida de peso asociada con hambruna reciente o enfermedad que se desarrolla muy rápidamente y es limitada en el tiempo.

Crónica: retardo de altura para la edad (A/E). Presenta consecuencias negativas para el aprendizaje de la persona.

Global: deficiencia de peso para la edad. Trastorno grave observado en niños y niñas de entre los diez meses y los tres años, por malnutrición severa y carencia de nutrientes vitales básicos.

Marasmo: grave decaimiento funcional del organismo provocado por una seria deficiencia de proteínas y de calorías.

Fuentes: http://www.who. int/topics/nutrition/es/

https://www.unicef.org/lac/ glosario_malnutricion.pdf

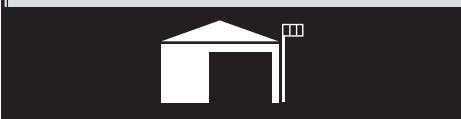

Exponemos al equipo el mapa conceptual elaborado en casa.

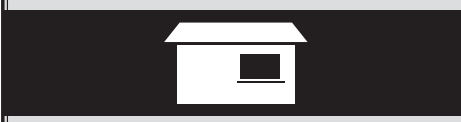

Elaboramos un listado de buenas prácticas para la salud de acuerdo con el tema visto en la sesión

Interpretamos la información que aparece en el esquema. Comentamos si conocemos personas en la comunidad que sufran de alguna de esas enfermedades.

No se transmiten de persona a persona. Son de larga duración y por lo general evolucionan lentamente.

También conocidas como enfermedades crónicas

Los cuatro tipos principales de enfermedades no transmisibles
Cardiovasculares (como ataques cardíacos y accidentes cerebrovasculares o derrames)

\section{Cáncer}

Las enfermedades respiratorias crónicas (como la enfermedad pulmonar obstructiva crónica y asma)

\section{Diabetes}

La organización mundial de la salud nos advierte que el 75\% de las muertes por enfermedades no transmisibles en el mundo se registra en países de ingresos bajos y medios. Entre los factores de riesgo que favorecen estas enfermedades están las dietas malsanas, la inactividad física, la exposición al humo de tabaco o el uso nocivo del alcohol.

La gordura es también un riesgo asociado a mayor probabilidad de obesidad adulta, muerte prematura y discapacidad. Niños y niñas con obesidad además tienen mayor riesgo de sufrir fracturas, problemas respiratorios, enfermedades cardiovasculares y resistencia a la insulina. Según la Organización Mundial de la Salud en los países con pobreza y pobreza extrema, es más probable que la nutrición prenatal, del lactante y de la niña o niño pequeño, sea inadecuada. Las niñas y los niños están expuestos a alimentos de alto contenido calórico ricos en grasa saturadas y grasas trans, azúcar y sal y pobres en micronutrientes. Suelen costar menos pero no proveen los nutrientes necesarios para una buena salud. Si a esta forma de alimentarse se le añade poca o ninguna actividad física, es posible que haya obesidad infantil. 


\section{Enfermedades psicosomáticas}

Estas afectan al cuerpo y la mente. Las enfermedades del cuerpo afectan el humor y el estado de ánimo, provocan preocupaciones. A la vez, las preocupaciones, baja autoestima, duelos, y problemas psicológicos afectan el cuerpo. La ansiedad, la depresión y el estrés producen cambios hormonales y en diferentes sistemas del organismo, lo que provoca enfermedades.En este caso, se dice que la persona somatiza un problema.

Entre los síntomas asociados a las enfermedades psicosomáticas se incluyen: colon irritable, úlceras gástricas, acné, alergias, y diabetes. Se llama hipocondría cuando una persona tiene la creencia de que permanentemente padece una enfermedad.

La depresión es una profunda tristeza que se prolonga por mucho tiempo. Puede estar producida por desequilibrios hormonales. Hay una sensación de vacío, desinterés; sentirse culpable, sin esperanza y con ideas de muerte o suicidio. Su presencia afecta al sistema inmunológico al disminuir las defensas; las bacterias, que son agentes oportunistas, aprovechan esa condición.

La ansiedad es un sistema de alerta natural del organismo. Sin embargo, cuando es exagerada, afecta la salud y las relaciones sociales y laborales. Causa pánico, angustia, fobias y obsesiones. Puede estar asociada a problemas sociales, sexuales o de relaciones interpersonales.

El estrés es un sentimiento de tensión física o emocional, asociado a nerviosismo o tensión. Es causado por problemas familiares o económicos, exceso de trabajo o enfermedades. Incide en enfermedades cardiovasculares, hipertensión, asma, cáncer, hiper e hipo tiroidismo e impotencia.

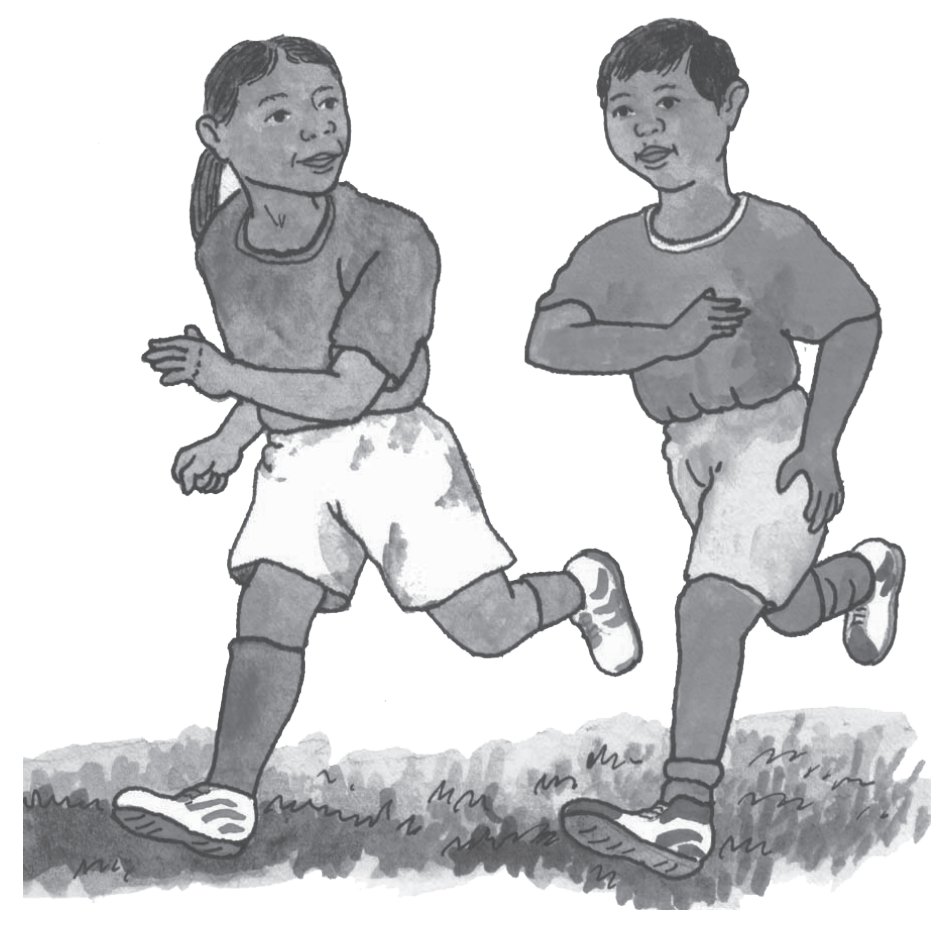

Las enfermedades psicosomáticas más comunes están relacionadas con la depresión, la ansiedad y el estrés. Para prevenirlas puedo practicar actividades que me produzcan bienestar: deportes, baile, caminatas al aire libre, montañismo, prácticas de relajación, yoga y meditación; actividades recreativas en sociedad, suficiente descanso y el apoyo de seres queridos.

Según la OMS (Organización Mundial de la Salud), el $90 \%$ de las enfermedades tienen un principio psicosomático, y esto se debe a que la influencia de la mente sobre el funcionamiento del cuerpo y los sistemas que lo integran es indiscutible.

Los juegos y deportes son excelentes para prevenir enfermedades psicosomáticas pues permiten liberar tensiones, afianzar relaciones y disfrutar el momento.

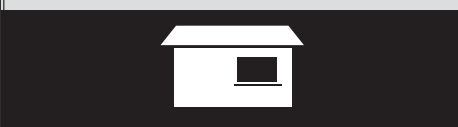

Identifico las condiciones de vida que generan estrés en mi familia y comunidad.

Elaboro un listado de las actividades que pueden realizarse en la comunidad para contrarrestar el estrés e incluirlas en el programa.

\section{(iiii}

Realicemos una actividad que nos lleve a movernos y hagamos una lista de buenas prácticas para prevenir enfermedades psicosomáticas en nuestra comunidad. 


\section{La Cuerra Fría y la salud mental de las comunidades de Guatemala}

En varios países del mundo, para frenar el avance del campo socialista, los gobiernos adoptaron políticas del Estado de bienestar. Fue por esta razón que negociaron con los movimientos sociales la mejora de salarios y condiciones de trabajo; servicios de salud, educación, seguridad social, vivienda, energía eléctrica, todo de carácter público.

- ¿Sucedió esto en Guatemala? Argumento mi respuesta.
La Guerra Fría fue el período de las relaciones de confrontación limitada y permanente, entre los Estados Unidos de Norte América (EUA) y la Unión de Repúblicas Socialistas Soviéticas (URSS). Luego del fin de la II Guerra Mundial, terminó la confrontación violenta directa entre ambos países debido a que se sabía de las graves consecuencias que hubiese provocado el uso de las armas nucleares. Sin embargo las tensiones se ampliaron a los países que se agruparon con EUA o con la URSS cada potencia intentando establecer su dominio en los territorios de otros países del mundo.

Según EUA, se trataba de frenar el intento de la URSS de expandir su dominio sobre territorios y economías alrededor del mundo. La URSS justificaba su actitud como algo defensivo, ya que los estados capitalistas junto a EUA lanzaban ataques de todo tipo contra los países socialistas y ellos solo trataban de coexistir pacíficamente. Estos bloques tenían ideas, políticas y económicas contrarias, por lo que se enfrentaron militarmente fuera de las fronteras de sus países. Recurrieron al espionaje, difamación y chantaje y apoyaron a los bandos en guerras internas, como en Guatemala.

La intervención de Estados Unidos en el conflicto armado interno de Guatemala, en un tiempo fue evidente, pero luego ayudó al Ejército de Guatemala por medio de otros gobiernos como el de Israel. La URSS apoyaba a las organizaciones insurgentes, aunque en menor medida. Si bien el conflicto armado interno en Guatemala tiene su origen en la pobreza, injusticia y falta de libertad política; la Guerra Fría también influyó y afectó la forma en que se desenvolvió el conflicto local y la polarización social.

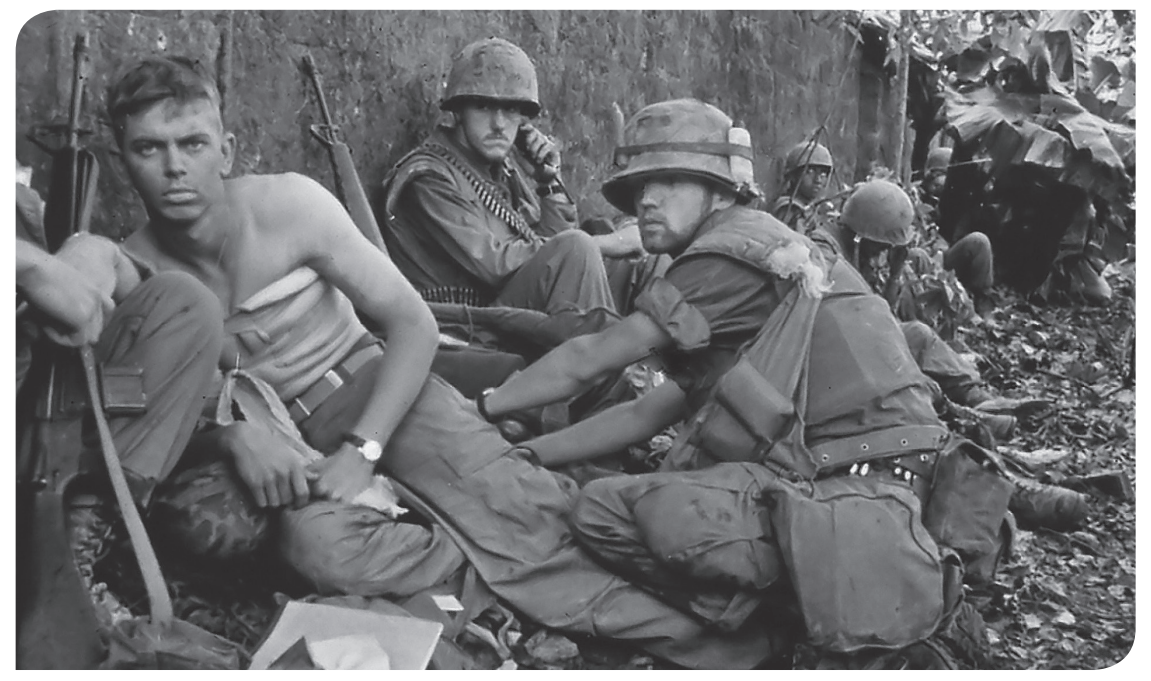

\section{Trabajamos en equipo:}

Analizamos de qué manera los problemas que se dan en una guerra afectan la salud mental de las comunidades. ¿Qué sabemos sobre el conflicto armado interno y su efecto en la salud de nuestra comunidad? 


\section{La Organización del Trałado del Atlántico Norte}

Es nombrada por sus siglas: OTAN. Es un pacto de defensa militar para enfrentar el peligro que sentían los países de Europa de que surgieran revoluciones socialistas que se proponían eliminar los negocios privados y crear un estado que resolviera los principales problemas económicos y sociales. Fue creada en 1949 con la participación de delegados de Estados Unidos, Canadá, Francia, Bélgica, Holanda, Luxemburgo y Gran Bretaña. Además de su carácter militar, también incluyó aspectos políticos y económicos; al mantener la apertura para que otros países europeos se incorporaran, logró incorporar a la mayoría.

Con la disolución de la URSS, la OTAN perdió sentido al ya no existir la amenaza del campo socialista. En la actualidad, los aspectos políticos y económicos se manifiestan en la Unión Europea; su esencia militar se mantiene al intervenir en las guerras del Mundo Árabe y tratar de evitar actos terroristas en Europa.

\section{Pacto de Varsovia}

Se trata de un pacto militar suscrito en 1955 por la Unión Soviética, Hungría, Checoslovaquia, Yugoslavia, Polonia, Bulgaria, República Democrática Alemana, Rumania y Albania. Surgió como una respuesta a la creación de la OTAN. Dicho pacto quedó disuelto en 1991. La mayoría de estos países se han incorporado a la OTAN.

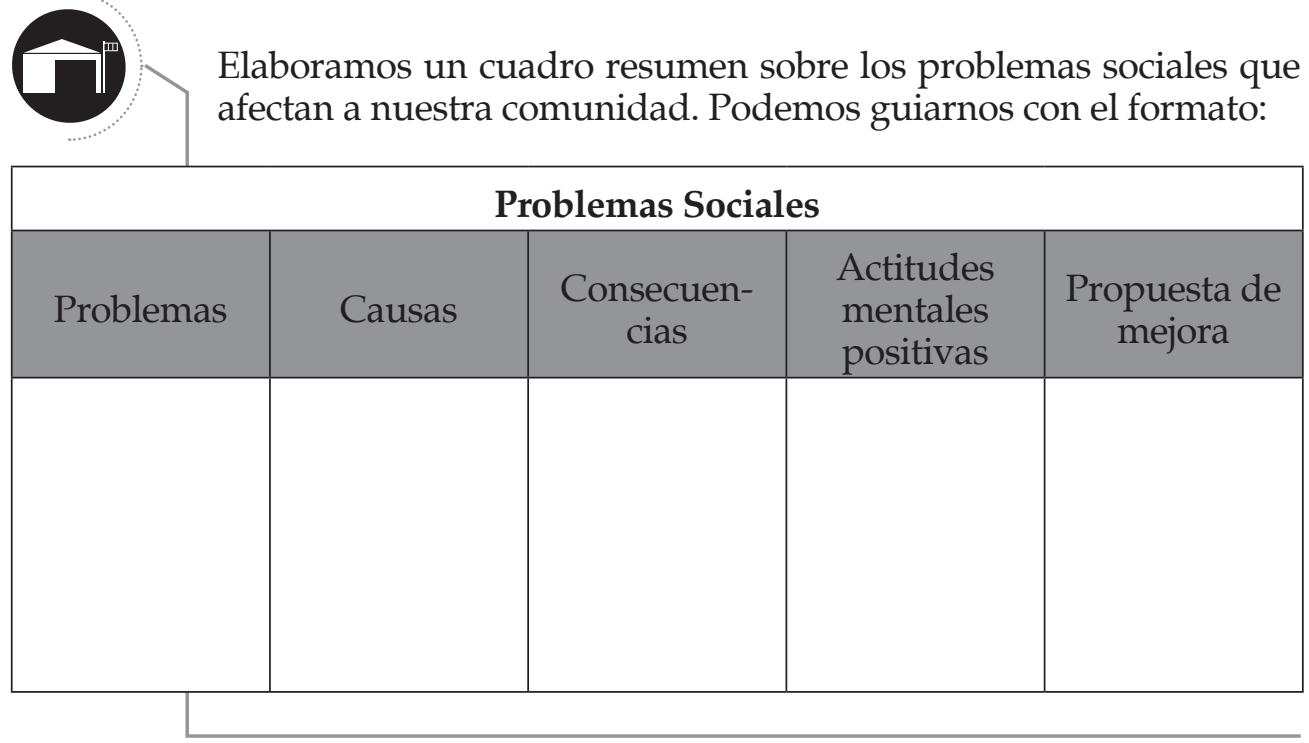

Formulemos, una propuesta de buenas prácticas para solventar un problema social de nuestra comunidad o para reducir los efectos que causa en la misma.

Integremos estas prácticas al programa para el mantenimiento de la salud integral.
- ¿Es esta la causa principal de las guerras en el mundo árabe? ¿Por qué?

"Para la opinión pública árabe la identidad de la OTAN no puede separarse de la de los países y potencias occidentales que la crearon y que constituyen sus miembros actuales. Por eso la imagen de la Alianza se ha ido formando a partir de las actitudes respecto a los acontecimientos que afectaron al mundo árabe en los que intervinieron sus principales miembros: el gobierno colonial francés y su guerra de Argelia, la intervención italiana en el Norte de África, la ocupación y posterior control e influencia por parte del Reino Unido de la región del Golfo, y el apoyo aparentemente ilimitado e inmutable a Israel por parte de Estados Unidos."

Fuente: Alani, M. (2005). La OTAN y Oriente Medio. Recuperado de: http:/ / www. nato.int/docu/review/2005/ issue4/spanish/art3.html

- ¿Cuáles países que se mencionan en el párrafo fueron fundadores de la OTAN?

- ¿Qué países señala el párrafo que intervienen directamente en una guerra y cuáles intervienen indirectamente? 


\section{Sintiendo el tiempo y el espacio}

Un espacio donde movernos a voluntad es importante para vivir bien. Desplazarnos sobre un espacio reducido puede incidir en la toma de decisiones de índole personal. Desplazarnos sin miedo a que nos miren, con ganas de comernos el mundo haciendo el bien a las y los demás. Cada movimiento de las extremidades puede pensarse como lo que pensamos, lo que emprendemos y lo que caminamos en el mundo.

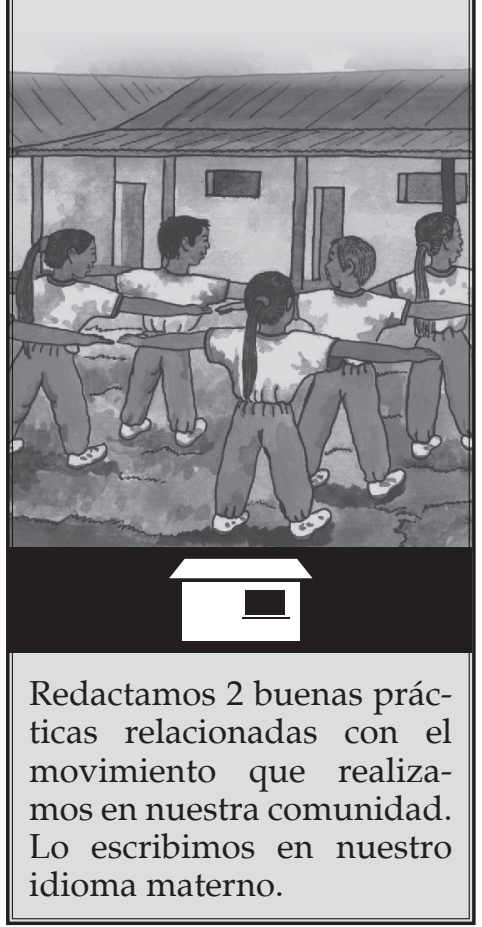

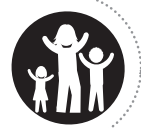

Desde antes de nacer ya hemos comenzado a aprender. El primer llanto de un nuevo ser es el resultado de su encuentro con el mundo exterior, salir a ese espacio lleno de sonidos y sensaciones desconocidas, implica una experiencia muy intensa. Desde ese mismo momento se comienza a aprender que existe un espacio y un tiempo en que ocurren todas las cosas de la vida. $Y$ en ese tiempo y espacio es necesario cultivar un cuerpo sano y una mente que sabe pensar y actuar en armonía. Al expresarnos con el cuerpo, hacemos que esté activo y presto al movimiento, y desarrollamos nuestra imaginación para transmitir ideas y mensajes, o bien para sentirnos a gusto con nuestro cuerpo.

La kinética estudia los movimientos del cuerpo y las destrezas de comunicación que con ellos se pueden desarrollar. Usar un tiempo rápido o lento para girar sobre los pies o desplazarse en cualquier espacio, son habilidades que requieren de mucha atención y que nos concentremos. En un mundo que puede estar muy agitado por la tecnología o por el trabajo, es bueno detenerse y aprovechar los beneficios del movimiento corporal con distintos tiempos de música, de lento a rápido y viceversa.

Trabajemos en grupo haciendo ejercicios de desplazamiento breve

- Nos separamos y sentamos en cuclillas en el suelo formando un círculo, sin tocarnos.

- Con un fondo musical suave y lento, cerramos los ojos y giramos la cabeza en el sentido de las agujas del reloj, luego al revés.

- Hacemos lo mismo con los brazos, lentamente como dibujando círculos en el aire, primero el izquierdo, luego el derecho.

- Ahora nos ponemos de pie y hacemos lo mismo con las piernas, en el aire dibujando círculos.

- Repetimos toda la serie con una música de ritmo mediano, luego con ritmo muy rápido.

Evaluemos y decidamos en equipo qué herramientas tecnológicas vamos a usar para la presentación del manual de buenas prácticas. Aprovechemos los recursos que hay en la comunidad. 


\section{Desplazamiento, ritmo y vida}

Al desplazarnos en espacios mayores, como un salón de clase o un patio, podemos pensar en lo que nos gustaría hacer ante la vida. Pensando siempre en mantener un cuerpo y una mente sanos a través de la actividad física y el ejercicio de las ideas, nos desplazamos largo y rápido. Podemos saltar con el ritmo de una música rápida, correr, mover las caderas, los hombros, la cabeza y dejarnos caer suavemente en el suelo, como una tragedia. También podemos elevarnos del suelo con movimientos alternos de rodamiento, alzando piernas y brazos, hasta levantarnos y saltar, como una victoria.

\section{Escogiendo nuestra coreografía}

En nuestra coreografía podemos incluir movimientos como los que se enunciaron arriba, buscando la armonía entre cada serie de movimientos. Saltos, pasos rápidos, movimiento de caderas, hombros y cabeza, rodamientos y alzamiento de piernas y brazos.

Escogemos entre las coreografías que presentó cada grupo, una que reúna al menos tres de los movimientos que se sugieren.

Definimos las secuencias y escribimos la coreografía para cumplirla al pie de la letra.

Asignamos roles a quienes dirigirán a cada fila en las secuencias. Ensayamos todos y cada uno de los movimientos y series escogidas.

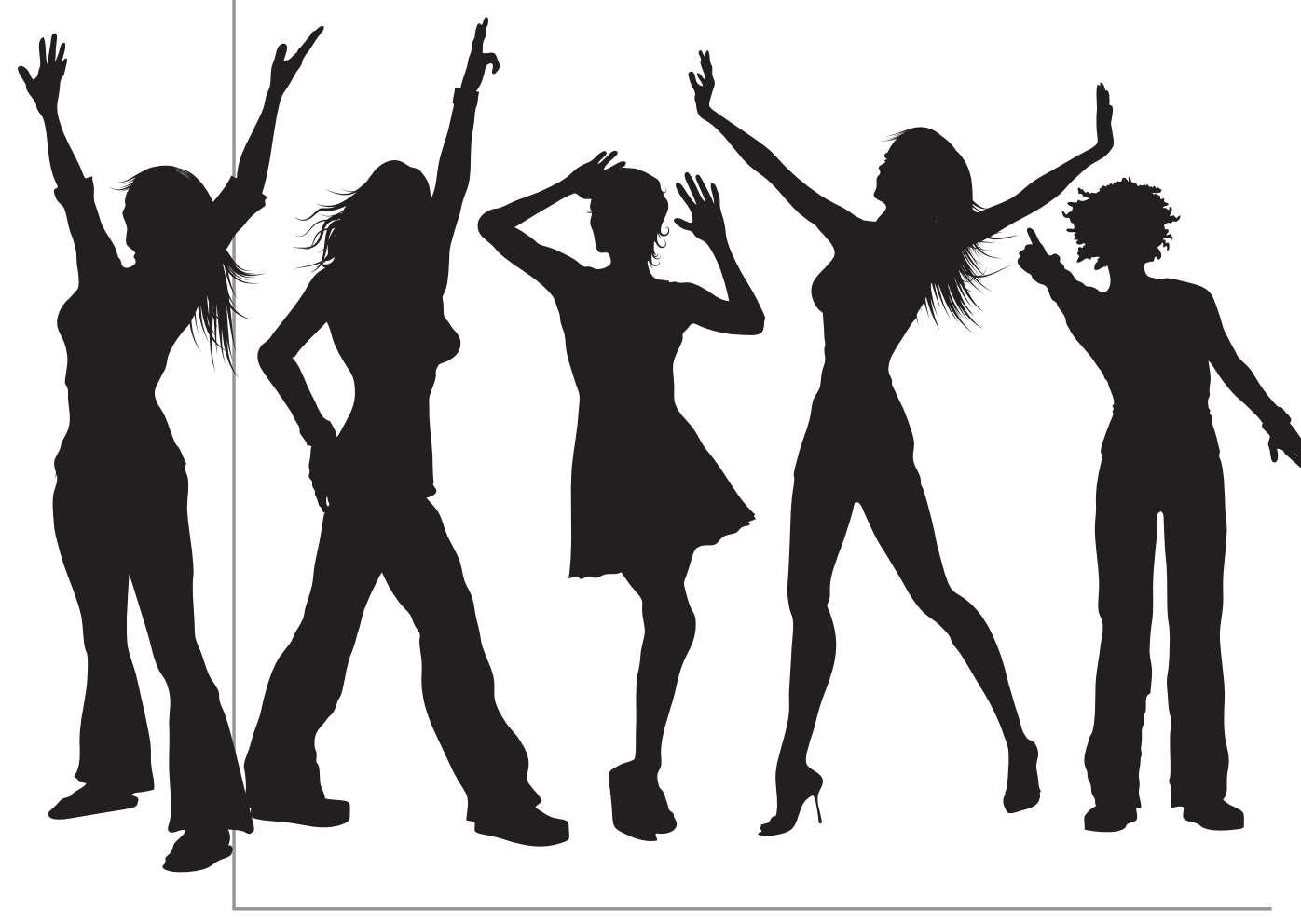

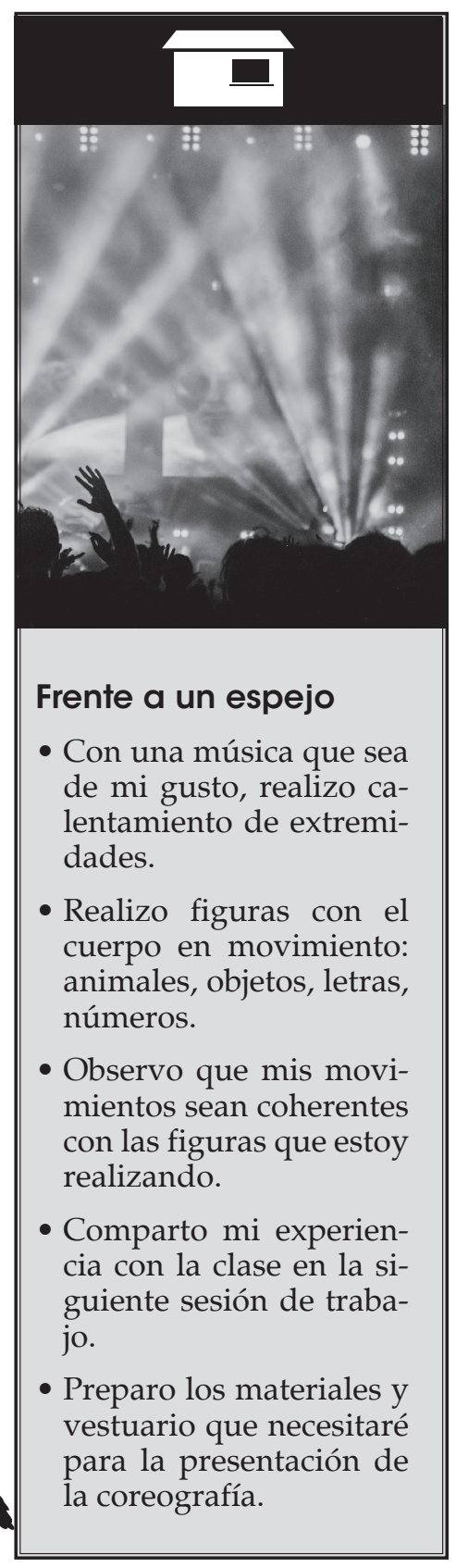

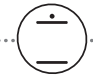




\section{Mejoremos nuestra capacidad de expresión}

Instituto Guatemalteco de Seguridad Social -IGSS-

El IGSS es responsable de atender a sus afiliadas $y$ afiliados en caso de enfermedad, maternidad y accidentes. Ofrece servicios de maternidad a las esposas de trabajadores y de pediatría a hijas e hijos menores de 5 años de las y los trabajadores.

En caso de accidente o enfermedad, la persona trabajadora tiene derecho a servicios médicos, hospitalarios y de rehabilitación. Cuando debido a enfermedad o accidente, la persona es suspendida recibe del IGSS una pensión equivalente a $2 / 3$ de su salario. En caso de incapacidad permanente, invalidez o vejez, la persona afiliada recibe una pensión.

Todas las empresas, las organizaciones y las entidades de gobierno que tienen tres o más personas trabajadoras deben inscribirse en el IGSS. El IGSS funciona con los aportes del $4.87 \%$ del salario de las personas trabajadoras y las y los patrones aportan el $10.67 \%$ del monto que paga en salarios.

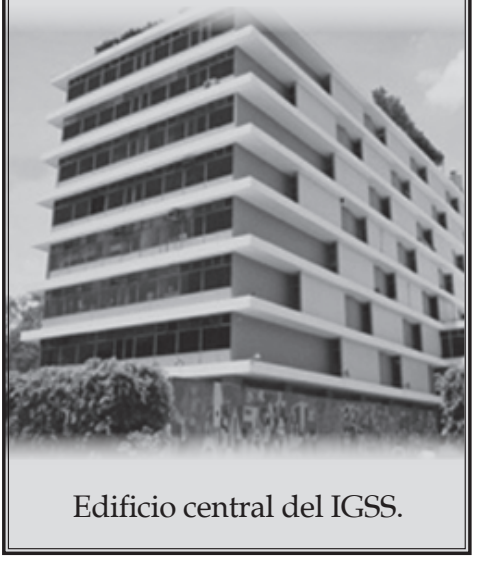

\section{Seguridad laboral e industrial}

Las y los patronos tienen obligación de proporcionar un ambiente de trabajo seguro para proteger la salud, la integridad corporal y la vida de las y los empleados. Las enfermedades y los accidentes laborales plantean problemas para la persona trabajadora y su familia, pero también para empleadores porque significa pérdida de días de trabajo. El Acuerdo Gubernativo 229-2014 del Ministerio de Trabajo regula las normas de seguridad e higiene laboral, así como las responsabilidades y derechos de empleadores y trabajadores.

El lugar de trabajo debe:

- Ser iluminado, limpio, ventilado y de un tamaño adecuado para el número de personas que lo ocupan.

- Contar con sanitarios y, según el tipo de trabajo a realizar, con cuartos de aseo separados para hombres y mujeres.

- Proporcionar herramientas y equipo necesario para realizar el trabajo y asegurar que el mismo esté en buen estado.

- Proporcionar el equipo de protección personal, según el tipo de trabajo a realizar; por ejemplo, casco, guantes, mascarillas, redecillas para el cabello, lentes protectores, delantales o uniformes.

El mismo Acuerdo prohíbe que se solicite a cualquier persona la prueba de VIH/SIDA como requisito para dar un trabajo. Las personas que padecen VIH/SIDA tienen derecho a no ser discriminadas en el trabajo, pero para resguardar la salud pública no pueden trabajar manipulando alimentos. Es ilegal destituir a alguien por padecer VIH/SIDA.

Las personas trabajadoras tienen la obligación de atender todas las instrucciones y medidas de seguridad e higiene, un patrono o patrona puede retirar del trabajo a quien se presente con embriaguez.

Según el Decreto 74-2008 del Congreso de la República, todos los ambientes de trabajo y lugares públicos deben estar libres de humo de tabaco.

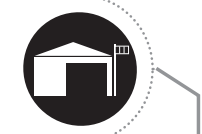

Visitamos un proceso productivo de la comunidad y anotamos todas las actividades. Analizamos si las personas trabajadoras aplican medidas de seguridad laboral. Si existe la posibilidad, podemos ver procesos productivos en lugares lejanos por medio de videos.

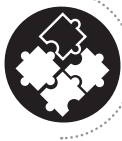

Investigamos también las palabras, símbolos y frases que se usan en inglés para atender las normas de seguridad en procesos productivos. Preparamos afiches en inglés, español y el idioma de esta comunidad. Si tenemos acceso a computadora podemos usar Paint y otros programas de computación para diseñar los afiches.

Investigamos sobre prácticas de higiene y seguridad en ámbitos productivos. Analizamos el efecto en las personas trabajadoras y la productividad debido a la puesta en práctica de medidas de seguridad en el ambiente laboral. 


\section{El ambiente laboral positivo}

Generalmente, nuestro día a día lo compartimos entre la familia y el trabajo. Por eso es tan importante que laboremos en un ambiente positivo, donde nos sintamos personas útiles y valoradas. El fomento del respeto y la escucha activa son primordiales. El respeto incluye no permitir expresiones y actos machistas que denigren a la mujer trabajadora, especialmente, el acoso sexual. El acoso sexual consiste en conductas que demandan atención y favores sexuales indeseados, generalmente de hombres hacia mujeres.

La producción y procesamiento de alimentos requieren la aplicación de medidas higiénicas y de seguridad ya sea que este sea un proceso industrial o familiar. Esta semana, además, hemos reflexionado sobre la importancia de que las personas trabajadoras se sientan protegidas y valoradas para mejorar su salud y bienestar y prevenir enfermedades y accidentes laborales, pero también para aumentar la producción y establecer la mejora continua laboral y empresarial.

También hemos aprendido y aplicado variados conceptos de otras materias al mismo tiempo que seguimos avanzando en la creación del programa de salud integral del Proyecto 5.

\begin{tabular}{|l|l|l|}
\hline \multicolumn{1}{|c|}{ ASPECTOS A EVALUAR } & Sí & No \\
\hline $\begin{array}{l}\text { Demostramos el uso de inecuaciones lineales para } \\
\text { representar problemas sociales. }\end{array}$ & & \\
\hline Valoramos el uso adecuado del género en la expresión. & & \\
\hline $\begin{array}{l}\text { Reconocemos la importancia de buenas prácticas para } \\
\text { prevenir enfermedades no transmisibles. }\end{array}$ & & \\
\hline $\begin{array}{l}\text { Analizamos los efectos de las problemáticas sociales } \\
\text { sobre la salud de nuestra comunidad . }\end{array}$ & & \\
\hline Practicamos la coreografía creada.. & & \\
\hline $\begin{array}{l}\text { Analizamos el impacto de medidas higiénicas y de } \\
\text { seguridad en el ámbito laboral. }\end{array}$ & & \\
\hline
\end{tabular}

\section{Protección a la madre trabajadora}

La Constitución Política y el Código de Trabajo protegen a las madres trabajadoras:

- las trabajadoras embarazadas o en periodo de lactancia no pueden ser despedidas;

- la madre tiene derecho a un descanso de 30 días antes del parto y 54 después; si la mujer no goza del beneficio del IGSS, el o la empleadora debe cubrir el salario de esos 84 días.

- Cuando la madre regresa a trabajar tiene derecho a una hora de lactancia durante diez meses; puede tomar la hora completa o media hora antes de entrar a trabajar y la otra, después.

- Los establecimientos con más de 30 mujeres trabajadoras tienen la obligación de tener una guardería en el lugar de trabajo.

- La salud y bienestar de la madre trabajadora es importante para ella misma, su hija/hijo y la empresa porque las ausencias serán menores y la productividad se mantendrá o mejorará.

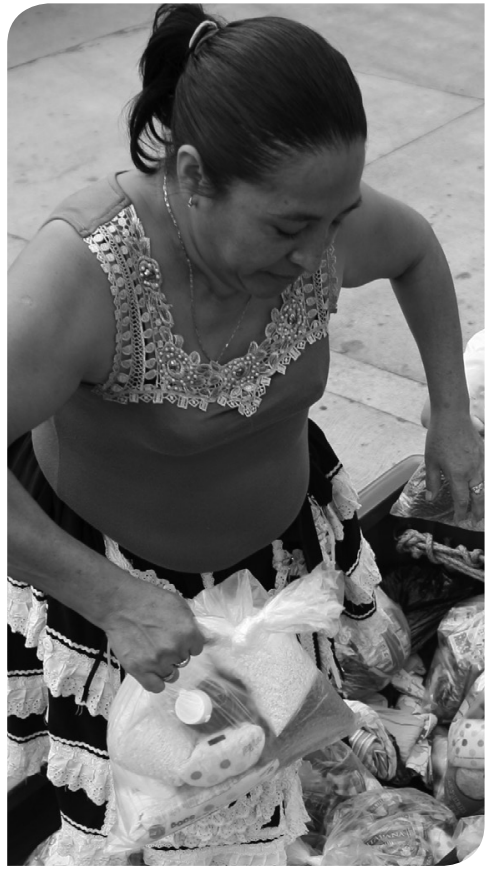




\section{Comunidad Económica Europea}

"En las zonas urbanas, las niñas abandonan la escuela con menor frecuencia que los niños, progresan a lo largo del ciclo escolar con menor repetición. En cambio, en las zonas rurales, las mujeres por regla general tienden a abandonar la escuela más tempranamente que los hombres, particularmente durante los primeros años de primaria, y en el caso de Guatemala un porcentaje mayor de niñas no ingresa al sistema o lo abandona sin completar el primer grado."

Fuente: Herrero, F. (2004). La integración centroamericana: beneficios y costes. México: CEPAL. Recuperado de: file:/ / /C:/Users/HP\%20 OAKLAND/Downloads / LCMEXL603s_es.pdf

- ¿Qué condiciones son barreras a la asistencia de niñas, jóvenes y mujeres a la escuela?

Argumento mi respuesta.

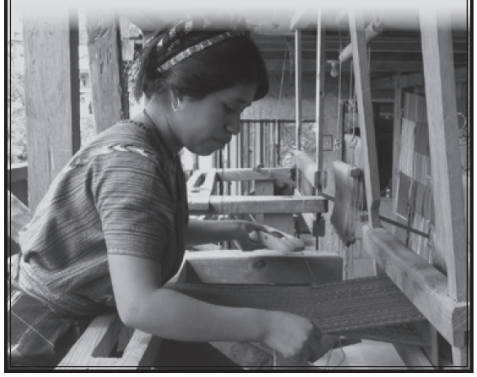

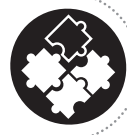

\section{Trabajamos en equipo:}

- Redactamos la historia de la comunidad con relación a todos los actos positivos que se han realizado en beneficio de la salud, deporte, educación y bienestar material de los y las integrantes.

- Elaboramos los lineamientos para construir una infografía que contenga la problemática de la comunidad con relación a las prácticas deportivas, causas, consecuencias.

En 1958, con la participación de Alemania, Bélgica, Francia, Italia, Luxemburgo y Países Bajos, se creó la Comunidad Económica Europea, -CEE-. Era un acuerdo para mejorar la cooperación entre los países miembros con el propósito de reducir los conflictos y evitar la posibilidad de que se diera una III Guerra Mundial. Después se sumaron otros países y formaron un mercado único. En 1993 pasó a llamarse Unión Europea, -UE-.

Hoy la UE está conformada por 27 países, los cuales comparten políticas económicas, ambientales, sociales, de seguridad y justicia, entre otras. Una mayoría también tiene moneda única. Las personas nacionales de los países miembros pueden viajar, vivir o trabajar libremente en cualquiera de los países que la integran. Todos los países que integran la UE tienen representación en el Parla-mento, en el Consejo Europeo (donde se definen las políticas generales) y en el Consejo de la Unión Europea (donde se definen las leyes y políticas específicas de la UE). La UE también impulsa el respeto a los derechos humanos tanto den-tro como fuera de su territorio, así como la transparencia de sus instituciones.

Aunque cada estado mantiene su soberanía, cada vez más se les ha reducido autonomía, principalmente en los aspectos económicos. Esto ha generado des-contento en algunos sectores de la población europea. En el caso específico de Inglaterra los desacuerdos por políticas económicas y migratorias provocó que en el año 2016 se realizara una consulta ciudadana sobre la permanencia del país en la UE; ganó la opción de separarse.

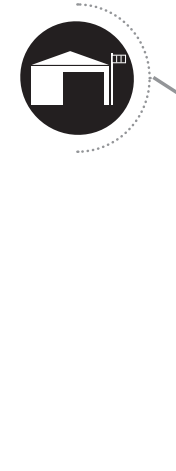

- Analizamos si existe a nivel centroamericano, latinoamericano o americano, una unión de países semejante a la Unión Europea y argumentamos nuestras conclusiones.

- Presentamos, a los miembros del equipo, nuestra lista de buenas prácticas para afrontar los problemas sociales de la comunidad. Consolidamos una lista grupal y la integramos al programa de salud integral.

- Prestamos atención a la presentación del cuarto grupo que expone el tema: Prácticas deportivas de la comunidad y realizamos nuestros

aportes. 


\section{Hechos históricos y cultura de la violencia}

En la historia de la humanidad, la violencia parece tener continuidad. La historia que aprendemos relata una serie de guerras y conflictos internos acompañados de violencia. La escuela ha enfocado como hilo conductor de la historia antigua del mundo oriental, la del mundo occidental y la de América prehispánica las guerras y los hechos violentos.

La historia colonial de Guatemala inicia con un relato de conquista violento y destructivo. Narra que durante esta época el dominio sobre la población originaria se logró con hechos violentos y que se sucedían tantos levantamientos que la estructura de poder era de carácter militar: una capitanía general. Los movimientos independentistas fueron frenados con violencia y siguieron las guerras, los alzamientos y las revoluciones.

Así llegamos a la Revolución de 1944 y a la Contra Revolución de 1954. Después sucede una persecución en contra de los partidarios de la revolución democrática, el asesinato del presidente de la Contra Revolución, la represión, la falta de libertades políticas y el surgimiento del movimiento guerrillero.

$\mathrm{Al}$ mismo tiempo que se dieron hechos violentos, se dieron otros hechos históricos. Se trata de relatos de creaciones maravillosas, descubrimientos admirables, obras artísticas de gran belleza, actos humanos que tienen como base la solidaridad, fraternidad, amor, honorabilidad, la paz y otros valores. Es una historia que merece ser reconstruida y narrada.

- Elaboro la infografía sobre las prácticas deportivas de la comunidad.

- Redacto y reviso la lista de buenas prácticas que favorecen la salud integral en la comunidad.

Pensamos una frase en nuestro idioma materno o en Inglés que motive al uso de las buenas prácticas en nuestra comunidad.

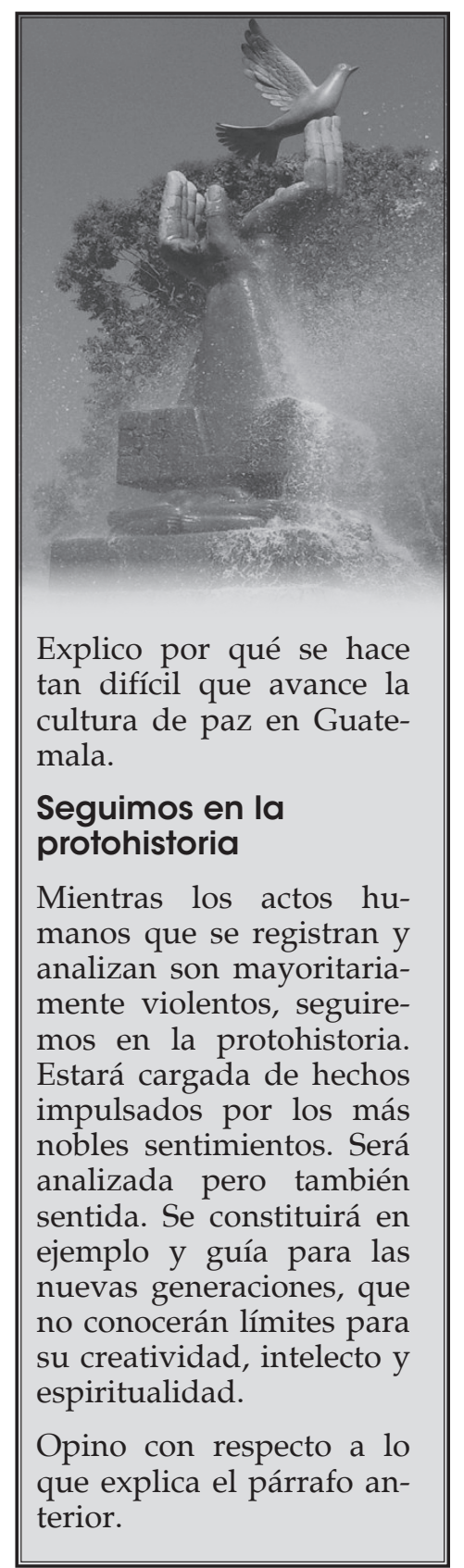




\section{Soluclôn gráfica de inecuaciones lineales y cuadráticas}

Un sistema de ecuaciones es un conjunto de dos o más ecuaciones. El número de incógnitas debe ser igual al número de ecuaciones en el sistema. En un sistema de dos ecuaciones simultáneas debe tener dos variables.

$$
\begin{aligned}
& 2 x-3 y=4 \\
& 3 x+2 y=19
\end{aligned}
$$

En equipos leemos la siguiente situación, luego contestamos:

En un mercado Alicia compró $2 \mathrm{lb}$ de naranjas y $5 \mathrm{lb}$ de papas por Q. 8.35. En el mismo puesto Luis compró $4 \mathrm{lb}$ de naranjas y $2 \mathrm{lb}$ de papas por Q.12.85. ¿Cuál es el precio, por libra, de las naranjas y las papas?

- ¿En nuestra comunidad quiénes realizan con mayor frecuencia las compras en el mercado; los hombres o las mujeres? ¿Qué situaciones viven las mujeres y las niñas cuando compran en el mercado? ¿Por qué es su derecho ir al mercado de forma segura? ¿Cómo garantizamos el bienestar de las niñas, jóvenes y mujeres en la comunidad?

Escogemos una letra para representar las libras de naranjas y otra letra para representar las libras de papas y escribimos una ecuación que represente lo que compró Alicia.

Utilizamos las mismas letras para escribir una ecuación que represente lo que compró Luis.

Utilizando ambas ecuaciones ¿podemos hallar el precio por libra de las papas y las naranjas? Comentamos y comparamos nuestras respuestas.

Para resolver sistemas de ecuaciones simultáneas, por el método de igualación o sustitución, debemos recordar cómo despejar una variable en una expresión algebraica. Observamos los ejemplos para recordar:

\begin{tabular}{|l|l|}
\hline Despejando $x:$ & Despejando $y:$ \\
$4 x-y=5$ & $x-2 y=2$ \\
$4 x=y+5$ & $-2 y=2-x$ \\
$\mathrm{x}=$ & $y=$ ó \\
\hline Despejando $x:$ & Despejando $y:$ \\
$3 x-=10$ & $2 x+2 y=18$ \\
$3 x=10+$ & $2 y=18-2 x$ \\
$x=+$ ó & $y=$ \\
& $y=9-x$ \\
\hline
\end{tabular}

Despejamos, en nuestro cuaderno, la variable que se indica en cada ecuación. Recordamos que para eliminar un término que suma debemos restar de ambos lados de la ecuación, para eliminar términos que restan debemos sumar en ambos lados del igual. Si deseamos eliminar un factor que multiplica se divide en ambos lados de la igualdad y si lo que se quiere es eliminar un número que divide se debe multiplicar también en ambos lados.

\begin{tabular}{|l|l|l|}
\hline $\begin{array}{l}\text { Despejando } x: \\
x+y=10\end{array}$ & $\begin{array}{l}\text { Despejando } x: \\
x+5=2 y\end{array}$ & $\begin{array}{l}\text { Despejando } y: \\
3 x-3 y=9\end{array}$ \\
\hline $\begin{array}{l}\text { Despejando } x: \\
y=3 x+7\end{array}$ & $\begin{array}{l}\text { Despejando } y: \\
2 x+3 y=1\end{array}$ & $\begin{array}{l}\text { Despejando } y: \\
9 y+3=y-x\end{array}$ \\
\hline
\end{tabular}




\section{Método de igualación}

Para resolver sistemas de ecuaciones simultáneas de dos variables por el método de igualación debemos seguir los siguientes pasos:

$1^{\circ}$ Despejar la misma variable en ambas ecuaciones.

$2^{\circ}$ Igualar las expresiones que quedaron al despejar la variable.

$3^{\text {o }}$ Despejar la variable que quedó al igualar.

$4^{\circ}$ Sustituir el valor de la variable hallada en cualquiera de las dos ecuaciones parte del sistema.

$5^{\circ}$ Despejar para hallar el valor de la segunda variable.

Ejemplo:

$2 x+3 y=45$

$3 x+4 y=64$

Despejamos $x$ en ambas ecuaciones:

$x=$

$x=$

Igualamos:

$=$

Despejamos $y$ :

$y=7$

Sustituímos para hallar $x$ :

$2 x+3(7)=45$

$x=12$

\section{Método de sustitución}

Para resolver sistemas de ecuaciones simultáneas de dos variables por el método de sustitución debemos seguir los siguientes pasos:

$1^{\circ}$ Despejar una de las variables en cualquiera de las dos ecuaciones.

$2^{2}$ Sustituir esa expresión en la otra ecuación.

$3^{\circ}$ Despejar la variable que quedó en la ecuación.

4 o Sustituir el valor de la variable hallada en cualquiera de las dos ecuaciones parte del sistema.

$5^{\mathrm{o}}$ Despejar para hallar el valor de la segunda variable.

Ejemplo:

$2 x+3 y=45$

$3 x+4 y=64$

Despejamos $x$ en la primera ecuación:

$x=$

Sustituimos esta expresión en la segunda ecuación:

3()$+4 y=64$

Despejamos $y$ :

$y=7$

Sustituimos para hallar $x$ :

$2 x+3(7)=45$

$x=12$
El conjunto solución de un sistema de ecuaciones simultáneas son las coordenadas $(x, y)$ que satisfacen al mismo tiempo a las dos ecuaciones. Al resolverlas por el método gráfico se pueden ver ubicadas en el plano cartesiano.

$$
\left\{\begin{array}{l}
2 x+y=5 \\
x-y=1
\end{array}\right.
$$

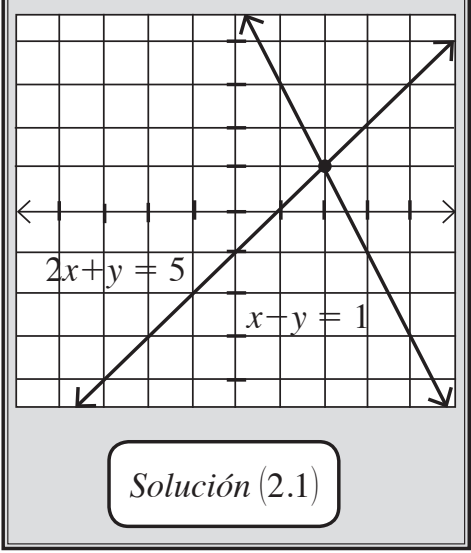

- Investigamos otros métodos para la solución de ecuaciones simultáneas: el método de igualación y el método gráfico. Copiamos en nuestro cuaderno dos ejemplos resueltos de cada método.

Resolvemos, en nuestro cuaderno, los siguientes sistemas de ecuaciones. Indicamos qué método utilizamos.

\begin{tabular}{|c|c|c|}
\hline 1) $\begin{array}{l}y=x-3 \\
2 x+y=12\end{array}$ & $\begin{array}{l}\text { 2) } x=y-1 \\
4 \mathrm{x}-3 y=0\end{array}$ & 3) $\begin{array}{c}3 y+2 x=13 \\
y=x+6\end{array}$ \\
\hline 4) $4 x+y=0$ & 5) $\begin{array}{l}y=3 x+6 \\
2 x+y=13\end{array}$ & 6) $\begin{aligned} x+5 y & =15 \\
2 x-y & =-3\end{aligned}$ \\
\hline
\end{tabular}




\section{Inteccoiones de transmisión sexual (ITS)}

\section{ITS más comunes}

Algunas ITS, como la sífilis, gonorrea, clamidiasis y vaginosis; son transmitidas por bacterias. Algunos síntomas que se pueden presentar en los genitales o en el ano incluyen:

- secreciones amarillentas y espesas

- molestias al orinar

- picazón anal

- cambios en la menstruación

- sangrado durante el coito

- flujo vaginal maloliente y grisáceo.
A partir de la siguiente información recordamos qué son las infecciones de transmisión sexual, (ITS).

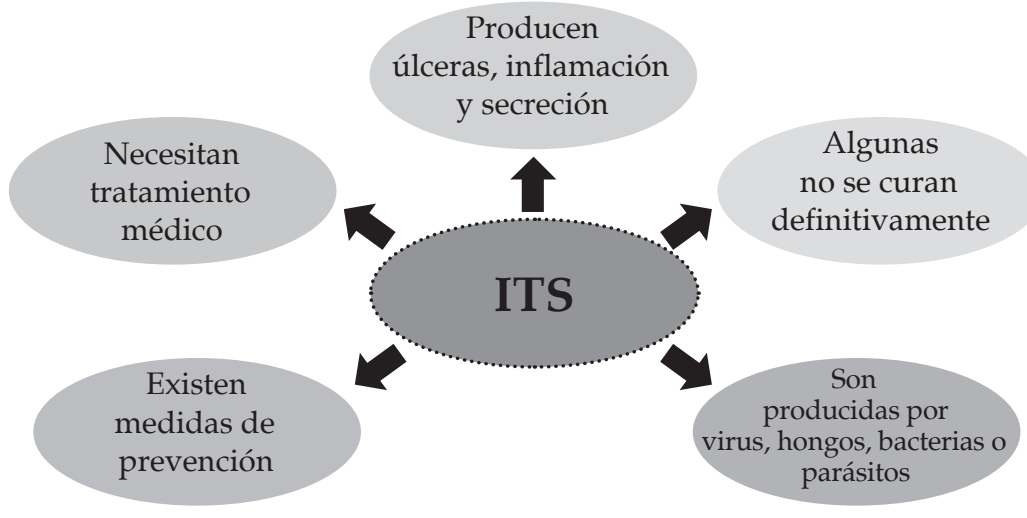

$\| \equiv \leqslant$ Identificamos las buenas prácticas que prevenienen el contagio de una ITS y el VIH.

\begin{tabular}{|l|l|l|}
\hline \multicolumn{1}{|c|}{ Práctica } & Previene & $\begin{array}{c}\text { Aumenta el } \\
\text { riesgo }\end{array}$ \\
\hline $\begin{array}{l}\text { Se practican relaciones sexogenitales, anales u } \\
\text { orales sin protección. }\end{array}$ & & \\
\hline $\begin{array}{l}\text { Se practican relaciones sexogenitales usando } \\
\text { un condón. }\end{array}$ & & \\
\hline $\begin{array}{l}\text { Se facilita en las escuelas e institutos la } \\
\text { educación integral en sexualidad. }\end{array}$ & \\
\hline $\begin{array}{l}\text { No se habla de sexo, sexualidad o educación } \\
\text { sexual. }\end{array}$ & & \\
\hline $\begin{array}{l}\text { Se tiene confianza con la pareja para hablar } \\
\text { sobre el tema y pedir que se haga una prueba } \\
\text { de VIH. }\end{array}$ & & \\
\hline
\end{tabular}

Las ITS se transmiten por contacto sexual o por transfusiones de sangre o plasma; o por compartir jeringas contaminadas. La gonorrea, sífilis, clamidiasis, hepatitis B y VIH, pueden transmitirse por la madre durante el embarazo o a través de la leche materna.

La mayoría de ITS no presentan síntomas de inmediato o presentan síntomas leves, que impiden un diagnóstico rápido. Algunos síntomas de las ITS, son flujo vaginal, secreción uretral, ardor en los genitales, picazón, úlceras genitales y dolor.

La candidiasis genital es producida por un hongo y en ocasiones puede transmitirse a través de las relaciones sexogenitales, aunque quien la transmita no se haya contagiado por vía sexual. La Hepatits $\mathrm{C}$ tiene como forma más común de contagio la vía sanguínea, pero también puede transmitirse por vía sexual. El padecimiento de una ITS de forma prolongada sin recurrir a tratamiento médico, puede provocar esterilidad en la persona que la padece y aumentar la vulnerabilidad de contraer otra ITS. 
De acuerdo con el Centro para la Prevención y el Control de las Enfermedades (CDC), en el año 2006 se produjeron en el mundo, 4.3 millones de nuevos contagios de ITS o VIH, lo que equivale a casi 12.000 nuevas infecciones diarias. La cifra de personas que viven con el SIDA a nivel mundial, alcanza ya 40 millones. Según la OMS, cada día, un millón de personas son contagiadas de alguna ITS; siendo las más comunes: clamidiasis, gonorrea, sífilis y tricomoniasis. Según la misma fuente, más de 290 millones de mujeres están contagiadas de papiloma humano.

El tratamiento para ITS de origen bacterial como clamidiasis, gonorrea, sífilis, granuloma inguinal y las causadas por protozoos, como tricomoniasis, es efectivo con el uso adecuado de antibióticos. En el caso de ITS de origen viral, como herpes, papiloma humano y hepatitis B, son eficaces los antivirales, que no curan la enfermedad, pero la mantienen controlada.

Comparto con mi familia y amistades la información obtenida con relación con las ITS y VIH. Les solicito opiniones y consejos para evitar el contagio. Escribo un listado de las recomendaciones de buenas prácticas comunitarias para la prevención de ITS y VIH, este se incluye en el Programa. Analizo el nivel de conocimiento que los miembros de mi familia tienen del tema y aclaro mitos que en relación con el mismo pueden surgir.
La prevención de las ITS inicia con Educación integral en sexualidad, asesoramiento de personal preparado convenientemente en la prevención, diagnóstico y tratamiento de ITS, para orientar acerca de prácticas sexuales más seguras, uso adecuado de preservativos tanto para hombres, como para mujeres, recomendación de la circuncisión médica voluntaria en varones. Asesoría y acompañamiento a grupos vulnerables, como: trabajadoras y trabajadores del sexo, personas consumidoras de drogas intravenosas.

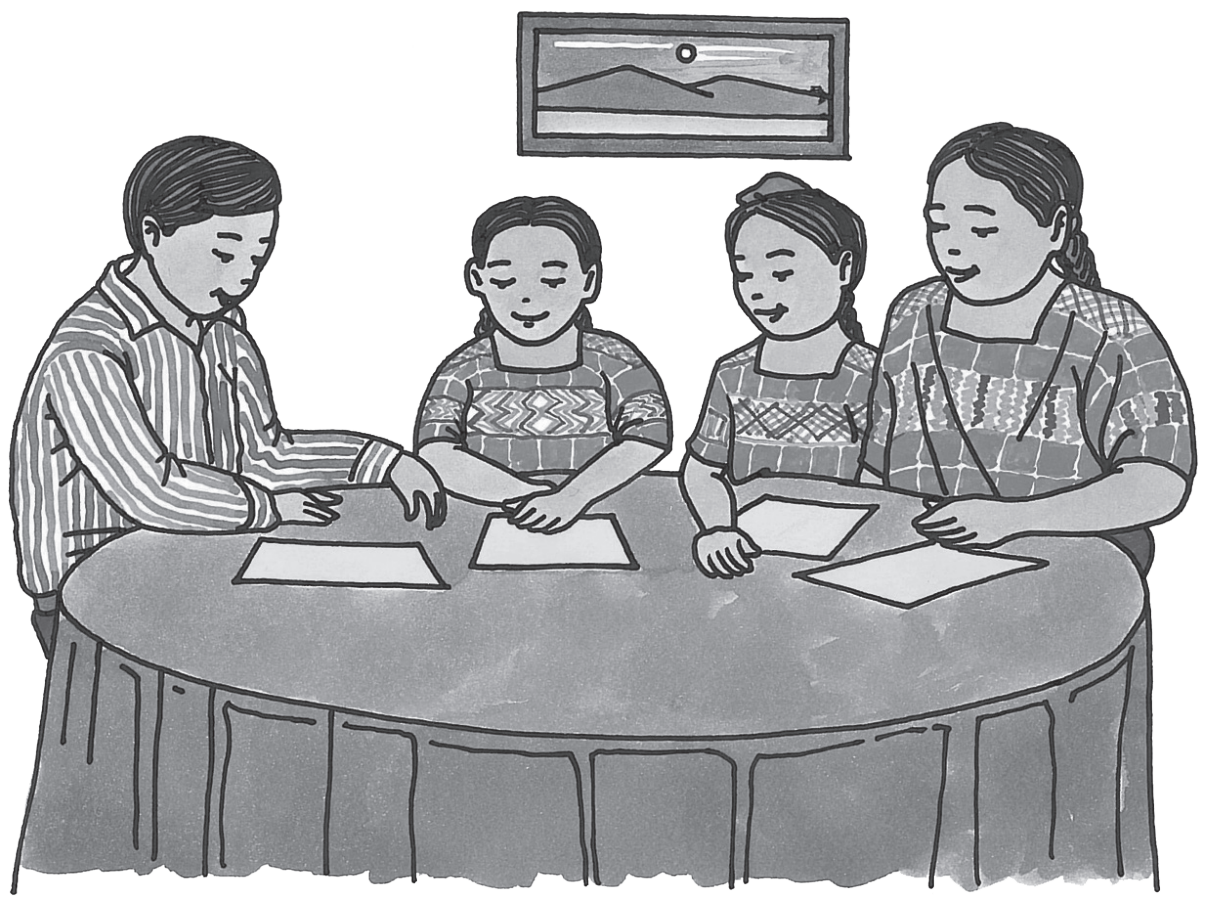




\section{Promovemos el ejercicio con argumentos}

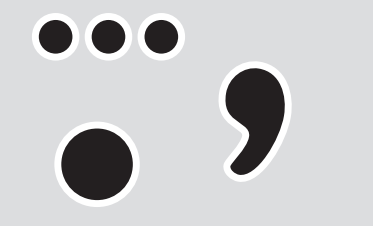

\section{Signos ortográficos}

La coma: sirve para marcar una pausa y una bajada de tono en la redacción. Se usa:

- al enumerar cosas: Llevo en mi morral, cuadernos, lápices, regla y marcadores.

- antes y después de oraciones explicativas: La abuela, que estaba enferma, se curó con la adecuada alimentación.

- para separar el vocativo en una oración: Hola, María, ¿cómo te fue en tu examen de control pre natal?

El punto y seguido: Señala el final de una oración, pero cuya idea continuará en el mismo párrafo.

Marta fue al parque. Al volver trajo flores para agradecer el gesto de solidaridad.

El punto y final: Indica que lo que teníamos que decir ya está dicho.

El proyecto concluye la próxima semana.

Los puntos suspensivos: dejan en suspenso una oración al meditar una respuesta, al expresar duda o en frases incompletas.

«Ya sé... ya sé qué hacer para mejorar mi condición».

\section{El discurso argumentativo}

La argumentación es una variedad del discurso que pretende defender nuestra opinión y que intenta, por medio de razonamientos lógicos, convencer a la persona con la que argumentamos para que cambie de actitud o de comportamiento.

La capacidad persuasiva: Cuando los argumentos que proponemos están relacionados con la tesis que defendemos y tienen fuerza argumentativa (son difícilmente refutables).

La demostrativa: usa argumentos afectivos.

La función: Es lograr nuestra finalidad a través de concesiones, argumentos de apoyo a la idea que defendemos, refutaciones sólidas ante lo que no acordamos y contraargumentos que refuten lo que expone la persona con la que estamos argumentando.

- Luego de la presentación del grupo formaremos argumentos persuasivos sobre la práctica del deporte.

- Apoyamos en la revisión y evaluación de la lista de buenas prácticas escrita por nuestras compañeras y compañeros.

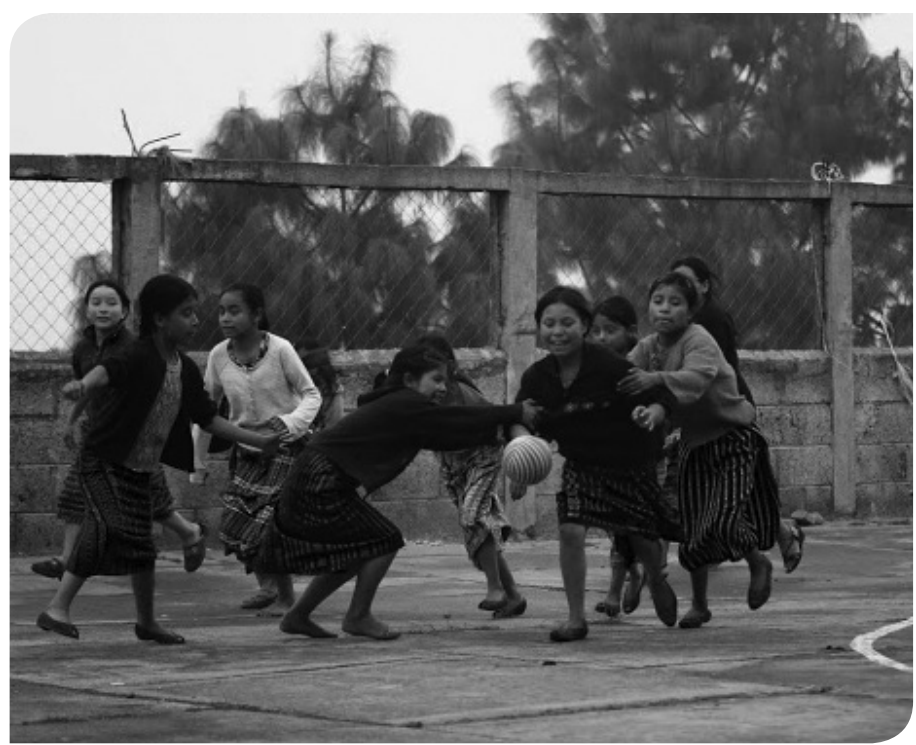

Semana 11

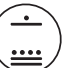




\section{La literatura grecolatina y las consejas guatemaltecas}

La literatura grecolatina o grecorromana es la producción literaria que se llevó a cabo durante la Antigua Grecia y durante la Antigua Roma. Casi todos los géneros literarios que conocemos tuvieron su origen en el mundo griego y se dividen en tres grandes grupos: épico, lírico y dramático.

La poesía épica cantaba las hazañas de sus héroes, un pasado que se transmitía de boca en boca. Los dos poetas más representativos de la poesía épica son Homero (s. VIII a.C) y Hesíodo (s. VII a.C).

La lírica: Se le llamó así porque era la poesía tocada al son de la lira y exaltaba la individualidad de la persona. Le cantaba al amor, las penas, el dolor, la amistad, etc.

El teatro: Surgió ante la decadencia de la poesía lírica, que era casi exclusiva de la aristocracia. El teatro, por el contrario, se representaba ante todo el pueblo por lo que se convirtió en un género popular en el que se escenificaban obras trágicas o cómicas.

La fábula, proviene de las tradiciones culturales orales de esta época. Tiene la característica de que sus personajes son siempre animales y termina con una moraleja (lección o enseñanza que nos deja un cuento o una fábula).

El apólogo - otro género muy utilizado en Grecia - es una narración cuyo propósito es adoctrinar sobre un valor ético. La diferencia con la fábula es que en el apólogo los personajes no son animales sino seres humanos.

En Guatemala, se les llama consejas a los relatos de tradición oral que pasan de generación en generación y que son parte de la identidad de nuestro país. Las consejas son narradas con la sabiduría de las personas ancianas y, por ello, dan forma al pensamiento de quienes las escuchan.

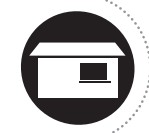

- Redactaremos una fábula relacionada con el tema de los deportes que contenga una moraleja de las consecuencias de no ejercitarse.

- Investigo en mi comunidad e identifico una conseja que pueda compartir con mi clase en la próxima sesión, practicando el idioma de mi comunidad.

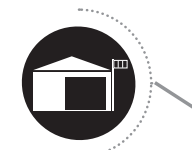

Planificamos cómo queremos realizar la presentación del programa de buenas prácticas para la salud integral. Elaboramos una agenda, asignamos responsables de cada punto y corroboramos que tenemos todos lo materiales necesarios. ¡Ensayemos la presentación!

Verificamos a partir de todo el trabajo realizado en este proyecto que toda la información está contenida en el manual de buenas prácticas. Revisamos ortografía, redacción, diseño y corregimos lo que sea necesario. 


\section{Hobilidades y movimientos de la actuación}

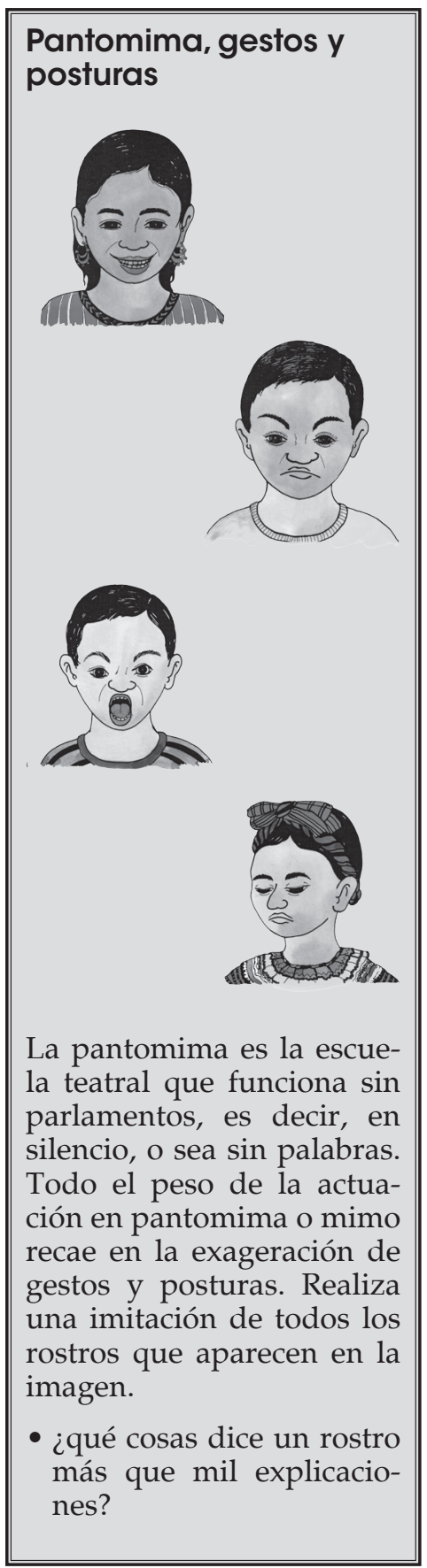

Al actuar y al danzar se realizan varios procesos en el cuerpo y en la mente. El cuerpo debe tener una condición física que es posible si se practica una vida sana. Resistencia y potencia son dos cualidades que quienes danzan y quienes actúan deben desarrollar. Sin embargo, la resistencia y potencia tienen como fin último el desarrollo de la expresión corporal. Los músculos se fortalecen para soportar el peso del cuerpo en los diversos procesos de la expresión artística.

Quienes actúan desarrollan la destreza del desplazamiento por un escenario pequeño o grande. En él deben manejar adecuadamente el espacio en el que intervienen. En este desarrollo entra también el de la voz, como medio que comunica verbalmente lo que dicen los personajes. Un buen volumen y dicción se necesitan para que el auditorio comprenda todo lo que el personaje dice. Y la disposición a mantener la atención sobre su personaje, hace de las actrices y actores, seres muy complejos e interesantes.

\section{Trabajemos en grupo}

- En círculo, hacemos rutina de estiramiento de brazos, pies, cabeza. Luego gesticulamos abriendo y cerrando la boca, torciéndola en todas direcciones.

- De puntillas, imaginamos alcanzar un objeto muy alto, nos estiramos para alcanzarlo, se cae al suelo y lo levantamos, jugamos con él en el aire, lo lanzamos muy lejos.

- En parejas, frente a frente, hacemos gesticulación de lanzarnos un objeto y atraparlo en el aire, lo devolvemos y relanzamos.

- Leemos en voz alta un párrafo de cuatro líneas preparados por la tutora o el tutor relacionado con nuestra propuesta de proyecto.

- Si tenemos acceso a cámaras podemos tomar fotografías de deportistas, personas trabajando, jóvenes y otros que estén desarrollando buenas prácticas para la salud. Estas se pueden incluir en la presentación o en el trifoliar.

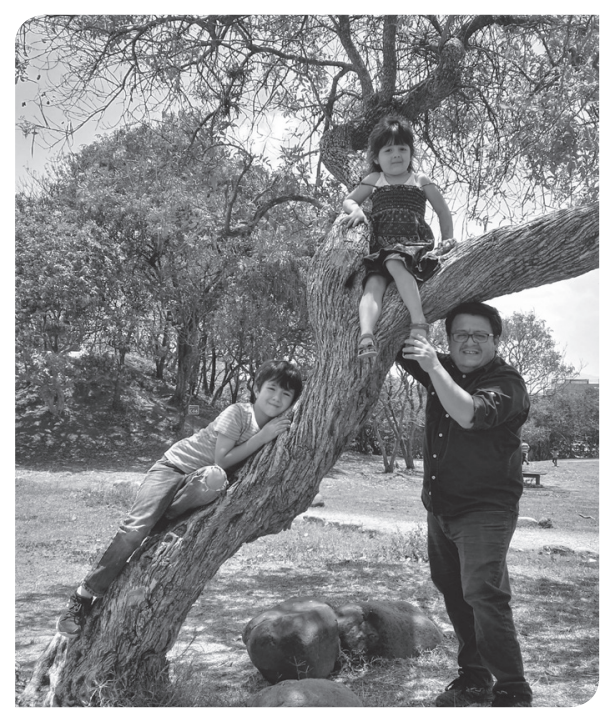




\section{Elementos teatrales en una coreografía}

En una coreografía, además de bailar, se cuenta un relato. El tema de nuestro proyecto es una vida saludable. Podemos agregar elementos teatrales que resalten ese aspecto. Las buenas prácticas para la salud mental y corporal, que hemos visto, pueden ser el centro de la historia.

$\mathrm{Al}$ agregar los aspectos teatrales, pueden presentarse momentos de la coreografía realizados por solistas que actúan con pantomima lo que se necesita resaltar. Se puede agregar alguna utilería sencilla, es decir, objetos de uso común que refuercen el tema.

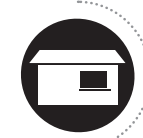

Realizamos el ensayo general de la coreografía que presentaremos. Consideramos la posibilidad de incluir un juego escénico.

\section{Juego escénico: actuamos mientras bailamos}

- En grupos, organizaremos un juego escénico que se presente mientras se baila la coreografía.

- Cada grupo creará una historia sobre aspectos y buenas prácticas que influyen en la salud: alimentación, ejercicio, el cultivo de las artes, la expresión de emociones.

- Cada grupo contará la historia y se escogerá la mejor para agregarla a la coreografía. Es necesario definir tres momentos de la historia: introducción, nudo y desenlace.

\section{Ejemplo:}

Introducción: dos parejas compran alimentos en un mercadito o tienda en la esquina del escenario, y los llevan a su casa, en la otra esquina.

Nudo: la pareja 1 come sanamente y luego sale a correr y jugar. La pareja 2 se atiborra de alimentos y luego se pone a ver televisión y se duerme.

Desenlace: la pareja 1 sigue jugando, corriendo, tiene mucha vitaliad. La pareja 2 está obesa, le cuesta moverse, sigue su rutina de ver televisión y consume sustancias adictivas.

En la dramatización podemos valernos de objetos que apoyen la interpretación teatral que estamos realizando.

- ¿Qué objetos usa este malabarista para realizar su interpretación en el escenario?

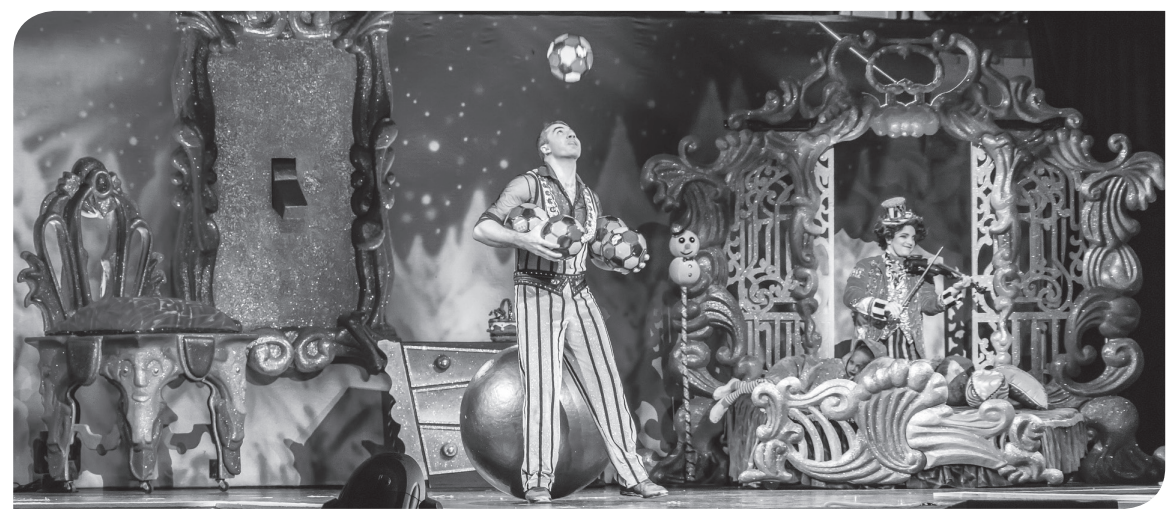

\section{Ensayo y memorizo mi} papel

Es importante que cada cual realice adecuadamente su papel dentro de la coreografía. Si soy solista, con mayor razón debo memorizar cada parte de los movimientos que realizo. Si soy parte de las o los bailarines, también debo medir mis pasos según las secuencias determinadas. Ensayo y memorizo todos mis movimientos.

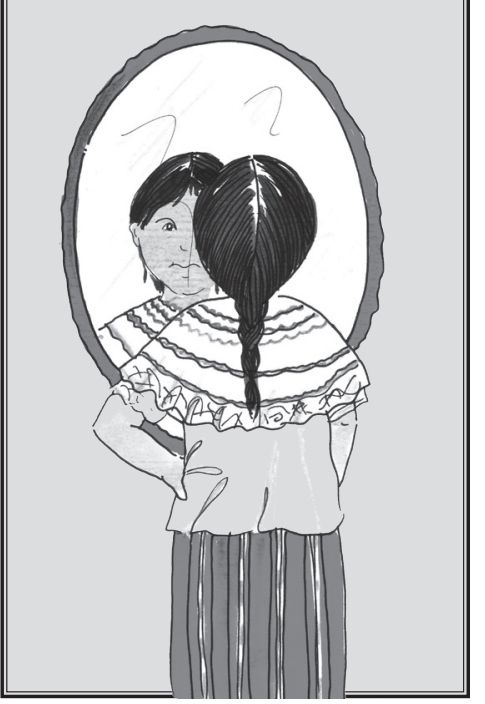




\section{Los hábitos higiénicos}

\section{Uso de mayúsculas}

Se escribirán con letra inicial mayúscula:

1. Nombres de persona, animal o cosa singularizada: Cecilia, Rocinante, Programa Abriendo Oportunidades.

2. Nombres geográficos: América, Quetzaltenango, Petén, Usumacinta. Cuando el artículo forme parte oficialmente del nombre propio, ambas palabras comenzarán por mayúscula: El Salvador, La Antigua Guatemala, El Progreso.

3. Nombres de obras de arte (libros, música, pinturas, etc.): La mansión del pájaro serpiente, Las meninas, El Mesías.

4. Al empezar una oración y al escribirla, después de un punto: Llegamos al lago. Nunca pensamos que sería tan hermoso.
Practicar diariamente hábitos higiénicos es importante para conservar la salud y prevenir enfermedades e infecciones. El agua y el jabón alejan de nuestra piel y cabello gérmenes, bacterias y parásitos, como piojos, garrapatas o lombrices que pueden acceder a órganos internos, como los intestinos.

Nuestra boca y dientes son muy importantes para alimentarnos y mantener nuestra salud. La pérdida de dientes o muelas dificulta la alimentación; si no podemos alimentarnos nuestro cuerpo se debilita y enferma fácilmente. Lavar los dientes, por lo menos dos veces al día, previene enfermedades en las encías (gingivitis) y caries, que si no son tratadas pueden hacer que perdamos nuestros dientes. Los ojos, los oídos y la nariz son órganos muy delicados, debemos tratarlos con cuidado y no introducir objetos que los puedan dañar.

Los hábitos higiénicos nos ayudan a mantener nuestra salud y tener buen aspecto y olor agradable, los cuales son importantes para relacionarnos con otras personas y en el trabajo. Pero también es importante recordar que, si nuestro trabajo implica el manejo de alimentos, debemos hacerlo con las máximas medidas higiénicas. Si nuestro trabajo requiere que manipulemos sustancias peligrosas o tóxicas, la práctica de hábitos higiénicos después del trabajo es imprescindible para no enfermar.

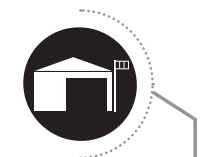

En nuestros grupos terminamos la elaboración del Programa de prácticas de hábitos higiénicos y de seguridad en el ámbito productivo, así como de prácticas que promueven el bienestar físico. Aseguramos de incorporar las prácticas para el bienestar que se han venido mencionando a lo largo de las semanas.

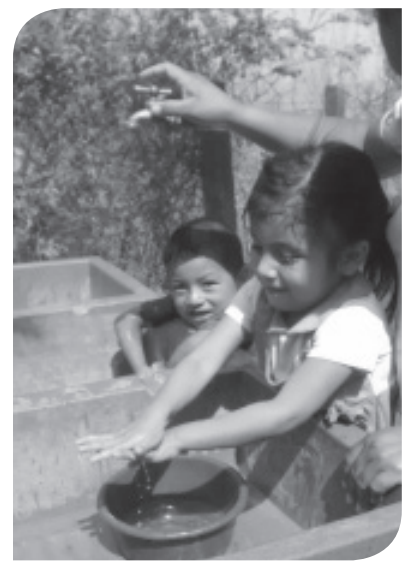

- Elaboremos afiches que promuevan las hábitos higiénicos para compartir con niños y niñas de la comunidad.

- Podemos hacerlos en varios idiomas.

- Podemos usar programas de computación para el diseño. 


\section{Hábitos higiénicos en la manipulación de alimentos}

La práctica de hábitos higiénicos es esencial en la producción y manipulación de alimentos, ya sea a nivel industrial, agrícola o familiar. La contaminación de alimentos no solo puede producir un foco de infección y enfermedad a muchas personas sino además puede producir pérdidas económicas por rechazo de un producto. Mientras se manipulan alimentos NO se debe fumar, comer, secarse el sudor con la mano, masticar chicle, estornudar, escupir o toser sobre los alimentos. NO debemos peinarnos o rascarnos, probar los alimentos con el dedo o con un utensilio que continuamos usando con los alimentos, o tocar dinero.

Nos acercamos a la fecha de la presentación del Proyecto 5. Evaluaremos las actividades de esta semana.

\begin{tabular}{|l|l|l|}
\hline \multicolumn{1}{|c|}{ ASPECTOS A EVALUAR } & Sí & No \\
\hline $\begin{array}{l}\text { Presentamos el tema "Actividades deportivas en la } \\
\text { comunidad" }\end{array}$ & & \\
\hline Redactamos el programa de salud integral. & & \\
\hline $\begin{array}{l}\text { Desarrollamos argumentos persuasivos para la práctica } \\
\text { deportiva en la comunidad }\end{array}$ & & \\
\hline Ensayamos la coreografía que presentaremos & & \\
\hline Validamos el prácticas de bienestar integral en familia & & \\
\hline
\end{tabular}

Redactamos un informe sobre la práctica de hábitos higiénicos en el trabajo. Incorporamos estas recomendaciones al programa de salud integral del Proyecto 5.

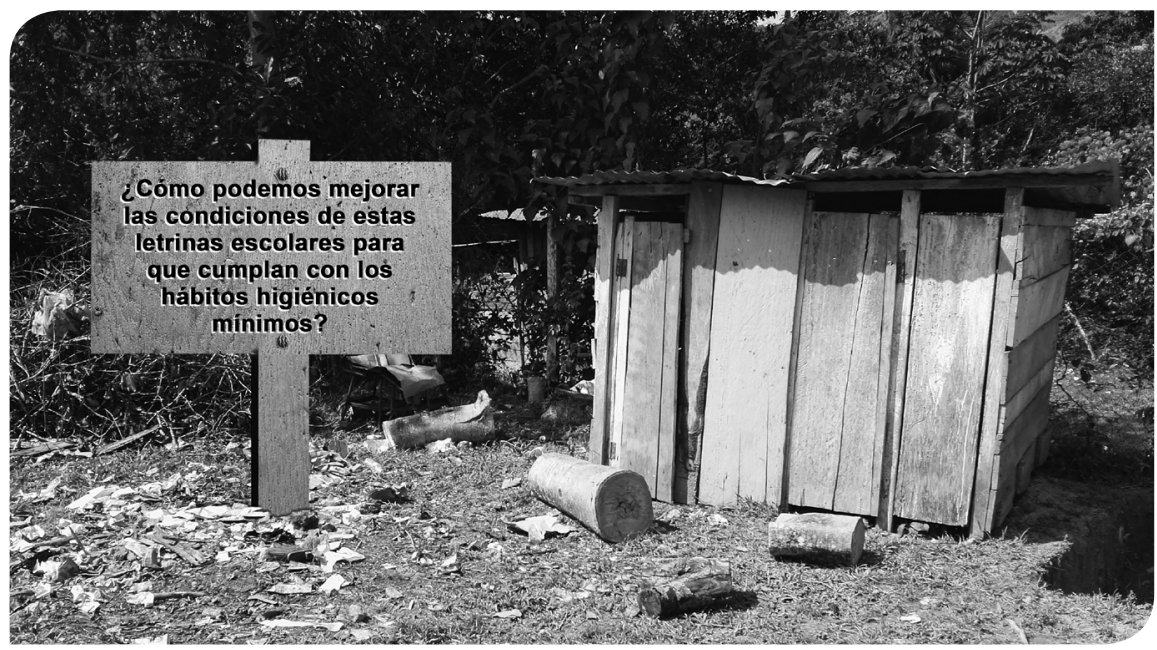

\section{Protección durante el} uso de agroquímicos

Los agroquímicos (herbicidas, pesticidas, fungicidas) son sustancias químicas tóxicas. Es necesario tomar precauciones para su transporte, almacenamiento, uso y disposición de envases vacíos, así como uso de equipo de protección personal para no dañar la salud de las personas, otros seres vivos y el ambiente.

Es importante seguir cuidadosamente las instrucciones de preparación o aplicación. No por aplicar más, los cultivos estarán mejor; al contrario, el uso excesivo de agroquímicos contamina las cosechas y dañan los suelos. Durante la aplicación no se debe comer ni fumar.

El equipo de protección personal es imprescindible para manejarlos. Es necesario usar mascarilla, lentes protectores, guantes, botas y overol y gorra. Este equipo protege de intoxicaciones, quemaduras y otros problemas de salud. Al terminar la aplicación, lavar cuidadosamente el equipo de protección y la ropa, lavar bien manos y cuerpo.

Los envases vacíos nunca deben reusarse porque los residuos son peligrosos para la salud. 


\section{Couusas del confilicto armado interno en Guatemala}

- ¿Por qué un régimen autoritario está más propenso a provocar conflictos internos que aquellos que practican la democracia?

Leamos acerca de cómo inició el conflicto armado interno en Guatemala:

"El levantamiento del 13 de noviembre de 1960, pese a que fracasó, sentó las bases de la rebelión de izquierda que penetró en diversos sectores de la sociedad guatemalteca y se tornó en alzamiento armado debido a la exclusión económica y social y a la ausencia de apertura en el ámbito político. Varios de los oficiales que participaron en ese movimiento se exiliaron en México y a su regreso - unos meses después-, continuaron sus actividades insurgentes..."

Fuente: Romero, S. (2009). El Estatuto de Roma como medio de prevención del delito de genocidio (tesis). Recuperado de: http:/ / biblioteca.usac.edu.gt/tesis/04/04_7869.pdf

- ¿Coincide lo afirmado en la cita y lo que dice el texto con respecto a las causas que originaron el conflicto armado?

Argumento mi respuesta.

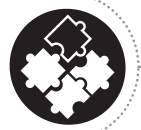

\section{Trabajamos en equipo}

- Comparamos las causas del conflicto armado interno de Guatemala con las limitantes de la comunidad para que todos sus integrantes gocen de buena salud.

El conflicto armado tiene causas internas y externas. Las externas se aglutinan principalmente en los sucesos de la Guerra Fría y el papel que Guatemala tenía en la economía mundial de la época, como exportador de productos agrícolas e importador de bienes industriales y servicios. Estos tienen sus raíces en los intereses particulares del proceso de la Contra Revolución, como los de la United Fruit Company para mantener la estructura agraria del país y con ello mantener todos sus privilegios.

En cuanto a las causas internas, desde la Época Colonial inicia la concentración de los recursos económicos principalmente la concentración de la tierra como medio de producción. Cuando se originó el conflicto, la economía guatemalteca seguía basada en la agricultura y menos del 3\% de la población era dueña de más del $60 \%$ de las tierras cultivables. Esto implicaba una enorme desigualdad en la distribución de los beneficios de la actividad productiva.

Otra causa fue el racismo que se originó durante la colonia y se ha marcado con el transcurrir del tiempo. En el proceso de la Independencia y al imponer la idea de que debíamos ser un solo pueblo, con cultura única, con un sólo idioma, una sola religión y un solo sistema jurídico se creó mucho menosprecio hacia los pueblos que no compartían la cultura ladina. En 1871 la transición del poder del sector de los criollos a los ladinos incluyó el control sobre la tierra, el comercio de los principales productos y el poder municipal. La Revolución de 1944 trató de revertir todo esto, pero la Contra Revolución reforzó las prácticas racistas anteriores y el modelo económico concentrador de la tierra.

También la tradición dictatorial y de autoritarismo como método de gobierno fue una causa del conflicto. Luego de la contra revolución, a partir de 1955 se mantuvo el estilo de gobiernos previos como el de Rafael Carrera, Justo Rufino Barrios, Manuel Estrada Cabrera y Jorge Ubico. Los golpes de estado para garantizar la transición de un presidente militar a otro militar se volvió una práctica recurrente, así como la prohibición de la diversidad de pensamientos políticos.

- Discutimos con el grupo, ¿cuál de las causas del conflicto armado se ha resuelto más?

- Participo en la presentación del Programa de Buenas Prácticas para la salud integral. 


\section{Ideas enfrentadas durante la Guerra Fría}

La Guerra Fría fue una de las principales causas externas del conflicto armado interno en Guatemala. Aquí también hubo confrontación entre las ideas que defendía cada parte en el conflicto. Observemos el siguiente cuadro:

\begin{tabular}{|c|c|c|}
\hline Aspecto & $\begin{array}{l}\text { Bloque occidental liderado } \\
\text { por Estados Unidos de } \\
\text { América: liberalismo }\end{array}$ & $\begin{array}{c}\text { Bloque oriental } \\
\text { liderado por la Unión } \\
\text { Soviética: socialismo- } \\
\text { comunismo }\end{array}$ \\
\hline \multirow{3}{*}{ Económico } & $\begin{array}{l}\text { El sector empresarial define } \\
\text { lo que se produce }\end{array}$ & $\begin{array}{l}\text { El Estado planifica la } \\
\text { producción }\end{array}$ \\
\hline & $\begin{array}{l}\text { Producen al menor costo y } \\
\text { con nivel de calidad acorde a } \\
\text { la demanda y necesidades de } \\
\text { ganancia. }\end{array}$ & $\begin{array}{l}\text { La producción se orga- } \\
\text { niza colectivamente, } \\
\text { con los lineamientos } \\
\text { que da el Estado. }\end{array}$ \\
\hline & $\begin{array}{l}\text { Las ganancias quedan en } \\
\text { poder de los propietarios de } \\
\text { los medios de producción o } \\
\text { empresarios. }\end{array}$ & $\begin{array}{l}\text { Las ganancias (una } \\
\text { vez cubiertos los cotos, } \\
\text { incluidos los salarios) } \\
\text { se distribuyen colecti- } \\
\text { vamente mediante el } \\
\text { Estado. }\end{array}$ \\
\hline \multirow{3}{*}{ Político } & $\begin{array}{l}\text { Sistema de partidos politicos } \\
\text { diversos. }\end{array}$ & Partido único. \\
\hline & $\begin{array}{l}\text { Los ciudadanos tienen liber- } \\
\text { tad de afiliarse a un partido } \\
\text { que es financiado por diver- } \\
\text { sos sectores, incluyendo las } \\
\text { empresas. }\end{array}$ & $\begin{array}{l}\text { Los ciudadanos tienen } \\
\text { la obligación de par- } \\
\text { ticipar en las organi- } \\
\text { zaciones de base: por } \\
\text { cuadra, caserío, centro } \\
\text { de producción, etc. }\end{array}$ \\
\hline & $\begin{array}{l}\text { Cada determinado tiempo, } \\
\text { puede ser } 4,5 \text { o } 6 \text { años, se or- } \\
\text { ganizan elecciones populares. }\end{array}$ & $\begin{array}{l}\text { Cada uno, dos o más } \\
\text { años, las organizacio- } \\
\text { nes de base eligen a } \\
\text { sus representantes, } \\
\text { en congresos locales, } \\
\text { regionales y nacionales } \\
\text { se elige a las autorida- } \\
\text { des. }\end{array}$ \\
\hline Social & $\begin{array}{l}\text { Los servicios están privatiza- } \\
\text { dos. En ocasiones el Estado } \\
\text { ayuda a quien no puede } \\
\text { pagarlos. }\end{array}$ & $\begin{array}{l}\text { Los servicios son } \\
\text { proporcionados por } \\
\text { el Estado y deben ser } \\
\text { iguales para todas las } \\
\text { personas. }\end{array}$ \\
\hline
\end{tabular}

Choque entre
liberalismo y
comunismo
El comunismo plantea que
se debe eliminar la propie-
dad privada de los medios
de producción, con ello
todos los seres humanos
serían iguales, no habría
clases sociales ni Estado.
El liberalismo afirma que
debe darse toda clase de
libertades a los dueños
de los medios de produc-
ción ya que con su inicia-
tiva captan las señales del
mercado, producen lo que
las personas necesitan y
lo venden a un precio que
permite distribuir los be-
neficios de manera justa.
Opino sobre lo que plan-
tean ambas ideologías.

- De la ideología a la realidad hay diferencias:

- Analizamos en grupo, qué diferencias hay entre lo que plantea cada ideología. Identificamos qué aspectos describen de mejor forma lo que hoy sucede en Guatemala. 


\section{Prevención de lo expạnsión del contagio de VIH y SIDA}

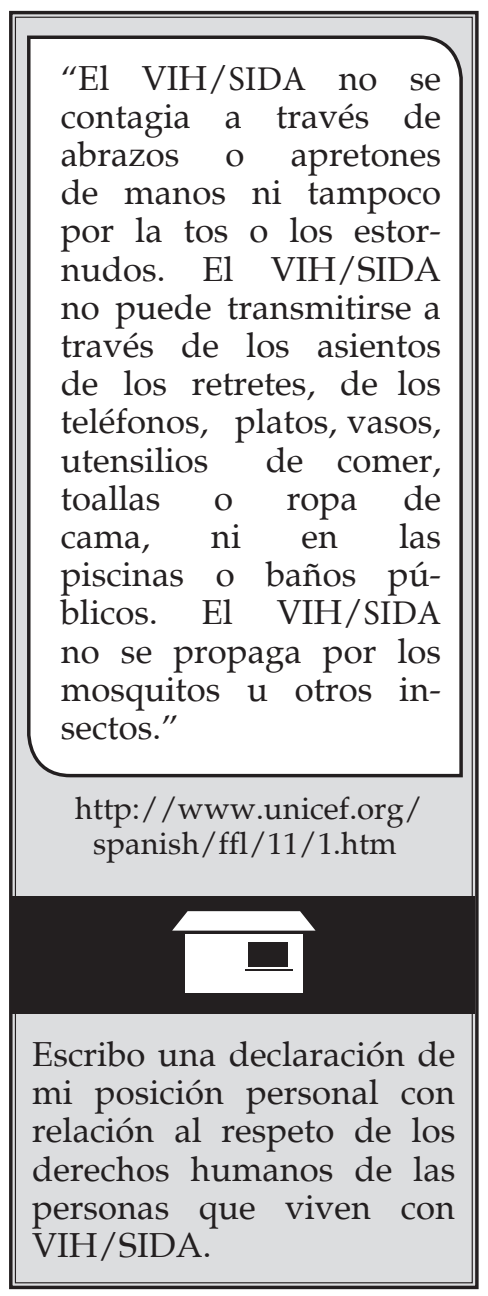

En grupo enumeramos las formas de contagio del VIH

Observamos el mapa que plantea información relacionada con la incidencia del VIH, en el país. Comparamos los datos y definimos los departamentos con mayor tasa de casos. Analizamos la situación del departamento en el que habitamos.

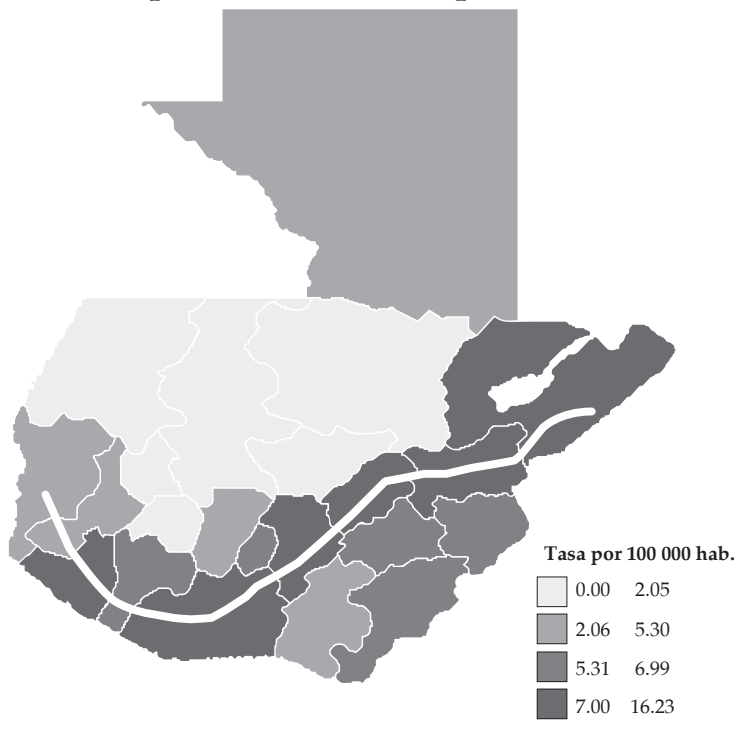

La política pública VIH/SIDA establece como objetivo: "controlar la expansión de la epidemia y reducir el impacto negativo de la misma, tanto para las per-sonas afectadas como para su entorno". Para lograrlo propone acciones como:

Consejería en salud sexual y reproductiva para mujeres que viven con VIH y SIDA.

Seguimiento y acceso a tratamiento antirretroviral a mujeres que viven con VIH y SIDA durante su embarazo y antes y después del parto.

Programas de información sobre peligros de uso de drogas y sobre los riesgos de compartir jeringas.

Sensibilización acerca de la utilidad e importancia de atención sanitaria temprana y de carácter periódico para las personas que viven con $\mathrm{VIH}$ y afectadas.

Implementación de servicios accesibles de atención médica e información a las personas que viven con VIH o que padecen de otras ITS atendidas en los servicios de salud.

Capacitación continua del personal de salud, según niveles de atención clínica y psico-social para la atención de personas que viven con $\mathrm{VIH}$ y SIDA y su familia.

Realización de campañas de prevención, dirigidas especialmente a adolescentes, con énfasis en los más vulnerables.

Acciones de sensibilización a actores sociales relevantes y población general.

1 ¿Qué medidades para evitar el contagio de VIH, podemos poner en práctica a nivel personal y comunitario? 


\section{Prevención a nivel comunitario}

Debido a que la epidemia del VIH es un problema a nivel mundial la prevención es una necesidad también global. A nivel nacional se han emitido leyes que coadyuvan a prevenir la expansión no solo del VIH/SIDA, sino de todas las ITS.

También se han sumado esfuerzos por evitar la exclusión de las personas que viven con VIH. Estos esfuerzos están plasmados en la Política Pública VIH sida, decreto 638-2005 y la Ley general para el combate del virus de inmunodeficiencia humana -VIH- y del síndrome de inmunodeficiencia humana adquirida SIDA- y de la promoción, protección y defensa de los derechos humanos ante del VIH-SIDA.

Marco en la siguiente tabla las medidas preventivas ante el contagio del VIH, que se observan en la comunidad.

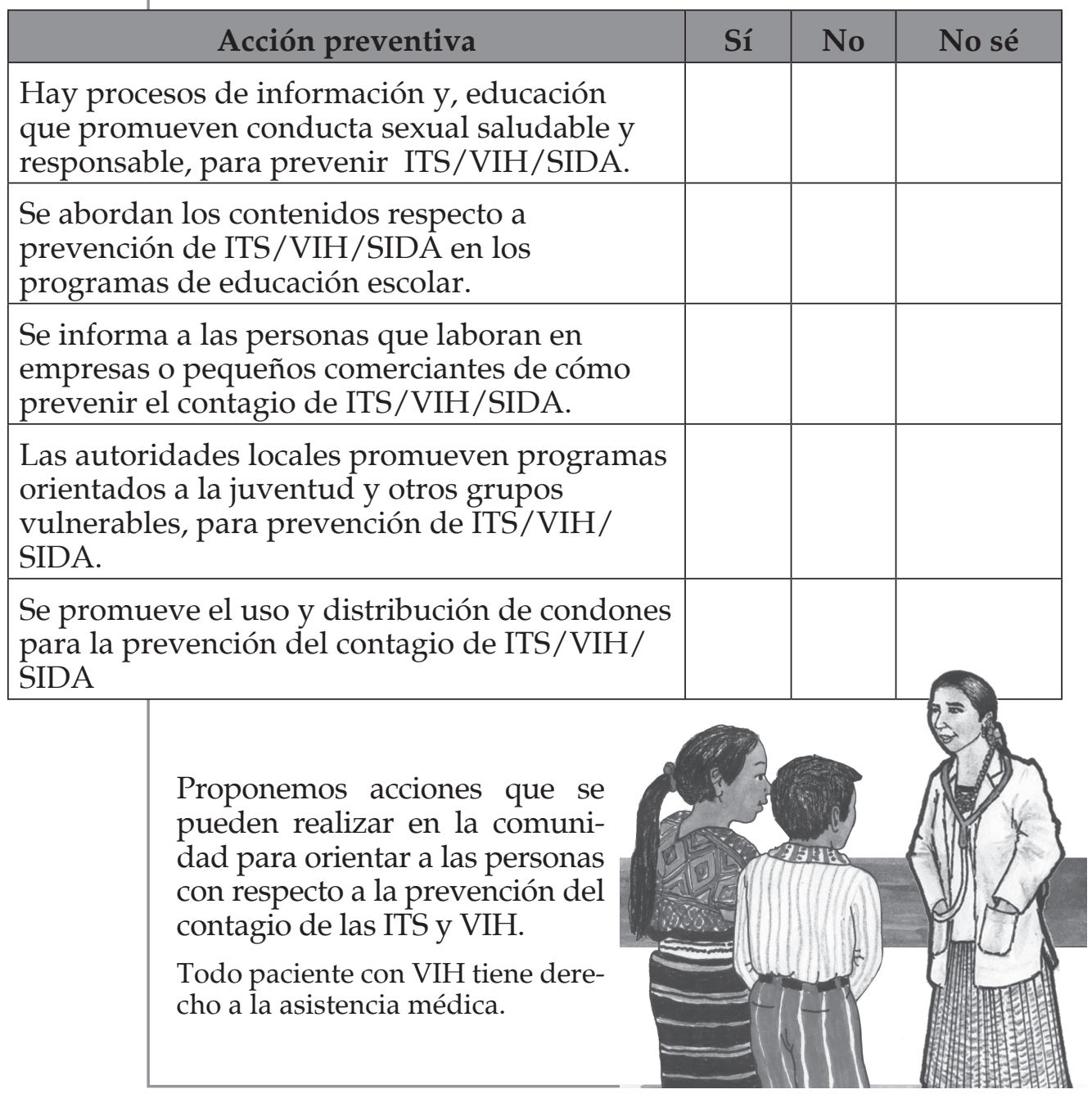

Para la defensa de los Derechos Humanos de las personas y comunidades afectadas por el VIH/ SIDA, el decreto 638-2005, propone, entre otras, las siguientes medidas:

- Promover disposiciones legales y de sensibilización que garanticen los derechos humanos de las personas viviendo con VIH/SIDA y que sancionen la discriminación y la estigmatización.

- Apoyo del Procurador de los Derechos Humanos y organizaciones de derechos humanos en el cumplimiento de sus recomendaciones al respecto.

- Acciones de promoción y defensa de los derechos específicos de las personas viviendo con VIH/SIDA y de las comunidades más vulnerables, especialmente:

- Derecho a la autonomía, a la salud y a la vida, a la información adecuada y oportuna, a no discriminación, a la confidencialidad, la dignidad y la privacidad.

Investigo en un centro de
salud y otras organizacio-
nes de la comunidad, si
promueven los derechos de
las personas que viven con
VIH.




\section{Mêto dos giráfico y de eliminación para la resolución de ecuciciones}

La pendiente es la medida de inclinación de una recta. Se representa con la letra $\mathrm{m}$. El punto 1 tiene las coordenadas $(x 1, y 1)$ y el punto $\operatorname{dos}(x 2$ y $y 2)$

$$
m=\frac{y^{2}-y_{1}}{x_{2}-x_{1}}
$$

Observamos la gráfica siguiente y, en equipos, contestamos las preguntas.

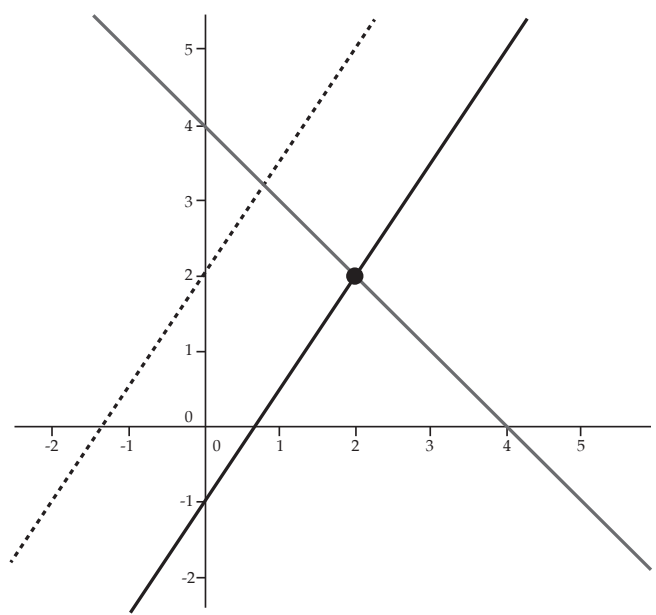

- ¿En dónde se intercepta con el eje Y la recta punteada?

- ¿En qué punto se cruzan las rectas clara y oscura?

- ¿Cuál es el intercepto con Y de la recta clara?

- ¿En qué punto se cruzan las rectas punteada y oscura?

- ¿La recta clara y la punteada tienen la misma inclinación? Comentamos.

Podemos graficar una función o ecuación lineal igualando a y la expresión y hallando los interceptos en $x$ y en $y$ de la misma.

$$
\begin{aligned}
& \text { Por ejemplo, para graficar } x \times \\
& y-1 \text {, despejamos } y \text { : } \\
& y=x+1 \\
& \text { El término independiente es el } \\
& \text { intercepto en } y \text {, en este caso } 1 . \\
& \text { Para hallar el intercepto en } x \\
& \text { hacemos } y=0 \text {, así: } \\
& 0=x+1 \\
& \text { Despejamos } x \text { : } \\
& x=-1 \\
& \text { Entonces tenemos que el in- } \\
& \text { tercepto en } x \text { de esta recta es } \\
& \text { igual a }-1 \text {. }
\end{aligned}
$$

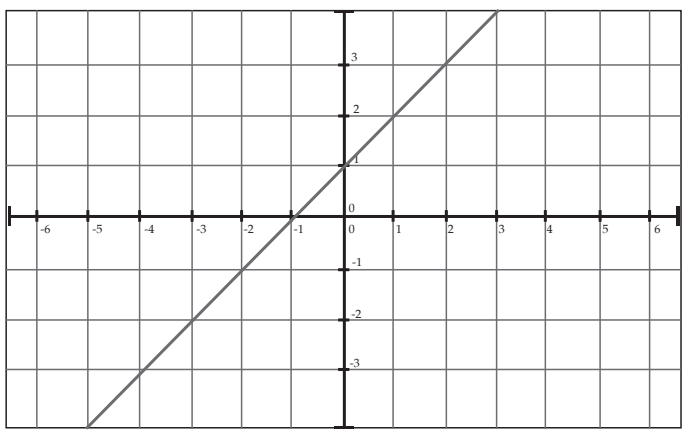

Graficamos las siguientes rectas, en nuestro cuaderno, utilizamos un instrumento apropiado para hacer las líneas.
1) $y=3+x$
2) $2 y=4 x+10$
3) $4 x-2 y=1$ 


\section{Método gráfico}

Para resolver sistemas de ecuaciones simultáneas de dos variables por el método gráfico debemos seguir los siguientes pasos:

$1^{\circ}$ Despejar y en ambas ecuaciones.

$2^{\circ}$ Graficar ambas ecuaciones en un mismo plano.

$3^{\text {o }}$ Ubicar el punto de intersección de ambas rectas; esas son las soluciones del

Ejemplo:

$$
\begin{gathered}
2 x+y=5 \\
x-y=1
\end{gathered}
$$

Despejamos y en ambas ecua-

$$
\begin{gathered}
y=-2 x+5 \\
y=x-1
\end{gathered}
$$

Graficamos ambas ecuaciones en un mismo plano:

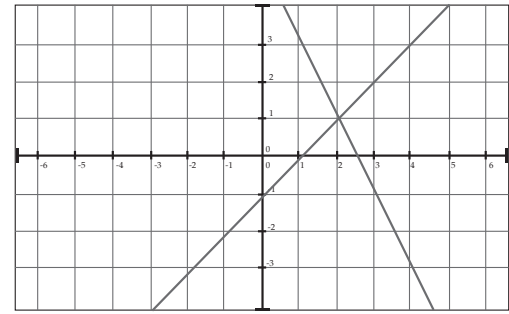

Ubicamos el punto de intersección en $(2,1)$ así que $x=2$ y $y=1$ sistema. ciones:

\section{Método de eliminación}

Para resolver sistemas de ecuaciones simultáneas de dos variables por el método de eliminación debemos seguir los siguientes pasos:

$1^{\circ}$ Ordenar ambas ecuaciones de la forma

$$
a x+b y=c
$$

$2^{\mathrm{o}}$ Multiplicar, si es necesario, alguna o ambas ecuaciones para que al sumarlas una de las dos variables se convierta en 0 .

$3^{\text {o }}$ Hacer la suma algebraica de ambas ecuaciones.

$4^{\circ}$ Despejar la variable que quedó.

5은 Sustituir el valor de la variable despejada en cualquiera de las ecuaciones originales del sistema y así hallar el valor de la segunda variable.

Ejemplo:

$$
\begin{gathered}
2 x+y=5 \\
x-y=1
\end{gathered}
$$

Ya están ordenadas, vemos si es necesario multiplicar. Como no es necesario sumamos para eliminar la variable $\mathrm{y}$.

$$
\begin{array}{cl}
2 x+y=5 & x-y=1 \\
3 x \quad=6
\end{array}
$$

Despejamos: $x=2$

Sustituimos en $x-y=1$

$$
\begin{gathered}
2-y=1 \\
y=1
\end{gathered}
$$

$\mathrm{Al}$ resolver sistemas de ecuaciones utilizando el método gráfico es recomendable hacerlo sobre papel cuadriculado o milimetrado. También es importante utilizar una regla para que nuestros resultados sean más precisos.

Resolvemos, en nuestro cuaderno, los siguientes sistemas de ecuaciones utilizando el método indicado.

\begin{tabular}{|c|c|}
\hline $\begin{array}{c}\text { Método } \\
\text { Gráfico }\end{array}$ & $\begin{array}{c}\text { Método de } \\
\text { eliminación }\end{array}$ \\
\hline 1) $y=3 x+6$ & 1) $x+2 y=4$ \\
$y=2-x$ & $3 x+y=7$ \\
\hline 2) $6 x+y=13$ & 2) $3 x+2 y=3$ \\
$2 x-3 y=16$ & $-x=-2 y+1$ \\
\hline 3) $2 x-3 y=4$ & 3) $x-5 y+3=0$ \\
$3 x+2 y=19$ & $4 x+5 y=13$ \\
\hline
\end{tabular}

Método Método de

Copiamos el siguiente cuadro en hojas cuadriculadas y lo completamos con la información que hace falta. Comentamos con nuestros compañeros y compañeras.

\begin{tabular}{|l|l|l|l|l|}
\hline & Variables & Ecuaciones & Inecuaciones & $\begin{array}{c}\text { Sistemas de } \\
\text { ecuaciones }\end{array}$ \\
\hline ¿Qué aprendimos? & & & & \\
\hline $\begin{array}{l}\text { ¿Qué dificultades } \\
\text { tuvimos? }\end{array}$ & & & & \\
\hline
\end{tabular}




\section{La buena comunicación es un arte}

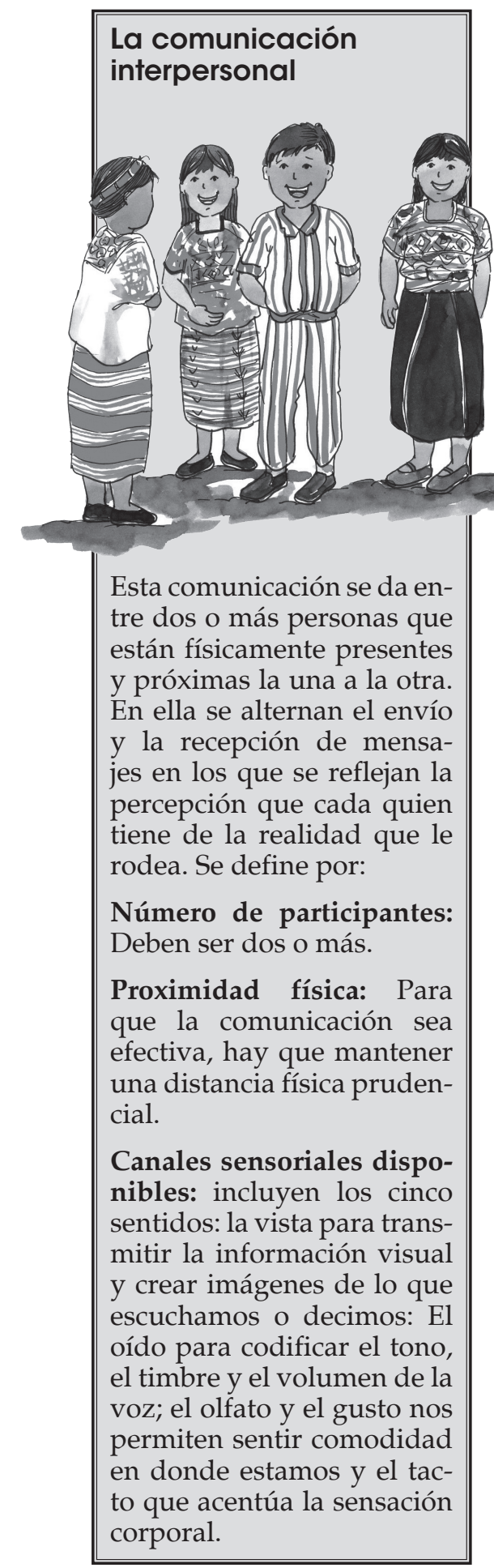

¿Por qué decimos que la comunicación es un arte? A veces nos encontramos con personas que transmiten sus ideas, sentimientos y conocimientos de una manera muy convincente. En algunas de ellas, esto resulta natural, pero todos los demás podemos lograrlo también. Si reflexionamos sobre lo que vamos a decir, pero también cuidamos los demás lenguajes por medio de los cuales nos comunicamos, lograremos perfeccionar este arte.

\section{El lenguaje corporal}

Se llama así a la transmisión de información a través de las posturas que adoptamos con nuestro cuerpo sin necesidad de articular palabras. Por este medio revelamos nuestros sentimientos de forma consciente o inconsciente. La comunicación verbal no puede separarse del lenguaje corporal: están intrínsecamente unidas en la comunicación interpersonal.

El lenguaje no verbal que incluye gestos, ademanes, expresiones faciales, postura y contacto visual y físico, pero, además, cómo nos comportamos, la ropa que usamos, la higiene personal e, incluso, los accesorios que usamos (aretes, collares, corbatas, calcetines, etc.) son parte de nuestro lenguaje corporal y aportan un gran significado al mensaje que enviamos.

$\mathrm{Al}$ interactuar con otras personas, es tan importante observar su lenguaje verbal y corporal como el nuestro para optimizar el proceso comunicativo.

En equipos, elaboremos una lista de cotejo sobre aspectos que pueden mejorar la comunicación oral, previo a la presentación, tales como: elevar la voz para que se nos escuche, hablar despacio y con claridad, pronunciar bien las palabras, eliminar sonidos o ruidos altos y evitar los vicios de dicción. Luego, presentémosla junto con estrategias para minimizar estos problemas.

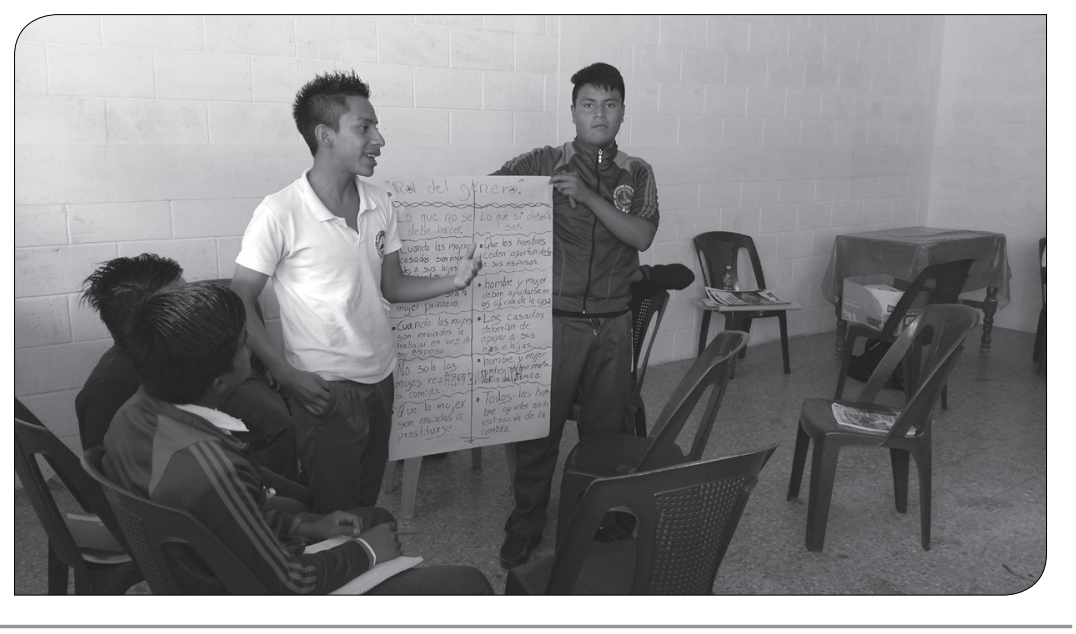




\section{Concordancia entre sustantivo y adjetivo y entre sujeto y verbo}

Uno de los problemas de la comunicación es la falta de corrección al hablar y al escribir. Por ejemplo, muchas personas se equivocan a la hora de establecer la concordancia entre las partes de la oración. Veamos:

\begin{tabular}{|l|l|l|}
\hline \multicolumn{3}{|c|}{ Concordancia entre sujeto y verbo y entre sustantivo y adjetivo } \\
\hline \multicolumn{1}{|c|}{ Núcleo del Sujeto } & Núcleo del Predicado & \\
\hline $\begin{array}{l}\text { La futuro exitosa de los } \\
\text { niños y las niñas }\end{array}$ & están en la educación. & (Incorrecto) \\
\hline $\begin{array}{l}\text { El futuro exitoso de los } \\
\text { niños y las niñas }\end{array}$ & está en la educación. & (Correcto) \\
\hline $\begin{array}{l}\text { Aquí, el núcleo del sujeto es el sustantivo futuro y el núcleo del predicado } \\
\text { es el verbo estar. Ambos deben estar de acuerdo en género y número. Por } \\
\text { su parte, los adjetivos son los artículos el y la y los calificativos exitosa y } \\
\text { exitoso. rección }\end{array}$ \\
\hline $\begin{array}{l}\text { El embarazo seguros en } \\
\text { las mujeres }\end{array}$ & $\begin{array}{l}\text { deben ser monitorea- } \\
\text { das por un especialista } \\
\text { de la salud. }\end{array}$ \\
\hline $\begin{array}{l}\text { El embarazo seguro en en } \\
\text { las mujeres }\end{array}$ & $\begin{array}{l}\text { debe ser monitoreado } \\
\text { por un especialista de la } \\
\text { salud. }\end{array}$ \\
\hline $\begin{array}{l}\text { En estos ejemplos, el núcleo del sujeto es el sustantivo embarazo y el núcleo } \\
\text { del predicado es la forma verbal compuesta deber ser. Ambos deben con- } \\
\text { cordar en género y número. Por su parte, los adjetivos son los artículos el y } \\
\text { los y los calificativos seguros y seguro. }\end{array}$ \\
\hline
\end{tabular}

El análisis anterior nos ilustra la importancia de que los diferentes elementos de la oración concuerden entre sí.

- Reunámonos en parejas para conocer las fábulas escritas por nuestras compañeras y compañeros. Apoyemos su aprendizaje mediante la evaluación. Pongamos especial atención en la concordancia gramatical.

- Luego, realicemos una puesta en común de las buenas prácticas promocionadas en cada fábula y elaboremos pequeños carteles o afiches con ellas y coloquémoslos en lugares visibles en el aula. 


\section{El piograma de buenas prácticas para una vida saludable}

\section{Hacemos nuestra presentación final}

Hacemos ejercicio de calentamiento con relajación y estiramiento.

Revisamos las rutinas y series de pasos de la coreografía.

Las y los bailarines que actúan ensayan su relato actuado por separado.

Ensayamos la obra completa. Utilizamos la utilería adecuada para la historia.

Repasamos varias veces, hasta que todo fluya con naturalidad, sin contratiempos ni confusiones. Cada quien hace lo que le corresponde dentro de la obra.

Agregamos un espacio en la escena donde actrices y actores solistas realizan juegos de la tradición popular, con juguetes o juegos de manos, entre otros.
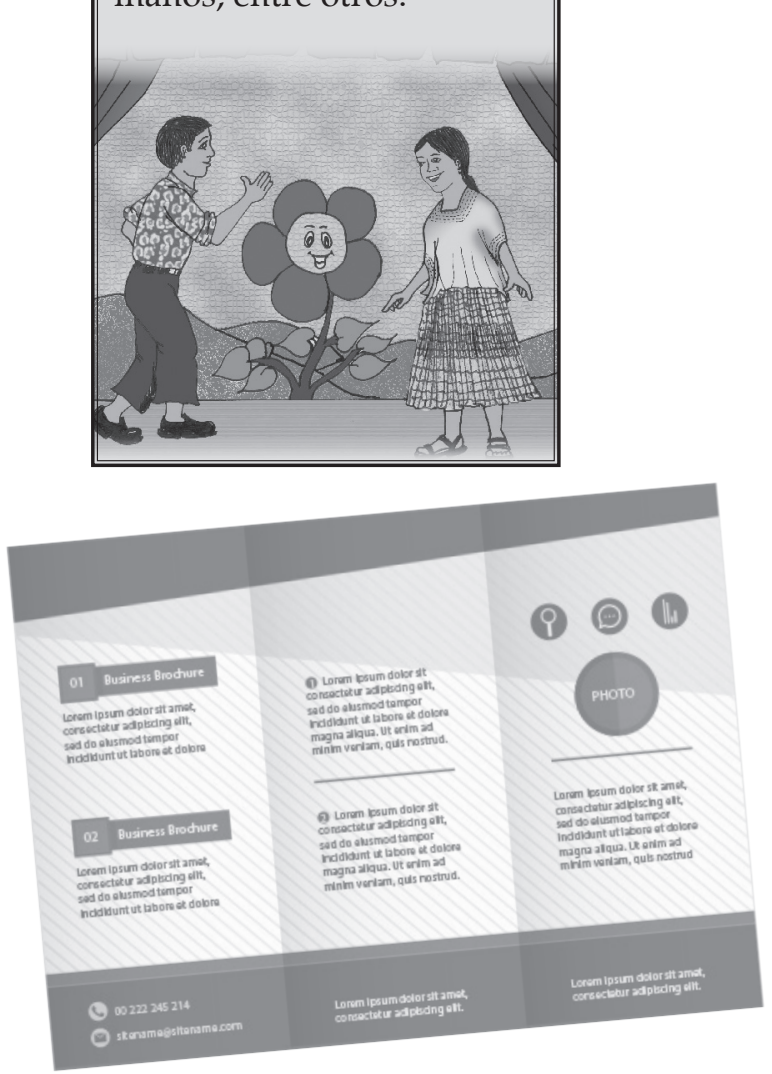

Hemos realizado actividades encaminadas al desarrollo de buenas prácticas para mantener una vida saludable. Hemos cultivado esas buenas costumbres para el cuerpo y para la mente, mediante el movimiento y la expresión corporal. Quien baila es más feliz porque allí canaliza mucha de la energía y libera endorfinas. Además, quien canta, actúa, pinta o dibuja, desarrolla su imaginación y disfruta la vida haciendo arte.

Ahora nos toca terminar y presentar el proyecto. Utilizando lo investigado y actuado diseñamos el trifoliar. Este es muy sencillo y contiene textos e ilustraciones mínimas. Luego ensayaremos nuestra presentación de danza y teatro sobre la salud integral.

\section{El diseño del trifoliar}

Trifoliar significa "tres folios", y cada folio es un lado para observar. Pero al darle vuelta se tienen otros tres lados, haciendo un total de caras donde colocar información textual o visual. Puede funcionar en una hoja de papel o en una cartulina grande. Si haremos solo uno, conviene hacerlo en grande, si lo reproducimos varias veces, conviene hacerlo con hojas tamaño oficio o carta.

- ¿Qué hacer en cada lado? Cada lado es un espacio para texto e imágenes.

\section{Cara 1, anterior}

\begin{tabular}{|l|l|l|}
\hline $\begin{array}{c}\text { Presentación y } \\
\text { Glosario }\end{array}$ & $\begin{array}{c}\text { Historias de Salud } \\
\text { Integral y en- } \\
\text { fermedad 1 }\end{array}$ & $\begin{array}{c}\text { Historias de Salud } \\
\text { Integral y en- } \\
\text { fermedad 2 }\end{array}$ \\
\hline$\ldots$ & $\ldots$ & $\ldots$ \\
$\ldots$ & $\ldots$ & $\ldots$ \\
$\ldots$ & $\ldots$ & $\ldots$ \\
\hline
\end{tabular}

\section{Cara 2, posterior}

\begin{tabular}{|l|l|l|}
\hline $\begin{array}{c}\text { Decálogo de la } \\
\text { Salud Integral }\end{array}$ & $\begin{array}{c}\text { Recomendaciones } \\
\text { saludables }\end{array}$ & Anuncios y otros \\
\hline$\ldots$ & $\ldots$ & $\ldots$ \\
$\ldots$ & $\ldots$ & $\ldots$ \\
$\ldots$ & $\ldots$ & $\ldots$ \\
\hline
\end{tabular}




\section{Utilería y otros accesorios}

La utilería no tiene porqué ser algo difícil de encontrar. Una mesa con trastos es suficiente para mostrar un comedor. Un par de sillas ya hacen una sala para sentarse. Sin embargo, como es una obra que combina danza con teatro, se debe cuidar que la utilería no obstruya el paso de los y las danzantes. Entonces conviene que la utilería no sea muy aparatosa o grande. Para nuestra obra pueden ser:

Mesas, sillas, platos, vasos, alfombras, petates, frutas y alimentos de plástico o naturales si los hay, muñecos, juguetes de ejercicio

una caja grande decorada como televisión vestuario adecuado para cada papel, actriz, actor o danzante.

Por esto es importante que cada movimiento sea claro y definido, utilizando los espacios de las esquinas donde no pasarán las o los bailarines, pues ambas cosas, la danza y la actuación, ocurren simultáneamente, o sea, al mismo tiempo.

\begin{tabular}{|l|l|l|l|l|l|l|}
\hline \multicolumn{1}{|c|}{ Actividad } & 1 & 2 & 3 & 4 & 5 & 6 \\
\hline Colaboré con el diseño de la coreografía y el trifoliar & & & & & & \\
\hline Realicé y participé en las actividades de música & & & & & & \\
\hline Realicé y participé en las actividades de danza & & & & & \\
\hline Realicé y participé en las actividades de teatro & & & & & \\
\hline $\begin{array}{l}\text { Participé en la elaboración del programa de buenas } \\
\text { costumbres para la salud integral }\end{array}$ & & & & & & \\
\hline Participé en la presentación artística final del proyecto & & & & & \\
\hline
\end{tabular}

Evaluemos nuestro desempeño desde la Expresión Artística

Marcamos el grado en que sí cumplimos con cada aspecto requerido durante el proyecto:

Rangos: 1-nunca; 2-pocas veces; 3-algunas veces; 4-bastante; 5- siempre.

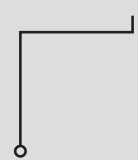

\section{Presentamos el programa a la comunidad}

Nos vestimos de gala para presentarlo a la comunidad, usando los recursos que tenemos a la mano sin incurrir en gastos. Hemos preparado un vestuario especial para las y los bailarines, así como para actrices y actores.

- Mostramos el trifoliar

- Leemos los resultados de la investigación que hemos anotado y las historias

- Explicamos la necesidad de una vida saludable con actividad física y mente sana mediante la expresión corporal y artística

- Presentamos la coreografía y relato danzado

- Agradecemos a las y los asistentes

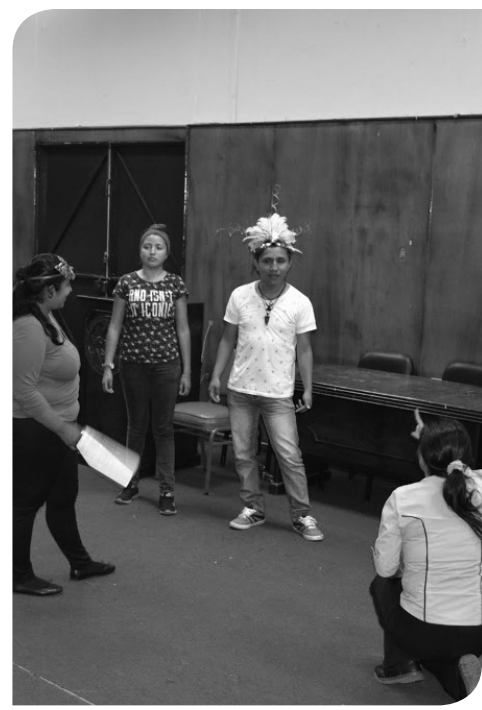




\section{Hóbitos hig fo hicos en la vivienda y el lugar de trabajo}

Protección de la espalda en el trabajo

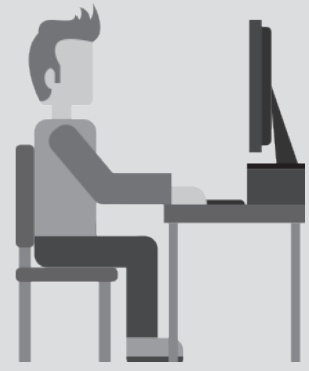

La espalda, donde está localizada la columna vertebral, puede sufrir lesiones debido al trabajo que realizamos, especialmente, si realizamos una misma tarea durante largos períodos de tiempo, por ejemplo, moler maíz, tejer en telar de cintura o cargar quintales de productos agrícolas.

Estar sentado o de pie por mucho tiempo en mala postura produce dolores musculares y tensión en las articulaciones. Los trabajos pesados mal realizados pueden provocar lesiones en la columna. Para evitar lesiones debemos mantener una buena postura y no permanecer en la misma posición por largas horas, lo mejor es tomar pequeños descansos cada cierto período para que el cuerpo no se entumezca y favorecer así la circulación de la sangre y el movimiento de músculos y articulaciones.
Tanto en la vivienda como en el lugar de trabajo tenemos que practicar ciertos hábitos higiénicos para mantener un ambiente saludable. ¿Cómo nos sentiríamos en un lugar de trabajo sucio y polvoriento cuando nos hemos bañado, limpiado y peinado? Seguramente, con el tiempo nos desmotivaría tanto que dejaríamos de cuidar nuestra apariencia y hábitos higiénicos personales. Entrar a un lugar limpio y tranquilo nos transmite sensación de paz. La higiene no solo promueve la salud física sino también mental y si nos sentimos bien, trabajamos mejor y producimos más.

En la cocina y el baño, la limpieza es primordial. No dejemos platos sucios que atraen moscas y otros insectos y parásitos. Tapemos todos los recipientes con comida para evitar que se paren las moscas y nos transmitan enfermedades. Lavemos todos los utensilios, ollas y sartenes que utilicemos, así como la estufa. Revisemos periódicamente nuestra despensa para evitar consumir alimentos ya vencidos o con gorgojos o palomillas.

El baño necesita limpieza diaria, ya sea lavable o letrina. Eso evitará malos olores y la producción de gérmenes, bacterias y hongos. Usemos jabón y desinfectante, o cal en el caso de letrina. Limpiemos todo alrededor y tratemos de que el área de la ducha no quede muy húmeda para que no salga moho. La letrina debe tener una tapadera y que después de cada uso, echemos cal. Tener una letrina es un hábito higiénico porque las defecaciones al aire libre atraen moscas y otros animales. Las heces, incluso, en ocasiones sirven de alimento a ciertos animales, como marranos, cuya carne después nos sirve de alimento.
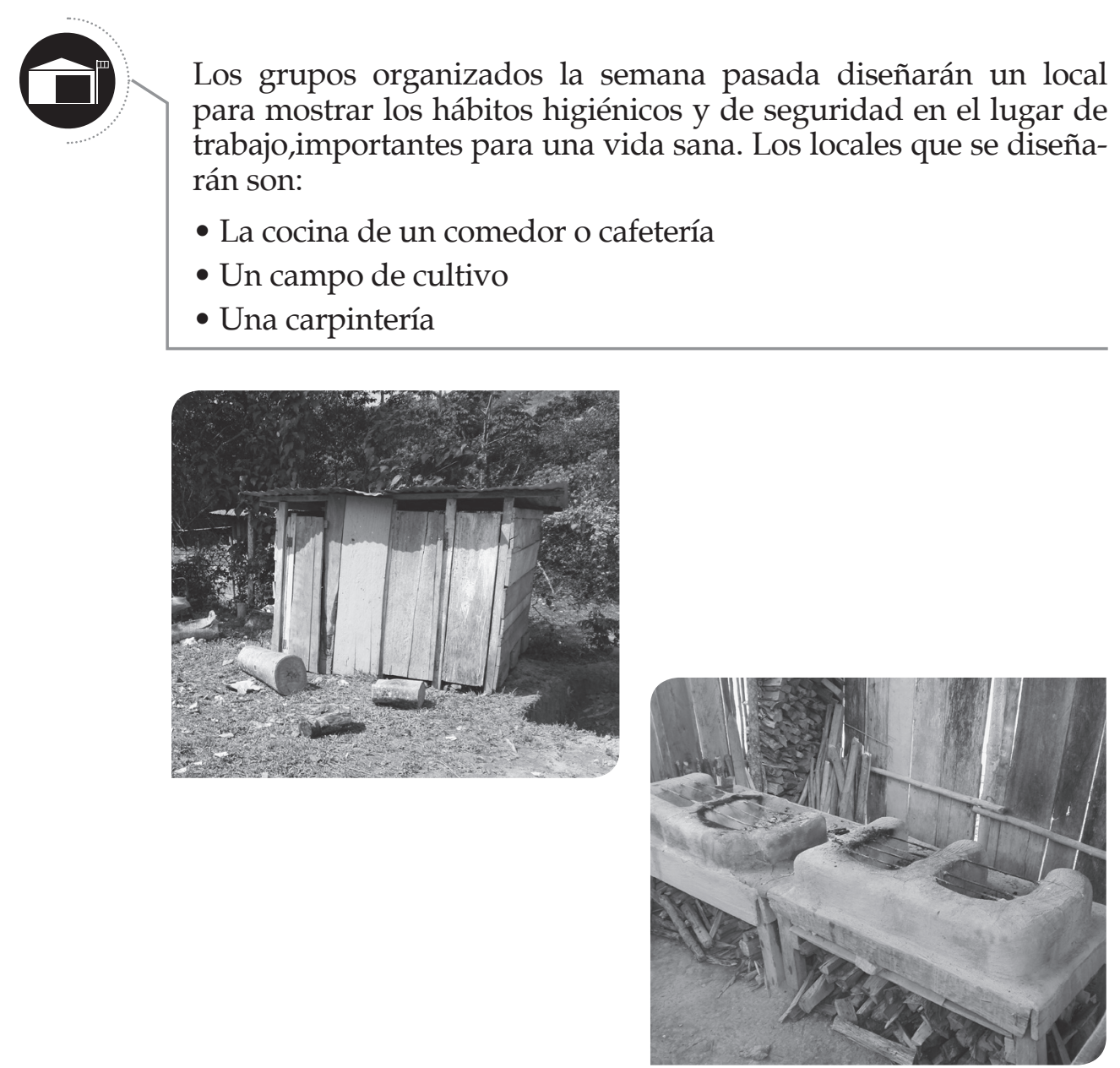
Barrer y trapear evita la acumulación de polvo; evitemos dejar residuos de comida en el piso para no atraer a roedores o cucarachas. Si el piso es de tierra, es mejor humedecerlo para evitar que levante polvo.

También hay que quitar el polvo y cualquier insecto que se esconda en los muebles, las paredes, el techo y las ventanas. Es conveniente abrir ventanas para dejar pasar el sol y el aire.

Alrededor y afuera de la vivienda y el lugar de trabajo también se limpia. Se recoge la basura para evitar atraer animales, especialmente si hay desperdicios de comida. Si tenemos pila o recipientes con agua, los mantenemos tapados para evitar la proliferación de zancudos y la contaminación del agua pues algún animal puede llegar a beber de ella o le puede caer alguna basura.

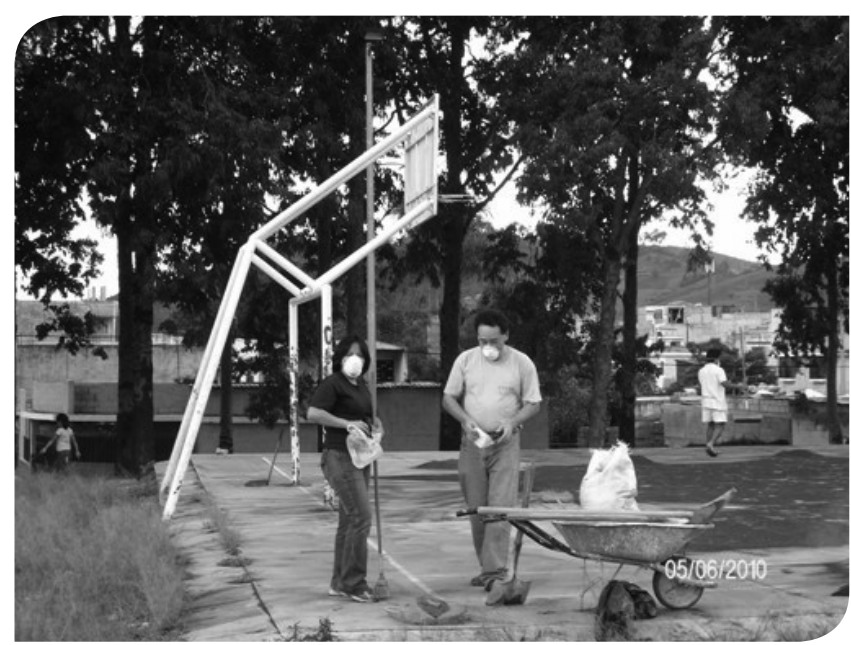

Esta semana terminamos el Proyecto 5 y presentamos a la comunidad nuestro programa de salud integral. Antes, realizamos ciertas actividades preparatorias que vamos a evaluar.

\begin{tabular}{|l|l|l|}
\hline \multicolumn{1}{|c|}{ ASPECTOS A EVALUAR } & Sí & No \\
\hline $\begin{array}{l}\text { Nuestra propuesta toma en cuenta nuestras costumbres y } \\
\text { cultura }\end{array}$ & & \\
\hline $\begin{array}{l}\text { Presentamos actividades que contribuyen al } \\
\text { mantenimiento de la salud integral utilizando variables } \\
\text { independientes y dependientes }\end{array}$ & & \\
\hline $\begin{array}{l}\text { Elaboramos una lista de cotejo para verificar aspectos de } \\
\text { la comunicación oral }\end{array}$ & & \\
\hline $\begin{array}{l}\text { Utilizamos códigos gestuales e iconográficos en } \\
\text { presentaciones orales }\end{array}$ & & \\
\hline $\begin{array}{l}\text { Elaboramos textos, gráficos y otros recursos para } \\
\text { discusión de temas }\end{array}$ & & \\
\hline $\begin{array}{l}\text { Ejecutamos una danza durante la presentación del } \\
\text { programa de salud integral }\end{array}$ & & \\
\hline Diseñamos un local para representar hábitos higiénicos & & \\
\hline $\begin{array}{l}\text { Presentamos nuestro programa de salud integral a la } \\
\text { comunidad acompañado de un trifoliar }\end{array}$ & & \\
\hline
\end{tabular}

Trabajo de menores de edad

En Guatemala, niños y niñas acompañan a las personas mayores en sus labores como una forma de aprender un oficio. En algunas ocasiones, también acompañan al resto de la familia a realizar trabajos remunerados, como el corte de café, para apoyar la economía familiar.

Según el Código de Trabajo, 14 años es la edad mínima para emplearse; pero si es un trabajo peligroso, la edad mínima es 18 años. Legalmente, niños y niñas menores de 14 años pueden trabajar solo si su empleador obtiene autorización escrita de la Inspección General de Trabajo del Ministerio de Trabajo. En este caso, las niñas y los niños que trabajan tiene los mismos derechos y obligaciones que las personas mayores: salario mínimo y prestaciones (bono 14, aguinaldo y vacaciones); el trabajo debe ser acorde a su edad y no debe afectar negativamente su educación y desarrollo mental, físico o emocional. 


\section{PROYECTO No. 5. Mente y cuerpo sanos}

A continuación se presentan varias categorías y su descripción para analizar detenidamente si se observan en el programa. Marque $\boldsymbol{X}$ en la casilla que corresponde.

\begin{tabular}{|c|c|c|c|c|c|c|c|}
\hline & \multicolumn{2}{|c|}{ 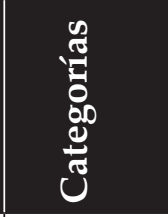 } & Descripción & 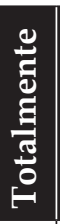 & 苞 & 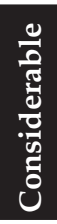 & 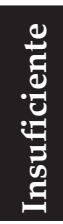 \\
\hline 1 & \multicolumn{2}{|c|}{$\begin{array}{l}\text { Descrip- } \\
\text { ción }\end{array}$} & $\begin{array}{l}\text { La descripción responde a las siguientes interrogantes: Qué necesidades, dónde, } \\
\text { quiénes y en quiénes se observan, a quienes va dirigido, quiénes apoyarán, en dón- } \\
\text { de se desarrollará, quiénes serán responsables de su desarrollo. }\end{array}$ & & & & \\
\hline 2 & \multirow{3}{*}{\multicolumn{2}{|c|}{$\frac{\sum^{2}}{2}$}} & $\begin{array}{l}\text { El objetivo general está enfocado a la solución del problema, debe ser realista, medible y } \\
\text { orientado a mejorar la salud. }\end{array}$ & & & & \\
\hline 3 & & & Se incluyen tres o más objetivos específicos. & & & & \\
\hline 4 & & & Están orientados a contribuir al logro del objetivo general. & & & & \\
\hline 5 & \multirow{5}{*}{\multicolumn{2}{|c|}{ 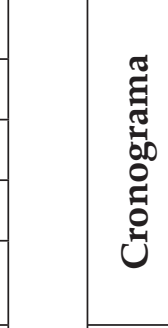 }} & Presenta las actividades en orden cronológico (meses, semanas, días). & & & & \\
\hline 6 & & & Utiliza un cuadro de doble entrada para visualizar actividad en secuencia y tiempo. & & & & \\
\hline 7 & & & Establece responsables por cada actividad. & & & & \\
\hline 8 & & & Promueven el deporte como recurso para mejorar la salud. & & & & \\
\hline 9 & & & $\begin{array}{l}\text { Incluyen estrategias de aprendizaje tales como: entrevistas, cuadros comparativos, videos, } \\
\text { preguntas y dinamicas reflexivas entre otros. }\end{array}$ & & & & \\
\hline 10 & \multirow{7}{*}{$\stackrel{\circ}{=}$} & \multirow{7}{*}{ 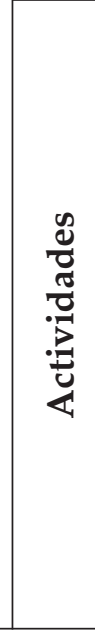 } & Fomentan el diálogo entre quienes participan. & & & & \\
\hline 11 & & & $\begin{array}{l}\text { Facilitan a quienes participan el análisis de los problemas sociales y el efecto que causan en a } \\
\text { comunidad. }\end{array}$ & & & & \\
\hline 12 & & & $\begin{array}{l}\text { Animan a quienes participan a analizar y reflexionar que la salud es un derecho y una re- } \\
\text { sponsabilidad del ciudadano guatemalteco. }\end{array}$ & & & & \\
\hline 13 & & & $\begin{array}{l}\text { Orientan a quienes participan a pensar qué hábitos deben cambiar, por qué y los beneficios } \\
\text { adquiridos. }\end{array}$ & & & & \\
\hline 14 & & & Identifican hábitos que previenen enfermedades. & & & & \\
\hline 15 & & & $\begin{array}{l}\text { Impulsan a quienes participan a tomar decisiones de cambio que favorecen la salud indi- } \\
\text { vidual, familiar y comunitaria }\end{array}$ & & & & \\
\hline 16 & & & $\begin{array}{l}\text { Incluyen entre las buenas prácticas: el deporte, ejercicio frecuente, dormir las horas indica- } \\
\text { das, ingerir alimentos balanceados, recreación, chequeos médicos periódicos, beber agua, } \\
\text { higiene bucal, baño diario, participar en actividades que promueven la salud física, mental, } \\
\text { emocional y espiritual. }\end{array}$ & & & & \\
\hline 17 & \multirow{4}{*}{\multicolumn{2}{|c|}{ 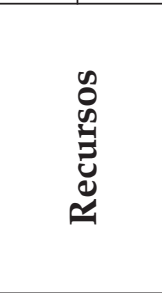 }} & $\begin{array}{l}\text { Enlista todos los materiales y establece el costo y la cantidad exacta a utilizar en cada activi- } \\
\text { dad }\end{array}$ & & & & \\
\hline 18 & & & $\begin{array}{l}\text { Especifica el recurso humano para cada actividad: estudiantes, docentes y personas invitadas } \\
\text { (especificar si cobrarán honorarios). }\end{array}$ & & & & \\
\hline 19 & & & Incluye la utilización de recurso tecnológico (especificar costos por alquiler) & & & & \\
\hline 20 & & & Estima el monto total del programa. & & & & \\
\hline 21 & \multirow{2}{*}{\multicolumn{2}{|c|}{ 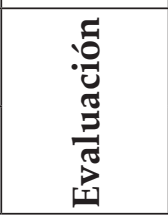 }} & $\begin{array}{l}\text { Establece una evaluación a la mitad del programa para verificar el avance y determinar si } \\
\text { necesita cambios. }\end{array}$ & & & & \\
\hline 22 & & & $\begin{array}{l}\text { Establece la evaluación final del programa, para verificar los resultados obtenidos y determi- } \\
\text { nar si se alcanzó los resultados esperados. }\end{array}$ & & & & \\
\hline
\end{tabular}




\section{Evaluación por Competencias}

\section{Reflexión}

A continuación se presentan varias categorías y su descripción para analizar detenidamente la actitud en relación con el aprendizaje. Marco con una $\boldsymbol{X}$ en la casilla que considero es el caso.

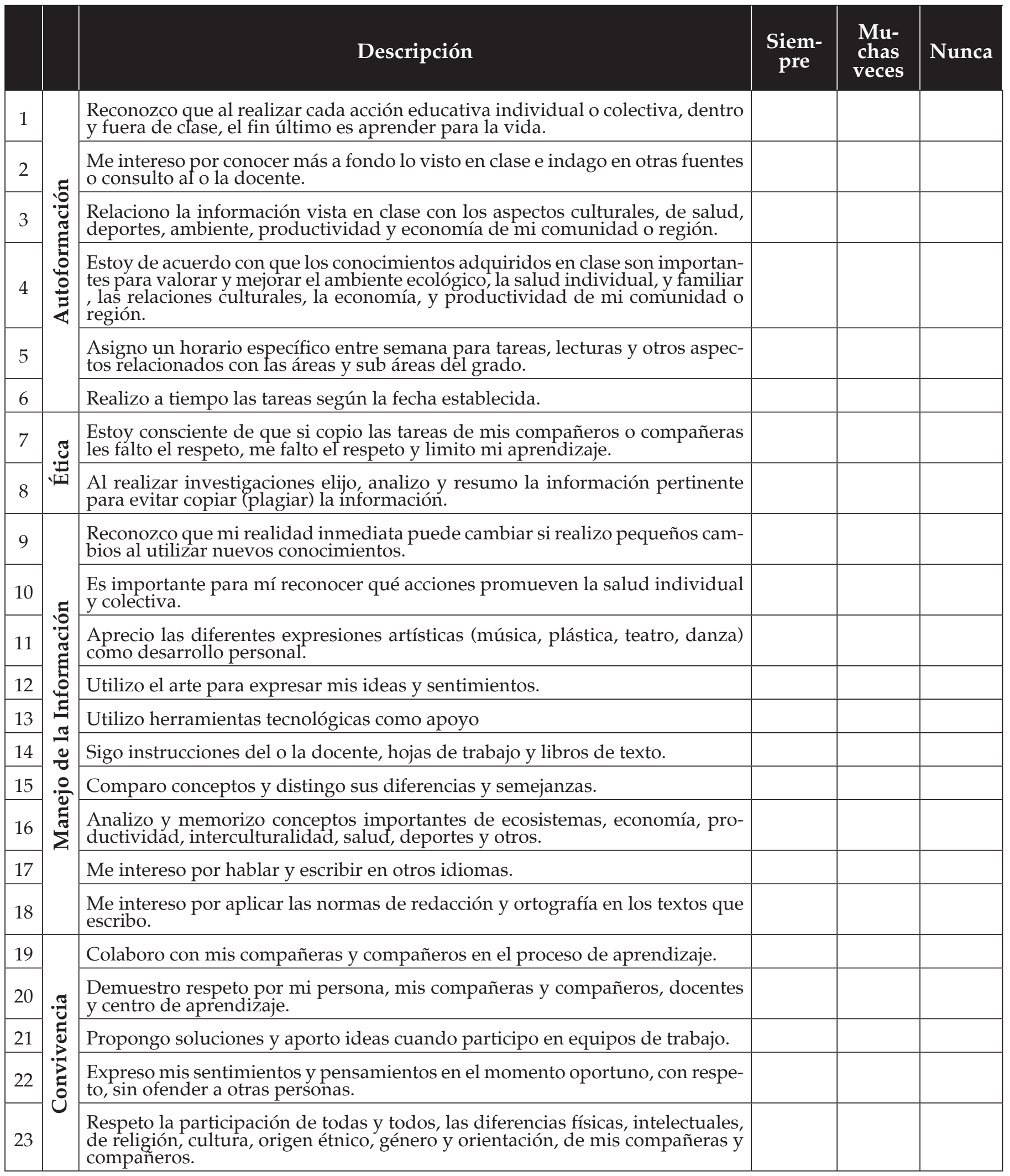




\section{El conocimiento al servicio de la sociedad y el ambiente}

En este proyecto las y los estudiantes aplicarán sus competencias a la producción de un bien tecnológico en beneficio de la comunidad y su ambiente. Para su realización se identificarán las necesidades del lugar y luego se propondrán soluciones teniendo en cuenta los recursos con los que cuenta la familia y la comunidad.

\section{¿Qué deseamos?}

Elaborar el prototipo de un producto para el servicio familiar y comunitario. Se presentarán propuestas de solución a algunas necesidades de la comunidad. Se procurará para ello la utilización de energía alternativa, en beneficio y cuidado del ambiente y por ser de bajo costo.

\section{¿Qué haremos?}

Identificaremos necesidades de la comunidad, conoceremos más sobre alternativas tecnológicas que responden a necesidades de la comunidad, planificaremos, ensayaremos y probaremos el diseño de un producto o servicio tecnológico. Vamos a exponer las experiencias o inventos que muestren la situación en la comunidad y región, con el apoyo de diversos recursos físicos y herramientas tecnológicas. Serán elaborados preferentemente con materiales de fácil acceso. Prepararemos el lugar de exposición con los elementos esenciales. Utilizaremos términos científicos apropiados para explicar los fenómenos y procesos físicos relacionados con los productos o servicios tecnológicos y el uso racional de los mismos.

Propondremos acciones realizables en cuatro ámbitos: individual, familiar, vecinal y comunitario para mejorar el ambiente y el aprovechamiento de la energía renovable. Finalmente realizaremos una presentación de las propuestas de generación y utilización de energía renovable en la comunidad. En todo el proceso manifestaremos habilidades comunicativas.

\section{¿Con quiénes trabajaremos?}

Organizaremos grupos de trabajo en los cuales la designación de responsabilidades garantiza la equidad en todos los niveles, incluido el de la toma de decisiones. Además, consultaremos con personas de la comunidad para identificar necesidades, conocer experiencias y alternativas, recibir asesoramiento en el desarrollo del producto.

\section{¿Cómo procedemos?}

\section{a. Investigación}

- Iniciamos con la detección de necesidades, en la familia y en la comunidad, relacionadas con el uso de energía para la solución de problemas ambientales o de servicios. Socializamos los hallazgos y determinamos para qué necesidad vamos a proponer una solución con el uso de energía alternativa.

- Luego realizamos una investigación acerca de las experiencias o inventos que se relacionan con la electricidad y otras formas de energía, en la comunidad. Por ejemplo, los recursos tecnológicos que se aplican para generar el funcionamiento de herramientas y aparatos con energía eléctrica y solar. Cada grupo acordará, por consenso, la experiencia que quiere presentar ante sus compañeros y compañeras, y la comunidad.

- Conocemos otras experiencias de uso de tecnología para la satisfacción de necesidades que se presentan.

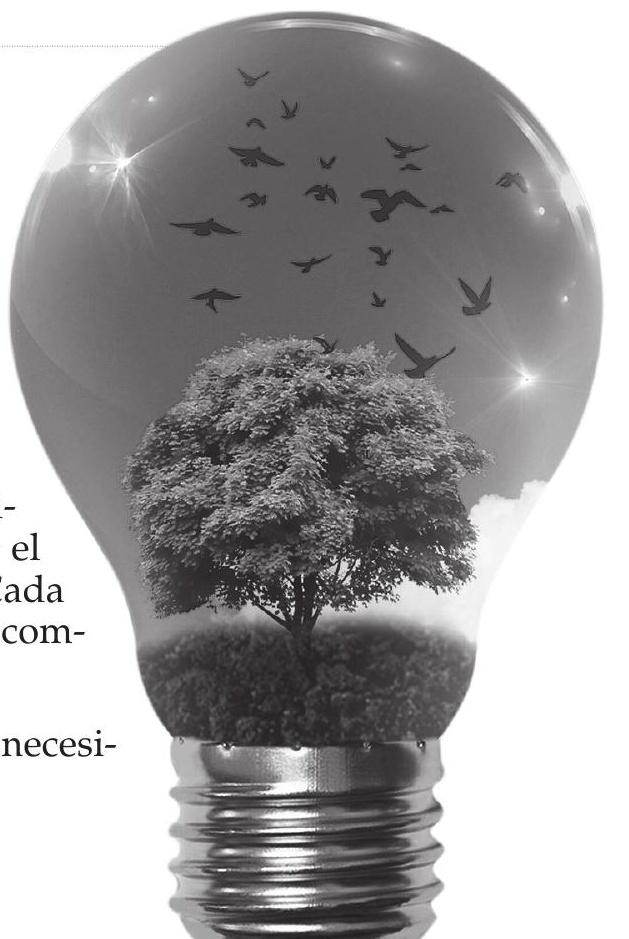




\section{PROYECTO}

\section{b. Organización}

- Analizamos la viabilidad de presentar los inventos o experiencias asociadas a fenómenos y procesos físicos relacionados con los tipos de energía que se generen de manera natural y el uso racional de los mismos. Luego elegimos el más relevante o el más adecuado a la necesidad seleccionada.

\section{c. Producto}

- Después de consultar con su grupo, las personas coordinadoras se reúnen para acordar los elementos que se expondrán y asignan las experiencias o inventos para que cada grupo elija sus materiales y diseñe su prototipo.

- Elaboramos los prototipos de las experiencias o inventos que se presentarán ante la comunidad.

- Colaboramos en el diseño y la elaboración del prototipo del producto o servicio tecnológico.

- Participamos en la exposición de los productos y servicios tecnológicos.

\section{¿A quién presentaremos nuestro producto?}

Con nuestra tutora o tutor, debemos acordar a quiénes invitaremos a la presentación. Puede ser a quienes estudian en el centro educativo y demás tutoras o tutores, a madres y padres de familia, autoridades, líderes y lideresas de la comunidad. Las personas relatoras pueden organizar una presentación ante quienes muestren interés en las experiencias e inventos que se presentarán.

\section{¿Cómo distribuiremos el tiempo?}

\begin{tabular}{|c|c|c|c|c|c|c|c|c|}
\hline & \multicolumn{8}{|c|}{ SEMANA } \\
\hline ACTIVIDAD & $1^{\mathrm{a}}$ & $2^{\frac{a}{a}}$ & $3^{\mathrm{a}}$ & $4^{\frac{a}{a}}$ & $5^{\underline{a}}$ & $6^{\frac{a}{a}}$ & $7^{\mathrm{a}}$ & $8^{\mathrm{a}}$ \\
\hline Detección de necesidades & $\checkmark$ & $\checkmark$ & & & & & & \\
\hline $\begin{array}{l}\text { Conocer mediante un panel foro las expe- } \\
\text { riencias de uso de energía alternativa en } \\
\text { la comunidad y búsqueda de alternativas } \\
\text { para responder a las necesidades en la } \\
\text { comunidad }\end{array}$ & & & $\checkmark$ & & & & & \\
\hline $\begin{array}{l}\text { Socialización de su ensayo y planificación } \\
\text { del producto o servicio tecnológico }\end{array}$ & & & & $\boldsymbol{V}$ & & & & \\
\hline Elaboración del producto & & & & & $\checkmark$ & $\checkmark$ & & \\
\hline $\begin{array}{l}\text { Modelaje del funcionamiento del producto } \\
\text { y convocatoria a comunidad educativa. }\end{array}$ & & & & & & & $\boldsymbol{V}$ & \\
\hline $\begin{array}{l}\text { Presentación del producto o servicio tecno- } \\
\text { lógico a la comunidad educativa y evalua- } \\
\text { ción. }\end{array}$ & & & & & & & & $\checkmark$ \\
\hline
\end{tabular}




\section{La energía en nuestra comunidad}

Los fenómenos más característicos de los cuerpos electrificados son las chispas y las fuerzas de atracción o de repulsión. Existen varias maneras de electrización un cuerpo.

La electrización por inducción ocurre cuando un cuerpo electrificado se acerca sin llegar a tocar otro originalmente no electrificado; entonces el segundo cuerpo también se electrifica. Esta electrificación desaparece cuando el primer cuerpo se aleja del segundo.

La electrización por contacto se produce cuando se toca un cuerpo con otro que posee carga. Entonces la carga eléctrica se distribuye entre los dos cuerpos, los cuales quedan cargados con el mismo tipo de carga

La electrización por frotamiento sucede cuando un cuerpo se frota, la carga se transfiere de un cuerpo al otro, uno de los cuerpos adquiere un exceso de carga positiva y el otro un exceso de carga negativa.

Un peine al frotarlo con el cabello, se electriza por frotamiento. Al acercar el peine a pedacitos de papel común o papel aluminio, este se electriza por contacto. Cuando solo se acerca un cuerpo cargado eléctricamente a otro sin carga eléctrica, ocurre la electrización por inducción.

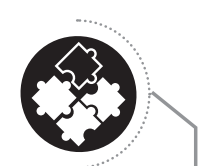

Realizamos las siguientes experiencias y luego de leer sobre los tipos de electrificación identificamos cuál se presenta en cada una.

1. Frotamos un peine con el cabello y lo acercamos a pedacitos de papel común, papel aluminio y otros objetos. ¿Qué observamos? Explicamos lo que sucede.

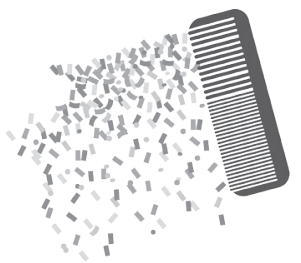

2. Colocamos sobre la mesa una lata de agua gaseosa en forma horizontal. Frotamos un globo en el cabello y lo acercamos a la lata sin que se toquen.

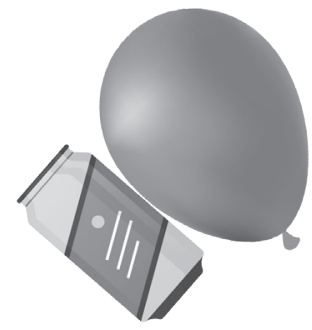

Toda la materia está conformada por átomos y estos a su vez contienen cargas eléctricas, tanto negativas (-) como positivas (+). Por lo general en la Naturaleza los átomos tienen la misma cantidad de cargas, y en esta condición se dice que son eléctricamente neutros. La electricidad es una forma de energía que se debe a la separación o movimiento de los electrones que forman los átomos. La electricidad estática aparece en un cuerpo cuando existen en él cargas eléctricas en reposo.

Existen materiales, como la lana, el plástico y las telas sintéticas, que tienen la tendencia de ganar o perder electrones cuando se rozan o se tocan, alterando su balance eléctrico. En la edad antigua los griegos ya sabían que al frotar una piedra de ámbar con una gamuza podrían atraerse materiales ligeros, como por ejemplo plumas, pelo o hilos; no tenían explicación para ello, tan solo lo interpretaban como un fenómeno mágico o divino. La palabra electricidad se derivó del griego elektron, nombre griego del ámbar. Entre los cuerpos constantemente están circulando las cargas eléctricas. Esto quiere decir que los electrones van de un cuerpo a otro. Los materiales que ganan electrones quedan cargados negativamente y los que pierden electrones quedan cargados positivamente.

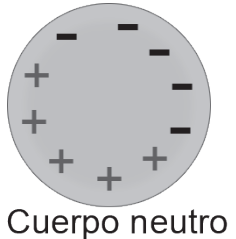

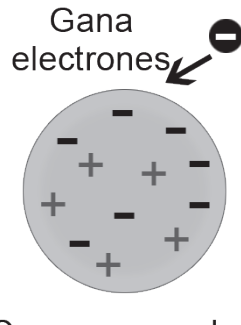

Cuerpo cargado negativamente
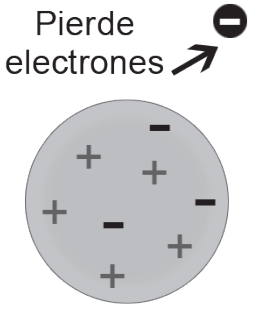

Cuerpo cargado positivamente 


\section{Elementos aisladores y conductores de energía en nuestro medio}

En la atmósfera las nubes negras se cargan eléctricamente y al acercarse unas a otras, provocan, por inducción, movimiento de cargas eléctricas y producen las enormes chispas eléctricas o descargas electroatmosféricas conocidas como rayos. Estos pueden surgir de nube a nube o de la Tierra a una nube. Las pequeñas gotas de agua de las nubes pierden o ganan electrones y se cargan eléctricamente por corrientes de aire. Cuando vemos un rayo o relámpagos, estamos viendo la acción de cargas eléctricas. Esta es una propiedad de la materia. Es responsable de producir la fuerza eléctrica (interacciones electrostáticas). Las cargas

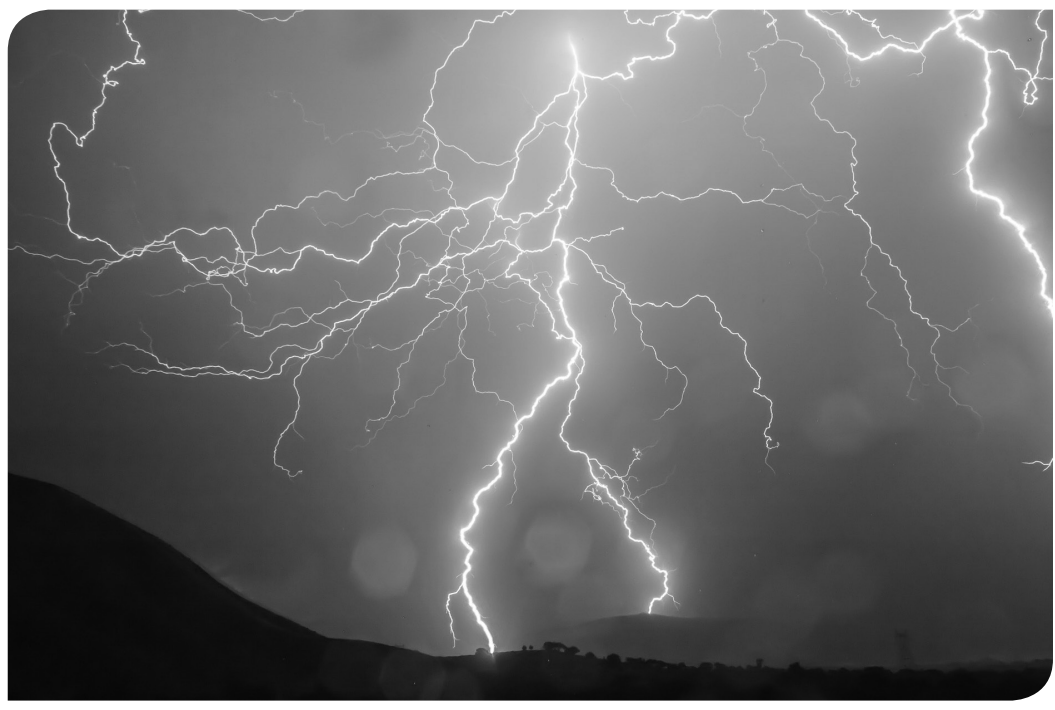
pueden circular libremente por determinados cuerpos y su unidad de medida es el coulomb.

La atracción o repulsión eléctrica ocurre por la acción de fuerzas eléctricas. Así en el experimento del peine y el papel común, interviene la fuerza de atracción eléctrica. $\mathrm{Al}$ acercar el peine a pedacitos de papel aluminio, interviene la fuerza de repulsión eléctrica. Estas fuerzas aumentan al incrementar el número de cargas en los objetos cargados eléctricamente. La fuerza eléctrica disminuye al aumentar la distancia. Esta relación se denomina ley de Coulomb que se expresa así: la intensidad de la fuerza de atracción o repulsión entre dos cuerpos cargados es directamente proporcional al producto de sus cargas e inversamente proporcional al cuadrado de la distancia que las separa.

La unidad de medida de la carga es el Coulomb (C).

$\mathrm{F}=\mathrm{kQq} / \mathrm{d} 2$ donde

F: Intensidad de la fuerza eléctrica de los cuerpos que se atraen o se repelen, medida en Newton $(\mathrm{N})$

k: constante de proporcionalidad igual a 9 X 109 Nm2/C2

Q: carga del primer cuerpo expresada en Coulomb

q: carga del segundo cuerpo expresada en Coulomb

$\mathrm{d}$ : distancia entre los cuerpos expresada en metros

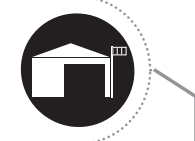

Analizamos lo que ocurre en los ejercicios iniciales y conversamos sobre las diferentes manifestaciones de energía eléctrica en la comunidad. Enumeramos las fuentes de energía eléctrica e identificamos si hay potencial para formas alternativas de generación de energía.

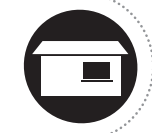

1. Elaboro una lista de cinco materiales conductores que hay en casa y cinco materiales aislantes.

2. Converso con mi familia respecto a la necesidad que pueda existir en la comunidad o en el hogar, de realizar un proyecto de electrificación, aprovechamiento de energía solar u otro que mejore la calidad de vida.

Todos los cuerpos tienen cargas eléctricas positivas y negativas. En algunos cuerpos su carga se encuentra fija en su estructura.

Cuerpos aisladores. No permiten el paso e intercambio de electrones periféricos siendo sus átomos normalmente estables. Son materiales aisladores: hule, vidrio, madera, aire, corcho, hule de espuma, plásticos, gomas y las resinas.

Cuerpos conductores. Permiten el movimiento de cargas eléctricas. Son conductores los metales como el oro, el hierro, el aluminio, la plata, el cobre, metal galvanizado, acero; y las soluciones de sales en agua. 


\section{AAprovechamos la energía humana?}

\section{Energía producida por} el cuerpo humano

Culturas antiguas como la China, Hindú y Maya, manifiestan que la energía de los seres vivos incide en la salud del cuerpo y el espíritu y las relaciones de unas personas con otras. Esto que informalmente llamamos "química o vibras", y que algunas veces percibimos sin saber por qué.

Actualmente, la ciencia está investigando la energía del cuerpo humano para otros usos. En Alemania se estudia la posibilidad de crear energía a partir de la diferencia de calor entre el cuerpo humano y el ambiente para construir termo generadores eléctricos, que podrían utilizarse en las salas de cuidado intensivo de los hospitales. En China, en cambio, se está tratando de utilizar las vibraciones del cuerpo humano y el ambiente para generar electricidad. En España, una empresa ofrece un aparato que mide la energía humana para conocer el estado de salud de una persona. Sin embargo, hay también intentos de generar energía de manera más sencilla, utilizando nuestros movimientos al caminar por medio de un colector de energía en nuestros zapatos y que se conectaría por wi-fi a dispositivos móviles, como teléfonos celulares.

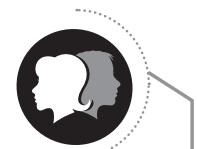

¿Te has sentido alguna

vez sin "energía"?

Describe los cam-

bios percibidos a

nivel físico y aní-

mico. Trata de

explicar las cau-

sas de esta sensa-

ción.

Los seres vivos uti-

lizamos energía para

que las funciones básicas

de nuestro organismo se realicen.

Las plantas transforman la energía del sol y nosotros utilizamos la energía de las plantas y otros alimentos para respirar, caminar, trabajar, etc. Nuestro cuerpo consume energía aún, cuando está en reposo, porque es necesaria para el funcionamiento de nuestros órganos. Nuestra salud depende de un equilibrado balance entre la cantidad de energía que consumimos (alimentación) y la que gastamos. Si gastamos menos de lo que consumimos, almacenamos esa energía en forma de grasa para uso posterior; si no gastamos esta energía, la grasa se acumula y daña nuestros órganos internos. Si exigimos más de los que consumimos, nuestro cuerpo desfallece o entra en shock y se produce, por ejemplo, un ataque al corazón o un paro respiratorio.

En el siguiente cuadro podemos comparar el número aproximado de calorías o energía utilizadas por una persona que pesa 154 libras para realizar distintos tipos de actividades durante una hora.

\begin{tabular}{|l|l|l|l|}
\hline $\begin{array}{c}\text { Actividad física } \\
\text { moderada }\end{array}$ & \multicolumn{1}{c|}{ Calorías } & \multicolumn{1}{c|}{$\begin{array}{c}\text { Actividad física } \\
\text { vigorosa }\end{array}$} & \multicolumn{1}{c|}{ Calorías } \\
\hline Caminar & 370 & Correr & 590 \\
\hline Jardinería & 330 & $\begin{array}{l}\text { Ciclismo (más } \\
\text { de } 10 \mathrm{~km} / \mathrm{hr})\end{array}$ & 590 \\
\hline Bailar & 330 & Nadar & 510 \\
\hline $\begin{array}{l}\text { Ciclismo (menos } \\
\text { de } 10 \mathrm{~km} / \mathrm{hr})\end{array}$ & 290 & Cortar leña & 440 \\
\hline Levantar pesas & 220 & Baloncesto & 440 \\
\hline
\end{tabular}

La energía almacenada lista para ser usada es llamada energía potencial, esta se desarrolla a partir de reacciones químicas. Los procesos metabólicos del cuerpo humano producen contracciones musculares que permiten movimientos como caminar, empujar, jalar, etc. Si subimos una montaña en bicicleta, acumulamos energía potencial y bajamos sin hacer ningún esfuerzo.

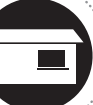

Desarrolla un resumen de los procesos productivos de la comunidad, resaltando las técnicas que favorecen la conservación ambiental, las reglas de seguridad y la optimización del uso de energía eléctrica. 


\section{Uso de tecnología en los procesos productivos}

Una de las características que definen al ser humano es la capacidad de crear herramientas para facilitar las tareas al fortalecer nuestras habilidades. Como, por ejemplo, la motocicleta nos ayuda a ser tan veloces como un venado y un tractor, a tener la fuerza de un elefante.

Desde que hombres y mujeres decidieron asentarse en un lugar y cultivar sus alimentos para depender menos de la caza y la recolección, su constante preocupación ha sido aumentar la producción conforme aumenta la población. El surgimiento de las grandes civilizaciones antiguas, como Maya, Inca y Azteca, dependió de su ingenio para crear sistemas de agricultura que produjeran suficientes alimentos para que parte de la población se dedicara a la artesanía, el arte, la escritura, la astronomía, etc.

Los incas cultivaban en terrazas para utilizar las laderas de las montañas sin provocar erosión y facilitar el riego, y en las zonas costeras utilizaron como fertilizante el guano, excremento de aves marinas. Los aztecas crearon chinampas, pequeñas áreas agrícolas rodeadas por los cuatro costados por canales de riego donde criaban peces. Los mayas utilizaban la rotación de tierras basándose en el sistema de roza, tumba y quema, así la tierra descansaba un periodo de tiempo para recuperar sus nutrientes antes de ser sembrada nuevamente.

La producción de suficientes alimentos es una de las principales preocupaciones de la familia y la comunidad. Listemos los procesos productivos que se realizan en la comunidad, agrícolas, pecuarios, artesanales o industriales

Organicemos grupos dependiendo del número de procesos productivos encontrados. Cada grupo investigará un proceso tomando en cuenta lo siguiente:

- Describir todo el proceso productivo.

- Hacer una lista de las etapas productivas y luego, una lista de las actividades que se realizan en cada etapa.

- Establecer el tipo de tecnología que se utiliza en cada etapa.

- Discutir en clase si la tecnología utilizada es amigable con el medio ambiente.

- Identificar en qué fase del proceso se usa energía.

- Identificar en qué fase del proceso se produce energía.

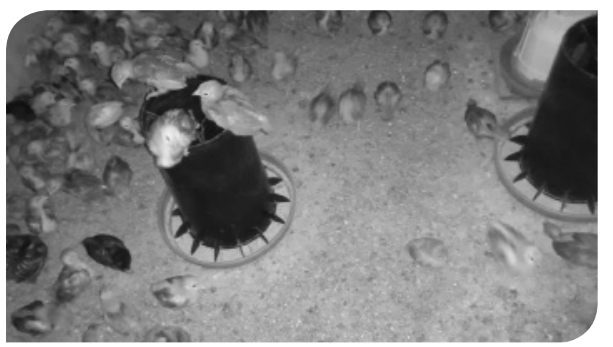

Energía humana, motor de la agricultura

La mayoría de personas agricultoras del país tiene pequeñas extensiones de tierra que no les permiten hacer uso de animales de tiro (yunta de bueyes) o maquinaria para realizar algunas tareas, por lo que emplean energía humana. En algunos procesos agrícolas se prefiere el uso de energía humana a la mecánica para asegurar la calidad del producto y obtener mejores precios de venta, por ejemplo, para el corte de algunos frutos como café o ejote francés.

La energía humana es "limpia" porque no utiliza combustibles fósiles, como gasolina, y no contamina. Pero como ya vimos antes, la energía humana se obtiene por medio de una alimentación nutritiva y balanceada. Es importante que las personas trabajadoras reciban un salario justo $y$ acorde a su esfuerzo, y se les otorguen los periodos de descanso y el pago según horario de trabajo estipulado en el Código de Trabajo para recobrar la energía que han invertido en su trabajo.

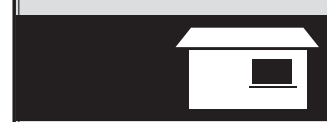

Discute en familia los tipos de agricultura que se practican alrededor de la comunidad, qué tipo de energía utilizan y su aporte a la producción de alimentos que son consumidos en la comunidad. 


\section{Comprender para aprender}

\section{Estrategias metacognitivas del aprendizaje}

Metacognición es una palabra compuesta en la cual «meta» se refiere al hecho consciente de saber lo que se está aprendiendo y «cognición» significa conocer. Por lo tanto, podríamos decir que «metacognición» es la capacidad de explicar a otros lo que hemos aprendido. Ejemplo: Hoy conocí los tipos de energía.

Las estrategias metacognitivas son:

Clasificación: Elegir el material que nos servirá para aprender sobre el tema asignado, por ejemplo: ¿cuáles avances tecnológicos pueden ayudarnos a mejorar nuestra comunidad?

Selección y comparación: Del material encontrado, elegir el que consideremos más completo y apropiado para nuestros fines.

Predicción: Trazar un plan de trabajo para realizar el estudio. Plantearnos tiempo y esfuerzo.

Evaluación: Durante y al final del proyecto, repasar y evaluar la calidad de lo aprendido.

Emisión de juicios: Tener una opinión propia, que podremos expresar y transmitir de forma coherente lo aprendido.
Como ya vimos con anterioridad, las fichas son instrumentos muy útiles para registrar y resumir información. Además de las que ya se mencionaron, podemos elaborar los siguientes tipos de fichas:

Reseña: se anota, en pocas palabras, el contenido de los textos consultados, teniendo mucho cuidado de no omitir o cambiarle el sentido a lo leído.

Resumen: se anota una síntesis, las ideas principales de lo investigado.

Instrucción: se anota paso a paso el desarrollo del proyecto.

Contenidos textuales: se copian citas tal y como las expresa quien las escribió. Van entre comillas y debe indicarse el nombre del autor.

Comentario: En este tipo de fichas se anota la opinión y el criterio personal de quien la escribe.

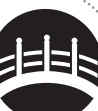

También podemos captar la energía del sol para calentar nuestros alimentos, usando materiales que tenemos a la mano.Vemos las imágenes a continuación de cómo construir un horno solar casero y dialogamos sobre la utilidad que podría tener este horno para las mujeres y los hombres de nuestra comunidad. ¿Lo elaboramos?

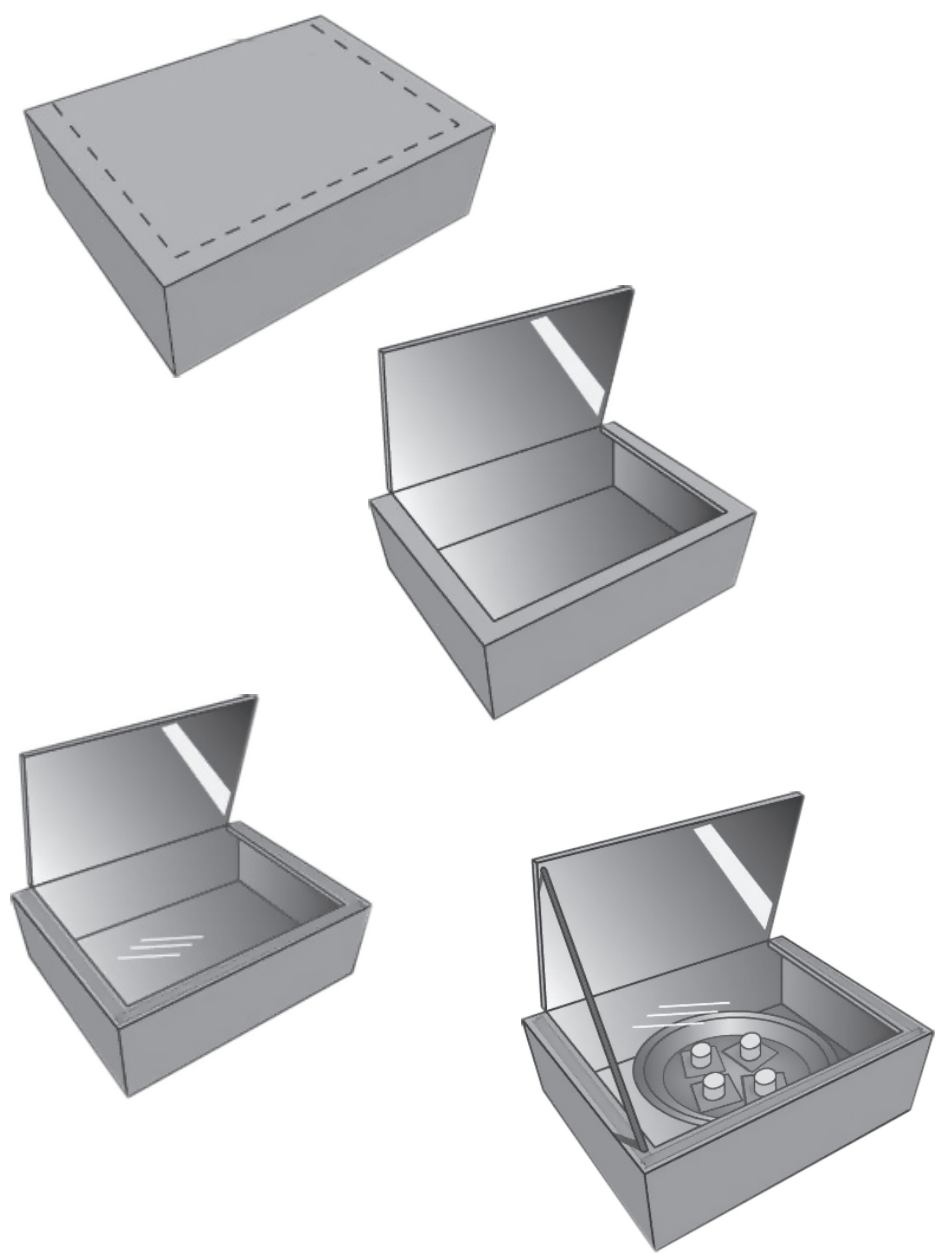

Fuente: https:/ / climatekids.nasa.gov/smores/ 


\section{Dialectos y registros de la lengua}

Se conocen como dialectos las derivaciones del idioma común de un país o región. Los dialectos no deben ser considerados formas simplificadas de una lengua específica, pues tienen sus formas particulares de hablar o escribir. Algunos dialectos no cuentan con tradición escrita o no se diferencian mucho de la lengua dominante. Suelen ser hablados por grupos pequeños y varían de una región a otra.

Como registro entendemos el uso que le damos a la lengua o idioma hablado de acuerdo a la situación en la que nos encontramos como hablantes. Entre las clases de registros están:

El familiar: Es espontáneo, abierto y desenvuelto. Se utiliza entre amigos cercanos y familiares.

El amistoso: Es espontáneo y natural. Lo hablamos al dirigirnos a compañeros, vecinos o gente de confianza.

El neutro: Lo adoptamos al hablar con desconocidos, solicitar algo por teléfono o en una tienda.

El elevado: Emplea tecnicismos. Es el que usamos cuando damos una conferencia.

El ritual: Se emplea en ceremonias o actos comunitarios.

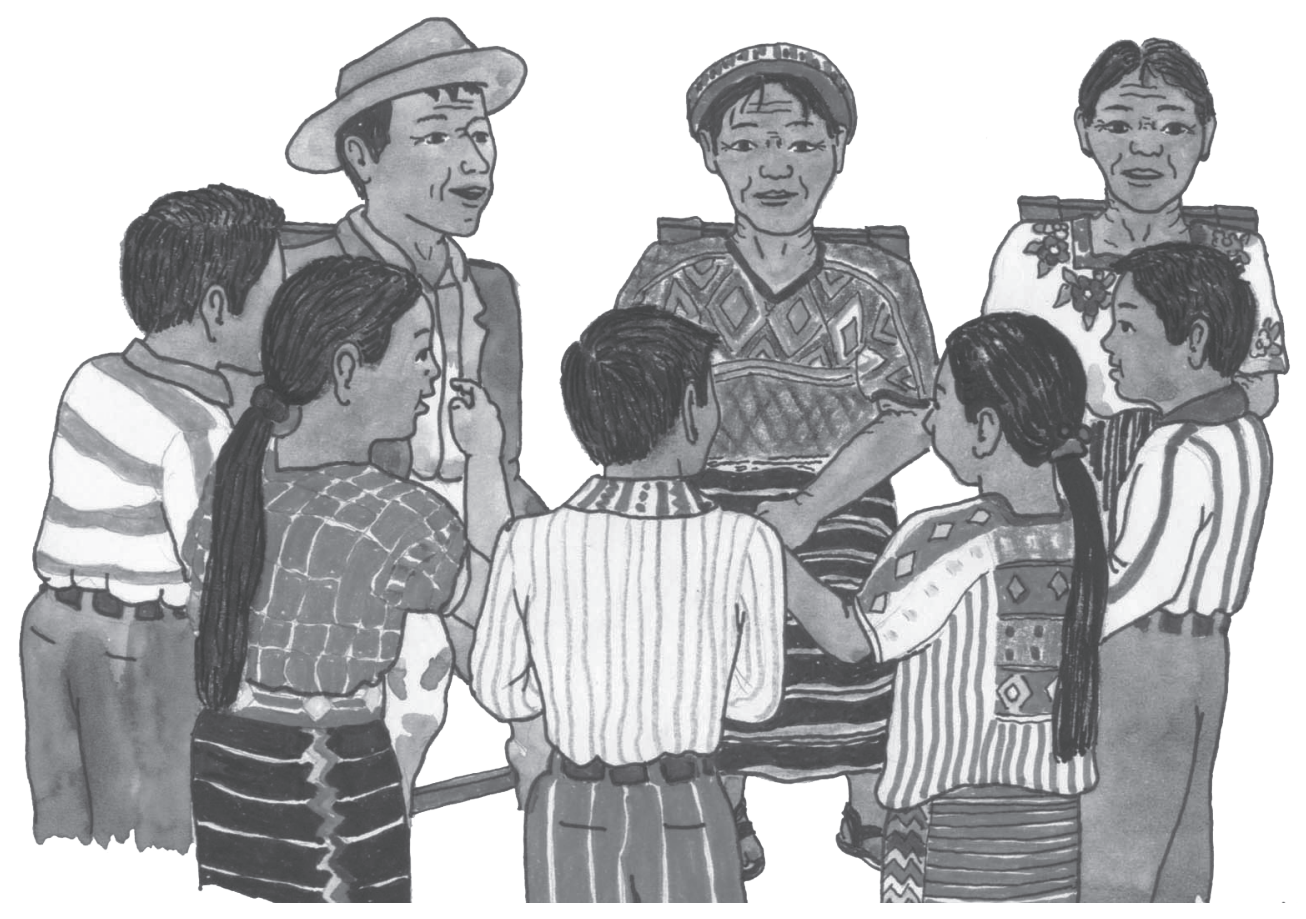

En grupos personificaremos diferentes momentos en la vida co-munitaria ejemplificando como se adecúan los diferentes regis-tros y la presentaremos como sociodrama. 


\section{Espacios para el diálogo}

Los espacios de diálogo son indispensables para manejar, resolver o transformar un conflicto. Por tal motivo se hacía imprescindible crear un espacio en donde las partes involucradas en el conflicto armado en países de Centro América pudiesen dialogar. En Centroamérica había varios países que enfrentaban conflictos armados. El Grupo de Contadora (Colombia, México, Venezuela y Panamá) fue el primero en crear un espacio de diálogo y asumir el papel de mediadores para promover la paz en Centroamérica. Posteriormente se creó el Grupo de Apoyo a Contadora, con la participación de Brasil, Argentina, Uruguay y Perú. A partir de 1990, el Grupo de Contadora cambió su nombre por el de Grupo de Río.

El Grupo de Contadora recibió el apoyo de la Asamblea General y el Consejo de Seguridad de la Organización de las Naciones Unidas. El Grupo facilitó que los países centroamericanos visualizaran las medidas y acciones que deberían tomar para alcanzar la paz en sus territorios y en el istmo. Por ello medió para que los representantes de los gobiernos centroamericanos orientaran el proceso con base en el derecho internacional y que tuviesen muy claro que la paz solo era posible si se desarrollaba o fortalecía el sistema democrático y si se establecían acuerdos para lograr un desarrollo económico que beneficiase a toda la población.

Aunque el Grupo de Contadora no logró la firma de la paz en Centroamérica, sentó las bases para que luego se alcanzaran los acuerdos en las declaraciones de Esquipulas I, II y III.

Formamos grupos para organizar las áreas de la comunidad en la que cada grupo estará realizando la investigación de necesidades de la comunidad.

Preparamos un instrumento de observación de necesidades, puede incluir fichas de observación, entrevistas y otras herramientas de investigación que hemos aprendido. Presentamos nuestro instrumento para consensuar uno a utilizar por toda la clase.

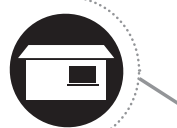

Realizamos la observación para detectar las necesidades según la organización acordada y usando el instrumento que consensuamos en clase.
- ¿Qué procedimiento debemos seguir para solucionar los conflictos mediante el diálogo y la negociación?

Procedimiento para alcanzar la paz

En 1987, en Guatemala, se acordó un procedimiento para alcanzar la paz firme y duradera. Dicho procedimiento estaba integrado por tres aspectos fundamentales: desarrollar el diálogo del gobierno con todos los grupos opositores, decretar amnistía para toda persona que se hubiese alzado en armas y la creación de una Comisión Nacional de Reconciliación. Esta comisión fue integrada por Roberto Carpio Nicolle, Rodolfo Quezada Toruño, Jorge Serrano Elías y Teresa Bolaños de Zarco, como miembros titulares. Monseñor Quezada Toruño jugó un importantísimo papel en el proceso de diálogo y negociación de los Acuerdos de paz. Después de varios altibajos y la conformación de otras comisiones en donde se incorporó la ONU, la paz firme y duradera se suscribió el 29 de diciembre de 1996.

Estimo el número de años que duró el proceso para alcanzar la paz en Guatemala.

Opino con respecto al procedimiento seguido para dialogar y llegar a los acuerdos. 


\section{Proposiciones loglcas compuestas para comprender necesidades y buscar alternativas}

Las proposiciones son enunciados que pueden ser verdaderos o falsos.

Las preguntas no son proposiciones.

Comentarios $\mathrm{u}$ opiniones subjetivas tampoco son proposiciones. Por ejemplo: "El experimento del cepillo de pelo es alegre de realizar" no es una proposición pues no se puede determinar si es verdadero o falso.

Algunas proposiciones pueden ser indeterminadas ya que no tienen el mismo valor para todas las personas; por ejemplo: "Mi sobrino tiene 5 años".
La estufa o cocina solar y la bici licuadora son aparatos de fácil construcción que optimizan el uso de energía para simplificarnos algunas tareas. Comentamos con nuestros compañeros y compañeras acerca de su uso en la comunidad. Luego resolvemos lo que se nos pide.
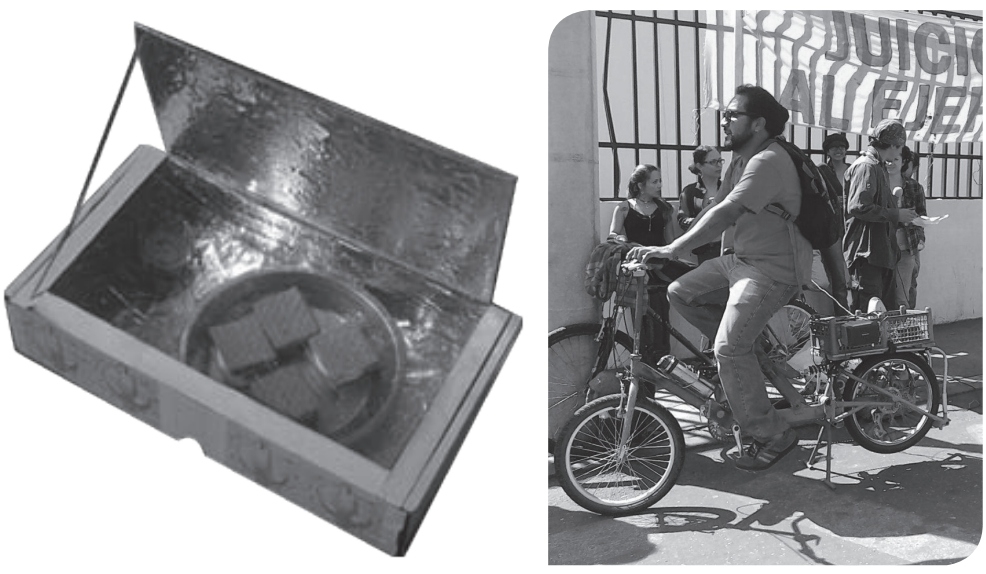

- ¿Cuáles de las siguientes proposiciones son ciertas para los aparatos?

- El aparato funciona únicamente en el día.

- El aparato requiere de una conexión eléctrica.

- El aparato requiere de una persona que lo impulse.

- El aparato se fabrica en casa.

- El aparato se utiliza para preparar alimentos.

- El aparato es costoso.

Identifica cuáles de los siguientes enunciados son proposiciones falsas, proposiciones verdaderas, o no son proposiciones.

- $18-3=12$

- Tus ojos son cafés.

- ¿Dónde está mi cuaderno?

- $25 \times 3=125$

La negación de una proposición p es "lo que no es p" y se escribe -p. El valor de verdad de la negación de p será el opuesto al de p. Por ejemplo:

$\mathrm{p}$ : Hoy es martes.

- $p$ : Hoy no es martes. 
Las proposiciones compuestas se forman de dos o más proposiciones simples unidas por conectivos lógicos.

\section{Disyunción}

Conjunción

Cuando dos o más proposiciones están unidas por la letra " $o$ " se forma una nueva proposición llamada disyunción. Su símbolo es V.

Ejemplo:

p: Carlota utiliza la estufa solar.

$q$ : Carlota utiliza la bicilicuadora.

p V $q=$ Carlota utiliza la estufa solar o utiliza la bicilicuadora.

\section{Implicación}

Cuando dos o más proposiciones están unidas por las palabras "si" y "entonces" se forma una nueva proposición llamada implicación. Su símbolo es $\Rightarrow$.

Ejemplo:

$p$ : Carlota utiliza la estufa solar.

$q$ : Carlota utiliza la bicilicuadora.

$p \Rightarrow q=$ Si Carlota utiliza la estufa solar entonces utiliza la bicilicuadora.
Cuando dos o más proposiciones están unidas por la letra " $y$ " se forma una nueva proposición llamada conjunción. Su símbolo es $\Lambda$.

Ejemplo:

p: Carlota utiliza la estufa solar.

$q$ : Carlota utiliza la bicilicuadora.

p $\Lambda q=$ Carlota utiliza la estufa solar y utiliza la bicilicuadora.

\section{Doble implicación}

Cuando dos o más proposiciones están unidas por las palabras "sí y solo si" se forma una nueva proposición llamada doble implicación. Su símbolo es $\leftrightarrow$.

Ejemplo:

p: Carlota utiliza la estufa solar.

$q$ : Carlota utiliza la bicilicuadora.

$p \leftrightarrow q=$ Carlota utiliza la estufa solar si y solo si utiliza la bicilicuadora
El valor de verdad de una proposición se refiere a si es verdadera o falsa.

Representamos las proposiciones utilizando letras como $p, q$ y $r$. Por ejemplo:

$p$ : Guatemala es un país de Centroamérica.

$q$ : El día tiene 26 horas.

$r: 20+8=25$

En equipos escribimos tres proposiciones lógicas compuestas que se relacionen con el tema del proyecto que estamos desarrollando. Las compartimos con el resto del grupo y determinamos su valor de verdad o si son indefinidas.

Utilizando las proposiciones que escribimos anteriormente escribimos, en nuestro cuaderno proposiciones compuestas. Investigamos sobre las tablas de verdad y las ejemplificamos en nuestro cuaderno por medio del uso de tablas. 


\section{Arte, oléncia y tecnología a nuestro servicio}

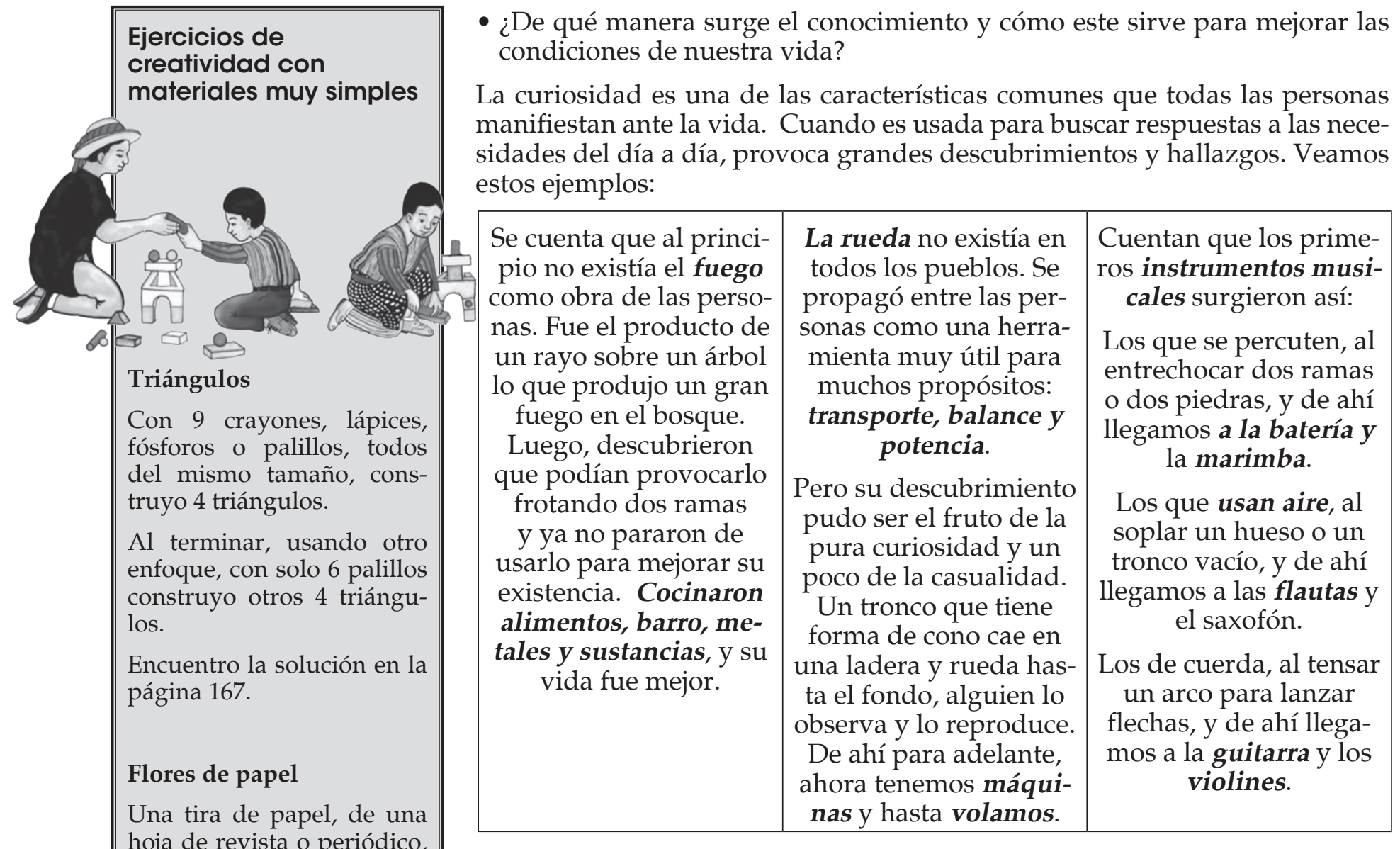

$\mathrm{Al}$ observar esto notamos que la curiosidad y el conocimiento son vitales para mejorar las condiciones de nuestra vida. El arte, la ciencia y la tecnología aportan a hacer más fáciles muchos procesos que viabilizan una vida digna en la sociedad.

dobla por la mitad. hace corte de flecos en la parte del doblez, hasta la mitad del ancho, en todo lo largo.

Se coloca una tirita de papel de otro color, luego se enrolla la tira completa y se va dando la forma de una flor. Los cortes definen los pétalos. Se asegura con hilo o cinta adhesiva.

\section{Trabajemos en grupo}

- Hagamos una lluvia de ideas sobre las necesidades familiares y comunitarias que requieren del uso de conocimiento artístico, científico y tecnológico.

- Para incluirlas en nuestro instrumento de investigación de necesidades.
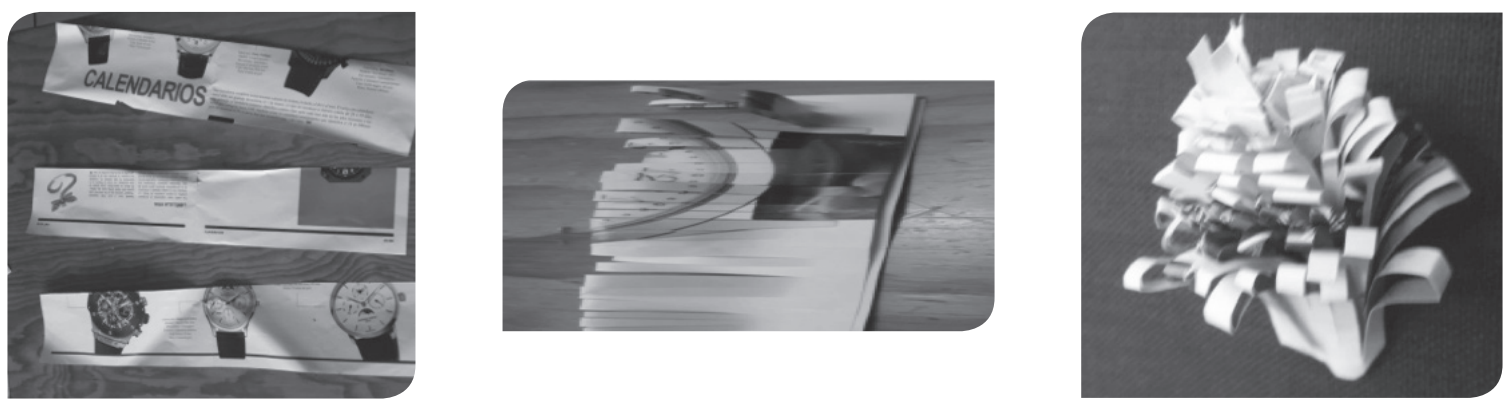


\section{Detectando las necesidades de la comunidad}

Nuestra comunidad tiene necesidades que para ser atendidas ameritan el uso de conocimiento científico, tecnológico y la creatividad. Algunas de ellas requieren el simple uso de una palanca, una polea o un punto de apoyo. Sin embargo, tal vez ni siquiera nos hemos dado cuenta de que existen esas necesidades, o las hemos atendido mediante otros métodos menos eficientes. Determinar un proceso para detectarlas y atenderlas es una manera de hacer que todo sea más fácil y rinda más en cualquier proceso de producción. Por eso es bueno estructurar un plan. El siguiente puede ser un ejemplo para ello:

Detectar necesidades

\section{Priorizar las más urgentes}

Ejercitamos nuestras habilidades de voleo, identificando cómo se transfiere la energía de nuestro cuerpo a la pelota y de vuelta.

- ¿Qué movimientos similares realizamos en las actividades laborales y productivas de las personas?

\section{Valoramos lo aprendido}

En todas las áreas de estudio hemos abordado la importancia del conocimiento en nuestra familia y comunidad. Para valorar lo aprendido esta semana, escribamos una lista de cinco conocimientos nuevos para atender las necesidades de nuestra comunidad por medio de la tecnología:
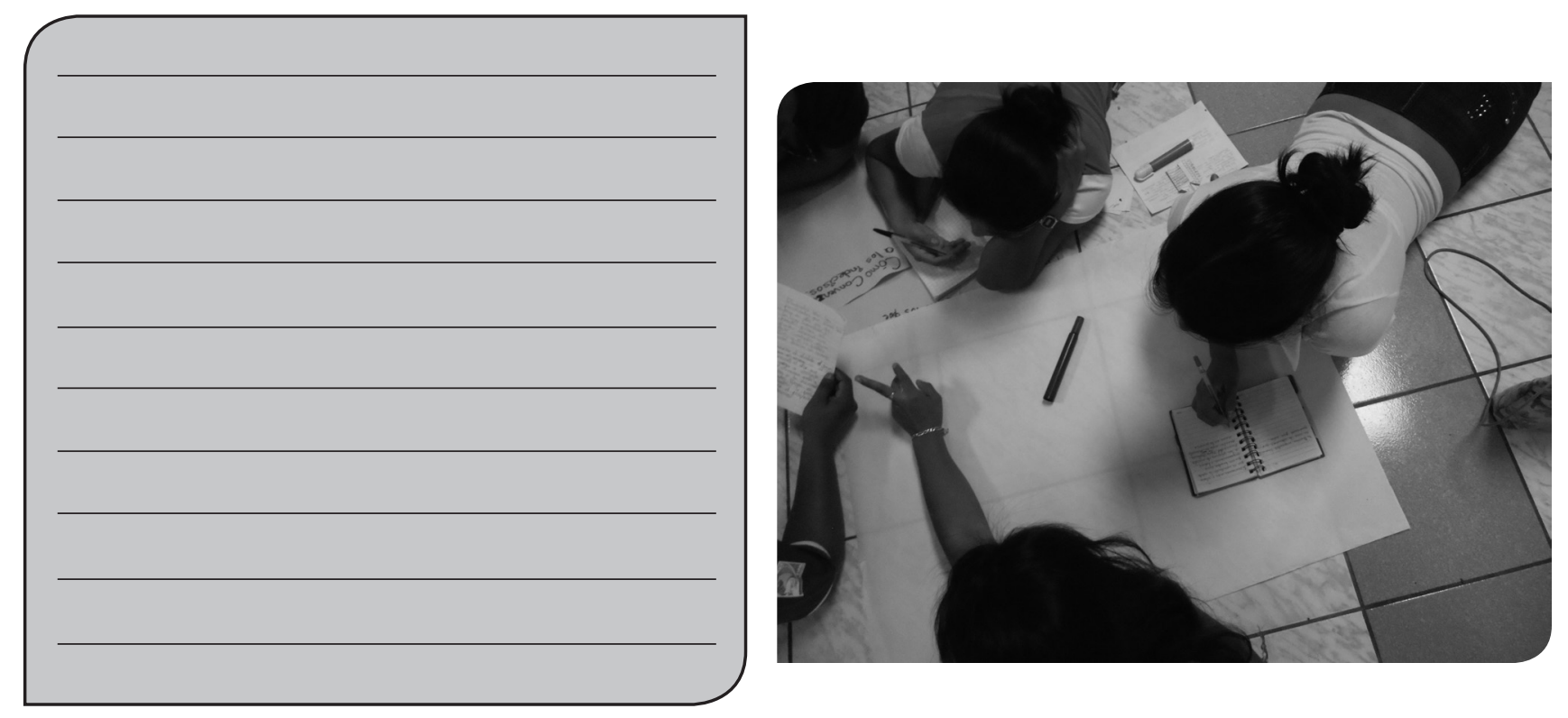

Realizamos ejercicios de respiración, vocalización y relajamiento. Organizamos equipos según nuestro tono de voz para recordar alguna canción tradicional de la comunidad. La cantamos y evaluamos si en ella se expresan algunas necesidades de la comunidad. 


\section{Construit una nueva sociedad con los Acuerdos de paz}

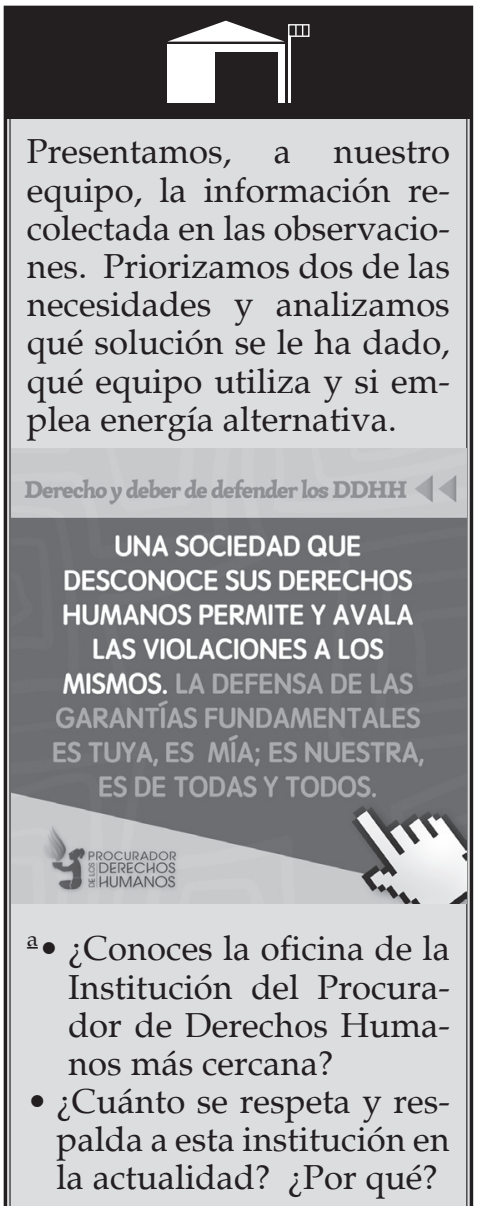

El cumplimiento de los Acuerdos de paz

"La situación de marginamiento de los pueblos indígenas es uno de los puntos cuestionados por las y los analistas. Rosalina Tuyuc, de la Coordinadora Nacional de Viudas de Guatemala, expresó: "Hay acuerdos que están en lista de espera, como lo referente a la identidad de los pueblos indígenas".

"Añadió: Estamos en una situación muy grave de conflictividad social, además de que se ha criminalizado la lucha social".

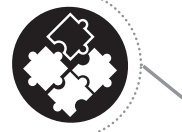

Luego de la investigación sobre necesidades, comentamos como grupos qué poblaciones enfrentan más dificultades para satisfacer sus necesidades. Después analizamos qué formas de discriminación sufren las poblaciones marginadas en la comunidad y en el país.

Posteriormente a los diálogos para finalizar alos conflictos armados en Centro América, Guatemala invirtió sus energías en escribir, acordar y firmar sus propios Acuerdos de Paz. Estos 12 acuerdos fueron negociados a lo largo de cinco años entre el Gobierno y la URNG para firmar el último de ellos en 1996. Algunos fueron cumplidos en el corto plazo porque solo se necesitaba la participación directa de las partes en conflicto, por ejemplo: el Acuerdo sobre el definitivo cese al fuego, Acuerdo sobre bases para la incorporación de la Unidad Revolucionaria Nacional Guatemalteca a la legalidad y el Acuerdo sobre el cronograma para la implementación, cumplimiento y verificación de los acuerdos de paz. Mientras otros, como el Acuerdo sobre reformas constitucionales y régimen electoral, que involucró una consulta popular, no fue cumplido. Hoy se mantienen muchas de las condiciones que dieron lugar al conflicto armado y que siguen generando grandes problemas y luchas dentro de la sociedad guatemalteca.

Algunos acuerdos han sido cumplidos formalmente, pero han generado conflictos e insatisfacciones debido a la resistencia que plantean algunos sectores de la sociedad guatemalteca. Entre estos acuerdos están: Acuerdo para el reasentamiento de las poblaciones desarraigadas por el enfrentamiento armado, Acuerdo sobre el establecimiento de la Comisión para el esclarecimiento histórico de las violaciones a los derechos humanos y los hechos de violencia que han causado sufrimientos a la población guatemalteca y el Acuerdo sobre fortalecimiento del poder civil y función del Ejército en una sociedad democrática.

Hay acuerdos que platean soluciones para resolver problemas que afectan a la sociedad guatemalteca y por lo tanto involucran a todos sus integrantes. Su cumplimiento es parcial y han respondido al equilibrio de fuerzas políticas, entre ellos:

- El Acuerdo global sobre derechos humanos, porque en él se establece que el Organismo Judicial, la Institución del Procurador de los Derechos Humanos y el Ministerio Público, deben ser respaldados y fortalecidos en el ejercicio de la protección de los derechos humanos. El Gobierno de la República se comprometió a respetar la autonomía y proteger la libertad de acción del Organismo Judicial y Ministerio Público, así como a desarticular a los Cuerpos Ilegales y Aparatos Clandestinos de Seguridad (CIACS), que agreden a defensores y defensoras de derechos humanos.

- Acuerdo Sobre Identidad y Derechos de los Pueblos Indígenas: busca que la sociedad guatemalteca respete y facilite el ejercicio de los derechos políticos, económicos y culturales de los pueblos maya, garífuna y xinka.

- Acuerdo sobre Aspectos Socioeconómicos y Situación Agraria: pretende lograr la justicia social y crecimiento económico sustentable, además del acceso a la tierra para los campesinos. 


\section{Recuperación de la memoria histórica}

En 1994 se firma el Acuerdo para establecer la "Comisión para el esclarecimiento histórico de las violaciones a los derechos humanos y los hechos de violencia que han causado sufrimientos a la población guatemalteca". En 1999 fue publicado el informe de dicha comisión, el cual se denominó: Guatemala: Memoria del Silencio. La Oficina de Derechos Humanos del Arzobispado de Guatemala (ODHAG) también desarrolló un proyecto denominado Recuperación de la Memoria Histórica, al informe se le tituló Guatemala: Nunca más, que fue publicado en 1998.

La recuperación de la memoria histórica, es el conjunto de acciones que la sociedad realiza para construir y contar la historia reciente. En el caso de Guatemala, registra los crímenes y abusos cometidos contra la población civil no combatiente, durante el conflicto armado. Esto se hizo para reconocer dichos actos, aportar a los procesos de justicia, reparar los daños y para que recordemos la lucha por los derechos humanos, la libertad y la justicia social que realizaron nuestras y nuestros compatriotas.

Quienes luchan por conocer lo que sucedió con sus familiares desaparecidos o asesinados durante el conflicto armado, ejercen un derecho. Mientras las personas y los grupos que dificultan que la verdad se conozca, mantienen la conducta de intolerancia que se manifestaba durante el conflicto armado interno. Es trascendental reconstruir la historia y resaltar la participación de los cuatro pueblos, de la juventud y de las mujeres, ya que la discriminación y violencia se recrudeció en su contra durante el conflicto armado. También es importante porque solo si se conoce la versad y se accede a la justicia, es posible desarrollar procesos de reconciliación.

Por ejemplo las mujeres de Sepur Zarco quienes vivieron violencia y esclavitud sexual y laboral, lograron una sentencia por esos hechos. Además, consiguieron atención para el desarrollo en su comunidad.

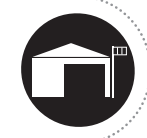

\section{Con nuestro equipo:}

- Relatamos algunos hechos que forman parte de la memoria histórica de nuestra comunidad.

- Presentamos los lineamientos para la organización de panel foro sobre proyectos ambientales y uso de energía alternativa.

- Escribimos una lista de invitados e invitadas con experiencia en este tipo de proyectos.

- Redactamos una carta de invitación.

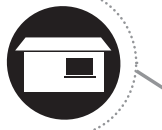

Sistematizamos la información que nos compartieron en clase por medio de una tabla, describimos la necesidad, soluciones, equipo y uso de energía renovable.

Convocamos a las invitadas e invitados con experiencia en proyectos socio ambientales y el uso de energía alternativa a participar en el panel foro de la semana siguiente.
- ¿Qué importancia tiene un juicio como el de Sepur Zarco para recuperar la memoria histórica?

"Familiares de desaparecidos durante el conflicto armado interno en Guatemala pidieron más acciones para localizar a unas 40,000 personas que aún permanecen desaparecidas tras la guerra.

En la conmemoración del Día Internacional contra las Desapariciones Forzadas, un grupo de indígenas guatemaltecos recibió los restos de nueve personas desaparecidas, y que fueron exhumadas dentro de un destacamento militar.

En ese recinto habrían sido asesinados y enterrados sus cuerpos en los años 80, entre ellos una niña de 3 años."

Fuente: Pérez, S. (2016). Guatemala busca a 40,000 desaparecidos de la guerra civil. El Nuevo Herald. Recuperado de: http:/ / www. elnuevoherald.com/noticias/ mundo/america-latina/article98886207.html

- ¿Piensas que aún falta mucho para recuperar la memora histórica en Guatemala? ¿Por qué? 


\section{La comunicación y la tecnología}

\section{Textos funcionales}

Correo electrónico: también se le conoce como «e-mail» por el término en inglés electronic mail. Es un sistema de intercambio de mensajes por medio de la red o internet. A través de los correos electrónicos podemos enviar textos, fotos, videos, audios, etc.

Resumen: es la exposición de lo más importante de un tema o materia. Puede elaborarse a partir de las ideas principales y las aportaciones básicas del autor o autora pero utilizando las propias palabras, con frases cortas y sin emitir juicios.

Sinopsis: Es un resumen general de un texto, película u obra en particular. Sirve para informar a quien nos escucha o lee, sobre los aspectos más relevantes de lo que estamos hablando o escribiendo.

Reseñas: son textos informativos elaborados con la intención de despertar el interés de una persona para leer un libro, ver una película o una obra de teatro. Las reseñas, al contrario que los resúmenes y las sinopsis, sí incluyen el criterio y opinión de quien las escribe.

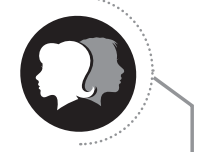

Exploraremos las diferentes redes sociales con las que nos comunicamos (whatsapp, facebook, instagram, twitter, etc.), elaboraremos un listado de los errores de lenguaje que más se cometen en ellas y prepararemos una puesta en común para discutir acerca de la importancia del buen uso del lenguaje al utilizarlas.

\section{Redactar con precisión para comunicar con fluidez}

Redactar es poner por escrito lo que queremos comunicar. Para que nuestro texto sea coherente, es necesario conocer muy bien el idioma en el que vamos a escribir y tener una idea muy clara de lo que queremos expresar. Para ello, debemos observar las siguientes reglas y sugerencias:

Orden cronológico: citar los hechos en el orden en que sucedieron, del primero al último. Por ejemplo, si contamos la vida de una persona utilizando el orden cronológico, empezaremos por su nacimiento y terminaremos con su muerte.

Orden espacial: describir un lugar o espacio físico para que quien lee pueda imaginarlo; debe ir de lo general a lo particular.

Comparación y contraste: mostrar las similitudes y diferencias que existen entre dos personas, dos cosas, dos lugares, etc. Las palabras más utilizadas para establecer esto son: «es parecido a», «como», «también»; «pero», «sin embargo», «a diferencia de».

Causa y efecto: establecer relaciones de cómo y por qué suceden los hechos. Las palabras más usadas en los párrafos que escribimos con causa y efecto son: «debido a», «ya que», "como resultado de»; " por lo tanto», "por eso», «por lo tanto».
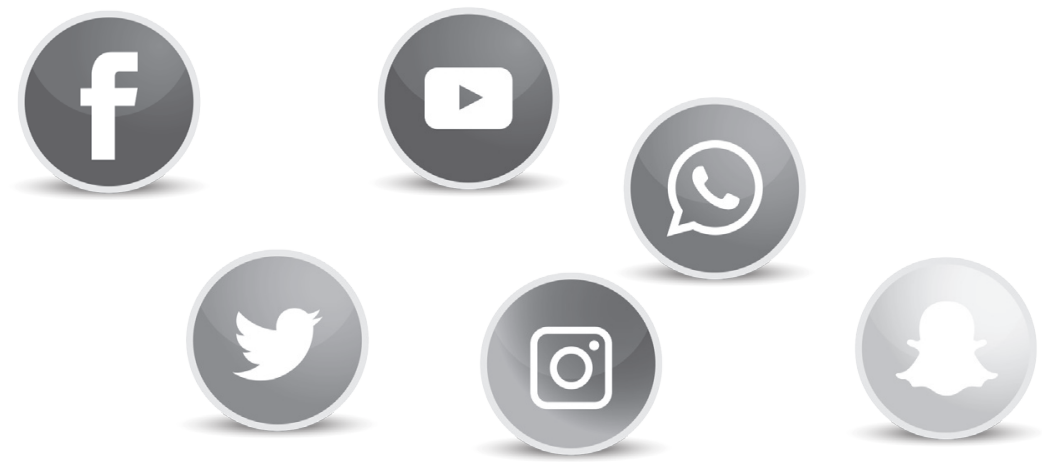

Organizamos tres grupos de trabajo: uno se encarga de la redacción de carta de invitación a las y los panelistas invitados al foro de la semana entrante, otro grupo se encarga de describir el desarrollo de alguna necesidad en la comunidad y cómo se le ha dado solución cuidando la descripción cronológica y del lugar; y el tercer grupo buscará más información acerca de inventos que usan tecnología alternativa para generación de energía. 


\section{Describir y narrar en prosa}

Entendemos como prosa a la expresión libre y natural del lenguaje. Se caracteriza por ser directa y sin rimas o versos. Existen varios tipos: literaria, coloquial, poética, didáctica y de ficción.

La descripción en prosa es la explicación detallada de las características de una persona, un lugar, un animal o un objeto. Describir sirve para ambientar la acción que se lleva a cabo en una narración y hacerla más creíble. Es conseguir que quien lee vea eso sobre lo que está leyendo.

Ejemplo:

«Con dificultad va descubriendo que se trata de un individuo gordo, entrando ya a viejo y dueño de una calvicie definitiva y reluciente; su ropa luce más bien desaliñada y de una de las bolsas traseras del pantalón le cuelga un pañuelo -más bien un trapo amarillento-» (Muñoz, Víctor, Posdata: ya no regreso).

La narración en prosa consiste en relatar uno o varios hechos, reales o imaginarios, ya sea en forma verbal o escrita. A la voz que cuenta la historia, según sea femenina o masculina se le llama «narrador» o «narradora» y quienes actúan en ella son «personajes».

\section{Ejemplo:}

«La lluvia cae sin parar desde hace ya un par de días. Hoy empecé a escribir mi guion. Por la mañana desperté lúcido. Me pareció sorprendente que las dudas se hubieran desvanecido, como una espesa neblina que disipa el calor» (Zardetto, Carol, La ciudad de los minotauros).

La diferencia entre descripción y narración es que en la primera él da una idea de los detalles físicos de la situación (olores, imágenes, sonidos, etc) aspecto externo de los hechos percibidos, mientras que la segunda intenta dar a conocer los sentimientos, el carácter y lo que impulsa a los personajes a actuar.

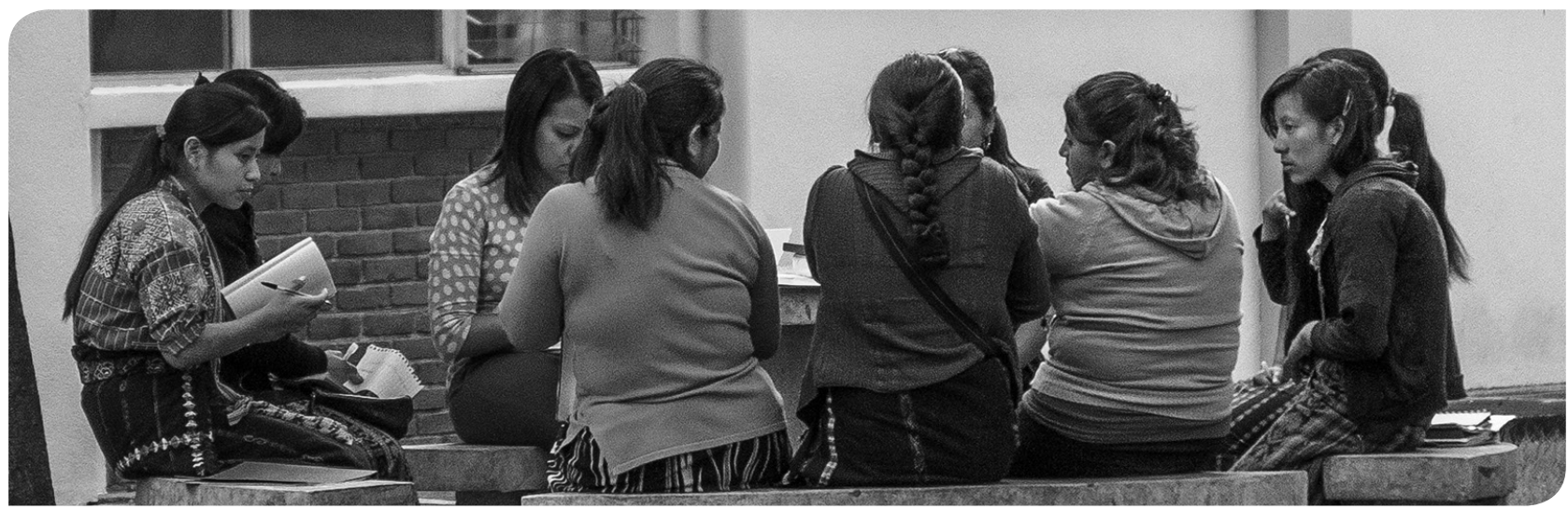

\section{Formamos dos equipos para trabajar:}

Equipo 1: Elabora la redacción de la invitación de participantes en el panel foro.

Equipo 2: Escribe el plan de panel foro incluyendo: objetivos, título y una sinopsis que describe el proyecto que se está realizando. 


\section{Luego de compartir analizamos la información}

Una conjunción es verdadera únicamente cuando las dos proposiciones originales son verdaderas.

En un diagrama de Venn el conjunto $p \wedge q$ corresponde a $p \cap q$.

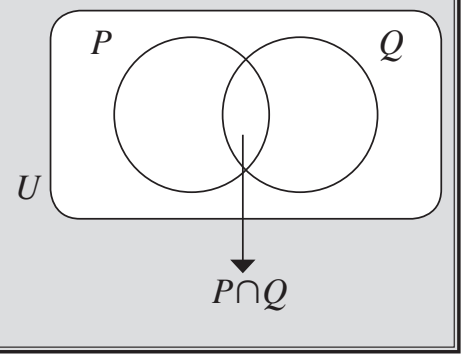

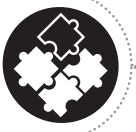

Determinamos el valor de verdad de cada una de las siguientes proposiciones.

$p=8$ es menor que 24

$q=7+5>15$

Copiamos en nuestro cuaderno y completamos, con palabras, la siguiente tabla:

$$
p \quad q \quad p \wedge q \quad p \vee q
$$

\section{Discutimos y contestamos:}

- ¿Cuál es el valor de verdad de las anteriores proposiciones compuestas?

- ¿Cómo pudimos averiguarlo?

- ¿El valor de verdad de las proposiciones p y q afecta el valor de verdad de las proposiciones compuestas?

Escribimos, en nuestro cuaderno, las siguientes proposiciones compuestas utilizando simbología lógica.

- Los paneles solares sirven para calentar alimentos o para generar energía eléctrica.

- Para construir una estufa solar se necesita papel aluminio y cinta adhesiva.

- La bicilicuadora ahorra energía eléctrica y no contamina el medio ambiente.

En equipos revisemos la información recopilada acerca de las necesidades y elaboremos 3 proposiciones a partir de ellas, seleccionemos un ejemplo para compartir a la clase y determinar el valor de verdad de la misma.

Consideremos las siguientes proposiciones:

$p=x$ es un número par

$q=x$ es menor que 7

- Copiamos el diagrama de Venn y lo completamos con los elementos de $p$ y $q$.

- Utilizamos el diagrama de Venn para hallar los elementos de $p \wedge q$.

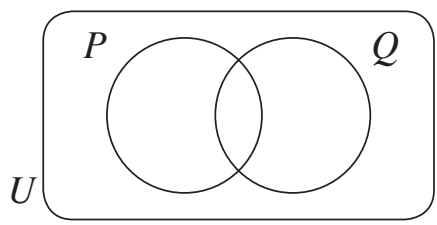


Una tabla de verdad organiza los valores de verdad de proposiciones compuestas para cada combinación posible de dos o más proposiciones simples. Al utilizar dos proposiciones los valores de verdad de cada una de ellas se distribuyen de la siguiente forma:

\begin{tabular}{|c|c|}
\hline$p$ & $q$ \\
\hline$V$ & $V$ \\
\hline$V$ & $F$ \\
\hline$F$ & $V$ \\
\hline$F$ & $F$ \\
\hline
\end{tabular}

\section{Tabla de verdad para} disyunción

\begin{tabular}{|c|c|c|}
\hline$p$ & $q$ & $p \vee q$ \\
\hline$V$ & $V$ & $V$ \\
\hline$V$ & $F$ & $V$ \\
\hline$F$ & $V$ & V \\
\hline$F$ & $F$ & $F$ \\
\hline
\end{tabular}

Tabla de verdad para conjunción

\begin{tabular}{|c|c|c|}
\hline$p$ & $q$ & $p / q$ \\
\hline$V$ & $V$ & $V$ \\
\hline$V$ & $F$ & $F$ \\
\hline$V$ & $F$ & $V$ \\
\hline$F$ & $F$ & $F$ \\
\hline
\end{tabular}

Leemos la descripción del día de Judith y elaboramos tabla de verdad a partir de la información que se presenta.

“Judith se levantó a las 4:00 y preparó las tortillas y el frijol para el desayuno. Acompañó a su hija a la escuela y luego a la reunión del COCODE. Almorzó caldo a las 12:00. Por la tarde llevó a su hija y un sobrino hasta el campo de juego de su comunidad y en la noche cenó con su familia."

Consideramos las siguientes proposiciones.

$p=$ Judith desayunó un pan con frijoles.

$q=$ Judith tiene 3 hijos.

$r=$ Judith almorzó a las 12:00 horas.

$s=$ Judith no fue a a la reunión del COCODE.

$t=$ Judith cenó con su familia.

En equipos, determinamos el valor de verdad de cada una de las proposiciones anteriores.

Según el valor de verdad de las proposiciones anteriores ahora determinamos el valor de verdad de las siguientes proposiciones compuestas.

$\begin{array}{ll}p \wedge-t & r \vee t \\ p \vee-s & t \wedge \mathrm{s}\end{array}$

Una disyunción es verdadera cuando una de las dos proposiciones originales que la conforman es verdadera. Una disyunción es falsa únicamente cuando las dos proposiciones que la forman son falsas.

En un diagrama de Venn $p$ $\vee q$ es equivalente a $p \cup q$.

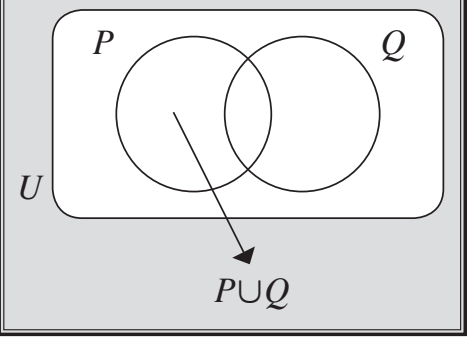




\section{Condensadores que almacenan la energía}

La energía eléctrica se puede almacenar en dispositivos que funcionan como depósitos de energía eléctrica. Son denominados condensadores o capacitores. Están formados por dos conductores separados por un material aislante que generalmente es aire, vidrio, plástico o hule. Los conductores pueden ser placas metálicas colocadas paralelamente. Un condensador está cargado si sus dos placas tienen cargas de signos opuestos. La placa con carga positiva, debe tener mayor potencial que la de carga negativa. Así los electrones del metal tenderán a moverse hacia la placa positiva. Por efecto del aislador, las cargas no se mueven. La unidad de capacidad es el faradio (F).

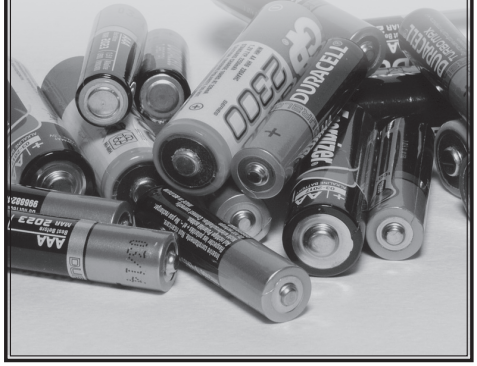

Las cargas eléctricas ejercen una fuerza radial a su alrededor y producen un campo de fuerza eléctrica. El campo eléctrico actúa en todo el espacio alrededor de la carga eléctrica y sobre otra carga eléctrica que se encuentre dentro del espacio del campo. Similar al campo energético que se percibe cuando una persona acerca su mano a la mano de otra persona, o cuando se enciende el televisor y se siente el campo energético en forma de calor y cosquilleo en la piel. Dos cuerpos con cargas eléctricas opuestas, se atraerán si se encuentran dentro del campo eléctrico.

Así como al escalar una montaña o subir un objeto de un sitio más abajo a otro más elevado se realiza un trabajo: así también al separar las cargas, cambia el valor de la energía potencial eléctrica. La energía potencial eléctrica es la energía potencial de un cuerpo cargado lo que depende de su posición en un campo eléctrico. A mayor carga del cuerpo, mayor su energía potencial. La energía potencial eléctrica, se denomina: Potencial eléctrico. La unidad de potencial, es el volt (V). La diferencia en el potencial eléctrico en dos puntos distintos de un campo de fuerza eléctrica, determina la cantidad de trabajo que se debe hacer para llevar una carga del lugar de menor potencial a un lugar de mayor potencial eléctrico. Se dice que hay alto voltaje cuando hay gran cantidad de energía más gran cantidad de carga. Por ejemplo, en las torres de transmisión de energía eléctrica.

1. En grupo encontramos ejemplos comparativos de situaciones de la vida cotidiana entre la energía potencial eléctrico y otras formas de energía potencial. Por ejemplo, los cuerpos que están a determinada altura, el caudal de agua que cae en un salto y la energía acumulada en un resorte estirado.

2. En nuestro equipo investigamos posibles soluciones a las necesidades de la comunidad e identificamos de cada una: equipo y material para su construcción y tipo de energía que utiliza (eléctrica o alternativa), si se vale de condensador o no. Preparamos una tabla que sintetiza esta información:

3. Necesidad, solución existente, equipo y materiales empleados, tipo de energía (alternativa o eléctrica).

1. Observa varias pilas que encuentres en aparatos que funcionen con electricidad. Observo los bornes o terminales de cada batería y determino cuál es el positivo y cuál el negativo. Respondo:

- ¿Cuál es la diferencia de potencial entre los extremos?

2. Averiguo el voltaje promedio del servicio de energía eléctrica residencial que se usa en Guatemala.

3. Busco ejemplos donde se lea la advertencia: "Peligro, alto voltaje". Identifico si hay alguna advertencia del peligro que representa acercarse a lugares electrificados.

4. Indago respecto del uso de energía alternativa en la comunidad. 


\section{Electrocinética}

Enciendo una bombilla de linterna con una pila o batería de $1.5 \mathrm{~V}$ (AA o AAA).

Sujeto con cinta adhesiva el extremo metálico del foco en el polo positivo de la pila.

Sujeto un trozo de alambre delgado o un extremo de un clip al extremo negativo de la pila.

Por breves momentos, hago contacto entre el otro extremo del alambre y el extremo metálico de la pila.

Respondo:

- ¿Se obtendría el mismo resultado al utilizar una bombilla de mayor número de watts?

- ¿Por qué razón debe sujetarse el alambre a los dos extremos de la pila?

La electrocinética, es la rama de la Física que estudia las cargas eléctricas en movimiento en el interior de un conductor. En forma similar al agua que se desplaza en un río, formando una corriente, las cargas en movimiento forman una corriente eléctrica. Si las terminales de un condensador se conectan a un cable metálico, la carga eléctrica se mueve de la placa de mayor voltaje a la placa de menor voltaje y se produce una corriente eléctrica hasta que la carga agote la energía almacenada.

Son fuentes o productoras de energía eléctrica, las pilas y las dinamos. Las pilas secas usadas en linternas y juguetes, generan electricidad como producto de reacciones químicas entre algunas sustancias como zinc y sal de amonio. Al terminar la reacción química, se agota una de las sustancias, la pila deja de funcionar y se agota su carga. La diferencia de potencial en los electrodos de las pilas se denomina fuerza electromotriz y se mide en volt $(\mathrm{V})$. Las dinamos son dispositivos que transforman energía mecánica en energía eléctrica. Son utilizados en hidroeléctricas en donde la corriente de agua mueve los dinamos que transforman la energía de la corriente de agua, en energía eléctrica.

Los focos de luz eléctrica y los aparatos eléctricos, son consumidores de energía eléctrica. Por efecto de la corriente eléctrica de una fuente a un consumidor, esta se convierte en luz, calor, movimiento. Es decir, ocurre un fenómeno de transformación de energía. En las pilas recargables y los acumuladores de los automóviles, se obtiene energía química a partir de la energía eléctrica lo que repone los compuestos consumidos.
Una batería es un impulsor de energía eléctrica. Realiza un trabajo al mover las cargas en un circuito eléctrico. Voltaje equivale a presión eléctrica que empuja los electrones de un extremo de mayor potencial a otro de menor potencial.

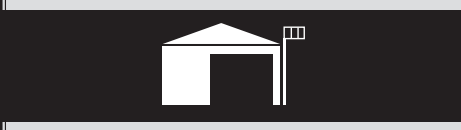

Echamos un poco de agua en un vaso. Por diferentes medios, pasamos el agua a otro recipiente, ya sea una pajilla, el émbolo de una jeringa, una manguera $u$ otro. Observamos el paso de la corriente de agua. Hacemos comparaciones con la corriente eléctrica.

- ¿Qué otros ejemplos de corrientes podemos encontrar en la vida cotidiana? Razonamos y compartimos opiniones.

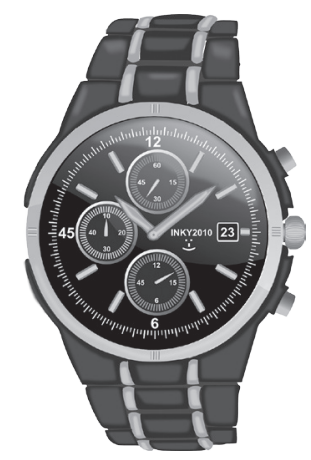

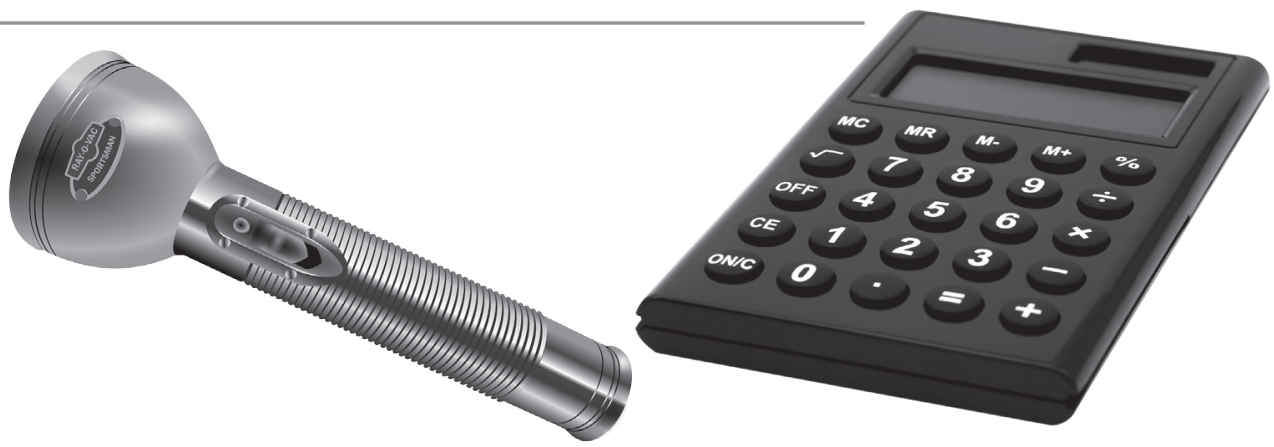




\section{La artesanía textil}

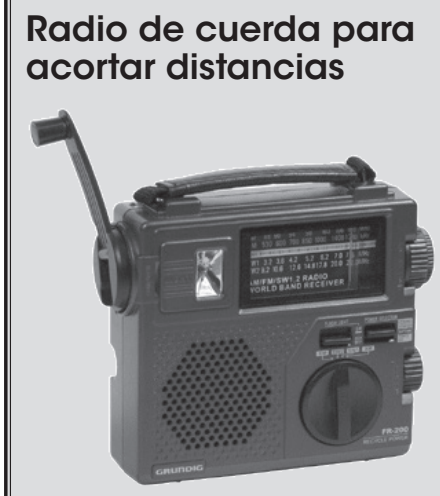

En el mundo todavía hay muchas comunidades aisladas o lejanas de centros urbanos. Debido a esa lejanía, generalmente, carecen de acceso a energía eléctrica, periódicos impresos o internet. La radio es el medio más usado para saber qué pasa fuera de la comunidad y para dar a conocer qué pasa en la comunidad.

Trevor Baylis creó en la década de 1990, una radio que funciona con una manivela para que las personas puedan tener acceso a información sin el gasto de comprar baterías. Deseaba que personas que vivían en África pudieran informarse fácilmente sobre el VIH/SIDA, prevenir la enfermedad y disminuir el avance de la epidemia.

Tomando de ejemplo el mecanismo de un reloj de cuerda, esta radio tiene una manivela que enrolla una cinta metálica, a manera de resorte, que cuando se suelta activa un pequeño dinamo o generador que hace que la radio funcione. Actualmente, el diseño ha sido modificado y utiliza baterías que se recargan con el mecanismo de cuerda. El mismo mecanismo se ha empleado para la creación de linternas de cuerda.
La artesanía textil es un sector productivo importante para las comunidades mayas. El proceso productivo tiene varias actividades:

- Obtención de la materia prima: lana de ovejas, fibras de maguey o algodón, seda de gusanos, sintéticas, etc.

- Preparación de las fibras: en el caso de las fibras naturales consiste en quitar las impurezas y lavar.

- Hilado: se estiran y tuercen las fibras largas combinándose para formar hilos.

- Preparación de los hilos: teñido y fijación de tintes.

- Tejido: existen varios tipos de telares para este propósito.

- Acabados: involucran la creatividad pero también la disciplina.

La tejeduría tradicional en Guatemala, usa únicamente energía humana para el hilado y el tejido. Las fibras naturales se retuercen para formar un hilo con la ayuda de un huso (que sirve para devanar el hilo) o una rueda de rueca (instrumento para hilar a mano). La rueca se activa dando vueltas a una manivela o pedaleando. La manivela es un mecanismo por medio del cual damos vuelta a un brazo para producir energía. Algunos pozos tienen una manivela para facilitar sacar agua y la máquina de coser emplea este mecanismo para mover la aguja. La bicicleta utiliza también este principio manejando los pedales como manivela para mover el eje que produce que las llantas giren.

El telar de cintura es de origen prehispánico y es utilizado únicamente por mujeres. Es una estructura pequeña y de fácil transporte que posibilita tensar hilos en la urdimbre que se separan para pasar la lanzadera con hilos transversales (trama). Todo esto se hace utilizando únicamente las manos. Su empleo significa para quien lo usa, permanecer largas jornadas en una misma posición. Requiere de una gran habilidad para el conteo de los hilos en cada pasada de la lanzadera.

Los telares de pie, de origen hispano, utilizan el mismo principio, pero en un telar fijo de mayores dimensiones. En Guatemala, estos telares generalmente son utilizados por hombres aunque recientemente hay más mujeres operando el telar, y son empleados para elaborar cortes, especialmente, jaspeados. Sin embargo, hay una diferencia interesante: el uso de un pedal. El pedal acciona un mecanismo que abre y cierra la urdimbre más fácilmente y que disminuye grandemente el tiempo de tejido. Otra diferencia importante es que en el telar de cintura se producen piezas únicas mientras que el telar de pie utiliza un proceso industrial a pequeña escala que produce muchos metros de tela igual.

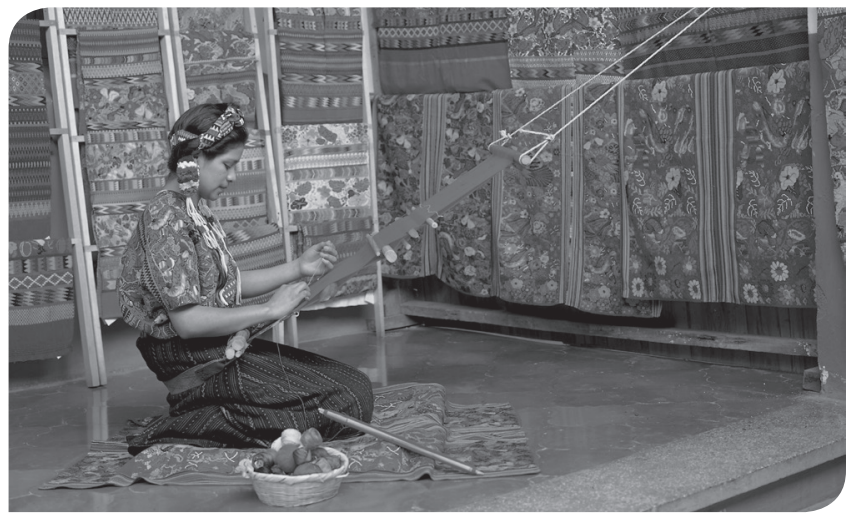




\section{Experimentando la fuerza de una manivela}

Buscamos a una persona de la comunidad que tenga un vehículo y le contamos sobre nuestro aprendizaje de las máquinas con manivela. Prestamos el gato o tricket de su vehículo y observamos cuidadosamente su funcionamiento. Luego, si es posible, pongámoslo en acción. Pedimos a la persona propietaria que nos permita elevar el vehículo usando el gato. La persona nos explicará en qué parte del auto se sitúa el gato y luego algún o alguna estudiante usará el gato. Pidamos a la persona más pequeña o más delgada de la clase que eleve el vehículo.

Ahora usemos nuestros conocimientos sobre máquinas simples para discutir el funcionamiento del gato y su uso como extensión de nuestro brazo y potenciador de nuestra fuerza.

- ¿Qué impacto tiene el tamaño y fuerza de una persona para utilizar el gato?

- Al utilizar un gato, ¿hace diferencia que el objeto que deseamos mover sea grande o pequeño, liviano o pesado?

- Imaginemos que conectamos un sistema de manivela a energía eléctrica, ¿qué usos le daríamos?
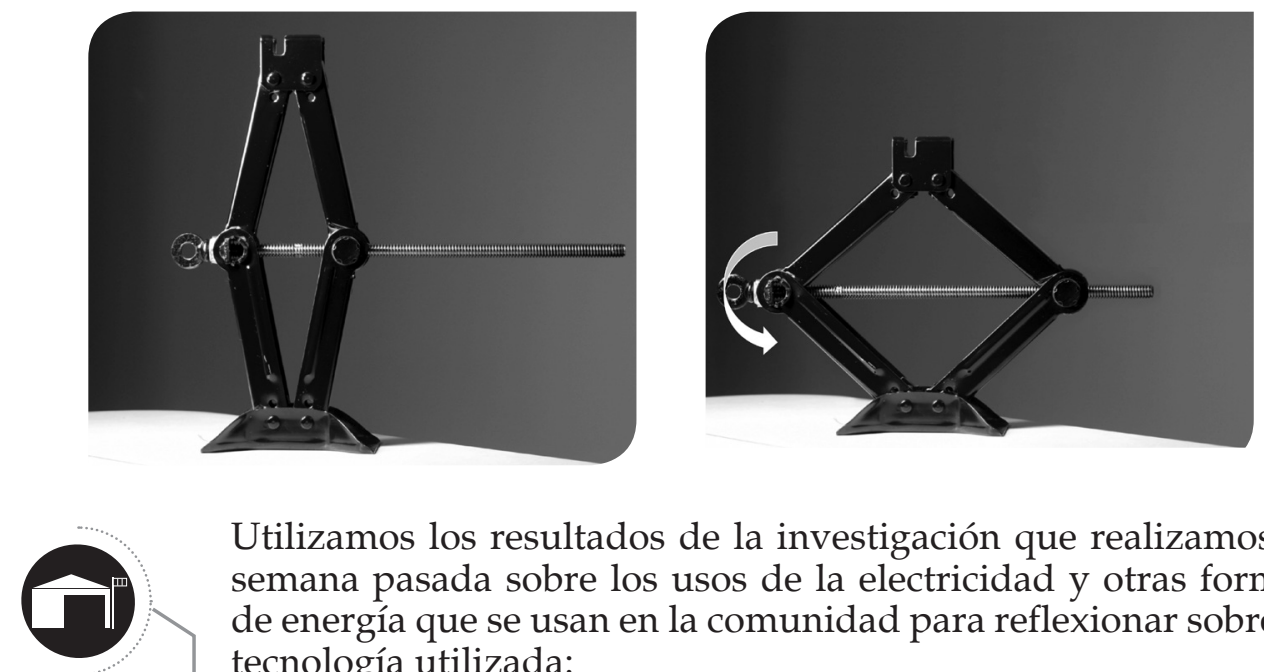

Utilizamos los resultados de la investigación que realizamos la semana pasada sobre los usos de la electricidad y otras formas de energía que se usan en la comunidad para reflexionar sobre la tecnología utilizada:

- ¿Qué impacto tiene esta tecnología en la producción de la comunidad?

- ¿Ha mejorado el uso de esta tecnología en los últimos 20 años?

- ¿Qué efectos tiene sobre el ambiente?

- ¿Cómo influye en el bienestar humano el uso de esta tecnología?

- ¿Se aplica la tecnología tomando en cuenta normas de calidad y procesos de mejora continua?

- ¿Qué necesitamos para mejorar esta tecnología?

Cada cual en casa realizará una propuesta de servicio o producto que considere es viable y contribuirá a resolver alguna de las necesidades que se identifican existen en la comunidad.

\section{Pedaleando el} desarrollo

Con las piernas podemos generar suficiente energía para transportarnos a pie, caminando o corriendo, o utilizando máquinas, como las bicicletas. Las bicicletas usan el mecanismo de manivela en sus pedales. La bicicleta como medio de transporte es una energía verde porque no produce contaminación, no usa combustibles fósiles $\mathrm{y}$, además, promueve la salud de quien la utiliza. Holanda es un país líder en el uso de la bicicleta como medio de transporte. Tiene carriles anchos exclusivos y edificios de parqueos para bicicletas.

Pedalear produce energía que puede ser usada para transportarse o para otro fin. Una persona normal puede producir 80 watts pedaleando durante una hora, pero un ciclista entrenado, en ese mismo tiempo puede generar hasta 400 watts. Una bombilla utiliza entre 25 a 60 watts.

Existen organizaciones en Guatemala que usan bicicletas viejas para convertirlas en bicimáquinas. Estas son máquinas que utilizan la energía generada pedaleando para moler, licuar, bombear agua, despulpar café, lavar ropa $\mathrm{y}$ afilar herramientas, entre otros usos. 


\section{Energía para cantar y comunicarnos}

\section{Tipos de canciones}

Las canciones responden a una necesidad de expresión. Existen canciones populares, religiosas, tradicionales, académicas, entre otras.

Canción Popular: sus mensajes son variados, sobre temas de la vida personal o social.

Canción Religiosa: sus temas son sobre aspectos espirituales de las religiones.

Tradicionales: por lo general se desconoce quién la compuso, se transmiten por tradición oral. Ayudan a generar identidad a la comunidad.

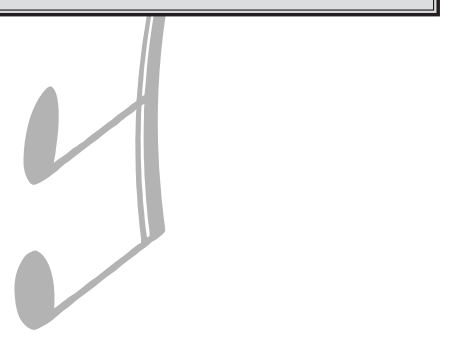

Todos los pueblos del mundo cantan porque el canto es una forma de comunicar ideas y sentimientos. Al cantar se exterioriza mucho de lo que llevamos dentro, también manifestamos nuestros estados de ánimo y nuestra cultura. La siguiente es una canción sobre una ciudad de Guatemala ubicada en la costa atlántica donde la cultura del pueblo garífuna es preponderante. $L i$ vingston, es una canción con forma binaria, porque tiene dos partes: estribi11 o (A) y una copla (B). La melodía del estribillo se repite dos veces, luego tiene intercalada una copla y al final, se repite la música del estribillo, pero con otra letra, para terminar. La canción tiene forma A-B-A.

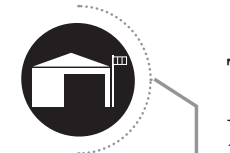

\section{Trabajemos en grupo}

Buscamos tutoriales sobre acordes de guitarra o teclado para acompañar canciones:

https:/ / www.youtube.com/watch?v=xubTUUyHocA\&spfreload=10

Observamos el video en el vínculo que se sugiere para escuchar la canción con un coro de niños escolares: https://www.youtube. $\mathrm{com} /$ watch?v=3w_miObF450

Acompañados o sin acompañamiento, cantamos la canción Livingston

Podemos acompañarnos de palmas u objetos sonoros de la clase.
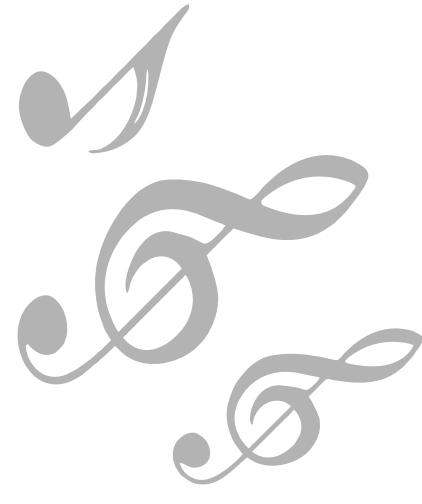

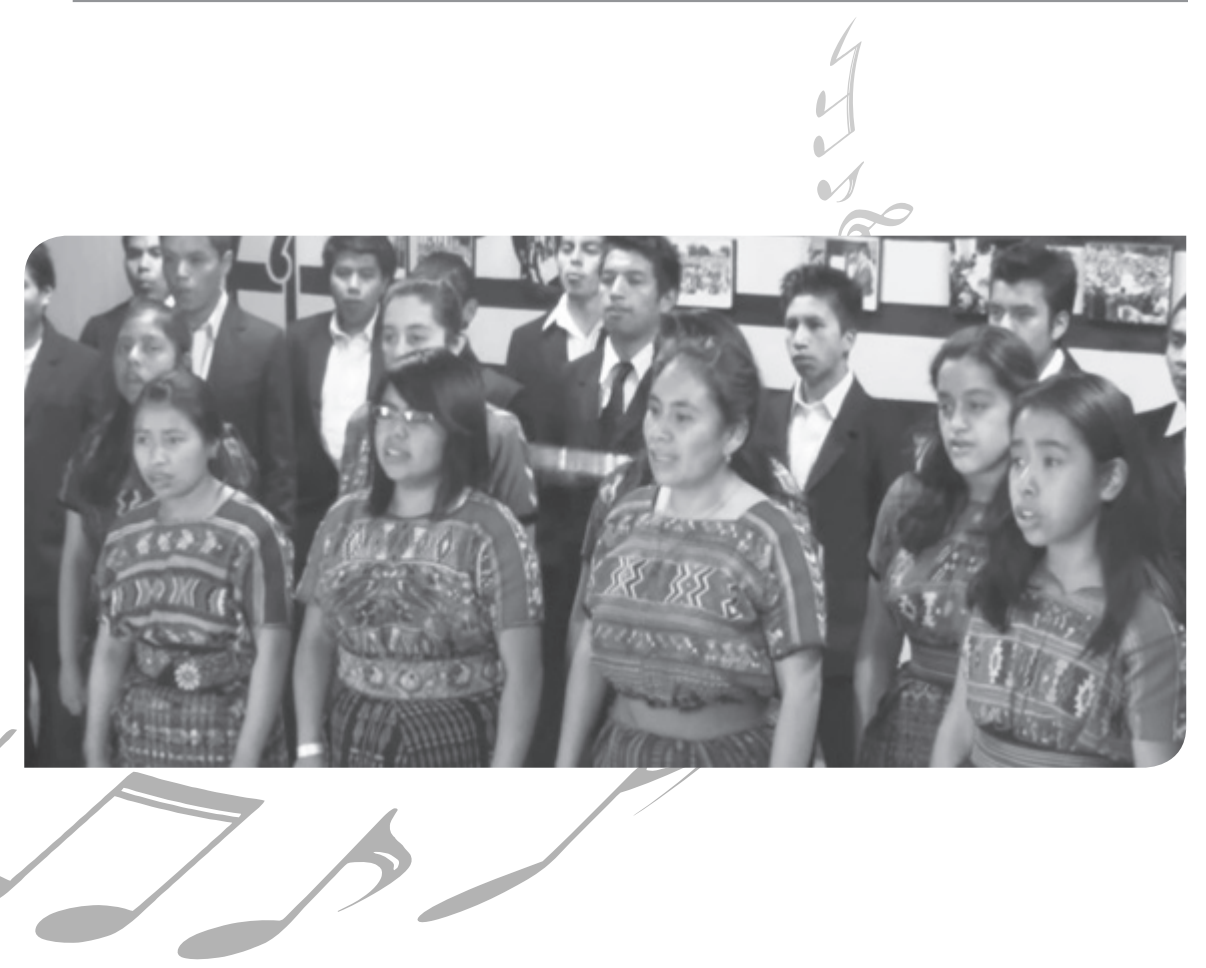




\begin{tabular}{|c|c|}
\hline $\begin{array}{l}\text { LIVINGSTON Por José Ernesto } \\
\text { Monzón }\end{array}$ & Forma de producción \\
\hline $\begin{array}{c}\text { Livingston, } \\
\text { ciudad porteña } \\
\text { eres la dueña } \\
\text { de mi canción... } \\
\\
\text { Livingston, } \\
\text { son tus morenas } \\
\text { lindas sirenas } \\
\text { que vierte el mar. }\end{array}$ & 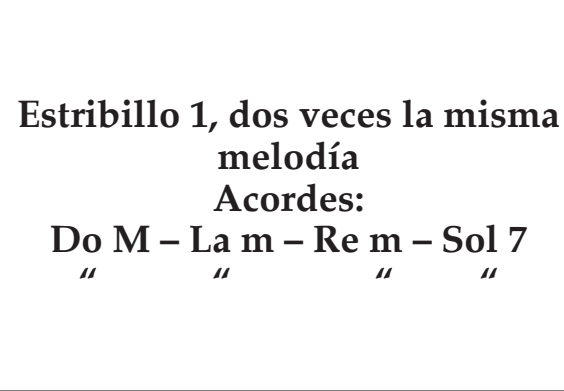 \\
\hline $\begin{array}{l}\text { Surcan goletas, } \\
\text { rompiendo al día, } \\
\text { las aguas quietas } \\
\text { de la bahía. } \\
\text { Y se remontan } \\
\text { en lento vuelo } \\
\text { lindas gaviotas } \\
\text { bajo tu cielo, } \\
\text { sobre la bruma } \\
\text { del ancho mar. }\end{array}$ & $\begin{array}{c}\text { Copla, una sola vez } \\
\text { Acordes: } \\
\text { Mi M - La m } \\
\text { Do M - Fa M - Re M - Sol M } \\
\text { Fa M - Sol M }\end{array}$ \\
\hline $\begin{array}{l}\text { Livingston, } \\
\text { el Río Dulce } \\
\text { te da un encanto } \\
\text { fascinador... } \\
\text { Livingston, } \\
\text { entre palmeras } \\
\text { eres mi fuente } \\
\text { de inspiración } \\
\text { de ins-pi-ra-ción. }\end{array}$ & 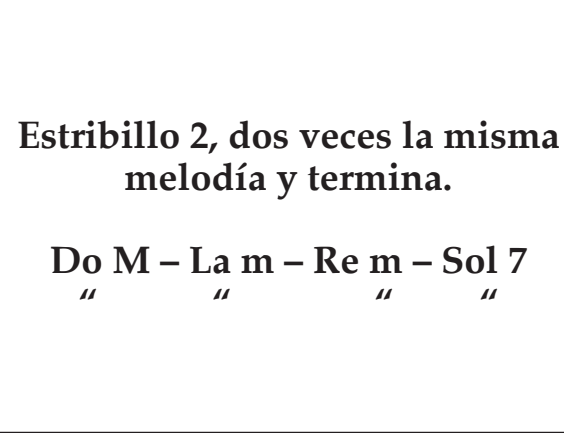 \\
\hline
\end{tabular}

\section{Conversatorio}

Organizamos un conversatorio para dialogar sobre la producción artística de la comunidad

Exponemos lo que cada quien conoce sobre esa producción, en música, artes plásticas, danza y teatro.

Planteamos cómo los productos artísticos pueden incidir en cubrir las principales necesidades familiares y comunitarias.

\section{Propongo un proyecto artístico}

Todas las producciones humanas son el efecto de una idea, convertida en proyecto. Propongo un proyecto artístico que ayude a solucionar las necesidades de las mujeres de mi familia y comunidad. El proyecto puede ser: un mural, una pieza de cerámica, una pintura, un dibujo, una escultura, entre otros. 


\section{EEstamos participando todas y todos para la mejoría de la comunidad?}

El período del gobierno de Juan José Arévalo amplió los mecanismos de participación a más sectores de la población a través de las profundas reformas administrativas, educativas y económicas, con sus leyes respectivas. Es en este período que se concede el derecho al voto para las mujeres, alfabetas. Casi 20 años después, en 1965, se amplió el derecho a voto a toda la población guatemalteca, hombres y mujeres mayores de de 18 años, independientemente de si eran o no personas alfabetas.

- ¿Cuántos años tiene el derecho al voto de ser universal en Guatemala?

- ¿Consideras que en el próximo proceso electoral podrás ir a votar? ¿Qué dificultades y facilidades existen para que lo hagas?

Además de votar, qué otros medios de participación ciudadana puedes ejercer.

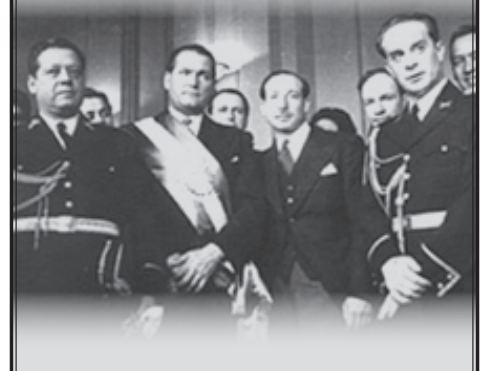

Juan José Arevalo Bermejo (segundo de izquierda a derecha) Jacobo Arbenz Guzmán (primero a la derecha)

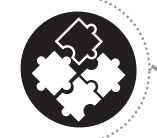

Pensamos y dialogamos sobre: ¿cómo influye el régimen político de un país en la producción de bienes tecnológicos para cuidar el ambiente y beneficiar a la comunidad?

- ¿cuánto apoyo se da a las instituciones que imparten formación tecnológica?

- ¿las leyes estimulan a las instituciones y personas para que realicen innovaciones tecnológicas?

- ¿Se promueve la protección al medio ambiente a través del desarrollo tecnológico?

- ¿Se garantiza que los bienes tecnológicos estén al servicio de toda la ciudadanía?

La definición básica de régimen democrático es una comunidad o país donde las personas que lo integran hacen las leyes; elaboran y aprueban los planes del Estado; participan activamente en la ejecución de todo lo aprobado. Este concepto de democracia surgió cuando las comunidades eran relativamente pequeñas y todas las personas que las integraban, o un número significativo de ellas, podían participar en su gobierno. Se le llamó democracia directa.

Luego surgieron comunidades muy numerosas y países muy poblados, entonces la democracia directa dejó de ser posible y se creó la democracia representativa. Se le llama así porque las personas eligen a un grupo reducido que las representa en el gobierno. Este modelo de gobierno se hizo más complejo. Se creó un sistema de partidos políticos y una estructura que organizara la forma y el período para que todas las personas que eran reconocidas como ciudadanas votaran por los candidatos o candidatas propuestas.

En la democracia participativa, es un reto garantizar que todas las personas participen en el proceso de elección de sus autoridades y representantes del gobierno, cómo se gobierna para resolver los problemas de todas las personas o para la mayoría de ellas y de qué manera se piensa mejorar en el futuro. La participación ciudadana es una forma para involucrarse en la vigilancia de las acciones de gobierno o rechazarlas, hacer auditoría social, promover consultas populares y, con base en la ley, quitarle la representatividad a una persona electa cuando no cumple con su mandato. Así que un régimen democrático en la actualidad es aquel que surge de elecciones libres y favorece una amplia participación ciudadana.

En Guatemala se habla de gobiernos democráticos cuando estos han sido electos de acuerdo con las leyes del país. En muchos casos son democráticos formalmente, pero ha hecho falta que fomenten y respeten la participación ciudadana para que se les pueda denominar gobiernos democráticos reales.

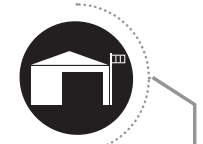

Participamos activamente en el panel foro sobre proyectos socioambientales y uso de energía alternativa. Para ello, podemos pensar sobre qué es un proyecto socio-ambiental y qué formas de energía alternativa podemos emplear en nuestra comunidad; luego formular preguntas para que las o los panelistas las aborden.

Analizamos los lineamientos para redactar un ensayo acerca de la utilización de energía alternativa en proyectos socio-ambientales a partir de lo que aprendimos en el panel foro. 


\section{Regímenes autoritarios}

Un régimen autoritario se caracteriza porque quienes gobiernan, en muchos casos, no han sido electos por la sociedad. También es común que estas personas sí hayan sido electas, pero al vencer el período para el que fueron electas no entreguen el poder.

La forma en que llegan a detentar el poder estas autoridades antidemocráticas puede variar, por ejemplo: alzamientos, revoluciones, golpes de Estado, asesinato, detención o exilio de las autoridades elegidas, simular elecciones, entre otras. Pero lo que mejor caracteriza a los regímenes autoritarios es el uso de la fuerza y la imposición para gobernar cuando las políticas que impulsan generan rechazo de parte de la población. A través de la violencia se mantienen en el gobierno.

Los regímenes autoritarios no toleran a la oposición, rechazan las propuestas de la sociedad civil y reducen al mínimo la participación ciudadana. La necesidad de usar la fuerza se debe a la imposición en su forma de llegar al poder y de que muchas de sus acciones perjudican o no beneficia a la mayoría de la población.

En Guatemala, entre 1954 y 1985, hubo gobiernos autoritarios que poseían varias o todas las características antes mencionadas. Esto provocó un enorme atraso en todos los aspectos de la vida social. De ser el país que había impulsado transformaciones novedosas, pasó a ser el país más desigual y con menor desarrollo humano en tierras continentales de América.

En este período gobernaron Guatemala ocho militares y un solo civil. Los militares fueron: Carlos Castillo Armas, Miguel Ydígoras Fuentes, Enrique Peralta Azurdia, Carlos Manuel Arana Osorio, Kjell Eugenio Laugerud García, Fernando Romeo Lucas García, Efraín Ríos Montt y Óscar Huberto Mejía Víctores. El único civil fue Julio César Méndez Montenegro, quien debió firmar un pacto con los militares para poder asumir la presidencia.

Durante el gobierno del General Romeo Lucas, inició la construcción de la hidroeléctrica Chixoy, en BajaVerapaz para dotar de energía a la población de la Ciudad Capital. El financiamiento para esta obra provino del Banco Mundial y el Banco Interamericano de Desarrollo. Para alimentar la hidroeléctrica se tenía que construir una represa, o sea que se inundó un área de gran extensión en la que vivían poblaciones de varias aldeas. El gobierno les obligó a moverse del lugar y ofreció llevarles a otras tierras. Algunas aldeas aceptaron, pero a la población de la aldea Rió Negro que existía en esas tierras desde la época prehispánica no le pareció la propuesta del gobierno porque les ofrecía tierras áridas que no eran convenientes para su actividad agrícola. Por la negativa de la población, desde 1981 iniciaron acciones represivas lideradas por el Ejército y las Patrullas de Autodefensa Civil en contra de la población de Río Negro. Estas incluyen violencia sexual, desapariciones, ejecuciones extrajudiciales y tortura entre otras. Los hechos más terribles se dieron en 1982 cuando se cometió lo que se conoce como la masacre de Río Negro después de la cual se continuó con la construcción del embalse.

"Meses después de la masacre del 13 de marzo de 1982, el INDE empezó a llenar el embalse. Como dice un declarante: "Después de la masacre, la gente sale y la empiezan a llenar, así de sencillo"
"La Comisión para el Esclarecimiento Histórico concluye que el Estado magnificó deliberadamente la amenaza militar de la insurgencia, práctica que fue acreditada en su concepto del enemigo interno. Incluir en un solo concepto a los opositores, demócratas o no; pacifistas o guerrilleros; legales o ilegales; comunistas y no comunistas, sirvió para justificar graves y numerosos crímenes. Frente a una amplia oposición de carácter político, socioeconómico y cultural, el Estado recurrió a operaciones militares dirigidas a aniquilar físicamente o amedrentarla por completo, a través de un plan represivo ejecutado principalmente por el Ejército y los demás cuerpos de seguridad nacional. Sobre esta base la Comisión del Esclarecimiento Histórico explica por qué la vasta mayoría de las víctimas de las acciones del Estado no fueron combatientes de los grupos guerrilleros sino civiles"

Fuente: Marroquín, F. (2011). Las medidas de reparación a las que el estado de Guatemala fue condenado en las sentencias emitidas por la Corte Interamericana de Derechos Humanos (tesina). Recuperado de: http:/ / www.repositorio.usac.edu. gt/3894/1/15_1531.pdf

Analizo el texto anterior y enumero los derechos humanos que se violaron. 


\section{El agua, motor de la agricultura}

Canales hidráulicos en Kaminal Juyú: tecnología al beneficio de la población

Kaminal Juyú es un sitio prehispánico maya de gran importancia en el período Preclásico, localizado en el territorio en el que más tarde se asentó la ciudad de Guatemala. Hoy quedan pocos vestigios debido a que es estructura de tierra, pero más aún debido al desarrollo urbano de la ciudad. Se caracteriza por una serie de canales que transportaban agua desde un lago, situado en el área hoy llamada Miraflores, hasta los campos de cultivo a varios kilómetros de distancia.

Excavaciones arqueológicas han determinado el uso de tres tecnologías en distintos periodos:

- Un canal con compuertas para inundaciones controladas.

- Un canal ancho con canales secundarios y un salto para aminorar la velocidad del agua y regar cultivos en tablones.

- Un canal conectado con el anterior y con posibles pozos de agua de lluvia con sistema de compuertas. El fondo del canal tiene declives para retener sedimentos.

El sistema de canales todavía es usado en la agricultura, algunas veces acompañado de sistemas de bombeo, especialmente porque el agua se extrae de pozos o se trae de nacimientos o ríos lejanos.
El agua es vital para todos los seres vivos. Necesitamos consumir agua todos los días para que nuestro cuerpo funcione adecuadamente. El $70 \%$ de la superficie del planeta está formada por agua, pero solo el $2.5 \%$ es agua dulce, apta para consumo humano. El agua dulce la encontramos en lagos, lagunas, ríos, manantiales y los casquetes polares. Desafortunadamente, perjudicamos nuestra fuente de vida: el cambio climático provoca que los glaciares se deshielen y nuestro estilo de vida y producción contamina muchas fuentes de agua dulce. Además, debido a la sobreexplotación de la tierra, la deforestación, la urbanización y las sequías se produce un proceso de desertificación o empobrecimiento de las tierras que amenaza la producción de alimentos. Como ya discutimos en semanas anteriores, consumir alimentos que han sido regados con agua contaminada aumenta el riesgo de padecer enfermedades.

El aprovisionamiento de agua es una constante preocupación de todos los pueblos. Las grandes civilizaciones antiguas comenzaron su desarrollo en lugares cercanos a fuentes de agua, pero conforme su población aumentó recurrieron a la ingeniería hidráulica para captar y dirigir caudales de agua a sus campos de cultivo y alimentar a una población cada vez mayor. En Petén, donde las lluvias son temporales, los mayas almacenaron agua de lluvia captada en plazas, edificios y caminos y la filtraban con arena de cuarzo.

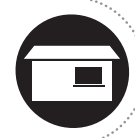

- ¿Cómo obtenemos agua en casa?

- ¿Qué medidas tomamos para no desperdiciarla y que no se contamine? 


\section{Agua al servicio de la comunidad}

La falta de disponibilidad de agua produce desasosiego, malestar además de pérdida de tiempo, recursos y esfuerzo en su acarreo. Por esto se ha declarado que el acceso al agua es un derecho humano. En Guatemala, no todas las comunidades tienen cerca una fuente de agua. En algunas comunidades de la Sierra de Los Cuchumatanes, existen pocas fuentes de agua disponibles, por lo que la población depende del almacenamiento de agua de lluvia.

Para tener una provisión constante de agua, las comunidades se organizan en el Comité de Agua o el Cocode para comprar una fuente de agua y luego trasladar el líquido a su comunidad. Los Comités de Agua comunitarios y Cocodes realizan un gran trabajo: organizan a la comunidad, buscan una fuente de agua, recolectan fondos y escriben proyectos para comprar la fuente de agua y su canalización, supervisan la construcción del sistema de agua, organizan la limpieza y distribución del agua, así como el pago del servicio.

Una vez localizada la fuente de agua, esta se canaliza hacia un tanque de captación cercano a la comunidad, pero situado en una parte alta para aprovechar la fuerza de gravedad para facilitar su distribución. Así se utiliza la energía potencial del agua y se evita gastos por bombeo. Los sistemas de distribución de agua por gravedad son más baratos y de fácil mantenimiento. El tanque de captación debe limpiarse periódicamente: lavar las paredes y el fondo con un cepillo y enjuagar varias veces.

Cuando la ciudad de Guatemala fue trasladada al valle de la Ermita, se aprovechó el Montículo de la Culebra, construida por los habitantes de Kaminal Juyú, para construir encima el Acueducto de Pinula. El propósito de ambas obras hidráulicas era trasladar agua a la ciudad. Sin agua no solo no hay vida, además ningún proceso productivo puede llevarse a cabo.

Generalmente, por la división desigual de tareas, las mujeres son las responsables de tener agua en la casa. ¿Cuánto tiempo y esfuerzo invierten ellas para tener agua en casa? ¿Qué riesgos corren al ir a traer el agua? ¿Hay un impacto en su cuerpo por las condiciones de recolección de agua? ¿Reciben ayuda? ¿De quién? ¿Opinan las mujeres respecto a los proyectos de agua comunitaria?

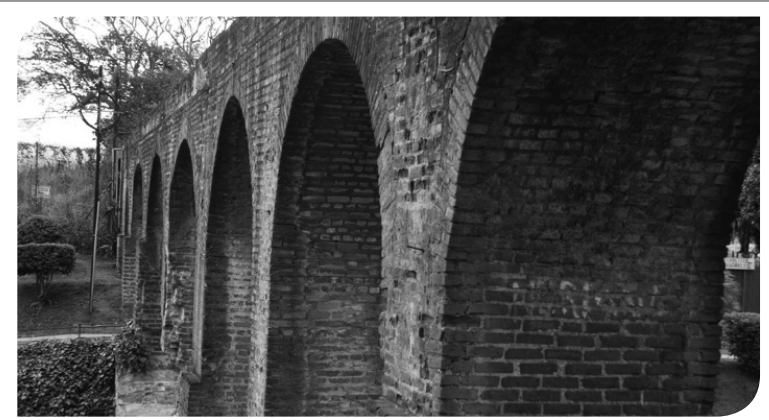

Presentamos a la clase nuestra propuesta de producto o servicio que utilice energía alternativa. Discutimos sobre las ventajas y desventajas del uso de energía en el proceso productivo.

- ¿Alguna se relaciona con el acceso y la distribución del agua?

\section{Agua limpia para beber}

Contar con agua fresca y limpia para beber, preparar alimentos, lavarse las manos y los trastos es imprescindible para estar saludables y prevenir enfermedades. Existen varios métodos para purificar el agua:

- Hervir el agua durante 10 minutos. Poner el agua al fuego y contar 10 minutos desde que comienza a burbujear. Antes de beberla podemos agitarla para que tenga aire nuevamente y su sabor recupere frescura.

- Clorar, se agregan 3 gotas de cloro a 1 litro de agua. Si agregamos menos cloro, el agua no se descontamina y si agregamos más, tiene mal sabor.

- Exponer al sol, se utiliza el método SODIS. Llenamos botellas de plástico o vidrio transparente y las ponemos al sol, al menos 6 horas en días soleados y dos días, en nublados. El agua se bebe o utiliza el mismo día que queda desinfectada para evitar que produzca microorganismos.

- Filtrar, utilizando uno de los filtros que promocionan diferentes ONG.

\begin{tabular}{l} 
1. Reflexiono respecto al \\
uso racional de la energía \\
eléctrica. \\
2. Escribo cinco maneras \\
de economizar energía \\
eléctrica en casa y en la \\
comunidad. \\
\hline
\end{tabular}




\section{Tablạs de verodád: Implicación y doble implicación.}

En una implicación la primera proposición " $p$ " se llama antecedente y la segunda proposición " $q$ " se denomina consecuente. También se puede leer como: " $p$ implica $q$ ".

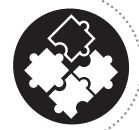

Consideremos la siguiente proposición compuesta:

"Si cocinamos con una estufa solar ahorramos energía".

Usamos simbología lógica para escribir en nuestro cuaderno la proposición compuesta y comentamos con el grupo sobre el valor de verdad.

En nuestro cuaderno, copiamos y completamos la siguiente tabla. Escribimos las proposiciones p y q con palabras. Comentamos con nuestro equipo cuál es el posible valor de verdad de cada proposición compuesta formada según la combinación de $V$ y $F$.

$p=$ Cocinamos con una estufa solar.

$q=$ Ahorramos energía.

\begin{tabular}{|c|c|l|l|}
\hline$p$ & $q$ & Proposición compuesta escrita en palabras $(p \Rightarrow p)$ & Valor de verdad $(p \Rightarrow q)$ \\
\hline V & V & & \\
\hline V & F & & \\
\hline F & V & & \\
\hline F & F & & \\
\hline
\end{tabular}

Comparamos la tabla que llenamos anteriormente con la siguiente. Contrastamos los valores de verdad que asignamos en la última columna con los valores asignados en la nueva tabla. Comentamos nuestras dudas.

\begin{tabular}{|c|c|l|c|}
\hline$p$ & $q$ & \multicolumn{1}{|c|}{ Proposición compuesta escrita en palabras $(p \Rightarrow q)$} & Valor de verdad $(\boldsymbol{p} \Rightarrow \boldsymbol{q})$ \\
\hline $\mathrm{V}$ & $\mathrm{V}$ & $\begin{array}{l}\text { Si cocinamos con una estufa solar ahorramos energía. } \\
\text { Dado que } p \text { y } q \text { son verdaderas, la proposición implicación es } \\
\text { verdadera pues } p \text { sí implica a } q .\end{array}$ & $\mathrm{V}$ \\
\hline $\mathrm{V}$ & $\mathrm{F}$ & $\begin{array}{l}\text { Si cocinamos con una estufa solar no ahorramos energía. } \\
\text { La proposición } p \text { es verdadera y } q \text { es falsa. La proposición } \\
\text { implicación es falsa pues } p \text { no implica a } q .\end{array}$ & $\mathrm{F}$ \\
\hline $\mathrm{F}$ & $\mathrm{V}$ & $\begin{array}{l}\text { Si no cocinamos con estufa solar ahorramos energía. } \\
\text { La proposición } p \text { es falsa pero } q \text { es verdadera. La prop- } \\
\text { osición implicación es verdadera pues si } p \text { es falsa no } \\
\text { puede implicar a } q \text { pues no ocurre a causa de } p \text {. }\end{array}$ & $\mathrm{V}$ \\
\hline $\mathrm{F}$ & $\mathrm{F}$ & $\begin{array}{l}\text { Si no cocinamos con estufa solar no ahorramos energía. } \\
\text { Ambas proposiciones son falsas. La proposición } q \text { es falsa } \\
\text { como implicación de que } p \text { es falsa. }\end{array}$ & $\mathrm{V}$ \\
\hline
\end{tabular}




\begin{tabular}{|c|c|c|c|c|c|}
\hline \multicolumn{3}{|c|}{$\begin{array}{l}\text { Tabla de verdad para } \\
\text { implicación }\end{array}$} & \multicolumn{3}{|c|}{$\begin{array}{l}\text { Tabla de verdad para } \\
\text { doble implicación }\end{array}$} \\
\hline$p$ & $q$ & $p \Rightarrow q$ & $p$ & $q$ & $p \Rightarrow q$ \\
\hline $\mathrm{V}$ & $\mathrm{V}$ & $\mathrm{V}$ & $\mathrm{V}$ & $\mathrm{V}$ & $\mathrm{V}$ \\
\hline V & $\mathrm{F}$ & $\mathrm{F}$ & $\mathrm{V}$ & $\mathrm{F}$ & $\mathrm{F}$ \\
\hline $\mathrm{F}$ & $\mathrm{V}$ & $\mathrm{V}$ & $\mathrm{F}$ & $\mathrm{V}$ & $\mathrm{V}$ \\
\hline $\mathrm{F}$ & $\mathrm{F}$ & $\mathrm{V}$ & $\mathrm{F}$ & $\mathrm{F}$ & $\mathrm{V}$ \\
\hline
\end{tabular}

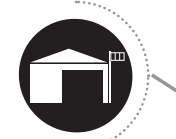

En parejas construimos proposiciones lógicas compuestas a partir de la información compartida en el panel foro y las demostramos en tablas de verdad.

\section{(1i)}

Consideremos las siguientes proposiciones:

$p=$ Utilizamos energía alternativa.

$q=$ Ahorramos agua.

Escribimos las siguientes proposiciones compuestas utilizando símbolos:

- Si utilizamos energías alternativas entonces ahorramos agua.

- Si ahorramos agua entonces utilizamos energía alternativa.

- No utilizamos energía alternativa.

- No ahorramos agua.

- Si no utilizamos energía alternativa entonces no ahorramos agua.

- Utilizamos energia alternativa si y solo si ahorramos agua.

- No utilizamos energía alternativa si y solo si no ahorramos agua.

Para las siguientes proposiciones p y q escribimos con palabras $p \leftrightarrow p$ y determinamos el valor de verdad de la misma.
1) $p \times$ Cobán es la cabecera de Alta Verapaz. cabecera de Santa Rosa
2) $p=3+4=8$
$q=$ Santa Rosa es la
$q=12-5=7$

La proposición compuesta llamada implicación es también conocida como condicional y la proposición compuesta de doble implicación se conoce también como bi condicional.

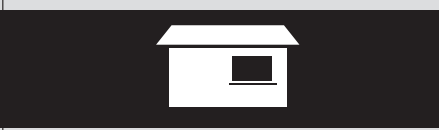

- ¿Conoces los términos inductivo y deductivo?

Investiga qué es el racionamiento inductivo y qué es el razonamiento deductivo. Luego contrasta ambos tipos de razonamiento escribiendo en qué se diferencian. 


\section{Intensidad de corriente}

La conductividad se refiere a la capacidad de un material o sustancia para dejar pasar libremente la corriente eléctrica. La conductividad de un material depende de su estructura atómica y molecular. Un material es semiconductor cuando se comporta o bien como conductor o bien como aislante en determinadas condiciones.

Si el cuerpo humano (compuesto en gran medida por agua y sal, una sustancia conductora) entra en contacto con esta electricidad, según los niveles de potencia podrá sentir desde un cosquilleo o de calambres, hasta las quemaduras graves e incluso morir.

Fuente : h t t p : / / w w w ejemplos.co / 30 -ejemplos-de-conductores-yaislantes/\#ixzz4Upa0XIgw

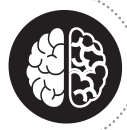

Observamos y analizamos el diagrama con el que se compara la intensidad de corriente eléctrica. Respondemos las preguntas:

- ¿En cuál de las tuberías la cantidad de agua que atraviesa es mayor en la unidad de tiempo?

- ¿En qué tubería podemos decir que es menor la intensidad de corriente de agua?

- ¿De qué manera se puede calcular la intensidad de corriente de agua?

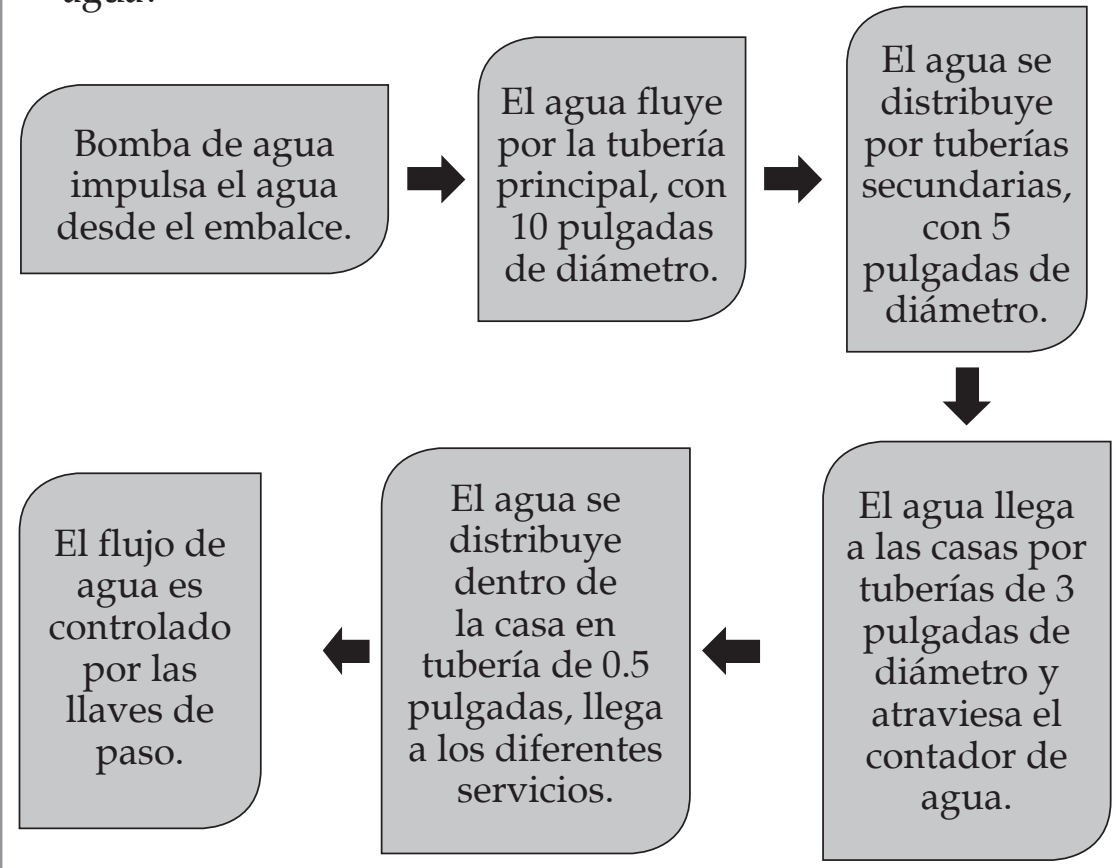

La intensidad de la corriente eléctrica es la cantidad de carga eléctrica que circula por una sección del conductor por unidad de tiempo. Está determinada por la magnitud de la fuerza electromotriz que la origina. A mayor fuerza electromotriz, mayor intensidad de corriente. En el Sistema Internacional de Unidades se expresa en $\mathrm{C} / \mathrm{s}$ (coulombios sobre segundo), unidad que se denomina amperio. Para medir la corriente eléctrica se utiliza un instrumento llamado amperímetro. La intensidad de corriente se puede calcular de la siguiente manera:

Intensidad de corriente $=\psi$ antidad de carga $/$ tiempo de circulación, $\mathrm{I}=\mathrm{Q} / \mathrm{s}$

Luego de escuchar, participar y aprender del panel foro, escribo el argumento central que quiero desarrollar en mi ensayo, siguiendo los lineamientos que me dará mi tutora.

Redacto un ensayo sobre el uso de la energía y la tecnología a beneficio de la comunidad usando la información que he recopilado, lo expuesto en el panel foro y mis argumentos. 
Explicamos cuál de los ejercicios siguientes representa la corriente eléctrica continua y cuál, la corriente alterna.

1. Nos organizamos en una hilera. Pasamos varias pelotas, una a una cada pelota en el orden de la hilera, del primero al último. ¿Qué tipo de corriente eléctrica puede representar esta actividad?

2. Nos colocamos formando una hilera. Pasamos una pelota de ida desde el primero al último y luego de regreso, del último al primero. En ambos sentidos. ¿Con qué tipo de corriente se puede relacionar una analogía?

Ahora por diversión vamos a realizar el ejercicio colocándonos en dos filas, una frente a la otra a una distancia de seis metros. Cada estudiante de la fila uno tiene una pelota la cual debe lanzar a su compañera (o) de la fila de enfrente usando la técnica correcta para maximizar la energía que usa. Luego la fila dos devuelve la pelota a la fila uno usando otro tipo de saque.

\begin{tabular}{|l|l|}
\hline \multicolumn{2}{|c|}{ Componentes del circuito eléctrico } \\
\hline Componente & \multicolumn{1}{c|}{ Función } \\
\hline $\begin{array}{l}\text { Fuente de voltaje o ten- } \\
\text { sión }\end{array}$ & $\begin{array}{l}\text { Transforma al- } \\
\text { gún tipo de energía } \\
\text { (química,hidráulica), en } \\
\text { energía eléctrica (tensión } \\
\text { eléctrica o voltaje) }\end{array}$ \\
\hline Conductores & $\begin{array}{l}\text { Transforma la energía eléc- } \\
\text { trica en la forma deseada }\end{array}$ \\
\hline Receptor & $\begin{array}{l}\text { Es el “convertidor" de } \\
\text { energía. }\end{array}$ \\
\hline
\end{tabular}

\section{Corriente continua}

La corriente eléctrica es un medio para transformar la energía eléctrica en otro tipo de energía, como energía mecánica, energía térmica y energía luminosa. La corriente es continua (CC) o corriente directa cuando las cargas eléctricas se mueven en un solo sentido. Es el caso de las pilas y muchos dinamos, por ejemplo, en las pilas de una linterna en la que la corriente siempre va hacia la bombilla

\section{Corriente alterna, CA}

Se denomina corriente alterna (CA) a la corriente eléctrica en la que la magnitud y sentido varían cíclicamente, es decir, que los electrones se mueven alternativamente en uno y otro sentido. La "corriente alterna" es el tipo de corriente de uso residencial e industrial. Es el tipo de electricidad que llega a los hogares. La mayoría de aparatos eléctricos funcionan con corriente alterna; aunque algunos dispositivos, como los focos y planchas, pueden funcionar con los dos tipos de corriente.

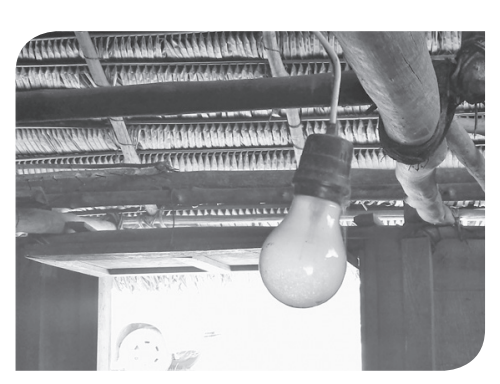

Componentes de los circuitos eléctricos

Un circuito eléctrico es el trayecto o ruta de una corriente eléctrica. El término se utiliza principalmente para definir un trayecto continuo compuesto por conductores y dispositivos receptores, que incluye una fuente de fuerza electromotriz que, al ejercer presión o tensión sobre las cargas, transporta la corriente por el circuito.

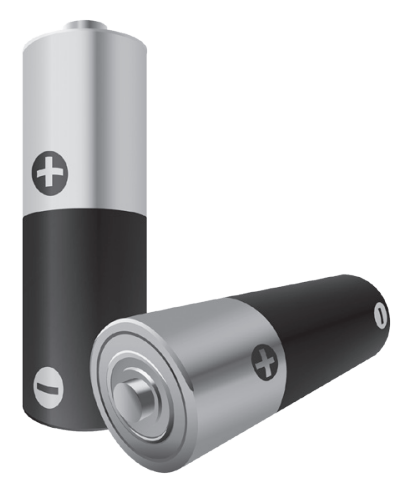




\section{Creación de Proyectos}

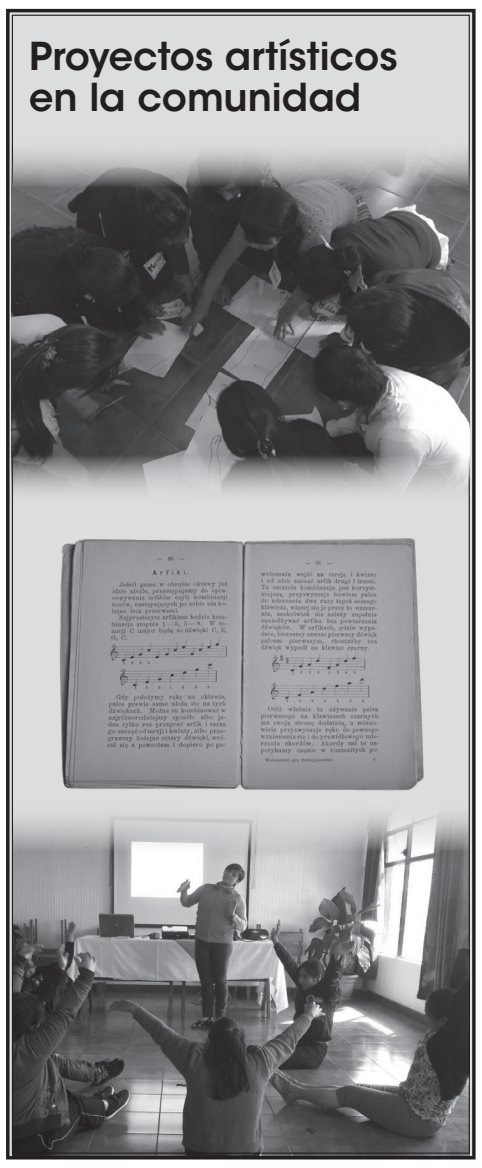

Todos los hombres y mujeres podemos generar ideas para solucionar las necesidades personales, familiares, comunitarias. Nuestro proyecto actual está dirigido a que las ideas generadas valoren el conocimiento para mejorar nuestra vida. Pero el conocimiento no surge de la nada, puede venir de una situación casual o de una duda sobre cualquier área. Crear un proyecto es generar ideas y ordenarlas para llevarlas a cabo. Para ello es importante hacerse preguntas que dirijan su planteamiento. Luego de haber identificado y priorizado las necesidades se estableció la acción/proyecto a desarrollar. Ahora los siguientes pasos en el proceso son:

- ¿Qué recursos necesito para actuar?

- ¿Cuánto tiempo me llevará?

- ¿Cómo puedo saber si ya está resuelta esa necesidad?

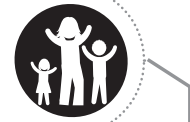

\section{Trabajemos en grupo}

Hagamos una lluvia de ideas sobre un proyecto artístico que beneficie a la comunidad.

Este proyecto puede ser: un mural, una exposición de artes visuales, una obra de teatro, un cancionero tradicional, un concierto de canciones, una presentación de danza.

Respondiendo a las preguntas que se formularon arriba, relacionemos el proyecto elegido con una necesidad concreta.

Si tenemos acceso a computadora podemos elaborar una matriz en excel sobre las necesidades detectadas en la comunidad. Se pueden identificar para cada necesidad, el grupo de población que se ve afectada, derechos asociados a esta necesidad y posibles soluciones. Si no tenemos computadora podemos trabajar en esta tabla.

\begin{tabular}{|l|l|l|}
\hline \multicolumn{3}{|c|}{ Necesidades de la comunidad } \\
\hline Grupo de población & Derechos asociados & Posibles soluciones \\
\hline & & \\
\hline & & \\
\hline & & \\
\hline & & \\
\hline & & \\
\hline
\end{tabular}




\section{Organizando las ideas}

Los organizadores gráficos nos permiten presentar nuestro proyecto fácilmente, como un mapa de lo que queremos exponer. En él se colocan solo las ideas principales, y sobre ellas se expone todo el proyecto. El siguiente es un ejemplo de cómo presentar un proyecto de mural:

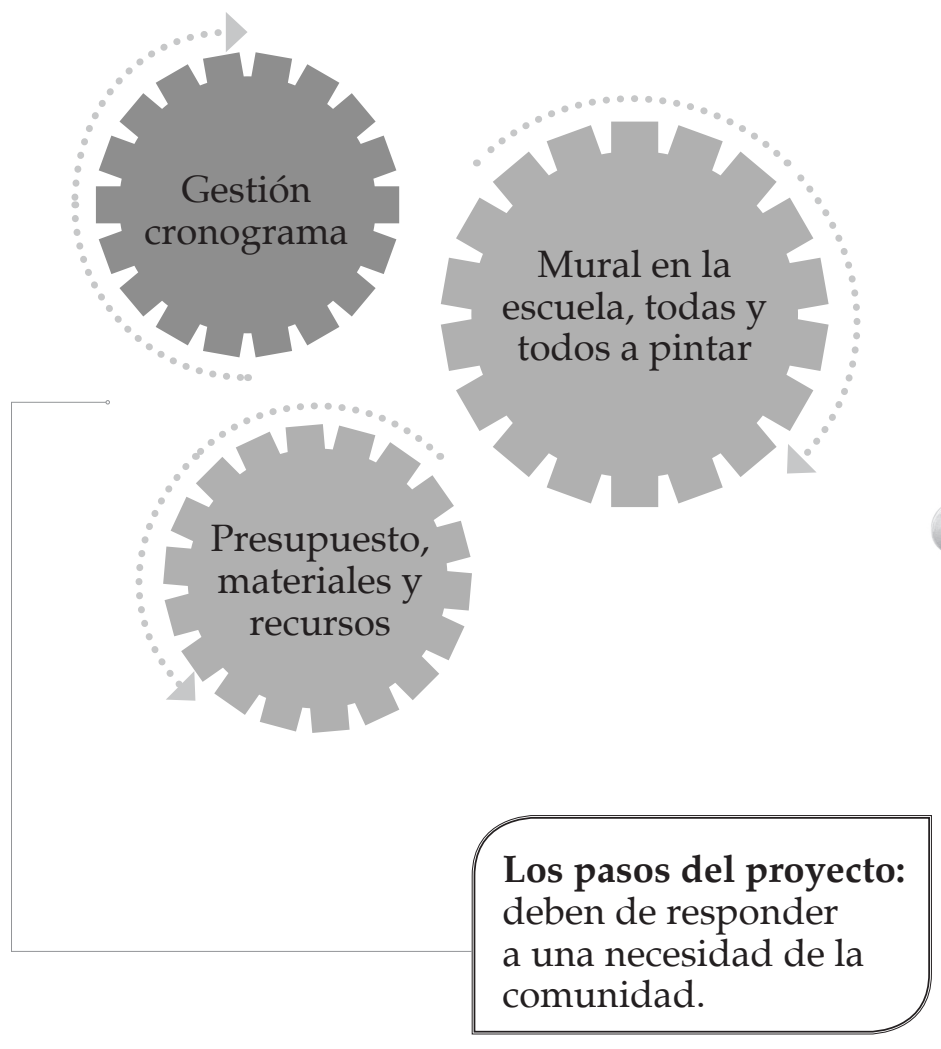

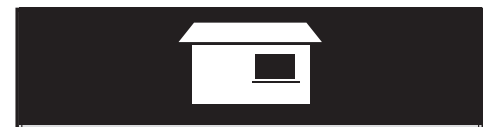

Hago juego de Mimos con mi familia

Jugamos de transmitir mensajes por medio de mímica Todos y todas tenemos que transmitir un mensaje de al menos un par de frases Pensemos por ejemplo: ¿cómo diríamos con mímica, "tengo hambre, quiero comer frutas y vegetales"? Cada quien inventa su frase, la actúa con mímica y el resto de la familia debe identificar el mensaje.

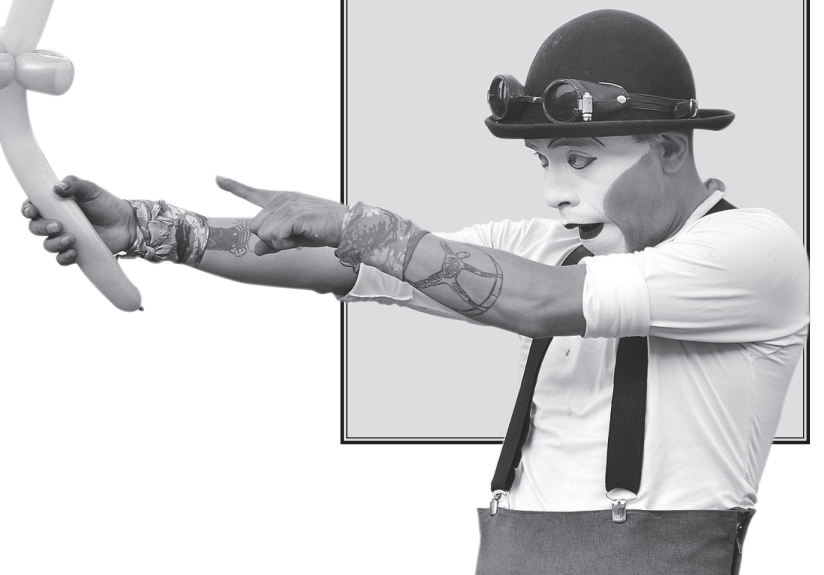

En parejas, medimos nuestra participación y rendimiento, lo que hemos aprendido:

\begin{tabular}{|c|c|c|c|c|c|c|}
\hline \multirow[t]{2}{*}{$\begin{array}{c}\text { Agregamos una } X \text { según lo que consideramos de } \\
\text { nuestro desempeño }\end{array}$} & \multicolumn{6}{|c|}{$\begin{array}{c}1=\text { deficiente, } 2=\text { regular, } 3=\text { regular, } 4= \\
\text { bueno, } 5=\text { excelente }\end{array}$} \\
\hline & $1^{\mathrm{a}}$ & $2^{\mathrm{a}}$ & $3^{\mathrm{a}}$ & $4^{\mathrm{a}}$ & $5^{\mathrm{a}}$ & \\
\hline \multicolumn{7}{|l|}{ Participamos en todas las actividades sugeridas } \\
\hline \multicolumn{7}{|l|}{ Aportamos ideas ante cada situación de aprendizaje } \\
\hline \multicolumn{7}{|l|}{$\begin{array}{l}\text { Utilizamos lo aprendido en beneficio de nuestra familia y } \\
\text { comunidad }\end{array}$} \\
\hline \multicolumn{7}{|l|}{$\begin{array}{l}\text { Tenemos siempre disposición a enfrentar los nuevos } \\
\text { retos que se nos plantean }\end{array}$} \\
\hline $\begin{array}{l}\text { Compartimos nuestras ideas y emociones por medio de } \\
\text { la expresión artística }\end{array}$ & & & & & & \\
\hline
\end{tabular}




\section{Comunicar para convencer}

\begin{tabular}{|c|c|c|c|c|}
\hline & PREPOSICIÓN & USO/EXPRESIÓN & $\begin{array}{c}\text { USO } \\
\text { CORRECTO }\end{array}$ & $\begin{array}{c}\text { USO } \\
\text { INCORRECTO }\end{array}$ \\
\hline & A & $\begin{array}{l}\text { Destino o localiza- } \\
\text { ción }\end{array}$ & $\begin{array}{l}\text { Cambiar a ener- } \\
\text { gía solar }\end{array}$ & Vamos a arriba \\
\hline & Bajo & $\begin{array}{l}\text { Localiza situación } \\
\text { inferior }\end{array}$ & $\begin{array}{l}\text { El motor está } \\
\text { bajo la mesa }\end{array}$ & $\begin{array}{l}\text { Bajo mi punto de } \\
\text { vista }\end{array}$ \\
\hline & Con & $\begin{array}{l}\text { Compañía o colabo- } \\
\text { ración }\end{array}$ & $\begin{array}{l}\text { Planifico con mi } \\
\text { mamá }\end{array}$ & $\begin{array}{l}\text { Con excepción de } \\
\text { ella, todos llega- } \\
\text { ron }\end{array}$ \\
\hline & & & & Contra más cami- \\
\hline \multirow{3}{*}{$\begin{array}{l}\text { Preposiciones } \\
\text { Son palabras que relacio- } \\
\text { nan elementos de una ora- } \\
\text { ción. Indican origen, des- } \\
\text { tino, lugar, procedencia o } \\
\text { motivo y son: a, ante, bajo, } \\
\text { cabe, con, contra, de, desde, } \\
\text { durante, en, entre, hacia, } \\
\text { hasta, mediante, para, por, } \\
\text { según, sin, sobre, tras. Al- } \\
\text { gunas tienden a ser usadas } \\
\text { erróneamente: }\end{array}$} & Contra & o ubicación & el muro & $\begin{array}{l}\text { no, más me duele } \\
\text { el pie. }\end{array}$ \\
\hline & De & Espacial & Me voy de viaje & $\begin{array}{l}\text { Tengo que ver } \\
\text { algo de urgencia }\end{array}$ \\
\hline & En & Ubicación espacial & $\begin{array}{l}\text { Estoy en el } \\
\text { molino }\end{array}$ & Regreso en un día \\
\hline
\end{tabular}

\section{Intención comunicativa}

La intención comunicativa es el propósito que tenemos cuando decimos algo y la utilizamos para convencer a quien nos escucha de que nuestro razonamiento es el correcto. De acuerdo a lo que queremos expresar, las intenciones puedes ser: informativas o referenciales, apelativas, emotivas, poéticas y fáticas.

Informativas o referenciales: Se utiliza un lenguaje objetivo y verificable. Se utilizan términos técnicos y científicos.

Apelativas: Se espera que el receptor o receptora reaccione a lo que decimos. Para ello, utilizamos expresiones imperativas o interrogativas.

Emotivas: Se hace énfasis en los sentimientos que tenemos. Predomina la subjetividad.

Poéticas: Se hace uso de figuras retóricas, como metáforas, comparaciones o hipérboles. Se usan en los poemas y canciones.

Fáticas: Establece, prolonga o interrumpe para mantener contacto con el hablante. Se utilizan muletillas, frases breves y repeticiones.

Redactaremos nuestro ensayo usando algunas de las intenciones comunicativas descritas arriba, aplicando nuestros conocimientos para mejorar nuestra comunidad. Tomaremos en cuenta los temas en este proyecto: desarrollo de tecnología al servicio de la comunidad, necesidades de la comunidad, energía alternativa, beneficios de proyectos productivos, desarrollo de mural artístico.

Al terminar mi borrador de ensayo verifico:

- Uso correcto de las preposiciones

- Que contenga introducción, desarrollo y conclusión

- Inclusión de citas de documentos, comentarios de autoridades, cifras y datos que respalden mi opinión.

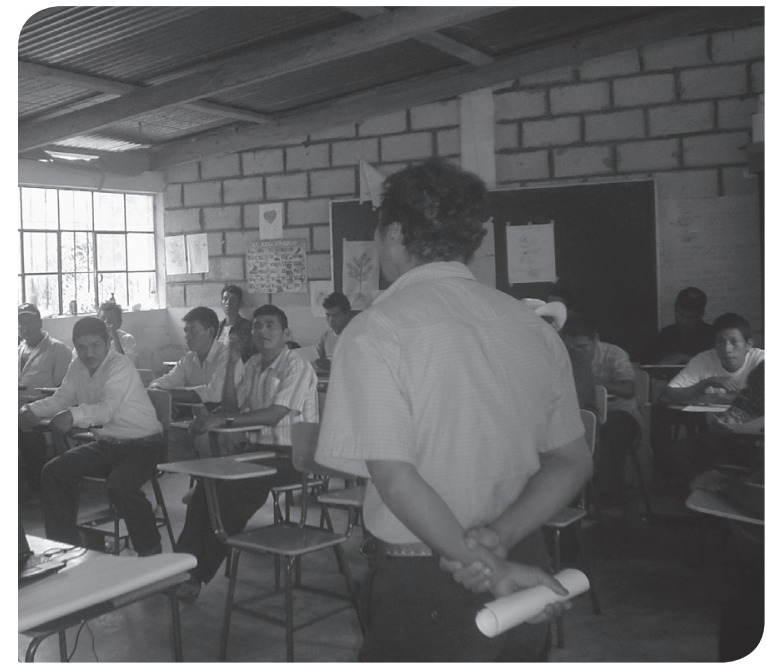


- ¿Por qué el movimiento estudiantil y otros movimientos ciudadanos representan amenazas a los gobiernos autoritarios?

Para vencer el sufrimiento

La política de tierra arrasada se sufrió en más de 600 comunidades del país, la mayoría con población de origen maya. Para sobrevivir y vencer las secuelas de este holocausto, las personas aplicaron varias estrategias.

"Para alguna gente, el dar un significado a los sueños, el hablar de su experiencia de tortura o de peligro, era su manera de enfrentar la violencia. Para la cultura maya, los sueños hilan la vida de hoy y la vida pasada de la persona, orientando su futuro y guardan la comunicación con los antepasados. Las personas que sufrieron tortura cuentan que los sueños les ayudaron a mantener la mente activa y a no perder la esperanza."

Fuente: Oficina de Derechos Humanos del Arzobispado de Guatemala. (2000). Memoria, verdad y esperanza. Recuperado de: http:/ / www.odhag.org.gt/pdf/ tomo_1.pdf

- ¿Me sirve alguna de estas estrategias para reponerme de un sufrimiento muy grande? ¿Por qué?

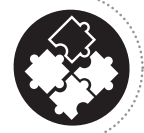

Explicamos el papel que juega la participación ciudadana y la cultura de paz en el ejercicio de nuestro derecho de aprovechar los recursos tecnológicos y naturales para resolver problemas familiares y de la comunidad.

\section{Desarrollo del conflicto armado interno}

Después de la contra revolución en 1954, las y los partidarios de la Revolución de Octubre que no salieron al exilio sufrieron persecución, encarcelamiento y asesinato. Se les acusó de ser comunistas, se prohibió las organizaciones obreras, campesinas, estudiantiles, políticas y sindicales. El Partido Guatemalteco del Trabajo (PGT), de ideología comunista, fue prohibido y pasó a la clandestinidad. Las medidas que habían tomado los gobiernos de la revolución para combatir la pobreza y la injusticia fueron anuladas. Debido a la represión del gobierno, el pueblo no podía mostrar su inconformidad por la vía política, el diálogo, ni la negociación.

En 1960, un grupo de oficiales jóvenes del Ejército quienes rechazaban el uso del territorio nacional para entrenamiento de tropas extranjeras lideró un levantamiento armado, el cual fue derrotado. Algunos sobrevivientes se incorporaron a la primera organización guerrillera: las Fuerzas Armadas Rebeldes -FARque fue creciendo en apoyo y capacidad. El Ejército de Guatemala comenzó a recibir asesoramiento de militares estadounidenses para derrocar a los grupos de la guerrilla y a partir de 1966 comienza una campaña para sembrar terror y restar apoyo a la guerrilla. Esta campaña deja aproximadamente ocho mil muertos, principalmente población civil. La guerrilla afirmaba que la lucha armada era la continuación de la lucha política, pero por otra vía; el Ejército planteaba que para mantener la paz debía reprimir a la guerrilla y a la población que la apoyase.

El movimiento guerrillero, se organiza, diversifica y despliega en todas las regiones. Se conforman tres organizaciones guerrilleras: Fuerzas Armadas Rebeldes, Ejército Guerrillero de los Pobres y la Organización del Pueblo en Armas (FAR, EGP y ORPA). En 1982, las tres organizaciones guerrilleras y una facción del Partido Guatemalteco del Trabajo (PGT) se unieron para formar la Unidad Revolucionaria Nacional Guatemalteca (URNG).

Con la idea de derrotar a la guerrilla a finales de 1981, el Ejército impulsa la política de tierra arrasada. Esto produjo graves sufrimientos a la población civil quienes recibieron agresiones directas y muchas veces colectivas por el Ejército de Guatemala.

Presentamos, a quienes integran nuestro equipo, el ensayo elaborado para recibir sus aportes (insumos), mediante una evaluación.

Tomamos en cuenta lo que cada integrante informa al grupo sobre las necesidades familiares y comunitarias que pueden ser satisfechas con innovaciones tecnológicas y los recursos de la comunidad. 


\section{La cultura de paz y el ejercicio de ciudadanía}

La sociedad guatemalteca necesita recuperarse de los efectos de la guerra. Para ello es fundamental que aprendamos a dialogar aun cuando tengamos visiones diferentes, para acordar lo que convenga a la totalidad o a la mayoría, respetando los derechos de todas y todos.

En una cultura de paz es fundamental respetar las ideas de las y los demás, su identidad, costumbres y formas de ver el mundo. Nuestro país tiene una gran riqueza cultural que se puede aprovechar mediante el reconocimiento y el respeto a la diversidad.

El desarrollo humano sostenible y la aplicación de la justicia son responsabilidad de todas y todos. Las autoridades estatales y municipales son responsables de planificar, administrar recursos y ejecutar acciones. La población debe participar activamente y vigilar el respeto a los derechos humanos. Todas y todos podemos colaborar en proyectos, proponer cambios en algunas políticas, solicitar información y cuentas claras, oponernos a medidas arbitrarias o injustas, entre otras acciones.

Los limitadas avances que se han tenido en el cumplimiento de los Acuerdos de Paz, son resultado de 20 años de participación y presión ciudadana. Cuando es organizada y con criterios claros, puede lograr cambios profundos y sostenidos.
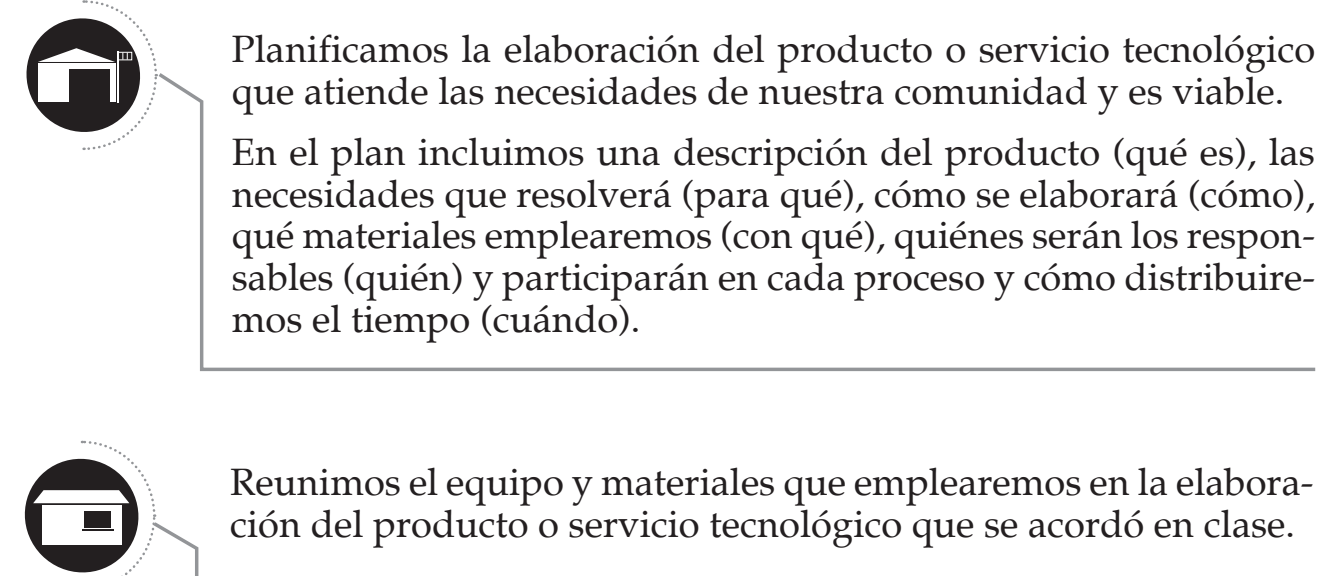

Reunimos el equipo y materiales que emplearemos en la elaboración del producto o servicio tecnológico que se acordó en clase.

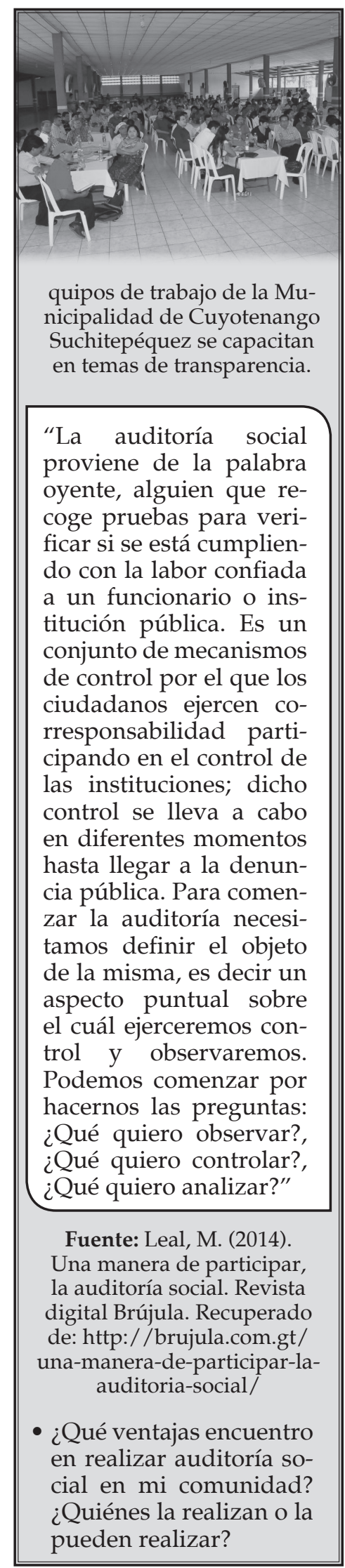




\section{La techología de los circuitos eléctricos}

\section{Resistencia eléctrica}

Es toda oposición que encuentra la corriente a su paso por un circuito eléctrico cerrado, atenuando o frenando el libre flujo de circulación de las cargas eléctricas o electrones. Según sea la magnitud de esta medida, los materiales se pueden clasificar en conductor, aislante y semiconductor. Existen además ciertos materiales en los que, en determinadas condiciones de temperatura, aparece la superconductividad, en el que el valor de la resistencia es prácticamente nulo.

\section{Circuitos en serie}

Es característica de estos circuitos que si la energía se interrumpe en alguna resistencia se corta en todo el circuito. Toda la corriente que pasa por un elemento, pasa por el resto de elementos del circuito. La mayoría de focos navideños están hechos con circuitos en serie. Por eso, al quemarse un foco ya no enciende ninguna luz, porque se interrumpe el flujo eléctrico. Estos circuitos son sencillos de elaborar con materiales de fácil alcance, generalmente de uso doméstico o casero.

\section{Circuitos en paralelo}

En muchas instalaciones eléctricas, es posible conectar y desconectar las resistencias a voluntad e independiente unas de otras. Las resistencias están conectadas en paralelo unas con otras y todas a la fuente de voltaje. Todas las resistencias se encuentran sometidas a la misma tensión o voltaje. En el caso de dos focos conectados a una pila, estos brillan con menos intensidad. En cambio, dos focos conectados en paralelo brillan con la misma intensidad.
Circuito en serie

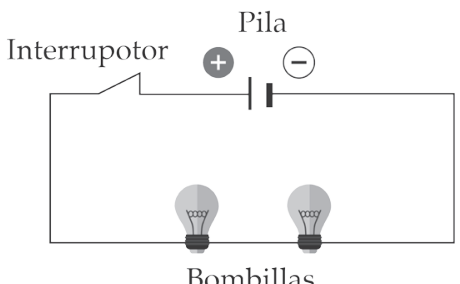

Bombillas
Circuito en paralelo

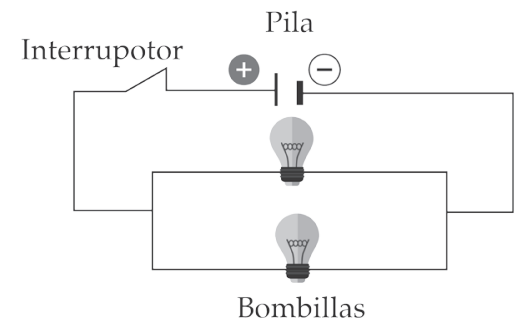

Identificamos si la siguiente imagen representa circuito en serie o en paralelo.

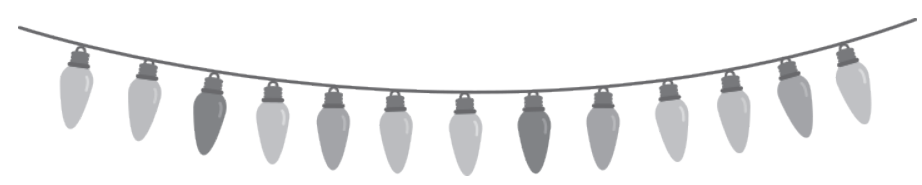

Para complementar la planificación del producto o servicio tecnológico que vamos a realizar contestamos a las siguientes preguntas:

- ¿Es de interés para la comunidad, para ser reproducido posteriormente?

- ¿Cómo beneficia a las mujeres para que alcancen sus derechos?

- ¿Qué impacto genera sobre el ambiente natural y social de la comunidad?

- ¿Alguna entidad de la comunidad o municipalidad estará interesada en patrocinarlo? 


\section{Resistencia eléctrica y ley de Ohm}

La transformación de energía se realiza en un receptor de electricidad mediante una oposición al movimiento de los electrones que, en el caso más sencillo, puede determinarse mediante la magnitud eléctrica denominada resistencia eléctrica. Todos los materiales conductores tienen cierta cantidad de resistencia, la cual depende del material del que está hecho, de su longitud y de su grosor. Algunos tienen más resistencia al paso de la corriente y otros tienen menos resistencia. Así, en un cable conductor, entre mayor sea su diámetro, menor su resistencia; entre más largo, mayor su resistencia. La resistencia se mide en Ohmios, $\Omega$.
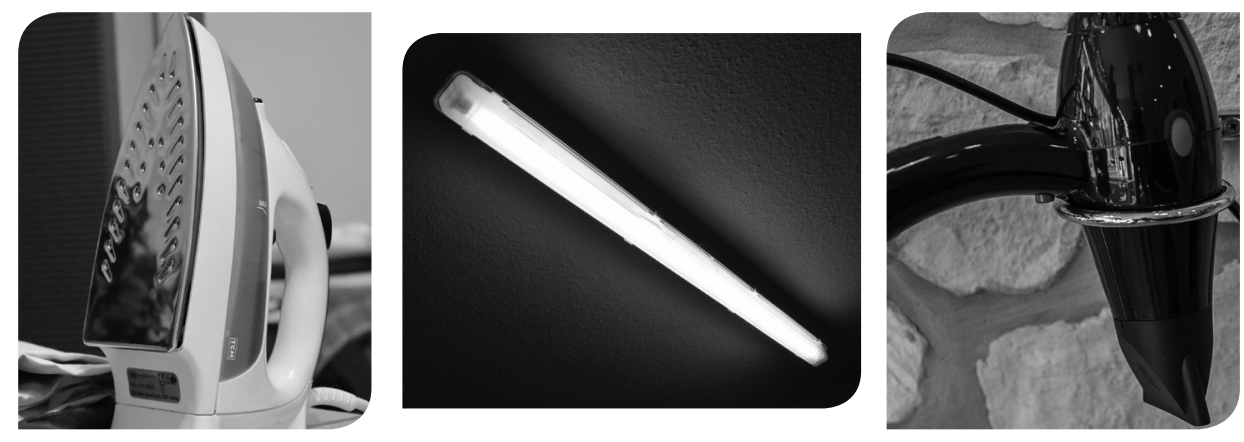

\section{Ley de Ohm}

La corriente fluye por un circuito eléctrico siguiendo varias leyes definidas. La ley básica del flujo de la corriente es la ley de Ohm, así llamada en honor a su descubridor, el físico alemán Georg Ohm. Según la ley de Ohm, la cantidad de corriente que fluye por un circuito formado por elementos y resistencias puras es directamente proporcional a la fuerza electromotriz aplicada al circuito (voltaje), e inversamente proporcional a la resistencia total del circuito. Esta ley suele expresarse mediante la fórmula I $=V / R$, siendo I la intensidad de corriente, medida en amperios, $V$ es la fuerza electromotriz en voltios y R la resistencia en ohmios. La ley de Ohm se aplica, tanto a los circuitos de corriente continua (CC) como a los de corriente alterna (CA).

$\mathrm{V}=\mathrm{I} \times \mathrm{R}$, dónde:

V: diferencia de potencial o voltaje aplicado a la resistencia, Voltios

I: corriente que atraviesa la resistencia, Amperios

R: resistencia, Ohmios $\Omega$

\section{Comprendo el efecto de la electricidad en el cuerpo humano.}

“¿Qué causa el choque ("toques") eléctrico en el cuerpo humano, la corriente o el voltaje? De acuerdo con la ley de Ohm se puede ver que esa corriente depende del voltaje que se aplique, y también de la resistencia eléctrica del cuerpo humano."

1. Concluyo en cuál de los siguientes casos el choque eléctrico es más fuerte:

- El cuerpo está seco

- El cuerpo está mojado con agua

- El cuerpo está mojado con agua salada

2. Investigo en Internet acerca de la importancia de la electrónica en el desarrollo humano. Anoto ejemplos de aplicación en el ámbito local.
Resistividad. Propiedad del material conductor. Una resistividad baja indica un material que permite fácilmente el movimiento de carga eléctrica, como sucede en el oro, la plata y el cobre. Para usos comerciales y el transporte de energía eléctrica se prefiere el cobre por ser abundante y más barato. La resistividad de los metales aumenta al someterlos a altas temperaturas y disminuye al enfriarlos hasta un valor cercano al cero absoluto, es decir, a -273.15 grados centígrados. Esta propiedad se denomina superconductividad. 


\section{Pensamiento inductivo y deductivo}

Una proposición compuesta es una Tautología si todos los valores de verdad de la última columna de su tabla de verdad son verdaderos.

\begin{tabular}{|c|c|c|c|}
\hline$p$ & $q$ & $p \wedge q$ & $(p \wedge q) \Rightarrow p$ \\
\hline $\mathrm{V}$ & $\mathrm{V}$ & $\mathrm{V}$ & $\mathrm{V}$ \\
\hline $\mathrm{V}$ & $\mathrm{F}$ & $\mathrm{F}$ & $\mathrm{V}$ \\
\hline $\mathrm{F}$ & $\mathrm{V}$ & $\mathrm{F}$ & $\mathrm{V}$ \\
\hline $\mathrm{F}$ & $\mathrm{F}$ & $\mathrm{F}$ & $\mathrm{V}$ \\
\hline
\end{tabular}

Copiamos en nuestro cuaderno y completamos, con ayuda de nuestro facilitador o facilitadora, la siguiente tabla de verdad para la proposición compuesta $(-q \wedge p) \wedge(q \vee-p)$

Podemos consultar las tablas de las semanas pasadas.

\begin{tabular}{|c|c|c|c|l|l|l|}
\hline$p$ & $q$ & $-p$ & $-q$ & $(-q \wedge p)$ & $(q \vee-p)$ & $(-q \wedge p) \wedge(q \vee-p)$ \\
\hline $\mathrm{V}$ & $\mathrm{V}$ & & & & & \\
\hline $\mathrm{V}$ & $\mathrm{F}$ & & & & & \\
\hline $\mathrm{F}$ & $\mathrm{V}$ & & & & & \\
\hline $\mathrm{F}$ & $\mathrm{F}$ & & & & & \\
\hline
\end{tabular}

Compartimos nuestras respuestas a las siguientes preguntas con las demás compañeras y compañeros.

- ¿Tuvimos alguna dificultad al completar la tabla?

- ¿Todos los compañeros y compañeras obtuvimos los mismos valores de verdad en la última columna?

- ¿Cuáles son los valores de verdad que corresponden a la última columna?

Consideremos las siguientes proposiciones. En nuestro cuaderno, escribimos con palabras, las proposiciones compuestas indicadas abajo y elaboramos tablas de verdad para cada una de ellas. Observamos si son tautologías o contradicciones.

$p=$ Dinora diseñará un aparato para proveer energía alternativa al molino

$q=$ Dinora aplicará lo que aprendió en sus cursos

$$
\begin{gathered}
(-q \wedge-p) \\
(-p \vee q) \\
(q \leftrightarrow-p) \\
(-p \wedge-q)
\end{gathered}
$$


Dos proposiciones compuestas tienen equivalencia lógica si tienen los mismos valores de verdad en la última columna de sus tablas de verdad.

Copiamos en nuestro cuaderno y completamos las siguientes tablas de verdad.

$$
-(p \wedge q)
$$

\begin{tabular}{|c|c|c|c|}
\hline$p$ & $q$ & $p \wedge q$ & $-(p \wedge q)$ \\
\hline $\mathrm{V}$ & $\mathrm{V}$ & & \\
\hline $\mathrm{V}$ & $\mathrm{F}$ & & \\
\hline $\mathrm{F}$ & $\mathrm{V}$ & & \\
\hline $\mathrm{F}$ & $\mathrm{F}$ & & \\
\hline
\end{tabular}

$-\boldsymbol{p} \vee-\boldsymbol{q}$

\begin{tabular}{|c|c|c|c|c|}
\hline$p$ & $q$ & $-p$ & $-q$ & $-p \vee-q$ \\
\hline $\mathrm{V}$ & $\mathrm{V}$ & & & \\
\hline $\mathrm{V}$ & $\mathrm{F}$ & & & \\
\hline $\mathrm{F}$ & $\mathrm{V}$ & & & \\
\hline $\mathrm{F}$ & $\mathrm{F}$ & & & \\
\hline
\end{tabular}

\section{Contestamos y comentamos:}

- ¿Las proposiciones compuestas anteriores tienen equivalencia lógica?

- ¿Has escuchado acerca del pensamiento inductivo y el pensamiento deductivo? Consulta e investiga sobre estas formas de pensamiento y elabora un ejemplo para cada tipo de pensamiento.

- ¿Consideras que el pensamiento que se ha usado para seleccionar el proyecto a desarrollar es inductivo o deductivo? ¿Por qué?

Consideremos las siguientes proposiciones:

$p=$ En nuestra comunidad utilizamos estufas solares.

$q=$ En nuestra comunidad utilizamos bicilicuadoras.

En nuestro cuaderno escribimos con palabras las siguientes proposiciones compuestas y construimos una tabla de verdad para cada una de ellas.

- $(p \vee q)$

- $p \wedge-q$

¿Las proposiciones anteriores tienen equivalencia lógica? Compartimos y discutimos con el resto del grupo.
Una proposición compuesta es una Contradicción si todos los valores de verdad de la última columna de su tabla de verdad son falsos.

\begin{tabular}{|c|c|c|}
\hline$p$ & $\neg p$ & $p \wedge \neg p$ \\
\hline $\mathrm{V}$ & $\mathrm{F}$ & $\mathrm{F}$ \\
\hline $\mathrm{V}$ & $\mathrm{F}$ & $\mathrm{F}$ \\
\hline $\mathrm{F}$ & $\mathrm{V}$ & $\mathrm{F}$ \\
\hline $\mathrm{F}$ & $\mathrm{V}$ & $\mathrm{F}$ \\
\hline
\end{tabular}




\section{La fuerza del agua}

Tecnología del
microrriego
Riego por goteo con gotero
de carrizo
Es un sistema que utiliza
poca agua de manera con-
trolada para que las plantas
reciban justo la que necesi-
tan a la hora más apropiada
para aumentar las cosechas.
Hay varios tipos:
- Por goteo: mediante man-
gueras con goteadores
dirigidos a la base de la
planta.
- Por aspersión: con dis-
persores que tiran el agua
en forma de lluvia sobre
las plantas.
- El riego californiano: que
expulsa el agua en forma
de chorro.
Por inundación: que for-
agua.
Los sistemas de microrrie-
go pueden combinarse con
macrotúneles. Estos son
estructuras sencillas que
cubren cierta extensión de
cultivo para protegerlo de
las tormentas, vientos fuer-
tes e insectos. Con estos la
temperatura es más estable
y requiere menor cantidad
de agua.

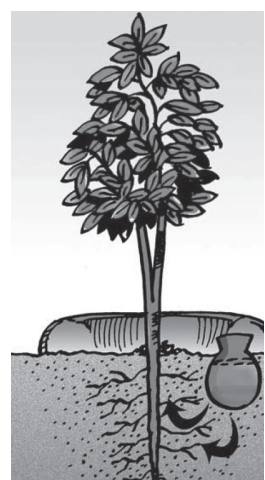

Riego por infiltración con ollas de barro

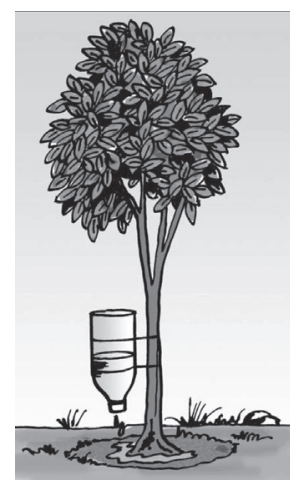

Riego por goteo con botellas plásticas

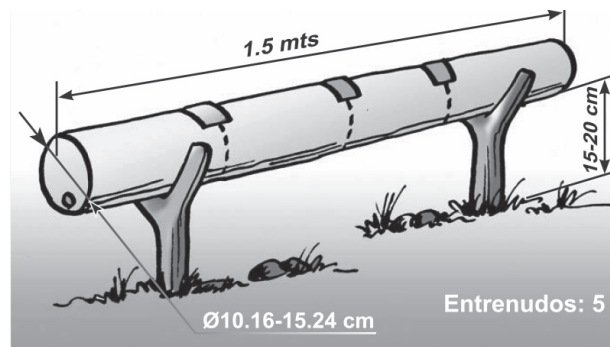

Riego por goteo con bambú

Los pueblos hacen uso de la gravedad para dirigir la circulación de agua obtenida de reservorios utilizando canales. Con ello se aprovecha la energía potencial del agua. También podemos aprovechar el movimiento del agua para producir energía cinética que mueva mecanismos que faciliten procesos productivos.

La fuerza del agua de río ha sido aprovechada de diferentes maneras, una de ellas es el uso de molinos de agua. El molino de agua utiliza una rueda de paletas; esta rueda es movida por la fuerza que trae el agua por diferencias de altura del caudal. La fuerza del agua mueve las paletas y la totalidad de la rueda hace rotar un eje conectado a un sistema de engranajes que mueve una máquina conectada a él. Este mecanismo se ha usado para moler granos, aserrar metales o formar metales.

El área de Totonicapán ha sido conocida por el cultivo de trigo, a la orilla de sus ríos hace mucho tiempo trabajaban algunos molinos de granos. Las paletas de madera hacían rodar una rueda conectada por un eje con engranajes que hacían girar dos enormes piedras horizontales situadas en paralelo entre las cuales se ponía el trigo para ser molido.

En Santa Cruz, Alta Verapaz, se conserva parte de un antiguo beneficio de café construido por alemanes a principios del siglo XX. La maquinaría de esa época incluye una rueda metálica con paletas de metal que se mueve con agua retenida en una presa. Al igual que los molinos de granos de Totonicapán, esta tecnología es antigua, por lo que las instalaciones son consideradas patrimonio histórico que debe ser resguardado para que sean conocidas por las nuevas generaciones.

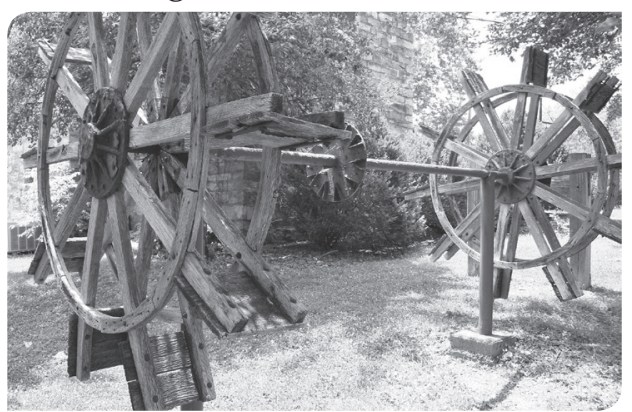

Semana 16

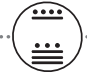




\section{Hidroeléctricas}

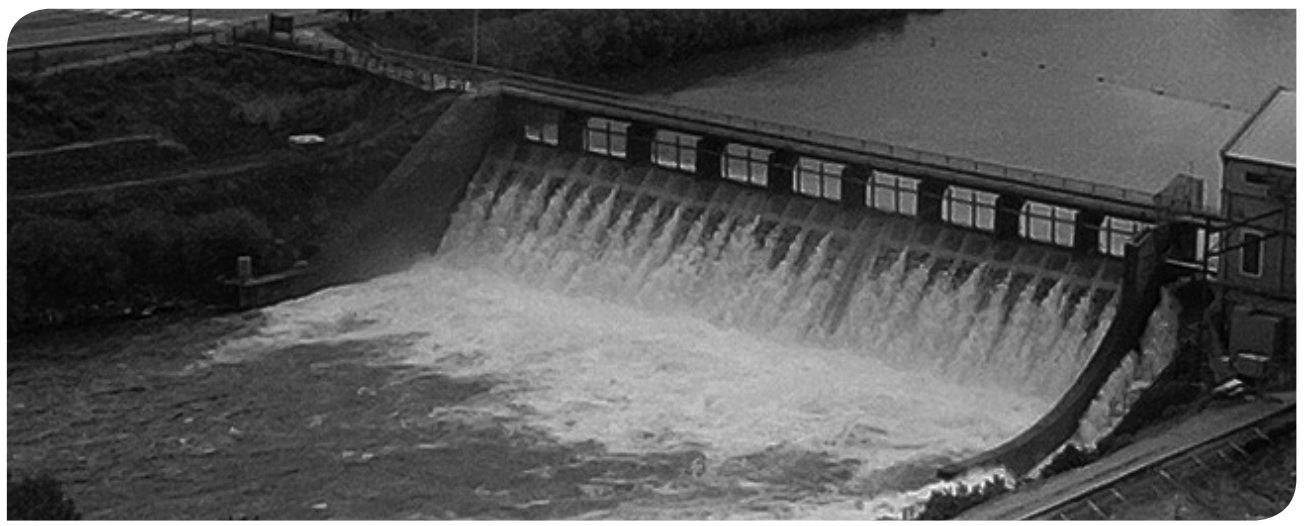

La mayor parte de la energía eléctrica que utilizamos en Guatemala se genera por medio de energía hidráulica a través de hidroeléctricas. Actualmente, esta es la forma más barata de generar electricidad, a pesar de haber sido inventada hace más de cien años.

La energía hidroeléctrica aprovecha el movimiento de ríos de grandes caudales para mover turbinas que generan electricidad. Esta es una electricidad limpia porque no produce contaminación y, además, es renovable. Esto significa que tendremos electricidad siempre y cuando exista suficiente caudal de agua.

Las plantas hidroeléctricas constan de:

1. Una gran presa, para almacenar y manejar el caudal de agua y acumular energía potencial utilizando un sistema de compuertas.

2. Una aducción, que canaliza y transporta el agua hacia la turbina.

3. Una casa de máquinas, donde está la turbina y el generador de electricidad, además de otras máquinas auxiliares.

4. Una succión, que recoge el agua y la devuelve a su cauce natural.

Las grandes presas pueden ser aprovechadas para otras actividades, como pesca, turismo y abastecimiento de sistemas de riego. Sin embargo, su construcción puede suponer desplazamiento de poblaciones humanas y animales, modificación de los ecosistemas, pérdida de tierras fértiles o baja del caudal o pérdida de agua por desviación de los ríos. Por otra parte, la baja del caudal debido a sequías produce menos generación de energía, por lo que deben tomarse medidas de prevención y mitigación ante el cambio climático. Además, se debe considerar el impacto ambiental y su efecto sobre las comunidades que viven aledañas al caudal que alimenta la presa. Antes de su construcción, se debe realizar una consulta con las poblaciones cercanas para conocer su decisión y actuar en sintonía con ésta.

En clase nos organizamos en grupos; cada grupo selecciona un campo productivo, investiga sobre los materiales y elementos que utiliza y comienza a elaborar un álbum con recortes de revistas o periódicos, fotografías o dibujos sobre los materiales y elementos del campo productivo seleccionado.

\section{Hidroponía}

La hidroponía es una técnica que permite cultivar plantas sin suelo y poca agua, por lo que permite cultivar hortalizas y plantas aromáticas y medicinales en cualquier espacio: terrazas, balcones, jardines, e incluso, áreas infértiles. La hidroponía utiliza una solución nutritiva a base de minerales que se agrega al agua de riego.

Existen tres técnicas de cultivo hidropónico:

- Raíz flotante: las plantas crecen alrededor de una base, como duroport, que flota sobre un poco de agua con la solución nutritiva. Las raíces crecen en el agua.

- Sistema NFT: las plantas se ajustan en aberturas en canales inclinados de PVC donde corre constantemente el agua con nutrientes.

- Sustrato: las plantas crecen en cajones poco hondos rellenos de materiales como piedra pómez, fibra de coco, aserrín y otros. El agua con nutrientes se utiliza como agua de riego.

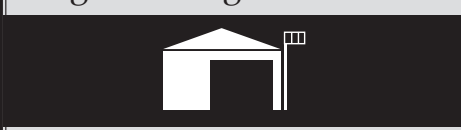

Contactemos una persona especialista en ingeniería agronómica para que nos dé una charla sobre ventajas y desventajas de técnicas agrícolas, como el microrriego, los macrotúneles, la hidroponía y otros, que ayuden a aumentar la productividad aprovechando mejor los recursos naturales respetando el equilibrio de la naturaleza. 


\section{La leotura nos fortalece para diseñar el futuro}

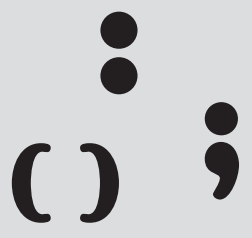

Signos de puntuación

Dos puntos:

Llaman la atención, anuncian y crean expectativa sobre lo que vamos a decir a continuación. Normalmente se usa letra minúscula detrás de los dos puntos. Se emplean en:

- los saludos de las cartas (Estimada Doctora Güit:)

- antes de empezar a enumerar (en el interior de la caja había: dos pilas, tres paletas y un cable)

- antes de una cita textual (Sócrates dijo: «Solo sé que no sé nada»)

- en los diálogos, detrás de los verbos del habla (dijo:, preguntó:, contestó:)

Paréntesis:

Los paréntesis son un signo doble ( ) que se usa para insertar, dentro de una oración, un comentario o nota aclaratoria. Ejemplo:

El MINEDUC (Ministerio de Educación) garantiza el derecho a la educación.

Punto y coma:

El punto y coma se usa para separar oraciones que tienen relación una con la otra:

No sé dónde queda el río; también ahí está el molino.
Entendemos por habilidad interpretativa el proceso mental de entender lo que leemos, tanto en lo que se refiere al significado de cada una de las palabras que conforman un texto, como a la comprensión global de lo que hemos leído. Este tipo de habilidad abarca cuatro aspectos básicos que debemos tomar en cuenta luego de establecer el objetivo del tipo de lectura que se nos presenta, ya seanarrativa, descriptiva, expositiva, argumentativa, poética, científica o periodística:

1. Interpretar: formarse una opinión de lo leído.

Razonar el contexto

Identificar las ideas centrales

Valorar las ideas secundarias

Sacar conclusiones

2. Retener: aprehender aspectos importantes.

Conceptos clave

Detalles relevantes

Datos trascendentales

3. Organizar: darle forma a nuestra reacción ante el texto.

Seguir instrucciones si se trata de un instructivo

Formular hipótesis si estamos investigando

Resumir el texto

Generalizar las ideas o contenido

\section{Valorar}

Captar el sentido de lo que se indica

Deducir relaciones causa-efecto, es decir la razón de algo que sucede

Distinguir qué es un hecho y qué una opinión, separar los datos de las ideas

Diferenciar la realidad de la fantasía o ficción

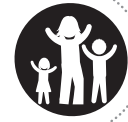

Escribamos nuestro punto de vista en relación con el proyecto propuesta en clase.

- ¿Podrían escribirlo en un idioma extranjero?

Revisemos el uso de los signos de puntuación en nuestro ensayo. 


\section{Evitemos confusiones, comprendamos el contexto}

\section{Polisemia de las palabras}

La palabra polisemia proviene de «poli-», muchos y del griego «semia», significado. En lingüística, una palabra polisémica es la que tiene dos o más significados. El idioma español cuenta con muchas palabras de este tipo.

Las palabras polisémicas se distinguen de las palabras homónimas en que las homónimas tienen diferente origen etimológico, por lo que siempre han tenido diferente significado, aunque se escriban igual. Las polisémicas, en cambio, mantienen su mismo origen, pero han adquirido diferentes significados a lo largo de la historia y la evolución del lenguaje.

Ejemplo de diálogos polisémicos:

— ¿Usted no nada nada en nuestro río?

-Sí, pero no traje traje.

— ¿Me prestas tu regla para medir el molino?

—La regla dice que al molino no se lleva nada.

\section{Otros ejemplos:}

Cubo: 1. Recipiente para guardar agua. 2. Figura geométrica de seis lados.

Bomba: 1. Explosivo. 2. Máquina para sacar agua de un pozo y trasladarla a otro lado.

Banco: 1. Asiento para dos o más personas. 2. Institución donde guardamos nuestro dinero.

Derecho: 1. Posición opuesta al izquierdo. 2. Facultad que deriva de ser una persona. Ejemplo: derechos de la mujer.

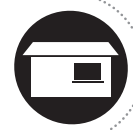

Buscaremos en el diccionario el significado polisémico de las siguientes palabras y escribiremos una oración con cada una de ellas, dándoles el significado correspondiente:

Sierra, corriente, planta, hoja, campo, cabo, canino, cobra, cola, celular.
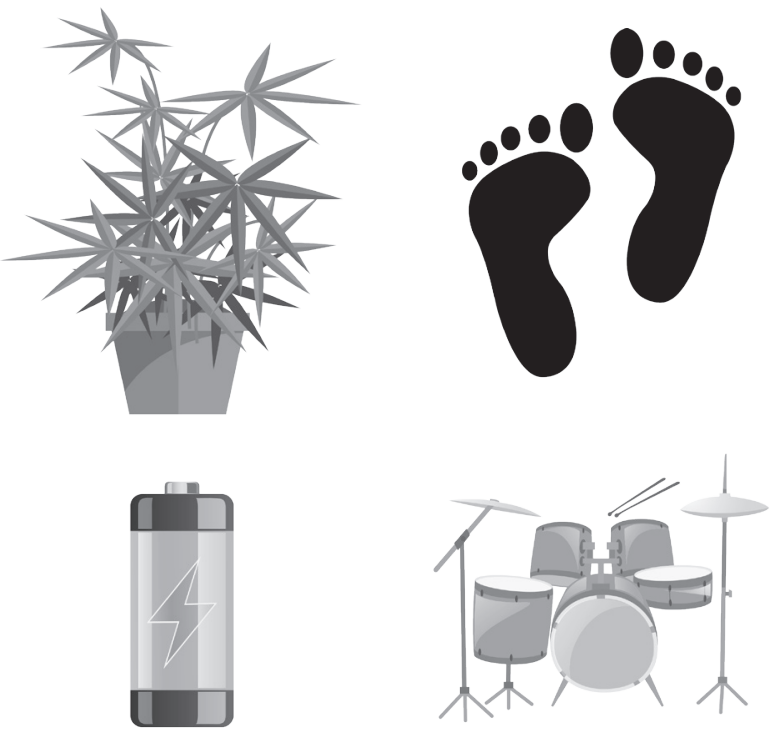

Colectamos anuncios publicitarios en revistas y prensa para trabajar en la próxima tutoría.

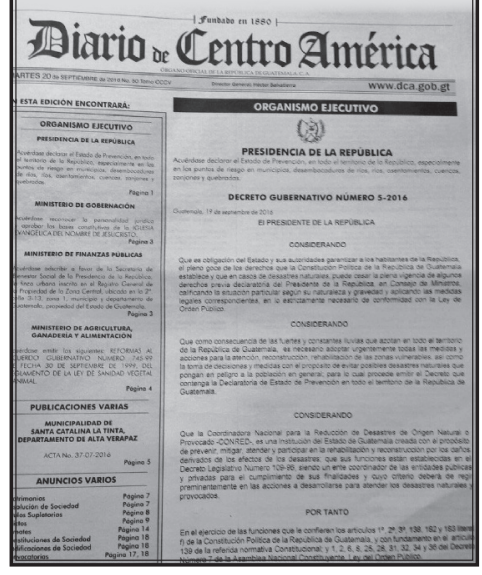




\section{Murailismo para promover el conocimiento}

El muralismo es una técnica profesional de la pintura. Muchos y muchas artistas de la plástica en el mundo han dejado obras muy importantes en muros y paredes de las grandes ciudades. Puede hacerse con muchos colores, con pinturas a base de productos naturales, con elementos extraídos de la naturaleza, sin dañar el medio ambiente. Algunos ejemplos de colores que pueden ser obtenidos naturalmente son:

\begin{tabular}{|l|l|l|l|l|l|l|l|}
\hline Color & Verde & Rojo & Azul & Amarillo & Morado & $\begin{array}{l}\text { Marrón } \\
\text { Na negro } \\
\text { Persona } \\
\text { ebria }\end{array}$ \\
\hline Se puede hacer a base de & $\begin{array}{l}\text { perejil, } \\
\text { menta, } \\
\text { acelga, } \\
\text { espina- } \\
\text { ca }\end{array}$ & $\begin{array}{l}\text { Cerezas } \\
\text { Fuesas } \\
\text { Fresas } \\
\text { Tomates } \\
\text { Pimien- } \\
\text { tos }\end{array}$ & $\begin{array}{l}\text { Arán- } \\
\text { danos }\end{array}$ & $\begin{array}{l}\text { Azafrán } \\
\text { Mostaza, } \\
\text { Cúrcuma }\end{array}$ & $\begin{array}{l}\text { Remola- } \\
\text { cha } \\
\text { Moras } \\
\text { negras }\end{array}$ & $\begin{array}{l}\text { Zanaho- } \\
\text { rias } \\
\text { Cásca- } \\
\text { ra de } \\
\text { naranja }\end{array}$ & $\begin{array}{l}\text { Nij de } \\
\text { Baja Ve- } \\
\text { rapaz } \\
\text { Té ne- } \\
\text { gro, } \\
\text { Café, } \\
\text { Cacao }\end{array}$ \\
\hline
\end{tabular}

Para elaborar la pintura se puede usar cualquiera de estos procedimientos:

Moliendo o licuando las verduras o frutas. Hirviendo el jugo para evaporar el exceso de agua.

Cortando las frutas o verduras en trozos. Poner en remojo en agua, alcohol o aceite durante varios días, mientras suelta el color.

Tomado de: http:/ / www. bricoydeco.com/colorantesnaturales-para-pintar/
El muralismo representa una oportunidad de reflexión y análisis. Al quedar plasmado, se convierte en un recurso educativo popular. Todas las personas que lo observan se benefician de este arte magnífico.
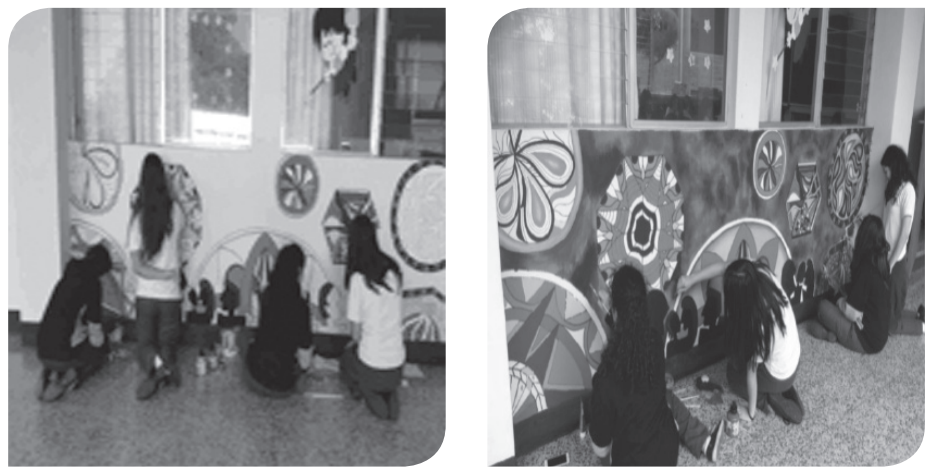

Es por eso que el arte que realicemos como proyecto para valorar el conocimiento debe ir en función de fortalecer a la comunidad y cuidar el ambiente.

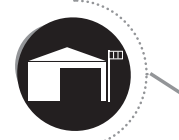

\section{Elaborando nuestros materiales}

Organizamos grupos para elaborar las pinturas a base de materiales orgánicos

Definimos los colores que queremos usar en el mural

Asignamos colores para elaborar en grupos según los materiales disponibles 


\section{Desarrollando nuestro mural}

Para desarrollar un mural es importante planificar los espacios en que se llevará a cabo. El tema debe estar seleccionado y todos y todas deben participar en su elaboración. Las fases principales para la elaboración de un mural suelen ser:

Boceto: se hace sobre papel un dibujo de todo lo que se quiere plasmar en el muro o pared.

Cuadrícula: sobre el boceto se traza una cuadrícula para medir los espacios proporcionales en la pared. Esto permitirá imitar los trazos que corresponden al dibujo en boceto, y transferirlo a la gran dimensión de un muro.

Proyección: se traza una cuadrícula sobre el muro, y se realiza el boceto de todo el dibujo.

Pintura: se pintan con colores todos los temas que se desea plasmar en el mural.

\section{Diseñando el mural en grupo:}

El tema es el conocimiento, la tecnología y la energía al servicio de la sociedad y el ambiente. Los objetos a pintar tendrán que tener relación con el tema.
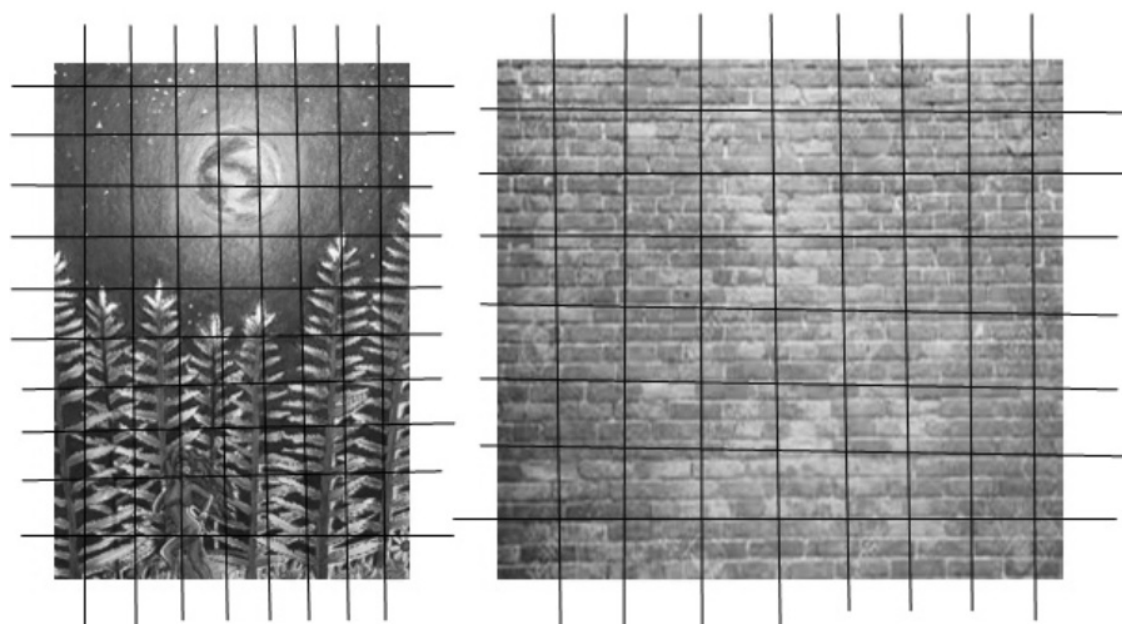

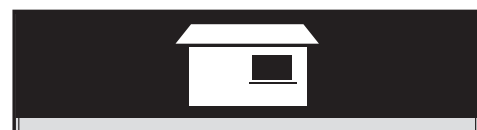

Busco los materiales para procesar los colores: frutas y vegetales.

Como el proceso tomará varios días, es bueno prepararlo ahora para usarlo en la próxima sesión.

Realizamos los procesos del color y sus mezclas para lograr la consistencia deseada

Es importante tomar en cuenta que las pinturas se oxidan y cambian de color por ser naturales, por eso deben usarse inmediatamente. Todo lo demás ya debe estar adelantado.

Realizo diseños para colocar en el mural. Los realizo en hojas, los dibujo con lápiz, los pinto con crayones o témperas. Luego trazo la cuadrícula para poder proyectarlos al mural.

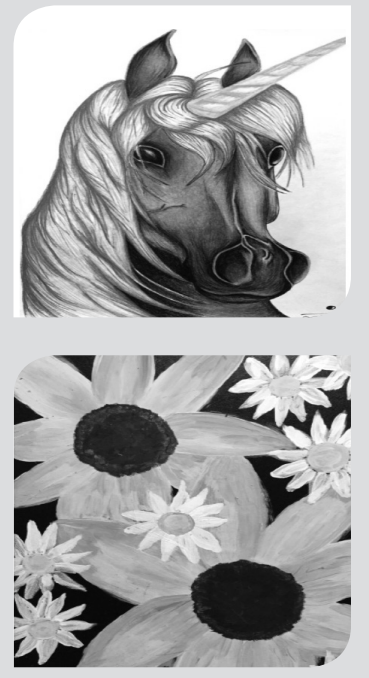




\section{Identidad personal, social y cultural}

Los mensajes negativos del lenguaje corporal

Nuestro lenguaje corporal transmite el $93 \%$ de lo que queremos decir. Hay personas que, aunque se comporten cordialmente, no generan confianza; eso es porque su lenguaje verbal y su lenguaje corporal se contradicen. Otras personas, en cambio, sin hablar mucho, dan confianza; su lenguaje corporal está alineado con su expresión verbal. Estudiemos nuestro lenguaje corporal, eliminemos los signos que no nos ayudan y actuemos con naturalidad.

Ciertos estudios indican que algunos de los gestos que transmiten mensajes son:

Taparse la boca al hablar: lo que decimos no es totalmente cierto.

Rascarse el cuello: duda o falta de comprensión.

Mantener la vista baja: sumisión o falta de interés.

Mirar el reloj o las uñas: aburrimiento.

No mirar a los ojos a quien le hablamos: falta de interés o incomodidad.

Encoger los hombros: Baja autoestima.

Estrechar los ojos o fruncir el ceño: enojo o incredulidad.
En nuestra casa, sin nadie a nuestro alrededor, nos miraremos en un espejo durante cinco minutos. De acuerdo con lo que observemos, sintamos y pensemos, escribiremos un texto que responda a la pregunta ¿Quién soy yo? Apliquemos los criterios de identidad descritos abajo.

Podemos decir que la identidad son todos los rasgos y circunstancias que nos definen como persona única y a la vez como parte de un grupo al que pertenecemos. En psicología se denomina «autoconcepto» y está formado por la identidad personal y la identidad social.

La identidad personal es la que nos define de acuerdo a cómo nos vemos a nosotras o nosotros mismos. El criterio que tenemos de nosotras y nosotros como personas individuales. La identidad personal se forma desde que somos niñas y niños. El simple hecho de tener una fecha de nacimiento y un nombre nos da identidad

personal única.

La identidad social nos determina según el grupo o comunidad a la que pertenecemos. Tenemos tantas identidades sociales como grupos con los que nos identificamos. El idioma que hablamos, la ciudad, pueblo o aldea donde vivimos, la espiritualidad o religión que profesamos, la profesión o actividad que realicemos y la familia nos dan sensación de pertenencia.

La identidad cultural es el conjunto de valores, tradiciones, creencias y comportamientos que nos hacen sentir orgullo de lo que somos. La identidad cultural engloba a las dos anteriores.

Basándonos en el ejercicio anterior, realizaremos un conversatorio sobre el papel de las mujeres en la comunidad, el municipio y en el país, para resolver necesidades a través de la tecnología.

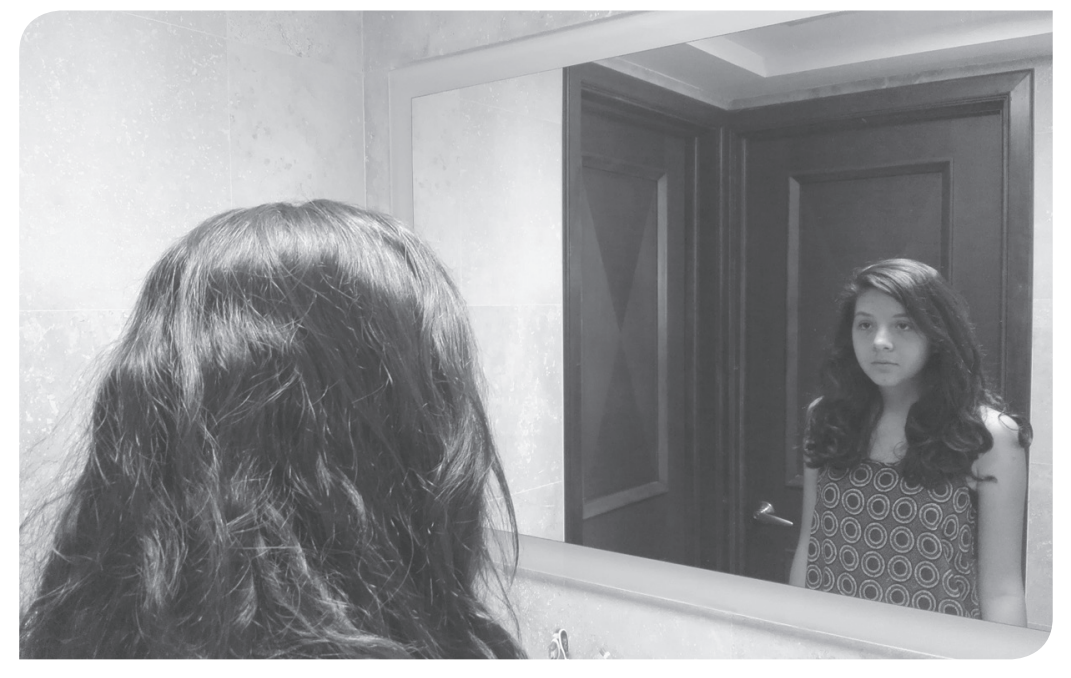




\section{El papel de las mujeres en la historia, visto a través de la literatura}

A lo largo de la historia se mantuvo la idea de que lo más conveniente era que las mujeres se dedicaran a la formación de la familia y las labores de casa. Las decisiones sobre la economía familiar, la comunidad, la seguridad y hasta aspectos de la vida de las mujeres etc. eran tomadas por los hombres. Sin embargo, algunas obras literarias señalan ciertos avances en el papel de las mujeres. Así, en el siglo XVII, Miguel de Cervantes (1547-1616) apoya el derecho de las mujeres a elegir marido. A través de sus obras critica la postura machista de los hombres de la época y da soluciones triunfantes a los amores elegidos libremente.

En su obra Anna Karenina, León Tolstoi (1828-1910), hace una crítica a la hipocresía que predominaba en la sociedad rusa, la cual dejaba pasar el hecho de que un hombre tuviera una relación con una mujer casada, mientras que a dicha mujer la condenaban y despreciaban.

Gustav Flaubert (1821-1880) aborda en su novela, Madame Bovary, la búsqueda de la mujer por una vida plena y con objetivos personales.

En Guatemala, las mujeres se han abierto paso a través de la literatura. María Josefa García Granados (17941848) criticó, a través de sus poemas publicados con el pseudónimo «Juan de las Viñas» a la sociedad guatemalteca, a sus jefes liberales y a sus esposas y familias.

La poetisa guatemalteca, Luz Méndez de la Vega (1919-2012), es una referencia obligatoria en la poesía feminista del siglo XX. Cuando la libre expresión literaria era duramente castigada por las dictaduras militares, Méndez de la Vega publica, a partir de 1980, sus libros de poesía existencial. Además de Luz Méndez de la Vega, hay otras mujeres escritoras que destacan por su rebeldía ante el sistema patriarcal. Mencionamos entre otras a Isabel Garma (Norma García Mainieri), Ana María Rodas, Isabel de Los Ángeles Ruano.

Identificaremos una o varias mujeres de la comunidad que han destacado por aportar a resolver las necesidades de la comunidad. La o las entrevistamos para conocer sus valores y presentarlos en un organizador gráfico.

Redacto un borrador del instructivo del proceso de producción del producto. Esto lo puedo hacer en mi idioma materno o en idioma extranjero. Cuido el uso de signos de puntuación y la ortografía.

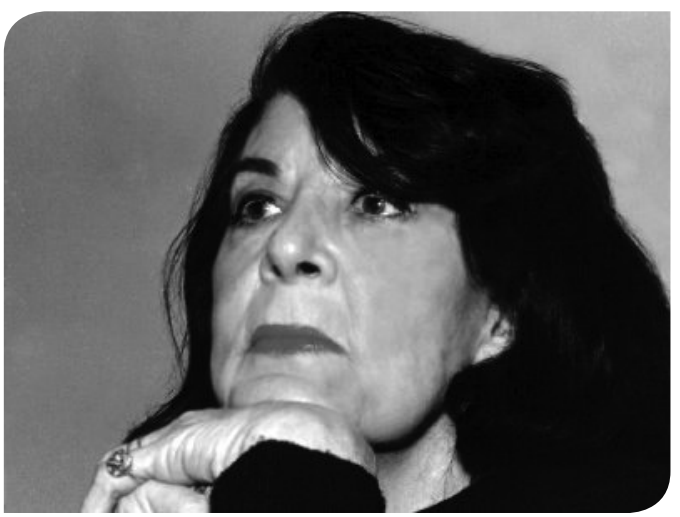

Foto: Luz Méndez de la Vega

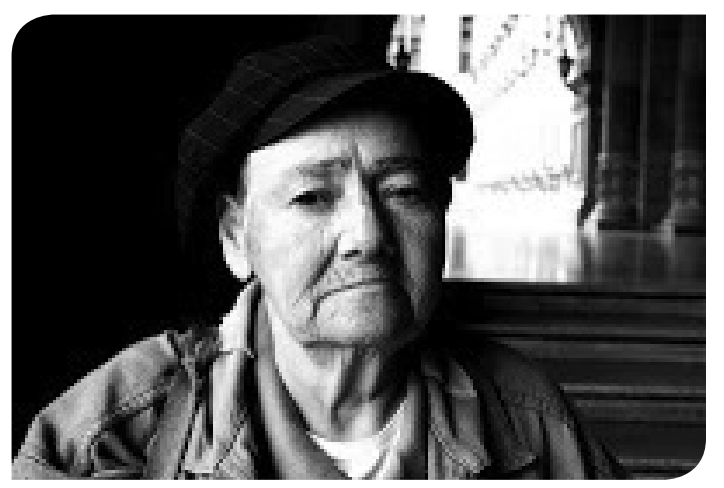

Foto: Isabel de los Ángeles Ruano 


\section{Potencia eléctrica}

Calor eléctrico. Se produce cuando por "un conductor circula corriente eléctrica, parte de la energía cinética de los electrones se transforma en calor debido a los choques que sufren con los átomos del material conductor por el que circulan, elevando la temperatura del mismo". Este fenómeno lo descubrió el físico británico James Prescott Joule.

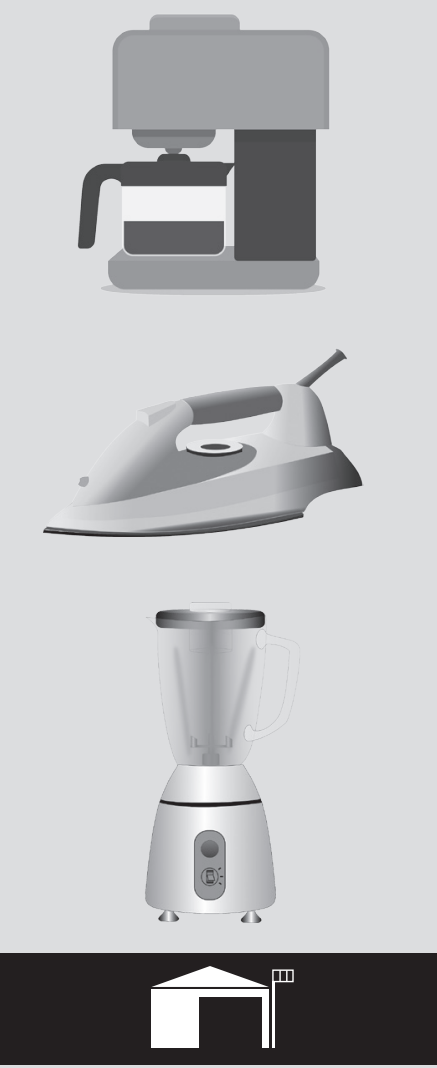

Calculo la energía eléctrica en aparatos eléctricos que utilizo en el hogar. Busco los datos de la corriente que circula por ellos, voltaje o la potencia que consumen.

- Construyo una tabla que contenga la siguiente información: Aparato, Potencia eléctrica (Watts), Intensidad de corriente (Amperios), voltaje (V) y energía (J).

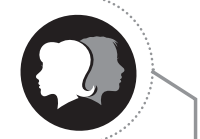

De los aparatos eléctricos que conocemos, que hay en nuestra casa o escuela: ¿cuáles producen calor o se calientan cuando están en funcionamiento?

Un efecto muy común de la corriente eléctrica es la producción de calor. La cantidad de energía desprendida en un circuito se mide en julios. La potencia consumida se mide en vatios; 1 vatio o watt (W) equivale a 1 julio por segundo. La potencia "P" consumida por un circuito determinado puede calcularse a partir de la expresión:

$$
\frac{\mathrm{V}^{2}}{\mathrm{R}}
$$

Para calcular el calor generado por una resistencia eléctrica al ser atravesada por una corriente eléctrica, se usa el siguiente factor de conversión:

$$
1 \text { watt / 0,2389 calorías / segundo }
$$

\section{Resolvemos los siguientes problemas.}

- ¿Cuánta corriente produciría un voltaje de 10 Voltios, a través de una resistencia de $5 \mathrm{Ohmios}$ ?

- En un circuito en serie con resistencias ¿cuál es la corriente que circula en el sistema formado por cinco resistencias, conectadas a una fuente de 90 voltios?

2. Analizamos la conveniencia de utilizar las bicimáquinas en la comunidad.

Las bicimáquinas son máquinas impulsadas con fuerza de pedales que sirve para apoyar la economía familiar. Esto nos permite obtener una capacidad más alta que la manual. Se han inventado bicimolinos, bicibombas de agua, bicidespulpadoras de café, biciesmeril, bicilavadora de ropa, biciarado, biciazadón, entre otras. Ya en Guatemala se ha impulsado este tipo de herramientas. La generación de energía eléctrica para el uso de electrodomésticos es otra de las aplicaciones interesantes; por ejemplo, se ha inventado la bicilicuadora.

Algunos sistemas de generación eléctrica con pedaleo parten de un principio básico que es producir la electricidad con un generador de corriente continua para que sea almacenada a una batería y de esta convertirla si es necesario a corriente alterna para alimentar pequeños electrodomésticos caseros.
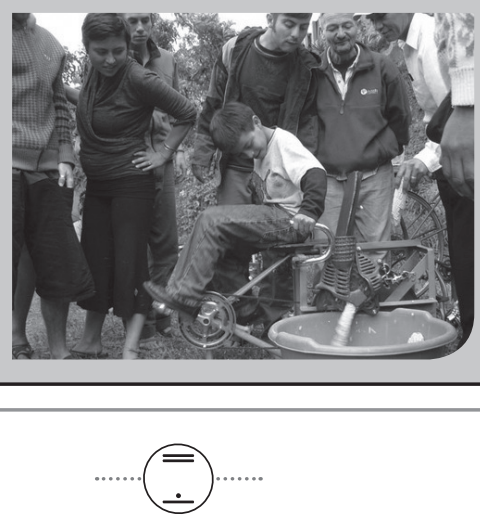


\section{Fuentes de energía alternativa}

En grupo, imaginamos cómo sería nuestra comunidad si se utilizaran formas de energía alternativa.

Exponemos los beneficios que se obtendrían y cómo repercutiría en el cuidado del ambiente.

La Energía Clásica o Convencional es toda aquella energía cuyo uso es frecuente en el mundo o que son fuentes más comunes para producir energía eléctrica. Por ejemplo, la combustión del carbón mineral, el gas natural y el petróleo, al utilizarlo para calentar el agua, y transformarla en vapor de agua, para mover las aspas de una turbina o motor eléctrico y generar también de esta forma electricidad.

Los tipos de energía como la solar, eólica, mareomotriz, biomasa, geotérmica son denominadas energías alternativas. Según algunos autores también se les denomina energías renovables o verdes. Otros autores la definen más ampliamente como, todo tipo de energía que no implica la combustión de combustibles fósiles. Dentro de las energías alternativas se encuentra la energía solar "fotovoltaica", denominada energía del futuro.

Observamos las siguientes imágenes. Analizamos y escribimos 2 formas alternativas de energía y 2 formas de energía convencional o clásica.

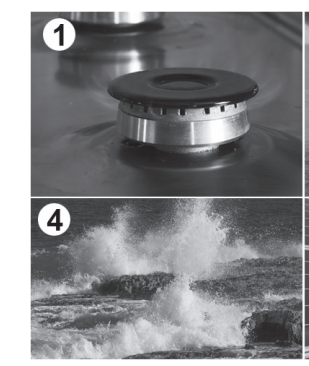

Alternativa

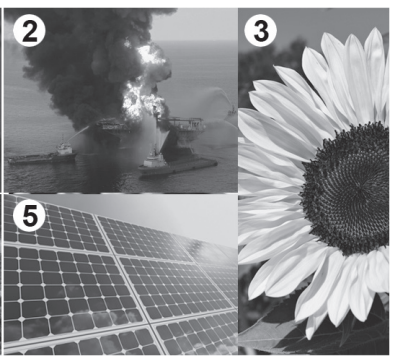

Clásica

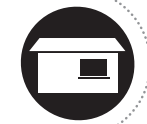

1. Investigo sobre: qué tipo de energías obtendría de los residuos sólidos urbanos.

2. Tipo de energía alternativa ideal en las áreas de ríos, volcanes, cañones y a orilla del mar.

3. Comparto con mi familia la información relacionada con las bicimáquinas.

4. Describo el proceso desarrollado en la elaboración de productos, utilizando un diagrama de flujo.

5. Autoevalúo la aplicación del diagrama de flujo para explicar el proyecto. Utilizo una lista de cotejo.

\begin{tabular}{|c|c|c|}
\hline Criterios & SÍ & NO \\
\hline 1. Se utilizan los símbolos de principio y fin. & & \\
\hline $\begin{array}{l}\text { 2. Se observan líneas de flujo que indican hacia dónde debe seguir la información } \\
\text { hasta obtener el producto o servicio. }\end{array}$ & & \\
\hline 3. Se evidencia secuencia y coherencia entre los pasos señalados y otros. & & \\
\hline
\end{tabular}




\section{Toblas de verdad con tres proposiciones}

Cuando trabajamos con proposiciones compuestas formadas por tres proposiciones simples usualmente utilizamos las letras p, q y r.

\begin{tabular}{|c|c|c|}
\hline$p$ & $q$ & $r$ \\
\hline V & V & V \\
\hline V & V & F \\
\hline V & F & V \\
\hline V & F & F \\
\hline F & V & V \\
\hline F & V & F \\
\hline F & F & V \\
\hline F & F & F \\
\hline
\end{tabular}

Consideremos las siguientes proposiciones:

$p=$ La estufa solar es utilizada en nuestra comunidad.

$q=$ La bicilicuadora permite ahorrar energía.

$r=$ Los páneles solares pueden generar electricidad.

En nuestro cuaderno escribimos, con palabras, las siguientes proposiciones compuestas.

\begin{tabular}{|l|l|}
\hline 1) $q \vee r$ & 2) $(p \wedge q) \wedge r$ \\
\hline 3) $p \wedge q$ & 4) $p \wedge(q \wedge r)$ \\
\hline
\end{tabular}

- ¿Qué notamos al escribir las proposiciones 2 y 4 ?

Copiamos en nuestro cuaderno y completamos la siguiente tabla de verdad para la proposición compuesta $(p \vee q) \wedge r \simeq$

\begin{tabular}{|c|c|c|c|c|}
\hline$p$ & $q$ & $r$ & $p \vee q$ & $(p \vee q) \wedge r$ \\
\hline V & V & V & & \\
\hline V & V & F & & \\
\hline V & F & V & & \\
\hline V & F & F & & \\
\hline F & V & V & & \\
\hline F & V & F & & \\
\hline F & F & V & & \\
\hline F & F & F & & \\
\hline
\end{tabular}

Escribimos tres proposiciones simples $(p, q$ y $r)$ y formamos tres proposiciones compuestas utilizándolas. Compartimos nuestro trabajo con el resto de compañeros y compañeras.

Escogemos una de las proposiciones compuestas que formamos y elaboramos su tabla de verdad; la copiamos en media cartulina para presentarla a los demás compañeros y compañeras. 
Dadas las siguientes proposiciones:

$p=$ El bus sale de la terminal.

$q=$ El bus no saldrá esta mañana.

$r=$ El bus sale de la estación del norte.

- En nuestro cuaderno escribimos con palabras la proposición:

$$
p \Rightarrow(-r \wedge-q)
$$

- Escribimos, con símbolos, las siguientes proposiciones.

1) El bus no saldrá de la terminal o no saldrá esta mañana si y solo si sale de la estación norte.

2) Si el bus no sale de la estación norte y saldrá esta mañana, entonces sale de la terminal.

3) Si el bus sale esta mañana, entonces saldrá de la terminal o de la estación norte.

4) El bus no saldrá esta mañana y no saldrá de la estación norte ni de la terminal.

- Comparamos nuestras proposiciones con las del resto del grupo.

- Utilizamos las proposiciones de la tabla anterior para construir tablas de verdad.

- Indicamos si la proposición es una tautología, una negación o ninguna de las dos.

- ¿Existe equivalencia lógica entre algunas de las proposiciones anteriores? Explicamos.

Aprovechamos a terminar el producto o servicio si todavía no está completado.

Copiamos en nuestro cuaderno y completamos las siguientes tablas de verdad con tres proposiciones.

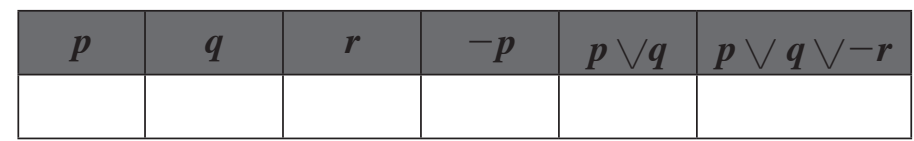

\begin{tabular}{|l|l|l|l|l|l|l|}
\hline$p$ & $q$ & $r$ & $-p$ & $-r$ & $p \wedge q$ & $-r(p \wedge r)$ \\
\hline & & & & & & \\
\hline
\end{tabular}

\begin{tabular}{|l|l|l|l|l|l|}
\hline$p$ & $q$ & $r$ & $-p$ & $-p \wedge q$ & $(-p \wedge q) \Rightarrow r$ \\
\hline & & & & & \\
\hline
\end{tabular}

El siguiente diagrama de Venn, con los conjuntos $P$, $Q$ y $R$ representa a las proposiciones $p, q \mathrm{y} r$.

Sombreamos la región que represente:

$$
p \vee(q \wedge r)
$$

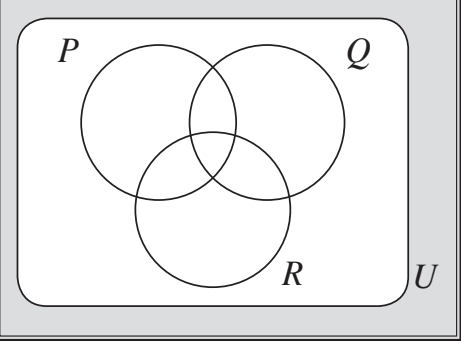


- ¿En qué dependencia del Ejecutivo ubicas a esta autoridad?

El sistema de gobierno de Guatemala es presidencialista. Esto significa que en las elecciones generales el pueblo elige al presidente $\mathrm{o}$ presidenta y, por separado, elige a las y los diputados que integrarán el Congreso de la República. En el sistema de gobierno parlamentario, el pueblo elige solo a las o los diputados; después, cuando se constituye el Congreso, este elige a la presidenta o presidente. Ambos sistemas tienen ventajas y desventajas.

Analizamos que ventajas y desventajas un sistema de gobierno presidencialista.

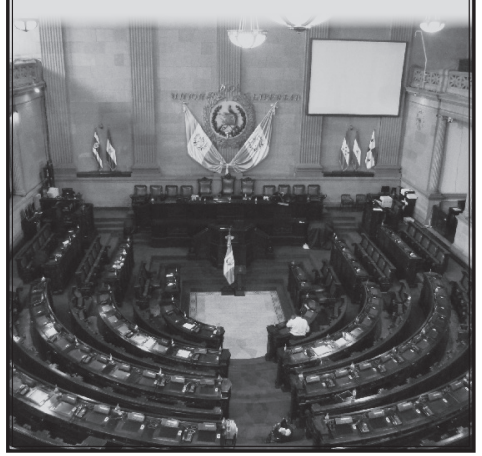

El Organismo Ejecutivo, en casi todos los regímenes democráticos representativos, es uno de los tres poderes que gobierna junto al organismo Legislativo y el Judicial. El poder del gobierno Ejecutivo lo delega el pueblo en el o la Presidente de la República y, para suplir en los casos que establece la ley, en el o la Vicepresidente. La Presidencia se encarga de administrar las tareas de un gobierno. Para hacerlo, cuenta con el apoyo de las ministras, ministros, gobernadores, así como otras y otros funcionarios, a quienes nombra la Presidencia de la República.

El Ejecutivo tiene dos componentes: el político directivo, es electo por el pueblo y toma decisiones políticas (Presidencia y Vicepresidencia), y el administrativo, que es nombrado por la Presidencia: ministras o ministros: viceministros, directores y demás personal de oficinas públicas que labora para dicho organismo. Este personal del Organismo Ejecutivo es el que está organizado en dependencias para planificar y ejecutar las políticas, programas, proyectos y acciones.

Las principales dependencias del Ejecutivo en Guatemala son los ministerios, los cuales están a cargo de un ministro o ministra. La Presidencia, Vicepresidencia, ministros o ministras forman el Consejo de Ministros. Otras dependencias del Ejecutivo son las secretarías de la Presidencia (General, Privada, de Coordinación Ejecutiva, de la Mujer, de Planificación y Programación, etc.) comisiones presidenciales (contra la discriminación, presidencial por los derechos humanos) gobernaciones departamentales, dependencias y órganos que administrativa o jerárquicamente dependan de la Presidencia, también comités temporales, consejos especializados como el de Seguridad y gabinetes específicos.

La estructura mínima de un ministerio es:

\section{Despacho Ministerial \\ (ministro y \\ viceministros)}




\section{La tributación}

Tributar es pagar impuestos. Un impuesto es un pago que las personas de un país hacen al Estado, según sus ingresos o ganancias, con la finalidad de que proporcione educación, salud, seguridad, entre otros servicios públicos. En todo Estado se establece un sistema tributario, es decir una estructura encargada de captar el pago de impuestos y entregarlos a la administración estatal, además de una ley tributaria. Esta ley establece quién paga impuestos, cuánto paga, cuándo hace el pago, por qué circunstancias y qué sanciones se le impone a la persona que evade pagar un impuesto o se queda con una parte del impuesto que cobró para entregarlo a las autoridades fiscales, entre otros aspectos.

La Constitución establece que es un deber cívico contribuir a los gastos públicos. Para que funcionen los juzgados, centros de salud, centros educativos, se construyan carreteras y puentes, las y los deportistas participen en competencias internacionales, entre otros servicios públicos, se necesita pagar impuestos. Por tal motivo, un ciudadano o ciudadana no puede argumentar que no paga impuestos porque se hace un mal uso de los recursos o que se roban una parte. Lo que sí puede exigir es transparencia del gasto y auditoría o fiscalización social. Esto significa que toda persona puede ver en qué y cómo se gastan los recursos o participar con un grupo de ciudadanos en la revisión de las cantidades y la forma en que se gastaron los recursos de una entidad estatal.

Los impuestos se clasifican en directos e indirectos. Los impuestos indirectos son los que se cobran a las personas cuando compran algo, también se llaman impuestos al consumo, como el IVA. Los impuestos directos son los que se cobran de acuerdo con los ingresos que obtiene una persona y por tener determinadas riquezas (fincas, mansiones, barcos, etc.). Al régimen tributario que se basa en los impuestos directos se le llama progresivo, al que se basa en impuestos indirectos se le denomina regresivo.

\section{Analizamos con nuestro equipo:}

En el régimen tributario progresivo, las personas que tienen más riqueza deben pagar más impuestos, ¿es justo esto? ¿Por qué?

Los impuestos indirectos en Guatemala constituyen más del $70 \%$ de los ingresos tributarios. De acuerdo con esta información, ¿qué régimen tributario tiene Guatemala?

Verificamos que los materiales e insumos necesarios para finalizar el producto o servicio tecnológico estén completos y sean los necesarios.

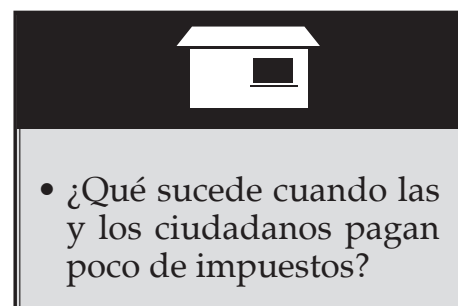

\section{Los impuestos en} Guatemala

Desde 1990, Guatemala es el país en donde se pagan menos impuestos en Latinoamérica.

Así que no pagar impuestos causa un gran daño al país. En 2016, la SAT descubrió varios casos de enorme evasión tributaria y recuperó miles de millones de quetzales. Se trata de casos de evasión descarada, pero otros son más sofisticados y hasta legales, por ejemplo, las inversiones en empresas fuera de plaza, llamadas offshore.

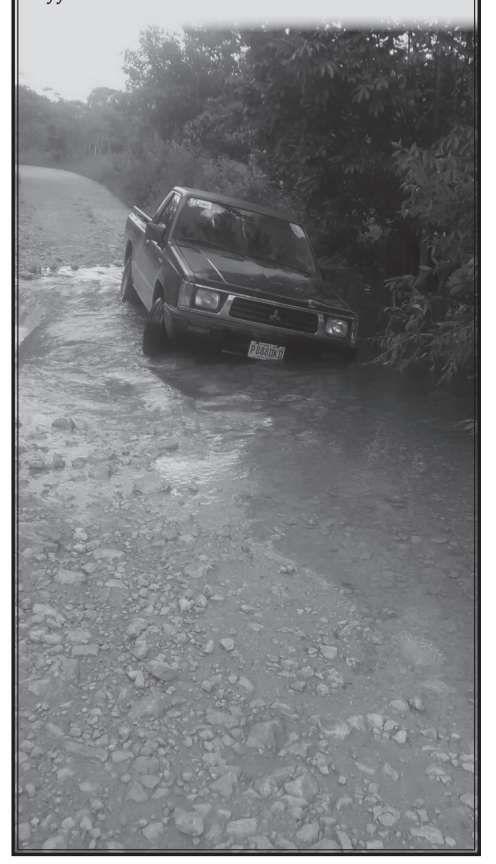




\section{Mimas y mimos en acción}

\section{El lenguaje del cuerpo}

Nuestro cuerpo habla por sí mismo. A veces pensamos que solo el rostro dice mensajes, pero no es así. Todo el cuerpo manifiesta mensajes que fácilmente pueden ser captados por quienes nos observan.

Una pierna cruzada muestra una actitud defensiva, aunque en ocasiones también relajación.

Brazos cruzados pueden estar mostrando indiferencia, o defensa ante una amenaza.

La cabeza agachada muestra timidez.
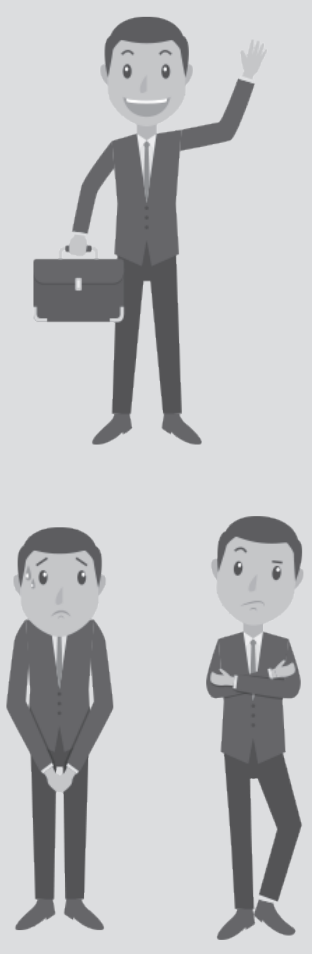

El mimo es una técnica de actuación que se realiza solo con gestos. Se gesticula mucho con el rostro y se exageran los movimientos del cuerpo. Anteriormente abordamos la pantomima y revisamos diversas caras que se pueden gesticular para transmitir mensajes. No es solo el rostro sino todo el cuerpo el que habla sin palabras. La característica principal del mimo es que todo se hace en silencio. Sin embargo, el mimo necesita algunos accesorios que son específicos de este tipo de actuación.

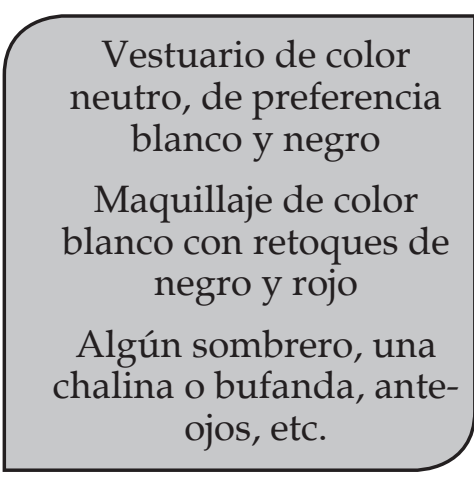

Para hacer mimo es importante que cada acción se resalte con gestos y movimientos exagerados $\mathrm{y}$ coordinados. Una expresión triste no solo es del rostro, también del cuerpo ligeramente agachado. De igual forma, una expresión de sorpresa requiere de gestos en el rostro y movimiento de brazos y piernas.

\section{Trabajemos en grupo}

- Actuamos una rutina de caras según los estados de ánimo: tristeza, alegría, cansancio, sorpresa, ánimo, angustia, dolor, enamoramiento, rencor.

- Agregamos una rutina en la que a cada rostro le agregamos dos movimientos de brazos. Si es necesario, agregamos piernas.

- Escogemos un estado de ánimo, ponemos una silla en el centro del grupo, y cada estudiante pasa a realizar una rutina completa con estado de ánimo.

- Creamos una historia en la que contamos algo del proyecto realizado usando los movimientos del mimo. 


\section{Proyectos que resuelven necesidades}

A lo largo de estas semanas hemos desarrollado ideas para resolver problemas que nos afectan a nivel familiar y a nivel comunitario. En todas las áreas hemos explorado cómo el conocimiento puede estar al servicio de la sociedad y del ambiente. Se han planteado ideas innovadoras a partir de lo que ya conocíamos, o bien se han implementado medidas aplicadas a casos específicos. Estos casos tienen relación con los proyectos realizados.

En la siguiente actividad grupal, analizaremos los proyectos que en todas las áreas nos han ayudado a resolver problemas y necesidades a partir del conocimiento.

\section{Dramatización con técnica del mimo}

- Planteamos los proyectos que han valorado la participación de las mujeres y la cultura cívica sobre derechos y deberes que nos corresponden.

- Exponemos las razones por las que consideramos que esos proyectos son importantes.

- Actuamos escenas que reflejen esos proyectos, con mimos.

- Valoramos el trabajo realizado por todas y todos.

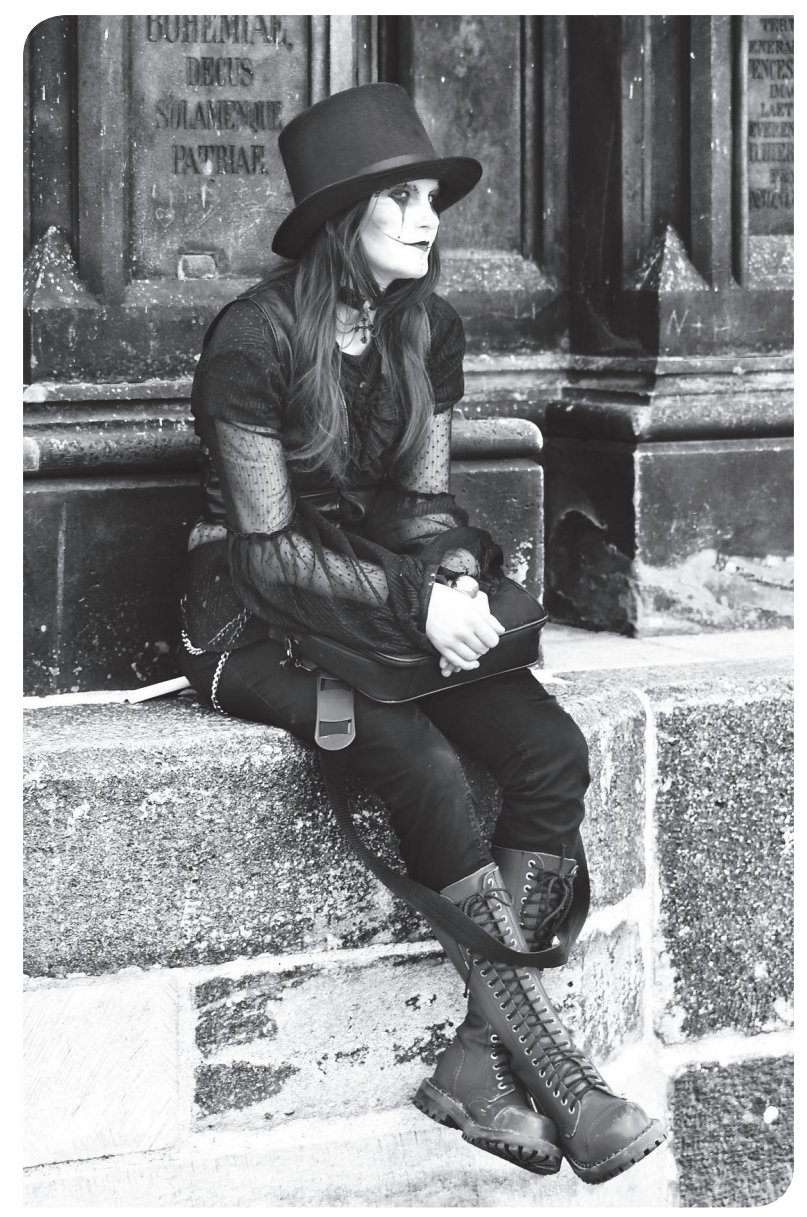

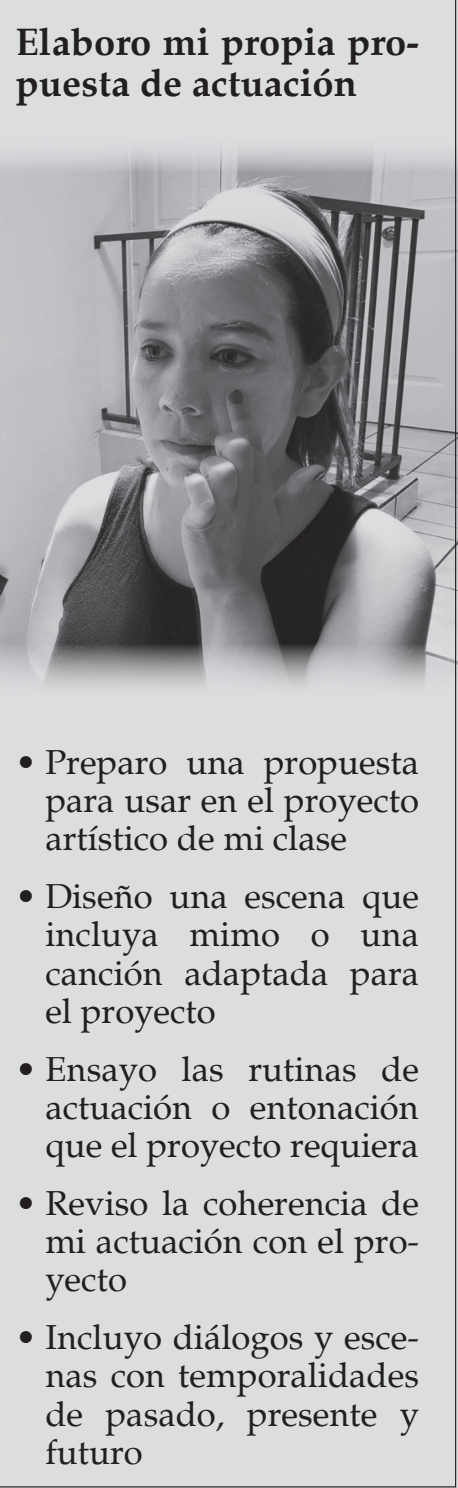




\section{La producción de alimentos}

\section{Manejo forestal sostenible}

Guatemala tiene vocación forestal. Esto significa que en muchas áreas del país los bosques se dan mejor que el maíz, frijol y hortalizas.

De los bosques podemos obtener energía (leña, carbón y ocote), protección de la erosión de los suelos, biodiversidad, y producción de agua. Además, pueden ser fuente de ingresos: producen hongos comestibles $\mathrm{y}$ con las hojas podemos fabricar abono o artesanías, vender madera, crear un vivero o un sitio turístico.

Un bosque manejado en forma sostenible requiere tiempo, pero da grandes frutos. En los bosques de madera o leña se realizan periódicamente talas seleccionadas y resiembras para que se conserve, al mismo tiempo que los árboles talados producen madera o leña para consumo o venta.

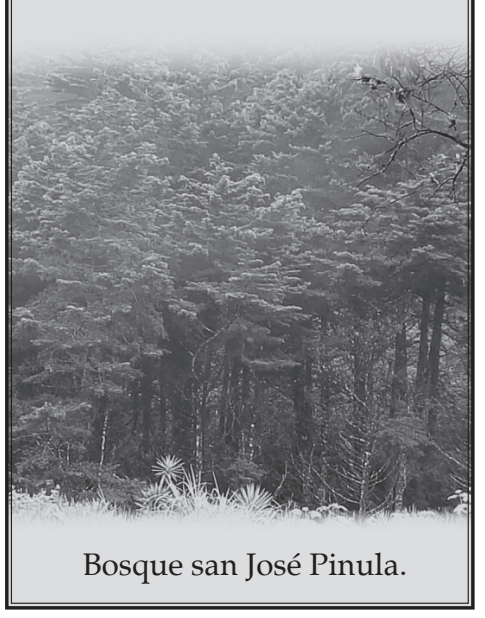

Los principales materiales de este campo productivo son los mismos alimentos; la proveniencia, la variedad, el nivel de madurez y calidad y los tipos y cantidades de fertilizantes, herbicidas y pesticidas utilizados determinarán el valor nutricional, así como la frescura y sabor de cualquier platillo. El tipo de alimentos y cocción influyen no solo en el sabor sino también en los costos de preparación.

Tanto la preparación de alimentos como la cría de animales domésticos exigen cumplir con normas de calidad. Los corrales deben contar con agua y drenajes para que el suelo esté seco. Además, se necesita suficiente espacio para que se puedan mover. También se requiere de un espacio techado para que los animales se resguarden de la lluvia y el frío; el piso, los comederos y los bebederos siempre deben estar limpios por lo que se necesita supervisión constante para extraer el estiércol. Los animales deben contar con suficiente agua y alimento. Al igual que con los humanos, si beben agua contaminada corren el riesgo de enfermarse. Su muerte representa graves pérdidas económicas. Por ello, también debe llevarse un control cuidadoso de la administración de vacunas y tomar precauciones para su cuidado, como entrar a los corrales con ropa y botas limpias.

Esto son algunos elementos de las buenas prácticas pecuarias, las cuales involucran cuatro aspectos:

- Seguridad de las personas: seguridad alimentaria, seguridad laboral y bienestar familiar.

- Inocuidad alimentaria: alimentos sanos no contaminados y de mayor calidad.

- Bienestar animal: cuidado y alimentación adecuada de los animales.

- Cuidado del medio ambiente: manejo racional y cuidado de los recursos naturales.

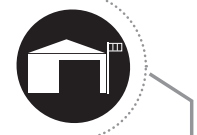

Presentamos en clase el álbum que preparamos con los materiales utilizados en diferentes campos productivos.

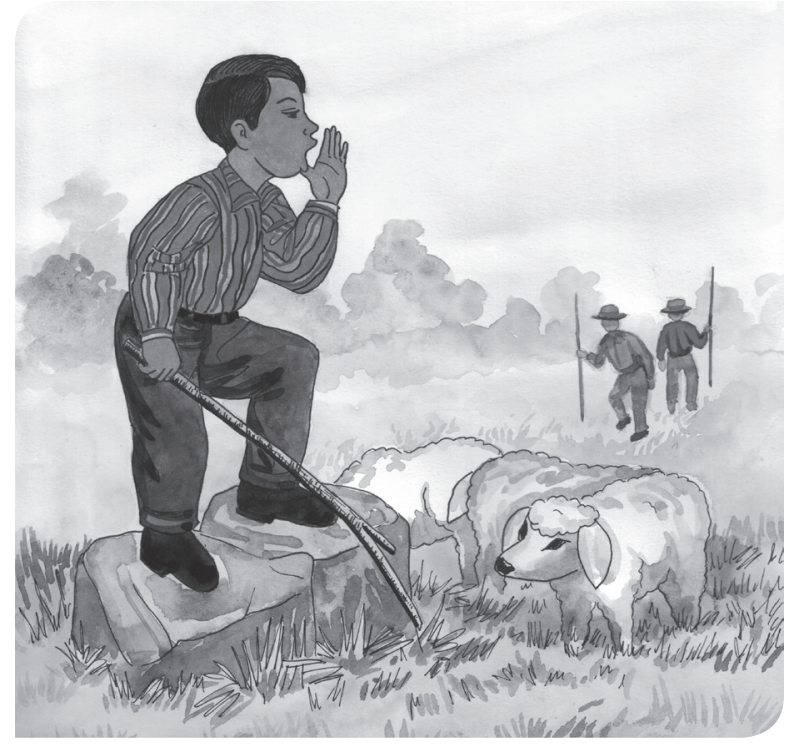


Para conservar el ambiente, es importante considerar el tipo de combustible usado para la cocción de los alimentos. Poco más de la mitad de los hogares guatemaltecos utiliza leña para cocinar sus alimentos y calentar su vivienda, principalmente, debido a la pobreza y la falta de servicio de energía eléctrica.

Muchas familias usan fogones abiertos, que consumen mayor cantidad de leña y producen humo que contamina el aire de las viviendas haciendo a sus habitantes más vulnerables a enfermedades respiratorias, particularmente, neumonías, así como enfermedades del corazón, derrames cerebrales y cáncer. Por ello, se promueve el uso de estufas mejoradas, que se caracterizan por:

- Una cámara de combustión cerrada que permite crear calor con menos leña. Ahorran leña y dinero, favoreciendo el ambiente.

- Una plancha donde se distribuye el calor permitiendo calentar varios platos a la vez durante un periodo largo de tiempo con la misma cantidad de leña.

- Una chimenea que expulsa el humo fuera del hogar.

Estas estufas son más higiénicas porque están elevadas del suelo por lo que impiden que caiga polvo en los alimentos o que perros o gatos se acerquen a ollas y platos. Son más fáciles de limpiar y más cómodas para cocinar. Al igual que los fogones abiertos, las estufas mejoradas permiten mantener prácticas culturales como reunirse alrededor del fuego para comer y platicar.

Esta semana comenzamos a planificar la preparación de un producto o servicio tecnológico útil a nuestra comunidad. Evaluemos nuestro trabajo.

\begin{tabular}{|l|l|l|}
\hline \multicolumn{1}{|c|}{ ASPECTOS A EVALUAR } & Sí & No \\
\hline $\begin{array}{l}\text { Argumentamos sobre el papel de la mujer en nuestra } \\
\text { comunidad y la sociedad. }\end{array}$ & & \\
\hline $\begin{array}{l}\text { Preparamos la argumentación y demostración } \\
\text { matemática del razonamiento del razonamiento } \\
\text { inductivo y deductivo. }\end{array}$ & & \\
\hline $\begin{array}{l}\text { Organizamos los equipos de trabajo para elaborar un } \\
\text { producto o servicio tecnológico para nuestra comunidad. }\end{array}$ & & \\
\hline $\begin{array}{l}\text { Verificamos que contamos con los materiales } \\
\text { necesarios para preparar el producto o servicio } \\
\text { tecnológico elegido. }\end{array}$ & & \\
\hline $\begin{array}{l}\text { Planificamos la preparación del producto o servicio } \\
\text { tecnológico }\end{array}$ & & \\
\hline $\begin{array}{l}\text { Iniciamos la preparación del producto o servicio } \\
\text { tecnológico según lo planificado. }\end{array}$ & & \\
\hline Presentamos nuestro proyecto artístico. & & \\
\hline Comenzamos a aprender a jugar ajedrez. & & \\
\hline
\end{tabular}

Calculamos el consumo semanal de leña en casa. Anotamos qué tipo de leña se utiliza, de dónde proviene, cuánto cuesta y cuánto rinde, en cantidad de tiempo de fuego. Si en nuestra familia hay otro tipo de estufa u horno, discutimos en familia para qué se usa cada uno y por qué, tratando de conocer si la cantidad de leña utilizada tiene alguna influencia en la decisión.

\section{Horno solar}

Generalmente, cuando hace mucho calor decimos en broma que podemos freír un huevo al sol. En este ejercicio aprovecharemos la energía del sol para cocinar alimentos.

\section{Necesitamos:}

- 1 caja grande de cartón con tapaderas y 1 más pequeña

- pedazos de papel periódico o arena

- papel aluminio o cartulina plateada

- cartulina o pintura negra

- tijera y goma

Instrucciones:

1. Quitar tapadera a la caja pequeña.

2. Pegar la cartulina negra o pintar el interior de la caja pequeña.

3. Forrar el interior de la tapadera de la caja grande con papel aluminio.

4. Meter la caja pequeña dentro de la grande.

5. Rellenar el espacio entre las dos cajas con el papel periódico o arena.

6. Abrir la tapadera de la caja negra con el papel aluminio viendo hacia arriba. Sujetar los lados de la tapadera con tape o algo que las mantenga levantadas.

El horno está listo. Colocarlo bajo el sol y poner dentro de la caja pequeña una olla con agua y verduras en rodajas o palitos con angelitos para que se derritan. 


\section{La fuerza del magnetismo}

\section{Campo magnético}

El campo magnético es el espacio en el imán donde se ejercen fuerzas sobre las cargas en movimiento. El campo magnético disminuye cuando se aleja el objeto que se desea atraer, y aumenta cuando se acerca el objeto y al imán. El campo magnético se representa mediante líneas de fuerza que son una líneas imaginarias cerradas, que van del polo norte al polo sur, por fuera del imán y en sentido contrario en el interior de este.

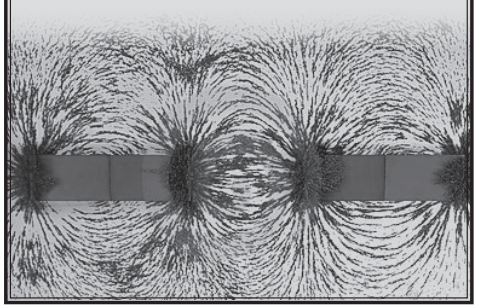

Al hablar de magnetismo pensamos en imanes y la capacidad que tienen de atraer clavos y otros objetos de metal. ¿Hemos jugado con imanes alguna vez? ¿Hemos pasado entre la tierra los imanes y hemos observado que trozos pequeños de un material oscuro quedan adheridos al imán? ¿Qué fuerzas actúan para que ocurran estos fenómenos?.

La palabra magnetismo proviene de la antigua región de Magnesia de Tesalia, en Grecia. Allí, hace más dos mil años se encontraron unas piedras que podían atraer trozos de hierro. Esas piedras se denominaron: piedras imán, hoy llamada magnetita. Ciertos materiales denominados ferromagnéticos, ejercen fuerzas, ya sea de atracción o de repulsión, sobre otros materiales con los que interactúan. Algunos materiales tales como el níquel, hierro, cobalto y sus correspondientes aleaciones llamadas imanes ejercen esas fuerzas magnéticas. En el resto de sustancias existen fuerzas magnéticas, pero no se observan a simple vista.

Sabías acerca de los imanes que: Son cuerpos que tienen la propiedad de atraer objetos de hierro o de acero.

- Todo imán tiene dos polos: el norte $(\mathrm{N},+)$ y el sur $(\mathrm{S},-)$.

- Entre los polos de dos imanes siempre surgen fuerzas de atracción o de repulsión.

- Dos imanes se atraen cuando se enfrentan por los polos de distinto signo, y se repelen cuando se enfrentan por los polos del mismo signo.

- Cuando un imán se parte en dos pedazos se convierte en dos nuevos imanes; esto es por la inseparabilidad de los polos.

- La fuerza de atracción o de repulsión es mayor en los polos y menor en el cetro del imán.

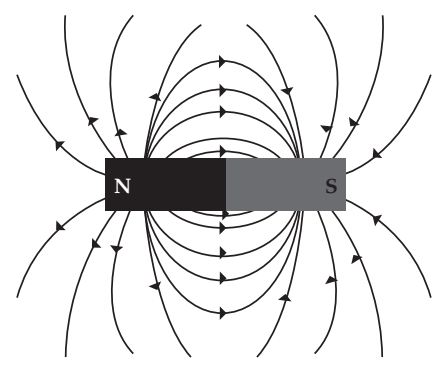

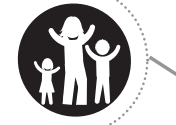

Analizamos en cuál de las imágenes se representa fuerza de repulsión y en cual la fuerza de atracción. Explicamos las causas.
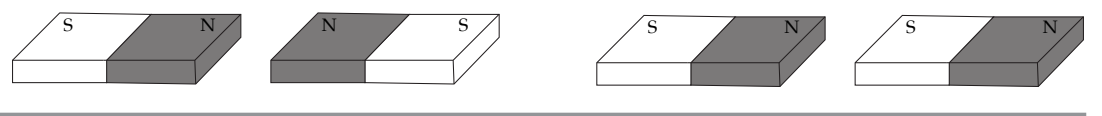

En grupo evaluamos los productos o servicios que estamos construyendo considerando: su utilidad para la comunidad, la accesibilidad y costo de materiales empleados, tipo de energía que utiliza y el interés que generará en la comunidad.

Videos recomendados:

https://www.youtube.com/watch?v=PyMK_UGlGIw

https://www.youtube.com/watch?v=ylkM_H2qGF0

Investigo qué objetos de mi casa y comunidad utilizan imanes. 


\section{Imanes en la vida cotidiana}

Los imanes naturales son minerales de hierro; el más conocido y abundante es la magnetita. Con un imán natural es relativamente sencillo obtener un imán artificial. Una aguja, por ejemplo, se convierte en un imán artificial si es frotada durante cierto tiempo contra un imán natural, cuidando siempre de hacerlo en la misma dirección. Este proceso se llama imantación. Los objetos de hierro se pueden convertir en imanes artificiales por frotamiento, aunque su capacidad magnética suele durar poco tiempo. En cambio, los objetos de acero se pueden convertir en imanes permanentes. Los imanes se usan en la vida cotidiana, en cerraduras de puertas, de muebles, en juguetes, en pizarrones especiales, alfileteros, juguetes, entre otros.
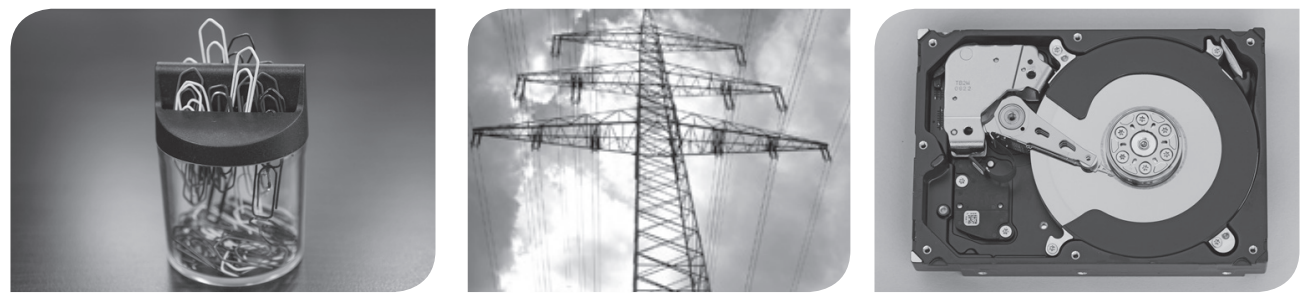

\section{Magnetismo terrestre}

La Tierra y todos los astros funcionan como imanes y producen un campo magnético.

Sus polos se encuentran cerca de los polos geográficos: el polo norte magnético está situado cerca del polo sur geográfico y el polo sur magnético está cerca del polo n orte geográfico.

El campo magnético de la Tierra ejerce una fuerza sobre todos los imanes; si estos están suspendidos, se orientan en dirección norte-sur magnéticos. En este hecho se basa el funcionamiento de la brújula.

La brújula consiste en una caja que contiene en su interior una aguja que se mueve en forma libre, pero que está imantada, y por ello su orientación será siempre norte-sur.

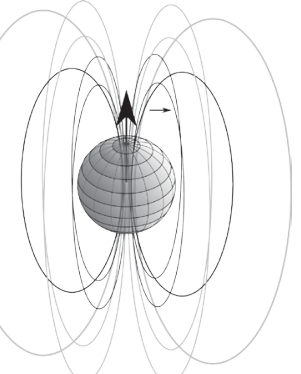

Observemos las líneas del campo magnético de la Tierra.

Materiales: una esfera de duropor, una cuchilla, un imán de tamaño del radio de la esfera y limadura de hierro.

- Partimos la esfera de duropor en dos partes iguales con la cuchilla.

- Luego colocamos el imán en el interior de la esfera. Rociamos la limadura de hierro alrededor de la esfera.

- Explicamos cómo están representadas las líneas del campo magnético y por qué.
En el interior de la materia existen pequeñas corrientes cerradas debido al movimiento de los electrones que tienen los átomos. Cada una de ellas origina un microscópico imáno dipolo (compuesto que tiene dos polos, uno negativo y otro positivo, pero cercanos entre sí). Cuando esos pequeños imanes están orientados en todas direcciones, sus efectos se anulan mutuamente y el material no presenta propiedades magnéticas; en cambio si todos los imanes se alinean actuando como un único imán, decimos que la sustancia se ha magnetizado. Imantar un material es ordenar sus imanes atómicos. En la figura se observa en primer lugar un material sin imantar y debajo un material imantado. El campo magnético se representa con una $\mathrm{B}$

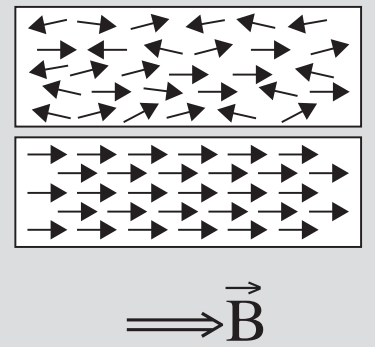




\section{El teatro y su expresión artística}

\section{Los códigos en la} publicidad

Los códigos publicitarios pueden ser verbales (oral o escrito) o no verbales (sonido o música). En los verbales se intenta decir mucho con el menor número de palabras posible y que, a la vez, el mensaje permanezca en la mente de quien lo percibe. Los códigos no verbales se apoyan en sonidos o melodías contagiosas que luego se asocian a la imagen o las palabras utilizadas. Para obtener estos resultados, la publicidad utiliza la polisemia y los juegos de palabras e imágenes. En ellos, lo que se dice en palabras no es lo mismo que lo que muestra la imagen, pero recibimos el mensaje que nos están enviando. A esto se le llama «Plurisignificación». Ejemplo:

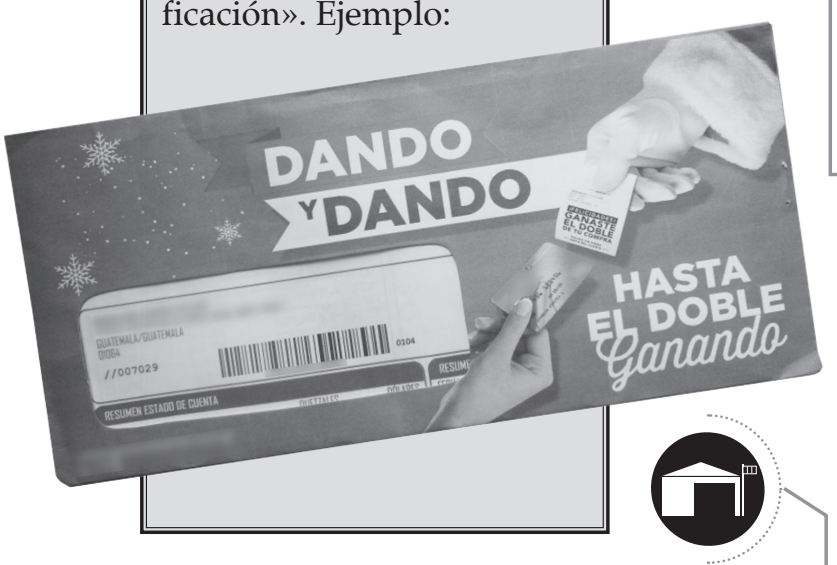

- ¿Hemos visto alguna obra de teatro? ¿En qué se parece el teatro al cine?

El teatro nació en la antigua Grecia y es una rama del arte escénico en el que, frente a una audiencia o público, se representan historias. La persona que escribe obras de teatro se llama dramaturgo o dramaturga.

\section{Existen varios tipos de teatro:}

Teatro cómico: Tiene la finalidad de hacer reír al público a través de situaciones absurdas o simpáticas; suele tener finales felices.

Teatro trágico: En él, los personajes se enfrentan a situaciones que no tienen remedio o amores imposibles. Normalmente concluyen con la muerte de una o uno de los protagonistas y el sufrimiento de quienes quedan con vida.

Teatro mímico: En él, las emociones y los sentimientos se expresan por medio de gestos, muecas y movimientos corporales; pues es mudo, no se habla ni se usan sonidos.

Teatro de vanguardia: Surgió en Francia en la década de los 50. No tiene una estructura lógica, ni diálogos lógicamente planteados y personajes definidos. El teatro de vanguardia refleja un mundo del absurdo, privilegia la puesta en escena por sobre el lenguaje.

Leeremos textos teatrales de diferentes épocas y movimientos. Escribiremos y escenificaremos una obra de teatro que manifieste los beneficios de nuestro proyecto a diferentes grupos de la comunidad: mujeres, niñas, jóvenes. Al final cada equipo podrá presentar, en idioma materno, los avances que lleva del proyecto en desarrollo. Si hay disponibilidad pueden recurrir a Power Point $u$ otro medio tecnológico para ello. 


\section{La comunicación a través del diálogo}

El diálogo es la comunicación verbal o escrita que utilizan dos o más personas para relacionarse entre sí. Al dialogar exponemos nuestras ideas, puntos de vista y opiniones y escuchamos a las demás personas. Es un componente primordial para las obras de teatro.

\section{En literatura teatral existen varios tipos de diálogo:}

\section{Diálogo directo}

En él hablan los personajes directamente. Quien narra sale de escena y solo interviene para acotar o aclarar qué personaje está hablando. Los diálogos directos se identifican con la raya o guion largo:

- Mañana no va a haber clase — dijo, Marta.

- ¿Por qué? - preguntó Jaime.

- La maestra nos ha pedido que presentemos nuestros proyectos a la comunidad. - intervino Zoila-. La tiene que ver la doctora.

\section{Diálogo indirecto}

En este tipo de diálogo prevalece la voz de quien narra. Es quien dice lo que está pensando el personaje:

«Ana, sin quitarle los ojos de encima, pensó que nunca había visto tan orgullosa a su abuela».

Planificaremos, organizaremos y elaboraremos un informe o discurso en nuestro idioma para presentar y promover, dentro de los miembros de la comunidad, las ventajas del proyecto que estamos trabajando. Tratamos de utilizar la mayor cantidad de técnicas de expresión y de poner mucho énfasis en nuestro lenguaje no verbal, para evitar transmitir mensajes negativos. Para ello, practicaremos el discurso frente a un espejo.

Si tienes acceso a internet o a una biblioteca, puedes investigar sobre inventos hechos en Estados Unidos y otros países que han aportada a la solución de problemáticas locales. 


\section{Enerolo alternativa en procesos productivos}

Biogás producido con desechos de café

Se pueden mezclar los desechos del café con estiércol de animales para generar gas mediante biodigestores. El biodigestor es un depósito cerrado donde la materia orgánica se descompone y por la humedad y la falta de oxígeno produce el biogás, que puede ser quemado como cualquier combustible. Cuando se emplea en beneficios de café, al usar las aguas mieles del beneficio se evita contaminar las fuentes de agua. El biogás puede ser utilizado para mover máquinas en el beneficio. Las familias pueden sustituir las estufas de leña. Eso sí, se debe conocer bien su funcionamiento ya que como cualquier otro gas, si no se utiliza adecuadamente se corre el riesgo de una explosión.
El café, cuya producción se ha extendido en todo el país, es uno de los principales productos de exportación y en su producción trabajan una gran cantidad de personas. Actualmente, existen más de medio millón de pequeños productores que aportan más de la mitad de la producción cafetalera del país.

Como cualquier proceso productivo, iniciar una plantación de café requiere planificación tomando en cuenta la inversión (costo y gastos), el presupuesto disponible, la recuperación de la inversión y la futura ganancia. Es importante tomar en cuenta que el cafeto produce frutos hasta seis años después de su siembra y su nivel de producción comienza a disminuir a los 15 años, momento en el que se recomienda un proceso sistemático de renovación de la plantación para evitar la propagación de enfermedades y plagas.

El primero a considerar es tipo de semilla sus ventajas y desventajas. El café de sombra, se aprovecha para obtener ingresos adicionales con la siembra de banano o aguacate. El deshierbe, la limpieza, la fertilización y la fumigación de la plantación debe hacerse siguiendo las normas de calidad y seguridad.

Durante la época de cosecha se recoge únicamente el fruto rojo y diariamente se pone en recibidores. Los frutos defectuosos salen a flote en los recibidores; para uso responsable del agua, los recibidores contienen agua que se bombea para ser usada repetidas veces. El despulpado, clasificado, fermentación y lavado utilizan el apoyo de máquinas, las cuales pueden ser accionadas con energía eléctrica, hidroeléctrica o solar. El café es secado al sol o en secadoras para ser vendido como café pergamino; después de tostado, se convierte en café oro. El café puede ser vendido en grano o molido.

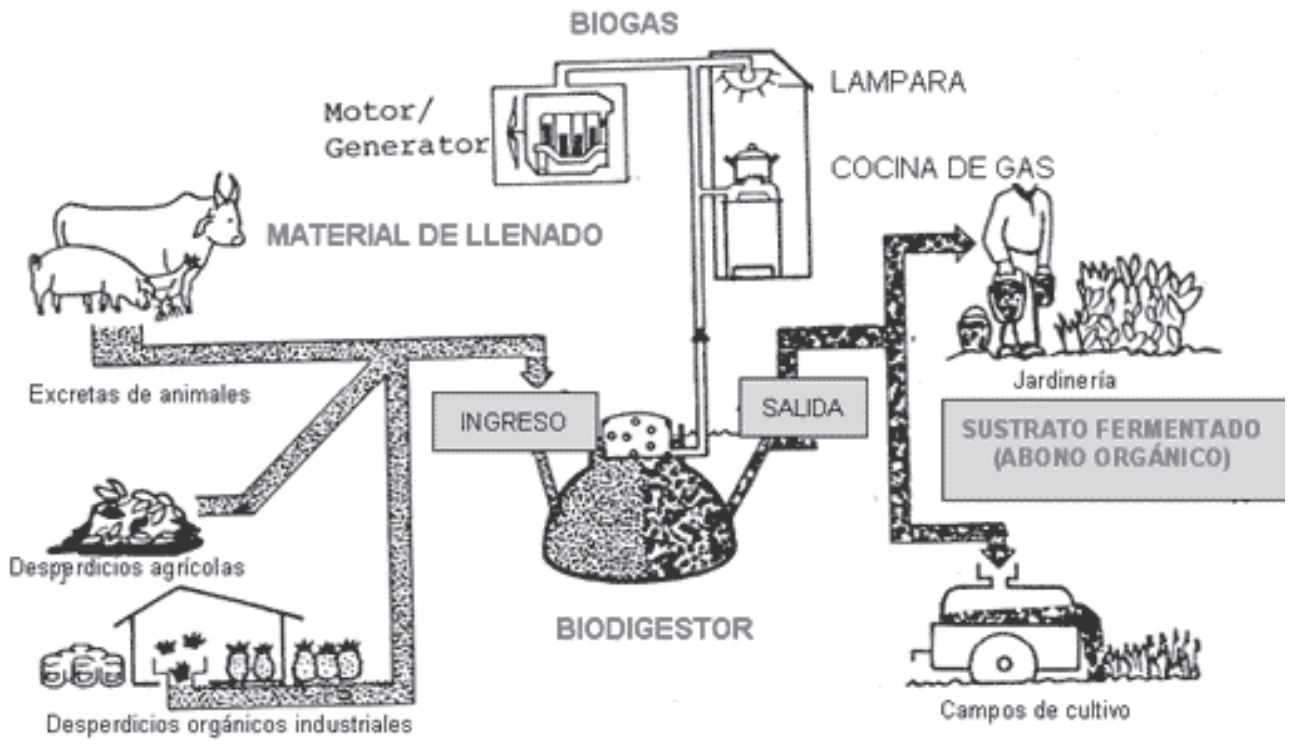

Fuente: http:/ /images.engormix.com/s_articles/biodigestores02.gif 
Aunque algunos beneficios de café utilizan maquinaria eléctrica, varios utilizan energía hidroeléctrica aprovechando desniveles en el terreno y acceso a ríos. Una hidroeléctrica puede proveer suficiente energía para mover las despulpadoras y las cribas de clasificación, así como las secadoras. Debido al alto costo de estos equipos, los pequeños productores se unen en asociaciones o cooperativas para beneficiar su café y venderlo a mejor precio.

El proceso productivo del café puede ser amigable con el ambiente por medio de árboles de sombra que ayudan a conservar la biodiversidad, los residuos de pulpa pueden ser utilizados para elaborar lombricompost, la cascarilla del café pergamino puede ser quemada como combustible. Sin embargo, debe tenerse cuidado para que el agua utilizada en el beneficio, llamada aguas mieles, reciban un tratamiento adecuado para evitar la contaminación de cuerpos de agua.

Esta semana continuamos presentamos el producto o servicio a nuestra comunidad educativa. Evaluemos nuestro avance.

\begin{tabular}{|l|l|l|}
\hline \multicolumn{1}{|c|}{ ASPECTOS A EVALUAR } & Sí & No \\
\hline $\begin{array}{l}\text { Elaboramos una presentaciónpara promover el producto } \\
\text { o servicio tecnológico que estamos elaborando. }\end{array}$ & & \\
\hline $\begin{array}{l}\text { Preparamos la argumentación y demostración } \\
\text { matemática del razonamiento del producto o servicio } \\
\text { tecnológico que presentamos a nuestros compañeros. }\end{array}$ & & \\
\hline $\begin{array}{l}\text { Verificamos las características del producto o servicio } \\
\text { tecnológico que proponemos. }\end{array}$ & & \\
\hline $\begin{array}{l}\text { Hemos avanzado en el desarrollo de nuestro producto o } \\
\text { servicio tecnológico. }\end{array}$ & & \\
\hline $\begin{array}{l}\text { Presentamos los avances de nuestro proyecto a nuestra } \\
\text { clase. }\end{array}$ & & \\
\hline $\begin{array}{l}\text { Elaboramos un álbum sobre los materiales de diferentes } \\
\text { campos productivos. }\end{array}$ & & \\
\hline
\end{tabular}

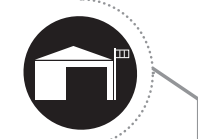

Presentamos en clase el álbum que elaboramos con recortes, fotografías o dibujos sobre un campo productivo. Compartimos y analizamos si hay materiales que podríamos aprovechar aún más en favor de nuestras familias y el ambiente.

Investigamos y conversamos en familia sobre las normas de seguridad empleadas en el campo productivo sobre el cual elaboramos el álbum.

Energía eléctrica de bagazo de caña de azúcar

Los ingenios azucareros más grandes de Guatemala están utilizando el bagazo de la caña de azúcar para producir energía eléctrica. Tienen patios separados para la caña para fabricar azúcar y para secar el bagazo. El bagazo ya seco se quema en calderas que producen vapor. El vapor se conduce a termogeneradores que producen energía con la que se alimentan los transformadores para convertirla en energía eléctrica. Una parte de la energía se usa para autoconsumo en el ingenio $y$ la otra partese vende. De esta manera, los ingenios azucareros ahorran dinero evitando la compra de energía eléctrica y además aprovechan el desecho de la caña de azúcar para generar ingresos vendiendo la energía producida.

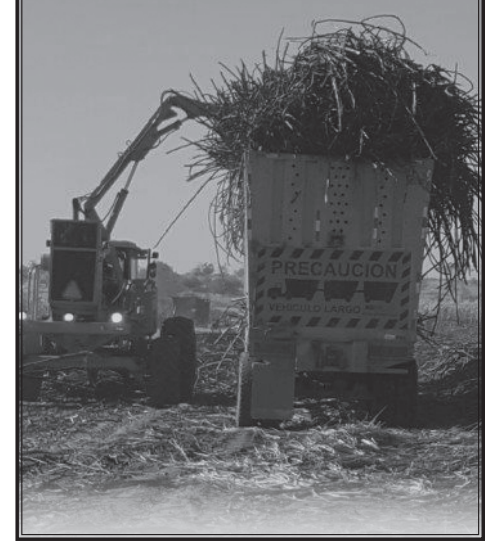




\section{La inequidad}

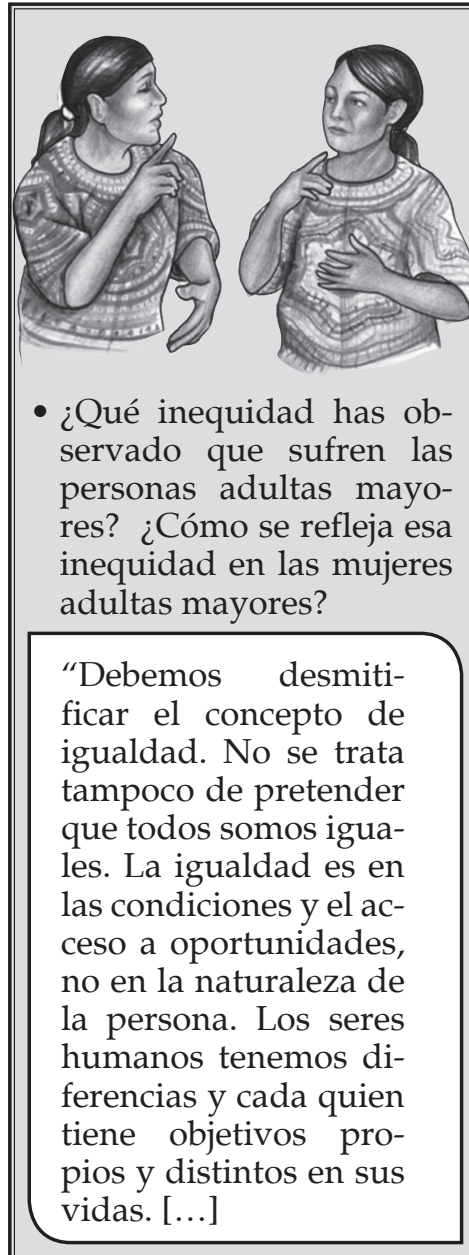

Fuente: Pérez-Attias, S. (2013). Inequidad y desarrollo. Prensa Libre. Recuperado de: http:/ / www.prensalibre. com/opinion/Inequidaddesarrollo_0_883111795.html
Cada persona es única y diferente al resto, hay diversidad en su historia, el lugar donde viven, el idioma que habla, y la forma en que las personas se comportan, aprenden, sienten y hacen su vida. Estas diferencias son naturales y normales. Cuando las condiciones sociales y económicas provocan desigualdades entre las personas por sus diferencias y limitan a algunas personas desarrollen sus capacidades o realicen actividades dentro de la comunidad ya no son condiciones naturales ni normales.

La palabra inequidad señala la desigualdad de condiciones entre personas. Por sus características, estas limitan que todas las personas vivan dignamente. El término también es usado para señalar las diferencias que se observan en las oportunidades que las personas tienen en la sociedad, para desarrollarse y vivir mejor. La palabra inequidad es mejor empleada cuando se habla de la desigualdad entre grupos de personas por su género, su cultura, origen, religión o clase social. La inequidad está directamente relacionada con la injusticia; y como es una condición creada, por lo tanto, la comunidad o sociedad puede transformarla.

Se puede hablar de inequidad entre grupos en muchos aspectos de la vida social. Por ejemplo en el empleo: hay desiguales oportunidades entre las personas según su nivel de estudio, su origen étnico, en el salario de las mujeres y los hombres, el acceso entre jóvenes y adultos, y también hay inequidad para las personas con discapacidades.

Cuando la inequidad entre grupos se repite en muchos ámbitos de la vida se habla de inequidad estructural. Por ejemplo, cuando las personas viviendo con ingresos insuficientes no tienen las mismas oportunidades que las personas de medianos y altos ingresos para recibir educación, salud, seguridad, tener una vivienda adecuada, energía eléctrica, agua potable, practicar deporte y recrearse.

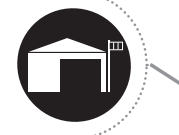

\section{Respondemos en equipo:}

- ¿Qué inequidad se evidencia más en nuestra comunidad?

- ¿Observamos inequidad en el acceso a la tecnología en nuestra comunidad? Explicamos nuestra respuesta.

- ¿Cómo podemos asegurar que nuestro producto no genere inequidad en la comunidad?

- ¿Cómo podemos asegurar que todos y todas tengan oportunidad de aprovechar los beneficios de nuestro producto?

Continuamos con la elaboración del producto o servicio tecnológico de acuerdo con la planificación que elaboramos. 


\section{La discriminación}

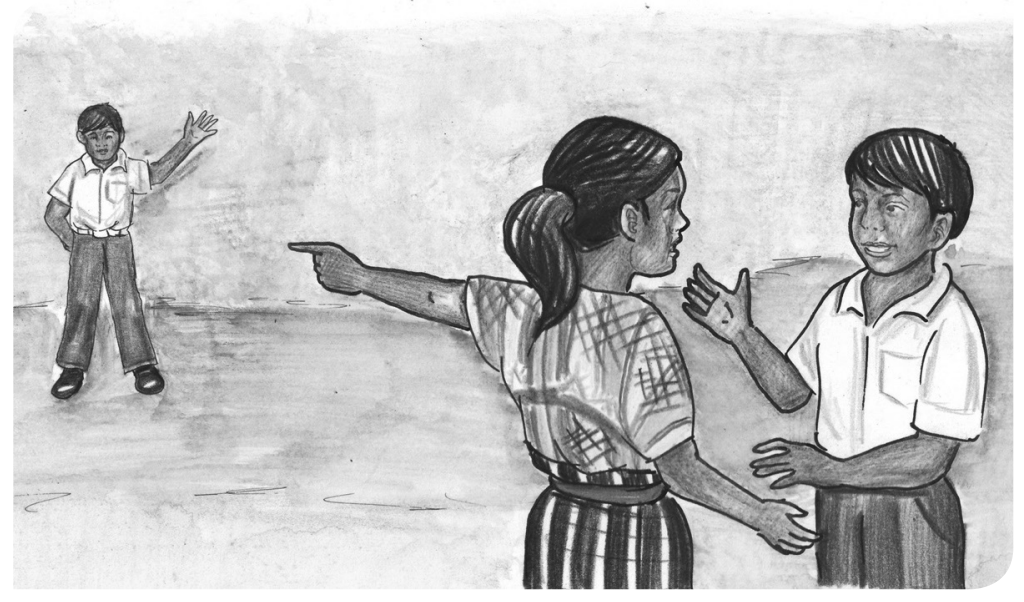

Todas y todos hemos sido alguna vez rechazados por un grupo o persona debido a que tenemos una característica diferente al resto, por ejemplo: comportarnos diferente, vivir otra cultura, practicar diferentes creencias espirituales o convicciones políticas, tener un rasgo físico que las otras personas no tienen. Cuando este rechazo se convierte en que la persona no puede acceder a una oportunidad, un bien o un servicio que le permite su desarrollo y ejercicio de libertad, se convierte en discriminación. La discriminación es un problema social, económico y político serio, es considerada como una de las violaciones de los derechos humanos que más ocurre en el mundo.

La discriminación se justifica por personas que creen que los otros seres humanos, que son diferentes, no tienen los mismos derechos que ellas. Por eso se atreven a negar derechos y hasta recurrir a la violencia.

La discriminación conlleva darle un trato de inferioridad a una persona o un grupo de personas por motivos raciales, religiosos, políticos, entre otros. Vulnera el principio de igualdad y se emplea el prejuicio contra personas y grupos humanos.

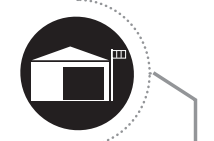

Comentamos con nuestro equipo algunas situaciones de discriminación que hemos observado en la comunidad y en nuestra comunidad educativa.

Revisamos y ajustamos el diseño del producto o servicio tecnológico para satisfacer las necesidades familiares y comunitarias, garantizando que no provoque discriminación a nadie en la comunidad.
- ¿Qué condiciones hacen que un grupo discrimine a una persona $u$ otro grupo?

- ¿Qué limitantes provoca en la vida de la persona o grupo discriminado?

\section{Discriminación a las personas adultas mayores}

Muchas personas mayores de 65 años reciben mal trato, son abandonadas, no les toma en cuenta para muchas actividades sociales $\mathrm{y}$, principalmente, son discriminadas. En el campo laboral se piensa que ya son ineficientes y poco productivas debido a que actúan con lentitud. Un número significativo de personas jóvenes y adultas piensa que las ideas y criterios de las personas adultas mayores ya están caducas, las hacen objeto de burlas y las aíslan en la familia y comunidad.

- ¿Cuáles características de las personas adultas mayores deben ser valoradas?

- ¿Cómo podemos valorar la dignidad de las personas adultas mayores de la familia y la comunidad?
Conversamos con adultos y adultas de la familia y la comunidad sobre el diseño del producto o servicio que elaboremos. Les preguntamos si usarían el producto o servicio que diseñamos y sus razones para usarlo o no hacerlo. Es importante verificar que nuestro producto no discrimine en cuanto a su uso o el beneficio que proporciona. 


\section{Argumentos válidos}

Un argumento está conformado por un conjunto de proposiciones. La primera parte se conoce como "premisa" y la última como "conclusión".
Observamos las siguientes proposiciones compuestas formando un argumento:

Si Pablo utiliza la estufa solar ahorrará leña.

Pablo utiliza la estufa solar.

Por lo tanto, Pablo ahorrará leña.

Si:

$p=$ Pablo utiliza la estufa solar.

$q=$ Pablo ahorrará leña.

- ¿Cómo podemos escribir el argumento utilizando simbología lógica? Comentamos nuestras respuestas con los demás compañeros y compañeras.

Copiamos en nuestro cuaderno y completamos el siguiente cuadro de conectivos lógicos.

\begin{tabular}{|l|l|}
\hline Nombre: Conjunción & Nombre: \\
Símbolo: & Símbolo: \\
& Ejemplo: Mañana juga- \\
& remos futbol si y solo si \\
& María trae la pelota. \\
\hline Nombre: & Nombre: Implicación o \\
Símbolo: V & condicional \\
Ejemplo: & Símbolo: \\
& Ejemplo: \\
\hline
\end{tabular}

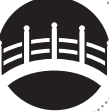

En equipos y en nuestro cuaderno escribimos 5 proposiciones compuestas como las que aparecen al inicio de la página.

Tomamos como referencia la información que ya recolectamos sobre las necesidades de la comunidad y el producto o servicio tecnológico que vamos a llevar a cabo en nuestro proyecto.

Cada equipo elegirá una de ellas y la presentará, a las demás compañeras y compañeros.

Comentaremos cada una de ellas. 
En un argumento, separamos la premisa de la conclusión con una línea horizontal. Por ejemplo:

Si Pablo utiliza la estufa solar ahorrará leña.

Pablo utiliza la estufa solar.

Premisa

Por lo tanto Pablo ahorrará leña.

Conclusión

$$
p \Rightarrow q
$$

Las proposiciones que quedan arriba de la línea forman la premisa; y la proposición que está debajo de la línea es la conclusión.

Para determinar la validez de un argumento lo podemos hacer mediante una tabla de verdad que contenga la premisa y la conclusión. El argumento será válido si la proposición compuesta que se forma del argumento es una tautología. La tabla de verdad a construir debe cumplir siempre con lo siguiente: (primera proposición $) \wedge($ segunda proposición $) \Rightarrow($ Conclusión $)$ $(p \Rightarrow q) \wedge(p) \Rightarrow(p)$

\begin{tabular}{|c|c|c|c|c|}
\hline$p$ & $q$ & $p \Rightarrow q$ & $(p \Rightarrow q) \wedge p$ & $(p \Rightarrow q) \wedge p \Rightarrow q$ \\
\hline $\mathrm{V}$ & $\mathrm{V}$ & $\mathrm{V}$ & $\mathrm{V}$ & $\mathrm{V}$ \\
\hline $\mathrm{V}$ & $\mathrm{F}$ & $\mathrm{F}$ & $\mathrm{F}$ & $\mathrm{V}$ \\
\hline $\mathrm{F}$ & $\mathrm{V}$ & $\mathrm{V}$ & $\mathrm{F}$ & $\mathrm{V}$ \\
\hline $\mathrm{F}$ & $\mathrm{F}$ & $\mathrm{V}$ & $\mathrm{F}$ & $\mathrm{V}$ \\
\hline
\end{tabular}

$\mathrm{Al}$ ser una tautología se concluye que el argumento es válido.

Construimos proposiciones para explicar el razonamiento usado en la selección del producto o servicio tecnológico que estamos elaborando y las necesidades que puede satisfacer en la comunidad.

En nuestro cuaderno realizamos una tabla de verdad para el siguiente argumento. Concluimos acerca de su validez.

Teresa tendrá que trabajar si y solo si es el primer fin de semana del mes.

No es el primer fin de semana del mes.

Por lo tanto, Teresa no tendrá que trabajar.

$$
\begin{gathered}
p \leftrightarrow q \\
-q \\
\hline-p
\end{gathered}
$$

Verificamos la secuencia de actividades para la realización del producto o servicio tecnológico que estamos construyendo.
Un Silogismo es un argumento compuesto de tres proposiciones. La tercera proposición debería ser la conclusión lógica de los primeros dos.

Por ejemplo:

Si me duermo no podré ir a la feria.

Si no voy a la feria no tomaré atol de elote.

Conclusión: Si me duermo no tomaré atol de elote.

En equipos determinamos cuáles de los siguientes argumentos son válidos. Respaldamos nuestras respuestas con tablas de verdad.

- Si $x$ es múltiplo de 4 entonces es par.

$x$ no es múltiplo de 4 .

Por lo tanto, $x$ no es par.

- A todos los estudiantes les gustan las papalinas.

Rubí es estudiante.

Por lo tanto, a Rubí le gustan las papalinas. 


\section{Cọmunicándonos a través del canto}

Acordes para la canción "Sólo le pido a Dios"
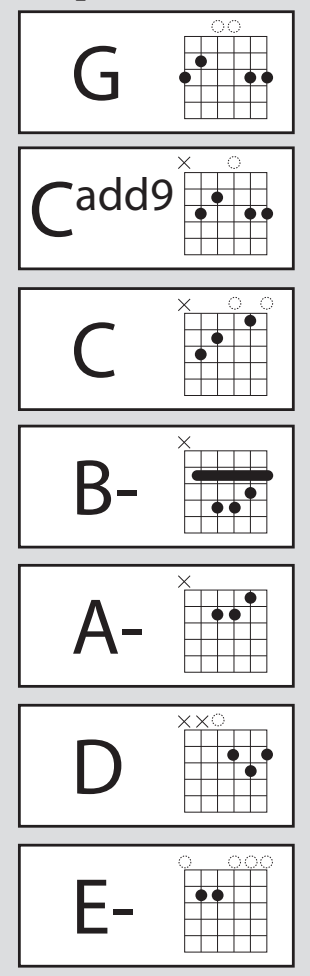

Para comprender los acordes:

$\mathrm{A}=\mathrm{La}, \mathrm{B}=\mathrm{Si}, \mathrm{C}=\mathrm{Do}, \mathrm{D}=\mathrm{Re}$, $\mathrm{E}=\mathrm{Mi}, \mathrm{F}=\mathrm{F}$ a y $\mathrm{G}=\mathrm{Sol}$

Si no tiene ningún signo es un acorde mayor

Si tiene guión menor $(-)$ es un acorde menor

Si tiene agregados (add9), el acorde tiene otras notas.

Secuencia para la canción:

G Cadd9 G Más fácil:

Sol M - Do 9 - Sol M

C Bm Am Más fácil:

Do M - Si m - La m

Bm G D Más fácil:

Si m - Sol M - Re M

C Bm Em Más fácil:

Do M - Si m - Mi m

Cantar es una de las manifestaciones más profundas del ser humano al expresarse con las demás personas. Muchas personas cantan mientras trabajan, caminan o están en algún lugar. Se entonan las melodías solas o con su letra original, a veces se les cambia la letra con intenciones de comunicar alguna idea.

Al producir música o hacer una canción existe la intención de comunicar un mensaje. Este mensaje puede ser religioso, comercial, político, un relato, una consigna o un manifiesto de propósitos. La siguiente canción tiene la finalidad de comunicar un deseo por la vida, la paz y la justicia.

\section{Solo le pido a Dios \\ (Leon Gieco, Argentina 1978)}

Solo le pido a Dios

Que el dolor no me sea indiferente

Que la reseca muerte no me encuentre

Vacio y solo sin haber hecho lo suficiente

Solo le pido a Dios

Que lo injusto no me sea indiferente Que no me abofeteen la otra mejilla

Después de que una garra me araño esta suerte

Solo le pido a Dios

Que la guerra no me sea indiferente Es un monstruo grande y pisa fuerte Toda la pobre inocencia de la gente

\section{Solo le pido a Dios}

Que el engaño no me sea indiferente si un traidor puede más que unos cuantos

Que esos cuantos no lo olviden fácilmente

Solo le pido a Dios

Que el futuro no me sea indiferente Desahuciado está el que tiene que marchar

A vivir una cultura diferente

\section{Solo le pido a dios}

Que la guerra no me sea indiferente Es un monstruo grande y pisa fuerte Toda la pobre inocencia de la gente

\section{Trabajemos en grupo}

Cantemos la canción con la ayuda de los siguientes vínculos para visualizar y escuchar la música:

Para aprender los acordes: https://www.youtube.com/ watch?v=5kWPFsyoq_0

Para cantar toda la canción: http://www.musica.com/video. asp? video $=12706$

Para ver al autor original: https://www.youtube.com/ watch?v=Ek4qqkJ9950 


\section{Un coro para celebrar la vida}

Cantar en coro es unir las voces para hacer que la música sea más incluyente. Todas y todos pueden cantar en un coro. Aunque hay voces que pueden cantar solas, la ventaja del coro es que todas y todos pueden participar y nadie debe quedar fuera. Al presentar el proyecto a la comunidad educativa, es decir a todas y todos los involucrados en nuestro aprendizaje, podemos invitarles a cantar con nosotros. Puede hacerse con tecnología muy avanzada: computadoras y proyectores; o bien con tecnología simple: un cartel.

Es importante que todo esté preparado y ensayado, ya sea con acompañamiento propio con guitarras o teclados, algunas percusiones y lo principal, las voces. Al presentarlo invitar a asistentes a que participen. Nuestro proyecto puede haberse desarrollado con la música o con el mural.

\section{Participando en conjunto}

Ensayamos la canción, preparamos sus detalles de acompañamiento.

Realizamos un cartel con la letra de la canción, para que sea vista por quienes asistan a la presentación.

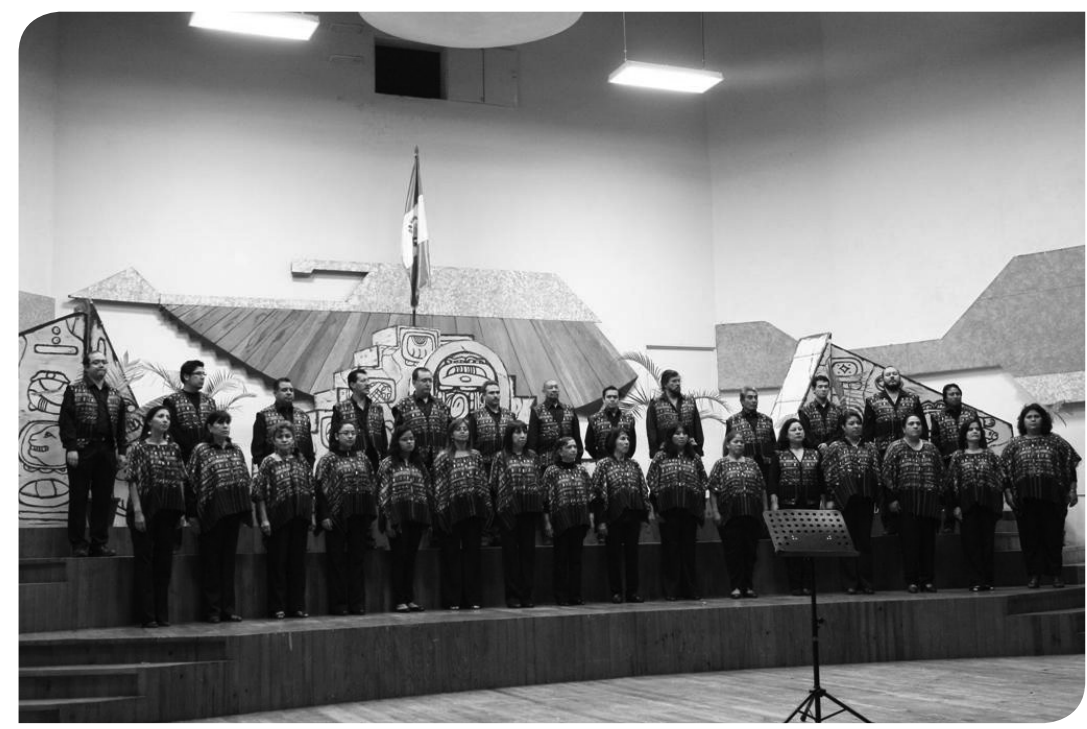

Valoro mi trabajo en todas las áreas.

Agrego una $\boldsymbol{X}$ según lo que considero de mi desempeño.

\begin{tabular}{|c|c|c|c|c|c|}
\hline \multirow[b]{2}{*}{ ASPECTOS A EVALUAR } & \multicolumn{5}{|c|}{$\begin{array}{l}\text { Escala de calificación: } \\
1 \text { a } 5 \text { de regular a excelente }\end{array}$} \\
\hline & $1^{\underline{a}}$ & $2^{\underline{a}}$ & $3^{\underline{a}}$ & $4^{\underline{a}}$ & $5^{\mathrm{a}}$ \\
\hline \multicolumn{6}{|l|}{ Participé en todas las actividades sugeridas } \\
\hline \multicolumn{6}{|l|}{ Aporté ideas ante cada situación de aprendizaje } \\
\hline \multicolumn{6}{|l|}{$\begin{array}{l}\text { Utilicé lo aprendido en beneficio de mi familia y } \\
\text { comunidad }\end{array}$} \\
\hline \multicolumn{6}{|l|}{ Ensayé y preparé lo necesario para la presentación final } \\
\hline $\begin{array}{l}\text { Los proyectos aportaron al espacio cultural de mi } \\
\text { comunidad }\end{array}$ & & & & & \\
\hline
\end{tabular}




\section{Lo ló gica del desarrollo y los corolarios}

Un axioma es una proposición que se acepta como verdadera sin tener que demostrarse. Por ejemplo:

$$
2+6=6+2
$$

Un teorema es una proposición verdadera que afirma una verdad que se puede demostrar. Por ejemplo: El Teorema de Pitágoras que afirma que en cualquier triángulo rectángulo la suma del cuadrado de los catetos siempre es igual al cuadrado de la hipotenusa.

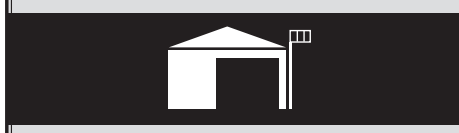

Presentamos el producto o servicio terminado para probar su funcionamiento. Escribimos un axioma para cada uno de los productos que nos presentan en la clase.
Leemos detenidamente las siguientes proposiciones de los números reales. Comentamos y consultamos nuestras dudas a nuestro facilitador o facilitadora.

1) Si dos números a y b pertenecen a los números reales, entonces $a+b$ y $a \times b$ también pertenecen a los números reales.

2) Si dos números a y b pertenecen a los números reales, entonces $a+b=b+a$ y $a \times b=b \times a$.

3) Si dos números a y b pertenecen a los números reales, entonces $a+(b+c)=(a+b)+c$ y $a \times(b \times c)=$ $(a \times b) \times c$.

4) Si dos números $a$ y $b$ pertenecen a los números reales, entonces $a \times(b+c)=a b+a c$.

\section{Comentamos y contestamos:}

- ¿Cuál es el valor de verdad de cada una de las proposiciones anteriores?

- ¿Cómo lo supimos?

Nos reunimos en equipos y escribimos, en nuestro cuaderno, un ejemplo para cada una de las proposiciones anteriores. Presentamos nuestros ejemplos al resto de compañeras y compañeros. Comparamos nuestro trabajo con el de los demás equipos. Comentamos.

La siguiente proposición, también llamada axioma de orden, indica que:

Para cualquiera dos números reales a y b, se cumple una y solo una de las siguientes afirmaciones:

1. $a=b$

2. $a<b$

3. $a>b$

\section{Contestamos:}

- Si $a=18$ y $b=5$ ¿con cuál afirmación cumplen $a$ y $b$ ?

- ¿Qué valor pueden tener a y b para que cumplan con la segunda afirmación?

- ¿En qué caso se cumple la primera afirmación?

- ¿Por qué no pueden cumplirse, al mismo tiempo, dos de las anteriores afirmaciones? 
El siguiente es un teorema formado por dos axiomas relacionados a las propiedades de los números reales.

\begin{tabular}{|l|}
\hline \multicolumn{1}{|c|}{ Teorema } \\
\hline $\begin{array}{l}\text { Si } a, b \text { y } c \text { pertenecen a los números reales y } a+c=b \\
+c \text { entonces } a=b .\end{array}$ \\
$\begin{array}{l}\text { Si } a, b \text { y } c \text { pertenecen a los números reales, } c \neq 0 \text { y } a c \\
=b c \text { entonces } a=b .\end{array}$ \\
\hline
\end{tabular}

- En equipos escribimos dos ejemplos para cada axioma. Los compartimos con los demás compañeras y compañeros y comentamos.

En hojas de papel bond o en media cartulina escribimos las definiciones de:

- Axioma

- Teorema

- Corolario

Escribimos también un ejemplo de la vida cotidiana para cada una de las definiciones anteriores.

Un corolario es un resultado que se obtiene de un teorema. Por ejemplo:

\begin{tabular}{|c|l|}
\hline & $\begin{array}{l}\text { Luego de haberse demostra- } \\
\text { do y comprobado que el área } \\
\text { de un cuadrilátero cualquie- } \\
\text { ra es el producto de la base } \\
\text { por su altura, se puede obte- } \\
\text { ner el siguiente corolario: } \\
\text { "El área de cualquier cuadra- } \\
\text { do resulta de elevar un lado } \\
\text { al cuadrado." }\end{array}$ \\
\hline
\end{tabular}

En equipos escribimos corolarios que surjan de los siguientes teoremas:

- Si un número termina en 5 o en 0 será divisible por 5 .

- Si dos ángulos son ángulos rectos entonces son ángulos congruentes.

- Existe una cantidad infinita de números primos.

Comentamos y comparamos nuestras respuestas con las del resto del grupo.
Un corolario es una afirmación lógica que es consecuencia inmediata de un teorema y que puede ser demostrado por lo que enuncia el teorema. Por ejemplo; del Teorema de Pitágoras se tienen estos corolarios:

- La longitud de cada cateto siempre es menor que la longitud de la hipotenusa.

- La suma de las longitudes de ambos catetos siempre es mayor que la longitud de la hipotenusa. 


\section{Propuestas para la eliminación de la inequidad}

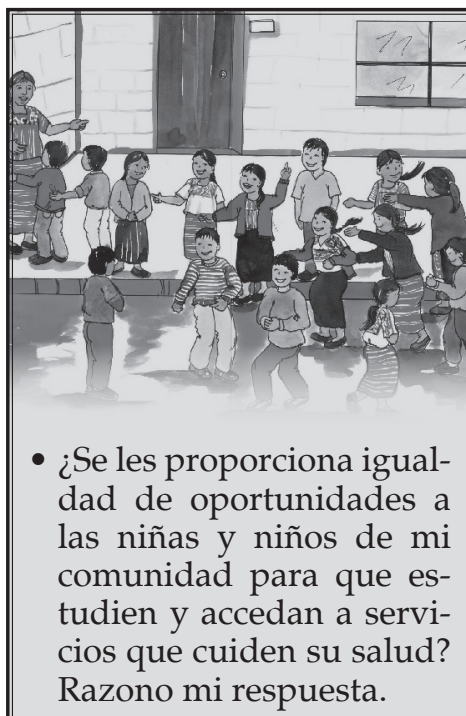

“...el sistema de atención debe producir la mejor salud posible, en cada situación específica y apuntar hacia la satisfacción individual y social considerando para ello la calidad y formas de la atención, todo lo cual tiene gran importancia por lo que incide en los resultados políticos deseados. La equidad es condición necesaria y estratégica para el acceso universal según necesidades y posibilidades. Un requisito para la satisfacción, la eficacia y la equidad es asegurar la integralidad de la atención progresiva que se requiera según el problema de la persona que se atiende."

Fuente: Pérez, F. (2007). La equidad en los servicios de salud. Recuperado de: http:/ / bvs.sld.cu/revistas/spu/ vol33_3_07/spu07307.htm

Según lo que escribe el autor de esta cita, ¿cómo se logra la equidad en los servicios de salud?

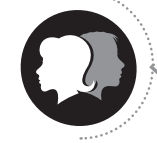

\section{Analicemos con nuestro equipo}

- ¿Aprovechar la oportunidad de estudiar permite que tengamos equidad? ¿Por qué?

- ¿Los productos que estamos desarrollando ayudarán a la autonomía de nuestra comunidad? ¿Por qué?

Ya hemos explicado que la inequidad se da en muchos aspectos de la vida social y entre varios grupos de personas. Estas inequidades se han conformado en nuestra sociedad a lo largo de muchos años y se encuentran entrelazadas. Como son resultado de acciones y voluntades humanas es posible eliminarlas a través de acciones intencionadas y planificadas.

Para que haya equidad, se necesita mejorar las condiciones socioeconómicas de las personas desfavorecidas y crear igualdad de oportunidades para que las personas accedan a aquellos bienes, servicios y condiciones que les permitirán desarrollo pleno. En muchos contextos estas acciones se establecen por medio de leyes, que reconocen y promueven los derechos de estos grupos en particular. A veces establecen acciones específicas que están hechas solo para estos grupos, según sus necesidades particulares, por ejemplo el derecho de las mujeres lactantes de tener tiempo para alimentar a su bebé. Si no existiera esa ley, hija y madre se verían en condiciones de desventaja: una de alimentación y la otra de trabajo. Eso se llama medidas afirmativas.

Una de las primeras metas para acabar con la inequidad es combatir la pobreza extrema. En Guatemala, de cada 100 personas, más de 22 viven en pobreza extrema. La pobreza extrema significa que las personas no reciben suficientes ingresos ni para alimentarse bien, lo cual implica que tampoco cuentan con servicios básicos. En esas condiciones, las niñas y los niños no pueden desarrollar a plenitud el potencial que poseen; es decir que no tendrán oportunidad de realizar un proyecto de vida digna, obtener ingresos para vivir dignamente, estudiar y trabajar y estar saludables.

Combatir la pobreza extrema requiere que el sector público y el privado cumplan con sus responsabilidades y respeten la ley. Algunas acciones que han favorecido la eliminación de la pobreza son la inversión social, los subsidios, las transferencias condicionadas a las personas extremadamente pobres. En tanto, el sector privado, además de pagar los impuestos que le corresponde, puede invertir en proyectos que aprovechen el emprendimiento personal y comunitario.

Otra medida que es fundamental para eliminar la inequidad es garantizar igualdad de oportunidades a los niños, niñas jóvenes, sin importar su condición, para que puedan estudiar hasta los niveles más altos de formación. Se trata de que las condiciones que rodean a una niña, niño o joven no limiten su futuro. Actualmente se necesita que muchas de estas medidas vayan encaminadas a favorecer especialmente la participación de las niñas y personas con discapacidades.

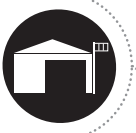

Mientras los grupos presentan podemos registrar las actividades por medio de fotografías y videos. Estas serán útiles para convocar a la comunidad a ver la presentación general. Evaluemos si podemos gestionar espacios en la radio comunitaria para convocar a vecinas y vecinos. 


\section{Propuestas para la eliminación de la discriminación étnica}

La discriminación étnica en Guatemala se originó desde la Conquista española. Antes de la publicación de las Leyes Nuevas, los conquistadores, sin restricciones, sometieron a esclavitud a los y las habitantes originarias de estas tierras.

Durante la Época Colonial, Independencia, Reforma Liberal y los gobiernos que le sucedieron se continuaron las formas de trabajo forzado a la población maya y a otros pueblos que surgieron. Además del trabajo forzado, se aplicó la discriminación a través de restricción de derechos, segregación de territorios, negación a la participación política etc.

En el presente siglo se ha avanzado en combatir esta discriminación, se han creado leyes internacionales y nacionales que la prohíben. También hay algunos avances en cuanto a educación y servicios de salud, pero estos no son suficientes. Las estadísticas e indicadores de desarrollo humano evidencian que la pobreza, desnutrición, morbilidad de niños y niñas menores de dos años, baja cobertura, mayor deserción y fracaso escolar se registra en las áreas en donde la población indígena es mayoritaria. Esto se debe a la limitada oferta de servicios que el Estado pone a disposición de la población así como las desfavorables condiciones de trabajo y producción que se han forjado en estos lugares.

Para combatir la discriminación étnica se requiere del fortalecimiento de las instituciones que se han creado para evitar la discriminación, mejorar la legislación, comenzando por la Constitución Política, pero también mejorar la aplicación de las normas que promueven igualdad étnica. El gobierno también tiene que mejorar la formulación de planes y programas que combaten la discriminación, fundamentalmente destinando una cantidad de recursos financieros adecuados, facilitar el acceso a la educación, reconocer la aplicación del pluralismo jurídico, identificar y modificar acciones y políticas que discriminan la diversidad. Los medios de comunicación, las escuelas, los hospitales, las empresas también pueden contribuir a fomentar la equidad mediante la eliminación de acciones y mensajes que fomenten la discriminación.

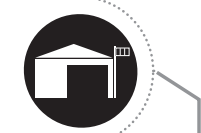

Con nuestro equipo, redactamos un inventario de las acciones que se realizan en nuestra comunidad para evitar la discriminación étnica.

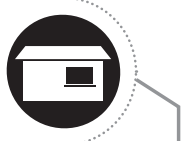

Definimos un plan de mejoramiento del producto o servicio tecnológico, según consideraciones de la o el facilitador, opinión de los otros equipos, familiares y vecinos con los que conversamos.
Además de las personas de origen maya, ¿se discrimina a otras personas en Guatemala por hablar un idioma distinto al español y tener una cultura diferente a la occidental? ¿A quiénes? ¿Por qué?

"La discriminación directa ejercida a través de la expresión verbal la encontramos en la calle, en los mercados, en el transporte público, en los centros educativos, en las instalaciones deportivas, entre otros. En estos espacios o lugares es común escuchar expresiones discriminatorias en $\mathrm{vOZ}$ alta como: "hijos de la Menchú", "vendedora de tomates", "María, ¿vienes a vender chuchitos o tomates?", "apúrate vos indio", "india tu madre", "ahí van algunos inditos", [...] Generalmente, estas frases son expresadas por gente mestiza o ladina contra los indígenas y los negros, las cuales terminan en actos de expresión racista porque son dichos que denigran tajantemente al otro, inferioriorizándolo racialmente. Aquí, la persona que discrimina tiene bien interiorizado en la mente que es superior racialmente al otro porque así le ha dicho la familia $y$ los amigos."

Fuente: Gonzales, J. (2013). La discriminación racial en Guatemala y sus consecuencias. Recuperado de: http:/ / espiritualidadmaya.blogspot. com/2013/07/la-discriminacion-racial-en-guatemala-y. html 


\section{Cómo decir mucho usando pocas palabras}

\section{Códigos iconográficos}

La iconografía es la ciencia que estudia el origen y la formación de las imágenes y su relación con el simbolismo.

Se llaman códigos iconográficos aquellos que contienen dibujos o imágenes creados con el propósito de enviar un mensaje visual que pueda ser comprendido incluso por personas que hablan diferentes idiomas o que tienen distintos niveles de desarrollo del lenguaje. Los símbolos iconográficos representan e identifican a una persona, una empresa, un producto o una institución.

Ejemplo de código iconográfico:

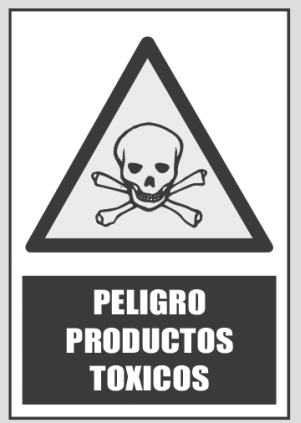

La comunicación más eficaz es la que dice mucho con pocas palabras. Anuncio publicitario: es un mensaje que busca informar a las personas sobre un hecho, un producto o un acontecimiento. Pueden enviarse a través de medios visuales (televisión, vallas, carteles, redes sociales, etc.) o auditivos (radio).

Invitación: a través de este medio se le pide a una persona que acuda a un evento, acto o celebración. Pueden ser verbales (visita, llamada telefónica, radio) o escrita (afiche, cartulina, correo electrónico, mensaje en redes sociales). Deben incluir el motivo, la fecha, la hora y el lugar de reunión.

Trifoliar: es un folleto gráfico de tres lados y seis caras, se usa mucho para dar información de una organización o una empresa y en los menús de los restaurantes. Presenta colores atractivos, imágenes que despierten interés y el uso positivo de las palabras.

Boletín: es un tipo de publicación que se realiza para llegar a un público en particular. Informa sobre temas, servicios o artículos que pueden interesar a quienes lo reciben. Suele distribuirse de forma regular, ya sea una vez a la semana, al mes, cada dos meses, etc. Actualmente, y por al auge de la tecnología, los boletines también son electrónicos.

En grupos, elaboraremos textos, íconos y otros recursos para informar e invitar a la presentación del producto o servicio tecnológico.

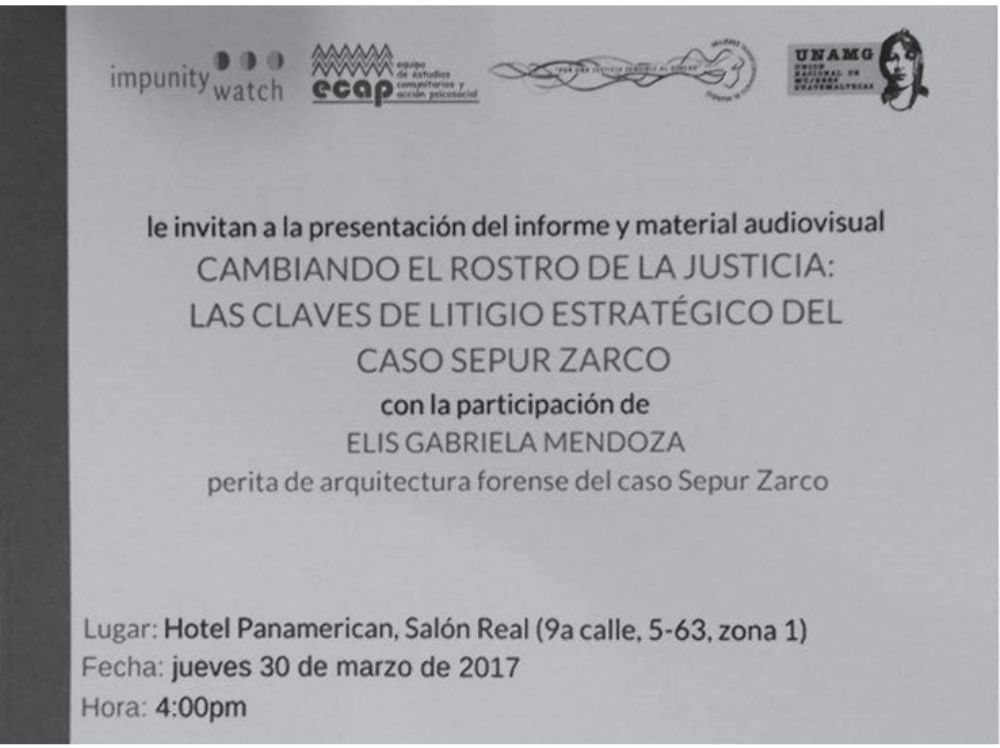




\section{La diferencia entre lenguaje formal y lenguaje informal}

Dependiendo de a quién va dirigido nuestro discurso, utilizaremos un lenguaje formal o uno informal. El lenguaje formal se emplea cuando hablamos con personas con las que tenemos una relación lejana o cuando la situación requiere que nos comportemos con seriedad. En estos casos, debemos construir las oraciones correctamente, pronunciar cada palabra con claridad, hablar pausado y suprimir las muletillas, los modismos y, sobre todo, los vulgarismos. El lenguaje formal se emplea en la transmisión de contenidos a través de noticieros, reuniones de trabajo, informes, actas, exposiciones, debates y conferencias, asambleas comunitarias, reuniones de comités de desarrollo.

El lenguaje informal o coloquial es el que utilizamos cuando estamos entre familiares, amigos o con los compañeros de trabajo, fuera del horario de oficina o en cartas o mensajes personales. Es espontáneo, cercano y expresivo. En él se permite el uso de muletillas, diminutivos, expresiones de afecto y modismos.
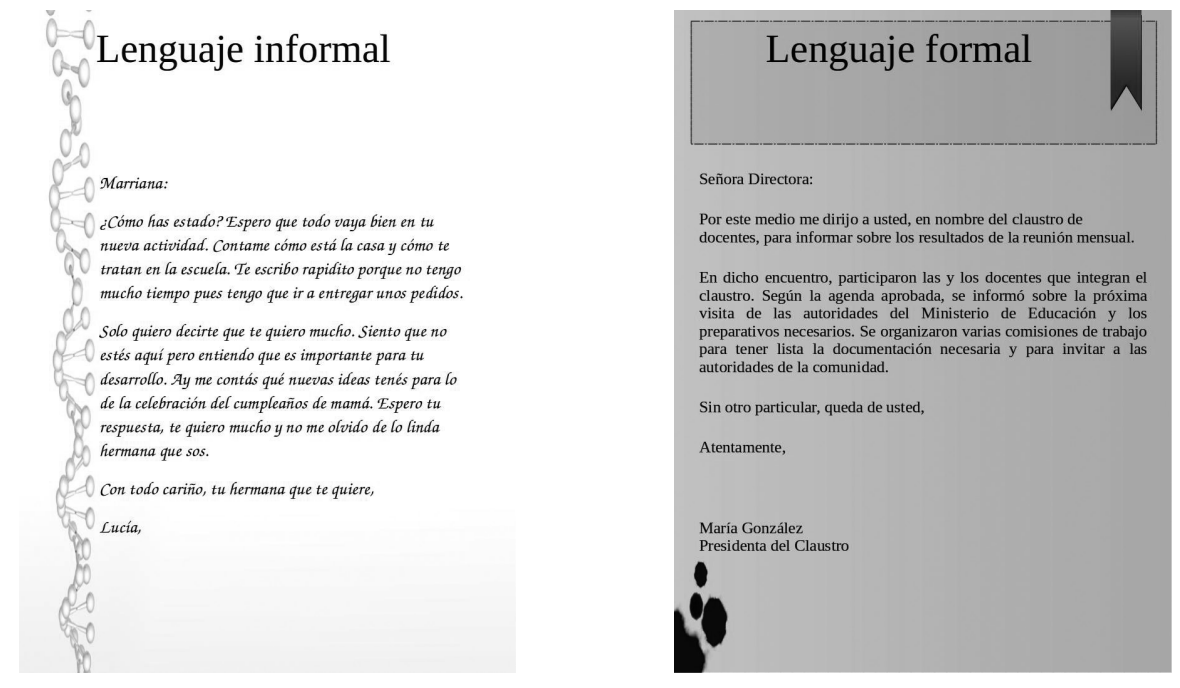

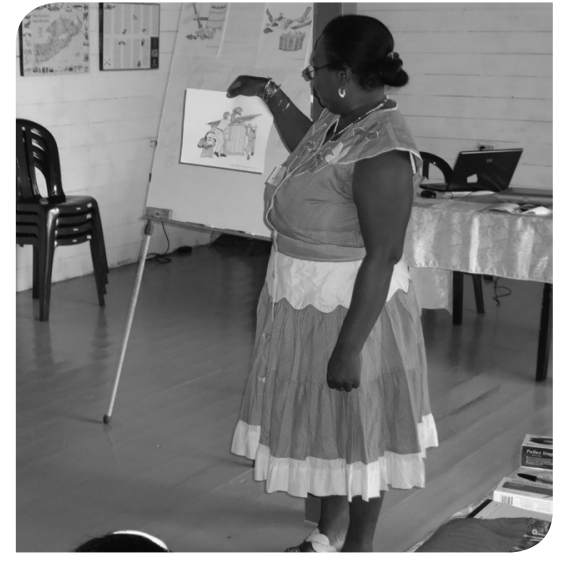

Lenguaje formal

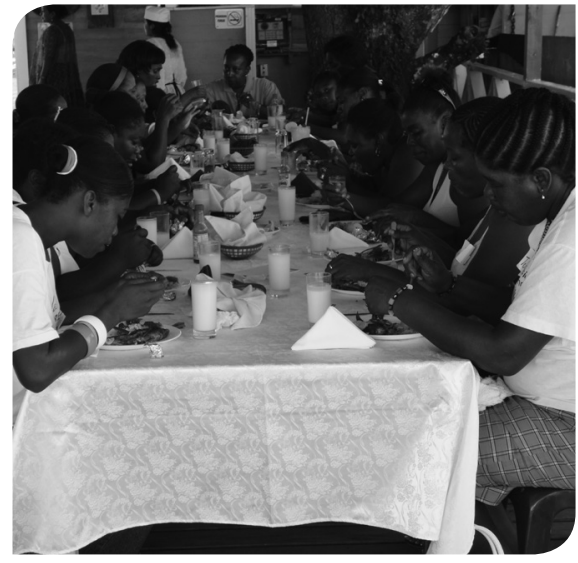

Lenguaje informal

En lenguaje formal elaboramos un manual para el uso del producto. 


\section{Thergias renovables y normas de seguridad}

\section{Energías renovables y mujeres}

Las energías renovables representan beneficios a las poblaciones debido a su bajo costo operativo que genera ahorro familiar, facilitan el acceso a servicios de salud o educación y aumentan las oportunidades de iniciar una empresa familiar que requiere energía eléctrica, por ejemplo, equipo de carpintería o herrería o congeladores para la venta de carne.

Como integrantes de la comunidad, las mujeres tienen derecho a conocer, opinar y decidir sobre cualquier proyecto que afecte su bienestar y futuro. Las mujeres deben tener la misma oportunidad que los hombres de formar parte de las organizaciones a cargo de proyectos de energía renovable, así como a participar en las capacitaciones sobre aspectos administrativos, financieros y técnicos. De esta manera, las mujeres también pueden adquirir habilidades, como manejo de presupuestos o realizar trabajos de carpintería o soldadura, entre otros. Las mujeres también deben participar en capacitaciones para implementar proyectos productivos que ayuden a mejorar la economía familiar, especialmente si son jefas de hogar.

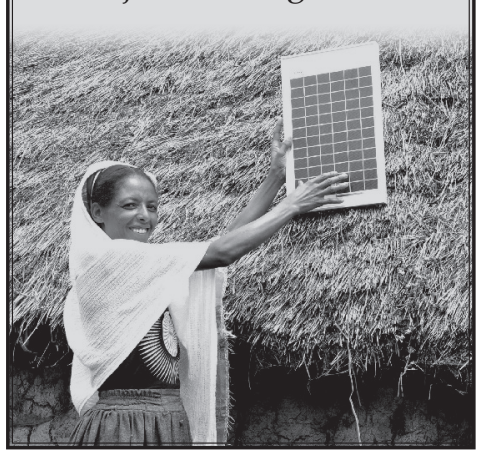

El objetivo de las energías renovables es la generación y transmisión de energía eléctrica. Para eso utilizan equipo especial y en algunos casos, equipo sofisticado y de alta tecnología, por lo que el personal a cargo debe conocer bien las especificaciones para la instalación y operación del sistema.

Es importante que las instalaciones sean de fácil acceso para llevar el equipo y para realizar supervisión y mantenimiento del mismo o en caso de ser necesario sea fácil evacuar al personal.

El equipo debe instalarse aprovechando de mejor manera los recursos naturales, por ejemplo, donde el caudal del río sea más amplio y tenga una fuerte caída o donde el sol alcance temperaturas más altas durante el mayor tiempo del día y el año.

Para seguridad es importante implementar medidas como:

- Seguir las instrucciones del fabricante para asegurar su mantenimiento y durabilidad.

- Los equipos deben estar resguardados para evitar que animales o personas extrañas tengan acceso a ellos.

- El área debe estar limpia y libre de residuos o materiales abandonados.

- Evitar equipo y materiales expuestos a la intemperie y para evitar la oxidación, recubrir las partes metálicas con pintura antioxidante.

- El equipo debe estar bien sujeto para evitar que se voltee o caiga, además, debe existir suficiente espacio entre cada pieza para que una persona pueda circular, revisar y arreglar cualquier desperfecto.

Aplicamos las normas de seguridad al producto o servicio que estamos elaborando.

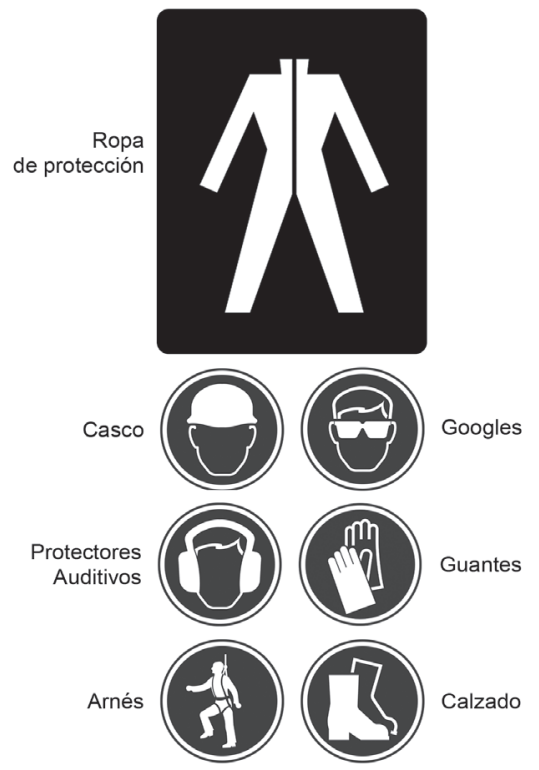




\section{Medidas de seguridad}

Las personas que trabajan en el mantenimiento del equipo o simplemente visitan las instalaciones deben utilizar equipo de seguridad.

- Casco

- Guantes para manejar material eléctrico.

- Calzado de seguridad con suela de hule para evitar un choque eléctrico.

- Si se necesita trabajar arriba del nivel del suelo, es importante el uso de arnés para evitar caídas y lesiones.

- Lentes de seguridad

- Cinturón para reforzar la espalda y evitar lesiones lumbares al cargar o mover objetos pesados.

Otros consejos generales que ayudan a prevenir accidentes:

- Todo el equipo de trabajo y los materiales deben guardarse en un lugar específico, de preferencia cerrado y con llave, para que esté disponible cada vez que necesite usarse, no se pierda y tampoco provoque accidentes.

- Es importante contar con una escalera del largo adecuado para hacer cualquier revisión o reparación.

- Las personas a cargo deben evtar contacto con superficies húmedas si están cerca de líneas de conducción eléctrica.

- Las instalaciones deben contar con interruptores que permitan cortar parcial o totalmente el suministro de energía si se necesita realizar una inspección o una reparación.

- No se deben hacer "chapuces" o conexiones temporales improvisadas porque se corre el riesgo de dañar el equipo además de poner en riesgo a la persona que realiza un trabajo de reparación.

- Utilizar siempre equipo de protección y equipo de trabajo en buen estado.

- Planificar revisiones periódicas del equipo y reportar su estado, especialmente, si se necesita alguna reparación.

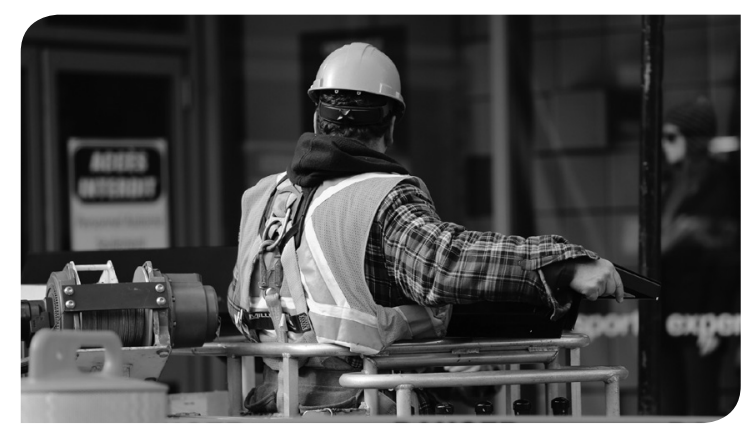

En casa incorporamos las anotaciones y recomendaciones que nos diera el o la tutora para la presentación de las medidas de seguridad de nuestro proyecto.

\section{Potencial energético} de Guatemala

Debido a su localización geográfica y sus características naturales, Guatemala está en una posición privilegiada respecto al uso de energías renovables. Contamos con varios ríos de grandes caudales y el relieve montañoso facilita la construcción de pesas y derivación de agua por gravedad. Estar situados en la franja tropical nos provee radiación solar todo el año en todo el país, y contamos con áreas de potencial geotérmico y eólico. Además, se ha comenzado a obtener energía de biomasa utilizando el bagazo de caña de azúcar.

Actualmente, nuestra energía eléctrica se produce mayoritariamente de fuentes renovables, principalmente a través de hidroeléctricas y luego, por plantas geotérmicas, pero todavía hace falta mucho para obtener energía del sol y el aire. Existen dos plantas solares ubicadas en Chiquimulilla, Santa Rosa y Estanzuela, Zacapa y una eólica en San Antonio El Sitio, Villa Canales mientras que tenemos 29 hidroeléctricas, 19 situadas a lo largo del río Chixoy.

- ¿Cómo aseguramos que el aprovechamiento de recursos naturales fomente la equidad entre toda la población? 


\section{Electromagnetismo}

El uso combinado de imanes y corrientes eléctricas tiene muchas aplicaciones. Por ejemplo, una brújula, un timbre eléctrico o un medidor de consumo de energía eléctrica, que usann imán el cual gira libremente. Un motor eléctrico tiene similares principios, como en la licuadora. El electromagnetismo se aplica para diferentes propósitos, por ejemplo, un generador eléctrico que es un dinamo que transforma energía mecánica en energía eléctrica, mediante espiras (que son las vueltas que da una hélice o espiral), y un imán se produce una fuerza electromotriz, un alternador transforma un campo magnético en corriente eléctrica, un transformador produce un campo magnético que disminuyen $\mathrm{o}$ aumentan el voltaje de una corriente alterna. Otros usos del electromagnetismo son las bandas magnéticas de las tarjetas de crédito y débito.
Desde que fueron descubiertos, los fenómenos de electricidad y el magnetismo se consideraron sin ninguna relación, hasta el siglo XIX. Se supo que al enrollar en espiral un alambre conductor formando lo que se conoce como una bobina o solenoide, si se coloca un imán en movimiento en el interior de la bobina, se genera corriente eléctrica. También que, la corriente eléctrica hace cambiar la dirección de una brújula. Así surgió el electromagnetismo.

Se descubrió que todo campo magnético variable, (imán en movimiento) produce una corriente eléctrica en conductores sometidos a su acción. A nivel elemental, una carga eléctrica en movimiento produce un campo magnético y una corriente de cargas produce un campo magnético.

Una bobina de alambre que conduce corriente es un electroimán. A mayor corriente mayor fuerza electromagnética producirá. Si al interior de la bobina se introduce una barra de hierro, aumenta la fuerza electromagnética. Ejemplo de potentes electroimanes son las grúas que levantan automóviles o las que utilizan en el reciclaje de chatarra.

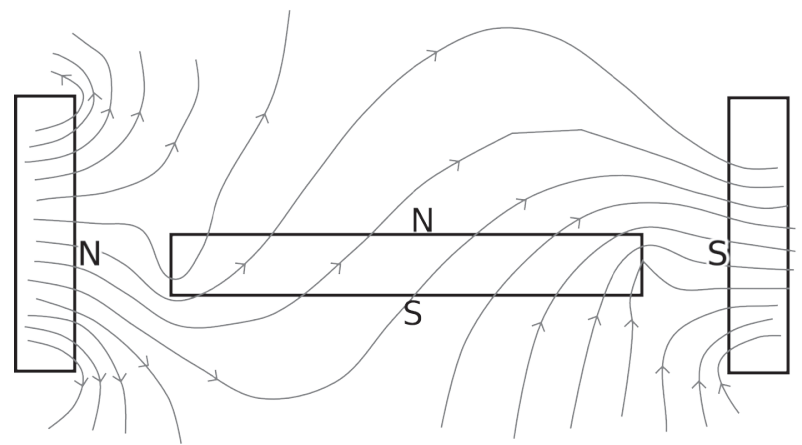

Los electroimanes formados por bobinas de superconductores, al no tener resistencia, no desperdician calor. Es decir, representan gran ahorro de energía. Son usados en la industria médica, en aparatos de resonancia magnética y en trenes de alta velocidad.

\section{Construimos un electroimán}

Necesitamos: dos pilas o baterías, un clavo de 4 pulgadas de largo, cinta adhesiva, alambre conductor delgado, alfileres, clip.

Procedimiento: unimos firmemente las pilas con cinta adhesiva, una a continuación de otra. El polo positivo de una debe tocar el negativo de la otra.

Enrollamos el alambre alrededor del clavo. Empezamos por la punta y cuidamos que queden apretadas las espiras; volvemos a enrollar alambre de modo que queden dos capas de alambre enrollado.

Unimos los extremos libres del alambre a los extremos del sistema de pilas (positivo y negativo).

Acerco un clip y alfileres al electroimán. Observo y describo lo que ocurre.

Entregamos la convocatoria en la comunidad para la presentación del producto tecnológico. Preparamos todo poniendo en marcha el plan de mejoría. 


\section{Ondas electromagnéticas y Electrónica}

En la Naturaleza hay dos tipos de ondas: las ondas mecánicas y las ondas electromagnéticas. Las olas del mar y las ondulaciones que se forman al lanzar una piedra sobre una charca o laguna son ejemplos de ondas mecánicas. El sonido viaja también en forma de ondas mecánicas.

La electrónica es el estudio y uso de sistemas que funcionan mediante la conducción y control de flujos de electrones. Sus aplicaciones están en la transmisión de información, ingeniería electrónica y electromecánica, la informática, diseño de programas de computación, distribución de información, telecomunicaciones y distribución de energía eléctrica, entre otras. Se fundamenta en el principio termoiónico que consiste en colocar una placa conductora dentro de una bombilla y pasarle corriente. Al calentarse el foco, se forma una nube de electrones en torno del filamento de la bombilla (el hilo metálico enrrollado en espiral que al calentarse produce la luz).

Luego de la presentación recibimos insumos de compañeras, compañeros y quien facilita, para elaborar el plan de mejoramiento.

Realizamos una evaluación del producto o servicio diseñado por cada grupo, mediante lista de cotejo.

\begin{tabular}{|l|l|l|}
\hline \multicolumn{1}{|c|}{ Criterio } & Sí & No \\
\hline $\begin{array}{l}\text { Responde a las interrogantes: qué, cómo, } \\
\text { con qué, cuánto. }\end{array}$ & & \\
\hline $\begin{array}{l}\text { Resuelve una necesidad detectada en la } \\
\text { familia o la comunidad. }\end{array}$ & & \\
\hline $\begin{array}{l}\text { Utiliza materiales y recursos del entorno, } \\
\text { accesibles y de bajo costo para los } \\
\text { estudiantes. }\end{array}$ & & \\
\hline $\begin{array}{l}\text { Utiliza energía alternativa en su } \\
\text { funcionamiento. }\end{array}$ & & \\
\hline $\begin{array}{l}\text { Es de interés a la comunidad, para ser } \\
\text { reproducido posteriormente. }\end{array}$ & & \\
\hline $\begin{array}{l}\text { Puede ser patrocinado con el apoyo de } \\
\text { alguna organización o entidad de la } \\
\text { comunidad. }\end{array}$ & & \\
\hline
\end{tabular}

La luz, los rayos $X$, las ondas de la televisión y la radio, son ejemplos de ondas electromagnéticas. Todas las ondas electromagnéticas viajan a $3 X$ $108 \mathrm{~m} / \mathrm{s}$, es decir, a la velocidad de la luz. Los hornos microondas y los teléfonos celulares funcionan mediante ondas electromagnéticas. Mediante las ondas electromagnéticas, se transmite información a grandes distancias, como los servicios de televisión, radio, radar, el internet y la telefonía celular.

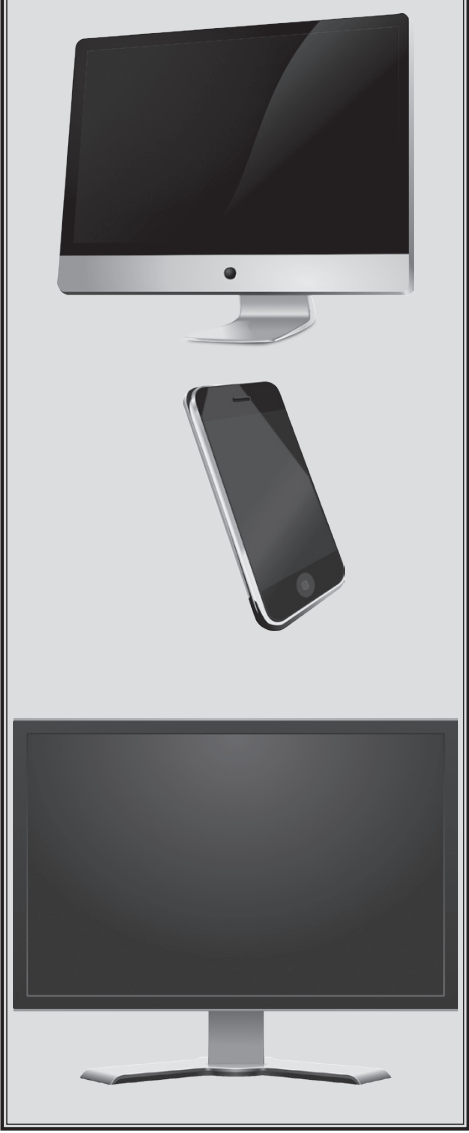




\section{Murales coros y otros productos artísticos}

\section{La forma de una canción}

La forma de la música tiene que ver con las partes de la melodía. La canción "Solo le pido a Dios" tiene una forma musical de una sola sección. En la página 176 vimos una canción de dos secciones. A cada sección la nombramos con una letra, por eso la canción "Livingston" tiene forma A-B, por eso es Binaria. Por tanto, "Sólo le pido a Dios" tiene solo la parte A, y es Primaria, la misma melodía se repite con los cuatro versos de cada estrofa.

Algunas canciones tienen forma Ternaria porque la parte A se vuelve a repetir y queda así: A-B-A. Otras formas como el rondó, incluyen varias partes más y su forma es circular, funcionan así: A-B-A-C-A-D-A.
Hemos realizado nuestros proyectos artísticos desde diversas expresiones. Es posible que otras sugerencias se hayan presentado y ahora tengamos muchas propuestas para desarrollar y mostrar a la comunidad. También es posible que otros proyectos se hayan postergado por falta de recursos. De cualquier forma, lo deseable es que se generen ideas y que con creatividad nos enfrentemos al reto de solucionar las necesidades de la familia y la comunidad.

Ahora, solo nos falta presentarlo a quienes puedan apreciar el valor de nuestra formación como factor de desarrollo para todas y todos. Desde el conocimiento científico y todo lo relacionado con el pensamiento y desde las emociones del arte, podemos cambiar y mejorar las condiciones de nuestra vida.

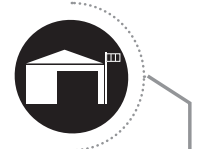

Nos toca verificar la organización de equipos para presentar el proyecto realizado. El conocimiento ha sido puesto en evidencia como motor de desarrollo y cuidado de la sociedad y del ambiente. ¿Lo evidenciamos así?:

- Presentando un diseño de modelaje del proyecto

- Elaborando y entregando la convocatoria a la comunidad

- Poniendo en práctica las normas para la presentación del modelaje

- Realizando el Plan de Mejoramiento

- Usando los proyectos artísticos como herramientas para presentar el proyecto
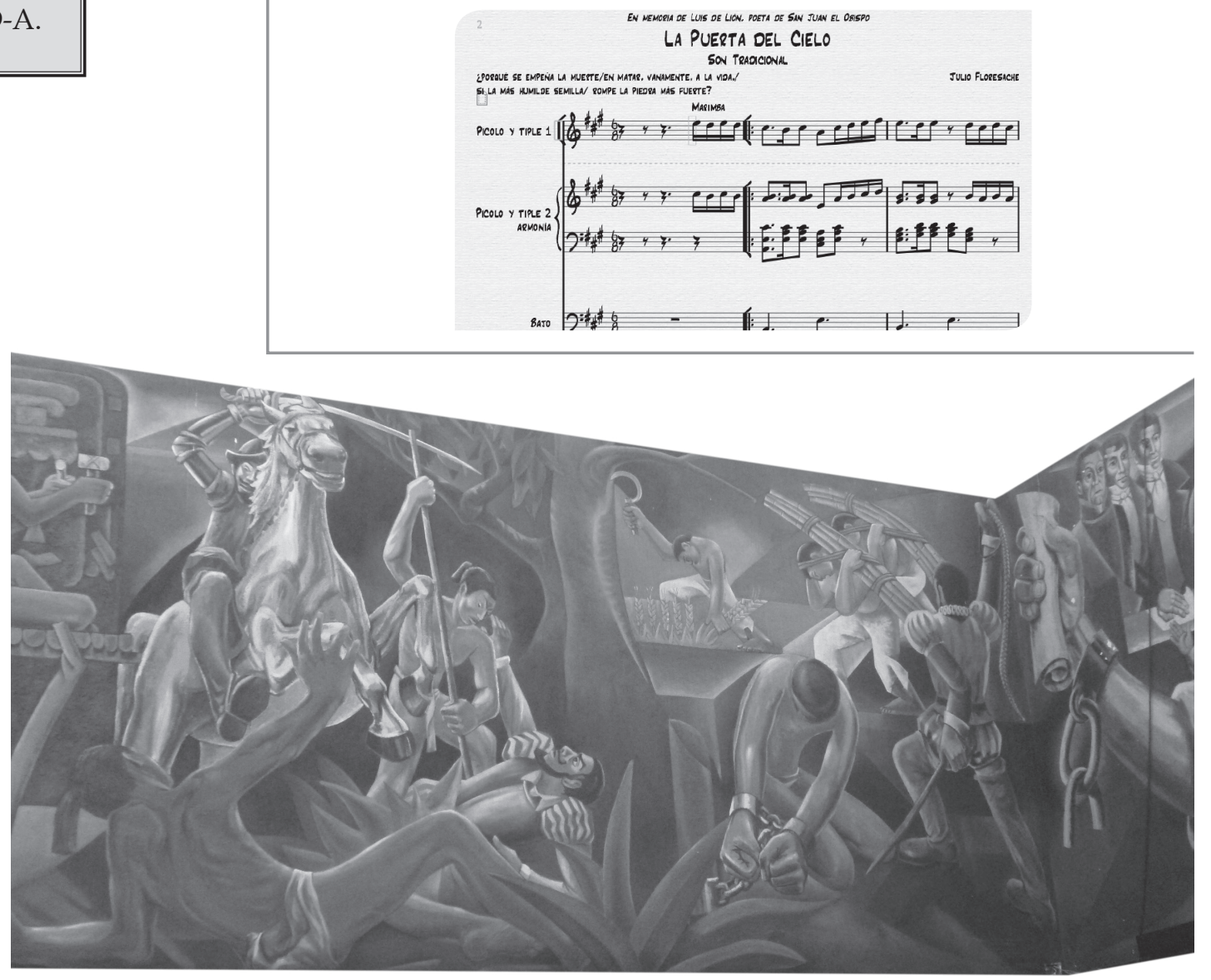


\section{Proyectos artísticos}

Los proyectos artísticos desarrollados son fuente de recreación para la vida. Nos admiramos de una pintura bien hecha, de una canción que nos conmueve de un baile que nos mueve y de una actuación que nos inspira a actuar. Por eso es importante esforzarnos por hacer bien nuestros proyectos artísticos y pulirlos hasta que sean más perfectos cada vez. El arte requiere disciplina y dedicación, por eso es también un trabajo que puede generar ganancia para la sobrevivencia. Quienes viven del arte merecen todo el respeto y aprecio porque su trabajo es muy importante para la sociedad. Y ese es también un conocimiento que armoniza con la sociedad y el ambiente.

¡Mostremos nuestro mural como toda una obra de arte y cantemos, actuemos o bailemos con todo el ánimo y las ganas del mundo!

\section{Hagamos una pausa}

Elegimos un espacio amplio para respirar, relajarnos y vocalizar

Escogemos una canción con ritmo suave. Respiramos contando los tiempos: de 4 en 4, luego de 2 en 2, de 1 en 1 . Luego lo hacemos en 6,8 y 12 tiempos. Inhalamos con los tiempos y luego exhalamos con la misma cantidad.

Entonamos un par de canciones, las que toda la clase sepa, con las vocales U, con A y con E. Luego las cantamos con su letra.

Ensayamos las canciones que vamos a presentar con el proyecto. Si trabajamos coreografías u obras de teatro, las ensayamos también y afinamos los detalles.

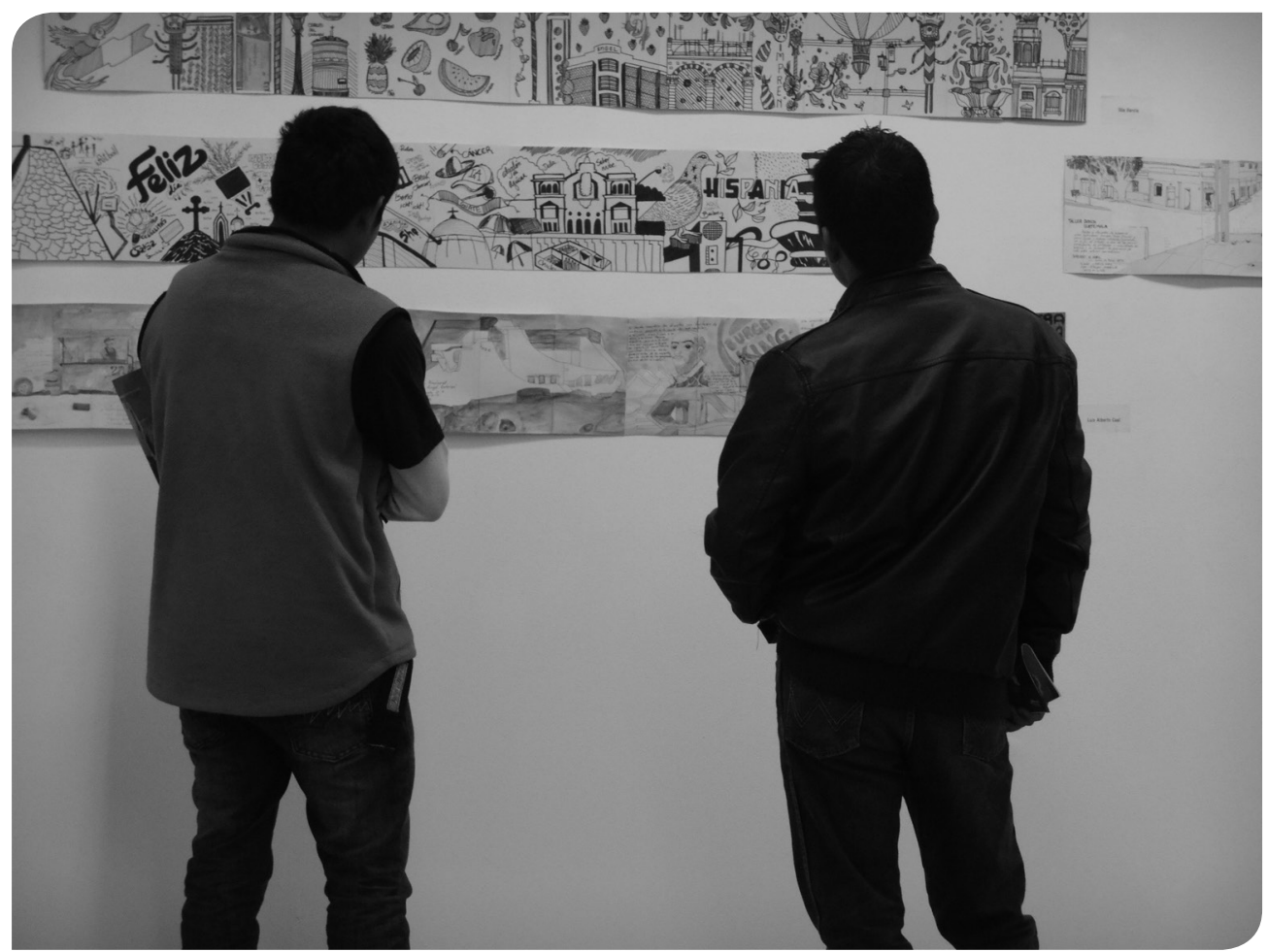

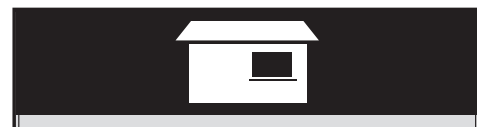

Practico mis atribuciones en los diversos procesos de la presentación:

Si actúo, canto, bailo o muestro, ensayo mis intervenciones para que todas tengan muy buen nivel

Si tengo que dirigir equipos, planifico las acciones a desarrollar durante la presentación

Anoto todo ordenadamente para tener claridad de lo que me toca hacer en cada fase de la ceremonia 


\section{Exponer con éxiło}

\section{El discurso, qué decir para convencer}

Un discurso es la exposición oral o escrita de un mensaje cuya finalidad principal es convencer a quien nos escucha. Para elaborar un buen discurso, es necesario seguir los siguientes pasos:

1. Tener un objetivo claro de lo que queremos decir. Para ello, debemos preguntarnos qué queremos lograr.

2. Ponerle un título interesante, que atraiga a quien nos escucha.

3. Preparar una introducción que le indique al público el tema central de nuestro discurso.

4. Ordenar las ideas para que tengan una secuencia coherente.

5. Preparar el final de nuestra exposición para saber exactamente hacia dónde encauzarlo y no perdernos dando información innecesaria.

6. Redactar el discurso y, una vez terminado, revisarlo varias veces hasta asegurarnos de que no le falta ningún detalle $y$, ensayarlo.
Una vez tenemos el discurso escrito, debemos:

1. Leerlo varias veces en voz alta para escucharnos. Si nos es posible, grabarnos.

2. Ensayarlo varias veces. Mejor si es frente a un espejo. No es necesario que nos lo aprendamos de memoria, pero sí conocer bien la secuencia que lleva.

3. Conocer quién será el público, para elegir el tono más adecuado (informativo, persuasivo o de entretenimiento).

En el momento de presentarnos frente a nuestro público:

1. Si hay micrófono, colocarlo a la altura correcta para que nuestra voz se escuche en todo el salón.

2. Cuidar tanto la expresión verbal como la expresión corporal. Transmitir confianza y seguridad.

3. Hablaremos como si nos dirigiéramos a una sola persona. Si leemos partes del discurso, cada cierto tiempo levantar la vista y fijarla ligeramente por encima de las cabezas de quienes nos escuchan.

4. Exponer únicamente las ideas principales. No extenderse mucho ni repetir conceptos que puedan aburrir a nuestra audiencia. No proporcionar datos irrelevantes al tema.

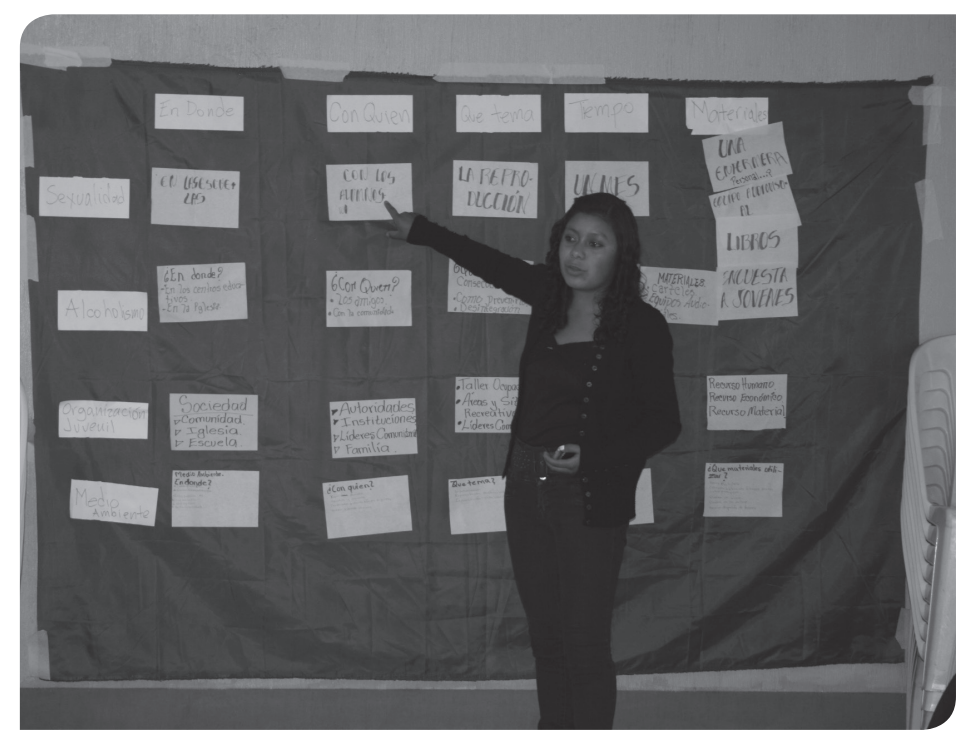

Elegiremos un tema que nos interese sobre la producción de un bien tecnológico que pueda elaborarse con materiales de fácil acceso (Ejemplo: captación de agua de lluvia, horno o panel solar, iluminación con botellas de agua, bici-molino de nixtamal, etc.). Investigaremos previamente sobre el tema y preparemos una puesta en común sobre la tecnología y el beneficio que puede brindar a la comunidad. 


\section{Propuestas para eliminar la discriminación de género}

Se trata de propuestas que buscan eliminar la exclusión de la mujer y de todo aquello que niega su reconocimiento, limita su papel, evita el goce de sus derechos o ejerce violencia en su contra. Con estas propuestas se busca que la mujer tenga las mismas oportunidades que el hombre y que participe de la vida social en igualdad de condiciones, le sean respetados sus derechos humanos y tenga las mismas libertades en lo político, económico, social, cultural y civil o en cualquier otro aspecto de la vida social. Entre ellas están:

Eliminar la discriminación contra la mujer en el campo laboral para que pueda realizarse como persona y, de ser el caso, contribuir a la supervivencia económica de su familia. Esto incluye, valorar su trabajo en los sectores no monetarios de la economía, garantizarle igual salario por igual trabajo, así como acceso a la seguridad social, entre otros.

Que el Estado y la iniciativa privada se abstengan de realizar actos o prácticas que discriminen a la mujer y con ello ejerzan violencia de cualquier tipo en su contra.

Evitar que la cultura y las tradiciones reproduzcan la discriminación contra las mujeres, así como enfrentar los estereotipos en los roles de hombres y mujeres, tanto en la casa como en la sociedad.

Proteger jurídicamente los derechos de la mujer para que esté en condiciones de igualdad en todos los aspectos.

Eliminar el femicidio (los asesinatos de mujeres por razón de su género), lo cual requiere exigencia para que se aplique la ley contra el mismo y que las autoridades intervengan con agilidad ante casos de violencia intrafamiliar o contra la mujer para evitar estos hechos, además de ser eficientes para esclarecerlos.

Proporcionar acceso al material informativo para asegurar su salud, incluida la información y el asesoramiento sobre planificación familiar, salud sexual y reproductiva; además de la comprensión adecuada de la maternidad como función social y una opción no obligación.

En el ámbito educativo, garantizar la igualdad de derechos y eliminar los conceptos estereotipados de los papeles masculino y femenino en todos los niveles y en todas las formas de enseñanza.

En el campo de la política, crear condiciones que promuevan su participación en la discusión de políticas, así como en procesos de elección, en igualdad de condiciones.

Presentamos nuestro producto o servicio tecnológico a la comunidad educativa.

Evaluamos el desarrollo del proyecto mediante una escala de rango. Redactamos una lista vertical de las actividades realizadas y en las siguientes columnas podemos colocar los rangos: excelente, muy bien, bien, necesito mejorar.

Formulamos un plan para mejorar nuestra participación en el producto obtenido.
- ¿En qué aspectos se discrimina más a las mujeres? Argumento mi respuesta.

Cómo medir y valorar el trabajo doméstico

"Hacer visible el aporte económico de las mujeres y valorar el trabajo doméstico y de cuidados que ellas realizan, es la primera condición para que puedan pensarse alternativas a la organización actual del trabajo doméstico.

En los últimos diez años, las reflexiones y reivindicaciones de los movimientos de mujeres en el mundo han sido fundamentales para que se reconozca la importancia de estas actividades para la reproducción social. No solo han descubierto la cara oculta (femenina) de la economía, sino que también han mostrado uno de los pilares en que se sustenta la subordinación de las mujeres, dado que esta no se basa solamente en la cultura o las ideas machistas sino que tiene bases económicas."

Fuente: Vásquez, C., Murguialday, C. y Mira, R. (2003). Con la sartén si el mango: El trabajo doméstico, base invisible de la economía. San Salvador: Asociación Equipo Maíz. Pp. 104-105.

- ¿Quién realiza el trabajo doméstico en mi hogar? ¿Qué recompensa recibe por su trabajo? ¿Es justo que así sea? Argumento mi respuesta. 


\section{Lógica formal y tipos de razonamiento}

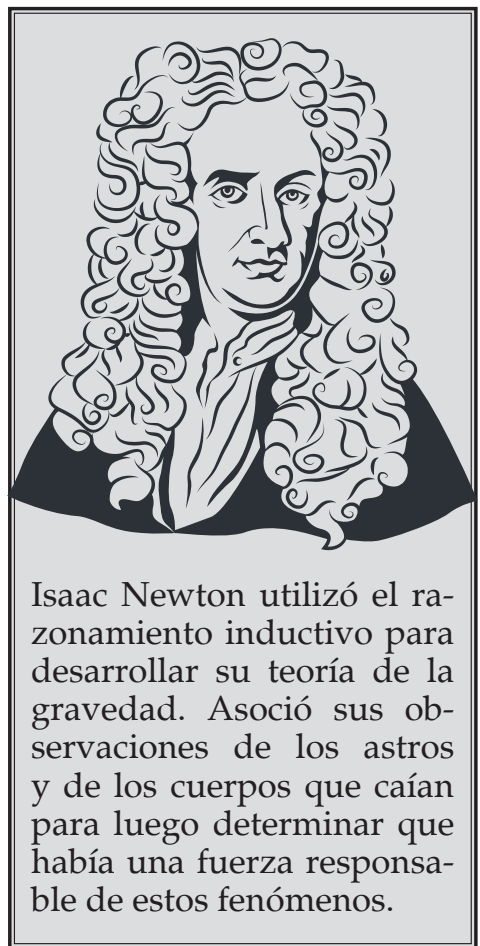

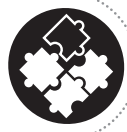

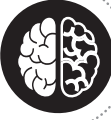

Leemos las siguientes proposiciones y luego comentamos:

Mi estufa solar es muy grande y la de mi vecina también lo es, por lo tanto todas las estufas solares son muy grandes.

Todas las estufas solares son muy grandes. La de mi vecina también lo es, por lo tanto mi estufa solar es muy grande.

- ¿Qué diferencias encontramos entre ambas proposiciones?

- ¿Podemos afirmar que ambos enunciados dicen lo mismo? Explicamos.

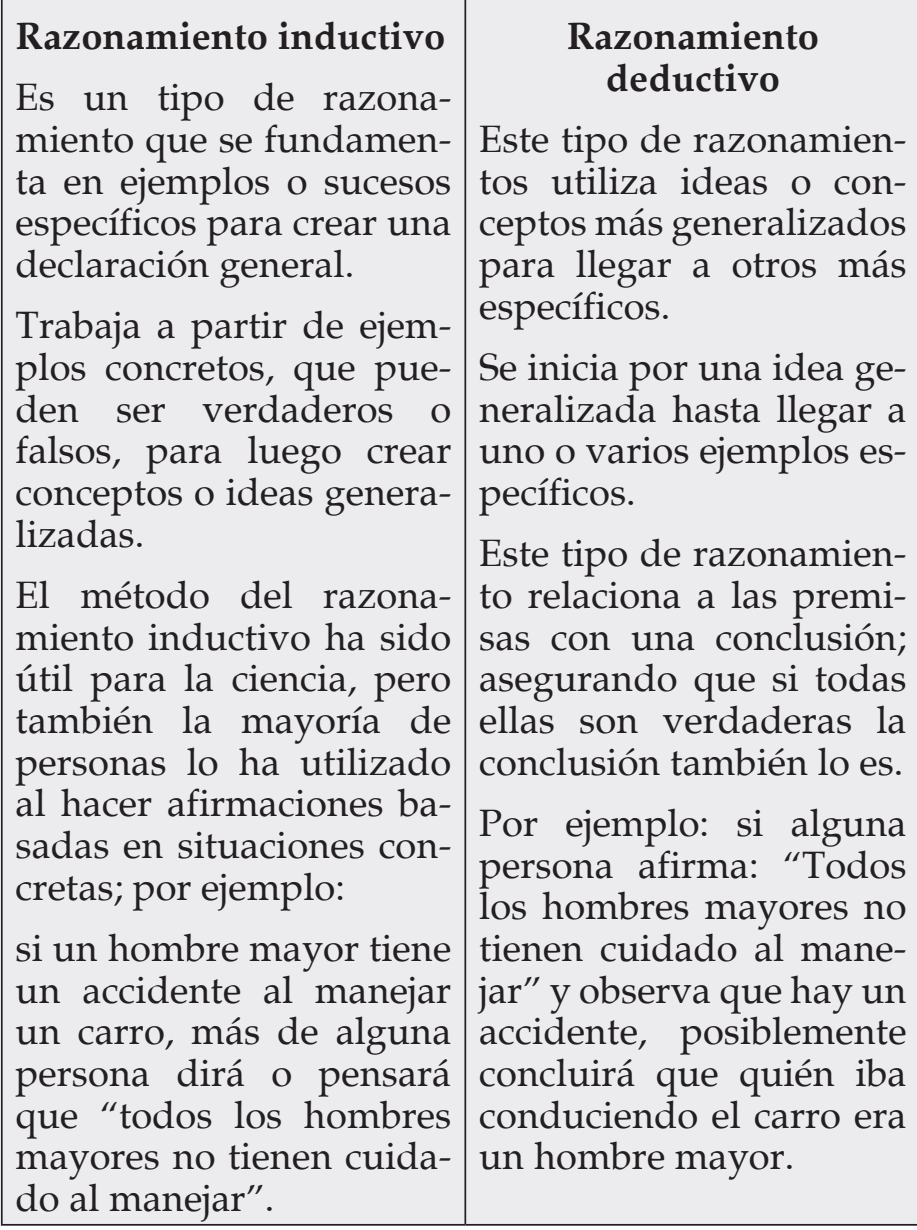

El proyecto que hemos venido realizando a lo largo de las últimas semanas ha requerido de investigación y análisis. Con base en el trabajo realizado en cada fase ¿podemos determinar qué tipo de razonamiento hemos utilizado para el mismo? Comentamos y discutimos con todos los compañeros y compañeras. Escuchamos todas las opiniones para poder concluir. 


\section{Impulsando el proyecto comunitario}

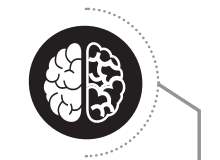

Para realizar con éxito un proyecto es necesario tener contar con personas que nos enseñen nuevos métodos de trabajo, por ejemplo, en el caso de nuestro proyecto, el apoyo técnico será una persona especialista que nos guiará para la construcción, operación y mantenimiento del sistema. El apoyo finan-

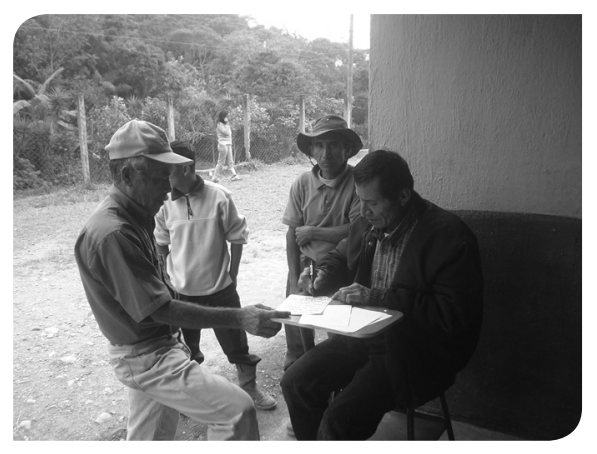
ciero, ya sea en forma de donación o préstamo, permitirá llevar a la realidad el proyecto. También es importante relacionarse con otras entidades gubernamentales o no que presten algún tipo de apoyo, por ejemplo, maquinaria, transporte, equipo y otros. También podemos visitar y consultar a líderes de otras comunidades que han realizado proyectos similares u organizaciones, como Madre Selva o Fundación Solar, que realizan proyectos comunitarios de energía hidroeléctrica o solar.

Es necesario contar con un perfil técnico del proyecto, incluyendo los estudios técnicos, legales, administrativos, financieros y mercadológicos (oferta/demanda) en base al cual realizar una planificación. Antes de comenzar la construcción, es importante contar con toda la información de diseño y los fondos necesarios para evitar gastos innecesarios, atrasos o problemas que desmotiven a la población. La sostenibilidad del proyecto es importante, por lo que la comunidad debe aceptar los términos y hacer sus contribuciones puntuales para que el proyecto opere y se renueve durante largo tiempo al contemplar la posibilidad de expansión para beneficio de otras familias conforme el número de vecinos aumenta.

Las personas responsables del proyecto deben tener conocimientos financieros y administrativos que permitan la elaboración del presupuesto, el flujo de efectivo, manejo de cuentas por cobrar, fijación de tarifas por consumo familiar y alumbrado público, revisión periódica de estas tarifas, lectura de contadores y otros. Además, un grupo de personas debe entrenarse para la operación y mantenimiento.

Otro aspecto a tomar en cuenta es el impacto que el proyecto genere. Por ejemplo, la luz eléctrica podría generar mayor actividad comercial y más basura. La comunidad puede evitar suciedad y contaminación creando basureros y promoviendo cultura de manejo de la basura y desperdicios.

Durante varias semanas de clase hemos venido elaborando un proyecto. Preparemos una presentación del mismo, organicemos una asamblea comunitaria para presentar nuestro proyecto $\mathrm{y}$ realizar una consulta para conocer la opinión de la comunidad.

Además, ponemos en práctica las normas de seguridad del proyecto para realizar cualquier cambio necesario.
Estudio de Impacto Ambiental y Consulta Comunitaria

Antes de iniciar un proyecto, especialmente uno grande como una hidroeléctrica o una mina, los encargados deben realizar una Evaluación de Impacto Ambiental (EIA) que identifique las acciones que provoquen impacto, los factores afectados y las medidas para mitigar y contrarrestar los efectos negativos. La EIA debe considerar los efectos ambientales, productivos y sociales; entre estos últimos, los económicos, sociales, culturales, tecnológicos y sobre la salud y seguridad de las poblaciones cercanas y sus trabajadores. El EIA es un documento público, debe ser del conocimiento de la sociedad, en particular de la comunidad directamente involucrada o afectada por el mismo. Por su parte, las comunidades tienen el derecho de opinar y decidir sobre el establecimiento de este tipo de proyectos por medio de consultas comunitarias, consultas a vecinos o consultas de buena fe.

El derecho a la consulta comunitaria se basa en el Convenio 169 de la OIT sobre Derechos de los Pueblos Indígenas, en la Declaración de Naciones Unidas sobre Derechos de los Pueblos Indígenas, en los artículos 60 al 66 del Código Municipal y en la Ley de Consejos de Desarrollo.

https://jpicguatemala.files. wordpress.com/2014/11/ consulta-en-cantela-quezaltenango.png 


\section{Arte y conoómiento en una sociedad más justa y feliz}

Hemos trabajado el proyecto enfocado en el conocimiento al servicio de la comunidad y del ambiente. Es notable que la sociedad necesita cultivar el conocimiento para desenvolverse mejor, y que ese desenvolvimiento mejora el nivel de vida de las personas. También resalta que el uso de tecnología, asociado con el conocimiento, es importante para soluciones puntuales a problemas comunes en todo grupo humano.

Pero no solo el cultivo del conocimiento es valioso, si no se ejercita también el espíritu y se recrean las emociones. Tampoco es adecuado el mal uso o abuso de los recursos naturales. Debe haber un equilibrio al emplear la riqueza que la madre tierra nos presta para vivir.

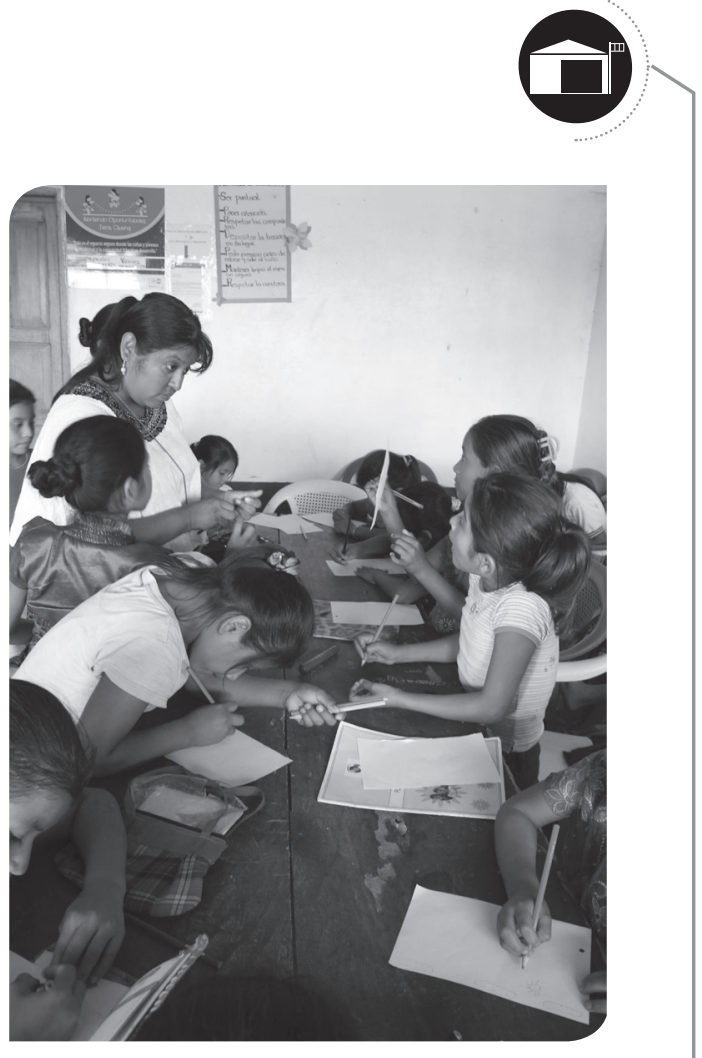

Cómo preservamos nuestros proyectos artísticos

1. La pintura mural es susceptible de desgaste y deterioro con el tiempo. Si se realiza en un espacio interior, bajo techo, aún puede llegarle la humedad.

Puede protegerse si se le aplica un barniz transparente, sin coloración, para que no afecte los colores originales.

También puede hacerse si fue realizado en espacios exteriores.

Protegerlo de la luz directa del sol también es importante, para evitar decoloración.

2. El coro puede seguir funcionando como una herramienta de expresión artística de la comunidad.

Pueden organizarse para mantener una rutina de ensayos semanales

Ubicar un espacio donde ensayar y propiciar la búsqueda de nuevas canciones

Se pueden buscar espacios donde presentar las canciones del coro y animarse a montar piezas cada vez más complejas, a dos, tres o cuatro voces.

3. Cualquier producto artístico que hayamos realizado a lo largo de nuestro estudio puede ser expuesto como fruto del conocimiento a favor de la sociedad, la familia y la comunidad.

\section{Evaluemos nuestro desempeño}

Marcamos si cumplimos con cada aspecto requerido durante el proyecto:

Rangos: 1-nunca; 2-pocas veces; 3-algunas veces; 4-bastante; 5- siempre.

\begin{tabular}{|c|c|c|c|c|c|}
\hline Actividad & $1^{\underline{a}}$ & $2^{\underline{a}}$ & $3^{\underline{a}}$ & $4^{\mathrm{a}}$ & $5^{\underline{a}}$ \\
\hline Colaboré con el diseño del proyecto o servicio tecnológico & & & & & \\
\hline Analicé las necesidades de mi familia y comunidad & & & & & \\
\hline $\begin{array}{l}\text { Propuse soluciones desde el conocimiento para la sociedad y el } \\
\text { ambiente }\end{array}$ & & & & & \\
\hline Realicé y participé en todas las actividades propuestas & & & & & \\
\hline Propuse ideas en la creación y montaje de los proyectos artísticos & & & & & \\
\hline Participé activamente en el montaje de los proyectos artísticos & & & & & \\
\hline
\end{tabular}




\section{Electrónica y desarrollo humano}

Son numerosas las aplicaciones tecnológicas del magnetismo en la actualidad. Algunas aplicaciones más importantes son las siguientes: En las memorias de las computadoras y en los dispositivos almacenadores de información, como los discos magnéticos y discos duros, así como en los trenes de alta velocidad que funcionan con levitación magnética, es decir se desplaza venciendo la gravedad por acción de las fuerzas electromagnéticas. Los trenes se desplazan suspendidos en el aire por acción de potentes imanes, son más silenciosos y veloces.

La finalidad de la industria electrónica es el logro de vida digna. Algunos países en Europa y Asia, están abandonando el consumo del petróleo y sus derivados e impulsan energías alternativas. Entre estas, la generación de energía eléctrica mediante la energía solar, el uso de automóviles eléctricos y bonos para los trabajadores que viajen en transporte público o en bicicleta. También incluyen ciclovías y carreteras inteligentes con sistema de recolección de energía pavimentados con paneles solares.

Video recomendado: http://www.periodistadigital.tv/carreteras-inteligentesque-generan-energia_a18aa4a1e.html\#.WHB5WfnhDIU

Por otro lado, se relaciona con la rapidez de los avances tecnológicos, la vida útil de los inventos y la moda. Los productos tecnológicos, desde su fabricación ya tienen predeterminado un tiempo de duración, que obliga al reemplazo del producto y la compra de uno nuevo. Esto deriva en exceso de desperdicio e incrementa la basura electrónica que constituye uno de los problemas ambientales más serios y constituyen un desafío para el mundo. Los componentes de la basura electrónica contienen muchos elementos contaminantes, para el planeta.

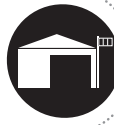

En grupo presentamos el producto o servicio tecnológico a la comunidad educativa.

Evaluamos la presentación del producto o servicio mediante la siguiente escala de rango.

\begin{tabular}{|l|l|l|l|}
\hline \multicolumn{1}{|c|}{ Criterios } & Bajo & Medio & Alto \\
\hline Interés de la comunidad por el proyecto. & & & \\
\hline Percepción del beneficio para la comunidad. & & & \\
\hline $\begin{array}{l}\text { Manifestación de factibilidad económica para } \\
\text { realizar el proyecto. }\end{array}$ & & & \\
\hline $\begin{array}{l}\text { Capacidad de implementación de parte de la } \\
\text { comunidad. }\end{array}$ & & & \\
\hline $\begin{array}{l}\text { Existencia de tecnología requerida para realizar } \\
\text { el proyecto. }\end{array}$ & & & \\
\hline $\begin{array}{l}\text { Potencialmente el proyecto aportará bienestar a } \\
\text { los habitantes de la comunidad. }\end{array}$ & & & \\
\hline
\end{tabular}

"La exposición a campos electromagnéticos no es un fenómeno nuevo. Sin embargo, en el siglo XX la exposición ambiental ha aumentado de forma continua conforme la creciente demanda de electricidad, el constante avance de las tecnologías y los cambios en los hábitos sociales han generado más y más fuentes artificiales de campos electromagnéticos." Todas y todos "(...) estamos expuestos a una combinación compleja de campos eléctricos y magnéticos débiles, tanto en el hogar como en el trabajo, desde los que producen la generación y transmisión de electricidad, los electrodomésticos $\mathrm{y}$ los equipos industriales, a los producidos por las telecomunicaciones y la difusión de radio y televisión."

Fuente: http:/ / www.who. int/peh-emf/about/WhatisEMF/es/index1.html

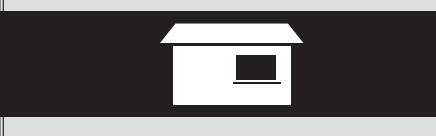

Realizo un anecdotario. Anoto mis experiencias en la elaboración del producto o servicio tecnológico y los resultados obtenidos en mi aprendizaje.

Escribo una reflexión relacionada con el consumo de energía por el uso de gran cantidad de aparatos electrónicos y la dependencia creada por la sociedad. 


\section{PROYECTO No. 6. Mente y cuerpo sanoscomo problemas sociales y para la salud}

A continuación se presentan varias categorías y su descripción para analizar detenidamente si se observan en el mural. Marque $\boldsymbol{X}$ en la casilla que corresponde.

\begin{tabular}{|c|c|c|c|c|c|c|}
\hline & 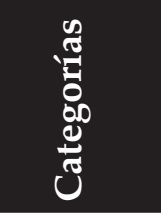 & Descripción & 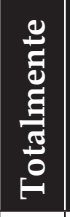 & 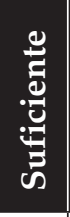 & $\begin{array}{l}0 \\
\frac{0}{0} \\
0 \\
0 \\
0 \\
0 \\
0 \\
0\end{array}$ & 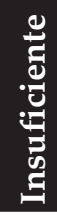 \\
\hline 1 & Datos & Nombre del Producto o Servicio Tecnológico & & & & \\
\hline 2 & les & Listado de materiales o recursos utilizados & & & & \\
\hline 3 & & Describe el proceso de selección de la población en donde se recolectó la información & & & & \\
\hline 4 & 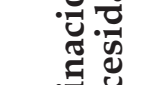 & $\begin{array}{l}\text { Refiere el instrumento utilizado en la recolección de la información para determinar las } \\
\text { necesidades de la población. }\end{array}$ & & & & \\
\hline 5 & 当 & Explica el proceso de análisis para priorizar la necesidad a cubrir & & & & \\
\hline 6 & $\stackrel{\frac{\pi}{0}}{0}$ & Determina la necesidad que debe ser cubierta & & & & \\
\hline 7 & & Explica la razón de la determinación de la necesidad & & & & \\
\hline 8 & & Presenta un plan para la elaboración del producto o servicio & & & & \\
\hline 9 & & Indica qué materiales y recursos eligió para elaborar el producto o servicio. & & & & \\
\hline 10 & 올.므 & Indica por qué eligió los materiales y recursos utilizados en el producto o servicio. & & & & \\
\hline 11 & . & $\begin{array}{l}\text { Incluye criterios de selección de materiales y recursos: bajo costo, reciclado o reutilizado y } \\
\text { disponibles en el entorno. }\end{array}$ & & & & \\
\hline 12 & $\stackrel{0}{0}$ & Explica el proceso de elaboración o procedimiento del producto o servicio, paso a paso. & & & & \\
\hline 13 & 2 & Menciona a quienes involucró en el proceso de elaboración. & & & & \\
\hline 14 & & $\begin{array}{l}\text { Indica si tuvo alguna dificultad en la elaboración del producto o servicio y cómo resolvió la } \\
\text { misma. }\end{array}$ & & & & \\
\hline 15 & $\stackrel{0}{\stackrel{2}{z}}$ & Realiza una demostración y explicación del funcionamiento del producto o servicio. & & & & \\
\hline 16 & $\ddot{\Xi}$ & Explica la utilización de la energía alternativa en el funcionamiento del producto o servicio. & & & & \\
\hline 17 & $\cdot \frac{0}{g}$ & Demuestra que la utilización del producto o servicio no atenta contra el ambiente. & & & & \\
\hline 18 & I工 & Justifica que el producto o servicio no perjudica los derechos de terceras personas. & & & & \\
\hline 19 & & $\begin{array}{l}\text { Explica qué grupo de la población en su comunidad se beneficia directamente con el pro- } \\
\text { ducto o servicio. }\end{array}$ & & & & \\
\hline 20 & $=$ & Manifiesta cómo y en qué beneficia el producto o servicio a la población. & & & & \\
\hline 21 & 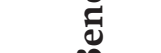 & Determina si el producto o servicio beneficia indirectamente a otro grupo de la población. & & & & \\
\hline 22 & & Presenta argumentos para convencer a las personas del beneficio del producto o servicio. & & & & \\
\hline
\end{tabular}




\section{Evaluación por Competencias}

\section{Reflexión}

A continuación se presentan varias categorías y su descripción para analizar detenidamente la actitud en relación con el aprendizaje. Marco con una $\boldsymbol{X}$ en la casilla que considero es el caso.

\begin{tabular}{|c|c|c|c|c|c|}
\hline$c^{x^{x^{+0}}}$ & & Descripción & $\begin{array}{l}\text { Siem- } \\
\text { pre }\end{array}$ & $\begin{array}{l}\text { Mu- } \\
\text { chas } \\
\text { veces }\end{array}$ & Nunca \\
\hline 1 & \multirow{6}{*}{ 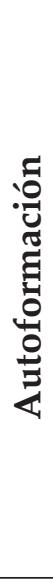 } & $\begin{array}{l}\text { Reconozco que al realizar cada acción educativa individual o colectiva, dentro } \\
\text { y fuera de clase, el fin último es aprender para la vida. }\end{array}$ & & & \\
\hline 2 & & $\begin{array}{l}\text { Me intereso por conocer más a fondo lo visto en clase e indago en otras fuentes } \\
\text { o consulto al o la docente. }\end{array}$ & & & \\
\hline 3 & & $\begin{array}{l}\text { Relaciono la información vista en clase con los aspectos culturales, de salud, } \\
\text { deportes, ambiente, productividad y economía de mi comunidad o región. }\end{array}$ & & & \\
\hline 4 & & $\begin{array}{l}\text { Estoy de acuerdo con que los conocimientos adquiridos en clase son importan- } \\
\text { tes para valorar y mejorar el ambiente ecológico, la salud individual, y familiar } \\
\text {, las relaciones culturales, la economía, y productividad de mi comunidad o } \\
\text { región. }\end{array}$ & & & \\
\hline 5 & & $\begin{array}{l}\text { Asigno un horario específico entre semana para tareas, lecturas y otros aspec- } \\
\text { tos relacionados con las áreas y sub áreas del grado. }\end{array}$ & & & \\
\hline 6 & & Realizo a tiempo las tareas según la fecha establecida. & & & \\
\hline 7 & \multirow{2}{*}{ 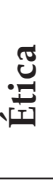 } & $\begin{array}{l}\text { Estoy consciente de que si copio las tareas de mis compañeros o compañeras } \\
\text { les falto el respeto, me falto el respeto y limito mi aprendizaje. }\end{array}$ & & & \\
\hline 8 & & $\begin{array}{l}\text { Al realizar investigaciones elijo, analizo y resumo la información pertinente } \\
\text { para evitar copiar (plagiar) la información. }\end{array}$ & & & \\
\hline 9 & \multirow{10}{*}{ 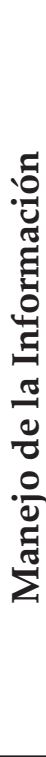 } & $\begin{array}{l}\text { Reconozco que mi realidad inmediata puede cambiar si realizo pequeños cam- } \\
\text { bios al utilizar nuevos conocimientos. }\end{array}$ & & & \\
\hline 10 & & $\begin{array}{l}\text { Es importante para mí reconocer qué acciones promueven la salud individual } \\
\text { y colectiva. }\end{array}$ & & & \\
\hline 11 & & $\begin{array}{l}\text { Aprecio las diferentes expresiones artísticas (música, plástica, teatro, danza) } \\
\text { como desarrollo personal. }\end{array}$ & & & \\
\hline 12 & & Utilizo el arte para expresar mis ideas y sentimientos. & & & \\
\hline 13 & & Utilizo herramientas tecnológicas como apoyo & & & \\
\hline 14 & & Sigo instrucciones del o la docente, hojas de trabajo y libros de texto. & & & \\
\hline 15 & & Comparo conceptos y distingo sus diferencias y semejanzas. & & & \\
\hline 16 & & $\begin{array}{l}\text { Analizo y memorizo conceptos importantes de ecosistemas, economía, pro- } \\
\text { ductividad, interculturalidad, salud, deportes y otros. }\end{array}$ & & & \\
\hline 17 & & Me intereso por hablar y escribir en otros idiomas. & & & \\
\hline 18 & & $\begin{array}{l}\text { Me intereso por aplicar las normas de redacción y ortografía en los textos que } \\
\text { escribo. }\end{array}$ & & & \\
\hline 19 & \multirow{5}{*}{ 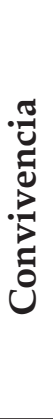 } & Colaboro con mis compañeras y compañeros en el proceso de aprendizaje. & & & \\
\hline 20 & & $\begin{array}{l}\text { Demuestro respeto por mi persona, mis compañeras y compañeros, docentes } \\
\text { y centro de aprendizaje. }\end{array}$ & & & \\
\hline 21 & & Propongo soluciones y aporto ideas cuando participo en equipos de trabajo. & & & \\
\hline 22 & & $\begin{array}{l}\text { Expreso mis sentimientos y pensamientos en el momento oportuno, con respe- } \\
\text { to, sin ofender a otras personas. }\end{array}$ & & & \\
\hline 23 & & $\begin{array}{l}\text { Respeto la participación de todas y todos, las diferencias físicas, intelectuales, } \\
\text { de religión, cultura, origen étnico, género y orientación, de mis compañeras y } \\
\text { compañeros. }\end{array}$ & & & \\
\hline
\end{tabular}


En la presente obra, se reconocen los derechos morales colectivos del Pueblo Maya y de los otros Pueblos de Guatemala: Xinka, Garífuna y Ladino; respecto de sus creaciones culturales y artísticas, entre ellas, su sistema de numeración, arquitectura, escultura, pintura, textiles y demás obras de su creación.

Debido a las características propias del internet, es posible que las fuentes consultadas, se modifiquen o desaparezcan.

Algunas imágenes donde aparecen menores de edad, fueron retocadas intencionalmente, para proteger la identidad de niñas y niños. Parte de las imágenes utilizadas en esta obra, fueron tomadas en préstamo de diferentes sitios web y bases de datos libres de derechos. Otras imágenes fueron cedidas para uso exclusivo de la presente obra por el Ministerio de Educación, Population Council, SEDEM, grupos familiares y personas individuales, quienes tienen la titularidad de las mismas. A continuación se enumeran las fuentes de las imágenes que por razones de espacio, no se les reconociió el crédito directamente al pie de la imagen.

\begin{tabular}{|c|c|}
\hline Autor de Imágenes & $\begin{array}{l}\text { Número de pá- } \\
\text { ginas }\end{array}$ \\
\hline Carlos Velásquez & 59 \\
\hline Carolina Macá & 166 \\
\hline Cecilia Garcés & $\begin{array}{r}26,109,136,182 \\
204,214\end{array}$ \\
\hline Claudia Roche & $\begin{array}{r}16,32,54,70,78, \\
79,80,88,213,216, \\
218,226,232,234,\end{array}$ \\
\hline Delia Aydée Caal & 82 \\
\hline Estefanía Morales Macá & 202,203, \\
\hline H.I.J.O.S. Guatemala & 164 \\
\hline $\begin{array}{l}\text { http:/ / 25depie.blogspot.com/2016/10/mapa- } \\
\text { de-guatemala-en-vectores-con.html }\end{array}$ & 142 \\
\hline http://anam.org.gt & 193 \\
\hline http://cdag.com.gt & 39 \\
\hline http:/ / climatekids.nasa.gov/smores & 160,164, \\
\hline http://commons.wikimedia.org & 35,177, \\
\hline http:/ / ecoosfera.com & 191 \\
\hline http:/ / factsreports.revues.org & 234 \\
\hline http://gt.undp.org & 63 \\
\hline http://ideopolis.org & 206 \\
\hline http://igss.gt.org & 126 \\
\hline http://mcd.gob.gt & 68,277, \\
\hline http://mildesmotivos.com & 16 \\
\hline http://muniguate.com & 129,183 \\
\hline http://www.Freepik.es & $\begin{array}{r}34,37,58,93,110, \\
114,125,150,156, \\
170,194,201,206, \\
212,242,\end{array}$ \\
\hline http://www.mag.gob.sv & 198 \\
\hline http://www.mineduc.edu.gt & 64 \\
\hline http://www.pdh.org.gt & 168 \\
\hline http://www.visitguatemala.com/descargas/ & 176 \\
\hline $\begin{array}{l}\text { https://1.bp.blogspot.com/- } \\
\text { aoDqlv0I12M/T236zB0VLlI/ } \\
\text { AAAAAAAAARA/3Dwj2Uz5OX0/s200/ } \\
\text { isabel+de+los+angeles.jpg }\end{array}$ & 205 \\
\hline $\begin{array}{l}\text { https://informacionlibre2000.files.wordpress. } \\
\text { com/2012/10/presidente.jpg }\end{array}$ & 180 \\
\hline
\end{tabular}

\begin{tabular}{|c|c|}
\hline Autor de Imágenes & $\begin{array}{l}\text { Número de pá- } \\
\text { ginas }\end{array}$ \\
\hline $\begin{array}{l}\text { https://letrasenvena.files.wordpress.com/2011/05/ } \\
\text { luz-vega.jpg }\end{array}$ & 205 \\
\hline https://pixabay.com/es/ & $\begin{array}{r}13,14,18,20,23, \\
27,42,45,53,66, \\
74,81,92,102,105, \\
108,118,119,122, \\
125,132,137,154, \\
155,157,158,162, \\
174,175,176,187, \\
188,189,195,198, \\
199,202,207,212, \\
213,217,235,236, \\
237,\end{array}$ \\
\hline https://serunserdeluz.wordpress.com/tag/cigarros/ & 20 \\
\hline $\begin{array}{l}\text { https://sites.google.com/site/magnetologiacom/ } \\
\text { atraccion-magnetica-2 Juan Carlos Aviles Morán }\end{array}$ & 216 \\
\hline https://www.youtube.com/watch?v=bFGy-RHdTSc & 178 \\
\hline Instituto Guatemalteco de Turismo -INGUAT- & 128 \\
\hline Jorge Galindo & $48,85,94,149, \begin{array}{r}151 \\
121\end{array}$ \\
\hline Julio Floresaché & 238, \\
\hline Margarita Ramírez & $\begin{array}{l}11,51,65,98,99, \\
138,159,91,127,\end{array}$ \\
\hline Ministerio de Educación & $\begin{array}{r}10,21,22,29,43, \\
44,50,56,61,67, \\
83,88,90,100,101, \\
113,121,124,133, \\
136,141,143,146, \\
148,161,166,214, \\
222,223,230,231, \\
137,\end{array}$ \\
\hline Pixabay & 47 \\
\hline Population Council & $\begin{array}{r}36,46,63,69,71 \\
75,78,79,81,85 \\
112,134,171,211 \\
233\end{array}$ \\
\hline Population Council, Cecilia Garcés & $\begin{array}{r}8,17,52,59,89,98 \\
139,150,187,188, \\
210,238\end{array}$ \\
\hline Population Council, Jeremy Bunch & 244 \\
\hline Population Council, Leyzer Chiquín & Portada, $7,28,89$ \\
\hline Population Council, Sandra Sebastián & $9,60,146$ \\
\hline Population Council, Vilma Chon & 50 \\
\hline Seguridad en Democracia -SEDEM- & $\begin{array}{r}49,112,167,190, \\
239,240,243\end{array}$ \\
\hline www.paho.org/els/ & 38,41 \\
\hline www.wordpress.com & 62 \\
\hline
\end{tabular}




\section{Recursos de aprendizaje Mapa mundi}

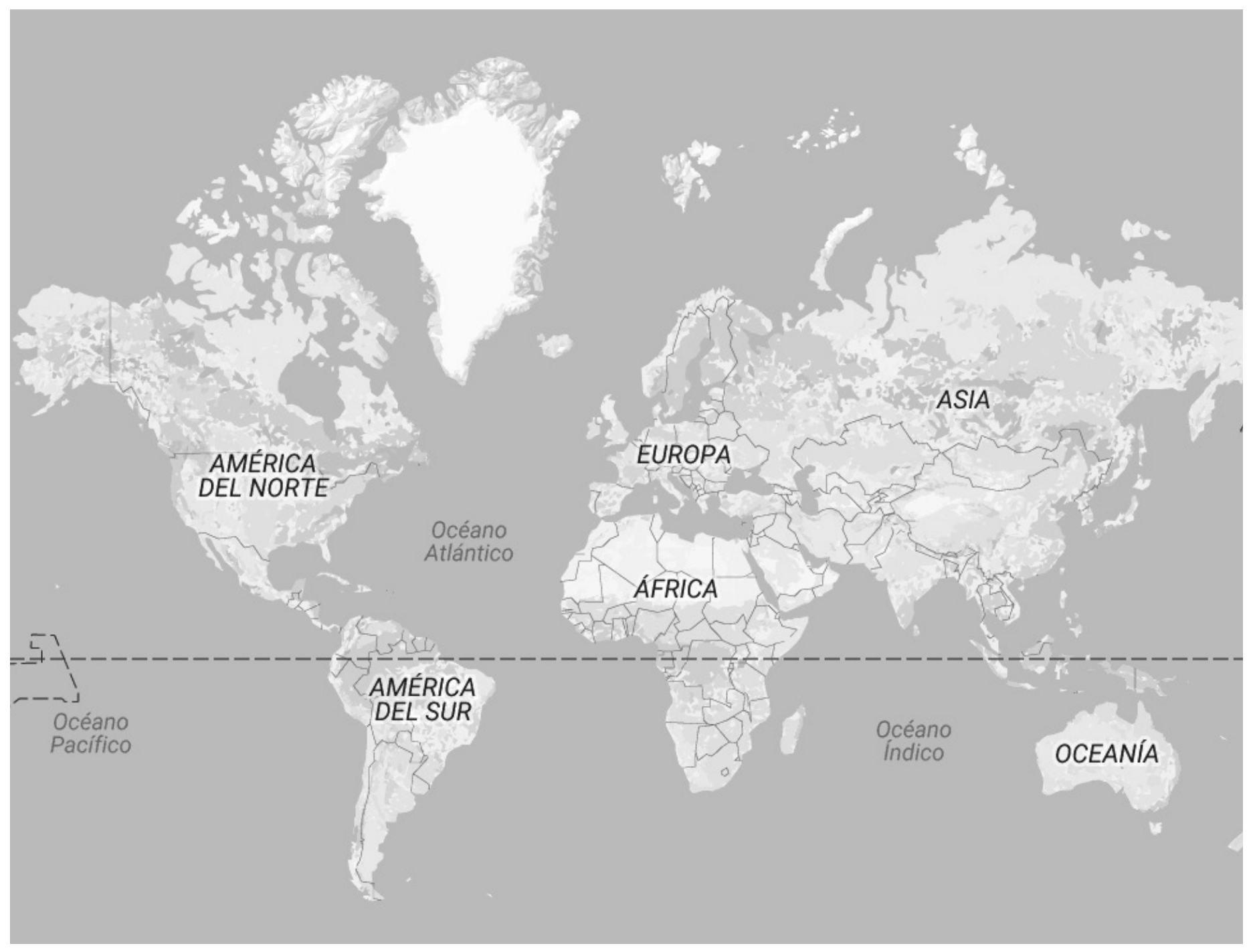

Fuente: http:/ / mapamundial.co/mapa-de-mundo-pantalla-completa.html 
- Procuraduría de los Derechos Humanos (PDH) ya sea en la auxiliatura o llamando al 1555.

- Fiscalía de la mujer, del Ministerio Público. 22306025

- Policía Nacional Civil (PNC), Tel. 110

- Fundación Sobrevivientes 22453300.

- Grupo Guatemalteco de Mujeres, 22500235, Asociación de Mujeres Garífunas de Guatemala (ASOMUGUA) 55186579

- PDH, Defensoría de Pueblos Indígenas, 1555

Actos de discriminación o racismo, vio-

- Documentar con fotos, grabaciones,

- Comisión Presidencial Contra la Disnotas, testimonios.

lencia sicológica o física por razón de

- Si es muy grave, salir del lugar y pepertenencia étnica. dir apoyo a PDH. criminación y el Racismo (CODISRA), 24945300. Coordinadora y convergencia Nacional Maya Wakib'Kej, 24349754.

- Denuncia

- ONEGUA 52166563.

- Parlamento del pueblo xinca 5030419840635605

- Documentar con fotos, grabaciones,

- PDH, Defensoría de la niñez y adolescencia, Tel. 1555

notas, testimonios.

Violencia contra la niñez y adolescen-

- Si es muy grave, salir del lugar y pedir apoyo a PDH.

- Procuraduría General de la Nación, 24148787

cia. Maltrato físico, explotación laboral, abuso o violencia sexual.

- Denuncia

- Alerta Alba Keneth 2501-0300

- Si se trata de robo o desaparición de niñas, niños o adolescentes, pedir activar Alerta Alba Keneth

- Fiscalía de la niñez y la víctima 22306030

- Asociación el Refugio de la Niñez, 23340806

- Documentar con fotos, grabaciones, notas, testimonios.

Violencia contra adultos y adultas mayores.

- Si es muy grave, salir del lugar y pedir apoyo a PDH.

- PDH, Defensoría de personas mayores. Teléfono 1555

- Denuncia

- Documentar con fotos, grabaciones,

Violencia contra la Juventud notas, testimonios.

- Denuncia

- PDH, Defensoría de la Juventud, Tel 1555

- Documentar con fotos, grabaciones, notas, testimonios.

Violencia física, psíquica, sexual, económica, contra personas con discapacidad

- Denuncia

- Documentar con fotos, grabaciones,

Violencia o ataques a defensoras o denotas, testimonios.

fensores de Derechos humanos

- Denuncia

- PDH, Defensoría de eprsonas con discapacidad, Tel 1555

- PDH, teléfono 1555

- Fiscalía de Derechos Humanos 22306033

- UDEFEGUA 22545840, 22544496
POPULATION COUNCIL

Ideas. Evidencia. Impacto.

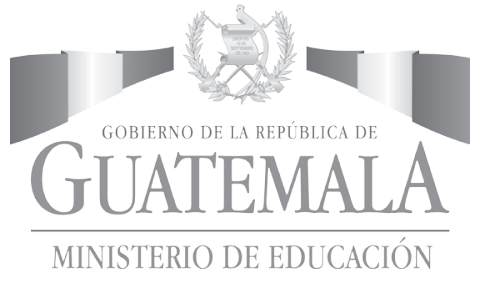

NoVo Foundation 